\title{
NEVADA TEST SITE RADIATION PROTECTION PROGRAM
}

Revision 1

June 2008

Prepared by:

Radiological Control Managers' Council Nevada Test Site 


\section{Disclaimer}

This report was prepared as an account of work sponsored by an agency of the U.S. Government. Neither the U.S. Government nor any agency thereof, nor any of their employees, nor any of their contractors, subcontractors or their employees, makes any warranty or representation, express or implied, or assumes any legal liability or responsibility for the accuracy, completeness, or usefulness of any information, apparatus, product, or process disclosed, or represents that its use would not infringe privately own rights. Reference herein to any specific commercial product, process, or service by trade name, trademark, manufacturer, or otherwise, does not necessarily constitute or imply its endorsement, recommendation, or favoring by the U.S. Government or any agency thereof. The views and opinions of authors expressed herein do not necessarily state or reflect those of the U.S. Government or any agency thereof.

Available for sale to the public, in paper, from:

U.S. Department of Commerce

National Technical Information Service

5285 Port Royal Road

Springfield, VA 22161-0002

Telephone: 800.553 .6847

Fax: 703.605.6900

E-mail: orders@ntis.fedworld.gov

Online ordering: http://www.ntis.gov/ordering.htm

Available electronically at: http://www.osti.gov/bridge

Available for a processing fee to the U.S. Department of Energy and its contractors, in paper, from:

U.S. Department of Energy

Office of Scientific and Technical Information

P.O. Box 62

Oak Ridge, TN 37831-0062

Telephone: 865.576 .8401

Fax: 865.576.5728

E-mail: reports@adonis.osti.gov 


\section{DOE/NV/25946--144}

FOR THE USE OF NEVADA TEST SITE TENANT ORGANIZATIONS AND THE U.S. DEPARTMENT OF ENERGY, NATIONAL NUCLEAR SECURITY ADMINISTRATION NEVADA SITE OFFICE

\section{NEVADA TEST SITE RADIATION PROTECTION PROGRAM}

Revision 1

June 2008

Coordinated and compiled by: National Security Technologies, LLC

P.O. Box 98521

Las Vegas, NV 89193-8521 
THIS PAGE LEFT INTENTIONALLY BLANK 


\section{REVISION LOG}

\begin{tabular}{||c|c|c|c||}
\hline Document Number & Document Title & Revision Number & Date \\
N/A & Nevada Test Site Radiation Protection Program & 0 & $12 / 12 / 1994$ \\
\hline $\begin{array}{l}\text { Training Required: N/A } \\
\text { Brief Description of Revision: Initial Issue }\end{array}$ \\
\hline
\end{tabular}

\begin{tabular}{||c|c|c|c||}
\hline \hline Document Number & \multicolumn{1}{|c||}{ Document Title } & $\underline{\text { Revision Number }}$ & $\underline{\text { Date }}$ \\
N/A & Nevada Test Site Radiation Protection Program & 1 & $5 / 25 / 1995$ \\
\hline $\begin{array}{l}\text { This document supersedes Nevada Test Site Radiation Protection Program, dated December 12, } 1994 . \\
\text { Brief Description of Revision: A complete revision to reflect the recent changes in mission and } \\
\text { organizational structure at the Nevada Test Site (NTS) and Yucca Mountain Project (YMP). }\end{array}$ \\
\hline
\end{tabular}

\begin{tabular}{|c|c|c|c|}
\hline $\begin{array}{l}\text { Document Number } \\
\text { DOE/NV/11432-203 }\end{array}$ & $\begin{array}{c}\text { Document Title } \\
\text { Nevada Test Site Radiation Protection Program }\end{array}$ & $\begin{array}{c}\text { Revision Number } \\
3 \\
\end{array}$ & $\begin{array}{c}\text { Date } \\
12 / 12 / 1995\end{array}$ \\
\hline $\begin{array}{l}1995 . \\
\text { Brief Description of } F \\
\text { with Title } 10 \text { Code of }\end{array}$ & $\begin{array}{l}\text { on: A complete revision to reflect the recen } \\
\text { ral Regulations (CFR) 835, "Occupational F } \\
\text { tice DOE N 441.1, "Radiological Protection }\end{array}$ & Revicion 1 & irement \\
\hline
\end{tabular}

\begin{tabular}{||c|c|c|c||}
\hline \hline $\begin{array}{c}\text { Document Number } \\
\text { DOE/NV/11432-203 }\end{array}$ & Nevada Test Site Radiation Protection Program & $\underline{\text { Revision Number }}$ & Date \\
\hline $\begin{array}{l}\text { This document supersedes DOE/NV/11432-203, Nevada Test Site Radiation Protection Program, Revision } \\
\text { 3, dated December 12, 1995. } \\
\text { Brief Description of Revision: A complete revision to reflect the recent changes in compliance requirements } \\
\text { with 10 CFR 835. }\end{array}$ \\
\hline
\end{tabular}

\begin{tabular}{||c|c|c|c|}
\hline $\begin{array}{c}\text { Document Number } \\
\text { DOE/NV/11432-203 }\end{array}$ & Nevada Test Site Radiation Protection Program & $\underline{\text { Revision Number }}$ & $\underline{\text { Date }}$ \\
\hline
\end{tabular}

This document supersedes DOE/NV/11432-203, Nevada Test Site Radiation Protection Program, Revision 4, dated May 20, 1999.

Brief Description of Revision: A complete revision to reflect the recent changes in compliance requirements with 10 CFR 835. 


\begin{tabular}{||c|c|c|c||}
\hline \hline Document Number & \multicolumn{1}{|c||}{ Document Title } & $\underline{\text { Revision Number }}$ & $\underline{\text { Date }}$ \\
DOE/NV/25946--144 & Nevada Test Site Radiation Protection Program & 0 & $08 / 09 / 2007$ \\
\hline $\begin{array}{l}\text { This document supersedes DOE/NV/11432-203, Nevada Test Site Radiation Protection Program, Revision } \\
\text { 4-A, dated November 10, 1999. } \\
\text { Brief Description of Revision: A complete revision to reflect the recent changes in Tenant Organization } \\
\text { contractors. Initial issue under National Security Technologies, LLC, contract. }\end{array}$ \\
\hline
\end{tabular}

\begin{tabular}{||c|c|c|c||}
\hline \hline Document Number & \multicolumn{1}{|c||}{ Document Title } & $\underline{\text { Revision Number }}$ & $\underline{\text { Date }}$ \\
DOE/NV/25946--144 & Nevada Test Site Radiation Protection Program & 1 & $06 / 11 / 2008$ \\
\hline $\begin{array}{l}\text { This document supersedes DOE/NV/25946--144, Nevada Test Site Radiation Protection Program, Revision } \\
\text { 0, dated August 9, 2007. } \\
\text { Brief Description of Revision: A complete revision to reflect the June 2007 updated 10 CFR 835 regulations } \\
\text { and include an implementation plan and schedule. }\end{array}$ \\
\hline
\end{tabular}




\section{DISTRIBUTION}

U.S. Department of Energy

National Nuclear Security Administration

Nevada Site Office

Technical Library

P.O. Box 98518, M/S 505

Las Vegas, NV 89193-8518

U.S. Department of Energy

National Nuclear Security Administration

Nevada Site Office

Public Reading Facility

c/o Nuclear Testing Archive

P.O. Box 98521, M/S 400

Las Vegas, NV 89193-8521

U.S. Department of Energy

Office of Scientific and Technical Information

P.O. Box 62

Oak Ridge, TN 37831-0062
$1 \mathrm{CD}$ (uncontrolled)

$1 \mathrm{CD}$ (uncontrolled)

1 electronic copy (uncontrolled)

The organization responsible for establishing additional distributions for this document is the National Security Technologies, LLC, Radiological Control Department.

Distribution information shall be forwarded, in writing, to:

National Security Technologies, LLC

Radiological Control

P.O. Box 677, M/S NTS271

Mercury, NV 89023-0677 
THIS PAGE LEFT INTENTIONALLY BLANK 
NEVADA TEST SITE RADIATION PROTECTION PROGRAM

TENANT ORGANIZATION MANAGEMENT CONCURRENCE

SENIOR SITE EXECUTIVES:
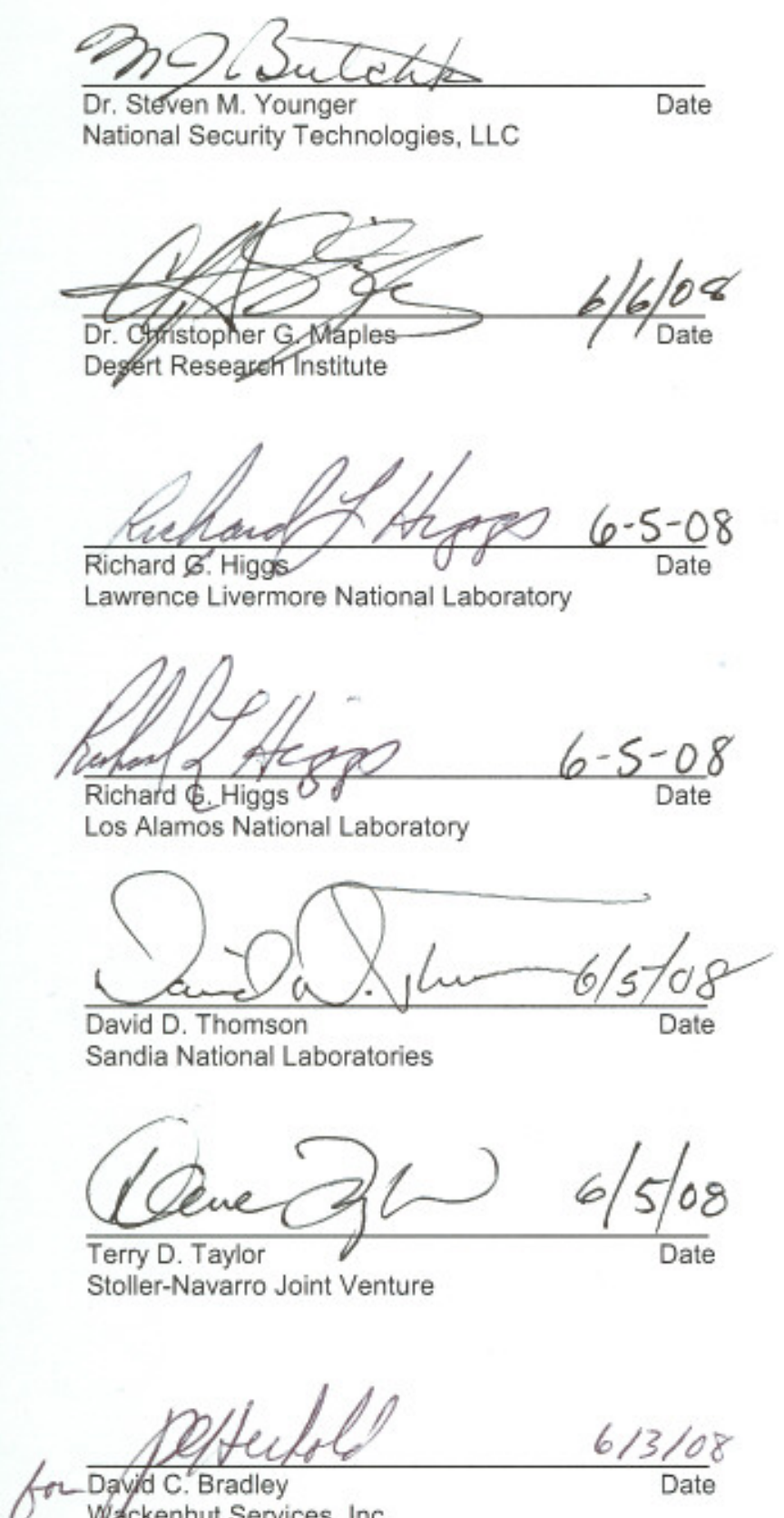

Wafckenhut Services, Inc.
RADIOLOGICAL CONTROL MANAGERS:
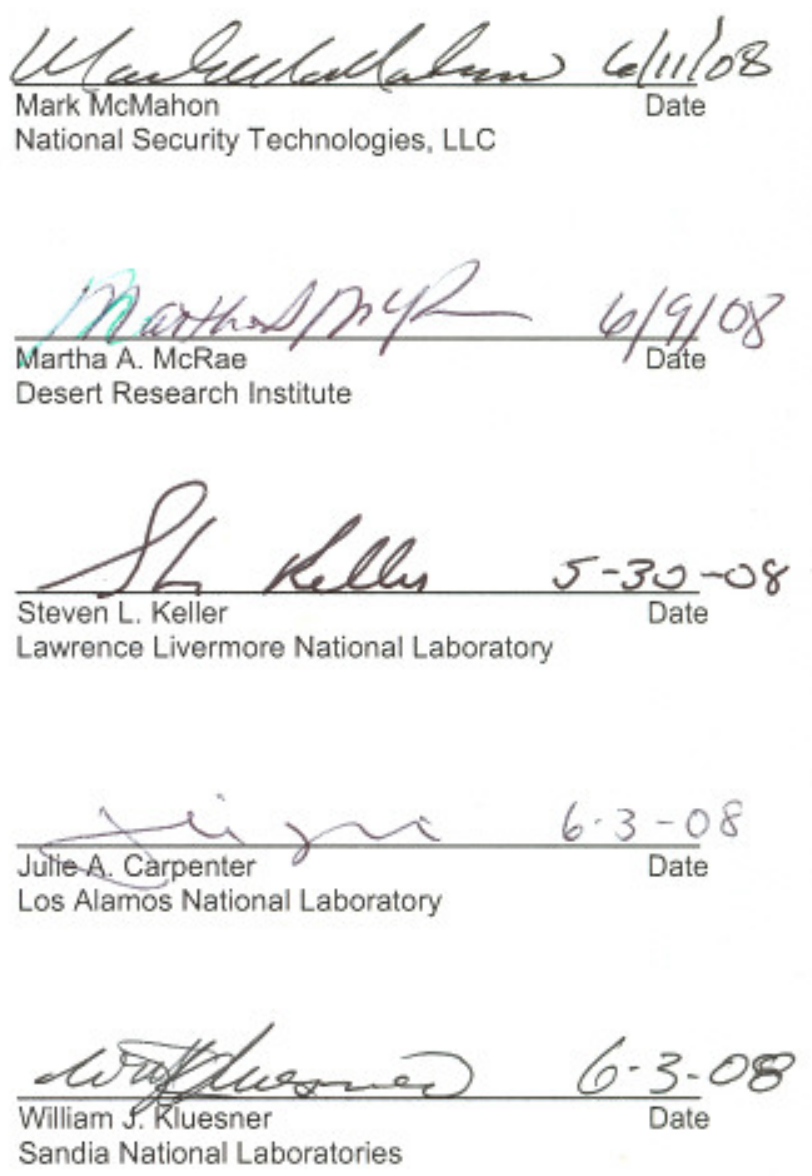

$\frac{\text { AnAl. Ansepratle }}{\text { Harold W. Anagnostopoulps }} \frac{6 / 3 / \%}{\text { Date }}$ Stoller-Navarro Joint Venture

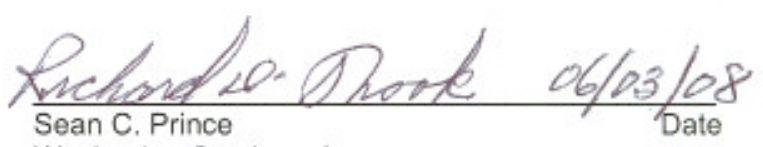
Wackenhut Services, Inc.

vii 
THIS PAGE LEFT INTENTIONALLY BLANK 


\section{TABLE OF CONTENTS}

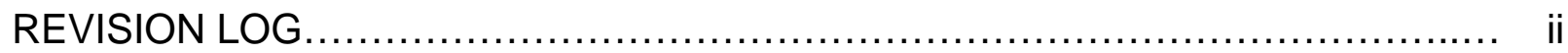

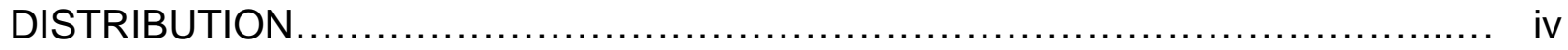

TENANT ORGANIZATION MANAGEMENT CONCURRENCES ..................... vii

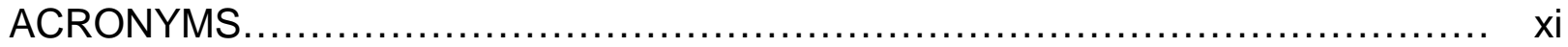

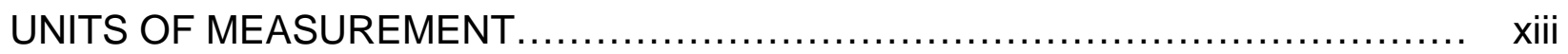

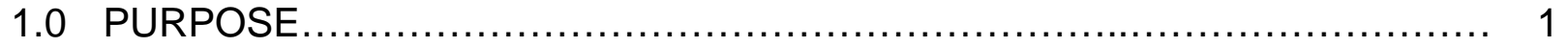

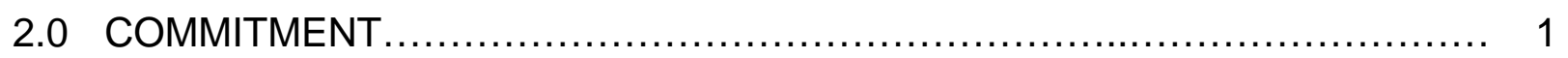

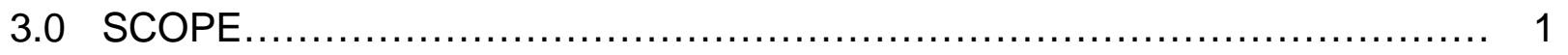

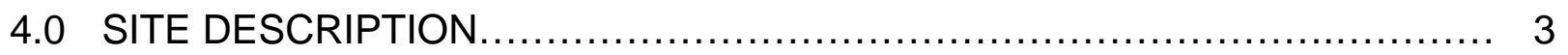

5.0 ORGANIZATIONAL RELATIONSHIPS...................................... 7

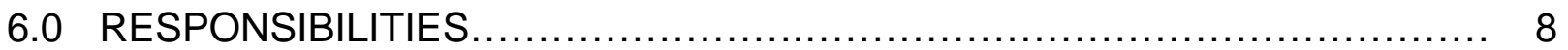

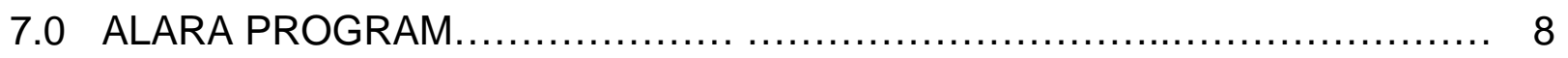

8.0 RADIATION PROTECTION PROGRAM REVISION ........................... 9

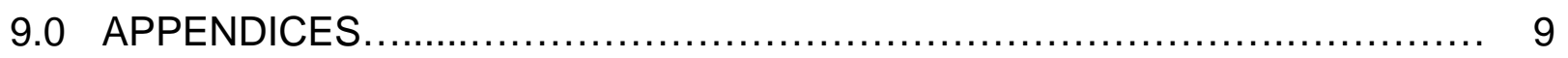

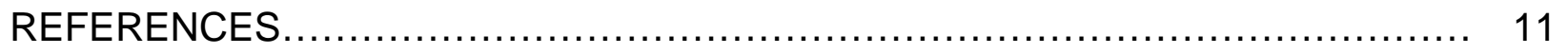

APPENDIX A - NATIONAL SECURITY TECHNOLOGIES, LLC .................. A-1

APPENDIX B - LAWRENCE LIVERMORE NATIONAL LABORATORY .............. B-1

APPENDIX C - LOS ALAMOS NATIONAL LABORATORY ....................... C-1

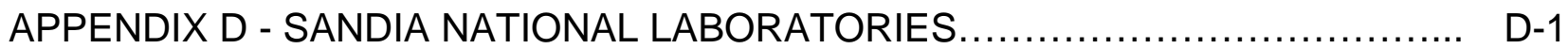

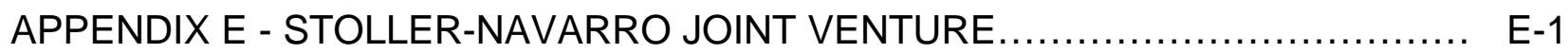

APPENDIX F - DESERT RESEARCH INSTITUTE ........................... F-1

APPENDIX G - WACKENHUT SERVICES, INCORPORATED $\ldots \ldots \ldots \ldots \ldots \ldots \ldots \ldots . . \ldots \ldots \ldots$

APPENDIX H - COMPLIANCE DEMONSTRATION TABLE........................ H-1

\section{LIST OF FIGURES}

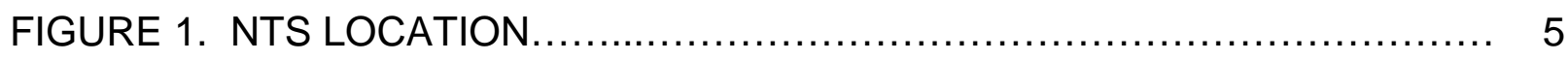

$\begin{aligned} \text { FIGURE 2. } & \text { NTS AREA DESIGNATIONS, PRINCIPAL } \\ & \text { FACILITIES, AND TESTING AREAS ............................... } 6\end{aligned}$ 
THIS PAGE LEFT INTENTIONALLY BLANK 


\section{ACRONYMS}

ALARA as low as reasonably achievable

AMAD Activity Median Aerodynamic Diameter

CBT Computer-Based Training

CED Committed Effective Dose

CEDE Committed Effective Dose Equivalent CFR Code of Federal Regulations $\mathrm{CP}$ .Control Point

CT-ESH Central Training - Environment, Safety, and Health

DAC Derived Air Concentration

DAF Device Assembly Facility

DOE U.S. Department of Energy DOELAP. U.S. Department of Energy Laboratory Accreditation Program DOT U.S. Department of Transportation

DRI Desert Research Institute EH\&S Environmental, Health and Safety ES\&H .Environment, Safety, and Health GERT General Employee Radiological Training HASP Health and Safety Plan ICRP International Commission on Radiological Protection JASPER Joint Actinide Shock Physics Experimental Research JNPO Joint Nevada Program Office LANL Los Alamos National Laboratory LANL/NTS Los Alamos National Laboratory/Nevada Test Site

LINAC Linear Accelerator

LLNL Lawrence Livermore National Laboratory

LLNL-N Lawrence Livermore National Laboratory-Nevada $\mathrm{M} \& \mathrm{O}$ Management and Operating NAC Nevada Administrative Code NNSA U.S. Department of Energy, National Nuclear Security Administration NNSA/NSO National Nuclear Security Administration Nevada Site Office NRC U.S. Nuclear Regulatory Commission 
NSO Nevada Site Office

NSTec National Security Technologies, LLC NTS Nevada Test Site NV Nevada

NV/ERP Nevada Environmental Restoration Program NV/YMP NTS and Yucca Mountain Project

OCRWM . Office of Civilian Radioactive Waste Management

$\mathrm{PC}$ Protective Clothing $\mathrm{RCO}$ Radiological Control Organization

$\mathrm{RCT}$. Radiological Control Technician

$\mathrm{RCM}$ Radiological Control Manual

REOP Real Estate/Operations Permit

RMA Radioactive Material Area

RPP. Radiation Protection Program

RSC. Radiation Safety Committee

RSM Radiation Safety Manual

RSO Radiation Safety Officer

RSPC Radiological Safety Prime Contractor

RW-I Radiological Worker I

RW-II Radiological Worker II RWP Radiological Work Permit SI Systems International

SNJV Stoller-Navarro Joint Venture

SNL

Sandia National Laboratories

SNL-NV Sandia National Laboratories - Nevada SSE Senior Site Executive STC. Special Tritium Compounds SWAC Site-Wide ALARA Committee

TA. Technical Area

TBD. .Technical Basis Document

TED. Total Effective Dose TEDE .Total Effective Dose Equivalent TO Tenant Organization 
UNR University of Nevada, Reno

WSI Wackenhut Services, Incorporated WSI/NV Wackenhut Services, Incorporated/Nevada Operations YMP Yucca Mountain Project

\section{UNITS OF MEASUREMENT}

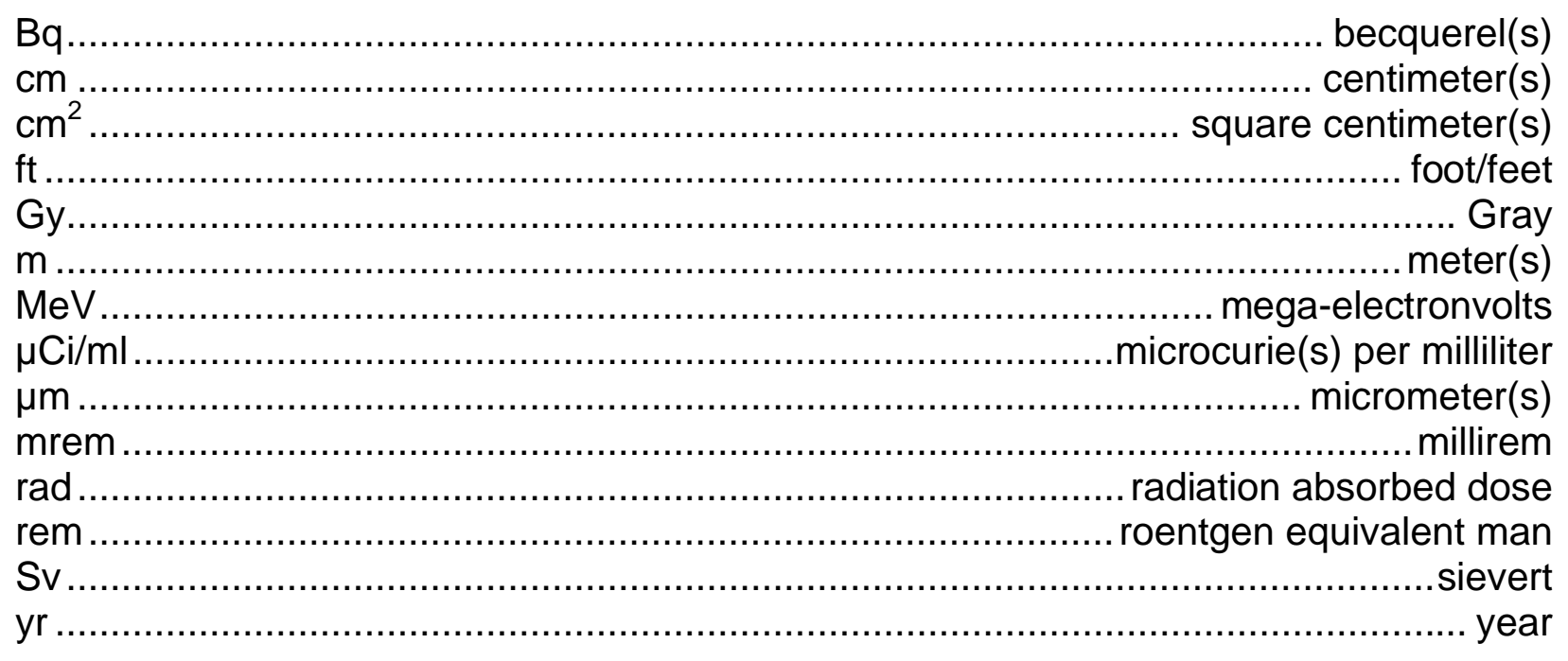


THIS PAGE LEFT INTENTIONALLY BLANK 


\subsection{PURPOSE}

Title 10 Code of Federal Regulations (CFR) Part 835, "Occupational Radiation Protection," establishes radiation protection standards, limits, and program requirements for protecting individuals from ionizing radiation resulting from the conduct of U.S. Department of Energy (DOE) activities. 10 CFR 835.101(a) mandates that DOE activities be conducted in compliance with a documented Radiation Protection Program (RPP) as approved by DOE. This document promulgates the RPP for the Nevada Test Site (NTS), related (on-site or off-site) U.S. Department of Energy, National Nuclear Security Administration Nevada Site Office (NNSA/NSO) operations, and environmental restoration off-site projects.

\subsection{COMMITMENT}

The Tenant Organizations (TOs) participating in this NTS RPP commit to using the current version of the NV/YMP Radiological Control Manual (Bechtel Nevada, 2004 ${ }^{1}$ ) (NV/YMP RCM) as the primary means for ensuring a program of radiological excellence at NNSA/NSO facilities. Company policy statements, safety manuals, and procedures are tied to the NV/YMP RCM as a means to transfer directives to the working level. Only articles of the NV/YMP RCM specific to demonstrating compliance with $10 \mathrm{CFR}$ 835 requirements are cited in Appendix H, "Compliance Demonstration Table," of this document. The NTS RPP establishes the policy by which each participating TO shall ensure that radiation doses to occupational workers are maintained within acceptable limits and as far below these limits as is reasonably achievable. The issuance of this document demonstrates the commitment of the participating NTS TOs to implement the requirements of this rule in the work place and in training programs, incorporating these requirements in appropriate documents and procedures. Each participating TO will conduct internal audits of their RPP in accordance with Appendix 1B of the NV/YMP RCM.

\subsection{SCOPE}

This NTS RPP promulgates the radiation protection standards, limits, and program requirements for occupational exposure to ionizing radiation resulting from NNSA/NSO activities at the NTS and other operational areas as stated in 10 CFR 835.1(a). NNSA/NSO activities (including design, construction, operation, and decommissioning) within the scope of this RPP may result in occupational exposures to radiation or radioactive material. Therefore, a system of control is implemented through specific references to the site-specific NV/YMP RCM. This system of control is intended to ensure that the following criteria are met: (1) occupational exposures are maintained as low as reasonably achievable (ALARA), (2) DOE's limiting values are not exceeded, (3) employees are aware of and are prepared to cope with emergency conditions, and (4) employees are not inadvertently exposed to radiation or radioactive material.

\footnotetext{
${ }^{1}$ Bechtel Nevada was the previous contractor responsible for the publishing of the NV/YMP RCM.
} 
Operational tasks with radiological implications within the scope of this NTS RPP are provided in the appendices of this document and are summarized below:

- Control of residual radioactive contamination including establishment and maintenance of radiologically controlled areas

- Radioactive waste storage, characterization, and disposal

- Environmental remediation operations that include decontamination and decommissioning activities, drilling and developing potentially contaminated wells, and sampling and characterizing radiologically contaminated media

- Dosimeter and instrument calibration

- Well logging

- Radiography

- Training exercises

- Experiments and tests

- Radioactive material receipt and handling

- Operation of radiation-generating devices and accelerators

- Maintenance of emergency response programs (e.g., Consequence Management Response Team/Federal Radiological Monitoring and Assessment Center, Aerial Measurements Services, Nuclear Emergency Support Team, Accident Response Group, and Radiological Assistance Program)

- Special activities supporting DOE worldwide

Tasks outside the scope of this RPP include:

- Radon and radon daughters, unless site selection is made or materials are introduced that enhance the concentration of the precursors of radon

- Exclusions as identified in 10 CFR 835.1

- Activities that are regulated through a license by the Nuclear Regulatory Commission or a State under an Agreement with the Nuclear Regulatory Commission, including activities certified by the Nuclear Regulatory Commission under section 1701 of the Atomic Energy Act (Public Law 585-79)

- Activities conducted under the authority of the Deputy Administrator for Naval Reactors, as described in Public Law 98-525 and 106-65

- Activities conducted under the Nuclear Explosive and Weapons Surety Program relating to the prevention of accidental or unauthorized nuclear detonations

- DOE activities conducted outside the United States on territory under the jurisdiction of a foreign government to the extent governed by occupational 
radiation protection requirements agreed to between the United States and the cognizant government

- Background radiation, radiation doses received as a patient for the purposes of medical diagnosis or therapy, or radiation doses received from voluntary participation as a subject in medical research programs

- Radioactive material on or within material, equipment, and real property that is approved for release when the radiological conditions of the material, equipment, and real property have been documented to comply with the criteria for release set forth in a DOE authorized limit that has been approved by a Secretarial Officer in consultation with the Chief Health, Safety and Security Officer

- Radioactive material transportation not performed by DOE or a DOE contractor.

However, occupational doses received as a result of excluded activities and radioactive material transportation, as listed in paragraph (b) (with the exception of $(b)(5)$ and (b)(6)) of 10 CFR 835.1, shall be considered when determining compliance with the occupational dose limits of 10 CFR 835.202 and 10 CFR 835.207, and with the limits for the embryo/fetus of 10 CFR 835.206.

Occupational doses resulting from authorized emergency exposures and planned special exposures shall not be considered when determining compliance with the dose limits of 10 CFR 835.202 and 10 CFR 835.207

The requirements in subparts $F$ and G of 10 CFR 835 do not apply to radioactive material transportation by DOE or a DOE contractor conducted under the continuous observation and control of an individual who is knowledgeable of and implements required exposure control measures, or in accordance with U.S. Department of Transportation regulations or DOE orders that govern such movements.

Except as provided in 10 CFR 835.101(h), any task outside the scope of this RPP shall not be initiated until an amendment of this RPP is approved by NNSA/NSO.

\subsection{SITE DESCRIPTION}

The NTS and the adjacent Yucca Mountain Project (YMP) are located in Nye County, Nevada. The NTS is located approximately 65 miles northwest of Las Vegas. It is a remote facility that covers approximately 1,375 square miles of land. The dimensions of the NTS vary from 28 to 35 miles in width (eastern to western border) and 40 to 55 miles in length (northern to southern border).

The NTS and YMP (located within and immediately adjacent to the western portion of NTS Area 25) are surrounded to the west, north, and east by additional thousands of acres of land withdrawn from the public domain for use as a protected wildlife range and as a military gunnery range. These public exclusion areas comprise the Nevada Test and Training Range and the Tonopah Test Range. These two areas provide a buffer 
zone between the test areas and public lands administered by the Bureau of Land Management.

The population density within Nye County, Nevada, is only 1.4 persons per square mile. The combination of the Nevada Test and Training Range and the NTS is one of the largest unpopulated land areas in the United States, comprising some 5,470 square miles. The open range surrounding the Nevada Test and Training Range is predominantly used for livestock grazing, mining, and recreation.

The NTS has been the primary location for testing nuclear explosives in the continental United States since 1951. The topographical and geological characteristics of the NTS afford some protection to the inhabitants of the surrounding areas from potential radiation exposure as a result of release of radioactivity or contamination from nuclear testing operations. Historically, testing programs at the NTS have included atmospheric testing in the 1950s and early 1960s; underground testing in drilled, vertical holes and horizontal tunnels; earth-cratering experiments; and nuclear rocket engine testing. Current activities include operating low-level radioactive and mixed waste disposal facilities; assembly and execution of subcritical experiments; confined critical experiments; assembly/disassembly of special experiments; operation of pulsed X-ray machines and neutron generators; accelerator experiments; development, testing, and evaluation of radiation detectors; surface cleanup and site characterization of contaminated land areas; environmental activity by the University of Nevada system; and non-nuclear test operations such as controlled spills of hazardous materials at the Nonproliferation Test and Evaluation Center.

YMP is involved with the characterization and suitability testing of a rolling volcanic ridge named "Yucca Mountain," located near the western boundary of the NTS, as the future repository for high-level radioactive waste generated within the United States. Current activities include test hole drilling and underground mining. The major potential for radiation exposure is from using sealed radioactive sources and possible future handling of radioactive waste. 


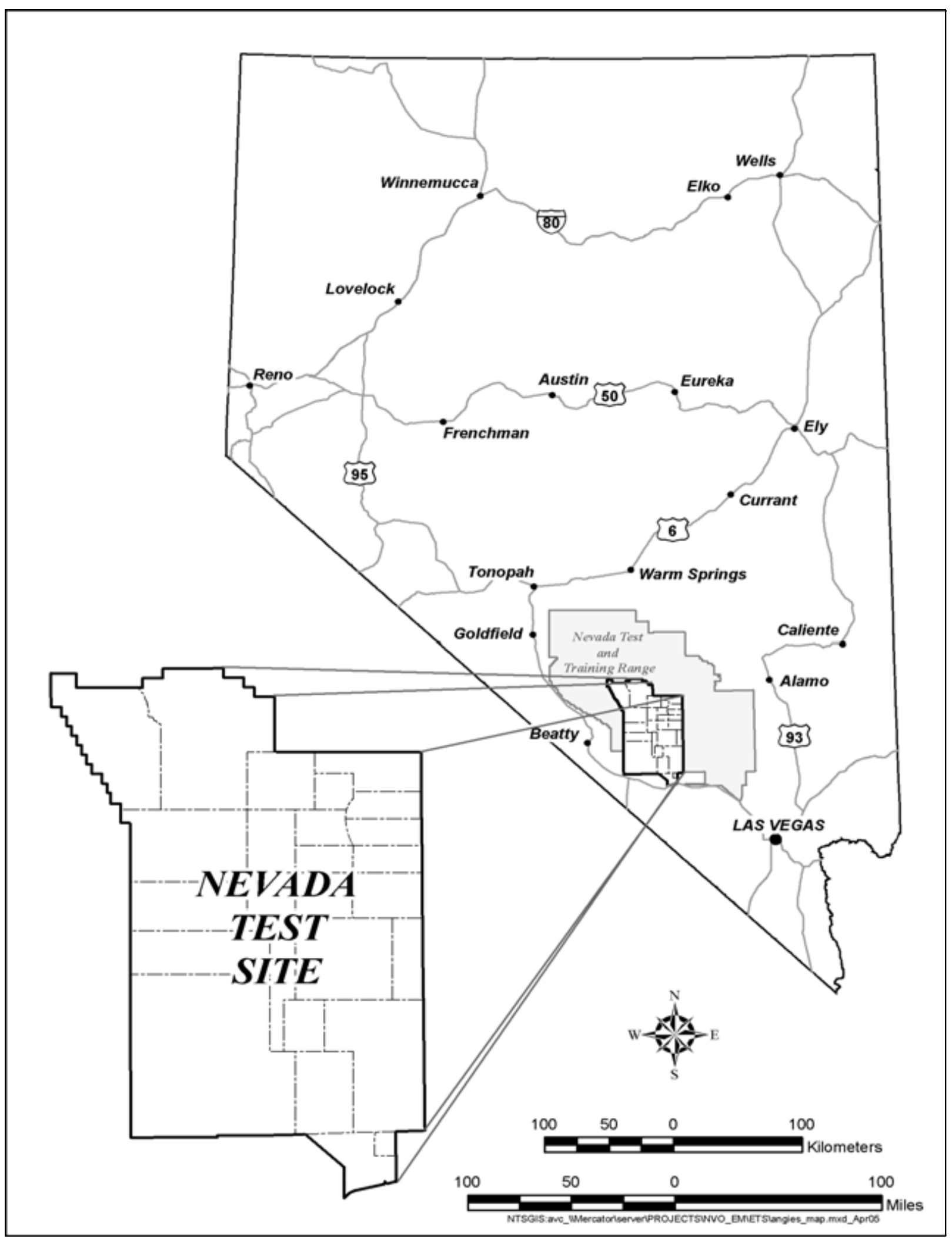

Figure 1. NTS Location 


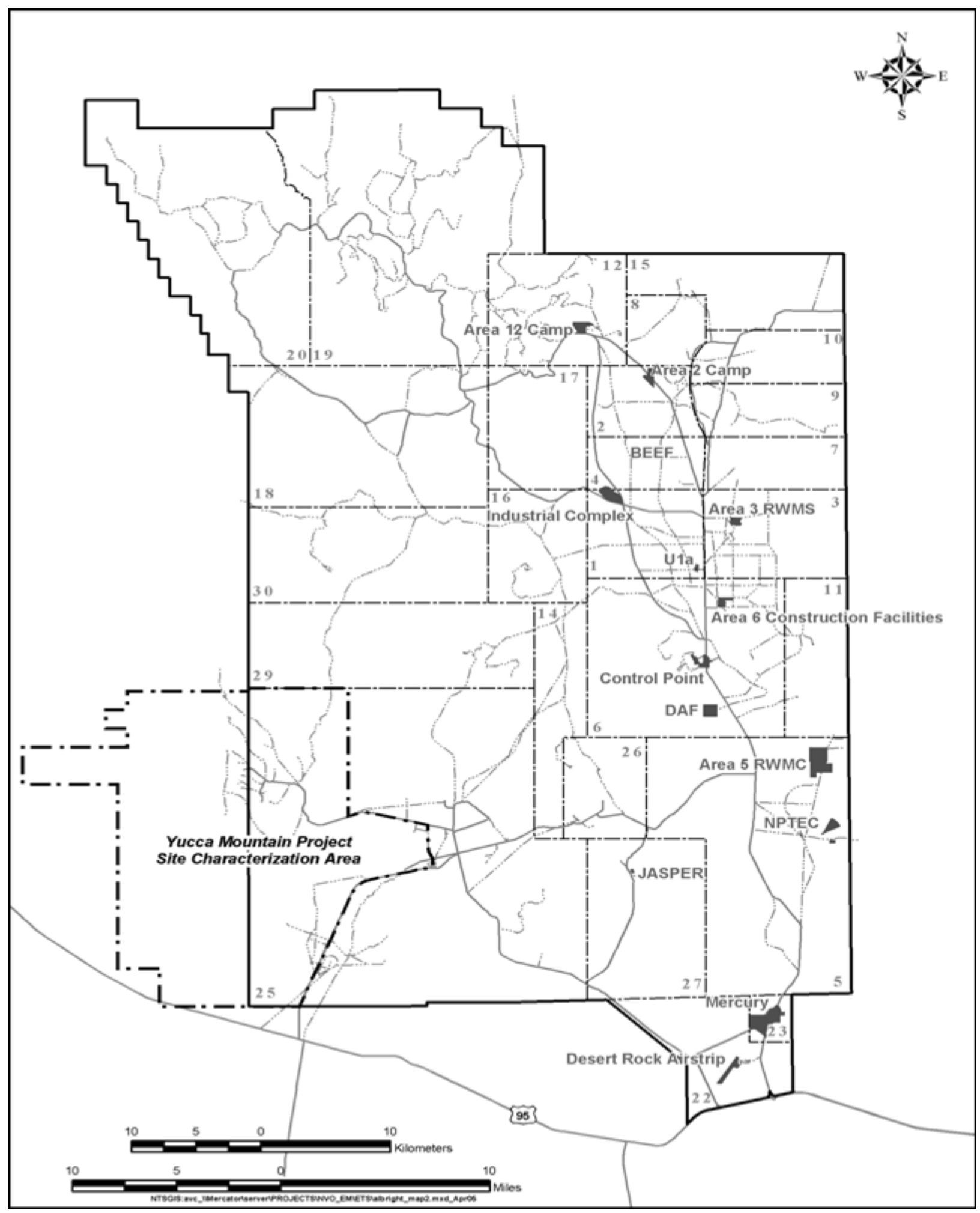

Figure 2. NTS Area Designations, Principal Facilities, and Testing Areas 


\subsection{ORGANIZATIONAL RELATIONSHIPS}

Activities at the NTS are diverse. They involve the application of many different skills and occupational specialties widely dispersed over a large geographical area. Several different organizations frequently perform work either as a closely integrated team or concurrently at any one location. In order to ensure that procedures and policies are uniformly considered and applied by all of the program participants, one organization is assigned radiological safety coordination responsibility by NNSA/NSO.

NTS radiological coordination responsibility for a facility, building, or complex is delegated to the TO by NNSA/NSO through NSO M 421.X-1B, "Nuclear Facility Safety Management" (an activity agreement); NSO M 412.X-1D, "Real Estate/Operations Permit"; and NSO O 412.X3B, "Work Control." Facilities not covered by activity agreements are delegated to the TO by NNSA/NSO through DOE Policy DOE P 450.4B, "Safety Management System Policy" (facility use permit). Radiological responsibility for any test location or other experimental development area is delegated by NNSA/NSO in writing.

National Security Technologies, LLC (NSTec), is presently responsible to NNSA/NSO (through the Management and Operating [M\&O] contract) for the coordination of the radiological safety of NTS operations not specifically transferred to another organization. NSTec is currently serving as the Radiological Safety Prime Contractor (RSPC).

Each NTS TO maintains a Radiological Control Organization (RCO). Each RCO is managed by a designated Radiological Control Manager under the authority of the TO's Senior Site Executive (SSE). Each SSE and Radiological Control Manager has radiological safety coordination responsibility as directed by NNSA/NSO for the scope of work under their control. The Radiological Control Managers meet at least quarterly at the Radiological Control Managers' Council to establish NTS radiological control policy.

The following TOs are participating in this NTS RPP:

- NSTec, the M\&O contractor for the NTS, performs radiological services to NTS contractors and users and operates under Contract No. DE-AC52-06NA25946.

- Lawrence Livermore National Laboratory (LLNL), national laboratory and site user, operates under Contract No. W7045-ENG-48.

- Los Alamos National Laboratory (LANL), national laboratory and site user, operates under Contract No. DE-AC52-06NA25396.

- Sandia National Laboratories (SNL), national laboratory and site user, is operated by Lockheed Martin under Contract No. DE-AC04-94AL85000. 
- Stoller-Navarro Joint Venture (SNJV), the prime contractor for Environmental Support Services at the NTS and other offsite locations for the Environmental Restoration Program, operates under Contract No. DE-AC52-03NA99205.

- Desert Research Institute (DRI), a nonprofit research campus of the Nevada System of Higher Education, operates under Contract No. DE-AC52-06NA26383.

- Wackenhut Services, Incorporated (WSI), the prime security contractor, operates under Contract No. DE-AC52-06NA14390.

\subsection{RESPONSIBILITIES}

The NTS RPP is organized into a format that provides information concerning the responsibilities and interrelationships among each of the participating TOs. Each TO participating in this RPP is responsible for complying with the requirements of $10 \mathrm{CFR}$ 835 as described in the text of this RPP and their respective appendix that specifically addresses the program of that organization. Approval signatures from each participating organization's SSE for their respective appendix constitute concurrence and approval of this entire document.

The general rule of 10 CFR 835.3 states that no person or DOE personnel shall take or cause to be taken any action inconsistent with the requirements of: (1) this part or (2) any program, plan, schedule, or other process established by this part. With respect to a particular DOE activity, contractor management shall be responsible for compliance with the requirements of this RPP. Where there is no contractor for a DOE activity, DOE shall ensure implementation of and compliance with the requirements of this part. However, nothing in this RPP shall be construed as limiting actions that may be necessary to protect health and safety.

\subsection{ALARA PROGRAM}

Elements of a successful ALARA program include management commitment, administrative control levels for control of radiation exposure to workers, ALARA goals/radiological performance goals, ALARA design review where applicable, ALARA job/experiment planning review, and records of these ALARA program elements. The concept of optimizing protection lends itself to a program with formal elements, plans, and measures that, when implemented, serves to reduce radiation exposures as far below regulatory dose limits as is reasonably achievable. The NTS TOs are committed to conducting operations in a manner that protects the safety and health of their employees and the public, minimizes damage or loss to government- and companyowned property, and protects the environment. The TOs are further committed to ensuring that potential safety and health risks, such as exposure to ionizing radiation, are reduced to ALARA.

The NTS Contractors' Site-Wide ALARA Committee provides oversight of ALARA activities at the NTS. It is an independent, multi-organizational group that reviews 
performance and advises NTS contractor organizations on improving progress towards minimizing radiation exposure and radiological releases.

\subsection{RADIATION PROTECTION PROGRAM REVISION}

Since the important aspect of the NTS RPP is to protect the safety and health of its workers and members of the public, proposed changes that decrease the effectiveness of the RPP shall not be implemented without submittal to and approval by NNSA/NSO.

Any changes to either the NTS RPP text or the RSPC's Appendix A could affect the other individual appendices of this document. Consequently, any revisions of the NTS RPP text or Appendix A require approval signatures of the SSEs from all participating TOs.

Changes to the remaining appendices need only be approved by that participating TO's SSE if the changes do not decrease the effectiveness of the RPP. All changes must be submitted to NNSA/NSO for review and may be modified or rejected by NNSA/NSO.

\subsection{APPENDICES}

The following appendices describe each participating TO's RPP. The NTS is implementing the requirements of 10 CFR 835 through specific related requirements in the current NV/YMP RCM, as outlined in Appendix $\mathrm{H}$ of this document.

\section{Appendix Organization}

Appendix A National Security Technologies, LLC

Appendix B Lawrence Livermore National Laboratory

Appendix C Los Alamos National Laboratory

Appendix D Sandia National Laboratories

Appendix E Stoller-Navarro Joint Venture

Appendix F Desert Research Institute

Appendix G Wackenhut Services, Incorporated

Appendix $\mathrm{H} \quad$ All TOs

\section{Senior Site Executive}

Dr. S. M. Younger

R. W. Braddy

R. W. Braddy

D. D. Thomson

T. D. Taylor

Dr. C. G. Maples

D. C. Bradley

All 
THIS PAGE LEFT INTENTIONALLY BLANK 


\section{REFERENCES}

Bechtel Nevada, 2004. NV/YMP Radiological Control Manual, DOE/NV/11718--079. Las Vegas, NV.

International Commission on Radiological Protection, 1990. ICRP Publication 60, "1990 Recommendations of the International Commission on Radiological Protection."

Lawrence Livermore National Laboratory, 2007. Environment, Safety \& Health Manual, Volume 6, Document 62.1, "Nevada Test Site Occupational Radiation Protection." Livermore, CA.

Nevada Administrative Code (NAC) 459, "Hazardous Materials," 2006.

Nevada Site Office Manual NSO M 412.X-1D, "Real Estate/Operations Permit."

Nevada Site Office Manual NSO M 421.X-1B, "Nuclear Facility Safety Management."

Nevada Site Office Order NSO O 412.X3B, "Work Control."

Public Law 585-79, Atomic Energy Act of 1946.

Public Law 98-525, Nuclear Energy Authorization Act of 1985.

Public Law 106-65, National Defense Authorization Act for Fiscal Year 2000.

Sandia National Laboratories, 1991. Environment, Safety, and Health Manual. Livermore, CA.

Title 5 United States Code (USC) 5529, "Privacy Act of 1974."

Title 10 Code of Federal Regulations (CFR) Part 835, "Occupational Radiation Protection," 2007.

Title 49 Code of Federal Regulations (CFR), "Transportation," 2003.

University of Nevada, Reno, 2005. Radiation Safety Manual, Reno, NV.

U.S. Department of Energy Guide DOE G 1324.5B, "Implementation Guide for use with 36 CFR Chapter XII - Subchapter B Records Management," 1996.

U.S. Department of Energy Manual DOE M 231.1-2, "Occurrence Reporting and Processing of Operations Information," 2003.

U.S. Department of Energy Order DOE O 420.1B,"Facility Safety," 2005.

U.S. Department of Energy Policy DOE P 450.4, "Safety Management System Policy," 1996. 
THIS PAGE LEFT INTENTIONALLY BLANK 


\section{APPENDIX A \\ NATIONAL SECURITY TECHNOLOGIES, LLC}

\subsection{PURPOSE}

National Security Technologies, LLC (NSTec), revises this Radiation Protection Program (RPP) as a result of an amendment by the U.S. Department of Energy (DOE) regarding Title 10 Code of Federal Regulations (CFR) Part 835, "Occupational Radiation Protection," requirements. DOE's amendments to 10 CFR 835 update its provisions to account for lessons learned from the initial adoption of these regulations, comments from the Defense Nuclear Facilities Safety Board and members of the public, and new recommendations from the International Commission on Radiological Protection (ICRP).

10 CFR 835 sets forth the nuclear safety requirements that provide radiological protection for DOE workers and members of the public in a controlled area at a DOE facility. DOE proposed 10 CFR 835 on December 9, 1991 (56 FR 64334), and published it as final on December 14, 1993 (58 FR 65458). DOE amended 10 CFR 835 on November 4, 1998 (63 FR 59662), and on November 28, 2006 (71 FR 68727). DOE proposed its latest amendment to 10 CFR 835 on August 10, 2006 (71 FR 45996). The final rule amends 10 CFR 835 dated June 8, 2007.

This document serves as the implementation plan and schedule to achieve compliance to the revisions prescribed by the final rule dated June 8, 2007.

This revised RPP, once approved, will be the governing document for implementation of the revised Rule, which will cause creation, revision, and/or deletion of existing company documents, as required, during the three year implementation process. The end result will be one fully implemented NSTec-wide Occupational Radiation Protection Program on or before July 1, 2010. Until such time that each company document is remedied, NSTec employees will be expected to comply with the current and approved company documents.

\subsection{SCOPE}

The Nevada Test Site (NTS) RPP applies to radiological protection activities conducted by NSTec. NSTec is designated by the U.S. Department of Energy, National Nuclear Security Administration Nevada Site Office (NNSA/NSO) as the NTS Radiological Safety Prime Contractor (RSPC) as well as the Management and Operating (M\&O) Contractor. As the site M\&O contractor, NSTec maintains the day-to-day NTS operations by performing the following services and functions:

- Construction

- Conventional weapons testing

- Development and manufacture of portable radiation detector systems

- Development and research

- Drilling research

- Emergency response training 
- Emergency response assets planning, maintenance, and deployment

- Environmental technologies studies

- Geophysical well logging

- Hazardous chemical spill testing

- Industrial radiography/materials testing

- Logistical support to user organizations

- Maintenance

- Mining research

- Radioactive waste storage, characterization, and disposal

- Seismic engineering research

- Staffs and supports emergency operations

- Testing and evaluation of radiation detectors and radiation detection systems

- Training

- Transportation

- Transuranic waste examination and characterization

As the RSPC, NSTec provides the following radiological support services:

- Calibration and maintenance of radiological instrumentation

- Demarcation of areas

- Dosimetry

- In-vitro bioassay

- Radioactive source and material accountability

- Radiological monitoring

- Radiological technical support

- Radiological work permit processes

NSTec also provides radiological control services for the on-site activities at the Yucca Mountain Repository in support of the U.S. Department of Energy Office of Civilian Radioactive Waste Management (DOE/OCRWM).

\subsection{FACILITY DESCRIPTION}

Radiological activities within the scope of 10 CFR 835 may be conducted in facilities and areas for which NSTec has been delegated safety coordination responsibility by NNSA/NSO and offsite operational areas as directed by NNSA/NSO.

Over the next approximately one year, NSTec will be assuming the maintenance and operations aspects of the facilities listed in Section 2 of Appendices B, C, and D of this RPP. These facilities will continue to be utilized by the laboratories to conduct experiments and other related activities as authorized through Secondary Real Estate/Operations Permits (REOPs). Under this configuration, NSTec will be delegated safety coordination responsibility for general facility activities and these responsibilities will continue to be delegated to the laboratory conducting projects for those portions of the facility and time frames described in the Secondary REOPs. 
NSTec performs radiological operations for NNSA/NSO in the following locations:

- $\quad$ Livermore Operations, Livermore, California

- Los Alamos Operations, Los Alamos, New Mexico

- North Las Vegas, Nevada

- NTS, Mercury, Nevada including contiguous portions of the Nellis Air Force Range Complex and Tonopah Test Range

- $\quad$ Remote Sensing Laboratory-Andrews, Suitland, Maryland

- Remote Sensing Laboratory-Nellis, Las Vegas, Nevada

- Special Technologies Laboratory, Santa Barbara, California

- Other various locations

NSTec also performs radiological operations for DOE/OCRWM at the Yucca Mountain Repository in Nevada.

\subsection{HAZARD IDENTIFICATION}

NSTec, as the prime M\&O contractor, performs, among other activities, construction; drilling; engineering; laboratory analyses; waste storage, characterization, and disposal; transportation; and mining activities. Industrial health and safety hazards are addressed when planning, preparing for, and performing these activities.

NSTec deals with low specific activity radioactive materials that result in low exposures to alpha, beta, gamma, and neutron radiation. Residual contamination to soils from historical testing on the NTS result in a remote potential of internal uptake of radionuclides. Lower activity radioactive sources, in the nanocurie-to-millicurie range, are generally used for instrument operability and calibration checks. These sources result in little potential for personnel radiation exposure.

The potential for higher levels of radiation exposure to personnel exists as a result of using quantities of fissile material that potentially constitute a critical mass, sealed radioactive sources in the millicurie-to-kilocurie range, radiation-generating devices, and experimental equipment. Higher activity sources and radiation-generating devices, including accelerators, are used for industrial radiography, instrumentation calibration and testing, geophysical well logging, and materials and experimental testing.

Employee access to Radiation Areas and High Radiation Areas is governed by physical and/or strict administrative controls. Such measures include use of shielded containers and/or rooms with interlocks, alarms, and other devices to prevent exposure to high levels of radiation. Any source with detectable leakage of radioactive material will be controlled commensurate with the hazard.

\subsection{ALARA COMMITMENT}

NSTec's commitment of continuing improvement is essential to excellence in radiological control and maintaining radiation exposures as low as reasonably achievable (ALARA). Plans and measures for applying ALARA include the incorporation of ALARA processes in work planning, independent review of work plans 
and operations to ensure adequacy of ALARA provisions and performance, and development and tracking of company ALARA goals. NSTec maintains its own ALARA committee and is also a participating member of the NTS Contractors' Site-Wide ALARA Committee. By company procedure, NSTec assigns responsibilities and establishes methods for ensuring that radiation exposure is limited to the lowest level reasonably achievable. This procedure provides for the appointment of an ALARA Committee and describes methods of monitoring, controlling, and documenting radiation exposure to employees and the general public. Radiation exposure of the work force and public is controlled such that radiation exposures are well below regulatory limits, and there is no radiation exposure without commensurate benefits. During routine operations, combinations of administrative control procedures, radiological work permits, design features, engineering controls, and training are used to keep exposure levels ALARA. Each NSTec employee involved in radiological work is expected to demonstrate responsibility and accountability through an informed, disciplined, and cautious attitude toward radiation. This results in excellent performance of the ALARA processes, as evidenced by a program in which radiation exposures are maintained well below regulatory limits, contamination is minimized, and radiological spills or uncontrolled releases are prevented.

\subsection{EXCLUSIONS}

Radioactive materials transported to and from the NTS in support of NSTec operations shall be packaged, surveyed, and shipped in accordance with the U.S. Department of Transportation (DOT) regulations. NSTec will adhere to DOT requirements or the requirements of the NTS Transportation Safety Document (once approved). NSTec will conduct monitoring in accordance with 10 CFR 835.405(b) upon initial receipt of radioactive material shipments from a common carrier at the NTS; however, NSTec will not conduct additional monitoring when a radioactive material shipment occurs between facilities within the boundaries of the NTS. For example, when a radioactive material shipment is received from a common carrier at the NSTec warehouse, the Radiological Control Department is notified and a receipt survey is performed if required by CFR 835.405. If that shipment is then transferred to another NTS location, another receipt survey is not performed, unless some visible damage has occurred to the package in such transfer.

\subsection{IMPLEMENTATION SCHEDULE AND PLAN}

NSTec is not currently in compliance with the following requirements of 10 CFR 835 as revised: 10 CFR 835.1, 10 CFR 835.2, 10 CFR 835.4, 10 CFR 835.101, 202, 203, 205, 206, 401, 402, 405, 502, 602, 606, 702, 1001, 1003, 1202, 1301, Appendix A, Appendix C, Appendix D, and Appendix E. Program modifications will be developed as needed, and the NV/YMP Radiological Control Manual (NV/YMP RCM) (Bechtel Nevada, 2004 ${ }^{1}$ ) and/or NSTec performance documents will be revised and provided to NNSA/NSO to demonstrate compliance with these requirements by July 2010.

${ }^{1}$ Bechtel Nevada was the previous RSPC responsible for the publishing of the NV/YMP RCM. 
During the implementation period established in the updated regulation, NTS will consider the terms defined in the updated regulation to be equivalent as follows:

\begin{tabular}{|l|l|}
\hline \multicolumn{1}{|c|}{ Existing Term } & \multicolumn{1}{c|}{ Equivalent Term } \\
\hline Committed effective dose equivalent & Committed effective dose \\
\hline Committed dose equivalent & Committed equivalent dose \\
\hline $\begin{array}{l}\text { Cumulative total effective dose } \\
\text { equivalent }\end{array}$ & Cumulative total effective dose \\
\hline Dose equivalent & Equivalent dose \\
\hline Effective dose equivalent & Effective dose \\
\hline Quality factor & Radiation weighting factor \\
\hline Weighting factor & Tissue weighting factor \\
\hline Total effective dose equivalent & Total effective dose \\
\hline
\end{tabular}

\begin{tabular}{|l|l|}
\hline \multicolumn{1}{|c|}{$\begin{array}{c}\text { Deleted Terms } \\
\text { (Not defined in ICRP 60 or ICRP 68) }\end{array}$} & \multicolumn{1}{c|}{ Replacement Terms } \\
\hline Deep dose equivalent & Equivalent dose to the whole body \\
\hline Shallow dose equivalent & $\begin{array}{l}\text { Equivalent dose to the skin or to an } \\
\text { extremity }\end{array}$ \\
\hline Lens of the eye dose equivalent & Equivalent dose to the lens of the eye \\
\hline
\end{tabular}

\subsection{SUMMARY}

NSTec will gain full compliance with the amended 10 CFR 835 as demonstrated in Appendices A and H by July 2010. 
THIS PAGE LEFT INTENTIONALLY BLANK 


\section{APPENDIX B LAWRENCE LIVERMORE NATIONAL LABORATORY}

\subsection{SCOPE}

The Nevada Test Site (NTS) Radiation Protection Program (RPP) applies to radiological protection activities conducted by Lawrence Livermore National Laboratory (LLNL) at the NTS.

The Lawrence Livermore National Laboratory-Nevada (LLNL-N) activities within the scope of this NTS RPP are: (1) assembly, disassembly, interim staging, retrofitting, or inspection of nuclear explosive devices, subcritical experiments, components, simulated components, or weapons; (2) 9-mega-electronvolts (MeV) linear accelerator (LINAC), Cobalt-60 or Iridium-192 industrial radiography of nuclear explosive devices, subcritical experiments components, simulated components, or weapons; (3) packaging and handling of radioactive material shipments; (4) operation of radiation-producing machines or use of radioactive sources associated with operational checks of portable radiological instrumentation or with diagnostic or laboratory experiments; (5) use of sealed radioactive sources for the purpose of logging vertical or horizontal holes or use in other field experiments; and (6) gas gun-type experiments (e.g., plutonium and uranium).

LLNL-N does not provide radiological control/support for any LLNL-Yucca Mountain Project (YMP) activities at the NTS. All LLNL-YMP radiological activities are outside the scope of this RPP. LLNL employees assigned to YMP follow the Civilian Radioactive Waste Management System/Management and Operating Contractor/YMP RPP.

Planned special exposures (Title 10 Code of Federal Regulations [CFR] Part 835.204) are beyond the scope of LLNL operations at the NTS. Unless specifically addressed in Appendix H, 10 CFR 835.402, 10 CFR 835.702, 10 CFR 835.703, and 10 CFR 835.1304 requirements are addressed by National Security Technologies, LLC (NSTec), in Appendix A. NSTec provides U.S. Department of Energy (DOE) Laboratory Accreditation Program accredited personnel dosimetry, nuclear accident dosimetry (once developed), radiobioassay, internal dose assessments, recording personnel doses, and calibration of instrumentation in support of LLNL operations at the NTS.

General employee and radiological worker training courses are given to LLNL employees by NSTec or LLNL. NSTec and LLNL have the responsibility for developing the courses in accordance with DOE requirements. LLNL-N maintains the appropriate records in the NTS database.

LLNL and Los Alamos National Laboratory (LANL) are integrated in the Joint Nevada Program Office (JNPO). For the purpose of this RPP, LLNL and LANL are submitting separate columns in the RPP table to ensure that responsibilities of each are clearly described. The RPPs for LLNL and LANL are similar except when the home laboratory's procedures or processes are needed to complete the requirements. 


\subsection{FACILITY DESCRIPTION}

Radiological activities within the scope of 10 CFR 835 may be conducted in the following facilities and areas for which LLNL has been delegated safety coordination responsibility by the U.S. Department of Energy, National Nuclear Security Administration Nevada Site Office (NNSA/NSO) under the requirements of NTS activity agreements:

- Area 6, Building Control Point (CP)-60 is the site of LLNL's high pressure and gas systems test facility. LLNL may have experiments in the future that use radioactive materials in this facility.

- Area 6, Device Assembly Facility (DAF) is a JNPO facility shared by LANL and LLNL. Assembly, disassembly, retrofitting, and inspection of nuclear explosive devices or experiments are conducted by LLNL at DAF. Interim staging of weapons are conducted by LLNL at DAF. Industrial radiography is conducted by the JNPO using the 9-MeV LINAC, a sealed Cobalt-60 or an Iridium-192 radiography source, or other industrial-type radiography unit.

- Area 6, U1a Complex is a LANL underground drift complex connected to the surface by an approximately 1,000 foot shaft/man hoist access at U1a (main access) and U1g (emergency access). LLNL may use this facility to field subcritical experiments using weapon's grade plutonium, associated diagnostics experiments, and radiationgenerating devices to assess the performance of subcritical experiments.

- Area 6 , Wet \& Wild, K Compound is a JNPO facility used for storage of radioactive materials, potential radioactive waste, and potentially internally contaminated equipment.

- Area 4, Big Explosives Experimental Facility is the site of high-explosive experiments. LLNL has occasional experiments that use radioactive materials at this facility.

- Area 12, Core Library houses post-shot core samples collected from previous nuclear tests. This facility is used for storage purposes only and is rarely occupied.

- Area 23, Building 600 houses the LLNL-N organization. This facility is used for office space, staging operations, and radioactive source storage.

- Area 23, Building 128 is the LLNL-N warehousing facility. All radioactive material shipments received from offsite or sent offsite are staged/handled in this facility, excluding radioactive material shipments from a courier/safe secure transport to or from Area 27 or the DAF.

- Area 27, Able Compound is an LLNL facility that contains the Joint Actinide Shock Physics Experimental Research (JASPER) buildings. LLNL conducts gas-gun type experiments conducted for JASPER that use radioactive materials.

- Area 27, Baker Compound is an LLNL high explosive storage and staging facility. Radioactive materials are also stored and handled in this facility. 


\subsection{HAZARD IDENTIFICATION}

Assembly, disassembly, interim staging, retrofitting, and inspection of nuclear explosive devices, subcritical experiments, or other physics experiments involve work in Radiation Areas and potential work in Contamination Areas. The Radiation Areas may include both beta/gamma and neutron radiation fields. Contamination Areas may be the result of handling radioactive materials in the assembly bays.

Industrial radiography involves the generation of a Radiation or High Radiation Area, in the case of the sealed Cobalt-60 source or an Iridium-192 source, and a Very High Radiation Area, in the case of the 9-MeV LINAC. However, the Very High Radiation Areas are personnel exclusion areas, and no personnel access is permitted. Personnel radiation exposure is anticipated to be well below the administrative control level from these activities.

Packaging, handling, and transportation of radioactive material shipments may involve work in a Contamination Area or a Radiation Area with exposure occurring to the hands and the whole body. Radiation Area, Contamination Area, and Radioactive Material Area postings are used as required.

Radiation-producing machines operated for diagnostic experiments and line-of-sight X-ray machines may produce a Radiation Area. However, LLNL does not permit personnel access to these Radiation Areas. Radioactive "check" sources are used to operationally check portable radiological instrumentation. Radioactive Material Area postings are used as required. Personnel radiation exposure for both of these operations is anticipated to be well below the administrative control level from these activities.

Operation of neutron and gamma well logging sources involves work in a Radiation Area with exposure occurring to the hands. Radiation Area postings are required.

Handling of radioactive cores and associated debris involves work in a Radiation Area and potential work in a Contamination Area with exposure occurring to the hands and the whole body. Radiation Area and Contamination Area postings are used as required.

Gas-gun type experiments may involve operations in Contamination Areas and High Contamination Areas with exposure occurring by internal uptakes. Contamination Area or High Contamination Area postings are used as required.

\subsection{ALARA COMMITMENT}

The as low as reasonably achievable (ALARA) policy results from the well-recognized practice in the scientific and radiation protection community of avoiding unnecessary exposure to ionizing radiation. The International Commission on Radiological Protection (ICRP) states that all exposure shall be kept ALARA, taking into account economic and social factors (ICRP 60). The concept of optimizing protection lends itself to a program description with formal elements, plans, and measures that, when implemented, serves 
to reduce radiation exposures as far below regulatory dose limits as is reasonably achievable. LLNL-N conducts research programs that involve radioactive materials and ionizing-radiation-producing devices. The policy is to conduct operations in such a way that radiation exposure to LLNL employees, employees of other organizations, and the public be kept ALARA. The details of the ALARA policy are outlined in LLNL Environment, Safety \& Health Manual, Volume 6, Document 62.1, "Nevada Test Site Occupational Radiation Protection."

Elements of a successful ALARA program include management commitment, ALARA training for employees/workers, administrative control levels for control of radiation exposure to workers, ALARA goals/radiological performance goals, ALARA design review where applicable, ALARA job/experiment planning review, and records of these ALARA program elements.

\subsection{EXCLUSIONS}

Generally, LLNL-N activities or operations within the scope of the exclusions listed in 10 CFR 835.1(b) are not included in this RPP. However, LLNL-N does conduct activities on the NTS pursuant to 10 CFR 835.1(b)(3) and 10 CFR 835.1(b)(4), which requires LLNL-N to use these two exclusions:

- $\quad$ LLNL-N does conduct operations under the purview of the Nuclear Explosive and Weapons Surety Program at the DAF and U1a Complex, which requires the use of exclusion 10 CFR 835.1(b)(3). Requirements established in 10 CFR 835 that, if performed, would violate the requirements of the Nuclear Explosive and Weapons Surety Program shall not be implemented. For example, radiological portable monitoring instrumentation may not be brought into contact with an assembly during some stages of the operation. Alternatively, radioactive contamination surveys of items are conducted prior to starting assembly operations, and swipe surveys are conducted periodically during the assembly.

- $\quad$ LLNL-N does conduct radioactive material transportation operations on the NTS which requires the use of exclusion 10 CFR 835.1(b)(4). Until a radioactive material shipment is released from an LLNL-N facility, the requirements of 10 CFR 835 will be followed. For off-site shipments (leaving the NTS), LLNL-N will adhere to the requirements of the U.S. Department of Transportation (DOT). For on-site shipments (within the boundaries of the NTS), LLNL-N will adhere to DOT requirements or the requirements of the NTS Transportation Safety Document (once approved). Once a radioactive material shipment is received at an LLNL-N facility, LLNL-N will follow the requirements of 10 CFR 835. However, due to the use of this exclusion, LLNL-N will not conduct monitoring in accordance with 10 CFR 835.405(b) when receiving radioactive material shipments between LLNL-N facilities within the boundaries of the NTS. 


\subsection{IMPLEMENTATION SCHEDULE AND PLAN}

10 CFR 835 was recently revised. As a result, LLNL-N is not currently fully in compliance with the following requirements of 10 CFR 835 as revised: 10 CFR 835.1, 10 CFR 835.2, 10 CFR 835.4, 10 CFR 835.101, 202, 203, 205, 206, 401, 402, 405, 502, 602, 606, 702, 1001, 1003, 1202, 1301, Appendix A, Appendix C, Appendix D, and Appendix E. Program modifications will be developed as needed, and the NV/YMP Radiological Control Manual (NV/YMP RCM) (Bechtel Nevada, 2004 ${ }^{1}$ ) and/or LLNL-N documents will be revised and provided to NNSA/NSO to demonstrate compliance with these requirements by July 2010.

During the implementation period established in the updated regulation, NTS will consider the terms defined in the updated regulation to be equivalent as follows:

\begin{tabular}{|l|l|}
\hline \multicolumn{1}{|c|}{ Existing Term } & \multicolumn{1}{c|}{ Equivalent Term } \\
\hline Committed effective dose equivalent & Committed effective dose \\
\hline Committed dose equivalent & Committed equivalent dose \\
\hline $\begin{array}{l}\text { Cumulative total effective dose } \\
\text { equivalent }\end{array}$ & Cumulative total effective dose \\
\hline Dose equivalent & Equivalent dose \\
\hline Effective dose equivalent & Effective dose \\
\hline Quality factor & Radiation weighting factor \\
\hline Weighting factor & Tissue weighting factor \\
\hline Total effective dose equivalent & Total effective dose \\
\hline
\end{tabular}

\begin{tabular}{|l|l|}
\multicolumn{1}{|c|}{ Deleted Terms } & \multicolumn{1}{c|}{ Replacement Terms } \\
\hline Deep dose equivalent & Equivalent dose to the whole body \\
\hline Shallow dose equivalent & $\begin{array}{l}\text { Equivalent dose to the skin or to an } \\
\text { extremity }\end{array}$ \\
\hline Lens of the eye dose equivalent & Equivalent dose to the lens of the eye \\
\hline
\end{tabular}

${ }^{1}$ Bechtel Nevada was the previous primary contractor responsible for the publishing of the NV/YMP RCM. 
THIS PAGE LEFT INTENTIONALLY BLANK

B-6 


\section{APPENDIX C LOS ALAMOS NATIONAL LABORATORY}

\subsection{SCOPE}

Radiological protection activities at the Nevada Test Site (NTS) are performed by Los Alamos National Laboratory (LANL) in accordance with Title 10 Code of Federal Regulations (CFR) Part 835, "Occupational Radiation Protection," as described in this Appendix and in the Appendix $\mathrm{H}$ table for activities performed under a Joint Nevada Program Office (JNPO)-LANL Primary or Secondary Real Estate/Operations Permit (REOP).

The Lawrence Livermore National Laboratory (LLNL) and LANL/NTS radiation protection organizations are united under the JNPO. However, for the purpose of commitment to compliance with 10 CFR 835 through the NTS Radiation Protection Program (RPP) and identification of applicable Home Laboratory programs, LLNL and LANL have developed separate columns in Appendix $\mathrm{H}$ to ensure that the responsibilities of each are clearly described.

As the Radiation Safety Prime Contractor (RSPC) for the NTS, National Security Technologies, LLC (NSTec), is responsible for providing, in compliance with 10 CFR 835, core radiation protection services for the Tenant Organizations (TOs).

The 10 CFR 835 requirements that are implemented by the RSPC on behalf of the NTS TOs are identified in the Appendix $\mathrm{H}$ table and are outside the scope of LANL/NTS work. The 10 CFR 835 requirements that are implemented by the LANL Home Laboratory under the Los Alamos RPP on behalf of LANL/NTS are identified in the Appendix $\mathrm{H}$ table and are outside the scope of LANL/NTS work. The NTS RPP does not cover LANL activities conducted at the Yucca Mountain Project.

The RSPC provides the following radiological support services to the NTS TOs in compliance with 10 CFR 835 as described in Appendix H:

- Qualified radiological control technicians

- Radiological survey and swipe counting

- Personnel decontamination facilities

- Radiological control technician and site-monitoring services

- External and internal dosimetry

- Nuclear Accident Dosimetry (once developed)

- Radiological instruments, maintenance, and calibration

- Radiological safety training

- Accountable sealed radioactive source control program 
The LANL/NTS activities within the scope of this NTS RPP are:

- Nuclear material handling and measurement

- Assembly, disassembly, staging, insertion, and inspection of devices or experiments consisting of or containing depleted thorium, uranium, tritium, natural uranium, enriched uranium, special nuclear materials, and other transuranic nuclides

- Operation of radiation-generating devices and sealed source radiography of device or experiment components and completed assemblies

- Packing, unpacking, on-site transportation, and warehousing/handling of radioactive material shipments

- Instrument calibration and response studies with radioactive sources and radioactive materials

- Screening analysis of operational radiological samples containing alpha, beta, and/or gamma-emitting nuclides, including tritium

- Operation of radiation-generating devices for the purpose of diagnostic experimentation and radiography

- Radiation source handling and storage

- Post-experiment U1a drift complex and experiment area reentry operations

\subsection{FACILITY DESCRIPTION}

LANL is responsible for implementation of 10 CFR 835 requirements in accordance with this RPP for facilities held under a Primary or Secondary REOP per NSO M 412.X-1D, "Real Estate/Operations Permit," as a component of safety coordination responsibility. As examples, LANL performs work under a Primary and/or Secondary REOP at the following facilities:

- $\quad$ Area 6, Buildings Control Point (CP)-95A houses the LANL/NTS radiological control organization. These facilities are used for staging/use of radiological monitoring instrumentation, radioactive source storage/use, and preparation/radiological assessment of samples.

- Area 6, Building CP-100 is the JNPO warehousing facility. Radioactive material shipments are staged at this facility for off-site shipment or delivery to other facilities on the NTS. CP-111 is an unoccupied storage bunker located within the CP-100 fenced compound.

- Area 6, Device Assembly Facility (DAF). Assembly, disassembly, staging, and inspection of devices or experiments are conducted in the DAF under Secondary 
REOPs. This may include work in the Downdraft Table Building. Radiography is conducted with radiation-producing devices and/or sealed sources.

- $\quad$ Area 6, DAF, Technical Area (TA)-18. LANL project operations include nuclear material handling and measurement, radiography with radiation-producing devices, and handling of medical, industrial, and sealed radiation sources under a Secondary REOP.

- Area 6, U1a Complex is an underground drift complex connected to the surface by an approximately 1,000 foot shaft/man hoist access at U1a, U1h, and U1g (emergency access only). The test bed for LANL experiments containing weapon's grade plutonium and other radioactive materials is located in the underground portion of the complex. Diagnostic experiments, including radiation-generating devices, are also fielded in the U1a Complex to assess the performance of the main experiment.

- Area 6, U6c is an example of a test bed for LANL experiments located at a vertical emplacement ground zero complex. Diagnostic experiments will also be fielded at $\mathrm{U} 6 \mathrm{c}$ and similar test beds to assess the performance of the main experiment.

- Area 11, Los Alamos Technical Facility. Radioactive materials and sealed radiation sources are staged and used at this facility.

Additional areas and NTS facilities may be identified for future LANL projects. However, the scope of activities at these areas and facilities would be as described above.

\subsection{HAZARD IDENTIFICATION}

TA-18 nuclear material handling and measurement may involve work in Radiation or High Radiation Areas, and potential work in Contamination or High Contamination Areas. The Radiation and High Radiation Areas may include both beta/gamma and neutron radiation fields.

Assembly, disassembly, staging, and inspection of devices or experiments containing special nuclear material, uranium, tritium, and/or other transuranic nuclides may involve work in Radiation or High Radiation Areas, and potential work in Contamination or High Contamination Areas.

Radiography involves the generation of a High or Very High Radiation Area in the case of both sealed sources and radiation-generating devices. Very High Radiation Areas are personnel exclusion areas, and no personnel access is permitted.

Packing, unpacking, and warehousing/handling involves radioactive material shipments. Radioactive Material and Radiation Areas are posted as required.

Radiological screening analysis of operational samples involves work with radioactive materials and radioactive calibration sources in an area posted as a Radioactive Material Area. 
Radiation-generating devices operated as diagnostic experiments produce Radiation, High Radiation, or Very High Radiation Areas attributable to neutron and/or photon

fields. Very High Radiation Areas are personnel exclusion areas, and personnel access is not permitted.

\subsection{ALARA COMMITMENT}

The as low as reasonably achievable (ALARA) policy results from the well-recognized practice in the scientific and radiation protection community of avoiding unnecessary exposure to ionizing radiation. Exposure shall be kept ALARA, with economic and social factors being taken into account. The concept of optimizing protection lends itself to a description as a program with formal elements, plans, and measures that, when implemented, serves to reduce radiation exposures as far below regulatory dose limits as is reasonably achievable. LANL/NTS conducts research programs that involve radioactive materials and ionizing-radiation-producing devices. The LANL/NTS policy is to review and plan activities to assure that operations are conducted in such a way that radiation exposure to $L A N L$ employees, employees of other organizations, and the public be kept ALARA.

\subsection{EXCLUSIONS}

Exclusion 835.1(b)(3): The requirements of 10 CFR 835 that, if performed, would violate Nuclear Explosive Safety Study requirements or DAF explosive safety procedures shall not be implemented. For example, radiation monitoring instrumentation may not be brought in contact with and must remain at least 1 foot away from an assembly containing nuclear materials and explosives. Alternatively, radioactive contamination surveys of items are conducted prior to their introduction into the explosives assembly area, and swipe surveys are conducted periodically during the assembly.

Exclusion 835.1(b)(5): Background radiation and radiation doses received as a patient for the purposes of medical diagnosis or therapy are excluded from consideration as occupational radiation exposure.

Exclusion 835.1(b)(7): Radioactive material transportation that is not performed by the U.S. Department of Energy (DOE), National Nuclear Security Administration Nevada Site Office, or a DOE contractor is excluded.

\subsection{IMPLEMENTATION SCHEDULE AND PLAN}

LANL/NTS is not currently in compliance with the following requirements of 10 CFR 835 as revised: 10 CFR 835.2, 4, 101, 405, 606, Appendix A, Appendix C, Appendix D, and Appendix E.

Program modifications will be developed as needed, and the NV/YMP Radiological Control Manual (NV/YMP RCM) (Bechtel Nevada, 2004¹) and/or LANL/NTS procedures will be revised and provided to NNSA/NSO to demonstrate compliance with these requirements by July 2010. Procedure updates are required to incorporate 10 CFR 835 
changes in personnel dose nomenclature and derived air concentration values. References and procedures based on the RSPC's Internal and External Dosimetry Technical Basis Documents (TBDs) cannot be updated until the TBDs are updated. LANL/NTS procedures will be updated in accordance with the following:

\section{ACTIVITY}

Incorporate personnel dose nomenclature in procedures.

Incorporate changes to DAC values in procedures.

Incorporate changes to RSPC Internal Dosimetry TBD

work place indicators in procedures.
COMPLETION DATE

July 9,2010

July 9,2010

July 9,2010

During the implementation period established in the updated regulation, NTS will consider the terms defined in the updated regulation to be equivalent as follows:

\begin{tabular}{|l|l|}
\hline \multicolumn{1}{|c|}{ Existing Term } & \multicolumn{1}{c|}{ Equivalent Term } \\
\hline Committed effective dose equivalent & Committed effective dose \\
\hline Committed dose equivalent & Committed equivalent dose \\
\hline $\begin{array}{l}\text { Cumulative total effective dose } \\
\text { equivalent }\end{array}$ & Cumulative total effective dose \\
\hline Dose equivalent & Equivalent dose \\
\hline Effective dose equivalent & Effective dose \\
\hline Quality factor & Radiation weighting factor \\
\hline Weighting factor & Tissue weighting factor \\
\hline Total effective dose equivalent & Total effective dose \\
\hline
\end{tabular}

\begin{tabular}{|l|l|}
\hline \multicolumn{1}{|c|}{$\begin{array}{c}\text { Deleted Terms } \\
\text { (Not defined in ICRP 60 or ICRP 68) }\end{array}$} & \multicolumn{1}{c|}{ Replacement Terms } \\
\hline Deep dose equivalent & Equivalent dose to the whole body \\
\hline Shallow dose equivalent & $\begin{array}{l}\text { Equivalent dose to the skin or to an } \\
\text { extremity }\end{array}$ \\
\hline Lens of the eye dose equivalent & Equivalent dose to the lens of the eye \\
\hline
\end{tabular}

\footnotetext{
${ }^{1}$ Bechtel Nevada was the previous RSPC responsible for the publishing of the NV/YMP RCM.
} 
THIS PAGE LEFT INTENTIONALLY BLANK 


\section{APPENDIX D SANDIA NATIONAL LABORATORIES}

\subsection{SCOPE}

Appendix D of the Nevada Test Site (NTS) Radiation Protection Program (RPP) applies to activities conducted by Sandia National Laboratories (SNL) at the NTS. It includes the associated radiological protection activities conducted by SNL and the radiological control support provided through the NTS Radiological Safety Prime Contractor (RSPC), which is currently National Security Technologies, LLC (NSTec).

The SNL-Nevada (NV) activities within the scope of this NTS RPP are (1) receiving, storage, and inventory of special nuclear material and (2) work with and around radiation-generating devices.

SNL personnel provide oversight of the radiological protection program conducted in support of SNL-NV activities at the NTS with responsibility to review survey and monitoring records to assure that the requirements of Title 10 Code of Federal Regulations (CFR) Part 835, "Occupational Radiation Protection," are being met in SNL's radiation control program. The RSPC provides trained radiological control technicians for all monitoring, surveying, and posting activities required by SNL-NV; provides radioactive source control, inventory, and leak testing services; provides radioanalytical laboratory capability for sample analysis; provides instrument calibration services for all stationary and permanent instrumentation used for SNL-NV support; provides U.S. Department of Energy Laboratory Accreditation Program (DOELAP)accredited external dosimetry for SNL personnel; and performs internal dose assessments for SNL personnel whenever the bioassay sampling has been done at the NTS. Since all radiological support functions are provided through the RSPC, SNL activities at the NTS are conducted utilizing the standard operating procedures of the RSPC, supplemented by the corporate SNL Environment, Safety, and Health (ES\&H) Manual (SNL, 1991) and job-specific standard operating procedures or radiation work permits. All records generated in the performance of these services are maintained and archived by the RSPC.

Since SNL personnel working at the NTS are a mixture of personnel permanently assigned to the NTS and personnel on temporary duty status from the Albuquerque or Livermore facilities, general employee and radiological worker training may be obtained at any of the three locations. Radiological worker training received at the NTS is provided by NSTec training personnel; training received in Albuquerque or Livermore is supplemented by site-specific training provided by the SNL-NV ES\&H staff, either by oral presentation or a pamphlet. Development of the course materials in accordance with U.S. Department of Energy (DOE) requirements is the responsibility of the organization providing the training. The SNL-NV ES\&H staff are responsible for providing the appropriate information to the NSTec Training Department to update the NTS database for SNL-NV personnel.

The RSPC provides DOELAP-accredited external dosimetry services and DOELAPaccredited laboratory analyses of bioassay samples for internal dose assessment. 
SNL-NV ES\&H personnel shall identify the SNL personnel who require these dosimetry services; NSTec Dosimetry shall retain and archive all records generated in performing these dose assessments. Any positive radiation doses received by SNL personnel at the NTS shall be reported to the Sandia Dosimetry Records organization in Albuquerque for inclusion in the individual's occupational dose record. All reporting of dosimetry information to individuals shall remain a responsibility of the Sandia Dosimetry organization in Albuquerque.

\subsection{FACILITY DESCRIPTION}

Radiological activities within the scope of 10 CFR 835 may be conducted in, but are not limited to, the following facilities and areas for which SNL has been delegated safety coordination responsibility by the U.S. Department of Energy, National Nuclear Security Administration Nevada Site Office (NNSA/NSO):

- $\quad$ Area 6, Building Control Point (CP)-1 houses the SNL-NV arming and firing personnel and provides space for equipment maintenance, a vault for storage of classified components, data acquisition and recording facilities, and general office space.

- Area 23, Building 600 provides office space for resident administrative, technical, and support staff for SNL-NV NTS operations.

All radioactive material shipments received from offsite or sent offsite are received or shipped by the RSPC.

\subsection{HAZARD IDENTIFICATION}

SNL personnel are involved with radiation-generating devices while performing experiment and equipment setup and recovery activities. While participating in these operations, personnel are potentially exposed to X-ray, gamma, beta, alpha, or neutron radiation in High and Very High Radiation Areas. Employees are protected from these sources by strict administrative controls and by utilizing shielded installations with interlocks, alarms, and other devices to prevent exposure to high levels of radiation. Radioactive material shipments and work with and storage of radioactive and radioactively contaminated materials may involve work in a Contamination or Radiation Area with exposure to the hands and whole body. Radiation Area, Contamination Area, Airborne Radioactivity Area, and Radioactive Material Area postings are used as required. The potential exists for these activities to result in low-level contamination of personnel or facilities and internal and external radiation exposure. Personnel radiation exposure from these activities is anticipated to be well below the administrative control level.

\subsection{ALARA COMMITMENT}

SNL management at the NTS is fully committed to reducing radiation exposures to SNL personnel and to the general public to the lowest practicable levels. The goal is to provide positive control of radioactive materials and radiation-generating devices so that 
radiation doses to occupational workers and the public are minimized and radioactive materials do not leave authorized work areas. The primary control of radiation exposures remains with the individual and with the individual's supervisor, and radiological safety training is the primary mechanism by which the concept of maintaining personnel radiation dose equivalents as low as reasonably achievable (ALARA) is passed on to the individual.

Since the potential for SNL personnel at the NTS to be exposed to ionizing radiation is extremely low, SNL-NV ES\&H personnel participate in the NTS Contractors' Site-Wide ALARA Committee (SWAC) to effect their NTS ALARA program. Any SNL activity that has the potential to exceed NTS administrative limits shall be reviewed by the NTS Contractors' SWAC before being instituted. Thus, the SNL ALARA program includes management commitment, ALARA training for employees/workers, administrative control levels, and job/experiment planning review. The minutes of the NTS Contractors' SWAC meetings constitute the record of these ALARA program elements.

\subsection{EXCLUSIONS}

Radioactive materials transported to and from the NTS in support of SNL operations shall be packaged and shipped in compliance with U.S. Department of Transportation (DOT) regulations. However, SNL retains the option of requesting a deviation or exemption from DOT regulations for on-site transfer of radioactive materials. This would include, but is not limited to, the lack of receipt surveys of a package at a final SNL/NTS location. For example, when a radioactive material shipment is received from a common carrier at the SNL receiving area, NSTec's Radiological Control Department is notified and a receipt survey is performed. If that shipment is then transferred to another SNL location, another receipt survey is not accomplished unless visible damage has occurred to the package in such transfer. Conversely, because the potential for contamination is vanishingly small, and the hazard to the general population is negligible, some radioactive materials might be transferred onsite and will be packaged and shipped according to the RSPC on- and off-site transportation program for radioactive material. All on-site transfers of radioactive material by SNL are accomplished utilizing RSPC drivers trained according to the requirements of Title 49 CFR, "Transportation."

\subsection{IMPLEMENTATION SCHEDULE AND PLAN}

SNL is in compliance with applicable sections of 10 CFR 835 (dated November 4, 1998). 10 CFR 835 was updated on June 8, 2007. As a result, SNL is not fully in compliance with the following requirements of the updated 10 CFR 835 as applicable to SNL (see Appendix $\mathrm{H}$ for areas of applicability): 10 CFR 835.1, 10 CFR 835.2, 10 CFR 835.4, 10 CFR 835.101, 202, 203, 205, 206, 401, 402, 405, 502, 602, 606, 702, 1001, 1003, 1202, 1301, Appendix A, Appendix C, Appendix D, and Appendix E. Since SNL utilizes the RSPC for radiological services for activities conducted on the NTS, compliance depends on the RSPC schedule for implementation as described in Appendix A of this RPP. Program modifications will be developed as needed, and the 
NV/YMP Radiological Control Manual (NV/YMP RCM) (Bechtel Nevada, 2004 ${ }^{1}$ ) and/or other performance documents will be revised and provided to NNSA/NSO to demonstrate compliance with these requirements by July 2010 .

During the implementation period established in the updated regulation, NTS will consider the terms defined in the updated regulation to be equivalent as follows:

\begin{tabular}{|l|l|}
\hline \multicolumn{1}{|c|}{ Existing Term } & \multicolumn{1}{c|}{ Equivalent Term } \\
\hline Committed effective dose equivalent & Committed effective dose \\
\hline Committed dose equivalent & Committed equivalent dose \\
\hline $\begin{array}{l}\text { Cumulative total effective dose } \\
\text { equivalent }\end{array}$ & Cumulative total effective dose \\
\hline Dose equivalent & Equivalent dose \\
\hline Effective dose equivalent & Effective dose \\
\hline Quality factor & Radiation weighting factor \\
\hline Weighting factor & Tissue weighting factor \\
\hline Total effective dose equivalent & Total effective dose \\
\hline
\end{tabular}

\begin{tabular}{|l|l|}
\hline \multicolumn{1}{|c|}{$\begin{array}{c}\text { Deleted Terms } \\
\text { (Not defined in ICRP 60 or ICRP 68) }\end{array}$} & \multicolumn{1}{c|}{ Replacement Terms } \\
\hline Deep dose equivalent & Equivalent dose to the whole body \\
\hline Shallow dose equivalent & $\begin{array}{l}\text { Equivalent dose to the skin or to an } \\
\text { extremity }\end{array}$ \\
\hline Lens of the eye dose equivalent & Equivalent dose to the lens of the eye \\
\hline
\end{tabular}

${ }^{1}$ Bechtel Nevada was the previous RSPC responsible for the publishing of the NV/YMP RCM. 


\section{APPENDIX E STOLLER-NAVARRO JOINT VENTURE}

\subsection{SCOPE}

Title 10 Code of Federal Regulations (CFR) Part 835, "Occupational Radiation Protection," establishes radiation protection standards, limits, and program requirements to protect individuals from ionizing radiation that results from the conduct of U.S. Department of Energy (DOE) activities. Subsection 835.101(a) mandates that DOE activities be conducted in compliance with a documented Radiation Protection Program (RPP) as approved by DOE. This document promulgates the RPP for radiological activities conducted by Stoller-Navarro Joint Venture (SNJV) at the Nevada Test Site (NTS), related DOE sites, U.S. Department of Energy, National Nuclear Security Administration Nevada Site Office (NNSA/NSO) operations, and DOE environmental restoration projects.

The NTS RPP, which incorporates the SNJV RPP, applies to radiological activities conducted by SNJV at the direction of the DOE Nevada Environmental Restoration Program (NV ERP) at the NTS and other locations. SNJV is committed to using integrated safety management as the best method of conducting business and supports implementation of DOE Policy DOE P 450.4, "Safety Management Systems Policy." Safety, health, and protection of workers and the environment take precedence over expediency.

It is an SNJV policy to conduct radiological operations in a manner that ensures the health and safety of its employees, contractors, and the general public. In achieving this objective, SNJV shall ensure that radiation exposures to its workers and the public and releases of radioactivity to the environment are maintained below regulatory limits and deliberate efforts are taken to further reduce exposures and releases as low as reasonably achievable (ALARA). SNJV is fully committed to implementing a radiological control program of the highest quality to consistently reflect this policy.

The scope of NV ERP activities encompasses all phases of investigation and remediation of inactive radioactive and/or hazardous waste disposal or release sites under NNSA/NSO management. Activities range from site discovery and initial assessment, to site characterization and analysis of remedial action, periodic site monitoring, and regulatory closure. SNJV performs functions that include, but are not limited to, the following:

- $\quad$ Environmental restoration support

- $\quad$ Site assessments and characterizations

- $\quad$ Regulatory support

- $\quad$ Remedial actions

- $\quad$ Establishment and evaluation of corrective action levels for site remediation

- $\quad$ Data acquisition using existing and new technology

- $\quad$ Testing of newly developed technology for site characterization

- $\quad$ Testing new uses for existing technology

- $\quad$ Screening analysis of radiological samples for site characterization activities 
- Operation of radiation detection instrumentation for site characterization activities

- $\quad$ Geophysical well logging

- $\quad$ Operation of radiation-generating devices

- Use and transportation of radioactive material and radioactive sources

- $\quad$ Drilling and environmental technologies studies

- $\quad$ Radioactive waste characterization, storage, and disposal

- $\quad$ Radiological monitoring and worker protection services

- Decontamination and decommissioning

The Radiological Safety Prime Contractor (RSPC) is the organization responsible to NNSA/NSO for the coordination of the radiological safety aspects of NTS operations through the Management and Operating contract. The RSPC is responsible for providing radiological safety services to organizations operating at the NTS that meet requirements including, but not limited to, 10 CFR 835.203, 205, 209, 702, and 801. Dosimetry services are also provided by the RSPC. Training in accordance with the requirements in 10 CFR 835.901 is provided by the RSPC and/or SNJV. SNJV utilizes trained and qualified Radiological Control Technicians (RCTs) to implement radiological controls for work activities conducted in radiological areas. SNJV uses RSPC RCT support to ensure adequate coverage for radiological work conducted on the NTS and for work activities where RSPC personnel are required to work in radiological areas, as necessary. When RSPC radiological control support is utilized, the RSPC provides RCTs, radiological instrumentation, and the supplies necessary to implement radiological controls. Additionally, the RSPC documents the radiological monitoring results. The RCT support between the RSPC and SNJV is coordinated by the organization that is assigned radiological control responsibility for the work activity through the Real Estate/Operations Permit (REOP) process. For work conducted in radiological areas on and off the NTS not requiring RSPC personnel to work in radiological areas (e.g., SNJV and SNJV subcontractors), SNJV utilizes the radiological monitoring services of SNJV, the RSPC, or a qualified provider of radiological services, as necessary.

\subsection{FACILITIES DESCRIPTION}

SNJV is responsible for implementation of 10 CFR 835 requirements in accordance with this RPP for facilities held by SNJV under a Primary or Secondary REOP per NSO M 412.X-1D, "Real Estate/Operations Permit," as a component of safety coordination responsibility. As examples, SNJV performs work under a Primary REOP at the following facilities:

- Area 23, Building 153 is used for staging/use of radiological monitoring instrumentation, radioactive source storage/use, and preparation/assessment of samples.

- Area 6, Building 901 is used as a warehouse primarily for the Underground Test Area project. Generally samples and radioactive materials are not staged/used at this facility. 


\subsection{HAZARD IDENTIFICATION}

A hazard analysis is performed prior to startup of radiological work. The analysis identifies potential hazards that may be encountered during site activities, and the results of the analysis are documented in site-specific health and safety plans used to develop appropriate protective measures.

Radionuclides of concern vary among work sites. Most of the environmental restoration sites on the NTS and Tonopah Test Range are older than 20 years. Radionuclides that may be present include, but are not limited to, aged fission products (cesium-137 and strontium-90), uranium, plutonium, and tritium.

\subsection{ALARA COMMITMENT}

It is the policy of SNJV and subcontractors to conduct research and operations in a manner to protect the health and safety of employees, visitors, and members of the public. SNJV is committed to reduce safety or health risks associated with radioactive materials and ionizing radiation to levels that are ALARA. To accomplish this:

- No activity or operation shall be conducted unless its performance will produce a net positive benefit.

- All radiation exposures shall be kept ALARA considering economic and societal costs.

- No individual shall receive radiation doses in excess of federal or administrative limits.

SNJV maintains its own ALARA Committee and is also a participating member of the NTS Contractors' Site-Wide ALARA Committee. The SNJV ALARA Program is implemented through company procedures that assign responsibilities and establish the methods for integrating ALARA principles into work activities.

\subsection{SUMMARY}

Various work activities are performed by SNJV at the direction of the NV ERP for NNSA/NSO. In its conduct of work, SNJV is committed to using integrated safety management as the best method of conducting business and conducting its radiological operations in a manner that ensures the health and safety of all its employees, contractors, the general public, and the environment. In achieving this objective, SNJV ensures that radiation exposures to its workers and the public and releases of radioactivity to the environment are maintained below regulatory limits, and ensures that every effort is taken to reduce exposures and releases to levels that are ALARA.

SNJV complies with the requirements of 10 CFR 835. SNJV will fully implement the recent revision to 10 CFR 835 by July 2010, as provided in Appendix $\mathrm{H}$ of this document. 


\subsection{IMPLEMENTATION SCHEDULE AND PLAN}

SNJV is committed to completing the necessary changes to its radiological protection program procedures and practices to meet the 10 CFR 835 implementation deadline of July 9, 2010. SNJV management is committed to providing the resources required to revise the NV/YMP Radiological Control Manual (NV/YMP RCM) (Bechtel Nevada, $2004^{1}$ ), Radiological Worker training, and SNJV implementing documentation (including procedures, technical work documents, and forms). SNJV implementing documentation flows down from the NV/YMP RCM and Radiological Worker training and is dependent upon certain services provided by the RSPC. Therefore, the specific changes to SNJV implementing documentation will be scheduled and completed consistent with the changes to these documents. In addition to changes to internal procedures and practices, SNJV will:

- Publish an internal implementation notice to inform SNJV associates of the changes within 10 CFR 835 to explain the impacts to internal documentation and processes and to describe the differences in terminology.

- Continue its contributions in the NV/YMP RCM revision until such time as the revision is approved.

- Update the SNJV Radiological Worker training material.

The changes implemented by SNJV will undergo a validation and verification process before publication and prior to the July 9, 2010, deadline.

During the implementation period established in the updated regulation, NTS will consider the terms defined in the updated regulation to be equivalent as follows:

\begin{tabular}{|l|l|}
\hline \multicolumn{1}{|c|}{ Existing Term } & \multicolumn{1}{c|}{ Equivalent Term } \\
\hline Committed effective dose equivalent & Committed effective dose \\
\hline Committed dose equivalent & Committed equivalent dose \\
\hline $\begin{array}{l}\text { Cumulative total effective dose } \\
\text { equivalent }\end{array}$ & Cumulative total effective dose \\
\hline Dose equivalent & Equivalent dose \\
\hline Effective dose equivalent & Effective dose \\
\hline Quality factor & Radiation weighting factor \\
\hline Weighting factor & Tissue weighting factor \\
\hline Total effective dose equivalent & Total effective dose \\
\hline
\end{tabular}

\begin{tabular}{|l|l|}
\hline \multicolumn{1}{|c|}{$\begin{array}{c}\text { Deleted Terms } \\
\text { (Not defined in ICRP 60 or ICRP 68) }\end{array}$} & \multicolumn{1}{c|}{ Replacement Terms } \\
\hline Deep dose equivalent & Equivalent dose to the whole body \\
\hline Shallow dose equivalent & $\begin{array}{l}\text { Equivalent dose to the skin or to an } \\
\text { extremity }\end{array}$ \\
\hline Lens of the eye dose equivalent & Equivalent dose to the lens of the eye \\
\hline
\end{tabular}

${ }^{1}$ Bechtel Nevada was the previous RSPC responsible for the publishing of the NV/YMP RCM. 


\section{APPENDIX F \\ DESERT RESEARCH INSTITUTE}

\subsection{SCOPE}

This appendix pertains to activities conducted by the Desert Research Institute (DRI), a nonprofit research campus of the Nevada System of Higher Education, and its subcontractors at the Nevada Test Site (NTS), at other locations on behalf of the U.S. Department of Energy National Nuclear Security Administration Nevada Site Office (NNSA/NSO), and at the inactive Nevada Off-site Test Areas for the U.S. Department of Energy (DOE) Office of Legacy Management. It also applies to activities conducted by DRI for the Yucca Mountain Office of Repository Development. The radiological activities conducted by DRI personnel supporting the U.S. Department of Energy, National Nuclear Security Administration (NNSA) and non-NNSA projects at its facilities located in Las Vegas and Reno are not within the scope of this appendix, but are covered under the regulations stated in the Radioactive Material License issued to the University of Nevada, Reno (UNR) by the state of Nevada Radiological Health Section of the Department of Human Resources. In addition, DRI's use of radioactive materials or radioactive sealed sources on DOE sites similarly falls under the provision of the UNR's radioactive material license and their radiation safety program.

The DRI Environmental, Health and Safety (EH\&S) Office and the Office of the Executive Vice President for Research are responsible for the assurance that DRI employees are provided radiological safety training applicable to their job duties and that they participate in the radiological safety program, as required, under the rules and provisions stated in the NV/YMP Radiological Control Manual (NV/YMP RCM) (Bechtel Nevada, 2004 ${ }^{1}$ ) and/or as required under the conditions stated in Radioactive Material License \#16-13-0003-07 issued to UNR.

The definitions used in the NTS Radiation Protection Program (RPP) as defined in Title 10 Code of Federal Regulations (CFR) Part 835.2 and in the NV/YMP $\mathrm{RCM}$ are acceptable to DRI.

\subsection{FACILITY DESCRIPTION}

DRI works closely with the NNSA, other federal agencies, contractors, and National Weapons Laboratories on issues related to past and present testing at the NTS and other former testing locations, at Yucca Mountain, and at other locations on behalf of DOE. In addition, DRI conducts activities on the NTS on behalf of other agencies (e.g., National Science Foundation).

\footnotetext{
${ }^{1}$ Bechtel Nevada was the previous primary contractor responsible for the publishing of the NV/YMP RCM.
} 
Currently, DRI conducts a number of investigative programs compatible with its expertise, and within these programs, there are a number of activities applicable to the scope of this RPP. These programs include:

- Hydrologic Resource Management Program

- Environmental Restoration Project

- Waste Management Program

- Cultural Resources and Historical Preservation

- Containment Evaluation Program

- Test Control Panel and Test Readiness

- Nonproliferation and Emergency Management

- Inactive Off-site Test Areas

- Yucca Mountain

- Community Environmental Monitoring Program and other environmental monitoring off the NTS

- Technology and Energy Development and Testing

\subsection{HAZARD IDENTIFICATION}

On behalf of NNSA, DRI conducts a variety of investigative studies in security and radiological controlled areas at the NTS and the off-site locations. Many of the areas where DRI conducts field studies (including activities such as collecting of water, soil, air particulates, and cultural and historic materials) are areas that potentially have been contaminated with radioactive materials released from prior nuclear testing. Therefore, a potential occupational safety and health risk due to direct or indirect exposure to ionizing radiation exists.

DRI's RPP objectives are to establish and maintain a radiological protection program consistent with the scope of its activities at the NTS and to ensure that any radiological exposure is as low as reasonably achievable (ALARA). DRI is committed to conducting operations in a manner that not only protects the safety and health of our employees, but also minimizes damage or loss to governmentand company-owned property, and protects the environment and the public. The ALARA objectives are met by:

- Working under site-specific health and safety plans (HASPs) that address radiological exposure (as well as other health and safety hazard) controls developed by the lead contractor for a project. 
- Writing and working to site-specific HASPs when DRI is the lead organization on a project.

- Preparing this RPP and accepting relevant sections of the NV/YMP RCM, which provide measures to assess and report exposures, provide training requirements, and provide record-keeping requirements. The NV/YMP RCM also provides DRI employees the assurance that every attempt has been made to define the appropriate approach to avoid a radiation exposure as well as to define the regulatory limitations and requirements to perform their work safely.

- Adopting the radiation safety policies and procedures outlined in UNR's Radiation Safety Manual.

Unless specifically addressed in subsequent sections, many of the radiological protective services required by 10 CFR 835 are provided by the Radiological Safety Prime Contractor (RSPC). It is the responsibility of the DRI EH\&S Director/Radiological Control Manager to ensure that DRI employees comply with the conditions established by the RSPC for these services.

\subsection{ALARA COMMITMENT}

It is DRI's policy to conduct all operations and research in a manner protective of the health and safety of employees, visitors, and members of the public, as well as of property and the environment. As part of that policy, DRI follows sound radiological safety practices to ensure that potential safety and health risks associated with exposure to ionizing radiation are reduced to ALARA.

Elements of DRI's ALARA efforts include:

- $\quad$ The requirement for DRI employees to receive radiation safety training and education commensurate to the work conducted.

- $\quad$ The preparation of written procedures and protocols.

- The review of radiation safety protocols involving the NTS Contractors' SiteWide ALARA Committee (SWAC), the Radiological Control Manager's Council, and/or the UNR Radiation Safety Committee (RSC), as appropriate.

- The maintenance of radiation safety records.

In planning an operation involving the use of radioactive material, the use of radioactive sealed sources, or activities involving the disturbance of radiological contaminated lands and waters, the following ALARA principles are to be addressed: 
- Eliminating, to the extent possible, the necessity of an exposure to radioactive material by the substitution of other technologies or materials

- Use of suitable containment, ventilation, and processing

- Eliminating or reducing the time spent in the vicinity of a radiation source

- Performing work activities in such a manner that the source potential of the radiation field is at maximal distance

- Use of shielding between the worker and the radiation source

DRI is also represented at the NTS Contractors' SWAC, the Radiological Control Manager's Council, and the UNR RSC meetings.

\subsection{EXCLUSIONS}

DRI's activities involving radioactive materials outside of NNSA/NSO projects and DRI's use of radioactive materials including sealed sources on NNSA/NSO projects fall under UNR's radioactive materials license number 16-13-0003-07 issued by the State of Nevada, and are therefore excluded (§835.1(b) (1)).

On occasion, DRI may conduct radioactive material transportation operations on the NTS that require the use of exclusion 10 CFR 835.1(b)(4). For offsite shipments (leaving the NTS) and for on-site transportation (within the boundaries of the NTS), DRI will adhere to U.S. Department of Transportation requirements. Shipping papers for either scenario are prepared for DRI personnel by the UNR Radiation Safety Office.

\subsection{IMPLEMENTATION PLAN AND SCHEDULE}

DRI is in compliance with applicable sections of 10 CFR 835 (dated November 4, 1998) and the UNR Radioactive Materials License. 10 CFR 835 was updated on June 8,2007 . As a result, DRI is not fully in compliance with the following requirements of the updated $10 \mathrm{CFR} 835$ as applicable to DRI (see Appendix $\mathrm{H}$ for areas of applicability): 10 CFR 835.1, 10 CFR 835.2, 10 CFR 835.4, 10 CFR 835.101, 202, 203, 205, 206, 401, 402, 405, 502, 602, 606, 702, 1001, 1003, 1202, 1301, Appendix A, Appendix C, Appendix D, and Appendix E. Since DRI utilizes the RSPC for radiological services for activities conducted on the NTS, compliance depends on the RSPC schedule for implementation as described in Appendix A of this RPP. Program modifications will be developed as needed, and the NV/YMP RCM and/or other performance documents will be revised and provided to NNSA/NSO to demonstrate compliance with these requirements by July 2010. 
During the implementation period established in the updated regulation, NTS will consider the terms defined in the updated regulation to be equivalent as follows:

\begin{tabular}{|l|l|}
\hline \multicolumn{1}{|c|}{ Existing Term } & \multicolumn{1}{c|}{ Equivalent Term } \\
\hline Committed effective dose equivalent & Committed effective dose \\
\hline Committed dose equivalent & Committed equivalent dose \\
\hline $\begin{array}{l}\text { Cumulative total effective dose } \\
\text { equivalent }\end{array}$ & Cumulative total effective dose \\
\hline Dose equivalent & Equivalent dose \\
\hline Effective dose equivalent & Effective dose \\
\hline Quality factor & Radiation weighting factor \\
\hline Weighting factor & Tissue weighting factor \\
\hline Total effective dose equivalent & Total effective dose \\
\hline
\end{tabular}

\begin{tabular}{|l|l|}
\hline \multicolumn{1}{|c|}{$\begin{array}{l}\text { Deleted Terms( } \\
\text { Not defined in ICRP 60 or ICRP 68) }\end{array}$} & \multicolumn{1}{c|}{ Replacement Terms } \\
\hline Deep dose equivalent & Equivalent dose to the whole body \\
\hline Shallow dose equivalent & $\begin{array}{l}\text { Equivalent dose to the skin or to an } \\
\text { extremity }\end{array}$ \\
\hline Lens of the eye dose equivalent & Equivalent dose to the lens of the eye \\
\hline
\end{tabular}

\subsection{SUMMARY}

DRI is in compliance with applicable sections of 10 CFR 835 (dated November 4, 1998) and the UNR Radioactive Materials License. 10 CFR 835 was revised on June 8, 2007. DRI will demonstrate full compliance with the June 2007 update of 10 CFR 835 by July 2010. 
THIS PAGE LEFT INTENTIONALLY BLANK 


\section{APPENDIX G \\ WACKENHUT SERVICES, INCORPORATED}

\subsection{SCOPE}

Wackenhut Services, Incorporated/Nevada Operations (WSI/NV) is a subsidiary of the Wackenhut Corporation, a worldwide security and investigation corporation. WSI/NV provides security services to the U.S. Department of Energy (DOE) at the Nevada Test Site (NTS) and DOE-affiliated operations within Las Vegas, Nevada. WSI/NV provides security support operations through a variety of interagency agreements relative to underground tests, emergencies, and other related functional operations.

It is the policy of WSI/NV to conduct its radiological operations in a manner that ensures the health and safety of all its employees, contractors, and the general public. In achieving this objective, WSI/NV shall ensure that radiation exposures to its workers and the public and releases of radioactivity to the environment are maintained below regulatory limits and deliberate efforts are taken to further reduce exposures and releases as low as reasonably achievable (ALARA). WSI/NV is fully committed to implementing a radiological control program of the highest quality that consistently reflects this policy. Additionally, WSI/NV is committed to using integrated safety management as the best method of conducting business and supports implementation of DOE Policy DOE P 450.4, "Safety Management Systems Policy."

WSI/NV has approved the NV/YMP Radiological Control Manual (NV/YMP RCM) (Bechtel Nevada, 2004 ${ }^{1}$ ) and has implemented the articles that are applicable to WSI/NV operations. When WSI/NV performs work for other contractors, WSI/NV abides by the safety and radiological requirements established and implemented by the other contractor.

\subsection{ACTIVITIES}

WSI/NV conducts the following activities that are not delineated in the NV/YMP RCM.

- Radiological Emergencies

Description: When employed, WSI/NV will provide on-site security support for the Nuclear Emergency Search Team, Accident Response Group, and Federal Radiological Monitoring and Assessment Center.

- Access Control, Device Assembly Facility (DAF)

Description: WSI/NV employees will operate the X-ray system as part of the access control plans for the DAF. The X-ray source is permanently mounted inside of a leadlined cabinet, eliminating the potential for exposure except for when an access panel or door is opened.

${ }^{1}$ Bechtel Nevada was the previous prime contractor responsible for the publishing of the NV/YMP RCM. 
- Portal Monitor Testing, DAF

Description: WSI/NV Protective Force (Radiological Worker I or Radiological Worker II trained) are required to test special nuclear material detectors in the course of their normal duties using sealed radioactive sources.

- DAF Gas Defense System Project

Description: The Technical and Information Services Division, Electronic Systems Technicians (Radiological Worker I trained) are required to perform operational checks, preventive and corrective maintenance, periodic modifications, and system upgrades of the gas defense system. Work will be performed in a Radioactive Material Area, if required.

\subsection{ALARA COMMITMENT}

WSI/NV is fully committed to keeping radiation exposures to WSI personnel ALARA. It is the policy of WSI that employees practice ALARA principles in the conduct of day-today operations and adhere to the provisions of Title 10 Code of Federal Regulations (CFR) Part 835, "Occupational Radiation Protection," as defined by Appendix $\mathrm{H}$ of the NTS Radiation Protection Program. Radiological safety training is the primary mechanism by which the concept of maintaining personnel radiation dose equivalents ALARA is passed on to the individual. WSI/NV Environment, Safety, and Health $(E S \& H)$ personnel monitor measurements of occupational radiation dose to verify and document that doses are being maintained ALARA.

The WSI/NV ALARA program is implemented through company procedure. This procedure assigns responsibilities and establishes the methods for integrating ALARA principles into work activities. The WSI/NV ES\&H personnel review all plans for operations that may require WSI/NV personnel to be exposed to ionizing radiation.

The potential for exposure of WSI/NV personnel to ionizing radiation is extremely low. WSI ES\&H personnel participate in the NTS Contractors' Site-Wide ALARA Committee (SWAC) to affect their NTS ALARA program. Any WSI activity that has the potential to exceed NTS administrative limits shall be reviewed by SWAC before being instituted. The minutes of these meetings constitute the record of the WSI/NV ALARA program elements.

\subsection{IMPLEMENTATION PLAN}

WSI is in compliance with applicable sections of 10 CFR 835 (dated November 4, 1998). 10 CFR 835 was updated on June 8, 2007. As a result, WSI is not fully in compliance with the following requirements of the updated 10 CFR 835 as applicable to WSI (see Appendix $\mathrm{H}$ for areas of applicability): 10 CFR 835.1, 10 CFR 835.2, 10 CFR 835.4, 10 CFR 835.101, 202, 203, 205, 206, 401, 402, 405, 502, 602, 606, 702, 1001, 1003, 1202, 1301, Appendix A, Appendix C, Appendix D, and Appendix E. Since WSI utilizes the Radiation Safety Prime Contractor (RSPC) for radiological services for activities conducted on the NTS, compliance depends on the RSPC schedule for implementation as described in Appendix A of this RPP. Program modifications will be developed as needed, and the NV/YMP RCM and/or other performance documents will 
be revised and provided to the U.S. Department of Energy, National Nuclear Security Administration Nevada Site Office to demonstrate compliance with these requirements by July 2010 .

During the implementation period established in the updated regulation, NTS will consider the terms defined in the updated regulation to be equivalent as follows:

\begin{tabular}{|l|l|}
\hline \multicolumn{1}{|c|}{ Existing Term } & \multicolumn{1}{c|}{ Equivalent Term } \\
\hline Committed effective dose equivalent & Committed effective dose \\
\hline Committed dose equivalent & Committed equivalent dose \\
\hline $\begin{array}{l}\text { Cumulative total effective dose } \\
\text { equivalent }\end{array}$ & Cumulative total effective dose \\
\hline Dose equivalent & Equivalent dose \\
\hline Effective dose equivalent & Effective dose \\
\hline Quality factor & Radiation weighting factor \\
\hline Weighting factor & Tissue weighting factor \\
\hline Total effective dose equivalent & Total effective dose \\
\hline
\end{tabular}

\begin{tabular}{|l|l|}
\hline $\begin{array}{l}\text { Deleted Terms } \\
\text { (Not defined in ICRP } \mathbf{6 0} \text { or ICRP 68) }\end{array}$ & Replacement Terms \\
\hline Deep dose equivalent & Equivalent dose to the whole body \\
\hline Shallow dose equivalent & $\begin{array}{l}\text { Equivalent dose to the skin or to an } \\
\text { extremity }\end{array}$ \\
\hline Lens of the eye dose equivalent & Equivalent dose to the lens of the eye \\
\hline
\end{tabular}


THIS PAGE LEFT INTENTIONALLY BLANK

G-4 


\section{NEVADA TEST SITE RADIATION PROTECTION PROGRAM}

\section{APPENDIX H COMPLIANCE DEMONSTRATION TABLE}

\begin{tabular}{|c|c|c|c|c|c|c|c|c|}
\hline \multirow[t]{2}{*}{$\begin{array}{c}\text { Title } 10 \text { Code } \\
\text { of Federal } \\
\text { Regulations } \\
\text { (CFR) Part } \\
835\end{array}$} & $\begin{array}{c}\text { NV/YMP } \\
\text { Radiological } \\
\text { Control Manual } \\
\text { (NV/YMP RCM), } \\
\text { Revision 5 } \\
\text { and } \\
\text { Nevada Test Site } \\
\text { Radiation } \\
\text { Protection } \\
\text { Program (NTS } \\
\text { RPP), Revision 0 }\end{array}$ & $\begin{array}{c}\text { NATIONAL } \\
\text { SECURITY } \\
\text { TECHNOLOGIES } \\
\text { (NSTec) } \\
\text { Appendix A }\end{array}$ & $\begin{array}{c}\text { LAWRENCE } \\
\text { LIVERMORE } \\
\text { NATIONAL } \\
\text { LABORATORY } \\
\text { (LLNL) } \\
\text { Appendix B }\end{array}$ & $\begin{array}{l}\text { LOS ALAMOS } \\
\text { NATIONAL } \\
\text { LABORATORY } \\
\text { (LANL) } \\
\text { Appendix C }\end{array}$ & $\begin{array}{c}\text { SANDIA } \\
\text { NATIONAL } \\
\text { LABORATORIES } \\
\text { (SNL) } \\
\text { Appendix D }\end{array}$ & $\begin{array}{c}\text { STOLLER- } \\
\text { NAVARRO } \\
\text { JOINT VENTURE } \\
\text { (SNJV) } \\
\text { Appendix E }\end{array}$ & $\begin{array}{c}\text { DESERT } \\
\text { RESEARCH } \\
\text { INSTITUTE } \\
\text { (DRI) } \\
\text { Appendix F }\end{array}$ & $\begin{array}{l}\text { WACKENHUT } \\
\text { SERVICES } \\
\text { (WSI) } \\
\text { Appendix G }\end{array}$ \\
\hline & $\begin{array}{l}\text { Implementation } \\
\text { Reference }\end{array}$ & $\begin{array}{l}\text { Implementation } \\
\text { Reference }\end{array}$ & $\begin{array}{l}\text { Implementation } \\
\text { Reference }\end{array}$ & $\begin{array}{l}\text { Implementation } \\
\text { Reference }\end{array}$ & $\begin{array}{l}\text { Implementation } \\
\text { Reference }\end{array}$ & $\begin{array}{l}\text { Implementation } \\
\text { Reference }\end{array}$ & $\begin{array}{l}\text { Implementation } \\
\text { Reference }\end{array}$ & $\begin{array}{l}\text { Implementation } \\
\text { Reference }\end{array}$ \\
\hline
\end{tabular}

Appendix $\mathrm{H}$ is divided into nine columns containing the following information:

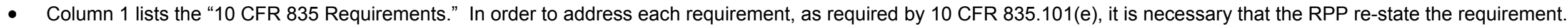

- Column 2 lists the RCM Rev 5 and RPP Rev 0 implementation language.

- $\quad$ Column 3 identifies the articles to be revised in the next RCM revision and lists the NSTec RPP implementation references.

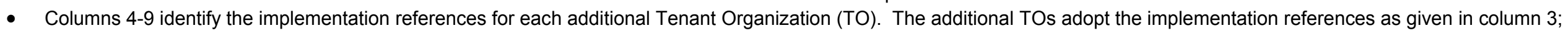
any variances to these implementation references are so noted.

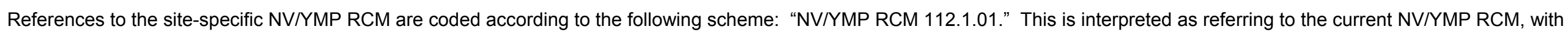
"112" corresponding to the article number, ". 1 " being the appropriate subparagraph, and ".01" pointing to the first sentence within the referenced subparagraph.

\begin{tabular}{|c|c|c|c|c|c|c|c|c|}
\hline $\begin{array}{l}\text { Subpart A-General } \\
\text { Provisions } \\
\text { 835.1 Scope. } \\
835.1(a) \text { General. } \\
\text { The rules in this part } \\
\text { establish radiation } \\
\text { protection standards, } \\
\text { limits, and program } \\
\text { requirements for } \\
\text { protecting individuals } \\
\text { from ionizing radiation } \\
\text { resulting from the } \\
\text { conduct of DOE } \\
\text { activities. }\end{array}$ & $\begin{array}{l}\text { NTS RPP } \\
\text { Narrative } \\
\text { Sections: } \\
\text { 1.0 Purpose, } \\
\text { 2.0 Commitment, } \\
\text { and 3.0 Scope }\end{array}$ & $\begin{array}{l}\text { NTS RPP } \\
\text { Narrative } \\
\text { Sections: } \\
\text { 1.0 Purpose, } \\
\text { 2.0 Commitment, } \\
\text { and 3.0 Scope }\end{array}$ & $\begin{array}{l}\text { Same as Column } \\
3\end{array}$ & $\begin{array}{l}\text { Same as Column } \\
3\end{array}$ & $\begin{array}{l}\text { Same as Column } \\
3\end{array}$ & $\begin{array}{l}\text { Same as Column } \\
3\end{array}$ & $\begin{array}{l}\text { Same as Column } \\
3\end{array}$ & $\begin{array}{l}\text { Same as Column } \\
3\end{array}$ \\
\hline $\begin{array}{l}835.1(b) \text { Exclusion. } \\
\text { Except as provided in }\end{array}$ & $\begin{array}{l}\text { NTS RPP } \\
\text { Narrative }\end{array}$ & $\begin{array}{l}\text { NTS RPP } \\
\text { Narrative }\end{array}$ & $\begin{array}{l}\text { Same as Column } \\
3 \text { and LLNL }\end{array}$ & $\begin{array}{l}\text { Same as Column } \\
3 \text { and LANL }\end{array}$ & $\begin{array}{l}\text { Same as Column } \\
3 \text { and SNL }\end{array}$ & $\begin{array}{l}\text { Same as Column } \\
3\end{array}$ & $\begin{array}{l}\text { Same as Column } \\
3 \text { and DRI }\end{array}$ & $\begin{array}{l}\text { Same as Column } \\
3\end{array}$ \\
\hline
\end{tabular}




\section{NEVADA TEST SITE RADIATION PROTECTION PROGRAM}

\section{APPENDIX H}

COMPLIANCE DEMONSTRATION TABLE

\begin{tabular}{|c|c|c|c|c|c|c|c|c|}
\hline \multirow[t]{2}{*}{10 CFR 835} & $\begin{array}{c}\text { NV/YMP RCM } \\
\text { Rev } 5 \text { and } \\
\text { NTS RPP } \\
\text { Revision } 0\end{array}$ & $\begin{array}{c}\text { NSTec } \\
\text { Appendix A }\end{array}$ & $\begin{array}{c}\text { LLNL } \\
\text { Appendix B }\end{array}$ & $\begin{array}{c}\text { LANL } \\
\text { Appendix C }\end{array}$ & $\begin{array}{c}\text { SNL } \\
\text { Appendix D }\end{array}$ & $\begin{array}{c}\text { SNJV } \\
\text { Appendix E }\end{array}$ & $\begin{array}{c}\text { DRI } \\
\text { Appendix F }\end{array}$ & $\begin{array}{c}\text { WSI } \\
\text { Appendix G }\end{array}$ \\
\hline & $\begin{array}{l}\text { Implementation } \\
\text { Reference }\end{array}$ & $\begin{array}{l}\text { Implementation } \\
\text { Reference }\end{array}$ & $\begin{array}{l}\text { Implementation } \\
\text { Reference }\end{array}$ & $\begin{array}{l}\text { Implementation } \\
\text { Reference }\end{array}$ & $\begin{array}{l}\text { Implementation } \\
\text { Reference }\end{array}$ & $\begin{array}{l}\text { Implementation } \\
\text { Reference }\end{array}$ & $\begin{array}{l}\text { Implementation } \\
\text { Reference }\end{array}$ & $\begin{array}{l}\text { Implementation } \\
\text { Reference }\end{array}$ \\
\hline
\end{tabular}

paragraph (c) of this section, the

requirements in this

part do not apply to:

(1) Activities that are

regulated through a

license by the Nuclear

Regulatory

Commission or a

State under an

Agreement with the

Nuclear Regulatory

Commission,

including activities

certified by the

Nuclear Regulatory

Commission under

section 1701 of the

Atomic Energy Act;

(2) Activities

conducted under the

authority of the

Deputy Administrator

for Naval Reactors, as

described in Pub. L.

98-525 and 106-65;

(3) Activities

conducted under the

Nuclear Explosive and

Weapons Surety

Program relating to

the prevention of

accidental or

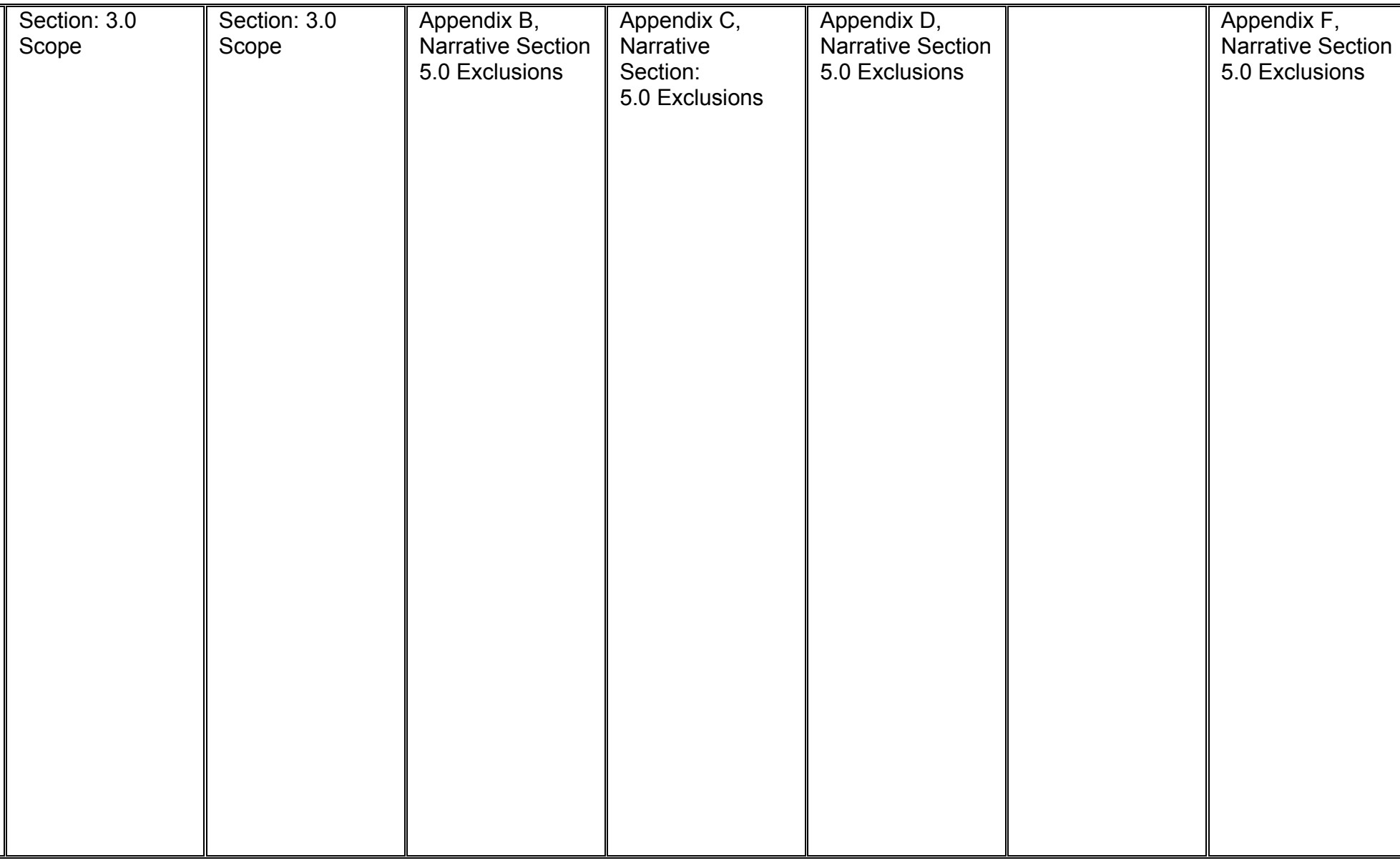




\section{NEVADA TEST SITE RADIATION PROTECTION PROGRAM}

\section{APPENDIX H}

COMPLIANCE DEMONSTRATION TABLE

\begin{tabular}{|c|c|c|c|c|c|c|c|c|}
\hline \multirow[t]{2}{*}{10 CFR 835} & $\begin{array}{l}\text { NV/YMP RCM } \\
\text { Rev } 5 \text { and } \\
\text { NTS RPP } \\
\text { Revision } 0\end{array}$ & $\begin{array}{c}\text { NSTec } \\
\text { Appendix A }\end{array}$ & $\begin{array}{c}\text { LLNL } \\
\text { Appendix B }\end{array}$ & $\begin{array}{c}\text { LANL } \\
\text { Appendix C }\end{array}$ & $\begin{array}{c}\text { SNL } \\
\text { Appendix D }\end{array}$ & $\begin{array}{c}\text { SNJV } \\
\text { Appendix E }\end{array}$ & $\begin{array}{c}\text { DRI } \\
\text { Appendix F }\end{array}$ & $\begin{array}{c}\text { WSI } \\
\text { Appendix G }\end{array}$ \\
\hline & $\begin{array}{l}\text { Implementation } \\
\text { Reference }\end{array}$ & $\begin{array}{l}\text { Implementation } \\
\text { Reference }\end{array}$ & $\begin{array}{l}\text { Implementation } \\
\text { Reference }\end{array}$ & $\begin{array}{l}\text { Implementation } \\
\text { Reference }\end{array}$ & $\begin{array}{l}\text { Implementation } \\
\text { Reference }\end{array}$ & $\begin{array}{l}\text { Implementation } \\
\text { Reference }\end{array}$ & $\begin{array}{l}\text { Implementation } \\
\text { Reference }\end{array}$ & $\begin{array}{l}\text { Implementation } \\
\text { Reference }\end{array}$ \\
\hline
\end{tabular}

unauthorized nuclear

detonations:

(4) DOE activities

conducted outside the

United States on

territory under the

jurisdiction of a

foreign government to

the extent governed

by occupational

radiation protection

requirements agreed

to between the United

States and the

cognizant

government

(5) Background

radiation, radiation

doses received as a

patient for the

purposes of medical

diagnosis or therapy,

or radiation doses

received from

voluntary participation

as a subject in

medical research

programs; or

(6) Radioactive

material on or within

material, equipment,

and real property

which is approved for

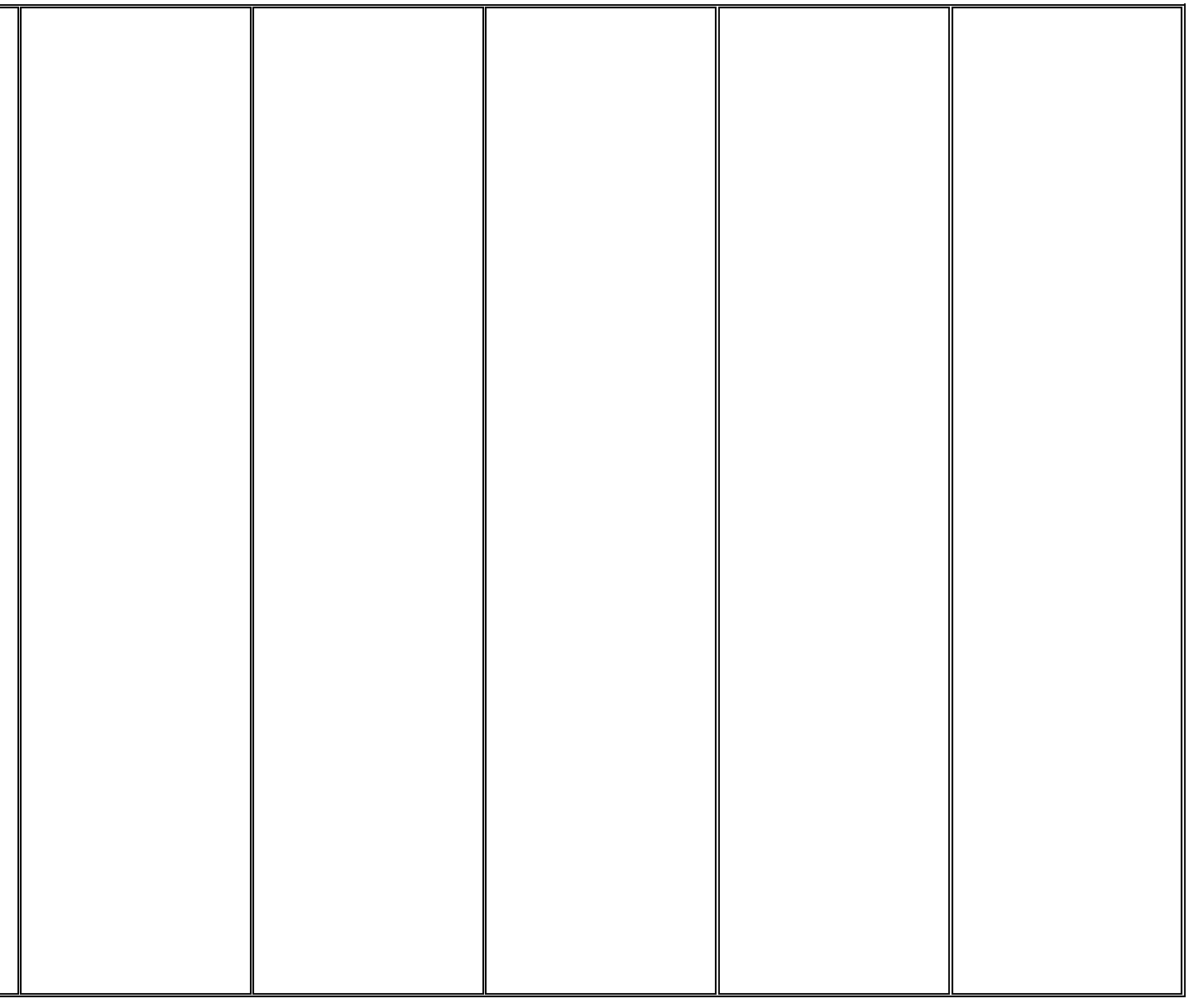




\section{NEVADA TEST SITE RADIATION PROTECTION PROGRAM}

\section{APPENDIX H}

COMPLIANCE DEMONSTRATION TABLE

\begin{tabular}{|c|c|c|c|c|c|c|c|c|}
\hline \multirow[t]{2}{*}{10 CFR 835} & $\begin{array}{l}\text { NV/YMP RCM } \\
\text { Rev } 5 \text { and } \\
\text { NTS RPP } \\
\text { Revision } 0 \\
\end{array}$ & $\begin{array}{c}\text { NSTec } \\
\text { Appendix A }\end{array}$ & $\begin{array}{c}\text { LLNL } \\
\text { Appendix B }\end{array}$ & $\begin{array}{c}\text { LANL } \\
\text { Appendix C }\end{array}$ & $\begin{array}{c}\text { SNL } \\
\text { Appendix D }\end{array}$ & $\begin{array}{c}\text { SNJV } \\
\text { Appendix E }\end{array}$ & $\begin{array}{c}\text { DRI } \\
\text { Appendix F }\end{array}$ & $\begin{array}{c}\text { WSI } \\
\text { Appendix G }\end{array}$ \\
\hline & $\begin{array}{l}\text { Implementation } \\
\text { Reference }\end{array}$ & $\begin{array}{l}\text { Implementation } \\
\text { Reference }\end{array}$ & $\begin{array}{l}\text { Implementation } \\
\text { Reference }\end{array}$ & $\begin{array}{l}\text { Implementation } \\
\text { Reference }\end{array}$ & $\begin{array}{l}\text { Implementation } \\
\text { Reference }\end{array}$ & $\begin{array}{l}\text { Implementation } \\
\text { Reference }\end{array}$ & $\begin{array}{l}\text { Implementation } \\
\text { Reference }\end{array}$ & $\begin{array}{c}\text { Implementation } \\
\text { Reference }\end{array}$ \\
\hline
\end{tabular}

\begin{tabular}{|c|c|c|c|c|c|c|c|c|}
\hline $\begin{array}{l}\text { release when the } \\
\text { radiological conditions } \\
\text { of the material, } \\
\text { equipment, and real } \\
\text { property have been } \\
\text { documented to } \\
\text { comply with the } \\
\text { criteria for release set } \\
\text { forth in a DOE } \\
\text { authorized limit which } \\
\text { has been approved by } \\
\text { a Secretarial Officer in } \\
\text { consultation with the } \\
\text { Chief Health, Safety } \\
\text { and Security Officer. } \\
\text { (7) Radioactive } \\
\text { material transportation } \\
\text { not performed by } \\
\text { DOE or a DOE } \\
\text { contractor. }\end{array}$ & & & & & & & & \\
\hline $\begin{array}{l}835.1(\mathrm{c}) \text { Occupational } \\
\text { doses received as a } \\
\text { result of excluded } \\
\text { activities and } \\
\text { radioactive material } \\
\text { transportation, listed } \\
\text { in paragraphs (b)(1) } \\
\text { through (b)(4) and } \\
\text { (b)(7) of this section, } \\
\text { shall be included to } \\
\text { the extent practicable } \\
\text { when determining } \\
\text { compliance with the }\end{array}$ & $\begin{array}{l}\text { NTS RPP } \\
\text { Narrative } \\
\text { Section: } 3.0 \\
\text { Scope }\end{array}$ & $\begin{array}{l}\text { NTS RPP } \\
\text { Narrative } \\
\text { Section: } 3.0 \\
\text { Scope }\end{array}$ & $\begin{array}{l}\text { Same as Column } \\
3\end{array}$ & $\begin{array}{l}\text { Same as Column } \\
3\end{array}$ & $\begin{array}{l}\text { Same as Column } \\
3\end{array}$ & $\begin{array}{l}\text { Same as Column } \\
3\end{array}$ & $\begin{array}{l}\text { Same as Column } \\
3\end{array}$ & $\begin{array}{l}\text { Same as Column } \\
3\end{array}$ \\
\hline
\end{tabular}




\section{NEVADA TEST SITE RADIATION PROTECTION PROGRAM}

\section{APPENDIX H}

COMPLIANCE DEMONSTRATION TABLE

\begin{tabular}{|c|c|c|c|c|c|c|c|c|}
\hline \multirow[t]{2}{*}{10 CFR 835} & $\begin{array}{l}\text { NV/YMP RCM } \\
\text { Rev } 5 \text { and } \\
\text { NTS RPP } \\
\text { Revision } 0 \\
\end{array}$ & $\begin{array}{c}\text { NSTec } \\
\text { Appendix A }\end{array}$ & $\begin{array}{c}\text { LLNL } \\
\text { Appendix B }\end{array}$ & $\begin{array}{c}\text { LANL } \\
\text { Appendix C }\end{array}$ & $\begin{array}{c}\text { SNL } \\
\text { Appendix D }\end{array}$ & $\begin{array}{c}\text { SNJV } \\
\text { Appendix E }\end{array}$ & $\begin{array}{c}\text { DRI } \\
\text { Appendix F }\end{array}$ & $\begin{array}{c}\text { WSI } \\
\text { Appendix G }\end{array}$ \\
\hline & $\begin{array}{l}\text { Implementation } \\
\text { Reference }\end{array}$ & $\begin{array}{l}\text { Implementation } \\
\text { Reference }\end{array}$ & $\begin{array}{l}\text { Implementation } \\
\text { Reference }\end{array}$ & $\begin{array}{l}\text { Implementation } \\
\text { Reference }\end{array}$ & $\begin{array}{l}\text { Implementation } \\
\text { Reference }\end{array}$ & $\begin{array}{l}\text { Implementation } \\
\text { Reference }\end{array}$ & $\begin{array}{l}\text { Implementation } \\
\text { Reference }\end{array}$ & $\begin{array}{c}\text { Implementation } \\
\text { Reference }\end{array}$ \\
\hline
\end{tabular}

\begin{tabular}{|c|c|c|c|c|c|c|c|c|}
\hline $\begin{array}{l}\text { occupational dose } \\
\text { limits at } \S \S 835.202 \\
\text { and } 835.207, \text { and with } \\
\text { the limits for the } \\
\text { embryo/fetus at } \S \\
835.206 \text {. } \\
\text { Occupational doses } \\
\text { resulting from } \\
\text { authorized emergency } \\
\text { exposures and } \\
\text { planned special } \\
\text { exposures shall not } \\
\text { be considered when } \\
\text { determining } \\
\text { compliance with the } \\
\text { dose limits at } \S \S \\
835.202 \text { and } 835.207 .\end{array}$ & & & & & & & & \\
\hline $\begin{array}{l}835.1(\mathrm{~d}) \text { The } \\
\text { requirements in } \\
\text { subparts } \mathrm{F} \text { and } \mathrm{G} \text { of } \\
\text { this part do not apply } \\
\text { to radioactive material } \\
\text { transportation by DOE } \\
\text { or a DOE contractor } \\
\text { conducted: } \\
\text { (1) Under the } \\
\text { continuous } \\
\text { observation and } \\
\text { control of an individual } \\
\text { who is knowledgeable } \\
\text { of and implements } \\
\text { required exposure } \\
\text { control measures, or }\end{array}$ & $\overline{N N / A}$ & $\begin{array}{l}\text { NTS RPP } \\
\text { Narrative } \\
\text { Section: } 3.0 \\
\text { Scope }\end{array}$ & $\begin{array}{l}\text { Same as Column } \\
3\end{array}$ & $\begin{array}{l}\text { Same as Column } \\
3\end{array}$ & $\begin{array}{l}\text { Same as Column } \\
3\end{array}$ & $\begin{array}{l}\text { Same as Column } \\
3\end{array}$ & $\begin{array}{l}\text { Same as Column } \\
3\end{array}$ & $\begin{array}{l}\text { Same as Column } \\
3\end{array}$ \\
\hline
\end{tabular}




\section{NEVADA TEST SITE RADIATION PROTECTION PROGRAM}

\section{APPENDIX H}

COMPLIANCE DEMONSTRATION TABLE

\begin{tabular}{|c|c|c|c|c|c|c|c|c|}
\hline \multirow[t]{2}{*}{10 CFR 835} & $\begin{array}{c}\text { NV/YMP RCM } \\
\text { Rev } 5 \text { and } \\
\text { NTS RPP } \\
\text { Revision } 0 \\
\end{array}$ & $\begin{array}{c}\text { NSTec } \\
\text { Appendix A }\end{array}$ & $\begin{array}{c}\text { LLNL } \\
\text { Appendix B }\end{array}$ & $\begin{array}{c}\text { LANL } \\
\text { Appendix C }\end{array}$ & $\begin{array}{c}\text { SNL } \\
\text { Appendix D }\end{array}$ & $\begin{array}{c}\text { SNJV } \\
\text { Appendix E }\end{array}$ & $\begin{array}{c}\text { DRI } \\
\text { Appendix F }\end{array}$ & $\begin{array}{c}\text { WSI } \\
\text { Appendix G }\end{array}$ \\
\hline & $\begin{array}{l}\text { Implementation } \\
\text { Reference }\end{array}$ & $\begin{array}{l}\text { Implementation } \\
\text { Reference }\end{array}$ & $\begin{array}{l}\text { Implementation } \\
\text { Reference }\end{array}$ & $\begin{array}{l}\text { Implementation } \\
\text { Reference }\end{array}$ & $\begin{array}{c}\text { Implementation } \\
\text { Reference }\end{array}$ & $\begin{array}{l}\text { Implementation } \\
\text { Reference }\end{array}$ & $\begin{array}{l}\text { Implementation } \\
\text { Reference }\end{array}$ & $\begin{array}{l}\text { Implementation } \\
\text { Reference }\end{array}$ \\
\hline
\end{tabular}

\begin{tabular}{|c|c|c|c|c|c|c|c|c|}
\hline $\begin{array}{l}\text { (2) In accordance with } \\
\text { Department of } \\
\text { Transportation } \\
\text { regulations or DOE } \\
\text { orders that govern } \\
\text { such movements. } \\
\end{array}$ & & & & & & & & \\
\hline 835.2 Definitions. & $\begin{array}{l}\text { NV/YMP RCM, } \\
\text { Glossary }\end{array}$ & $\begin{array}{l}\text { Revise: NV/YMP } \\
\text { RCM, Glossary } \\
\end{array}$ & $\begin{array}{l}\text { Same as Column } \\
3\end{array}$ & $\begin{array}{l}\text { Same as Column } \\
3 \\
\end{array}$ & $\begin{array}{l}\text { Same as Column } \\
3\end{array}$ & $\begin{array}{l}\text { Same as Column } \\
3\end{array}$ & $\begin{array}{l}\text { Same as Column } \\
3\end{array}$ & $\begin{array}{l}\text { Same as Column } \\
3 \\
\end{array}$ \\
\hline $\begin{array}{l}835.3 \text { General rule. } \\
\text { 835.3(a) No person or } \\
\text { DOE personnel shall } \\
\text { take or cause to be } \\
\text { taken any action } \\
\text { inconsistent with the } \\
\text { requirements of: } \\
\text { (1) This part; or } \\
\text { (2) Any program, plan, } \\
\text { schedule, or other } \\
\text { process established by } \\
\text { this part. }\end{array}$ & $\begin{array}{l}\text { NTS RPP } \\
\text { Narrative } \\
\text { Section: } \\
6.0 \\
\text { Responsibilities. }\end{array}$ & $\begin{array}{l}\text { NTS RPP } \\
\text { Narrative } \\
\text { Section: } \\
6.0 \\
\text { Responsibilities. }\end{array}$ & $\begin{array}{l}\text { Same as Column } \\
3\end{array}$ & $\begin{array}{l}\text { Same as Column } \\
3\end{array}$ & $\begin{array}{l}\text { Same as Column } \\
3\end{array}$ & $\begin{array}{l}\text { Same as Column } \\
3\end{array}$ & $\begin{array}{l}\text { Same as Column } \\
3\end{array}$ & $\begin{array}{l}\text { Same as Column } \\
3\end{array}$ \\
\hline $\begin{array}{l}835.3(b) \text { With respect } \\
\text { to a particular DOE } \\
\text { activity, contractor } \\
\text { management shall be } \\
\text { responsible for } \\
\text { compliance with the } \\
\text { requirements of this } \\
\text { part. }\end{array}$ & $\begin{array}{l}\text { NTS RPP } \\
\text { Narrative } \\
\text { Section: } \\
6.0 \\
\text { Responsibilities. }\end{array}$ & $\begin{array}{l}\text { NTS RPP } \\
\text { Narrative } \\
\text { Section: } \\
6.0 \\
\text { Responsibilities. }\end{array}$ & $\begin{array}{l}\text { Same as Column } \\
3\end{array}$ & $\begin{array}{l}\text { Same as Column } \\
3\end{array}$ & $\begin{array}{l}\text { Same as Column } \\
3\end{array}$ & $\begin{array}{l}\text { Same as Column } \\
3\end{array}$ & $\begin{array}{l}\text { Same as Column } \\
3\end{array}$ & $\begin{array}{l}\text { Same as Column } \\
3\end{array}$ \\
\hline $\begin{array}{l}835.3(\mathrm{c}) \text { Where there } \\
\text { is no contractor for a } \\
\text { DOE activity, DOE }\end{array}$ & $\begin{array}{l}\text { NTS RPP } \\
\text { Narrative } \\
\text { Section: }\end{array}$ & $\begin{array}{l}\text { NTS RPP } \\
\text { Narrative } \\
\text { Section: }\end{array}$ & $\begin{array}{l}\text { Same as Column } \\
3\end{array}$ & $\begin{array}{l}\text { Same as Column } \\
3\end{array}$ & $\begin{array}{l}\text { Same as Column } \\
3\end{array}$ & $\begin{array}{l}\text { Same as Column } \\
3\end{array}$ & $\begin{array}{l}\text { Same as Column } \\
3\end{array}$ & $\begin{array}{l}\text { Same as Column } \\
3\end{array}$ \\
\hline
\end{tabular}




\section{NEVADA TEST SITE RADIATION PROTECTION PROGRAM}

\section{APPENDIX H}

COMPLIANCE DEMONSTRATION TABLE

\begin{tabular}{|c|c|c|c|c|c|c|c|c|}
\hline \multirow[t]{2}{*}{10 CFR 835} & $\begin{array}{c}\text { NV/YMP RCM } \\
\text { Rev } 5 \text { and } \\
\text { NTS RPP } \\
\text { Revision } 0 \\
\end{array}$ & $\begin{array}{c}\text { NSTec } \\
\text { Appendix A }\end{array}$ & $\begin{array}{c}\text { LLNL } \\
\text { Appendix B }\end{array}$ & $\begin{array}{c}\text { LANL } \\
\text { Appendix C }\end{array}$ & $\begin{array}{c}\text { SNL } \\
\text { Appendix D }\end{array}$ & $\begin{array}{c}\text { SNJV } \\
\text { Appendix E }\end{array}$ & $\begin{array}{c}\text { DRI } \\
\text { Appendix F }\end{array}$ & $\begin{array}{c}\text { WSI } \\
\text { Appendix G }\end{array}$ \\
\hline & $\begin{array}{l}\text { Implementation } \\
\text { Reference }\end{array}$ & $\begin{array}{l}\text { Implementation } \\
\text { Reference }\end{array}$ & $\begin{array}{l}\text { Implementation } \\
\text { Reference }\end{array}$ & $\begin{array}{l}\text { Implementation } \\
\text { Reference }\end{array}$ & $\begin{array}{l}\text { Implementation } \\
\text { Reference }\end{array}$ & $\begin{array}{l}\text { Implementation } \\
\text { Reference }\end{array}$ & $\begin{array}{l}\text { Implementation } \\
\text { Reference }\end{array}$ & $\begin{array}{l}\text { Implementation } \\
\text { Reference }\end{array}$ \\
\hline
\end{tabular}

\begin{tabular}{|c|c|c|c|c|c|c|c|c|}
\hline $\begin{array}{l}\text { shall ensure } \\
\text { implementation of and } \\
\text { compliance with the } \\
\text { requirements of this } \\
\text { part. }\end{array}$ & $\begin{array}{l}6.0 \\
\text { Responsibilities. }\end{array}$ & $\begin{array}{l}6.0 \\
\text { Responsibilities. }\end{array}$ & & & & & & \\
\hline $\begin{array}{l}835.3(d) \text { Nothing in } \\
\text { this part shall be } \\
\text { construed as limiting } \\
\text { actions that may be } \\
\text { necessary to protect } \\
\text { health and safety. }\end{array}$ & $\begin{array}{l}\text { NTS RPP } \\
\text { Narrative } \\
\text { Section: } \\
6.0 \\
\text { Responsibilities. }\end{array}$ & $\begin{array}{l}\text { NTS RPP } \\
\text { Narrative } \\
\text { Section: } \\
6.0 \\
\text { Responsibilities. }\end{array}$ & $\begin{array}{l}\text { Same as Column } \\
3\end{array}$ & $\begin{array}{l}\text { Same as Column } \\
3\end{array}$ & $\begin{array}{l}\text { Same as Column } \\
3\end{array}$ & $\begin{array}{l}\text { Same as Column } \\
3\end{array}$ & $\begin{array}{l}\text { Same as Column } \\
3\end{array}$ & $\begin{array}{l}\text { Same as Column } \\
3\end{array}$ \\
\hline $\begin{array}{l}835.3(\mathrm{e}) \text { For those } \\
\text { activities that are } \\
\text { required by } \\
\S \S 835.102, \\
835.901(\mathrm{e}), \\
835.1202(\mathrm{a}), \text { and } \\
835.1202(\mathrm{~b}), \text { the time } \\
\text { interval to conduct } \\
\text { these activities may be } \\
\text { extended by a period } \\
\text { not to exceed } 30 \text { days } \\
\text { to accommodate } \\
\text { scheduling needs. }\end{array}$ & $\begin{array}{l}\text { NV/YMP RCM } \\
\text { 134.02. The TO } \\
\text { RadCon } \\
\text { Manager may } \\
\text { extend the time } \\
\text { interval by a } \\
\text { period not to } \\
\text { exceed } \\
30 \text { days. } \\
\text { NV/YMP RCM } \\
613.3 . b \text {. The } \\
24-\text { month period } \\
\text { may be extended } \\
\text { by the TO } \\
\text { RadCon } \\
\text { Manager, not to } \\
\text { exceed } 30 \text { days, } \\
\text { to meet } \\
\text { scheduling } \\
\text { needs. }\end{array}$ & $\begin{array}{l}\text { NV/YMP RCM } \\
\text { 134.02. The TO } \\
\text { RadCon } \\
\text { Manager may } \\
\text { extend the time } \\
\text { interval by a } \\
\text { period not to } \\
\text { exceed } \\
30 \text { days. } \\
\text { NV/YMP RCM } \\
613.3 . b . \text { The } \\
24-m o n t h \text { period } \\
\text { may be extended } \\
\text { by the TO } \\
\text { RadCon } \\
\text { Manager, not to } \\
\text { exceed } 30 \text { days, } \\
\text { to meet } \\
\text { scheduling } \\
\text { needs. }\end{array}$ & $\begin{array}{l}\text { Same as Column } \\
3\end{array}$ & $\begin{array}{l}\text { Same as Column } \\
3\end{array}$ & $\begin{array}{l}\text { Same as Column } \\
3\end{array}$ & $\begin{array}{l}\text { Same as Column } \\
3\end{array}$ & $\begin{array}{l}\text { Same as Column } \\
3\end{array}$ & $\begin{array}{l}\text { Same as Column } \\
3\end{array}$ \\
\hline
\end{tabular}




\section{NEVADA TEST SITE RADIATION PROTECTION PROGRAM}

\section{APPENDIX H}

COMPLIANCE DEMONSTRATION TABLE

\begin{tabular}{|c|c|c|c|c|c|c|c|c|}
\hline \multirow[t]{2}{*}{10 CFR 835} & $\begin{array}{l}\text { NV/YMP RCM } \\
\text { Rev } 5 \text { and } \\
\text { NTS RPP } \\
\text { Revision } 0 \\
\end{array}$ & $\begin{array}{c}\text { NSTec } \\
\text { Appendix A }\end{array}$ & $\begin{array}{c}\text { LLNL } \\
\text { Appendix B }\end{array}$ & $\begin{array}{c}\text { LANL } \\
\text { Appendix C }\end{array}$ & $\begin{array}{c}\text { SNL } \\
\text { Appendix D }\end{array}$ & $\begin{array}{c}\text { SNJV } \\
\text { Appendix E }\end{array}$ & $\begin{array}{c}\text { DRI } \\
\text { Appendix F }\end{array}$ & $\begin{array}{c}\text { WSI } \\
\text { Appendix G }\end{array}$ \\
\hline & $\begin{array}{l}\text { Implementation } \\
\text { Reference }\end{array}$ & $\begin{array}{c}\text { Implementation } \\
\text { Reference }\end{array}$ & $\begin{array}{l}\text { Implementation } \\
\text { Reference }\end{array}$ & $\begin{array}{l}\text { Implementation } \\
\text { Reference }\end{array}$ & $\begin{array}{l}\text { Implementation } \\
\text { Reference }\end{array}$ & $\begin{array}{l}\text { Implementation } \\
\text { Reference }\end{array}$ & $\begin{array}{l}\text { Implementation } \\
\text { Reference }\end{array}$ & $\begin{array}{l}\text { Implementation } \\
\text { Reference }\end{array}$ \\
\hline
\end{tabular}

\begin{tabular}{|c|c|c|c|c|c|c|c|c|}
\hline & $\begin{array}{l}\text { NV/YMP RCM, } \\
431.2 . f . \text { The } \\
\text { requirements for } \\
\text { inventory and } \\
\text { leak testing of } \\
\text { accountable } \\
\text { sealed sources } \\
\text { are: } \\
\text { f. The TO } \\
\text { RadCon } \\
\text { Manager may } \\
\text { extend the time } \\
\text { interval in Article } \\
431.2 . a \text { by a } \\
\text { period not to } \\
\text { exceed } \\
30 \text { days. }\end{array}$ & $\begin{array}{l}\text { NV/YMP RCM, } \\
\text { 431.2.f. The } \\
\text { requirements for } \\
\text { inventory and } \\
\text { leak testing of } \\
\text { accountable } \\
\text { sealed sources } \\
\text { are: } \\
\text { f. The TO } \\
\text { RadCon } \\
\text { Manager may } \\
\text { extend the time } \\
\text { interval in Article } \\
431.2 . a \text { by a } \\
\text { period not to } \\
\text { exceed } \\
30 \text { days. }\end{array}$ & & & & & & \\
\hline $\begin{array}{l}\text { 835.4 Radiological } \\
\text { units. } \\
\text { Unless otherwise } \\
\text { specified, the } \\
\text { quantities used in the } \\
\text { records required by } \\
\text { this part shall be } \\
\text { clearly indicated in } \\
\text { special units of curie, } \\
\text { rad, roentgen, or rem, } \\
\text { including multiples and } \\
\text { subdivisions of these } \\
\text { units, or other } \\
\text { conventional units, } \\
\text { such as, dpm, } \\
\end{array}$ & $\begin{array}{l}\text { NV/YMP RCM } \\
\text { 713.2.c. } \\
\text { Radiological } \\
\text { control records } \\
\text { shall not include: } \\
\text { c. The use of } \\
\text { Systems } \\
\text { International (SI) } \\
\text { units (such as } \\
\text { Bq, Gy, and Sv). }\end{array}$ & $\begin{array}{l}\text { Remove: } \\
\text { NV/YMP RCM } \\
\text { 713.2.c. and } \\
\text { 713.2.d. } \\
\\
\text { Revise: NV/YMP } \\
\text { RCM 713.3 - } \\
\text { The quantities } \\
\text { used in the } \\
\text { records required } \\
\text { by this part shall } \\
\text { be clearly } \\
\text { indicated in } \\
\text { special units of } \\
\text { curie, rad, } \\
\text { roentgen, or rem, }\end{array}$ & $\begin{array}{l}\text { Same as Column } \\
3\end{array}$ & $\begin{array}{l}\text { Same as Column } \\
3\end{array}$ & $\begin{array}{l}\text { Radiological } \\
\text { control records } \\
\text { for SNL activities } \\
\text { at NTS are } \\
\text { prepared and } \\
\text { maintained by } \\
\text { the Radiation } \\
\text { Safety Prime } \\
\text { Contractor } \\
\text { (RSPC). }\end{array}$ & $\begin{array}{l}\text { Same as Column } \\
3\end{array}$ & $\begin{array}{l}\text { Not a DRI } \\
\text { activity. Records } \\
\text { containing } \\
\text { radiological units } \\
\text { are generated for } \\
\text { DRI by the } \\
\text { RSPC (or } \\
\text { University of } \\
\text { Nevada, Reno, } \\
\text { [UNR] Radiation } \\
\text { Safety Office for } \\
\text { excluded } \\
\text { activities). }\end{array}$ & $\begin{array}{l}\text { Not a WSI/NV } \\
\text { activity. } \\
\text { Radiological } \\
\text { control records } \\
\text { for WSI are } \\
\text { prepared and } \\
\text { maintained by } \\
\text { the RSPC or TO } \\
\text { that has } \\
\text { radiological } \\
\text { control } \\
\text { responsibilities } \\
\text { for an activity. } \\
\text { Records } \\
\text { containing } \\
\text { radiological units }\end{array}$ \\
\hline
\end{tabular}




\section{NEVADA TEST SITE RADIATION PROTECTION PROGRAM}

\section{APPENDIX H}

COMPLIANCE DEMONSTRATION TABLE

\begin{tabular}{|c|c|c|c|c|c|c|c|c|}
\hline \multirow[t]{2}{*}{10 CFR 835} & $\begin{array}{c}\text { NV/YMP RCM } \\
\text { Rev } 5 \text { and } \\
\text { NTS RPP } \\
\text { Revision } 0 \\
\end{array}$ & $\begin{array}{c}\text { NSTec } \\
\text { Appendix A }\end{array}$ & $\begin{array}{c}\text { LLNL } \\
\text { Appendix B }\end{array}$ & $\begin{array}{c}\text { LANL } \\
\text { Appendix C }\end{array}$ & $\begin{array}{c}\text { SNL } \\
\text { Appendix D }\end{array}$ & $\begin{array}{c}\text { SNJV } \\
\text { Appendix E }\end{array}$ & $\begin{array}{c}\text { DRI } \\
\text { Appendix F }\end{array}$ & $\begin{array}{c}\text { WSI } \\
\text { Appendix G }\end{array}$ \\
\hline & $\begin{array}{l}\text { Implementation } \\
\text { Reference }\end{array}$ & $\begin{array}{l}\text { Implementation } \\
\text { Reference }\end{array}$ & $\begin{array}{l}\text { Implementation } \\
\text { Reference }\end{array}$ & $\begin{array}{l}\text { Implementation } \\
\text { Reference }\end{array}$ & $\begin{array}{l}\text { Implementation } \\
\text { Reference }\end{array}$ & $\begin{array}{l}\text { Implementation } \\
\text { Reference }\end{array}$ & $\begin{array}{l}\text { Implementation } \\
\text { Reference }\end{array}$ & $\begin{array}{l}\text { Implementation } \\
\text { Reference }\end{array}$ \\
\hline
\end{tabular}

\begin{tabular}{|c|c|c|c|c|c|c|c|c|}
\hline $\begin{array}{l}\text { dpm/100 } \mathrm{cm}^{2} \text { or mass } \\
\text { units. The SI units, } \\
\text { Becquerel }(\mathrm{Bq}) \text {, gray } \\
\text { (Gy), and sievert (Sv), } \\
\text { may be provided } \\
\text { parenthetically for } \\
\text { reference with } \\
\text { scientific standards. }\end{array}$ & & $\begin{array}{l}\text { including } \\
\text { multiples and } \\
\text { subdivisions of } \\
\text { these units, or } \\
\text { other } \\
\text { conventional } \\
\text { units, such as, } \\
\text { dpm, dpm/100 } \\
\mathrm{cm}^{2} \text { or mass } \\
\text { units. The SI } \\
\text { units, becquerel } \\
\text { (Bq), gray (Gy), } \\
\text { and sievert (Sv), } \\
\text { may be provided } \\
\text { parenthetically } \\
\text { for reference with } \\
\text { scientific } \\
\text { standards. }\end{array}$ & & & & & & $\begin{array}{l}\text { under the RPP } \\
\text { are generated by } \\
\text { the RSPC. }\end{array}$ \\
\hline $\begin{array}{l}\text { Subpart B - } \\
\text { Management and } \\
\text { Administrative } \\
\text { Requirements } \\
835.101 \text { Radiation } \\
\text { protection programs. } \\
101(a) \text { A DOE activity } \\
\text { shall be conducted in } \\
\text { compliance with a } \\
\text { documented radiation } \\
\text { protection program } \\
\text { (RPP) as approved by } \\
\text { the DOE. }\end{array}$ & $\begin{array}{l}\text { NV/YMP RCM } \\
112.1 .02 \text {. Any } \\
\text { DOE activity as } \\
\text { defined in } 10 \\
\text { CFR } 835 \text { shall be } \\
\text { planned and } \\
\text { conducted in } \\
\text { compliance with } \\
\text { a documented } \\
\text { RPP as } \\
\text { approved by } \\
\text { NNSA. }\end{array}$ & $\begin{array}{l}\text { NV/YMP RCM } \\
112.1 .02 \text {. Any } \\
\text { DOE activity as } \\
\text { defined in } 10 \\
\text { CFR } 835 \text { shall be } \\
\text { planned and } \\
\text { conducted in } \\
\text { compliance with } \\
\text { a documented } \\
\text { RPP as } \\
\text { approved by } \\
\text { NNSA. }\end{array}$ & $\begin{array}{l}\text { Same as Column } \\
3\end{array}$ & $\begin{array}{l}\text { Same as Column } \\
3\end{array}$ & $\begin{array}{l}\text { Same as Column } \\
3\end{array}$ & $\begin{array}{l}\text { Same as Column } \\
3\end{array}$ & $\begin{array}{l}\text { Same as Column } \\
3\end{array}$ & $\begin{array}{l}\text { Same as Column } \\
3\end{array}$ \\
\hline
\end{tabular}




\section{NEVADA TEST SITE RADIATION PROTECTION PROGRAM}

\section{APPENDIX H}

COMPLIANCE DEMONSTRATION TABLE

\begin{tabular}{|c|c|c|c|c|c|c|c|c|}
\hline \multirow[t]{2}{*}{10 CFR 835} & $\begin{array}{c}\text { NV/YMP RCM } \\
\text { Rev } 5 \text { and } \\
\text { NTS RPP } \\
\text { Revision } 0 \\
\end{array}$ & $\begin{array}{c}\text { NSTec } \\
\text { Appendix A }\end{array}$ & $\begin{array}{c}\text { LLNL } \\
\text { Appendix B }\end{array}$ & $\begin{array}{c}\text { LANL } \\
\text { Appendix C }\end{array}$ & $\begin{array}{c}\text { SNL } \\
\text { Appendix D }\end{array}$ & $\begin{array}{c}\text { SNJV } \\
\text { Appendix E }\end{array}$ & $\begin{array}{c}\text { DRI } \\
\text { Appendix F }\end{array}$ & $\begin{array}{c}\text { WSI } \\
\text { Appendix G }\end{array}$ \\
\hline & $\begin{array}{l}\text { Implementation } \\
\text { Reference }\end{array}$ & $\begin{array}{l}\text { Implementation } \\
\text { Reference }\end{array}$ & $\begin{array}{l}\text { Implementation } \\
\text { Reference }\end{array}$ & $\begin{array}{l}\text { Implementation } \\
\text { Reference }\end{array}$ & $\begin{array}{l}\text { Implementation } \\
\text { Reference }\end{array}$ & $\begin{array}{l}\text { Implementation } \\
\text { Reference }\end{array}$ & $\begin{array}{l}\text { Implementation } \\
\text { Reference }\end{array}$ & $\begin{array}{l}\text { Implementation } \\
\text { Reference }\end{array}$ \\
\hline
\end{tabular}

\begin{tabular}{|c|c|c|c|c|c|c|c|c|}
\hline $\begin{array}{l}101(b) \text { The DOE may } \\
\text { direct or make } \\
\text { modifications to a } \\
\text { RPP. }\end{array}$ & $\begin{array}{l}\text { NV/YMP RCM } \\
157.5 \text {. The } \\
\text { NNSA/NSO or } \\
\text { YMORD, as } \\
\text { appropriate, may } \\
\text { direct } \\
\text { modifications to } \\
\text { an RPP. }\end{array}$ & $\begin{array}{l}\text { Revise: NV/YMP } \\
\text { RCM 157.5. The } \\
\text { NNSA/NSO may } \\
\text { direct } \\
\text { modifications to } \\
\text { an RPP. }\end{array}$ & $\begin{array}{l}\text { Same as Column } \\
3\end{array}$ & $\begin{array}{l}\text { Same as Column } \\
3\end{array}$ & $\begin{array}{l}\text { Same as Column } \\
3\end{array}$ & $\begin{array}{l}\text { Same as Column } \\
3\end{array}$ & $\begin{array}{l}\text { Same as Column } \\
3\end{array}$ & $\begin{array}{l}\text { Same as Column } \\
3\end{array}$ \\
\hline $\begin{array}{l}101(\mathrm{c}) \text { The content of } \\
\text { each RPP shall be } \\
\text { commensurate with } \\
\text { the nature of the } \\
\text { activities performed } \\
\text { and shall include } \\
\text { formal plans and } \\
\text { measures for applying } \\
\text { the as low as } \\
\text { reasonably achievable } \\
\text { (ALARA) process to } \\
\text { occupational } \\
\text { exposure. }\end{array}$ & $\begin{array}{l}\text { NV/YMP RCM } \\
\text { 157.2.d. The } \\
\text { content of each } \\
\text { RPP shall: } \\
\text { d. Be } \\
\text { commensurate } \\
\text { with the nature of } \\
\text { the activities } \\
\text { performed and } \\
\text { shall include } \\
\text { formal plans and } \\
\text { measures for } \\
\text { applying the } \\
\text { ALARA process } \\
\text { to occupational } \\
\text { exposure. } \\
\text { NSTec Appendix } \\
\text { A, Narrative } \\
\text { Section } 4.0 \\
\text { ALARA } \\
\text { Commitment. }\end{array}$ & $\begin{array}{l}\text { NV/YMP RCM } \\
\text { 157.2.d. The } \\
\text { content of each } \\
\text { RPP shall: } \\
\text { d. Be } \\
\text { commensurate } \\
\text { with the nature of } \\
\text { the activities } \\
\text { performed and } \\
\text { shall include } \\
\text { formal plans and } \\
\text { measures for } \\
\text { applying the } \\
\text { ALARA process } \\
\text { to occupational } \\
\text { exposure. } \\
\text { RPP Narrative } \\
\text { Section } 7.0 \\
\text { ALARA Program. }\end{array}$ & $\begin{array}{l}\text { Same as Column } \\
3 \text { and LLNL } \\
\text { Appendix B, } \\
\text { Section } 4.0 \\
\text { ALARA } \\
\text { Commitments }\end{array}$ & $\begin{array}{l}\text { Same as Column } \\
3 \text { and LANL } \\
\text { Appendix C, } \\
\text { Section } 4.0 \\
\text { ALARA } \\
\text { Commitment }\end{array}$ & $\begin{array}{l}\text { Same as Column } \\
3 \text { and SNL } \\
\text { Appendix D } \\
\text { Narrative Section } \\
4.0 \text { ALARA } \\
\text { Commitment. }\end{array}$ & $\begin{array}{l}\text { Same as Column } \\
3 \text { and SNJV } \\
\text { Appendix E } \\
\text { Narrative } \\
\text { Sections: } 1.0 \\
\text { Scope, } 4.0 \\
\text { ALARA } \\
\text { Commitment. }\end{array}$ & $\begin{array}{l}\text { Same as Column } \\
3 \text { and DRI } \\
\text { Appendix F, } \\
\text { Narrative Section } \\
\text { 3.0 Hazard } \\
\text { Identification and } \\
\text { 4.0 ALARA } \\
\text { Commitment. }\end{array}$ & $\begin{array}{l}\text { Same as Column } \\
3 \text { and WSI/NV } \\
\text { Appendix G } \\
\text { Narrative Section } \\
1.0 \text { Scope and } \\
\text { Section } 3.0 \\
\text { ALARA } \\
\text { Commitment. }\end{array}$ \\
\hline $\begin{array}{l}101(d) \text { The RPP shall } \\
\text { specify the existing } \\
\text { and/or anticipated }\end{array}$ & $\begin{array}{l}\text { NV/YMP RCM } \\
\text { 157.2.c. The } \\
\text { content of each }\end{array}$ & $\begin{array}{l}\text { NV/YMP RCM } \\
\text { 157.2.c. The } \\
\text { content of each }\end{array}$ & $\begin{array}{l}\text { Same as Column } \\
3\end{array}$ & $\begin{array}{l}\text { Same as Column } \\
3\end{array}$ & $\begin{array}{l}\text { Same as Column } \\
3 \text { and See SNL } \\
\text { Appendix D, }\end{array}$ & $\begin{array}{l}\text { Same as Column } \\
3\end{array}$ & $\begin{array}{l}\text { Same as Column } \\
3 \text { and See DRI } \\
\text { Appendix F, }\end{array}$ & $\begin{array}{l}\text { Same as Column } \\
3 \text { and See } \\
\text { WSI/NV }\end{array}$ \\
\hline
\end{tabular}

$\mathrm{H}-10$ 


\section{NEVADA TEST SITE RADIATION PROTECTION PROGRAM}

\section{APPENDIX H}

COMPLIANCE DEMONSTRATION TABLE

\begin{tabular}{|c|c|c|c|c|c|c|c|c|}
\hline \multirow[t]{2}{*}{10 CFR 835} & $\begin{array}{l}\text { NV/YMP RCM } \\
\text { Rev } 5 \text { and } \\
\text { NTS RPP } \\
\text { Revision } 0 \\
\end{array}$ & $\begin{array}{c}\text { NSTec } \\
\text { Appendix A }\end{array}$ & $\begin{array}{c}\text { LLNL } \\
\text { Appendix B }\end{array}$ & $\begin{array}{c}\text { LANL } \\
\text { Appendix C }\end{array}$ & $\begin{array}{c}\text { SNL } \\
\text { Appendix D }\end{array}$ & $\begin{array}{c}\text { SNJV } \\
\text { Appendix E }\end{array}$ & $\begin{array}{c}\text { DRI } \\
\text { Appendix F }\end{array}$ & $\begin{array}{c}\text { WSI } \\
\text { Appendix G }\end{array}$ \\
\hline & $\begin{array}{l}\text { Implementation } \\
\text { Reference }\end{array}$ & $\begin{array}{l}\text { Implementation } \\
\text { Reference }\end{array}$ & $\begin{array}{l}\text { Implementation } \\
\text { Reference }\end{array}$ & $\begin{array}{l}\text { Implementation } \\
\text { Reference }\end{array}$ & $\begin{array}{l}\text { Implementation } \\
\text { Reference }\end{array}$ & $\begin{array}{l}\text { Implementation } \\
\text { Reference }\end{array}$ & $\begin{array}{l}\text { Implementation } \\
\text { Reference }\end{array}$ & $\begin{array}{c}\text { Implementation } \\
\text { Reference }\end{array}$ \\
\hline
\end{tabular}

\section{operational tasks that}

are intended to be

within the scope of the

RPP. Except as

provided in

$\S 835.101(\mathrm{~h})$, any task outside the scope of a

RPP shall not be

initiated until an

update of the RPP is

approved by DOE.

\section{RPP shall:}

c. Specify the

existing and/or

anticipated

operational tasks

that are intended

to be within the

scope of the

RPP.

NV/YMP RCM

157.3.b. An

update of the

RPP shall be

submitted to

NNSA/NSO or

YMORD:

b. Before the

initiation of a task

not within the

scope of the

RPP. Except as

provided in

Article 157.3.a.1,

any task outside

the scope of an

RPP shall not be

initiated until an

update of the

RPP is approved

by NNSA/NSO or

YMORD, as

appropriate.

\section{RPP shall:}

c. Specify the

existing and/or

anticipated

operational tasks

that are intended

to be within the

scope of the

RPP.

Revise: NV/YMP

RCM 157.3.b.

An update of the

RPP shall be

submitted to

NNSA/NSO:

b. Before the

initiation of a task

not within the

scope of the

RPP. Except as

provided in

Article 157.3.a.1

any task outside

the scope of an

RPP shall not be

initiated until an

update of the

RPP is approved

by NNSA/NSO.

\begin{tabular}{|l|} 
Narrative Section \\
1.0 Scope.
\end{tabular}

Narrative Section Appendix G

1.0 Scope.

Narrative Section

1.0 Scope and

Section 2.0

Activities. 


\section{NEVADA TEST SITE RADIATION PROTECTION PROGRAM}

\section{APPENDIX H}

COMPLIANCE DEMONSTRATION TABLE

\begin{tabular}{|c|c|c|c|c|c|c|c|c|}
\hline \multirow[t]{2}{*}{10 CFR 835} & $\begin{array}{l}\text { NV/YMP RCM } \\
\text { Rev } 5 \text { and } \\
\text { NTS RPP } \\
\text { Revision } 0 \\
\end{array}$ & $\begin{array}{c}\text { NSTec } \\
\text { Appendix A }\end{array}$ & $\begin{array}{c}\text { LLNL } \\
\text { Appendix B }\end{array}$ & $\begin{array}{c}\text { LANL } \\
\text { Appendix C }\end{array}$ & $\begin{array}{c}\text { SNL } \\
\text { Appendix D }\end{array}$ & $\begin{array}{c}\text { SNJV } \\
\text { Appendix E }\end{array}$ & $\begin{array}{c}\text { DRI } \\
\text { Appendix F }\end{array}$ & $\begin{array}{c}\text { WSI } \\
\text { Appendix G }\end{array}$ \\
\hline & $\begin{array}{l}\text { Implementation } \\
\text { Reference }\end{array}$ & $\begin{array}{l}\text { Implementation } \\
\text { Reference }\end{array}$ & $\begin{array}{l}\text { Implementation } \\
\text { Reference }\end{array}$ & $\begin{array}{l}\text { Implementation } \\
\text { Reference }\end{array}$ & $\begin{array}{l}\text { Implementation } \\
\text { Reference }\end{array}$ & $\begin{array}{l}\text { Implementation } \\
\text { Reference }\end{array}$ & $\begin{array}{l}\text { Implementation } \\
\text { Reference }\end{array}$ & $\begin{array}{c}\text { Implementation } \\
\text { Reference }\end{array}$ \\
\hline
\end{tabular}

\begin{tabular}{|c|c|c|c|c|c|c|c|c|}
\hline $\begin{array}{l}101(\mathrm{e}) \text { The content of } \\
\text { the RPP shall address, } \\
\text { but shall not } \\
\text { necessarily be limited } \\
\text { to, each requirement } \\
\text { in this part. }\end{array}$ & $\begin{array}{l}\text { NV/YMP RCM } \\
\text { 157.2.a. The } \\
\text { content of each } \\
\text { RPP shall: } \\
\text { a. Address, but } \\
\text { shall not } \\
\text { necessarily be } \\
\text { limited to, each } \\
\text { requirement in } \\
10 \text { CFR } 835 \text {. }\end{array}$ & $\begin{array}{l}\text { NV/YMP RCM } \\
\text { 157.2.a. The } \\
\text { content of each } \\
\text { RPP shall: } \\
\text { a. Address, but } \\
\text { shall not } \\
\text { necessarily be } \\
\text { limited to, each } \\
\text { requirement in } \\
10 \text { CFR } 835 \text {. }\end{array}$ & $\begin{array}{l}\text { Same as Column } \\
3\end{array}$ & $\begin{array}{l}\text { Same as Column } \\
3\end{array}$ & $\begin{array}{l}\text { Same as Column } \\
3\end{array}$ & $\begin{array}{l}\text { Same as Column } \\
3\end{array}$ & $\begin{array}{l}\text { Same as Column } \\
3\end{array}$ & $\begin{array}{l}\text { Same as Column } \\
3\end{array}$ \\
\hline $\begin{array}{l}101(f) \text { The RPP shall } \\
\text { include plans, } \\
\text { schedules, and other } \\
\text { measures for } \\
\text { achieving compliance } \\
\text { with regulations of this } \\
\text { part. Unless otherwise } \\
\text { specified in this part, } \\
\text { compliance with the } \\
\text { amendments to this } \\
\text { part, published on } \\
\text { June } 8,2007 \text { shall be } \\
\text { achieved no later than } \\
\text { July } 9,2010 \text {. }\end{array}$ & $\begin{array}{l}\text { NV/YMP RCM } \\
\text { 157.2.b. The } \\
\text { content of each } \\
\text { RPP shall: } \\
\text { b. Include plans, } \\
\text { schedules, and } \\
\text { other measures } \\
\text { for achieving } \\
\text { compliance with } \\
\text { the regulations } \\
\text { within } 10 \text { CFR } \\
835 . \\
\text { NV/YMP RCM } \\
157.4 \text {. An initial } \\
\text { RPP or an } \\
\text { update shall be } \\
\text { considered } \\
\text { approved } 180 \\
\text { days after its } \\
\text { submission } \\
\text { unless rejected } \\
\text { by NNSA/NSO or }\end{array}$ & $\begin{array}{l}\text { Revise: NV/YMP } \\
\text { RCM 157.2.b. } \\
\text { The content of } \\
\text { each RPP shall: } \\
\text { b. Include plans, } \\
\text { schedules, and } \\
\text { other measures } \\
\text { for achieving } \\
\text { compliance with } \\
\text { the amendments } \\
\text { to this part } \\
\text { published on } \\
\text { June } 8,2007, \text { no } \\
\text { later than July } 9 \text {, } \\
2010 .\end{array}$ & $\begin{array}{l}\text { Same as Column } \\
3\end{array}$ & $\begin{array}{l}\text { Same as Column } \\
3\end{array}$ & $\begin{array}{l}\text { Same as Column } \\
3\end{array}$ & $\begin{array}{l}\text { Same as Column } \\
3\end{array}$ & $\begin{array}{l}\text { Same as Column } \\
3\end{array}$ & $\begin{array}{l}\text { Same as Column } \\
3\end{array}$ \\
\hline
\end{tabular}




\section{NEVADA TEST SITE RADIATION PROTECTION PROGRAM}

\section{APPENDIX H}

COMPLIANCE DEMONSTRATION TABLE

\begin{tabular}{|c|c|c|c|c|c|c|c|c|}
\hline \multirow[t]{2}{*}{10 CFR 835} & $\begin{array}{l}\text { NV/YMP RCM } \\
\text { Rev } 5 \text { and } \\
\text { NTS RPP } \\
\text { Revision } 0 \\
\end{array}$ & $\begin{array}{c}\text { NSTec } \\
\text { Appendix A }\end{array}$ & $\begin{array}{c}\text { LLNL } \\
\text { Appendix B }\end{array}$ & $\begin{array}{c}\text { LANL } \\
\text { Appendix C }\end{array}$ & $\begin{array}{c}\text { SNL } \\
\text { Appendix D }\end{array}$ & $\begin{array}{c}\text { SNJV } \\
\text { Appendix E }\end{array}$ & $\begin{array}{c}\text { DRI } \\
\text { Appendix F }\end{array}$ & $\begin{array}{c}\text { WSI } \\
\text { Appendix G }\end{array}$ \\
\hline & $\begin{array}{l}\text { Implementation } \\
\text { Reference }\end{array}$ & $\begin{array}{l}\text { Implementation } \\
\text { Reference }\end{array}$ & $\begin{array}{l}\text { Implementation } \\
\text { Reference }\end{array}$ & $\begin{array}{l}\text { Implementation } \\
\text { Reference }\end{array}$ & $\begin{array}{l}\text { Implementation } \\
\text { Reference }\end{array}$ & $\begin{array}{l}\text { Implementation } \\
\text { Reference }\end{array}$ & $\begin{array}{l}\text { Implementation } \\
\text { Reference }\end{array}$ & $\begin{array}{l}\text { Implementation } \\
\text { Reference }\end{array}$ \\
\hline
\end{tabular}

\begin{tabular}{|c|c|c|c|c|c|c|c|c|}
\hline & $\begin{array}{l}\text { YMORD, as } \\
\text { appropriate, at } \\
\text { an earlier date. }\end{array}$ & & & & & & & \\
\hline $\begin{array}{l}101(\mathrm{~g}) \text { An update of } \\
\text { the RPP shall be } \\
\text { submitted to DOE: } \\
\text { (1) Whenever a } \\
\text { change or an addition } \\
\text { to the RPP is made; } \\
\text { (2) Prior to the } \\
\text { initiation of a task not } \\
\text { within the scope of the } \\
\text { RPP; or } \\
\text { (3) Within } 180 \text { days of } \\
\text { the effective date of } \\
\text { any modifications to } \\
\text { this part. }\end{array}$ & $\begin{array}{l}\text { NV/YMP RCM } \\
\text { 157.3.a-c. An } \\
\text { update of the } \\
\text { RPP shall be } \\
\text { submitted to } \\
\text { NNSA/NSO or } \\
\text { YMORD: } \\
\text { a. Whenever a } \\
\text { change or } \\
\text { addition to the } \\
\text { RPP is made } \\
\text { and } \\
\text { b. Before the } \\
\text { initiation of a task } \\
\text { not within the } \\
\text { scope of the } \\
\text { RPP. } \\
\text { c. Within } 180 \\
\text { days of the } \\
\text { effective date of } \\
\text { any modification } \\
\text { to } 10 \text { CFR } 835 \text {. }\end{array}$ & $\begin{array}{l}\text { Revise: NV/YMP } \\
\text { RCM 157.3.a-c. } \\
\text { An update of the } \\
\text { RPP shall be } \\
\text { submitted to } \\
\text { NNSA/NSO: } \\
\text { a. Whenever a } \\
\text { change or } \\
\text { addition to the } \\
\text { RPP is made. } \\
\text { b. Before the } \\
\text { initiation of a task } \\
\text { not within the } \\
\text { scope of the } \\
\text { RPP. } \\
\text { c. Within } 180 \\
\text { days of the } \\
\text { effective date of } \\
\text { any modification } \\
\text { to } 10 \text { CFR } 835 \text {. }\end{array}$ & $\begin{array}{l}\text { Same as Column } \\
3\end{array}$ & $\begin{array}{l}\text { Same as Column } \\
3\end{array}$ & $\begin{array}{l}\text { Same as Column } \\
3\end{array}$ & $\begin{array}{l}\text { Same as Column } \\
3\end{array}$ & $\begin{array}{l}\text { Same as Column } \\
3\end{array}$ & $\begin{array}{l}\text { Same as Column } \\
3\end{array}$ \\
\hline $\begin{array}{l}101(\mathrm{~h}) \text { Changes, } \\
\text { additions, or updates } \\
\text { to the RPP may } \\
\text { become effective } \\
\text { without prior } \\
\text { Department approval } \\
\text { only if the changes do } \\
\text { not decrease the }\end{array}$ & $\begin{array}{l}\text { NV/YMP RCM, } \\
\text { 157.3.a. An } \\
\text { update of the } \\
\text { RPP shall be } \\
\text { submitted to } \\
\text { NNSA/NSO or } \\
\text { YMORD: } \\
\text { a. Whenever a }\end{array}$ & $\begin{array}{l}\text { Revise: NV/YMP } \\
\text { RCM, 157.3.a. } \\
\text { An update of the } \\
\text { RPP shall be } \\
\text { submitted to } \\
\text { NNSA/NSO: } \\
\text { a. Whenever a } \\
\text { change or }\end{array}$ & $\begin{array}{l}\text { Same as Column } \\
3\end{array}$ & $\begin{array}{l}\text { Same as Column } \\
3\end{array}$ & $\begin{array}{l}\text { Same as Column } \\
3\end{array}$ & $\begin{array}{l}\text { Same as Column } \\
3\end{array}$ & $\begin{array}{l}\text { Same as Column } \\
3\end{array}$ & $\begin{array}{l}\text { Same as Column } \\
3\end{array}$ \\
\hline
\end{tabular}

H-13 


\section{NEVADA TEST SITE RADIATION PROTECTION PROGRAM}

\section{APPENDIX H}

COMPLIANCE DEMONSTRATION TABLE

\begin{tabular}{|c|c|c|c|c|c|c|c|c|}
\hline \multirow[t]{2}{*}{10 CFR 835} & $\begin{array}{l}\text { NV/YMP RCM } \\
\text { Rev } 5 \text { and } \\
\text { NTS RPP } \\
\text { Revision } 0 \\
\end{array}$ & $\begin{array}{c}\text { NSTec } \\
\text { Appendix A }\end{array}$ & $\begin{array}{c}\text { LLNL } \\
\text { Appendix B }\end{array}$ & $\begin{array}{c}\text { LANL } \\
\text { Appendix C }\end{array}$ & $\begin{array}{c}\text { SNL } \\
\text { Appendix D }\end{array}$ & $\begin{array}{c}\text { SNJV } \\
\text { Appendix E }\end{array}$ & $\begin{array}{c}\text { DRI } \\
\text { Appendix F }\end{array}$ & $\begin{array}{c}\text { WSI } \\
\text { Appendix G }\end{array}$ \\
\hline & $\begin{array}{l}\text { Implementation } \\
\text { Reference }\end{array}$ & $\begin{array}{l}\text { Implementation } \\
\text { Reference }\end{array}$ & $\begin{array}{l}\text { Implementation } \\
\text { Reference }\end{array}$ & $\begin{array}{l}\text { Implementation } \\
\text { Reference }\end{array}$ & $\begin{array}{l}\text { Implementation } \\
\text { Reference }\end{array}$ & $\begin{array}{l}\text { Implementation } \\
\text { Reference }\end{array}$ & $\begin{array}{l}\text { Implementation } \\
\text { Reference }\end{array}$ & $\begin{array}{c}\text { Implementation } \\
\text { Reference }\end{array}$ \\
\hline
\end{tabular}

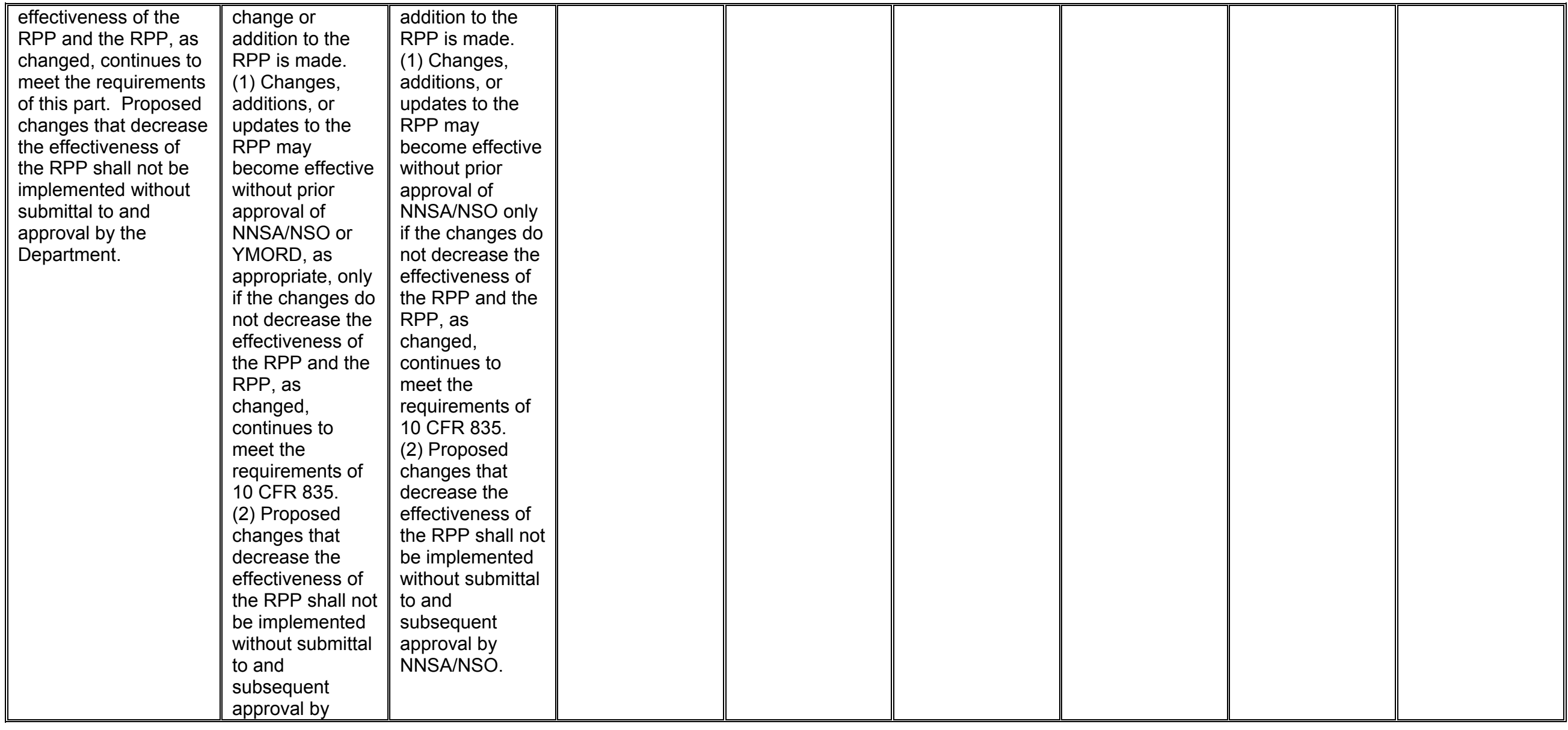




\section{NEVADA TEST SITE RADIATION PROTECTION PROGRAM}

\section{APPENDIX H}

COMPLIANCE DEMONSTRATION TABLE

\begin{tabular}{|c|c|c|c|c|c|c|c|c|}
\hline \multirow[t]{2}{*}{10 CFR 835} & $\begin{array}{l}\text { NV/YMP RCM } \\
\text { Rev } 5 \text { and } \\
\text { NTS RPP } \\
\text { Revision } 0\end{array}$ & $\begin{array}{c}\text { NSTec } \\
\text { Appendix A }\end{array}$ & $\begin{array}{c}\text { LLNL } \\
\text { Appendix B }\end{array}$ & $\begin{array}{c}\text { LANL } \\
\text { Appendix C }\end{array}$ & $\begin{array}{c}\text { SNL } \\
\text { Appendix D }\end{array}$ & $\begin{array}{c}\text { SNJV } \\
\text { Appendix E }\end{array}$ & $\begin{array}{c}\text { DRI } \\
\text { Appendix F }\end{array}$ & $\begin{array}{c}\text { WSI } \\
\text { Appendix G }\end{array}$ \\
\hline & $\begin{array}{l}\text { Implementation } \\
\text { Reference }\end{array}$ & $\begin{array}{l}\text { Implementation } \\
\text { Reference }\end{array}$ & $\begin{array}{l}\text { Implementation } \\
\text { Reference }\end{array}$ & $\begin{array}{l}\text { Implementation } \\
\text { Reference }\end{array}$ & $\begin{array}{l}\text { Implementation } \\
\text { Reference }\end{array}$ & $\begin{array}{l}\text { Implementation } \\
\text { Reference }\end{array}$ & $\begin{array}{l}\text { Implementation } \\
\text { Reference }\end{array}$ & $\begin{array}{l}\text { Implementation } \\
\text { Reference }\end{array}$ \\
\hline
\end{tabular}

\begin{tabular}{|c|c|c|c|c|c|c|c|c|}
\hline & $\begin{array}{l}\text { NNSA/NSO or } \\
\text { YMORD, as } \\
\text { appropriate. }\end{array}$ & & & & & & & \\
\hline $\begin{array}{l}101 \text { (i) An initial RPP or } \\
\text { an update shall be } \\
\text { considered approved } \\
180 \text { days after its } \\
\text { submission unless } \\
\text { rejected by DOE at an } \\
\text { earlier date. }\end{array}$ & $\begin{array}{l}\text { NV/YMP RCM } \\
157.4 \text {. An initial } \\
\text { RPP or an } \\
\text { update shall be } \\
\text { considered } \\
\text { approved } 180 \\
\text { days after its } \\
\text { submission } \\
\text { unless rejected } \\
\text { by NNSA/NSO or } \\
\text { YMORD, as } \\
\text { appropriate, at } \\
\text { an earlier date. }\end{array}$ & $\begin{array}{l}\text { Revise: NV/YMP } \\
\text { RCM 157.4. An } \\
\text { initial RPP or an } \\
\text { update shall be } \\
\text { considered } \\
\text { approved } 180 \\
\text { days after its } \\
\text { submission } \\
\text { unless rejected } \\
\text { by NNSA/NSO at } \\
\text { an earlier date. }\end{array}$ & $\begin{array}{l}\text { Same as Column } \\
3\end{array}$ & $\begin{array}{l}\text { Same as Column } \\
3\end{array}$ & $\begin{array}{l}\text { Same as Column } \\
3\end{array}$ & $\begin{array}{l}\text { Same as Column } \\
3\end{array}$ & $\begin{array}{l}\text { Same as Column } \\
3\end{array}$ & $\begin{array}{l}\text { Same as Column } \\
3\end{array}$ \\
\hline $\begin{array}{l}835.102 \text { Internal } \\
\text { audits. } \\
\text { Internal audits of the } \\
\text { radiation protection } \\
\text { program, including } \\
\text { examination of } \\
\text { program content and } \\
\text { implementation, shall } \\
\text { be conducted through } \\
\text { a process that ensures } \\
\text { that all functional } \\
\text { elements are reviewed } \\
\text { no less frequently than } \\
\text { every } 36 \text { months. }\end{array}$ & $\begin{array}{l}\text { NV/YMP RCM } \\
134.01 \text {. Internal } \\
\text { audits of the } \\
\text { radiological } \\
\text { control program } \\
\text { shall be } \\
\text { conducted such } \\
\text { that over a 36- } \\
\text { month period, all } \\
\text { functional } \\
\text { elements of } 10 \\
\text { CFR } 835 \text { are } \\
\text { assessed for } \\
\text { program } \\
\text { performance, } \\
\text { applicability, } \\
\text { content, and }\end{array}$ & $\begin{array}{l}\text { NV/YMP RCM } \\
134.01 \text {. Internal } \\
\text { audits of the } \\
\text { radiological } \\
\text { control program } \\
\text { shall be } \\
\text { conducted such } \\
\text { that over a 36- } \\
\text { month period, all } \\
\text { functional } \\
\text { elements of } 10 \\
\text { CFR } 835 \text { are } \\
\text { assessed for } \\
\text { program } \\
\text { performance, } \\
\text { applicability, } \\
\text { content, and }\end{array}$ & $\begin{array}{l}\text { Same as Column } \\
3\end{array}$ & $\begin{array}{l}\text { Same as Column } \\
3\end{array}$ & $\begin{array}{l}\text { Same as Column } \\
3\end{array}$ & $\begin{array}{l}\text { Same as Column } \\
3\end{array}$ & $\begin{array}{l}\text { Same as Column } \\
3\end{array}$ & $\begin{array}{l}\text { Same as Column } \\
3\end{array}$ \\
\hline
\end{tabular}




\section{NEVADA TEST SITE RADIATION PROTECTION PROGRAM}

\section{APPENDIX H}

COMPLIANCE DEMONSTRATION TABLE

\begin{tabular}{|c|c|c|c|c|c|c|c|c|}
\hline \multirow[t]{2}{*}{10 CFR 835} & $\begin{array}{c}\text { NV/YMP RCM } \\
\text { Rev } 5 \text { and } \\
\text { NTS RPP } \\
\text { Revision } 0 \\
\end{array}$ & $\begin{array}{c}\text { NSTec } \\
\text { Appendix A }\end{array}$ & $\begin{array}{c}\text { LLNL } \\
\text { Appendix B }\end{array}$ & $\begin{array}{c}\text { LANL } \\
\text { Appendix C }\end{array}$ & $\begin{array}{c}\text { SNL } \\
\text { Appendix D }\end{array}$ & $\begin{array}{c}\text { SNJV } \\
\text { Appendix E }\end{array}$ & $\begin{array}{c}\text { DRI } \\
\text { Appendix F }\end{array}$ & $\begin{array}{c}\text { WSI } \\
\text { Appendix G }\end{array}$ \\
\hline & $\begin{array}{l}\text { Implementation } \\
\text { Reference }\end{array}$ & $\begin{array}{l}\text { Implementation } \\
\text { Reference }\end{array}$ & $\begin{array}{l}\text { Implementation } \\
\text { Reference }\end{array}$ & $\begin{array}{l}\text { Implementation } \\
\text { Reference }\end{array}$ & $\begin{array}{l}\text { Implementation } \\
\text { Reference }\end{array}$ & $\begin{array}{l}\text { Implementation } \\
\text { Reference }\end{array}$ & $\begin{array}{l}\text { Implementation } \\
\text { Reference }\end{array}$ & $\begin{array}{l}\text { Implementation } \\
\text { Reference }\end{array}$ \\
\hline
\end{tabular}

\begin{tabular}{|c|c|c|c|c|c|c|c|c|}
\hline & implementation. & implementation. & & & & & & \\
\hline $\begin{array}{l}835.103 \text { Education, } \\
\text { training and skills. } \\
\text { Individuals responsible } \\
\text { for developing and } \\
\text { implementing } \\
\text { measures necessary } \\
\text { for ensuring } \\
\text { compliance with the } \\
\text { requirements of this } \\
\text { part shall have the } \\
\text { appropriate education, } \\
\text { training, and skills to } \\
\text { discharge these } \\
\text { responsibilities.. }\end{array}$ & $\begin{array}{l}\text { NV/YMP RCM } \\
142.3 \text {. } \\
\text { Individuals } \\
\text { responsible for } \\
\text { developing and } \\
\text { implementing } \\
\text { measures } \\
\text { necessary for } \\
\text { ensuring } \\
\text { compliance with } \\
\text { the requirements } \\
\text { of } 10 \text { CFR } 835 \\
\text { shall have the } \\
\text { appropriate } \\
\text { education, } \\
\text { training, and } \\
\text { skills to } \\
\text { discharge these } \\
\text { responsibilities. }\end{array}$ & $\begin{array}{l}\text { NV/YMP RCM } \\
142.3 . \\
\text { Individuals } \\
\text { responsible for } \\
\text { developing and } \\
\text { implementing } \\
\text { measures } \\
\text { necessary for } \\
\text { ensuring } \\
\text { compliance with } \\
\text { the requirements } \\
\text { of } 10 \text { CFR } 835 \\
\text { shall have the } \\
\text { appropriate } \\
\text { education, } \\
\text { training, and } \\
\text { skills to } \\
\text { discharge these } \\
\text { responsibilities. }\end{array}$ & $\begin{array}{l}\text { Same as Column } \\
3\end{array}$ & $\begin{array}{l}\text { Same as Column } \\
3\end{array}$ & $\begin{array}{l}\text { Same as Column } \\
3\end{array}$ & $\begin{array}{l}\text { Same as Column } \\
3\end{array}$ & $\begin{array}{l}\text { Same as Column } \\
3\end{array}$ & $\begin{array}{l}\text { Same as Column } \\
3\end{array}$ \\
\hline $\begin{array}{l}835.104 \text { Written } \\
\text { procedures. } \\
\text { Written procedures } \\
\text { shall be developed } \\
\text { and implemented as } \\
\text { necessary to ensure } \\
\text { compliance with this } \\
\text { part, commensurate } \\
\text { with the radiological } \\
\text { hazards created by the } \\
\text { activity and consistent } \\
\text { with the education, } \\
\text { training, and skills of }\end{array}$ & $\begin{array}{l}\text { NV/YMP RCM } \\
113.4 \text {. Written } \\
\text { procedures shall } \\
\text { be developed } \\
\text { and implemented } \\
\text { as necessary to } \\
\text { ensure } \\
\text { compliance with } \\
10 \text { CFR } 835 .\end{array}$ & $\begin{array}{l}\text { NV/YMP RCM } \\
113.4 \text {. Written } \\
\text { procedures shall } \\
\text { be developed } \\
\text { and implemented } \\
\text { as necessary to } \\
\text { ensure } \\
\text { compliance with } \\
10 \text { CFR } 835 .\end{array}$ & $\begin{array}{l}\text { Same as Column } \\
3\end{array}$ & $\begin{array}{l}\text { Same as Column } \\
3\end{array}$ & $\begin{array}{l}\text { Same as Column } \\
3\end{array}$ & $\begin{array}{l}\text { Same as Column } \\
3\end{array}$ & $\begin{array}{l}\text { Same as Column } \\
3\end{array}$ & $\begin{array}{l}\text { Same as Column } \\
3\end{array}$ \\
\hline
\end{tabular}

H-16 


\section{NEVADA TEST SITE RADIATION PROTECTION PROGRAM}

\section{APPENDIX H}

COMPLIANCE DEMONSTRATION TABLE

\begin{tabular}{|c|c|c|c|c|c|c|c|c|}
\hline \multirow[t]{2}{*}{10 CFR 835} & $\begin{array}{l}\text { NV/YMP RCM } \\
\text { Rev } 5 \text { and } \\
\text { NTS RPP } \\
\text { Revision } 0 \\
\end{array}$ & $\begin{array}{c}\text { NSTec } \\
\text { Appendix A }\end{array}$ & $\begin{array}{c}\text { LLNL } \\
\text { Appendix B }\end{array}$ & $\begin{array}{c}\text { LANL } \\
\text { Appendix C }\end{array}$ & $\begin{array}{c}\text { SNL } \\
\text { Appendix D }\end{array}$ & $\begin{array}{c}\text { SNJV } \\
\text { Appendix E }\end{array}$ & $\begin{array}{c}\text { DRI } \\
\text { Appendix F }\end{array}$ & $\begin{array}{c}\text { WSI } \\
\text { Appendix G }\end{array}$ \\
\hline & $\begin{array}{l}\text { Implementation } \\
\text { Reference }\end{array}$ & $\begin{array}{l}\text { Implementation } \\
\text { Reference }\end{array}$ & $\begin{array}{l}\text { Implementation } \\
\text { Reference }\end{array}$ & $\begin{array}{l}\text { Implementation } \\
\text { Reference }\end{array}$ & $\begin{array}{l}\text { Implementation } \\
\text { Reference }\end{array}$ & $\begin{array}{l}\text { Implementation } \\
\text { Reference }\end{array}$ & $\begin{array}{l}\text { Implementation } \\
\text { Reference }\end{array}$ & $\begin{array}{l}\text { Implementation } \\
\text { Reference }\end{array}$ \\
\hline
\end{tabular}

\begin{tabular}{|c|c|c|c|c|c|c|c|c|}
\hline \multicolumn{9}{|l|}{$\begin{array}{l}\text { the individuals } \\
\text { exposed to those } \\
\text { hazards. }\end{array}$} \\
\hline $\begin{array}{l}\text { Subpart C - } \\
\text { Standards for } \\
\text { Internal and External } \\
\text { Exposure } \\
\mathbf{8 3 5 . 2 0 1} \text { [Reserved] }\end{array}$ & & & & & & & & \\
\hline $\begin{array}{l}835.202 \\
\text { Occupational Dose } \\
\text { Limits for General } \\
\text { Employees. } \\
\text { 202(a) Except for } \\
\text { planned special } \\
\text { exposures conducted } \\
\text { consistent with } \\
\text { §835.204 and } \\
\text { emergency exposures } \\
\text { authorized in } \\
\text { accordance with } \\
\text { §835.1302, the } \\
\text { occupational dose } \\
\text { received by general } \\
\text { employees shall be } \\
\text { controlled such that } \\
\text { the following limits are } \\
\text { not exceeded in a } \\
\text { year: } \\
\text { (1) A total effective } \\
\text { dose of } 5 \text { rems ( } 0.05 \\
\text { Sv); } \\
\text { (2) The sum of the }\end{array}$ & $\begin{array}{l}\text { NV/YMP RCM } \\
\text { 213.1.a-d. } \\
\text { Except for } \\
\text { emergency } \\
\text { exposures } \\
\text { authorized } \\
\text { according to } \\
10 \text { CFR } \\
835.1302 \text {, the } \\
\text { occupational } \\
\text { dose received by } \\
\text { general } \\
\text { employees shall } \\
\text { be controlled } \\
\text { such that the } \\
\text { following limits } \\
\text { are not } \\
\text { exceeded in a } \\
\text { year. } \\
\text { a. A total } \\
\text { effective dose } \\
\text { equivalent } \\
\text { (TEDE) of } 5 \text { rem } \\
\text { (0.05 sievert). } \\
\text { b. The sum of }\end{array}$ & $\begin{array}{l}\text { Revise: NV/YMP } \\
\text { RCM } 213.1 \text { a-d. } \\
\text { Except for } \\
\text { planned special } \\
\text { exposures } \\
\text { conducted } \\
\text { consistent with } \\
\S 835.204 \text { and } \\
\text { emergency } \\
\text { exposures } \\
\text { authorized in } \\
\text { accordance with } \\
\S 835.1302, \text { the } \\
\text { occupational } \\
\text { dose received by } \\
\text { general } \\
\text { employees shall } \\
\text { be controlled } \\
\text { such that the } \\
\text { following limits } \\
\text { are not exceeded } \\
\text { in a year: } \\
\text { (a) A total } \\
\text { effective dose } \\
\text { (TED) of } 5 \text { rems }\end{array}$ & $\begin{array}{l}\text { Same as Column } \\
3\end{array}$ & $\begin{array}{l}\text { Same as Column } \\
3\end{array}$ & $\begin{array}{l}\text { Same as Column } \\
3\end{array}$ & $\begin{array}{l}\text { Same as Column } \\
3\end{array}$ & $\begin{array}{l}\text { DRI has adopted } \\
\text { the UNR } \\
\text { Radiation Safety } \\
\text { Manual (RSM). } \\
\text { Reference UNR } \\
\text { RSM Policy III: } \\
\text { Occupational } \\
\text { Dose Limits and } \\
\text { Contamination } \\
\text { Standards. }\end{array}$ & $\begin{array}{l}\text { Same as Column } \\
3\end{array}$ \\
\hline
\end{tabular}




\section{NEVADA TEST SITE RADIATION PROTECTION PROGRAM}

\section{APPENDIX H}

COMPLIANCE DEMONSTRATION TABLE

\begin{tabular}{|c|c|c|c|c|c|c|c|c|}
\hline \multirow[t]{2}{*}{10 CFR 835} & $\begin{array}{c}\text { NV/YMP RCM } \\
\text { Rev } 5 \text { and } \\
\text { NTS RPP } \\
\text { Revision } 0 \\
\end{array}$ & $\begin{array}{c}\text { NSTec } \\
\text { Appendix A }\end{array}$ & $\begin{array}{c}\text { LLNL } \\
\text { Appendix B }\end{array}$ & $\begin{array}{c}\text { LANL } \\
\text { Appendix C }\end{array}$ & $\begin{array}{c}\text { SNL } \\
\text { Appendix D }\end{array}$ & $\begin{array}{c}\text { SNJV } \\
\text { Appendix E }\end{array}$ & $\begin{array}{c}\text { DRI } \\
\text { Appendix F }\end{array}$ & $\begin{array}{c}\text { WSI } \\
\text { Appendix G }\end{array}$ \\
\hline & $\begin{array}{l}\text { Implementation } \\
\text { Reference }\end{array}$ & $\begin{array}{l}\text { Implementation } \\
\text { Reference }\end{array}$ & $\begin{array}{l}\text { Implementation } \\
\text { Reference }\end{array}$ & $\begin{array}{l}\text { Implementation } \\
\text { Reference }\end{array}$ & $\begin{array}{l}\text { Implementation } \\
\text { Reference }\end{array}$ & $\begin{array}{l}\text { Implementation } \\
\text { Reference }\end{array}$ & $\begin{array}{l}\text { Implementation } \\
\text { Reference }\end{array}$ & $\begin{array}{l}\text { Implementation } \\
\text { Reference }\end{array}$ \\
\hline
\end{tabular}

equivalent dose to the whole body for

external exposures

and the committed

equivalent dose to any

organ or tissue other

than the skin or the

lens of the eye of 50

rems (0.5 Sv);

(3) An equivalent dose

to the lens of the eye

of 15 rems ( $0.15 \mathrm{~Sv})$;

and

(4) The sum of the

equivalent dose to the

skin or to any

extremity for external

exposures and the

committed equivalent

dose to the skin or to

any extremity of 50

rems (0.5 Sv). the deep dose equivalent for external

exposures and

the committed

dose equivalent

to any organ or

tissue other than

the lens of the

eye of 50 rem

(0.5 sievert).

c. A lens of the

eye dose

equivalent of 15

rem $(0.15$

sievert).

d. A shallow

dose equivalent

of 50 rem $(0.5$

sievert) to the

skin or to any

extremity.

\section{NV/YMP RCM}

213.3. Planned

special

exposures are

beyond the

scope of

operations

conducted by

NNSA/NSO or

YMORD.

\section{(0.05 Sv);}

(b) The sum of the equivalent

dose to the

whole body for

external

exposures and

the committed

equivalent dose

to any organ or

tissue other than

the skin or the

lens of the eye of

50 rems (0.5 Sv)

(c) An equivalent

dose to the lens

of the eye of 15

rems $(0.15 \mathrm{~Sv})$

and

(d) The sum of

the equivalent

dose to the skin

or to any

extremity for

external

exposures and

the committed

equivalent dose

to the skin or to

any extremity of

50 rems $(0.5 \mathrm{~Sv})$. 


\section{NEVADA TEST SITE RADIATION PROTECTION PROGRAM}

\section{APPENDIX H}

COMPLIANCE DEMONSTRATION TABLE

\begin{tabular}{|c|c|c|c|c|c|c|c|c|}
\hline \multirow[t]{2}{*}{10 CFR 835} & $\begin{array}{c}\text { NV/YMP RCM } \\
\text { Rev } 5 \text { and } \\
\text { NTS RPP } \\
\text { Revision } 0\end{array}$ & $\begin{array}{c}\text { NSTec } \\
\text { Appendix A }\end{array}$ & $\begin{array}{c}\text { LLNL } \\
\text { Appendix B }\end{array}$ & $\begin{array}{c}\text { LANL } \\
\text { Appendix C }\end{array}$ & $\begin{array}{c}\text { SNL } \\
\text { Appendix D }\end{array}$ & $\begin{array}{c}\text { SNJV } \\
\text { Appendix E }\end{array}$ & $\begin{array}{c}\text { DRI } \\
\text { Appendix F }\end{array}$ & $\begin{array}{c}\text { WSI } \\
\text { Appendix G }\end{array}$ \\
\hline & $\begin{array}{l}\text { Implementation } \\
\text { Reference }\end{array}$ & $\begin{array}{l}\text { Implementation } \\
\text { Reference }\end{array}$ & $\begin{array}{l}\text { Implementation } \\
\text { Reference }\end{array}$ & $\begin{array}{l}\text { Implementation } \\
\text { Reference }\end{array}$ & $\begin{array}{l}\text { Implementation } \\
\text { Reference }\end{array}$ & $\begin{array}{l}\text { Implementation } \\
\text { Reference }\end{array}$ & $\begin{array}{l}\text { Implementation } \\
\text { Reference }\end{array}$ & $\begin{array}{l}\text { Implementation } \\
\text { Reference }\end{array}$ \\
\hline
\end{tabular}

\begin{tabular}{|c|c|c|c|c|c|c|c|c|}
\hline $\begin{array}{l}\text { 202(b) All occupational } \\
\text { doses received during } \\
\text { the current year, } \\
\text { except doses resulting } \\
\text { from planned special } \\
\text { exposures conducted } \\
\text { in compliance with } \\
\S 835.204 \text { and } \\
\text { emergency exposures } \\
\text { authorized in } \\
\text { accordance with } \\
\S 835.1302 \text {, shall be } \\
\text { included when } \\
\text { demonstrating } \\
\text { compliance with } \\
\S \S 835.202(a) \text { and } \\
835.207 .\end{array}$ & $\begin{array}{l}\text { NV/YMP RCM } \\
213.1 .03 \text { and } \\
\text {.04. The TEDE } \\
\text { during a year } \\
\text { shall be } \\
\text { determined by } \\
\text { summing the } \\
\text { effective dose } \\
\text { equivalent from } \\
\text { external } \\
\text { exposures and } \\
\text { the committed } \\
\text { effective dose } \\
\text { equivalent } \\
\text { (CEDE) from } \\
\text { intakes during } \\
\text { the year, and } \\
\text { shall be used } \\
\text { when } \\
\text { demonstrating } \\
\text { compliance with } \\
\text { Table 2-1 dose } \\
\text { limits. All } \\
\text { occupational } \\
\text { doses received } \\
\text { during the } \\
\text { current year } \\
\text { except } \\
\text { emergency } \\
\text { exposures } \\
\text { authorized } \\
\text { according to } \\
\text { 10 CFR } \\
\end{array}$ & $\begin{array}{l}\text { Revise: NV/YMP } \\
\text { RCM } 213.1 .03 \\
\text { and .04. The } \\
\text { TED during a } \\
\text { year shall be } \\
\text { determined by } \\
\text { summing the } \\
\text { effective dose } \\
\text { from external } \\
\text { exposures and } \\
\text { the committed } \\
\text { effective dose } \\
\text { (CED) from } \\
\text { intakes during } \\
\text { the year and } \\
\text { shall be used } \\
\text { when } \\
\text { demonstrating } \\
\text { compliance with } \\
\text { Table } 2-1 \text { dose } \\
\text { limits. All } \\
\text { occupational } \\
\text { doses received } \\
\text { during the } \\
\text { current year } \\
\text { except } \\
\text { emergency } \\
\text { exposures } \\
\text { authorized } \\
\text { according to } \\
10 \text { CFR } \\
835.1302 \text { shall } \\
\text { be included. }\end{array}$ & $\begin{array}{l}\text { Same as Column } \\
3\end{array}$ & $\begin{array}{l}\text { Same as Column } \\
3\end{array}$ & $\begin{array}{l}\text { Same as Column } \\
3\end{array}$ & $\begin{array}{l}\text { Same as Column } \\
3\end{array}$ & $\begin{array}{l}\text { Written dose } \\
\text { assessments for } \\
\text { DRI personnel } \\
\text { are determined } \\
\text { by the RSPC. }\end{array}$ & $\begin{array}{l}\text { By written } \\
\text { agreement, dose } \\
\text { assessments are } \\
\text { determined by } \\
\text { the RSPC for } \\
\text { WSI/NV. }\end{array}$ \\
\hline
\end{tabular}




\section{NEVADA TEST SITE RADIATION PROTECTION PROGRAM}

\section{APPENDIX H}

COMPLIANCE DEMONSTRATION TABLE

\begin{tabular}{|c|c|c|c|c|c|c|c|c|}
\hline \multirow[t]{2}{*}{10 CFR 835} & $\begin{array}{c}\text { NV/YMP RCM } \\
\text { Rev } 5 \text { and } \\
\text { NTS RPP } \\
\text { Revision } 0 \\
\end{array}$ & $\begin{array}{c}\text { NSTec } \\
\text { Appendix A }\end{array}$ & $\begin{array}{c}\text { LLNL } \\
\text { Appendix B }\end{array}$ & $\begin{array}{c}\text { LANL } \\
\text { Appendix C }\end{array}$ & $\begin{array}{c}\text { SNL } \\
\text { Appendix D }\end{array}$ & $\begin{array}{c}\text { SNJV } \\
\text { Appendix E }\end{array}$ & $\begin{array}{c}\text { DRI } \\
\text { Appendix F }\end{array}$ & $\begin{array}{c}\text { WSI } \\
\text { Appendix G }\end{array}$ \\
\hline & $\begin{array}{l}\text { Implementation } \\
\text { Reference }\end{array}$ & $\begin{array}{l}\text { Implementation } \\
\text { Reference }\end{array}$ & $\begin{array}{l}\text { Implementation } \\
\text { Reference }\end{array}$ & $\begin{array}{l}\text { Implementation } \\
\text { Reference }\end{array}$ & $\begin{array}{l}\text { Implementation } \\
\text { Reference }\end{array}$ & $\begin{array}{l}\text { Implementation } \\
\text { Reference }\end{array}$ & $\begin{array}{l}\text { Implementation } \\
\text { Reference }\end{array}$ & $\begin{array}{l}\text { Implementation } \\
\text { Reference }\end{array}$ \\
\hline
\end{tabular}

\begin{tabular}{|c|c|c|c|c|c|c|c|c|}
\hline & $\begin{array}{l}835.1302 \text { shall } \\
\text { be included. } \\
\text { NV/YMP RCM } \\
213.3 \text {. Planned } \\
\text { special } \\
\text { exposures are } \\
\text { beyond the } \\
\text { scope of } \\
\text { operations } \\
\text { conducted by } \\
\text { NNSA/NSO or } \\
\text { YMORD. }\end{array}$ & $\begin{array}{l}\text { Revise: NV/YMP } \\
\text { RCM 213.3. } \\
\text { Planned special } \\
\text { exposures are } \\
\text { beyond the } \\
\text { scope of } \\
\text { operations } \\
\text { conducted by } \\
\text { NNSA/NSO or } \\
\text { OCRWM. }\end{array}$ & & & & & & \\
\hline $\begin{array}{l}202(\mathrm{c}) \text { Doses from } \\
\text { background, } \\
\text { therapeutic and } \\
\text { diagnostic medical } \\
\text { radiation, and } \\
\text { participation as a } \\
\text { subject in medical } \\
\text { research programs } \\
\text { shall not be included in } \\
\text { dose records or in the } \\
\text { assessment of } \\
\text { compliance with the } \\
\text { occupational dose } \\
\text { limits. }\end{array}$ & $\begin{array}{l}\text { NV/YMP RCM } \\
\text { Table 2-1 Notes: } \\
\text { 3. Doses from } \\
\text { background, } \\
\text { therapeutic and } \\
\text { diagnostic } \\
\text { medical } \\
\text { radiation, and } \\
\text { participation as a } \\
\text { subject in } \\
\text { medical research } \\
\text { programs shall } \\
\text { not be included } \\
\text { in dose records } \\
\text { or in the } \\
\text { assessment of } \\
\text { compliance with } \\
\text { the occupational } \\
\text { dose limits. }\end{array}$ & $\begin{array}{l}\text { NV/YMP RCM } \\
\text { Table 2-1 Notes: } \\
\text { 3. Doses from } \\
\text { background, } \\
\text { therapeutic and } \\
\text { diagnostic } \\
\text { medical } \\
\text { radiation, and } \\
\text { participation as a } \\
\text { subject in } \\
\text { medical research } \\
\text { programs shall } \\
\text { not be included } \\
\text { in dose records } \\
\text { or in the } \\
\text { assessment of } \\
\text { compliance with } \\
\text { the occupational } \\
\text { dose limits. }\end{array}$ & $\begin{array}{l}\text { Same as Column } \\
3\end{array}$ & $\begin{array}{l}\text { This is outside } \\
\text { the scope of the } \\
\text { LANL/NTS } \\
\text { Radiological } \\
\text { Control Program. } \\
\text { The NTS RSPC } \\
\text { and, by written } \\
\text { agreement, the } \\
\text { LANL RP-2 Dose } \\
\text { Assessment } \\
\text { Team perform } \\
\text { the dose } \\
\text { assessments for } \\
\text { LANL/NTS. The } \\
\text { LANL RP-2 } \\
\text { Radiation } \\
\text { Information } \\
\text { Management } \\
\text { Team records } \\
\text { and maintains }\end{array}$ & $\begin{array}{l}\text { Same as Column } \\
3\end{array}$ & $\begin{array}{l}\text { Same as Column } \\
3\end{array}$ & $\begin{array}{l}\text { Same as Column } \\
\text { 3. Regarding } \\
\text { dually badged } \\
\text { employees, UNR } \\
\text { subtracts } \\
\text { background via } \\
\text { subtraction of } \\
\text { dose recorded } \\
\text { on a control } \\
\text { badge. }\end{array}$ & $\begin{array}{l}\text { Same as Column } \\
3\end{array}$ \\
\hline
\end{tabular}

$\mathrm{H}-20$ 


\section{NEVADA TEST SITE RADIATION PROTECTION PROGRAM}

\section{APPENDIX H}

COMPLIANCE DEMONSTRATION TABLE

\begin{tabular}{|c|c|c|c|c|c|c|c|c|}
\hline \multirow[t]{2}{*}{10 CFR 835} & $\begin{array}{c}\text { NV/YMP RCM } \\
\text { Rev } 5 \text { and } \\
\text { NTS RPP } \\
\text { Revision } 0 \\
\end{array}$ & $\begin{array}{c}\text { NSTec } \\
\text { Appendix A }\end{array}$ & $\begin{array}{c}\text { LLNL } \\
\text { Appendix B }\end{array}$ & $\begin{array}{c}\text { LANL } \\
\text { Appendix C }\end{array}$ & $\begin{array}{c}\text { SNL } \\
\text { Appendix D }\end{array}$ & $\begin{array}{c}\text { SNJV } \\
\text { Appendix E }\end{array}$ & $\begin{array}{c}\text { DRI } \\
\text { Appendix F }\end{array}$ & $\begin{array}{c}\text { WSI } \\
\text { Appendix G }\end{array}$ \\
\hline & $\begin{array}{l}\text { Implementation } \\
\text { Reference }\end{array}$ & $\begin{array}{l}\text { Implementation } \\
\text { Reference }\end{array}$ & $\begin{array}{l}\text { Implementation } \\
\text { Reference }\end{array}$ & $\begin{array}{l}\text { Implementation } \\
\text { Reference }\end{array}$ & $\begin{array}{l}\text { Implementation } \\
\text { Reference }\end{array}$ & $\begin{array}{l}\text { Implementation } \\
\text { Reference }\end{array}$ & $\begin{array}{l}\text { Implementation } \\
\text { Reference }\end{array}$ & $\begin{array}{l}\text { Implementation } \\
\text { Reference }\end{array}$ \\
\hline
\end{tabular}

\begin{tabular}{|c|c|c|c|c|c|c|c|c|}
\hline & & & & $\begin{array}{l}\text { LANL employee } \\
\text { dose } \\
\text { assessments } \\
\text { provided by the } \\
\text { NTS RSPC. }\end{array}$ & & & & \\
\hline $\begin{array}{l}835.203 \text { Combining } \\
\text { internal and external } \\
\text { dose equivalents. } \\
\text { 203(a) The total } \\
\text { effective dose during a } \\
\text { year shall be } \\
\text { determined by } \\
\text { summing the effective } \\
\text { dose from external } \\
\text { exposures and the } \\
\text { committed effective } \\
\text { dose from intakes } \\
\text { during the year. }\end{array}$ & $\begin{array}{l}\text { NV/YMP RCM } \\
213.1 .03 \text {. The } \\
\text { TEDE during a } \\
\text { year shall be } \\
\text { determined by } \\
\text { summing the } \\
\text { effective dose } \\
\text { equivalent from } \\
\text { external } \\
\text { exposures and } \\
\text { the CEDE from } \\
\text { intakes during } \\
\text { the year and } \\
\text { shall be used } \\
\text { when } \\
\text { demonstrating } \\
\text { compliance with } \\
\text { Table 2-1 dose } \\
\text { limits. }\end{array}$ & $\begin{array}{l}\text { Revise: NV/YMP } \\
\text { RCM 213.1.03. } \\
\text { The TED during } \\
\text { a year shall be } \\
\text { determined by } \\
\text { summing the } \\
\text { effective dose } \\
\text { from external } \\
\text { exposures and } \\
\text { the CED from } \\
\text { intakes during } \\
\text { the year and } \\
\text { shall be used } \\
\text { when } \\
\text { demonstrating } \\
\text { compliance with } \\
\text { Table 2-1 dose } \\
\text { limits. }\end{array}$ & $\begin{array}{l}\text { Dosimetry } \\
\text { services are } \\
\text { provided to LLNL } \\
\text { by the RSPC per } \\
\text { NV/YMP RCM } \\
\text { 141.3.e. }\end{array}$ & $\begin{array}{l}\text { This is outside } \\
\text { the scope of the } \\
\text { LANL/NTS } \\
\text { Radiological } \\
\text { Control Program. } \\
\text { The NTS RSPC } \\
\text { and, by written } \\
\text { agreement, the } \\
\text { LANL RP-2 Dose } \\
\text { Assessment } \\
\text { Team perform } \\
\text { the dose } \\
\text { assessments for } \\
\text { LANL/NTS. } \\
\text { The LANL RP-2 } \\
\text { Radiation } \\
\text { Information } \\
\text { Management } \\
\text { Team records } \\
\text { and maintains } \\
\text { LANL employee } \\
\text { dose } \\
\text { assessments } \\
\text { provided by the } \\
\text { NTS RSPC. }\end{array}$ & $\begin{array}{l}\text { Same as Column } \\
3\end{array}$ & $\begin{array}{l}\text { NV/YMP RCM } \\
\text { 141.3.e. The } \\
\text { RSPC shall } \\
\text { provide the } \\
\text { following: } \\
\text { e. External and } \\
\text { internal } \\
\text { dosimetry } \\
\text { services. }\end{array}$ & $\begin{array}{l}\text { Not applicable to } \\
\text { DRI. Dosimetry } \\
\text { services, } \\
\text { including the } \\
\text { calculation of } \\
\text { TED, are } \\
\text { provided to DRI } \\
\text { by the RSPC per } \\
\text { NV/YMP RCM } \\
\text { 141.3.e. }\end{array}$ & $\begin{array}{l}\text { By written } \\
\text { agreement, } \\
\text { dosimetry } \\
\text { services are } \\
\text { provided to } \\
\text { WSI/NV by the } \\
\text { RSPC per } \\
\text { NV/YMP RCM } \\
\text { 141.3.e. }\end{array}$ \\
\hline $\begin{array}{l}\text { 203(b) Determinations } \\
\text { of the effective dose }\end{array}$ & $\begin{array}{l}\text { NV/YMP RCM } \\
\text { Appendix 2B. }\end{array}$ & $\begin{array}{l}\text { Remove } \\
\text { NV/YMP RCM }\end{array}$ & $\begin{array}{l}\text { Dosimetry } \\
\text { services are }\end{array}$ & $\begin{array}{l}\text { This is outside } \\
\text { the scope of the }\end{array}$ & $\begin{array}{l}\text { Same as Column } \\
3\end{array}$ & $\begin{array}{l}\text { NV/YMP RCM } \\
\text { 141.3.e. The }\end{array}$ & $\begin{array}{l}\text { Dosimetry } \\
\text { services are }\end{array}$ & $\begin{array}{l}\text { By written } \\
\text { agreement, }\end{array}$ \\
\hline
\end{tabular}

$$
\mathrm{H}-21
$$




\section{NEVADA TEST SITE RADIATION PROTECTION PROGRAM}

\section{APPENDIX H}

COMPLIANCE DEMONSTRATION TABLE

\begin{tabular}{|c|c|c|c|c|c|c|c|c|}
\hline \multirow[t]{2}{*}{10 CFR 835} & $\begin{array}{l}\text { NV/YMP RCM } \\
\text { Rev } 5 \text { and } \\
\text { NTS RPP } \\
\text { Revision } 0 \\
\end{array}$ & $\begin{array}{c}\text { NSTec } \\
\text { Appendix A }\end{array}$ & $\begin{array}{c}\text { LLNL } \\
\text { Appendix B }\end{array}$ & $\begin{array}{c}\text { LANL } \\
\text { Appendix C }\end{array}$ & $\begin{array}{c}\text { SNL } \\
\text { Appendix D }\end{array}$ & $\begin{array}{c}\text { SNJV } \\
\text { Appendix E }\end{array}$ & $\begin{array}{c}\text { DRI } \\
\text { Appendix F }\end{array}$ & $\begin{array}{c}\text { WSI } \\
\text { Appendix G }\end{array}$ \\
\hline & $\begin{array}{l}\text { Implementation } \\
\text { Reference }\end{array}$ & $\begin{array}{l}\text { Implementation } \\
\text { Reference }\end{array}$ & $\begin{array}{l}\text { Implementation } \\
\text { Reference }\end{array}$ & $\begin{array}{l}\text { Implementation } \\
\text { Reference }\end{array}$ & $\begin{array}{l}\text { Implementation } \\
\text { Reference }\end{array}$ & $\begin{array}{l}\text { Implementation } \\
\text { Reference }\end{array}$ & $\begin{array}{l}\text { Implementation } \\
\text { Reference }\end{array}$ & $\begin{array}{l}\text { Implementation } \\
\text { Reference }\end{array}$ \\
\hline
\end{tabular}

\begin{tabular}{|c|c|c|c|c|c|c|c|c|}
\hline $\begin{array}{l}\text { shall be made using } \\
\text { the radiation and } \\
\text { tissue weighting factor } \\
\text { values provided in } \S \\
835.2 \text {. }\end{array}$ & $\begin{array}{l}\text { Table 2B-1, } \\
\text { Weighting } \\
\text { Factors for } \\
\text { Organs and } \\
\text { Tissues }\end{array}$ & $\begin{array}{l}\text { Appendix 2B. } \\
\text { Add: NV/YMP } \\
\text { RCM 213.1.06 } \\
\text { Determinations } \\
\text { of the effective } \\
\text { dose shall be } \\
\text { made using the } \\
\text { radiation and } \\
\text { tissue weighting } \\
\text { factors provided } \\
\text { in } 10 \text { CFR } 835.2 \text {, } \\
\text { "Radiation } \\
\text { Weighting } \\
\text { Factors." }\end{array}$ & $\begin{array}{l}\text { provided to LLNL } \\
\text { by the RSPC per } \\
\text { NV/YMP RCM } \\
\text { 141.3.e. }\end{array}$ & $\begin{array}{l}\text { LANL/NTS } \\
\text { Radiological } \\
\text { Control Program. } \\
\text { The NTS RSPC } \\
\text { and, by written } \\
\text { agreement, the } \\
\text { LANL RP-2 Dose } \\
\text { Assessment } \\
\text { Team perform } \\
\text { the dose } \\
\text { assessments for } \\
\text { LANL/NTS. The } \\
\text { LANL RP-2 } \\
\text { Radiation } \\
\text { Information } \\
\text { Management } \\
\text { Team records } \\
\text { and maintains } \\
\text { LANL employee } \\
\text { dose } \\
\text { assessments } \\
\text { provided by the } \\
\text { NTS RSPC. }\end{array}$ & & $\begin{array}{l}\text { RSPC shall } \\
\text { provide the } \\
\text { following: } \\
\text { e. External and } \\
\text { internal } \\
\text { dosimetry } \\
\text { services. }\end{array}$ & $\begin{array}{l}\text { provided to DRI } \\
\text { by the RSPC per } \\
\text { NV/YMP RCM } \\
\text { 141.3.e. }\end{array}$ & $\begin{array}{l}\text { dosimetry } \\
\text { services are } \\
\text { provided to } \\
\text { WSI/NV by the } \\
\text { RSPC per } \\
\text { NV/YMP RCM } \\
\text { 141.3.e. }\end{array}$ \\
\hline $\begin{array}{l}\text { 835.204 Planned } \\
\text { Special Exposures. } \\
\text { 204(a) A planned } \\
\text { special exposure may } \\
\text { be authorized for a } \\
\text { radiological worker to } \\
\text { receive doses in } \\
\text { addition to and } \\
\text { accounted for }\end{array}$ & $\begin{array}{l}\text { NV/YMP RCM } \\
213.3 \text {. Planned } \\
\text { special } \\
\text { exposures are } \\
\text { beyond the } \\
\text { scope of } \\
\text { operations } \\
\text { conducted by } \\
\text { NNSA/NSO or } \\
\text { YMORD. }\end{array}$ & $\begin{array}{l}\text { Revise: NV/YMP } \\
\text { RCM 213.3. } \\
\text { Planned special } \\
\text { exposures are } \\
\text { beyond the } \\
\text { scope of } \\
\text { operations } \\
\text { conducted by } \\
\text { NNSA/NSO or } \\
\text { OCRWM. }\end{array}$ & $\begin{array}{l}\text { Planned special } \\
\text { exposures are } \\
\text { beyond the } \\
\text { scope of } \\
\text { operations } \\
\text { conducted by } \\
\text { LLNL at the NTS. } \\
\text { LLNL will not } \\
\text { conduct a } \\
\text { planned special }\end{array}$ & $\begin{array}{l}\text { This is outside } \\
\text { the scope of the } \\
\text { LANL/NTS } \\
\text { Radiological } \\
\text { Control Program. } \\
\text { Planned special } \\
\text { exposures are } \\
\text { beyond the } \\
\text { scope of } \\
\text { operations }\end{array}$ & $\begin{array}{l}\text { Same as Column } \\
3\end{array}$ & $\begin{array}{l}\text { Same as Column } \\
3\end{array}$ & $\begin{array}{l}\text { The contents of } \\
\text { this section are } \\
\text { not applicable to } \\
\text { DRI as there are } \\
\text { no } \\
\text { circumstances } \\
\text { for planned } \\
\text { special } \\
\text { exposures to } \\
\text { employees }\end{array}$ & $\begin{array}{l}\text { The contents of } \\
\text { this section are } \\
\text { not applicable to } \\
\text { WSI/NV as there } \\
\text { are no } \\
\text { circumstances } \\
\text { for planned } \\
\text { special } \\
\text { exposures to } \\
\text { employees. }\end{array}$ \\
\hline
\end{tabular}

H-22 


\section{NEVADA TEST SITE RADIATION PROTECTION PROGRAM}

\section{APPENDIX H}

COMPLIANCE DEMONSTRATION TABLE

\begin{tabular}{|c|c|c|c|c|c|c|c|c|}
\hline \multirow[t]{2}{*}{10 CFR 835} & $\begin{array}{c}\text { NV/YMP RCM } \\
\text { Rev } 5 \text { and } \\
\text { NTS RPP } \\
\text { Revision } 0\end{array}$ & $\begin{array}{c}\text { NSTec } \\
\text { Appendix A }\end{array}$ & $\begin{array}{c}\text { LLNL } \\
\text { Appendix B }\end{array}$ & $\begin{array}{c}\text { LANL } \\
\text { Appendix C }\end{array}$ & $\begin{array}{c}\text { SNL } \\
\text { Appendix D }\end{array}$ & $\begin{array}{c}\text { SNJV } \\
\text { Appendix E }\end{array}$ & $\begin{array}{c}\text { DRI } \\
\text { Appendix F }\end{array}$ & $\begin{array}{c}\text { WSI } \\
\text { Appendix G }\end{array}$ \\
\hline & $\begin{array}{l}\text { Implementation } \\
\text { Reference }\end{array}$ & $\begin{array}{l}\text { Implementation } \\
\text { Reference }\end{array}$ & $\begin{array}{l}\text { Implementation } \\
\text { Reference }\end{array}$ & $\begin{array}{l}\text { Implementation } \\
\text { Reference }\end{array}$ & $\begin{array}{l}\text { Implementation } \\
\text { Reference }\end{array}$ & $\begin{array}{l}\text { Implementation } \\
\text { Reference }\end{array}$ & $\begin{array}{l}\text { Implementation } \\
\text { Reference }\end{array}$ & $\begin{array}{l}\text { Implementation } \\
\text { Reference }\end{array}$ \\
\hline
\end{tabular}

separately from the

doses received under

the limits specified in

$\S 835.202(a)$, provided

that each of the

following conditions is

satisfied:

(1) The planned

special exposure is

considered only in an

exceptional situation

when alternatives that

might prevent a

radiological worker

from exceeding the

limits in §835.202(a)

are unavailable or

impractical;

(2) The contractor

management (and

employer, if the

employer is not the

contractor) specifically

requests the planned

special exposure, in

writing; and

(3) Joint written

approval is received

from the appropriate

DOE Headquarters

program office and the

Secretarial Officer

responsible for

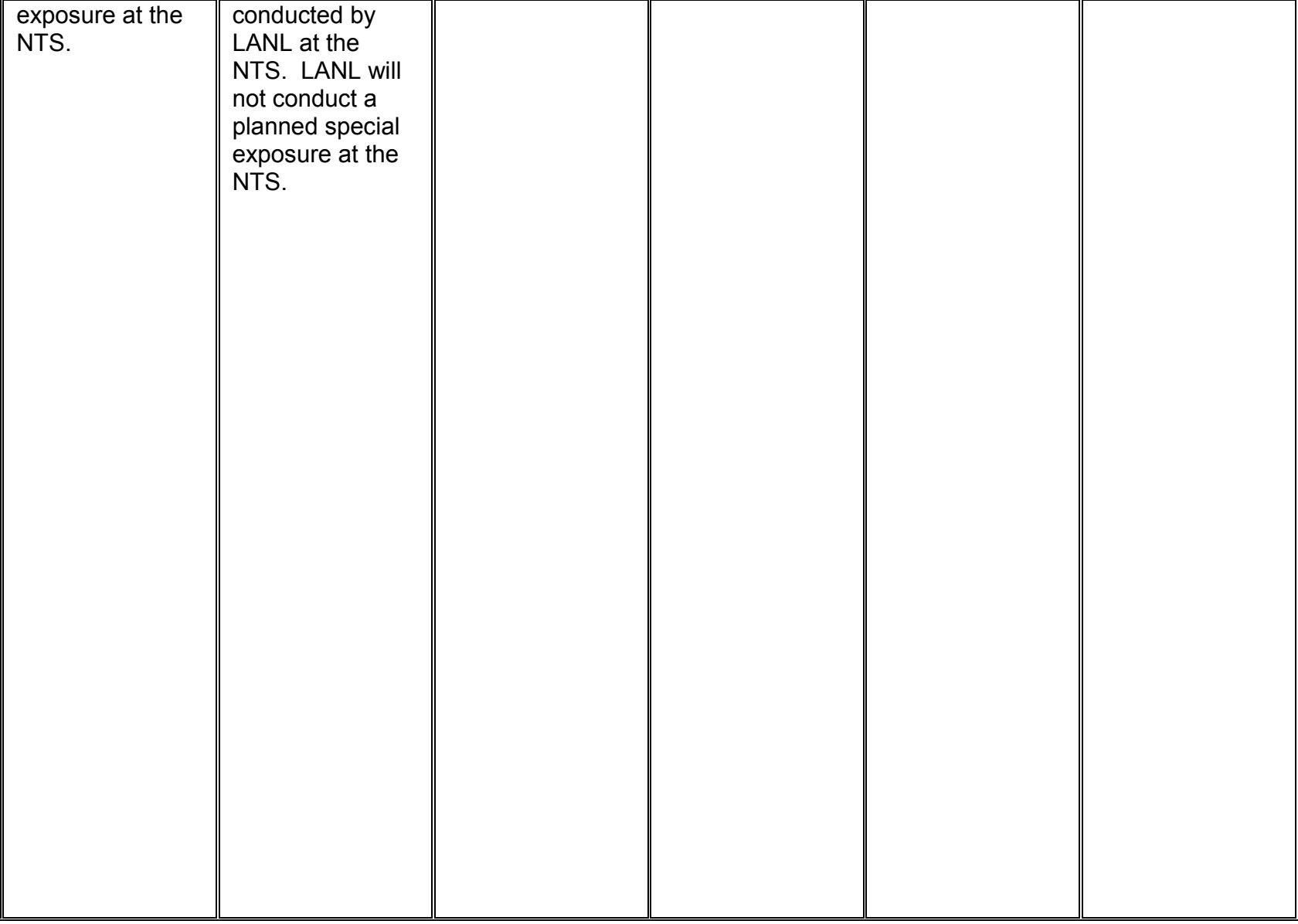




\section{NEVADA TEST SITE RADIATION PROTECTION PROGRAM}

\section{APPENDIX H}

COMPLIANCE DEMONSTRATION TABLE

\begin{tabular}{|c|c|c|c||c||c||c||c||c|}
\hline \multirow{2}{*}{ 10 CFR 835 } & $\begin{array}{c}\text { NV/YMP RCM } \\
\text { Rev 5 and } \\
\text { NTS RPP } \\
\text { Revision 0 }\end{array}$ & Appendix A & Appendix B & Appendix C & Appendix D & SNJV \\
\cline { 2 - 7 } & $\begin{array}{c}\text { Implementation } \\
\text { Reference }\end{array}$ & $\begin{array}{c}\text { Implementation } \\
\text { Reference }\end{array}$ & $\begin{array}{c}\text { Implementation } \\
\text { Reference }\end{array}$ & $\begin{array}{c}\text { Implementation } \\
\text { Reference }\end{array}$ & $\begin{array}{c}\text { Implementation } \\
\text { Reference }\end{array}$ & $\begin{array}{c}\text { Implementation } \\
\text { Reference }\end{array}$ & $\begin{array}{c}\text { Implementation } \\
\text { Reference }\end{array}$ & $\begin{array}{c}\text { Implementation } \\
\text { Reference }\end{array}$ \\
\hline
\end{tabular}

\begin{tabular}{|c|c|c|c|c|c|c|c|c|}
\hline $\begin{array}{l}\text { environment, safety } \\
\text { and health matters. }\end{array}$ & & & & & & & & \\
\hline $\begin{array}{l}204(b) \text { Prior to } \\
\text { requesting an } \\
\text { individual to participate } \\
\text { in an authorized } \\
\text { planned special } \\
\text { exposure, the } \\
\text { individual's dose from } \\
\text { all previous planned } \\
\text { special exposures and } \\
\text { all doses in excess of } \\
\text { the occupational dose } \\
\text { limits shall be } \\
\text { determined. }\end{array}$ & $\begin{array}{l}\text { NV/YMP RCM } \\
213.3 \text {. Planned } \\
\text { special } \\
\text { exposures are } \\
\text { beyond the } \\
\text { scope of } \\
\text { operations } \\
\text { conducted by } \\
\text { NNSA/NSO or } \\
\text { YMORD. }\end{array}$ & $\begin{array}{l}\text { Revise: NV/YMP } \\
\text { RCM 213.3. } \\
\text { Planned special } \\
\text { exposures are } \\
\text { beyond the } \\
\text { scope of } \\
\text { operations } \\
\text { conducted by } \\
\text { NNSA/NSO or } \\
\text { OCRWM. }\end{array}$ & $\begin{array}{l}\text { Planned special } \\
\text { exposures are } \\
\text { beyond the } \\
\text { scope of } \\
\text { operations } \\
\text { conducted by } \\
\text { LLNL at the NTS. } \\
\text { LLNL will not } \\
\text { conduct a } \\
\text { planned special } \\
\text { exposure at the } \\
\text { NTS. }\end{array}$ & $\begin{array}{l}\text { This is outside } \\
\text { the scope of the } \\
\text { LANL/NTS } \\
\text { Radiological } \\
\text { Control Program. } \\
\text { Planned special } \\
\text { exposures are } \\
\text { beyond the } \\
\text { scope of } \\
\text { operations } \\
\text { conducted by } \\
\text { LANL at the } \\
\text { NTS. LANL will } \\
\text { not conduct a } \\
\text { planned special } \\
\text { exposure at the } \\
\text { NTS. }\end{array}$ & $\begin{array}{l}\text { Same as Column } \\
3\end{array}$ & $\begin{array}{l}\text { Same as Column } \\
3\end{array}$ & $\begin{array}{l}\text { The contents of } \\
\text { this section are } \\
\text { not applicable to } \\
\text { DRI as there are } \\
\text { no } \\
\text { circumstances } \\
\text { for planned } \\
\text { special } \\
\text { exposures to } \\
\text { employees. }\end{array}$ & $\begin{array}{l}\text { The contents of } \\
\text { this section are } \\
\text { not applicable to } \\
\text { WSI/NV as there } \\
\text { are no } \\
\text { circumstances } \\
\text { for planned } \\
\text { special } \\
\text { exposures to } \\
\text { employees. }\end{array}$ \\
\hline $\begin{array}{l}204(c) \text { An individual } \\
\text { shall not receive a } \\
\text { planned special } \\
\text { exposure that, in } \\
\text { addition to the doses } \\
\text { determined in } \\
\text { \$835.204(b), would } \\
\text { result in a dose } \\
\text { exceeding the } \\
\text { following: } \\
\text { (1) In a year, the } \\
\text { numerical values of } \\
\text { the dose limits } \\
\text { established at }\end{array}$ & $\begin{array}{l}\text { NV/YMP RCM } \\
213.3 \text {. Planned } \\
\text { special } \\
\text { exposures are } \\
\text { beyond the } \\
\text { scope of } \\
\text { operations } \\
\text { conducted by } \\
\text { NNSA/NSO or } \\
\text { YMORD. }\end{array}$ & $\begin{array}{l}\text { Revise: NV/YMP } \\
\text { RCM 213.3. } \\
\text { Planned special } \\
\text { exposures are } \\
\text { beyond the } \\
\text { scope of } \\
\text { operations } \\
\text { conducted by } \\
\text { NNSA/NSO or } \\
\text { OCRWM. }\end{array}$ & $\begin{array}{l}\text { Planned special } \\
\text { exposures are } \\
\text { beyond the } \\
\text { scope of } \\
\text { operations } \\
\text { conducted by } \\
\text { LLNL at the NTS. } \\
\text { LLNL will not } \\
\text { conduct a } \\
\text { planned special } \\
\text { exposure at the } \\
\text { NTS. }\end{array}$ & $\begin{array}{l}\text { This is outside } \\
\text { the scope of the } \\
\text { LANL/NTS } \\
\text { Radiological } \\
\text { Control Program. } \\
\text { Planned special } \\
\text { exposures are } \\
\text { beyond the } \\
\text { scope of } \\
\text { operations } \\
\text { conducted by } \\
\text { LANL at the } \\
\text { NTS. LANL will } \\
\text { not conduct a }\end{array}$ & $\begin{array}{l}\text { Same as Column } \\
3\end{array}$ & $\begin{array}{l}\text { Same as Column } \\
3\end{array}$ & $\begin{array}{l}\text { The contents of } \\
\text { this section are } \\
\text { not applicable to } \\
\text { DRI as there are } \\
\text { no } \\
\text { circumstances } \\
\text { for planned } \\
\text { special } \\
\text { exposures to } \\
\text { employees. }\end{array}$ & $\begin{array}{l}\text { The contents of } \\
\text { this section are } \\
\text { not applicable to } \\
\text { WSI/NV as there } \\
\text { are no } \\
\text { circumstances } \\
\text { for planned } \\
\text { special } \\
\text { exposures to } \\
\text { employees. }\end{array}$ \\
\hline
\end{tabular}

$\mathrm{H}-24$ 


\section{NEVADA TEST SITE RADIATION PROTECTION PROGRAM}

\section{APPENDIX H}

COMPLIANCE DEMONSTRATION TABLE

\begin{tabular}{|c|c|c|c|c|c|c|c|c|}
\hline \multirow[t]{2}{*}{10 CFR 835} & $\begin{array}{l}\text { NV/YMP RCM } \\
\text { Rev } 5 \text { and } \\
\text { NTS RPP } \\
\text { Revision } 0 \\
\end{array}$ & $\begin{array}{c}\text { NSTec } \\
\text { Appendix A }\end{array}$ & $\begin{array}{c}\text { LLNL } \\
\text { Appendix B }\end{array}$ & $\begin{array}{c}\text { LANL } \\
\text { Appendix C }\end{array}$ & $\begin{array}{c}\text { SNL } \\
\text { Appendix D }\end{array}$ & $\begin{array}{c}\text { SNJV } \\
\text { Appendix E }\end{array}$ & $\begin{array}{c}\text { DRI } \\
\text { Appendix F }\end{array}$ & $\begin{array}{c}\text { WSI } \\
\text { Appendix G }\end{array}$ \\
\hline & $\begin{array}{l}\text { Implementation } \\
\text { Reference }\end{array}$ & $\begin{array}{l}\text { Implementation } \\
\text { Reference }\end{array}$ & $\begin{array}{l}\text { Implementation } \\
\text { Reference }\end{array}$ & $\begin{array}{l}\text { Implementation } \\
\text { Reference }\end{array}$ & $\begin{array}{l}\text { Implementation } \\
\text { Reference }\end{array}$ & $\begin{array}{l}\text { Implementation } \\
\text { Reference }\end{array}$ & $\begin{array}{l}\text { Implementation } \\
\text { Reference }\end{array}$ & $\begin{array}{l}\text { Implementation } \\
\text { Reference }\end{array}$ \\
\hline
\end{tabular}

\begin{tabular}{|c|c|c|c|c|c|c|c|c|}
\hline $\begin{array}{l}\text { §835.202(a); and } \\
\text { (2) Over the } \\
\text { individual's lifetime, } \\
\text { five times the } \\
\text { numerical values of } \\
\text { the dose limits } \\
\text { established at } \\
\S 835.202(a) .\end{array}$ & & & & $\begin{array}{l}\text { planned special } \\
\text { exposure at the } \\
\text { NTS. }\end{array}$ & & & & \\
\hline $\begin{array}{l}204(d) \text { Prior to a } \\
\text { planned special } \\
\text { exposure, written } \\
\text { consent shall be } \\
\text { obtained from each } \\
\text { individual involved. } \\
\text { Each such written } \\
\text { consent shall include: } \\
\text { (1) The purpose of the } \\
\text { planned operations } \\
\text { and procedures to be } \\
\text { used; (2) The } \\
\text { estimated doses and } \\
\text { associated potential } \\
\text { risks and specific } \\
\text { radiological conditions } \\
\text { and other hazards } \\
\text { which might be } \\
\text { involved in performing } \\
\text { the task; and } \\
\text { (3) Instructions on the } \\
\text { measures to be taken } \\
\text { to keep the dose } \\
\text { ALARA considering } \\
\text { other risks that may be }\end{array}$ & $\begin{array}{l}\text { NV/YMP RCM } \\
213.3 \text {. Planned } \\
\text { special } \\
\text { exposures are } \\
\text { beyond the } \\
\text { scope of } \\
\text { operations } \\
\text { conducted by } \\
\text { NNSA/NSO or } \\
\text { YMORD. }\end{array}$ & $\begin{array}{l}\text { Revise: NV/YMP } \\
\text { RCM } 213.3 . \\
\text { Planned special } \\
\text { exposures are } \\
\text { beyond the } \\
\text { scope of } \\
\text { operations } \\
\text { conducted by } \\
\text { NNSA/NSO or } \\
\text { OCRWM. }\end{array}$ & $\begin{array}{l}\text { Planned special } \\
\text { exposures are } \\
\text { beyond the } \\
\text { scope of } \\
\text { operations } \\
\text { conducted by } \\
\text { LLNL-N. LLNL } \\
\text { will not conduct a } \\
\text { planned special } \\
\text { exposure at the } \\
\text { NTS. }\end{array}$ & $\begin{array}{l}\text { This is outside } \\
\text { the scope of the } \\
\text { LANL/NTS } \\
\text { Radiological } \\
\text { Control Program. } \\
\text { Planned special } \\
\text { exposures are } \\
\text { beyond the } \\
\text { scope of } \\
\text { operations } \\
\text { conducted by } \\
\text { LANL at the } \\
\text { NTS. LANL will } \\
\text { not conduct a } \\
\text { planned special } \\
\text { exposure at the } \\
\text { NTS. }\end{array}$ & $\begin{array}{l}\text { Same as Column } \\
3\end{array}$ & $\begin{array}{l}\text { Same as Column } \\
3\end{array}$ & $\begin{array}{l}\text { The contents of } \\
\text { this section are } \\
\text { not applicable to } \\
\text { DRI as there are } \\
\text { no } \\
\text { circumstances } \\
\text { for planned } \\
\text { special } \\
\text { exposures to } \\
\text { employees. }\end{array}$ & $\begin{array}{l}\text { The contents of } \\
\text { this section are } \\
\text { not applicable to } \\
\text { WSI/NV as there } \\
\text { are no } \\
\text { circumstances } \\
\text { for planned } \\
\text { special } \\
\text { exposures to } \\
\text { employees. }\end{array}$ \\
\hline
\end{tabular}




\section{NEVADA TEST SITE RADIATION PROTECTION PROGRAM}

\section{APPENDIX H}

COMPLIANCE DEMONSTRATION TABLE

\begin{tabular}{|c|c|c|c||c||c||c||c||c|}
\hline \multirow{2}{*}{ 10 CFR 835 } & $\begin{array}{c}\text { NV/YMP RCM } \\
\text { Rev 5 and } \\
\text { NTS RPP } \\
\text { Revision 0 }\end{array}$ & Appendix A & Appendix B & Appendix C & Appendix D & SNJV \\
\cline { 2 - 7 } & $\begin{array}{c}\text { Implementation } \\
\text { Reference }\end{array}$ & $\begin{array}{c}\text { Implementation } \\
\text { Reference }\end{array}$ & $\begin{array}{c}\text { Implementation } \\
\text { Reference }\end{array}$ & $\begin{array}{c}\text { Implementation } \\
\text { Reference }\end{array}$ & $\begin{array}{c}\text { Implementation } \\
\text { Reference }\end{array}$ & $\begin{array}{c}\text { Implementation } \\
\text { Reference }\end{array}$ & $\begin{array}{c}\text { Implementation } \\
\text { Reference }\end{array}$ & $\begin{array}{c}\text { Implementation } \\
\text { Reference }\end{array}$ \\
\hline
\end{tabular}

\begin{tabular}{|c|c|c|c|c|c|c|c|c|}
\hline present. & & & & & & & & \\
\hline $\begin{array}{l}204(e) \text { Records of the } \\
\text { conduct of a planned } \\
\text { special exposure Shall } \\
\text { be maintained and a } \\
\text { written report } \\
\text { submitted within } 30 \\
\text { days after the planned } \\
\text { special exposure to } \\
\text { the approving } \\
\text { organizations } \\
\text { identified in } \\
\S 835.204(a)(3) .\end{array}$ & $\begin{array}{l}\text { NV/YMP RCM } \\
213.3 \text {. Planned } \\
\text { special } \\
\text { exposures are } \\
\text { beyond the } \\
\text { scope of } \\
\text { operations } \\
\text { conducted by } \\
\text { NNSA/NSO or } \\
\text { YMORD. }\end{array}$ & $\begin{array}{l}\text { Revise: NV/YMP } \\
\text { RCM } 213.3 . \\
\text { Planned special } \\
\text { exposures are } \\
\text { beyond the } \\
\text { scope of } \\
\text { operations } \\
\text { conducted by } \\
\text { NNSA/NSO or } \\
\text { OCRWM. }\end{array}$ & $\begin{array}{l}\text { Planned special } \\
\text { exposures are } \\
\text { beyond the } \\
\text { scope of } \\
\text { operations } \\
\text { conducted by } \\
\text { LLNL at the NTS. } \\
\text { LLNL will not } \\
\text { conduct a } \\
\text { planned special } \\
\text { exposure at the } \\
\text { NTS. }\end{array}$ & $\begin{array}{l}\text { This is outside } \\
\text { the scope of the } \\
\text { LANL/NTS } \\
\text { Radiological } \\
\text { Control Program. } \\
\text { Planned special } \\
\text { exposures are } \\
\text { beyond the } \\
\text { scope of } \\
\text { operations } \\
\text { conducted by } \\
\text { LANL at the } \\
\text { NTS. LANL will } \\
\text { not conduct a } \\
\text { planned special } \\
\text { exposure at the } \\
\text { NTS. }\end{array}$ & $\begin{array}{l}\text { Same as Column } \\
3\end{array}$ & $\begin{array}{l}\text { Same as Column } \\
3\end{array}$ & $\begin{array}{l}\text { The contents of } \\
\text { this section are } \\
\text { not applicable to } \\
\text { DRI as there are } \\
\text { no } \\
\text { circumstances } \\
\text { for planned } \\
\text { special } \\
\text { exposures to } \\
\text { employees. }\end{array}$ & $\begin{array}{l}\text { The contents of } \\
\text { this section are } \\
\text { not applicable to } \\
\text { WSI/NV as there } \\
\text { are no } \\
\text { circumstances } \\
\text { for planned } \\
\text { special } \\
\text { exposures to } \\
\text { employees. }\end{array}$ \\
\hline $\begin{array}{l}204(f) \text { The dose from } \\
\text { planned special } \\
\text { exposures is not to be } \\
\text { considered in } \\
\text { controlling future } \\
\text { occupational dose of } \\
\text { the individual under } \\
\S 835.202(a), \text { but is to } \\
\text { be included in records } \\
\text { and reports required } \\
\text { under this part. }\end{array}$ & $\begin{array}{l}\text { NV/YMP RCM } \\
\text { 213.3. Planned } \\
\text { special } \\
\text { exposures are } \\
\text { beyond the } \\
\text { scope of } \\
\text { operations } \\
\text { conducted by } \\
\text { NNSA/NSO or } \\
\text { YMORD. }\end{array}$ & $\begin{array}{l}\text { Revise: NV/YMP } \\
\text { RCM } 213.3 . \\
\text { Planned special } \\
\text { exposures are } \\
\text { beyond the } \\
\text { scope of } \\
\text { operations } \\
\text { conducted by } \\
\text { NNSA/NSO or } \\
\text { OCRWM. }\end{array}$ & $\begin{array}{l}\text { Planned special } \\
\text { exposures are } \\
\text { beyond the } \\
\text { scope of } \\
\text { operations } \\
\text { conducted by } \\
\text { LLNL at the NTS. } \\
\text { LLNL will not } \\
\text { conduct a } \\
\text { planned special } \\
\text { exposure at the } \\
\text { NTS. }\end{array}$ & $\begin{array}{l}\text { This is outside } \\
\text { the scope of the } \\
\text { LANL/NTS } \\
\text { Radiological } \\
\text { Control Program. } \\
\text { Planned special } \\
\text { exposures are } \\
\text { beyond the } \\
\text { scope of } \\
\text { operations } \\
\text { conducted by } \\
\text { LANL at the } \\
\text { NTS. LANL will } \\
\text { not conduct a } \\
\end{array}$ & $\begin{array}{l}\text { Same as Column } \\
3\end{array}$ & $\begin{array}{l}\text { Same as Column } \\
3\end{array}$ & $\begin{array}{l}\text { The contents of } \\
\text { this section are } \\
\text { not applicable to } \\
\text { DRI as there are } \\
\text { no } \\
\text { circumstances } \\
\text { for planned } \\
\text { special } \\
\text { exposures to } \\
\text { employees. }\end{array}$ & $\begin{array}{l}\text { The contents of } \\
\text { this section are } \\
\text { not applicable to } \\
\text { WSI/NV as there } \\
\text { are no } \\
\text { circumstances } \\
\text { for planned } \\
\text { special } \\
\text { exposures to } \\
\text { employees. }\end{array}$ \\
\hline
\end{tabular}

H-26 


\section{NEVADA TEST SITE RADIATION PROTECTION PROGRAM}

\section{APPENDIX H}

COMPLIANCE DEMONSTRATION TABLE

\begin{tabular}{|c|c|c|c|c|c|c|c|c|}
\hline \multirow[t]{2}{*}{10 CFR 835} & $\begin{array}{c}\text { NV/YMP RCM } \\
\text { Rev } 5 \text { and } \\
\text { NTS RPP } \\
\text { Revision } 0 \\
\end{array}$ & $\begin{array}{c}\text { NSTec } \\
\text { Appendix A }\end{array}$ & $\begin{array}{c}\text { LLNL } \\
\text { Appendix B }\end{array}$ & $\begin{array}{c}\text { LANL } \\
\text { Appendix C }\end{array}$ & $\begin{array}{c}\text { SNL } \\
\text { Appendix D }\end{array}$ & $\begin{array}{c}\text { SNJV } \\
\text { Appendix E }\end{array}$ & $\begin{array}{c}\text { DRI } \\
\text { Appendix F }\end{array}$ & $\begin{array}{c}\text { WSI } \\
\text { Appendix G }\end{array}$ \\
\hline & $\begin{array}{l}\text { Implementation } \\
\text { Reference }\end{array}$ & $\begin{array}{l}\text { Implementation } \\
\text { Reference }\end{array}$ & $\begin{array}{l}\text { Implementation } \\
\text { Reference }\end{array}$ & $\begin{array}{l}\text { Implementation } \\
\text { Reference }\end{array}$ & $\begin{array}{l}\text { Implementation } \\
\text { Reference }\end{array}$ & $\begin{array}{l}\text { Implementation } \\
\text { Reference }\end{array}$ & $\begin{array}{l}\text { Implementation } \\
\text { Reference }\end{array}$ & $\begin{array}{l}\text { Implementation } \\
\text { Reference }\end{array}$ \\
\hline
\end{tabular}

\begin{tabular}{|c|c|c|c|c|c|c|c|c|}
\hline & & & & $\begin{array}{l}\text { planned special } \\
\text { exposure at the } \\
\text { NTS. } \\
\end{array}$ & & & & \\
\hline $\begin{array}{l}835.205 \\
\text { Determination of } \\
\text { compliance for non- } \\
\text { uniform exposure of } \\
\text { the skin. } \\
\text { 205(a) Non-uniform } \\
\text { exposures of the skin } \\
\text { from X-rays, beta } \\
\text { radiation, and/or } \\
\text { radioactive material on } \\
\text { the skin are to be } \\
\text { assessed as specified } \\
\text { in this section. }\end{array}$ & $\begin{array}{l}\text { NV/YMP RCM } \\
\text { Appendix 2C-. } 01 . \\
\text { Non-uniform } \\
\text { exposures of the } \\
\text { skin from X-rays, } \\
\text { beta radiation, } \\
\text { and radioactive } \\
\text { materials on the } \\
\text { skin, shall be } \\
\text { assessed and } \\
\text { recorded as } \\
\text { specified in the } \\
\text { following table. } \\
\text { (Table 2C-1). }\end{array}$ & $\begin{array}{l}\text { NV/YMP RCM } \\
\text { Appendix 2C-.01. } \\
\text { Non-uniform } \\
\text { exposures of the } \\
\text { skin from X-rays, } \\
\text { beta radiation, } \\
\text { and radioactive } \\
\text { materials on the } \\
\text { skin, shall be } \\
\text { assessed and } \\
\text { recorded as } \\
\text { specified in the } \\
\text { following table. } \\
\text { (Table 2C-1). }\end{array}$ & $\begin{array}{l}\text { Dosimetry } \\
\text { services are } \\
\text { provided to LLNL } \\
\text { by the RSPC. }\end{array}$ & $\begin{array}{l}\text { This is outside } \\
\text { the scope of the } \\
\text { LANL/NTS } \\
\text { Radiological } \\
\text { Control Program. } \\
\text { The NTS RSPC } \\
\text { and, by written } \\
\text { agreement, the } \\
\text { LANL RP-2 Dose } \\
\text { Assessment } \\
\text { Team perform } \\
\text { the dose } \\
\text { assessments for } \\
\text { LANL/NTS. The } \\
\text { LANL RP-2 } \\
\text { Radiation } \\
\text { Information } \\
\text { Management } \\
\text { Team records } \\
\text { and maintains } \\
\text { LANL employee } \\
\text { dose } \\
\text { assessments } \\
\text { provided by the } \\
\text { NTS RSPC. } \\
\end{array}$ & $\begin{array}{l}\text { Same as Column } \\
3\end{array}$ & $\begin{array}{l}\text { NV/YMP RCM } \\
\text { 141.3.e. The } \\
\text { RSPC shall } \\
\text { provide the } \\
\text { following: } \\
\text { e. External and } \\
\text { internal } \\
\text { dosimetry } \\
\text { services. }\end{array}$ & $\begin{array}{l}\text { Dosimetry } \\
\text { services are } \\
\text { provided to DRI } \\
\text { by the RSPC. }\end{array}$ & $\begin{array}{l}\text { By written } \\
\text { agreement, } \\
\text { dosimetry } \\
\text { services are } \\
\text { provided to } \\
\text { WSI/NV by the } \\
\text { RSPC. }\end{array}$ \\
\hline $\begin{array}{l}205(b) \text { For purposes } \\
\text { of demonstrating } \\
\text { compliance with } \\
\S 835.202(a)(4) \text {, } \\
\text { assessments shall be }\end{array}$ & $\begin{array}{l}\text { NV/YMP RCM } \\
\text { Appendix 2C, } \\
\text { Table 2C-1. } \\
\text { Items 1, 2, and } 3 .\end{array}$ & $\begin{array}{l}\text { Revise and verify } \\
\text { terminology: } \\
\text { NV/YMP RCM } \\
\text { Appendix 2C. }\end{array}$ & $\begin{array}{l}\text { Dosimetry } \\
\text { services are } \\
\text { provided to LLNL } \\
\text { by the RSPC. }\end{array}$ & $\begin{array}{l}\text { This is outside } \\
\text { the scope of the } \\
\text { LANL/NTS } \\
\text { Radiological } \\
\text { Control Program. }\end{array}$ & $\begin{array}{l}\text { Same as Column } \\
3\end{array}$ & $\begin{array}{l}\text { NV/YMP RCM } \\
\text { 141.3.e. The } \\
\text { RSPC shall } \\
\text { provide the } \\
\text { following: }\end{array}$ & $\begin{array}{l}\text { Dosimetry } \\
\text { services are } \\
\text { provided to DRI } \\
\text { by the RSPC. }\end{array}$ & $\begin{array}{l}\text { By written } \\
\text { agreement, } \\
\text { dosimetry } \\
\text { services are } \\
\text { provided to }\end{array}$ \\
\hline
\end{tabular}

$$
\text { H-27 }
$$




\section{NEVADA TEST SITE RADIATION PROTECTION PROGRAM}

\section{APPENDIX H}

COMPLIANCE DEMONSTRATION TABLE

\begin{tabular}{|c|c|c|c|c|c|c|c|c|}
\hline \multirow[t]{2}{*}{10 CFR 835} & $\begin{array}{l}\text { NV/YMP RCM } \\
\text { Rev } 5 \text { and } \\
\text { NTS RPP } \\
\text { Revision } 0 \\
\end{array}$ & $\begin{array}{c}\text { NSTec } \\
\text { Appendix A }\end{array}$ & $\begin{array}{c}\text { LLNL } \\
\text { Appendix B }\end{array}$ & $\begin{array}{c}\text { LANL } \\
\text { Appendix C }\end{array}$ & $\begin{array}{c}\text { SNL } \\
\text { Appendix D }\end{array}$ & $\begin{array}{c}\text { SNJV } \\
\text { Appendix E }\end{array}$ & $\begin{array}{c}\text { DRI } \\
\text { Appendix F }\end{array}$ & $\begin{array}{c}\text { WSI } \\
\text { Appendix G }\end{array}$ \\
\hline & $\begin{array}{l}\text { Implementation } \\
\text { Reference }\end{array}$ & $\begin{array}{l}\text { Implementation } \\
\text { Reference }\end{array}$ & $\begin{array}{l}\text { Implementation } \\
\text { Reference }\end{array}$ & $\begin{array}{l}\text { Implementation } \\
\text { Reference }\end{array}$ & $\begin{array}{l}\text { Implementation } \\
\text { Reference }\end{array}$ & $\begin{array}{l}\text { Implementation } \\
\text { Reference }\end{array}$ & $\begin{array}{l}\text { Implementation } \\
\text { Reference }\end{array}$ & $\begin{array}{c}\text { Implementation } \\
\text { Reference }\end{array}$ \\
\hline
\end{tabular}

\begin{tabular}{|c|c|c|c|c|}
\hline $\begin{array}{l}\text { conducted as follows: } \\
\text { (1) Area of skin } \\
\text { irradiated is } 100 \mathrm{~cm}^{2} \\
\text { or more. The non- } \\
\text { uniform equivalent } \\
\text { dose received during } \\
\text { the year shall be } \\
\text { averaged over the } 100 \\
\mathrm{~cm}^{2} \text { of the skin } \\
\text { receiving the } \\
\text { maximum dose, added } \\
\text { to any uniform } \\
\text { equivalent dose also } \\
\text { received by the skin, } \\
\text { and recorded as the } \\
\text { equivalent dose to any } \\
\text { extremity or skin for } \\
\text { the year. } \\
(2) \text { Area of skin } \\
\text { irradiated is } 10 \mathrm{~cm}^{2} \text { or } \\
\text { more, but is less than } \\
100 \mathrm{~cm}{ }^{2} \text {. The non- } \\
\text { uniform equivalent } \\
\text { dose }(\mathrm{H}) \text { to the } \\
\text { irradiated area } \\
\text { received during the } \\
\text { year shall be added to } \\
\text { any uniform equivalent } \\
\text { dose also received by } \\
\text { the skin and recorded } \\
\text { as the equivalent dose } \\
\text { to any extremity or } \\
\text { skin for the year. } \mathrm{H} \text { is }\end{array}$ & $\begin{array}{l}\text { NV/YMP RCM } \\
\text { Appendix 2C, } \\
\text { Table 2C-1. } \\
\text { Items } 1,2 \text {, and } 3 .\end{array}$ & $\begin{array}{l}\text { The NTS RSPC } \\
\text { and, by written } \\
\text { agreement, the } \\
\text { LANL RP-2 Dose } \\
\text { Assessment } \\
\text { Team perform } \\
\text { the dose } \\
\text { assessments for } \\
\text { LANL/NTS. } \\
\text { The LANL RP-2 } \\
\text { Radiation } \\
\text { Information } \\
\text { Management } \\
\text { Team records } \\
\text { and maintains } \\
\text { LANL employee } \\
\text { dose } \\
\text { assessments } \\
\text { provided by the } \\
\text { NTS RSPC. }\end{array}$ & $\begin{array}{l}\text { e. External and } \\
\text { internal } \\
\text { dosimetry } \\
\text { services. }\end{array}$ & $\begin{array}{l}\text { WSI/NV by the } \\
\text { RSPC. }\end{array}$ \\
\hline
\end{tabular}




\section{NEVADA TEST SITE RADIATION PROTECTION PROGRAM}

\section{APPENDIX H}

COMPLIANCE DEMONSTRATION TABLE

\begin{tabular}{|c|c|c|c|c|c|c|c|c|}
\hline \multirow[t]{2}{*}{10 CFR 835} & $\begin{array}{l}\text { NV/YMP RCM } \\
\text { Rev } 5 \text { and } \\
\text { NTS RPP } \\
\text { Revision } 0\end{array}$ & $\begin{array}{c}\text { NSTec } \\
\text { Appendix A }\end{array}$ & $\begin{array}{c}\text { LLNL } \\
\text { Appendix B }\end{array}$ & $\begin{array}{c}\text { LANL } \\
\text { Appendix C }\end{array}$ & $\begin{array}{c}\text { SNL } \\
\text { Appendix D }\end{array}$ & $\begin{array}{c}\text { SNJV } \\
\text { Appendix E }\end{array}$ & $\begin{array}{c}\text { DRI } \\
\text { Appendix F }\end{array}$ & $\begin{array}{c}\text { WSI } \\
\text { Appendix G }\end{array}$ \\
\hline & $\begin{array}{l}\text { Implementation } \\
\text { Reference }\end{array}$ & $\begin{array}{l}\text { Implementation } \\
\text { Reference }\end{array}$ & $\begin{array}{l}\text { Implementation } \\
\text { Reference }\end{array}$ & $\begin{array}{l}\text { Implementation } \\
\text { Reference }\end{array}$ & $\begin{array}{l}\text { Implementation } \\
\text { Reference }\end{array}$ & $\begin{array}{l}\text { Implementation } \\
\text { Reference }\end{array}$ & $\begin{array}{l}\text { Implementation } \\
\text { Reference }\end{array}$ & $\begin{array}{l}\text { Implementation } \\
\text { Reference }\end{array}$ \\
\hline
\end{tabular}

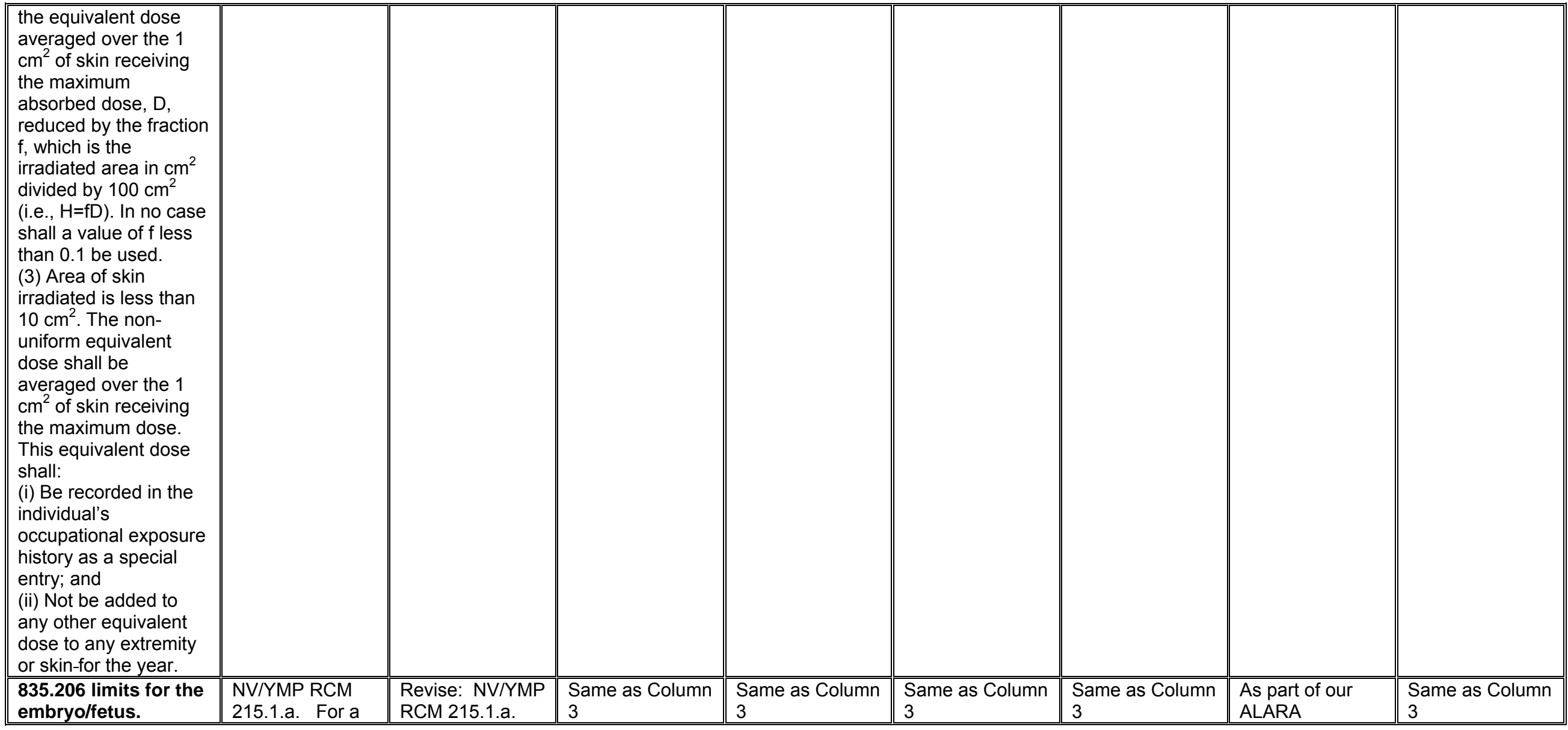




\section{NEVADA TEST SITE RADIATION PROTECTION PROGRAM}

\section{APPENDIX H}

COMPLIANCE DEMONSTRATION TABLE

\begin{tabular}{|c|c|c|c|c|c|c|c|c|}
\hline \multirow[t]{2}{*}{10 CFR 835} & $\begin{array}{c}\text { NV/YMP RCM } \\
\text { Rev } 5 \text { and } \\
\text { NTS RPP } \\
\text { Revision } 0 \\
\end{array}$ & $\begin{array}{c}\text { NSTec } \\
\text { Appendix A }\end{array}$ & $\begin{array}{c}\text { LLNL } \\
\text { Appendix B }\end{array}$ & $\begin{array}{c}\text { LANL } \\
\text { Appendix C }\end{array}$ & $\begin{array}{c}\text { SNL } \\
\text { Appendix D }\end{array}$ & $\begin{array}{c}\text { SNJV } \\
\text { Appendix E }\end{array}$ & $\begin{array}{c}\text { DRI } \\
\text { Appendix F }\end{array}$ & $\begin{array}{c}\text { WSI } \\
\text { Appendix G }\end{array}$ \\
\hline & $\begin{array}{l}\text { Implementation } \\
\text { Reference }\end{array}$ & $\begin{array}{l}\text { Implementation } \\
\text { Reference }\end{array}$ & $\begin{array}{l}\text { Implementation } \\
\text { Reference }\end{array}$ & $\begin{array}{l}\text { Implementation } \\
\text { Reference }\end{array}$ & $\begin{array}{l}\text { Implementation } \\
\text { Reference }\end{array}$ & $\begin{array}{l}\text { Implementation } \\
\text { Reference }\end{array}$ & $\begin{array}{l}\text { Implementation } \\
\text { Reference }\end{array}$ & $\begin{array}{l}\text { Implementation } \\
\text { Reference }\end{array}$ \\
\hline
\end{tabular}

\section{6(a) The equivalent} dose limit for the

embryo/fetus from the period of conception to birth, as a result of occupational exposure of a declared pregnant worker, is 0.5 rem (0.005 Sv).

\section{6(b) Substantia}

variation above a

uniform exposure rate

that would satisfy the

limits provided in

§835.206(a) shall be

avoided.

\section{declared}

pregnant worker

who chooses to

continue working

as a radiological

worker: a. The

dose limit for the

embryo/fetus

from conception

to birth (entire

gestation period)

is 500 mrem.

\section{NV/YMP RCM}

215.1.b.01. For

a declared

pregnant worker

who chooses to

continue working

as a radiological

worker:

b. Measures

shall be taken to

\begin{tabular}{|c|c|c|c|c|c|c|}
\hline $\begin{array}{l}\text { For a declared } \\
\text { pregnant worker } \\
\text { who chooses to } \\
\text { continue working } \\
\text { as a radiological } \\
\text { worker: a. The } \\
\text { equivalent dose } \\
\text { limit for the } \\
\text { embryo/fetus } \\
\text { from conception } \\
\text { to birth (entire } \\
\text { gestation period) } \\
\text { is } 500 \text { mrem. }\end{array}$ & & & & & $\begin{array}{l}\text { commitment, DRI } \\
\text { has adopted the } \\
\text { policies and } \\
\text { procedures } \\
\text { outlined in the } \\
\text { UNR RSM. } \\
\text { Reference UNR } \\
\text { RSM Policy III: } \\
\text { Occupational } \\
\text { Dose Limits and } \\
\text { Contamination } \\
\text { Standards. } \\
\text { The allowed } \\
\text { occupational } \\
\text { dose to the } \\
\text { declared } \\
\text { pregnant } \\
\text { worker/fetus may } \\
\text { not exceed } 0.5 \\
\text { rem/yr (Nevada } \\
\text { Administrative } \\
\text { Code NAC } \\
459.325-3355) \text {. }\end{array}$ & \\
\hline $\begin{array}{l}\text { NV/YMP RCM } \\
215.1 . b .01 \text {. For } \\
\text { a declared } \\
\text { pregnant worker } \\
\text { who chooses to } \\
\text { continue working } \\
\text { as a radiological } \\
\text { worker: } \\
\text { b. Measures } \\
\text { shall be taken to }\end{array}$ & $\begin{array}{l}\text { Same as Column } \\
3\end{array}$ & $\begin{array}{l}\text { Same as Column } \\
3\end{array}$ & $\begin{array}{l}\text { Same as Column } \\
3\end{array}$ & $\begin{array}{l}\text { Same as Column } \\
3\end{array}$ & $\begin{array}{l}\text { As part of our } \\
\text { ALARA } \\
\text { commitment, DRI } \\
\text { has adopted the } \\
\text { policies and } \\
\text { procedures } \\
\text { outlined in the } \\
\text { UNR RSM. } \\
\text { Reference UNR } \\
\text { RSM Policy III: }\end{array}$ & $\begin{array}{l}\text { Same as Column } \\
3\end{array}$ \\
\hline
\end{tabular}

H-30 


\section{NEVADA TEST SITE RADIATION PROTECTION PROGRAM}

\section{APPENDIX H}

COMPLIANCE DEMONSTRATION TABLE

\begin{tabular}{|c|c|c|c|c|c|c|c|c|}
\hline \multirow[t]{2}{*}{10 CFR 835} & $\begin{array}{l}\text { NV/YMP RCM } \\
\text { Rev } 5 \text { and } \\
\text { NTS RPP } \\
\text { Revision } 0 \\
\end{array}$ & $\begin{array}{c}\text { NSTec } \\
\text { Appendix A }\end{array}$ & $\begin{array}{c}\text { LLNL } \\
\text { Appendix B }\end{array}$ & $\begin{array}{c}\text { LANL } \\
\text { Appendix C }\end{array}$ & $\begin{array}{c}\text { SNL } \\
\text { Appendix D }\end{array}$ & $\begin{array}{c}\text { SNJV } \\
\text { Appendix E }\end{array}$ & $\begin{array}{c}\text { DRI } \\
\text { Appendix F }\end{array}$ & $\begin{array}{c}\text { WSI } \\
\text { Appendix G }\end{array}$ \\
\hline & $\begin{array}{l}\text { Implementation } \\
\text { Reference }\end{array}$ & $\begin{array}{l}\text { Implementation } \\
\text { Reference }\end{array}$ & $\begin{array}{l}\text { Implementation } \\
\text { Reference }\end{array}$ & $\begin{array}{l}\text { Implementation } \\
\text { Reference }\end{array}$ & $\begin{array}{l}\text { Implementation } \\
\text { Reference }\end{array}$ & $\begin{array}{l}\text { Implementation } \\
\text { Reference }\end{array}$ & $\begin{array}{l}\text { Implementation } \\
\text { Reference }\end{array}$ & $\begin{array}{l}\text { Implementation } \\
\text { Reference }\end{array}$ \\
\hline
\end{tabular}

\begin{tabular}{|c|c|c|c|c|c|c|c|c|}
\hline & $\begin{array}{l}\text { avoid substantial } \\
\text { variation above } \\
\text { the uniform } \\
\text { exposure rate } \\
\text { necessary to } \\
\text { meet the } 500 \\
\text { mrem limit for the } \\
\text { gestation period. }\end{array}$ & $\begin{array}{l}\text { avoid substantial } \\
\text { variation above } \\
\text { the uniform } \\
\text { exposure rate } \\
\text { necessary to } \\
\text { meet the } 500 \\
\text { mrem limit for the } \\
\text { gestation period. }\end{array}$ & & & & & $\begin{array}{l}\text { Occupational } \\
\text { Dose Limits and } \\
\text { Contamination } \\
\text { Standards. } \\
\text { UNR has set the } \\
\text { administrative } \\
\text { limit to the fetus } \\
\text { as } 50 \text { mrem/yr } \\
\text { (10\% of the } \\
\text { regulatory limit). }\end{array}$ & \\
\hline $\begin{array}{l}206(\mathrm{c}) \text { If the equivalent } \\
\text { dose to the } \\
\text { embryo/fetus is } \\
\text { determined to have } \\
\text { already exceeded } 0.5 \\
\text { rem (0.005 Sv) by the } \\
\text { time a worker declares } \\
\text { her pregnancy, the } \\
\text { declared pregnant } \\
\text { worker shall not be } \\
\text { assigned to tasks } \\
\text { where additional } \\
\text { occupational exposure } \\
\text { is likely during the } \\
\text { remaining gestation } \\
\text { period }\end{array}$ & $\begin{array}{l}\text { NV/YMP RCM } \\
215.2 \text {. If the } \\
\text { dose to the } \\
\text { embryo/fetus is } \\
\text { determined to } \\
\text { have already } \\
\text { exceeded } 500 \\
\text { mrem when a } \\
\text { worker notifies } \\
\text { her employer of } \\
\text { her pregnancy, } \\
\text { the worker shall } \\
\text { not be assigned } \\
\text { to tasks where } \\
\text { additional } \\
\text { occupational } \\
\text { radiation } \\
\text { exposure is likely } \\
\text { during the } \\
\text { remainder of the } \\
\text { gestation period. }\end{array}$ & $\begin{array}{l}\text { Revise: NV/YMP } \\
\text { RCM 215.2. If } \\
\text { the equivalent } \\
\text { dose to the } \\
\text { embryo/fetus is } \\
\text { determined to } \\
\text { have already } \\
\text { exceeded } 500 \\
\text { mrem when a } \\
\text { worker notifies } \\
\text { her employer of } \\
\text { her pregnancy, } \\
\text { the worker shall } \\
\text { not be assigned } \\
\text { to tasks where } \\
\text { additional } \\
\text { occupational } \\
\text { radiation } \\
\text { exposure is likely } \\
\text { during the } \\
\text { remainder of the } \\
\text { gestation period. }\end{array}$ & $\begin{array}{l}\text { Same as Column } \\
3\end{array}$ & $\begin{array}{l}\text { Same as Column } \\
3\end{array}$ & $\begin{array}{l}\text { Same as Column } \\
3\end{array}$ & $\begin{array}{l}\text { Same as Column } \\
3\end{array}$ & $\begin{array}{l}\text { As part of our } \\
\text { ALARA } \\
\text { commitment, DRI } \\
\text { has adopted the } \\
\text { policies and } \\
\text { procedures } \\
\text { outlined in the } \\
\text { UNR RSM. } \\
\text { Reference UNR } \\
\text { RSM Policy III: } \\
\text { Occupational } \\
\text { Dose Limits and } \\
\text { Contamination } \\
\text { Standards. Dose } \\
\text { to the fetus may } \\
\text { not exceed } 0.5 \\
\text { rem and dose to } \\
\text { a pregnant } \\
\text { worker shall not } \\
\text { exceed } 0.01 \\
\text { rem/month or } 0.1 \\
\text { rem/yr. }\end{array}$ & $\begin{array}{l}\text { Same as Column } \\
3\end{array}$ \\
\hline
\end{tabular}




\section{NEVADA TEST SITE RADIATION PROTECTION PROGRAM}

\section{APPENDIX H}

COMPLIANCE DEMONSTRATION TABLE

\begin{tabular}{|c|c|c|c|c|c|c|c|c|}
\hline \multirow[t]{2}{*}{10 CFR 835} & $\begin{array}{l}\text { NV/YMP RCM } \\
\text { Rev } 5 \text { and } \\
\text { NTS RPP } \\
\text { Revision } 0 \\
\end{array}$ & $\begin{array}{c}\text { NSTec } \\
\text { Appendix A }\end{array}$ & $\begin{array}{c}\text { LLNL } \\
\text { Appendix B }\end{array}$ & $\begin{array}{c}\text { LANL } \\
\text { Appendix C }\end{array}$ & $\begin{array}{c}\text { SNL } \\
\text { Appendix D }\end{array}$ & $\begin{array}{c}\text { SNJV } \\
\text { Appendix E }\end{array}$ & $\begin{array}{c}\text { DRI } \\
\text { Appendix F }\end{array}$ & $\begin{array}{c}\text { WSI } \\
\text { Appendix G }\end{array}$ \\
\hline & $\begin{array}{l}\text { Implementation } \\
\text { Reference }\end{array}$ & $\begin{array}{l}\text { Implementation } \\
\text { Reference }\end{array}$ & $\begin{array}{l}\text { Implementation } \\
\text { Reference }\end{array}$ & $\begin{array}{l}\text { Implementation } \\
\text { Reference }\end{array}$ & $\begin{array}{l}\text { Implementation } \\
\text { Reference }\end{array}$ & $\begin{array}{l}\text { Implementation } \\
\text { Reference }\end{array}$ & $\begin{array}{l}\text { Implementation } \\
\text { Reference }\end{array}$ & $\begin{array}{l}\text { Implementation } \\
\text { Reference }\end{array}$ \\
\hline
\end{tabular}

\begin{tabular}{|c|c|c|c|c|c|c|c|c|}
\hline & & & & & & & $\begin{array}{l}\text { Reassignment } \\
\text { will take place if } \\
\text { these limits are } \\
\text { likely to be } \\
\text { exceeded during } \\
\text { the remainder of } \\
\text { the gestation } \\
\text { period. }\end{array}$ & \\
\hline $\begin{array}{l}835.207 \\
\text { Occupational Dose } \\
\text { Limits for Minors. } \\
\text { The dose limits for } \\
\text { minors occupationally } \\
\text { exposed to radiation } \\
\text { and/or radioactive } \\
\text { materials at a DOE } \\
\text { activity are } 0.1 \text { rem } \\
(0.001 \text { Sv) total } \\
\text { effective dose in a } \\
\text { year and } 10 \text { percent of } \\
\text { the occupational dose } \\
\text { limits specified at } \\
\S 835.202(a)(3) \text { and } \\
\text { (a)(4). }\end{array}$ & $\begin{array}{l}\text { NV/YMP RCM } \\
\text { Table 2-1, Item } \\
6 .\end{array}$ & $\begin{array}{l}\text { NV/YMP RCM } \\
\text { Table 2-1, Item } \\
6 .\end{array}$ & $\begin{array}{l}\text { Same as Column } \\
3\end{array}$ & $\begin{array}{l}\text { Same as Column } \\
3\end{array}$ & $\begin{array}{l}\text { Same as Column } \\
3\end{array}$ & $\begin{array}{l}\text { Same as Column } \\
3\end{array}$ & $\begin{array}{l}\text { As part of our } \\
\text { ALARA } \\
\text { commitment, DRI } \\
\text { has adopted the } \\
\text { policies and } \\
\text { procedures } \\
\text { outlined in the } \\
\text { UNR RSM. } \\
\text { Reference UNR } \\
\text { RSM Policy III: } \\
\text { Occupational } \\
\text { Dose Limits and } \\
\text { Contamination } \\
\text { Standards. } \\
\text { Exposures to } \\
\text { minors shall not } \\
\text { exceed } 0.01 \\
\text { rem/month or } 0.1 \\
\text { rem/yr. }\end{array}$ & $\begin{array}{l}\text { Not applicable to } \\
\text { WSI/NV. } \\
\text { WSI/NV does not } \\
\text { employ minors. }\end{array}$ \\
\hline $\begin{array}{l}835.208 \text { Limits for } \\
\text { Members of the } \\
\text { Public Entering A } \\
\text { Controlled Area. } \\
\text { The total effective } \\
\text { dose limit for members }\end{array}$ & $\begin{array}{l}\text { NV/YMP RCM } \\
214.02 \text {. The } \\
\text { TEDE limits for } \\
\text { members of the } \\
\text { public exposed } \\
\text { to radiation }\end{array}$ & $\begin{array}{l}\text { Revise: NV/YMP } \\
\text { RCM 214.02. } \\
\text { The TED limits } \\
\text { for members of } \\
\text { the public } \\
\text { exposed to }\end{array}$ & $\begin{array}{l}\text { Same as Column } \\
3\end{array}$ & $\begin{array}{l}\text { Same as Column } \\
3\end{array}$ & $\begin{array}{l}\text { Same as Column } \\
3\end{array}$ & $\begin{array}{l}\text { Same as Column } \\
3\end{array}$ & $\begin{array}{l}\text { As part of our } \\
\text { ALARA } \\
\text { commitment, DRI } \\
\text { has adopted the } \\
\text { policies and } \\
\text { procedures }\end{array}$ & $\begin{array}{l}\text { WSI/NV } \\
\text { complies with the } \\
\text { site-wide } \\
\text { guidance for } \\
\text { public access to } \\
\text { controlled areas, }\end{array}$ \\
\hline
\end{tabular}

H-32 


\section{NEVADA TEST SITE RADIATION PROTECTION PROGRAM}

\section{APPENDIX H}

COMPLIANCE DEMONSTRATION TABLE

\begin{tabular}{|c|c|c|c|c|c|c|c|c|}
\hline \multirow[t]{2}{*}{10 CFR 835} & $\begin{array}{c}\text { NV/YMP RCM } \\
\text { Rev } 5 \text { and } \\
\text { NTS RPP } \\
\text { Revision } 0 \\
\end{array}$ & $\begin{array}{c}\text { NSTec } \\
\text { Appendix A }\end{array}$ & $\begin{array}{c}\text { LLNL } \\
\text { Appendix B }\end{array}$ & $\begin{array}{c}\text { LANL } \\
\text { Appendix C }\end{array}$ & $\begin{array}{c}\text { SNL } \\
\text { Appendix D }\end{array}$ & $\begin{array}{c}\text { SNJV } \\
\text { Appendix E }\end{array}$ & $\begin{array}{c}\text { DRI } \\
\text { Appendix F }\end{array}$ & $\begin{array}{c}\text { WSI } \\
\text { Appendix G }\end{array}$ \\
\hline & $\begin{array}{l}\text { Implementation } \\
\text { Reference }\end{array}$ & $\begin{array}{l}\text { Implementation } \\
\text { Reference }\end{array}$ & $\begin{array}{l}\text { Implementation } \\
\text { Reference }\end{array}$ & $\begin{array}{l}\text { Implementation } \\
\text { Reference }\end{array}$ & $\begin{array}{l}\text { Implementation } \\
\text { Reference }\end{array}$ & $\begin{array}{l}\text { Implementation } \\
\text { Reference }\end{array}$ & $\begin{array}{l}\text { Implementation } \\
\text { Reference }\end{array}$ & $\begin{array}{l}\text { Implementation } \\
\text { Reference }\end{array}$ \\
\hline
\end{tabular}

\begin{tabular}{|c|c|c|c|c|c|c|c|c|}
\hline $\begin{array}{l}\text { of the public exposed } \\
\text { to radiation and/or } \\
\text { radioactive material } \\
\text { during access to a } \\
\text { controlled area is } 0.1 \\
\text { rem }(0.001 \mathrm{~Sv} \text { in a } \\
\text { year. }\end{array}$ & $\begin{array}{l}\text { and/or } \\
\text { radioactive } \\
\text { material during } \\
\text { access to a } \\
\text { Controlled Area } \\
\text { is } 0.1 \text { rem } \\
\text { ( } 0.001 \text { sievert) in } \\
\text { a year. }\end{array}$ & $\begin{array}{l}\text { radiation and/or } \\
\text { radioactive } \\
\text { material during } \\
\text { access to a } \\
\text { Controlled Area } \\
\text { is } 0.1 \text { rem } \\
(0.001 \text { sievert) in } \\
\text { a year. }\end{array}$ & & & & & $\begin{array}{l}\text { outlined in the } \\
\text { UNR RSM. } \\
\text { Reference UNR } \\
\text { RSM Policy III: } \\
\text { Occupational } \\
\text { Dose Limits and } \\
\text { Contamination } \\
\text { Standards. } \\
\text { Exposures to the } \\
\text { public shall not } \\
\text { exceed } 0.1 \text { rem } \\
(0.001 \mathrm{~Sv}) / \mathrm{yr} . \\
\end{array}$ & $\begin{array}{l}\text { as defined by the } \\
\text { RSPC. }\end{array}$ \\
\hline $\begin{array}{l}835.209 \\
\text { Concentrations of } \\
\text { Radioactive Material } \\
\text { in Air. } \\
209(a) \text { The derived air } \\
\text { concentration (DAC) } \\
\text { values given in } \\
\text { appendices A and C of } \\
\text { this part shall be used } \\
\text { in the control of } \\
\text { occupational } \\
\text { exposures to airborne } \\
\text { radioactive material. }\end{array}$ & $\begin{array}{l}\text { NV/YMP RCM } \\
235.3 \text {. DAC } \\
\text { values for use } \\
\text { with } \\
\text { Table } 2-4 \text { as } \\
\text { found in } 10 \text { CFR } \\
835 \text { shall be } \\
\text { used in the } \\
\text { control of } \\
\text { occupational } \\
\text { exposure to } \\
\text { airborne } \\
\text { radioactive } \\
\text { material. } \\
\end{array}$ & $\begin{array}{l}\text { NV/YMP RCM } \\
235.3 \text {. DAC } \\
\text { values for use } \\
\text { with } \\
\text { Table } 2-4 \text { as } \\
\text { found in } 10 \text { CFR } \\
835 \text { shall be } \\
\text { used in the } \\
\text { control of } \\
\text { occupational } \\
\text { exposure to } \\
\text { airborne } \\
\text { radioactive } \\
\text { material. } \\
\end{array}$ & $\begin{array}{l}\text { Same as Column } \\
3\end{array}$ & $\begin{array}{l}\text { Same as Column } \\
3\end{array}$ & $\begin{array}{l}\text { Same as Column } \\
3\end{array}$ & $\begin{array}{l}\text { Same as Column } \\
3\end{array}$ & $\begin{array}{l}\text { Same as Column } \\
3\end{array}$ & $\begin{array}{l}\text { Same as Column } \\
3\end{array}$ \\
\hline $\begin{array}{l}209(\mathrm{~b}) \text { The estimation } \\
\text { of internal dose shall } \\
\text { be based on bioassay } \\
\text { data rather than air } \\
\text { concentration values } \\
\text { unless bioassay data } \\
\text { are: }\end{array}$ & $\begin{array}{l}\text { NV/YMP RCM } \\
521.2 \text {. The } \\
\text { determination of } \\
\text { internal dose } \\
\text { shall be based } \\
\text { on bioassay data } \\
\text { rather than air }\end{array}$ & $\begin{array}{l}\text { NV/YMP RCM } \\
521.2 \text {. The } \\
\text { determination of } \\
\text { internal dose } \\
\text { shall be based } \\
\text { on bioassay data } \\
\text { rather than air }\end{array}$ & $\begin{array}{l}\text { Same as Column } \\
3\end{array}$ & $\begin{array}{l}\text { This is outside } \\
\text { the scope of the } \\
\text { LANL/NTS } \\
\text { Radiological } \\
\text { Control Program. } \\
\text { The NTS RSPC } \\
\text { and, by written }\end{array}$ & $\begin{array}{l}\text { Same as Column } \\
3\end{array}$ & $\begin{array}{l}\text { Same as Column } \\
3 \text { and NV/YMP } \\
\text { RCM 141.3.e. } \\
\text { The RSPC shall } \\
\text { provide the } \\
\text { following: } \\
\text { (e) External and }\end{array}$ & $\begin{array}{l}\text { Not applicable to } \\
\text { DRI. Dosimetry } \\
\text { services are } \\
\text { provided to DRI } \\
\text { by the RSPC. }\end{array}$ & $\begin{array}{l}\text { Not applicable to } \\
\text { WSI/NV. By } \\
\text { written } \\
\text { agreement, the } \\
\text { RSPC provides } \\
\text { dosimetry } \\
\text { services to }\end{array}$ \\
\hline
\end{tabular}

$$
\mathrm{H}-33
$$




\section{NEVADA TEST SITE RADIATION PROTECTION PROGRAM}

\section{APPENDIX H}

COMPLIANCE DEMONSTRATION TABLE

\begin{tabular}{|c|c|c|c||c||c||c||c||c|}
\hline \multirow{2}{*}{ 10 CFR 835 } & $\begin{array}{c}\text { NV/YMP RCM } \\
\text { Rev 5 and } \\
\text { NTS RPP } \\
\text { Revision 0 }\end{array}$ & Appendix A & Appendix B & Appendix C & Appendix D & SNJV \\
\cline { 2 - 7 } & $\begin{array}{c}\text { Implementation } \\
\text { Reference }\end{array}$ & $\begin{array}{c}\text { Implementation } \\
\text { Reference }\end{array}$ & $\begin{array}{c}\text { Implementation } \\
\text { Reference }\end{array}$ & $\begin{array}{c}\text { Implementation } \\
\text { Reference }\end{array}$ & $\begin{array}{c}\text { Implementation } \\
\text { Reference }\end{array}$ & $\begin{array}{c}\text { Implementation } \\
\text { Reference }\end{array}$ & $\begin{array}{c}\text { Implementation } \\
\text { Reference }\end{array}$ & $\begin{array}{c}\text { Implementation } \\
\text { Reference }\end{array}$ \\
\hline
\end{tabular}

\begin{tabular}{|c|c|c|c|c|c|c|c|c|}
\hline $\begin{array}{l}\text { (1) unavailable; } \\
\text { (2) inadequate; or } \\
\text { (3) internal dose } \\
\text { estimates based on air } \\
\text { concentration values } \\
\text { are demonstrated to } \\
\text { be as or more } \\
\text { accurate. }\end{array}$ & $\begin{array}{l}\text { concentration } \\
\text { values unless } \\
\text { bioassay data } \\
\text { are: } \\
\text { a. Unavailable. } \\
\text { b. Inadequate. } \\
\text { c. Internal dose } \\
\text { estimates based } \\
\text { on representative } \\
\text { air concentration } \\
\text { values are } \\
\text { demonstrated to } \\
\text { be as or more } \\
\text { accurate. }\end{array}$ & $\begin{array}{l}\text { concentration } \\
\text { values unless } \\
\text { bioassay data } \\
\text { are: } \\
\text { a. Unavailable. } \\
\text { b. Inadequate. } \\
\text { c. Internal dose } \\
\text { estimates based } \\
\text { on representative } \\
\text { air concentration } \\
\text { values are } \\
\text { demonstrated to } \\
\text { be as or more } \\
\text { accurate. }\end{array}$ & & $\begin{array}{l}\text { agreement, the } \\
\text { LANL RP-2 Dose } \\
\text { Assessment } \\
\text { Team perform } \\
\text { the dose } \\
\text { assessments for } \\
\text { LANL/NTS. The } \\
\text { LANL RP-2 } \\
\text { Radiation } \\
\text { Information } \\
\text { Management } \\
\text { Team records } \\
\text { and maintains } \\
\text { LANL employee } \\
\text { dose } \\
\text { assessments } \\
\text { provided by the } \\
\text { NTS RSPC. }\end{array}$ & & $\begin{array}{l}\text { internal } \\
\text { dosimetry } \\
\text { services. }\end{array}$ & & WSI/NV. \\
\hline \multicolumn{9}{|l|}{$\begin{array}{l}\text { Subpart D - } \\
\text { [Reserved] }\end{array}$} \\
\hline $\begin{array}{l}\text { Subpart E- } \\
\text { Monitoring of } \\
\text { Individuals and } \\
\text { Areas. } \\
835.401 \text { General } \\
\text { Requirements. } \\
401(a) \text { Monitoring of } \\
\text { individuals and areas } \\
\text { shall be performed to: } \\
\text { (1) Demonstrate } \\
\text { compliance with the }\end{array}$ & $\begin{array}{l}\text { NV/YMP RCM } \\
551.1 . \\
\text { Monitoring of } \\
\text { individuals and } \\
\text { areas shall be } \\
\text { performed to: } \\
\text { a. Demonstrate } \\
\text { compliance with } \\
\text { the regulations in } \\
10 \text { CFR } 835 \text { - } \\
\text { Subpart E- } \\
\text { "Monitoring of } \\
\text { Individuals and }\end{array}$ & $\begin{array}{l}\text { Revise: NV/YMP } \\
\text { RCM 551.1. } \\
\text { Monitoring of } \\
\text { individuals and } \\
\text { areas shall be } \\
\text { performed to: } \\
\text { a. Demonstrate } \\
\text { compliance with } \\
\text { the regulations in } \\
10 \text { CFR } 835 \text { - } \\
\text { Subpart E- } \\
\text { "Monitoring of } \\
\text { Individuals and }\end{array}$ & $\begin{array}{l}\text { The NTS RSPC } \\
\text { provides trained } \\
\text { and qualified } \\
\text { Radiological } \\
\text { Control } \\
\text { Technicians to } \\
\text { perform and } \\
\text { document } \\
\text { radiological } \\
\text { surveys per NTS } \\
\text { RSPC } \\
\text { procedures } \\
\text { compliant with }\end{array}$ & $\begin{array}{l}\text { The NTS RSPC } \\
\text { provides trained } \\
\text { and qualified } \\
\text { Radiological } \\
\text { Control } \\
\text { Technicians to } \\
\text { perform and } \\
\text { document } \\
\text { radiological } \\
\text { surveys per NTS } \\
\text { RSPC } \\
\text { procedures } \\
\text { compliant with }\end{array}$ & $\begin{array}{l}\text { Workplace } \\
\text { monitoring for } \\
\text { Sandia activities } \\
\text { provided by } \\
\text { RSPC. }\end{array}$ & $\begin{array}{l}\text { Same as Column } \\
3\end{array}$ & $\begin{array}{l}\text { Not a DRI } \\
\text { activity. These } \\
\text { activities are } \\
\text { performed by the } \\
\text { RSPC. } \\
\text { Where DRI has } \\
\text { the lead } \\
\text { responsibility for } \\
\text { engineering and } \\
\text { administrative } \\
\text { controls, DRI will } \\
\text { access data } \\
\text { generated by the }\end{array}$ & $\begin{array}{l}\text { WSI/NV does not } \\
\text { have any } \\
\text { Radiological } \\
\text { Areas that } \\
\text { require } \\
\text { monitoring. } \\
\text { By written } \\
\text { agreement, the } \\
\text { RSPC provides } \\
\text { monitoring of } \\
\text { individuals and } \\
\text { resulting records, } \\
\text { surveys, and }\end{array}$ \\
\hline
\end{tabular}

H-34 


\section{NEVADA TEST SITE RADIATION PROTECTION PROGRAM}

\section{APPENDIX H}

COMPLIANCE DEMONSTRATION TABLE

\begin{tabular}{|c|c|c|c|c|c|c|c|c|}
\hline \multirow[t]{2}{*}{10 CFR 835} & $\begin{array}{c}\text { NV/YMP RCM } \\
\text { Rev } 5 \text { and } \\
\text { NTS RPP } \\
\text { Revision } 0 \\
\end{array}$ & $\begin{array}{c}\text { NSTec } \\
\text { Appendix A }\end{array}$ & $\begin{array}{c}\text { LLNL } \\
\text { Appendix B }\end{array}$ & $\begin{array}{c}\text { LANL } \\
\text { Appendix C }\end{array}$ & $\begin{array}{c}\text { SNL } \\
\text { Appendix D }\end{array}$ & $\begin{array}{c}\text { SNJV } \\
\text { Appendix E }\end{array}$ & $\begin{array}{c}\text { DRI } \\
\text { Appendix F }\end{array}$ & $\begin{array}{c}\text { WSI } \\
\text { Appendix G }\end{array}$ \\
\hline & $\begin{array}{l}\text { Implementation } \\
\text { Reference }\end{array}$ & $\begin{array}{l}\text { Implementation } \\
\text { Reference }\end{array}$ & $\begin{array}{l}\text { Implementation } \\
\text { Reference }\end{array}$ & $\begin{array}{l}\text { Implementation } \\
\text { Reference }\end{array}$ & $\begin{array}{l}\text { Implementation } \\
\text { Reference }\end{array}$ & $\begin{array}{l}\text { Implementation } \\
\text { Reference }\end{array}$ & $\begin{array}{l}\text { Implementation } \\
\text { Reference }\end{array}$ & $\begin{array}{l}\text { Implementation } \\
\text { Reference }\end{array}$ \\
\hline
\end{tabular}

\section{regulations in this part;}

(2) Document

radiological conditions:

(3) Detect changes in

radiological conditions;

(4) Detect the gradual buildup of radioactive

material

(5) Verify the

effectiveness of

engineered and

administrative controls

in containing

radioactive material

and reducing radiation

exposure; and

(6) Identify and control

potential sources of

individual exposure to

radiation and/or

radioactive material.

\section{Areas.}

b. Document

radiological

conditions.

c. Detect

changes in

radiological

conditions.

d. Detect the

gradual buildup

of radioactive

material.

e. Verify the

effectiveness of

engineering and

administrative

controls in

containing

radioactive

material and

reducing

radiation

exposures.

f. Identify and

control potential

sources of

individual

exposure to

radiation and/or

radioactive

material.

NV/YMP RCM

\section{Areas."}

b. Document

radiological

conditions.

c. Detect

changes in

radiological

conditions.

d. Detect the

gradual buildup

of radioactive

material.

e. Verify the

effectiveness of

engineered and

administrative

controls in

containing

radioactive

material and

reducing

radiation

exposures.

f. Identify and

control potential

sources of

individual

exposure to

radiation and/or

radioactive

material.

NV/YMP RCM

\section{CFR 835.}

LLNL determines

radiological

survey

parameters.

parameters.

\section{CFR 835. \\ LANL/NTS \\ determines \\ radiological \\ survey \\ parameters.}

RSPC to

determine their

effectiveness.

Where DRI is the

lead agency on a

project, DRI will

access data

generated by the

RSPC to

determine

potential sources

of exposure and

will implement

appropriate

control

measures. workplace

monitoring. 


\section{NEVADA TEST SITE RADIATION PROTECTION PROGRAM}

\section{APPENDIX H}

COMPLIANCE DEMONSTRATION TABLE

\begin{tabular}{|c|c|c|c|c|c|c|c|c|}
\hline \multirow[t]{2}{*}{10 CFR 835} & $\begin{array}{c}\text { NV/YMP RCM } \\
\text { Rev } 5 \text { and } \\
\text { NTS RPP } \\
\text { Revision } 0 \\
\end{array}$ & $\begin{array}{c}\text { NSTec } \\
\text { Appendix A }\end{array}$ & $\begin{array}{c}\text { LLNL } \\
\text { Appendix B }\end{array}$ & $\begin{array}{c}\text { LANL } \\
\text { Appendix C }\end{array}$ & $\begin{array}{c}\text { SNL } \\
\text { Appendix D }\end{array}$ & $\begin{array}{c}\text { SNJV } \\
\text { Appendix E }\end{array}$ & $\begin{array}{c}\text { DRI } \\
\text { Appendix F }\end{array}$ & $\begin{array}{c}\text { WSI } \\
\text { Appendix G }\end{array}$ \\
\hline & $\begin{array}{l}\text { Implementation } \\
\text { Reference }\end{array}$ & $\begin{array}{l}\text { Implementation } \\
\text { Reference }\end{array}$ & $\begin{array}{l}\text { Implementation } \\
\text { Reference }\end{array}$ & $\begin{array}{l}\text { Implementation } \\
\text { Reference }\end{array}$ & $\begin{array}{c}\text { Implementation } \\
\text { Reference }\end{array}$ & $\begin{array}{l}\text { Implementation } \\
\text { Reference }\end{array}$ & $\begin{array}{l}\text { Implementation } \\
\text { Reference }\end{array}$ & $\begin{array}{l}\text { Implementation } \\
\text { Reference }\end{array}$ \\
\hline
\end{tabular}

551.6. Surveys

shall be

performed

before, during,

and at the

completion of

work that has the

potential for

causing changes

in radiation

exposure/dose

rates or

contamination

levels.

551.6. Surveys

shall be

performed

before, during,

and at the

completion of

work that has the

potential for

causing changes

in radiation

exposure/dose

rates or

contamination

levels.

NV/YMP RCM

551.7. Survey

frequencies

should be

established

based on

potential

radiological

conditions,

probability of

change in

conditions, and

area occupancy

factors.

NV/YMP RCM

551.7. Survey

frequencies

should be

established

based on

potential

radiological

conditions,

probability of

change in

conditions, and

area occupancy

factors.

NV/YMP RCM

711.01.

NV/YMP RCM

711.01.

Radiological

Radiological 


\section{NEVADA TEST SITE RADIATION PROTECTION PROGRAM}

\section{APPENDIX H}

COMPLIANCE DEMONSTRATION TABLE

\begin{tabular}{|c|c|c|c|c|c|c|c|c|}
\hline \multirow[t]{2}{*}{10 CFR 835} & $\begin{array}{c}\text { NV/YMP RCM } \\
\text { Rev } 5 \text { and } \\
\text { NTS RPP } \\
\text { Revision } 0 \\
\end{array}$ & $\begin{array}{c}\text { NSTec } \\
\text { Appendix A }\end{array}$ & $\begin{array}{c}\text { LLNL } \\
\text { Appendix B }\end{array}$ & $\begin{array}{c}\text { LANL } \\
\text { Appendix C }\end{array}$ & $\begin{array}{c}\text { SNL } \\
\text { Appendix D }\end{array}$ & $\begin{array}{c}\text { SNJV } \\
\text { Appendix E }\end{array}$ & $\begin{array}{c}\text { DRI } \\
\text { Appendix F }\end{array}$ & $\begin{array}{c}\text { WSI } \\
\text { Appendix G }\end{array}$ \\
\hline & $\begin{array}{l}\text { Implementation } \\
\text { Reference }\end{array}$ & $\begin{array}{l}\text { Implementation } \\
\text { Reference }\end{array}$ & $\begin{array}{l}\text { Implementation } \\
\text { Reference }\end{array}$ & $\begin{array}{l}\text { Implementation } \\
\text { Reference }\end{array}$ & $\begin{array}{l}\text { Implementation } \\
\text { Reference }\end{array}$ & $\begin{array}{l}\text { Implementation } \\
\text { Reference }\end{array}$ & $\begin{array}{l}\text { Implementation } \\
\text { Reference }\end{array}$ & $\begin{array}{l}\text { Implementation } \\
\text { Reference }\end{array}$ \\
\hline
\end{tabular}

\section{1(b) Instruments} and equipment used

for monitoring shall be:

(1) Periodically maintained and calibrated on an established frequency;

(2) Appropriate for the type(s), levels, and energies of the radiation(s) encountered;

(3) Appropriate for existing environmental conditions; and

(4) Routinely tested for operability.

\section{control records}

shall be

maintained as

necessary to

document

compliance with

the requirements

of 10 CFR 835

NV/YMP RCM

551.2.

Instruments and equipment used for monitoring

shall be:

a. Periodically maintained and calibrated on an

established

frequency. b. Appropriate for the type(s), levels, and energies of radiation(s) encountered.

c. Appropriate for existing environmental conditions. d. Routinely tested for operability.

\section{control records}

shall be

maintained as

necessary to

document

compliance with

the requirements

of 10 CFR 835

NV/YMP RCM

551.2.

Instruments and equipment used for monitoring

shall be:

a. Periodically

maintained and calibrated on an

established

frequency.

b. Appropriate for

the type(s),

levels, and

energies of

radiation(s)

encountered.

c. Appropriate for existing

environmental

conditions.

d. Routinely

tested for

operability.

\section{This service is} provided to LLNL by the NTS RSPC in compliance with 10 CFR 835.

NV/YMP RCM

551.2.b-d.

Instruments and equipment used for monitoring shall be:

b. Appropriate for the type(s)

levels, and

energies of

radiation(s)

encountered.

c. Appropriate for existing

environmental

conditions.

d. Routinely tested for

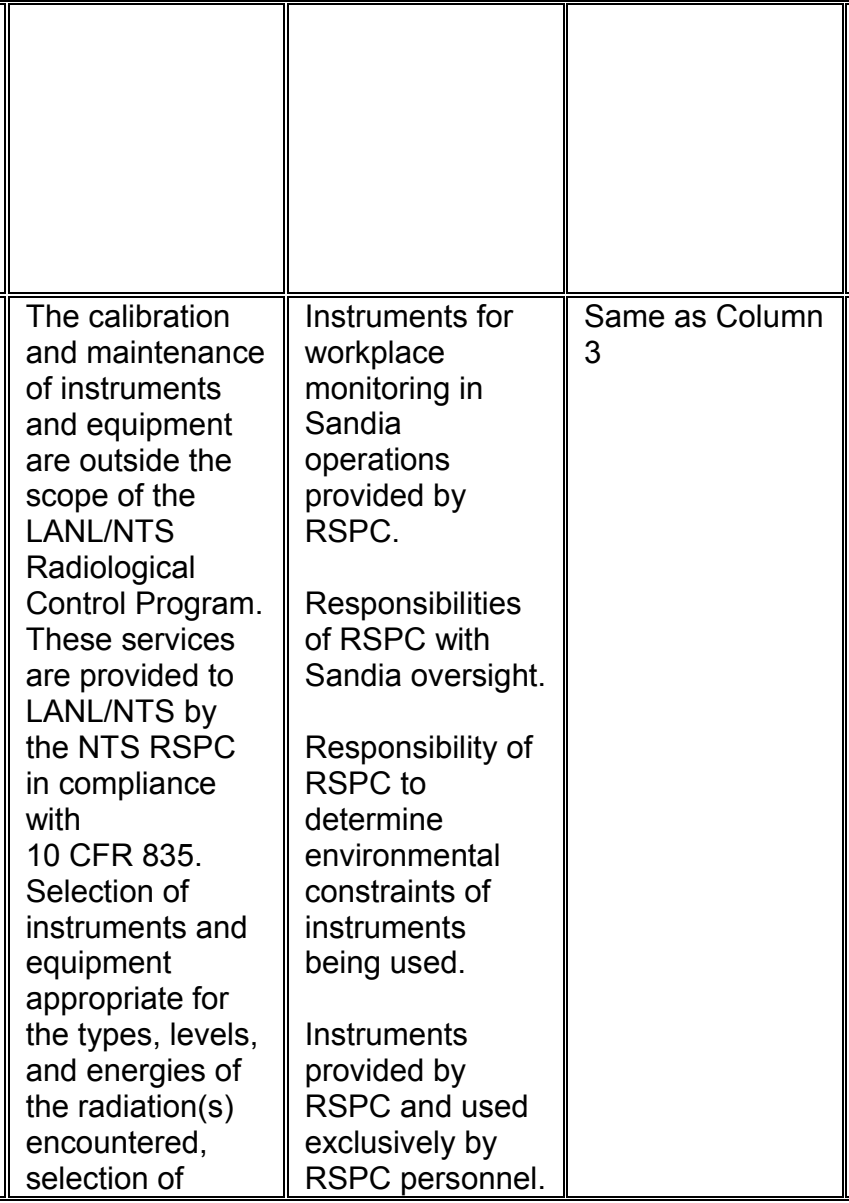

\begin{tabular}{||l||l||}
\hline \multicolumn{1}{||l||}{} & \\
& \\
& \\
\hline Not a DRI & By written \\
activity. & agreement, the \\
Instruments and & RSPC provides \\
equipment used & instruments and \\
for monitoring & equipment used \\
are provided by & for monitoring. It \\
the RSPC and & is the \\
used exclusively & responsibility of \\
by RSPC & the RSPC to \\
personnel. & maintain and \\
Therefore, it is & calibrate \\
their & instruments and \\
responsibility to & equipment used \\
determine & for monitoring, to \\
environmental & ensure the \\
constraints of & instruments and \\
instruments & equipment used \\
being used. & for monitoring \\
& are appropriate \\
& for the type(s), \\
level(s), and \\
energies of the \\
radiation(s) \\
encountered, to \\
ensure the \\
\hline
\end{tabular}




\section{NEVADA TEST SITE RADIATION PROTECTION PROGRAM}

\section{APPENDIX H}

COMPLIANCE DEMONSTRATION TABLE

\begin{tabular}{|c|c|c|c|c|c|c|c|c|}
\hline \multirow[t]{2}{*}{10 CFR 835} & $\begin{array}{c}\text { NV/YMP RCM } \\
\text { Rev } 5 \text { and } \\
\text { NTS RPP } \\
\text { Revision } 0 \\
\end{array}$ & $\begin{array}{c}\text { NSTec } \\
\text { Appendix A }\end{array}$ & $\begin{array}{c}\text { LLNL } \\
\text { Appendix B }\end{array}$ & $\begin{array}{c}\text { LANL } \\
\text { Appendix C }\end{array}$ & $\begin{array}{c}\text { SNL } \\
\text { Appendix D }\end{array}$ & $\begin{array}{c}\text { SNJV } \\
\text { Appendix E }\end{array}$ & $\begin{array}{c}\text { DRI } \\
\text { Appendix F }\end{array}$ & $\begin{array}{c}\text { WSI } \\
\text { Appendix G }\end{array}$ \\
\hline & $\begin{array}{l}\text { Implementation } \\
\text { Reference }\end{array}$ & $\begin{array}{l}\text { Implementation } \\
\text { Reference }\end{array}$ & $\begin{array}{l}\text { Implementation } \\
\text { Reference }\end{array}$ & $\begin{array}{l}\text { Implementation } \\
\text { Reference }\end{array}$ & $\begin{array}{l}\text { Implementation } \\
\text { Reference }\end{array}$ & $\begin{array}{l}\text { Implementation } \\
\text { Reference }\end{array}$ & $\begin{array}{l}\text { Implementation } \\
\text { Reference }\end{array}$ & $\begin{array}{l}\text { Implementation } \\
\text { Reference }\end{array}$ \\
\hline
\end{tabular}

\section{NV/YMP RCM}

562.1.01.

Radiological

instruments shall

be used only to

measure the

radiation for

which their

calibrations are

valid.

NV/YMP RCM

562.4. The

effects of

environmental

conditions on an

instrument,

including

interfering

radiation, shall

be known before

use.

NV/YMP RCM

551.4.01.

Instruments used

to perform

radiation surveys

shall be readily

available and

performance-

checked daily or

before operation.

\section{NV/YMP RCM}

562.1.01.

Radiological

instruments shall

be used only to

measure the

radiation for

which their

calibrations are

valid.

NV/YMP RCM

\subsection{The}

effects of

environmental

conditions on an

instrument,

including

interfering

radiation, shall

be known before

use.

NV/YMP RCM

551.4.01.

Instruments used

to perform

radiation surveys

shall be readily

available and

performance-

checked daily or

before operation.

\section{instruments}

appropriate to

environmental

conditions, and

routine testing for

operability are

LANL/NTS

responsibilities.

\section{NV/YMP RCM}

551.2.b.

Instruments and

equipment used

for monitoring

shall be:

b. Appropriate for

the type(s),

levels, and

energies of

radiation(s)

encountered. instruments and

equipment used

for monitoring

are appropriate

for existing

environmental

conditions, and

to ensure the

instruments and

equipment used

for monitoring

are routinely

tested for

operability. 


\section{NEVADA TEST SITE RADIATION PROTECTION PROGRAM}

\section{APPENDIX H}

COMPLIANCE DEMONSTRATION TABLE

\begin{tabular}{|c|c|c|c|c|c|c|c|c|}
\hline \multirow[t]{2}{*}{10 CFR 835} & $\begin{array}{c}\text { NV/YMP RCM } \\
\text { Rev } 5 \text { and } \\
\text { NTS RPP } \\
\text { Revision } 0 \\
\end{array}$ & $\begin{array}{c}\text { NSTec } \\
\text { Appendix A }\end{array}$ & $\begin{array}{c}\text { LLNL } \\
\text { Appendix B }\end{array}$ & $\begin{array}{c}\text { LANL } \\
\text { Appendix C }\end{array}$ & $\begin{array}{c}\text { SNL } \\
\text { Appendix D }\end{array}$ & $\begin{array}{c}\text { SNJV } \\
\text { Appendix E }\end{array}$ & $\begin{array}{c}\text { DRI } \\
\text { Appendix F }\end{array}$ & $\begin{array}{c}\text { WSI } \\
\text { Appendix G }\end{array}$ \\
\hline & $\begin{array}{l}\text { Implementation } \\
\text { Reference }\end{array}$ & $\begin{array}{l}\text { Implementation } \\
\text { Reference }\end{array}$ & $\begin{array}{l}\text { Implementation } \\
\text { Reference }\end{array}$ & $\begin{array}{l}\text { Implementation } \\
\text { Reference }\end{array}$ & $\begin{array}{l}\text { Implementation } \\
\text { Reference }\end{array}$ & $\begin{array}{l}\text { Implementation } \\
\text { Reference }\end{array}$ & $\begin{array}{l}\text { Implementation } \\
\text { Reference }\end{array}$ & $\begin{array}{l}\text { Implementation } \\
\text { Reference }\end{array}$ \\
\hline
\end{tabular}

\begin{tabular}{|c|c|c|c|c|c|c|c|c|}
\hline $\begin{array}{l}\text { 835.402 Individual } \\
\text { Monitoring. } \\
\text { 402(a) For the } \\
\text { purpose of monitoring } \\
\text { individual exposures to } \\
\text { external radiation, } \\
\text { personnel dosimeters } \\
\text { shall be provided to } \\
\text { and used by: } \\
\text { (1) Radiological } \\
\text { workers who, under } \\
\text { typical conditions, are } \\
\text { likely to receive one or } \\
\text { more of the following: } \\
\text { (i) An effective dose } \\
\text { of } 0.1 \text { rem (0.001 Sv) } \\
\text { or more in a year; } \\
\text { (ii) An equivalent dose } \\
\text { to the skin or to any } \\
\text { extremity of } 5 \text { rems } \\
\text { (0.05 Sv) or more in a } \\
\text { year; } \\
\text { (iii) An equivalent } \\
\text { dose to the lens of the } \\
\text { eye of } 1.5 \text { rems ( } 0.015 \\
\text { Sv) or more in a year; } \\
\text { (2) Declared pregnant } \\
\text { workers who are likely } \\
\text { to receive from } \\
\text { external sources an } \\
\text { equivalent dose to the } \\
\text { embryo/fetus in }\end{array}$ & $\begin{array}{l}\text { NV/YMP RCM } \\
511.1 . a . \\
\text { Individual } \\
\text { dosimetry shall } \\
\text { be required for } \\
\text { the following: } \\
\text { a. Individuals } \\
\text { who under } \\
\text { typical conditions } \\
\text { are likely to } \\
\text { receive an } \\
\text { annual external } \\
\text { whole-body dose } \\
\text { greater than } 100 \\
\text { mrem or an } \\
\text { annual dose to } \\
\text { the extremities or } \\
\text { organs and other } \\
\text { tissues (including } \\
\text { the lens of the } \\
\text { eye and skin) } \\
\text { greater than } 10 \\
\text { percent of the } \\
\text { corresponding } \\
\text { limits specified in } \\
\text { Table } 2-1 . \\
\text { NV/YMP RCM } \\
511.1 . b . \\
\text { Individual } \\
\text { dosimetry shall } \\
\text { be required for } \\
\text { the following: }\end{array}$ & $\begin{array}{l}\text { Revise: NV/YMP } \\
\text { RCM } 511.1 . \\
\text { Individual } \\
\text { dosimetry shall } \\
\text { be required for } \\
\text { the following: } \\
\text { a. Radiological } \\
\text { workers who } \\
\text { under typical } \\
\text { conditions are } \\
\text { likely to receive } \\
\text { an effective dose } \\
\text { of } 100 \text { mrem or } \\
\text { more in a year, } \\
\text { an equivalent } \\
\text { dose to the skin } \\
\text { or to any } \\
\text { extremity of } 5 \\
\text { rems or more in } \\
\text { a year, or an } \\
\text { equivalent dose } \\
\text { to the lens of the } \\
\text { eye of } 1.5 \text { rems } \\
\text { ore more in a } \\
\text { year or greater } \\
\text { than } 10 \text { percent } \\
\text { of the } \\
\text { corresponding } \\
\text { limits specified in } \\
\text { Table } 2-1 . \\
\text { b. Declared } \\
\text { pregnant workers } \\
\text { who are }\end{array}$ & $\begin{array}{l}\text { Same as Column } \\
3 \text { and LLNL-N } \\
\text { will have the } \\
\text { responsibility to } \\
\text { determine which } \\
\text { Livermore } \\
\text { personnel need } \\
\text { dosimetry. }\end{array}$ & $\begin{array}{l}\text { Same as Column } \\
3\end{array}$ & $\begin{array}{l}\text { Same as Column } \\
3 \text { and SNL-NV } \\
\text { will have the } \\
\text { responsibility to } \\
\text { determine which } \\
\text { Sandia } \\
\text { personnel need } \\
\text { dosimetry. } \\
\text { Dosimeters are } \\
\text { provided and } \\
\text { processed by } \\
\text { RSPC. }\end{array}$ & $\begin{array}{l}\text { Same as Column } \\
3\end{array}$ & $\begin{array}{l}\text { Same as Column } \\
3 \text { and Cross } \\
\text { reference } \\
\text { NV/YMP RCM } \\
511.1 . f . \text { and } \\
\text { Table 6-1, Item } \\
7 . \\
\text { Dosimetry will be } \\
\text { required should } \\
\text { DRI employees } \\
\text { enter a High } \\
\text { Radiation Area. } \\
\text { Entry into Very } \\
\text { High Radiation } \\
\text { Areas will not be } \\
\text { permitted. }\end{array}$ & $\begin{array}{l}\text { Same as Column } \\
3 \text { and (revised) } \\
\text { NV/YMP RCM } \\
511.1 . a \text {. b. and f. } \\
\text { Individual } \\
\text { dosimetry shall } \\
\text { be required for } \\
\text { the following: } \\
\text { a. Radiological } \\
\text { workers who } \\
\text { under typical } \\
\text { conditions are } \\
\text { likely to receive } \\
\text { an effective dose } \\
\text { of } 100 \text { mrem or } \\
\text { more in a year, } \\
\text { an equivalent } \\
\text { dose to the skin } \\
\text { or to any } \\
\text { extremity of } 5 \\
\text { rems or more in } \\
\text { a year, or an } \\
\text { equivalent dose } \\
\text { to the lens of the } \\
\text { eye of } 1.5 \text { rems } \\
\text { ore more in a } \\
\text { year or greater } \\
\text { than } 10 \text { percent } \\
\text { of the } \\
\text { corresponding } \\
\text { limits specified in } \\
\text { Table } 2-1 . \\
\text { b. Declared }\end{array}$ \\
\hline
\end{tabular}




\section{NEVADA TEST SITE RADIATION PROTECTION PROGRAM}

\section{APPENDIX H}

COMPLIANCE DEMONSTRATION TABLE

\begin{tabular}{|c|c|c|c|c|c|c|c|c|}
\hline \multirow[t]{2}{*}{10 CFR 835} & $\begin{array}{l}\text { NV/YMP RCM } \\
\text { Rev } 5 \text { and } \\
\text { NTS RPP } \\
\text { Revision } 0 \\
\end{array}$ & $\begin{array}{c}\text { NSTec } \\
\text { Appendix A }\end{array}$ & $\begin{array}{c}\text { LLNL } \\
\text { Appendix B }\end{array}$ & $\begin{array}{c}\text { LANL } \\
\text { Appendix C }\end{array}$ & $\begin{array}{c}\text { SNL } \\
\text { Appendix D }\end{array}$ & $\begin{array}{c}\text { SNJV } \\
\text { Appendix E }\end{array}$ & $\begin{array}{c}\text { DRI } \\
\text { Appendix F }\end{array}$ & $\begin{array}{c}\text { WSI } \\
\text { Appendix G }\end{array}$ \\
\hline & $\begin{array}{l}\text { Implementation } \\
\text { Reference }\end{array}$ & $\begin{array}{l}\text { Implementation } \\
\text { Reference }\end{array}$ & $\begin{array}{l}\text { Implementation } \\
\text { Reference }\end{array}$ & $\begin{array}{l}\text { Implementation } \\
\text { Reference }\end{array}$ & $\begin{array}{l}\text { Implementation } \\
\text { Reference }\end{array}$ & $\begin{array}{l}\text { Implementation } \\
\text { Reference }\end{array}$ & $\begin{array}{l}\text { Implementation } \\
\text { Reference }\end{array}$ & $\begin{array}{l}\text { Implementation } \\
\text { Reference }\end{array}$ \\
\hline
\end{tabular}

\begin{tabular}{|c|c|}
\hline $\begin{array}{l}\text { excess of } 10 \text { percent } \\
\text { of the applicable limit } \\
\text { at } \$ 835.206(a) \text {. } \\
\text { (3) Occupationally } \\
\text { exposed minors likely } \\
\text { to receive a dose in } \\
\text { excess of } 50 \text { percent } \\
\text { of the applicable limits } \\
\text { in } \$ 835.207 \text { in a year } \\
\text { from external sources; } \\
\text { (4) Members of the } \\
\text { public entering a } \\
\text { controlled area likely } \\
\text { to receive a dose in } \\
\text { excess of } 50 \text { percent } \\
\text { of the limit at } \$ 835.208 \\
\text { in a year from external } \\
\text { sources; and } \\
\text { (5) Individuals } \\
\text { entering a high or very } \\
\text { high radiation area. }\end{array}$ & $\begin{array}{l}\text { b. Declared } \\
\text { pregnant workers } \\
\text { who are } \\
\text { expected to } \\
\text { receive from } \\
\text { external sources } \\
\text { a dose } \\
\text { equivalent of } 50 \\
\text { mrem or more to } \\
\text { the embryo/fetus } \\
\text { during the } \\
\text { gestation period. } \\
\text { NV/YMP RCM } \\
511.1 . c . \\
\text { Individual } \\
\text { dosimetry shall } \\
\text { be required for } \\
\text { the following: } \\
\text { C. Occupationally } \\
\text { exposed minors } \\
\text { and members of } \\
\text { the public likely } \\
\text { to receive an } \\
\text { annual external } \\
\text { whole-body dose } \\
\text { equivalent of } 50 \\
\text { mrem or more in } \\
\text { a year. } \\
\text { NV/YMP RCM } \\
511.1 . d \text {. } \\
\text { lndividual }\end{array}$ \\
\hline
\end{tabular}

expected to
receive from
external sources
an equivalent
dose of 50 mrem
or more to the
embryo/fetus
during the
gestation period.
c. Occupationally
exposed minors
and members of
the public likely
to receive a total
effective dose of
50 mrem or more
in a year.
d. Occupationally
exposed minors
likely to receive
an equivalent
dose of 1.5 rems
to the lens of the
eye.
e. Occupationally
exposed minors
likely to receive
the sum of the
skin or an
extremity for
external
exposures and
the committed

the committed

||

external sources

an equivalent

dose of 50 mrem

or more to the

embryo/fetus

during the

gestation period.

f. Individuals

entering a High

Radiation Area.

835.402 (a) (3)

and (4) is not

applicable to

WSI/NV.

WSI/NV does not

employ minors

and does not

have radiological

control

responsibilities

for members of

the public

entering a

controlled area.

WSI/NV is

responsible for

determining 


\section{NEVADA TEST SITE RADIATION PROTECTION PROGRAM}

\section{APPENDIX H}

COMPLIANCE DEMONSTRATION TABLE

\begin{tabular}{|c|c|c|c|c|c|c|c|c|}
\hline \multirow[t]{2}{*}{10 CFR 835} & $\begin{array}{l}\text { NV/YMP RCM } \\
\text { Rev } 5 \text { and } \\
\text { NTS RPP } \\
\text { Revision } 0 \\
\end{array}$ & $\begin{array}{c}\text { NSTec } \\
\text { Appendix A }\end{array}$ & $\begin{array}{c}\text { LLNL } \\
\text { Appendix B }\end{array}$ & $\begin{array}{c}\text { LANL } \\
\text { Appendix C }\end{array}$ & $\begin{array}{c}\text { SNL } \\
\text { Appendix D }\end{array}$ & $\begin{array}{c}\text { SNJV } \\
\text { Appendix E }\end{array}$ & $\begin{array}{c}\text { DRI } \\
\text { Appendix F }\end{array}$ & $\begin{array}{c}\text { WSI } \\
\text { Appendix G }\end{array}$ \\
\hline & $\begin{array}{l}\text { Implementation } \\
\text { Reference }\end{array}$ & $\begin{array}{l}\text { Implementation } \\
\text { Reference }\end{array}$ & $\begin{array}{l}\text { Implementation } \\
\text { Reference }\end{array}$ & $\begin{array}{l}\text { Implementation } \\
\text { Reference }\end{array}$ & $\begin{array}{l}\text { Implementation } \\
\text { Reference }\end{array}$ & $\begin{array}{l}\text { Implementation } \\
\text { Reference }\end{array}$ & $\begin{array}{l}\text { Implementation } \\
\text { Reference }\end{array}$ & $\begin{array}{l}\text { Implementation } \\
\text { Reference }\end{array}$ \\
\hline
\end{tabular}

\begin{tabular}{|c|c|c|c|c|c|c|c|c|}
\hline & $\begin{array}{l}\text { dosimetry shall } \\
\text { be required for } \\
\text { the following: } \\
\text { d. Individuals } \\
\text { entering a High } \\
\text { Radiation Area. } \\
\text { NV/YMP RCM } \\
\text { Table 6-1 Item } 7 . \\
\text { Entry into Very } \\
\text { High Radiation } \\
\text { Areas Not } \\
\text { Permitted. }\end{array}$ & $\begin{array}{l}\text { equivalent dose } \\
\text { to the skin or to } \\
\text { any extremity of } \\
5 \text { rems. } \\
\text { f. Individuals } \\
\text { entering a High } \\
\text { Radiation Area. } \\
\text { NV/YMP RCM } \\
\text { Table 6-1 Item } 7 . \\
\text { Entry into Very } \\
\text { High Radiation } \\
\text { Areas Not } \\
\text { Permitted. }\end{array}$ & & & & & & $\begin{array}{l}\text { which WSI } \\
\text { personnel need } \\
\text { dosimetry. }\end{array}$ \\
\hline $\begin{array}{l}\text { 402(b) External dose } \\
\text { monitoring programs } \\
\text { implemented to } \\
\text { demonstrate } \\
\text { compliance with } \\
\text { §835.402(a) shall be } \\
\text { adequate to } \\
\text { demonstrate } \\
\text { compliance with the } \\
\text { dose limits established } \\
\text { in subpart C of this } \\
\text { part and shall be: } \\
\text { (1) Accredited, or } \\
\text { excepted from } \\
\text { accreditation, in } \\
\text { accordance with the } \\
\text { DOE Laboratory } \\
\text { Accreditation Program } \\
\text { for Personnel }\end{array}$ & $\begin{array}{l}\text { NV/YMP RCM } \\
512.1 .10 \text { CFR } \\
835 \text { requires } \\
\text { accreditation of } \\
\text { personnel } \\
\text { external } \\
\text { dosimetry } \\
\text { monitoring } \\
\text { programs by } \\
\text { NNSA/NSO or } \\
\text { YMORD external } \\
\text { dosimetry } \\
\text { programs shall } \\
\text { be DOELAP } \\
\text { accredited. }\end{array}$ & $\begin{array}{l}\text { Revise: NV/YMP } \\
\text { RCM } 512.1 . \text { The } \\
\text { RSPC shall } \\
\text { maintain an } \\
\text { external } \\
\text { monitoring } \\
\text { program that is } \\
\text { adequate to } \\
\text { demonstrate } \\
\text { compliance with } \\
\text { Subpart C of } 10 \\
\text { CFR } 835 \text { and } \\
\text { that is accredited } \\
\text { in accordance } \\
\text { with DOELAP. }\end{array}$ & $\begin{array}{l}\text { This service is } \\
\text { provided to LLNL } \\
\text { at the NTS by } \\
\text { the RSPC or } \\
\text { LLNL-Livermore. } \\
\text { LLNL-N will } \\
\text { verify that the } \\
\text { RSPC standards } \\
\text { in this } \\
\text { requirement by } \\
\text { insuring their } \\
\text { programs are } \\
\text { accredited by the } \\
\text { DOELAP for } \\
\text { personnel } \\
\text { dosimetry. }\end{array}$ & $\begin{array}{l}\text { This is outside } \\
\text { the scope of the } \\
\text { LANL/NTS } \\
\text { Radiological } \\
\text { Control Program. } \\
\text { This service is } \\
\text { provided to LANL } \\
\text { at the NTS by } \\
\text { the NTS RSPC } \\
\text { in compliance } \\
\text { with } \\
10 \text { CFR } 835 .\end{array}$ & $\begin{array}{l}\text { SNL utilizes the } \\
\text { dosimetry } \\
\text { services } \\
\text { provided by the } \\
\text { RSPC, which is } \\
\text { DOELAP } \\
\text { accredited. SNL- } \\
\text { NV is } \\
\text { responsible for } \\
\text { assuring that the } \\
\text { proper dosimetry } \\
\text { is used by } \\
\text { personnel } \\
\text { engaged in SNL } \\
\text { activities at NTS. }\end{array}$ & $\begin{array}{l}\text { NV/YMP RCM } \\
\text { 141.3.e. The } \\
\text { RSPC shall } \\
\text { provide the } \\
\text { following: } \\
\text { e. External and } \\
\text { internal } \\
\text { dosimetry } \\
\text { services. }\end{array}$ & $\begin{array}{l}\text { Not applicable to } \\
\text { DRI. Dosimetry } \\
\text { services, } \\
\text { including } \\
\text { external dose } \\
\text { monitoring are } \\
\text { provided to DRI } \\
\text { by RSPC. }\end{array}$ & $\begin{array}{l}\text { By written } \\
\text { agreement, } \\
\text { dosimetry } \\
\text { services are } \\
\text { provided to } \\
\text { WSI/NV by the } \\
\text { RSPC. WSI will } \\
\text { verify that the } \\
\text { RSPC maintains } \\
\text { DOELAP } \\
\text { accreditation. }\end{array}$ \\
\hline
\end{tabular}




\section{NEVADA TEST SITE RADIATION PROTECTION PROGRAM}

\section{APPENDIX H}

COMPLIANCE DEMONSTRATION TABLE

\begin{tabular}{|c|c|c|c|c|c|c|c|c|}
\hline \multirow[t]{2}{*}{10 CFR 835} & $\begin{array}{l}\text { NV/YMP RCM } \\
\text { Rev } 5 \text { and } \\
\text { NTS RPP } \\
\text { Revision } 0 \\
\end{array}$ & $\begin{array}{c}\text { NSTec } \\
\text { Appendix A }\end{array}$ & $\begin{array}{c}\text { LLNL } \\
\text { Appendix B }\end{array}$ & $\begin{array}{c}\text { LANL } \\
\text { Appendix C }\end{array}$ & $\begin{array}{c}\text { SNL } \\
\text { Appendix D }\end{array}$ & $\begin{array}{c}\text { SNJV } \\
\text { Appendix E }\end{array}$ & $\begin{array}{c}\text { DRI } \\
\text { Appendix F }\end{array}$ & $\begin{array}{c}\text { WSI } \\
\text { Appendix G }\end{array}$ \\
\hline & $\begin{array}{l}\text { Implementation } \\
\text { Reference }\end{array}$ & $\begin{array}{l}\text { Implementation } \\
\text { Reference }\end{array}$ & $\begin{array}{l}\text { Implementation } \\
\text { Reference }\end{array}$ & $\begin{array}{l}\text { Implementation } \\
\text { Reference }\end{array}$ & $\begin{array}{l}\text { Implementation } \\
\text { Reference }\end{array}$ & $\begin{array}{l}\text { Implementation } \\
\text { Reference }\end{array}$ & $\begin{array}{l}\text { Implementation } \\
\text { Reference }\end{array}$ & $\begin{array}{l}\text { Implementation } \\
\text { Reference }\end{array}$ \\
\hline
\end{tabular}

\begin{tabular}{|c|c|c|c|c|c|c|c|c|}
\hline $\begin{array}{l}\text { Dosimetry; or } \\
\text { (2) Determined by the } \\
\text { Secretarial Officer } \\
\text { responsible for } \\
\text { environment, safety } \\
\text { and health matters to } \\
\text { have performance } \\
\text { substantially } \\
\text { equivalent to that of } \\
\text { programs accredited } \\
\text { under the DOE } \\
\text { Laboratory } \\
\text { Accreditation Program } \\
\text { for Personnel } \\
\text { Dosimetry. }\end{array}$ & & & & & & & & \\
\hline $\begin{array}{l}\text { 402(c) For the } \\
\text { purpose of monitoring } \\
\text { individual exposures to } \\
\text { internal radiation, } \\
\text { internal dosimetry } \\
\text { programs (including } \\
\text { routine bioassay } \\
\text { programs) shall be } \\
\text { conducted for: } \\
\text { (1) Radiological } \\
\text { workers who, under } \\
\text { typical conditions, are } \\
\text { likely to receive a } \\
\text { committed effective } \\
\text { dose of } 0.1 \text { rem }(0.001 \\
\text { Sv) or more from all } \\
\text { occupational } \\
\text { radionuclide intakes in }\end{array}$ & $\begin{array}{l}\text { NV/YMP RCM } \\
521.1 \text {. The } \\
\text { following } \\
\text { individuals shall } \\
\text { participate in an } \\
\text { internal } \\
\text { dosimetry } \\
\text { program: } \\
\text { a. Individuals } \\
\text { entering } \\
\text { radiological } \\
\text { areas who under } \\
\text { typical conditions } \\
\text { are likely to } \\
\text { receive intakes } \\
\text { resulting in a } \\
\text { CEDE of } \\
100 \text { mrem or }\end{array}$ & $\begin{array}{l}\text { Revise: NV/YMP } \\
\text { RCM 521.1. The } \\
\text { following } \\
\text { individuals shall } \\
\text { participate in an } \\
\text { internal } \\
\text { dosimetry } \\
\text { program: } \\
\text { a. Radiological } \\
\text { Workers entering } \\
\text { radiological } \\
\text { areas who under } \\
\text { typical conditions } \\
\text { are likely to } \\
\text { receive intakes } \\
\text { resulting in a } \\
\text { CED of } 100 \\
\text { mrem or more in }\end{array}$ & $\begin{array}{l}\text { Same as Column } \\
3\end{array}$ & $\begin{array}{l}\text { Same as Column } \\
3\end{array}$ & $\begin{array}{l}\text { Same as Column } \\
3\end{array}$ & $\begin{array}{l}\text { Same as Column } \\
3\end{array}$ & $\begin{array}{l}\text { Internal exposure } \\
\text { monitoring } \\
\text { services are } \\
\text { provided by } \\
\text { RSPC at the } \\
\text { request of DRI. } \\
\text { Revise: NV/YMP } \\
\text { RCM } 214.01 . \\
\text { Members of the } \\
\text { public who are } \\
\text { permitted access } \\
\text { to NNSA/NSO } \\
\text { and OCRWM } \\
\text { Controlled Areas } \\
\text { shall be limited to } \\
\text { an annual } \\
\text { radiation dose of }\end{array}$ & $\begin{array}{l}\text { NV/YMP RCM } \\
521.1 . a-b . \text { The } \\
\text { following } \\
\text { individuals shall } \\
\text { participate in an } \\
\text { internal } \\
\text { dosimetry } \\
\text { program: } \\
\text { a. Individuals } \\
\text { entering } \\
\text { radiological } \\
\text { areas who under } \\
\text { typical conditions } \\
\text { are likely to } \\
\text { receive intakes } \\
\text { resulting in a } \\
\text { CED of } \\
100 \text { mrem or }\end{array}$ \\
\hline
\end{tabular}




\section{NEVADA TEST SITE RADIATION PROTECTION PROGRAM}

\section{APPENDIX H}

COMPLIANCE DEMONSTRATION TABLE

\begin{tabular}{|c|c|c|c|c|c|c|c|c|}
\hline \multirow[t]{2}{*}{10 CFR 835} & $\begin{array}{l}\text { NV/YMP RCM } \\
\text { Rev } 5 \text { and } \\
\text { NTS RPP } \\
\text { Revision } 0 \\
\end{array}$ & $\begin{array}{c}\text { NSTec } \\
\text { Appendix A }\end{array}$ & $\begin{array}{c}\text { LLNL } \\
\text { Appendix B }\end{array}$ & $\begin{array}{c}\text { LANL } \\
\text { Appendix C }\end{array}$ & $\begin{array}{c}\text { SNL } \\
\text { Appendix D }\end{array}$ & $\begin{array}{c}\text { SNJV } \\
\text { Appendix E }\end{array}$ & $\begin{array}{c}\text { DRI } \\
\text { Appendix F }\end{array}$ & $\begin{array}{c}\text { WSI } \\
\text { Appendix G }\end{array}$ \\
\hline & $\begin{array}{l}\text { Implementation } \\
\text { Reference }\end{array}$ & $\begin{array}{l}\text { Implementation } \\
\text { Reference }\end{array}$ & $\begin{array}{l}\text { Implementation } \\
\text { Reference }\end{array}$ & $\begin{array}{l}\text { Implementation } \\
\text { Reference }\end{array}$ & $\begin{array}{l}\text { Implementation } \\
\text { Reference }\end{array}$ & $\begin{array}{l}\text { Implementation } \\
\text { Reference }\end{array}$ & $\begin{array}{l}\text { Implementation } \\
\text { Reference }\end{array}$ & $\begin{array}{l}\text { Implementation } \\
\text { Reference }\end{array}$ \\
\hline
\end{tabular}

\section{a year;}

(2) Declared pregnant workers likely to

receive an intake or

intakes resulting in an equivalent dose to the embryo/fetus in

excess of 10 percent of the limit stated at \$835.206(a);

(3) Occupationally exposed minors who are likely to receive a dose in excess of 50 percent of the applicable limit stated at $\S 835.207$ from all radionuclide intakes in a year; or

(4) Members of the public entering a controlled area likely to receive a dose in excess of 50 percent of the limit stated at $\$ 835.208$ from all radionuclide intakes in a year.

402(d) Internal dose monitoring programs implemented to

demonstrate

compliance with

\section{more in a year.}

b. Declared

pregnant workers

likely to receive

intakes resulting

in a dose

equivalent to the

embryo/fetus of

50 mrem or more

during the

gestation period.

c. Occupationally

exposed minors

and members of

the public likely

to receive

intakes resulting

in a CEDE of 50

mrem or more in

a year

\section{a year.}

b. Declared

pregnant workers

kely to receive

intakes resulting

in an equivalent

dose to the

embryo/fetus of

50 mrem or more

during the

gestation period.

c. Occupationally

exposed minors

and members of

the public likely

to receive

intakes resulting

in a CED of 50

mrem or more in

a year.
NV/YMP RCM

522.1. $10 \mathrm{CFR}$

835 requires

accreditation of

the internal

\begin{tabular}{|l||} 
\\
\\
\\
This service is \\
provided to LLNL \\
at the NTS by \\
the RSPC or \\
LLNL-Livermore \\
\hline
\end{tabular}

522.1. $10 \mathrm{CFR}$

835 requires

accreditation of

LLNL-Livermore

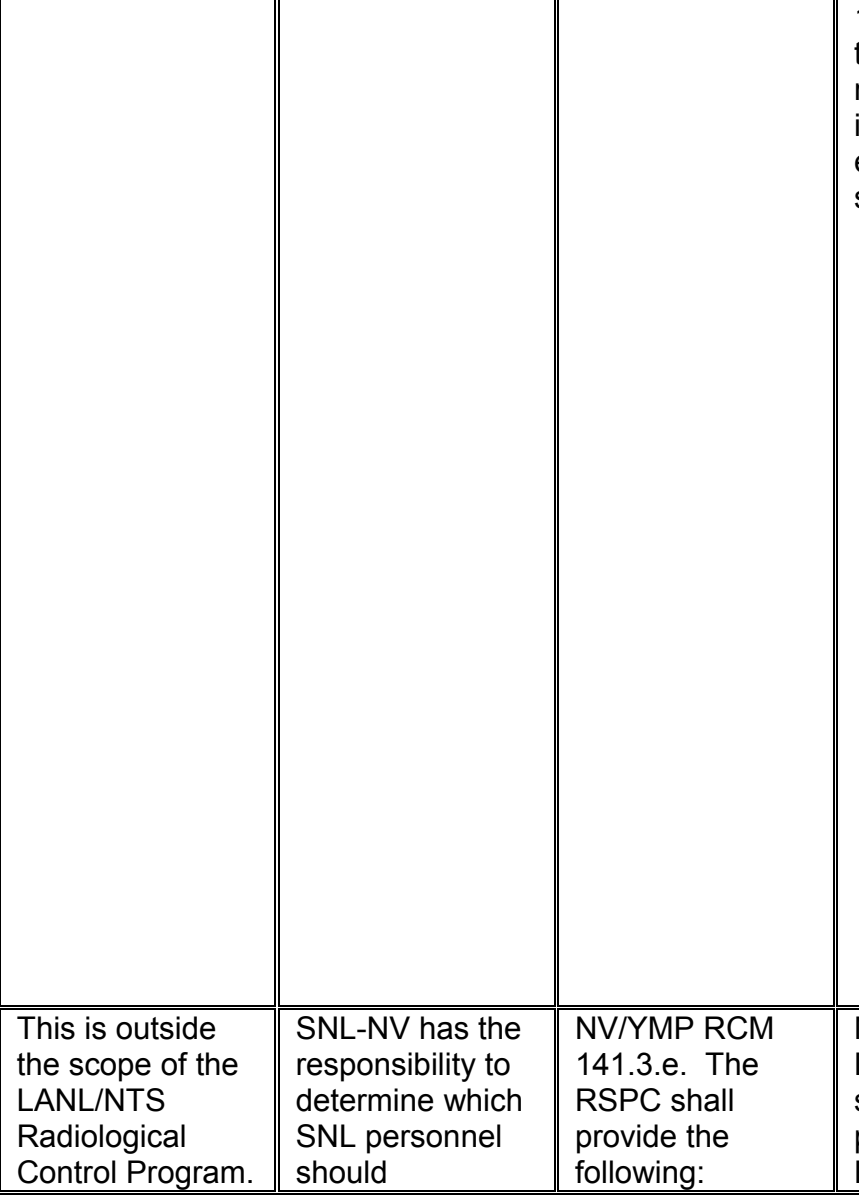

100 millirem from

the sum of doses
received from

internal and

external radiation

sources.

more in a year.

b. Declared

pregnant workers

likely to receive

intakes resulting

in an equivalent

dose to the

embryo/fetus of

50 mrem or more

during the

gestation period.

835.402(c) (3)

and (4) is not

applicable to

WSI/NV. WSI

does not employ

minors or control

members of the

public entering a

controlled area.

H-43 ot applicable to

DRI. This

service is

rovided by the

RSPC and it is
By written

agreement

dosimetry

services are

provided by the 


\section{NEVADA TEST SITE RADIATION PROTECTION PROGRAM}

\section{APPENDIX H}

COMPLIANCE DEMONSTRATION TABLE

\begin{tabular}{|c|c|c|c|c|c|c|c|c|}
\hline \multirow[t]{2}{*}{10 CFR 835} & $\begin{array}{c}\text { NV/YMP RCM } \\
\text { Rev } 5 \text { and } \\
\text { NTS RPP } \\
\text { Revision } 0 \\
\end{array}$ & $\begin{array}{c}\text { NSTec } \\
\text { Appendix A }\end{array}$ & $\begin{array}{c}\text { LLNL } \\
\text { Appendix B }\end{array}$ & $\begin{array}{c}\text { LANL } \\
\text { Appendix C }\end{array}$ & $\begin{array}{c}\text { SNL } \\
\text { Appendix D }\end{array}$ & $\begin{array}{c}\text { SNJV } \\
\text { Appendix E }\end{array}$ & $\begin{array}{c}\text { DRI } \\
\text { Appendix F }\end{array}$ & $\begin{array}{c}\text { WSI } \\
\text { Appendix G }\end{array}$ \\
\hline & $\begin{array}{l}\text { Implementation } \\
\text { Reference }\end{array}$ & $\begin{array}{l}\text { Implementation } \\
\text { Reference }\end{array}$ & $\begin{array}{l}\text { Implementation } \\
\text { Reference }\end{array}$ & $\begin{array}{l}\text { Implementation } \\
\text { Reference }\end{array}$ & $\begin{array}{l}\text { Implementation } \\
\text { Reference }\end{array}$ & $\begin{array}{l}\text { Implementation } \\
\text { Reference }\end{array}$ & $\begin{array}{l}\text { Implementation } \\
\text { Reference }\end{array}$ & $\begin{array}{l}\text { Implementation } \\
\text { Reference }\end{array}$ \\
\hline
\end{tabular}

\begin{tabular}{|c|c|c|c|c|c|c|c|c|}
\hline $\begin{array}{l}\text { §35.402(c) shall be } \\
\text { adequate to } \\
\text { demonstrate } \\
\text { compliance with the } \\
\text { dose limits established } \\
\text { in subpart C of this } \\
\text { part and shall be: } \\
\text { (1) Accredited, or } \\
\text { excepted from } \\
\text { accreditation, in } \\
\text { accordance with the } \\
\text { DOE Laboratory } \\
\text { Accreditation Program } \\
\text { for Radiobioassay; or } \\
\text { (2) Determined by the } \\
\text { Secretarial Officer } \\
\text { responsible for } \\
\text { environment, safety } \\
\text { and health matters to } \\
\text { have performance } \\
\text { substantially } \\
\text { equivalent to that of } \\
\text { programs accredited } \\
\text { under the DOE } \\
\text { Laboratory } \\
\text { Accreditation Program } \\
\text { for Radiobioassay. }\end{array}$ & $\begin{array}{l}\text { radiobioassay } \\
\text { monitoring } \\
\text { program by } \\
\text { DOELAP. The } \\
\text { RSPC internal } \\
\text { radiobioassay } \\
\text { program shall be } \\
\text { DOELAP } \\
\text { accredited. }\end{array}$ & $\begin{array}{l}\text { radiobioassay } \\
\text { monitoring } \\
\text { program by } \\
\text { DOELAP. The } \\
\text { RSPC internal } \\
\text { radiobioassay } \\
\text { program shall be } \\
\text { DOELAP } \\
\text { accredited. }\end{array}$ & $\begin{array}{l}\text { or LANL-New } \\
\text { Mexico. LLNL-N } \\
\text { will verify that the } \\
\text { RSPC meets the } \\
\text { standards in this } \\
\text { requirement by } \\
\text { participating in } \\
\text { the } 36 \text { month } \\
\text { internal audit } \\
\text { program. }\end{array}$ & $\begin{array}{l}\text { The NTS RSPC } \\
\text { and, by written } \\
\text { agreement, the } \\
\text { LANL RP-2 Dose } \\
\text { Assessment } \\
\text { Team perform } \\
\text { the dose } \\
\text { assessments for } \\
\text { LANL/NTS. The } \\
\text { LANL RP-2 } \\
\text { Radiation } \\
\text { Information } \\
\text { Management } \\
\text { Team records } \\
\text { and maintains } \\
\text { LANL employee } \\
\text { dose } \\
\text { assessments } \\
\text { provided by the } \\
\text { NTS RSPC. }\end{array}$ & $\begin{array}{l}\text { participate in an } \\
\text { internal } \\
\text { dosimetry } \\
\text { program. }\end{array}$ & $\begin{array}{l}\text { (e) External and } \\
\text { internal } \\
\text { dosimetry } \\
\text { services. }\end{array}$ & $\begin{array}{l}\text { their } \\
\text { responsibility to } \\
\text { be DOELAP } \\
\text { accredited. }\end{array}$ & $\begin{array}{l}\text { RSPC. It is the } \\
\text { responsibility of } \\
\text { the RSPC to } \\
\text { have the } \\
\text { program } \\
\text { accredited by } \\
\text { DOELAP. } \\
\text { WSI/NV will } \\
\text { verify that the } \\
\text { RSPC maintains } \\
\text { DOELAP } \\
\text { accreditation. }\end{array}$ \\
\hline $\begin{array}{l}835.403 \text { Air } \\
\text { Monitoring. } \\
\text { 403(a) Monitoring of } \\
\text { airborne radioactivity } \\
\text { shall be performed: }\end{array}$ & $\begin{array}{l}\text { NV/YMP RCM } \\
555.1 . \\
\text { Monitoring of } \\
\text { airborne } \\
\text { radioactivity shall } \\
\text { be performed: } \\
\end{array}$ & $\begin{array}{l}\text { NV/YMP RCM } \\
555.1 . \\
\text { Monitoring of } \\
\text { airborne } \\
\text { radioactivity shall } \\
\text { be performed: } \\
\end{array}$ & $\begin{array}{l}\text { Same as Column } \\
3\end{array}$ & $\begin{array}{l}\text { Same as Column } \\
3\end{array}$ & $\begin{array}{l}\text { Same as Column } \\
3\end{array}$ & $\begin{array}{l}\text { Same as Column } \\
3\end{array}$ & $\begin{array}{l}\text { Not applicable to } \\
\text { DRI. This } \\
\text { service is } \\
\text { provided by the } \\
\text { RSPC. }\end{array}$ & $\begin{array}{l}\text { By written } \\
\text { agreement, the } \\
\text { RSPC performs } \\
\text { air monitoring. }\end{array}$ \\
\hline
\end{tabular}

H-44 


\section{NEVADA TEST SITE RADIATION PROTECTION PROGRAM}

\section{APPENDIX H}

COMPLIANCE DEMONSTRATION TABLE

\begin{tabular}{|c|c|c|c||c||c||c||c||c|}
\hline \multirow{2}{*}{ 10 CFR 835 } & $\begin{array}{c}\text { NV/YMP RCM } \\
\text { Rev 5 and } \\
\text { NTS RPP } \\
\text { Revision 0 }\end{array}$ & Appendix A & Appendix B & Appendix C & Appendix D & SNJV \\
\cline { 2 - 7 } & $\begin{array}{c}\text { Implementation } \\
\text { Reference }\end{array}$ & $\begin{array}{c}\text { Implementation } \\
\text { Reference }\end{array}$ & $\begin{array}{c}\text { Implementation } \\
\text { Reference }\end{array}$ & $\begin{array}{c}\text { Implementation } \\
\text { Reference }\end{array}$ & $\begin{array}{c}\text { Implementation } \\
\text { Reference }\end{array}$ & $\begin{array}{c}\text { Implementation } \\
\text { Reference }\end{array}$ & $\begin{array}{c}\text { Implementation } \\
\text { Reference }\end{array}$ & $\begin{array}{c}\text { Implementation } \\
\text { Reference }\end{array}$ \\
\hline
\end{tabular}

\begin{tabular}{|c|c|c|c|c|c|c|c|c|}
\hline $\begin{array}{l}\text { (1) Where an } \\
\text { individual is likely to } \\
\text { receive an exposure of } \\
40 \text { or more DAC-hours } \\
\text { in a year; or } \\
\text { (2) As necessary to } \\
\text { characterize the } \\
\text { airborne radioactivity } \\
\text { hazard where } \\
\text { respiratory protective } \\
\text { devices for protection } \\
\text { against airborne } \\
\text { radionuclides have } \\
\text { been prescribed. }\end{array}$ & $\begin{array}{l}\text { a. Where an } \\
\text { individual is likely } \\
\text { to receive an } \\
\text { exposure of } 40 \\
\text { or more DAC- } \\
\text { hours in a year. } \\
\text { b. As necessary } \\
\text { to characterize } \\
\text { the airborne } \\
\text { radioactivity } \\
\text { hazard where } \\
\text { respiratory } \\
\text { protective } \\
\text { devices for } \\
\text { protection } \\
\text { against airborne } \\
\text { radionuclides } \\
\text { have been } \\
\text { prescribed. }\end{array}$ & $\begin{array}{l}\text { a. Where an } \\
\text { individual is likely } \\
\text { to receive an } \\
\text { exposure of } 40 \\
\text { or more DAC- } \\
\text { hours in a year. } \\
\text { b. As necessary } \\
\text { to characterize } \\
\text { the airborne } \\
\text { radioactivity } \\
\text { hazard where } \\
\text { respiratory } \\
\text { protective } \\
\text { devices for } \\
\text { protection } \\
\text { against airborne } \\
\text { radionuclides } \\
\text { have been } \\
\text { prescribed. }\end{array}$ & & & & & & \\
\hline $\begin{array}{l}403(b) \text { Real-time air } \\
\text { monitoring, shall be } \\
\text { performed as } \\
\text { necessary to detect } \\
\text { and provide warning of } \\
\text { airborne radioactivity } \\
\text { concentrations that } \\
\text { warrant immediate } \\
\text { action to terminate } \\
\text { inhalation of airborne } \\
\text { radioactive material. }\end{array}$ & $\begin{array}{l}\text { NV/YMP RCM } \\
555.2 \text {. Real-time } \\
\text { air monitoring } \\
\text { shall be } \\
\text { performed, as } \\
\text { necessary, to } \\
\text { detect and } \\
\text { provide warning } \\
\text { of airborne } \\
\text { radioactivity } \\
\text { concentrations } \\
\text { that warrant } \\
\text { immediate action } \\
\text { to terminate }\end{array}$ & $\begin{array}{l}\text { NV/YMP RCM } \\
555.2 \text {. Real-time } \\
\text { air monitoring } \\
\text { shall be } \\
\text { performed, as } \\
\text { necessary, to } \\
\text { detect and } \\
\text { provide warning } \\
\text { of airborne } \\
\text { radioactivity } \\
\text { concentrations } \\
\text { that warrant } \\
\text { immediate action } \\
\text { to terminate }\end{array}$ & $\begin{array}{l}\text { Same as Column } \\
3\end{array}$ & $\begin{array}{l}\text { Same as Column } \\
3\end{array}$ & $\begin{array}{l}\text { Same as Column } \\
3\end{array}$ & $\begin{array}{l}\text { Same as Column } \\
3\end{array}$ & $\begin{array}{l}\text { Not applicable to } \\
\text { DRI. This } \\
\text { service is } \\
\text { provided by the } \\
\text { RSPC. }\end{array}$ & $\begin{array}{l}\text { By written } \\
\text { agreement, the } \\
\text { RSPC performs } \\
\text { air monitoring. }\end{array}$ \\
\hline
\end{tabular}




\section{NEVADA TEST SITE RADIATION PROTECTION PROGRAM}

\section{APPENDIX H}

COMPLIANCE DEMONSTRATION TABLE

\begin{tabular}{|c|c|c|c|c|c|c|c|c|}
\hline \multirow[t]{2}{*}{10 CFR 835} & $\begin{array}{c}\text { NV/YMP RCM } \\
\text { Rev } 5 \text { and } \\
\text { NTS RPP } \\
\text { Revision } 0 \\
\end{array}$ & $\begin{array}{c}\text { NSTec } \\
\text { Appendix A }\end{array}$ & $\begin{array}{c}\text { LLNL } \\
\text { Appendix B }\end{array}$ & $\begin{array}{c}\text { LANL } \\
\text { Appendix C }\end{array}$ & $\begin{array}{c}\text { SNL } \\
\text { Appendix D }\end{array}$ & $\begin{array}{c}\text { SNJV } \\
\text { Appendix E }\end{array}$ & $\begin{array}{c}\text { DRI } \\
\text { Appendix F }\end{array}$ & $\begin{array}{c}\text { WSI } \\
\text { Appendix G }\end{array}$ \\
\hline & $\begin{array}{l}\text { Implementation } \\
\text { Reference }\end{array}$ & $\begin{array}{l}\text { Implementation } \\
\text { Reference }\end{array}$ & $\begin{array}{l}\text { Implementation } \\
\text { Reference }\end{array}$ & $\begin{array}{l}\text { Implementation } \\
\text { Reference }\end{array}$ & $\begin{array}{l}\text { Implementation } \\
\text { Reference }\end{array}$ & $\begin{array}{l}\text { Implementation } \\
\text { Reference }\end{array}$ & $\begin{array}{l}\text { Implementation } \\
\text { Reference }\end{array}$ & $\begin{array}{l}\text { Implementation } \\
\text { Reference }\end{array}$ \\
\hline
\end{tabular}

\begin{tabular}{|c|c|c|c|c|c|c|c|c|}
\hline & $\begin{array}{l}\text { inhalation of } \\
\text { airborne } \\
\text { radioactive } \\
\text { material. }\end{array}$ & $\begin{array}{l}\text { inhalation of } \\
\text { airborne } \\
\text { radioactive } \\
\text { material. }\end{array}$ & & & & & & \\
\hline \multicolumn{9}{|l|}{835.404 [Reserved] } \\
\hline $\begin{array}{l}835.405 \text { Receipt of } \\
\text { Packages Containing } \\
\text { Radioactive Material. } \\
\text { 405(a) If packages } \\
\text { containing quantities } \\
\text { of radioactive material } \\
\text { in excess of a Type A } \\
\text { quantity (as defined at } \\
10 \text { CFR 71.4) are } \\
\text { expected to be } \\
\text { received from } \\
\text { radioactive material } \\
\text { transportation, } \\
\text { arrangements shall be } \\
\text { made to either: } \\
\text { (1) Take possession of } \\
\text { the package when the } \\
\text { carrier offers it for } \\
\text { delivery; or } \\
\text { (2) Receive notification } \\
\text { as soon as practicable } \\
\text { after arrival of the } \\
\text { package at the } \\
\text { carrier's terminal and } \\
\text { to take possession of } \\
\text { the package }\end{array}$ & $\begin{array}{l}\text { NV/YMP RCM } \\
\text { 423.4.a. Receipt } \\
\text { of packages } \\
\text { containing } \\
\text { radioactive } \\
\text { material: } \\
\text { a. When } \\
\text { packages } \\
\text { containing } \\
\text { quantities of } \\
\text { radioactive } \\
\text { material in } \\
\text { excess of Type A } \\
\text { quantity (as } \\
\text { defined in } 10 \\
\text { CFR 71.4) are } \\
\text { expected to be } \\
\text { received from } \\
\text { radioactive } \\
\text { material } \\
\text { transportation, } \\
\text { arrangements } \\
\text { shall be made to } \\
\text { either: (1) Take } \\
\text { possession of } \\
\text { the package } \\
\text { when the carrier }\end{array}$ & $\begin{array}{l}\text { NV/YMP RCM } \\
\text { 423.4.a. Receipt } \\
\text { of packages } \\
\text { containing } \\
\text { radioactive } \\
\text { material: } \\
\text { a. When } \\
\text { packages } \\
\text { containing } \\
\text { quantities of } \\
\text { radioactive } \\
\text { material in } \\
\text { excess of Type A } \\
\text { quantity (as } \\
\text { defined in } 10 \\
\text { CFR 71.4) are } \\
\text { expected to be } \\
\text { received from } \\
\text { radioactive } \\
\text { material } \\
\text { transportation, } \\
\text { arrangements } \\
\text { shall be made to } \\
\text { either: (1) Take } \\
\text { possession of } \\
\text { the package } \\
\text { when the carrier }\end{array}$ & $\begin{array}{l}\text { Same as Column } \\
3\end{array}$ & $\begin{array}{l}\text { Same as Column } \\
3\end{array}$ & $\begin{array}{l}\text { Same as Column } \\
3\end{array}$ & $\begin{array}{l}\text { Same as Column } \\
3\end{array}$ & $\begin{array}{l}\text { Not applicable to } \\
\text { DRI. All } \\
\text { radioactive } \\
\text { material used by } \\
\text { DRI employees } \\
\text { need to be } \\
\text { approved by the } \\
\text { UNR radiation } \\
\text { safety committee } \\
\text { as required by } \\
\text { the UNR } \\
\text { Radioactive } \\
\text { Material License } \\
\text { 16.13-0003-07. } \\
\text { DRI will follow } \\
\text { UNR Radiation } \\
\text { Safety Procedure } \\
\text { III: Radiation } \\
\text { source control for } \\
\text { any radioactive } \\
\text { material in } \\
\text { excess of Type A } \\
\text { quantities. }\end{array}$ & $\begin{array}{l}\text { Receipt of } \\
\text { packages } \\
\text { containing } \\
\text { radioactive } \\
\text { material is } \\
\text { outside the } \\
\text { scope of WSI/NV } \\
\text { activities. }\end{array}$ \\
\hline
\end{tabular}

the package when the carrie 


\section{NEVADA TEST SITE RADIATION PROTECTION PROGRAM}

\section{APPENDIX H}

COMPLIANCE DEMONSTRATION TABLE

\begin{tabular}{|c|c|c|c|c|c|c|c|c|}
\hline \multirow[t]{2}{*}{10 CFR 835} & $\begin{array}{c}\text { NV/YMP RCM } \\
\text { Rev } 5 \text { and } \\
\text { NTS RPP } \\
\text { Revision } 0 \\
\end{array}$ & $\begin{array}{c}\text { NSTec } \\
\text { Appendix A }\end{array}$ & $\begin{array}{c}\text { LLNL } \\
\text { Appendix B }\end{array}$ & $\begin{array}{c}\text { LANL } \\
\text { Appendix C }\end{array}$ & $\begin{array}{c}\text { SNL } \\
\text { Appendix D }\end{array}$ & $\begin{array}{c}\text { SNJV } \\
\text { Appendix E }\end{array}$ & $\begin{array}{c}\text { DRI } \\
\text { Appendix F }\end{array}$ & $\begin{array}{c}\text { WSI } \\
\text { Appendix G }\end{array}$ \\
\hline & $\begin{array}{l}\text { Implementation } \\
\text { Reference }\end{array}$ & $\begin{array}{l}\text { Implementation } \\
\text { Reference }\end{array}$ & $\begin{array}{l}\text { Implementation } \\
\text { Reference }\end{array}$ & $\begin{array}{l}\text { Implementation } \\
\text { Reference }\end{array}$ & $\begin{array}{l}\text { Implementation } \\
\text { Reference }\end{array}$ & $\begin{array}{l}\text { Implementation } \\
\text { Reference }\end{array}$ & $\begin{array}{l}\text { Implementation } \\
\text { Reference }\end{array}$ & $\begin{array}{l}\text { Implementation } \\
\text { Reference }\end{array}$ \\
\hline
\end{tabular}

\begin{tabular}{|c|c|c|c|c|c|c|c|c|}
\hline $\begin{array}{l}\text { expeditiously after } \\
\text { receiving such } \\
\text { notification. }\end{array}$ & $\begin{array}{l}\text { offers it for } \\
\text { delivery; or } \\
\text { (2) Receive } \\
\text { notification as } \\
\text { soon as practical } \\
\text { after arrival of } \\
\text { the package at } \\
\text { the carrier's } \\
\text { terminal and take } \\
\text { possession of } \\
\text { the package } \\
\text { expeditiously } \\
\text { after receiving } \\
\text { such notification. }\end{array}$ & $\begin{array}{l}\text { offers it for } \\
\text { delivery; or } \\
\text { (2) Receive } \\
\text { notification as } \\
\text { soon as practical } \\
\text { after arrival of } \\
\text { the package at } \\
\text { the carrier's } \\
\text { terminal and take } \\
\text { possession of } \\
\text { the package } \\
\text { expeditiously } \\
\text { after receiving } \\
\text { such notification. }\end{array}$ & & & & & & \\
\hline $\begin{array}{l}\text { 405(b) Upon receipt } \\
\text { from radioactive } \\
\text { material } \\
\text { transportation, } \\
\text { external surfaces of } \\
\text { packages known to } \\
\text { contain radioactive } \\
\text { material shall be } \\
\text { monitored if the } \\
\text { package: } \\
\text { (1) Is labeled with a } \\
\text { Radioactive White I, } \\
\text { Yellow II or Yellow III } \\
\text { label (as specified at } \\
49 \text { CFR 172.403 and } \\
172.436-440 \text { ); or } \\
\text { (2) Has been } \\
\text { transported as low } \\
\text { specific activity }\end{array}$ & $\begin{array}{l}\text { NV/YMP RCM } \\
423.4 . b . \text { Receipt } \\
\text { of packages } \\
\text { containing } \\
\text { radioactive } \\
\text { material: } \\
\text { b. Upon receipt } \\
\text { from radioactive } \\
\text { material } \\
\text { transportation, } \\
\text { external surfaces } \\
\text { of the packages } \\
\text { known to contain } \\
\text { radioactive } \\
\text { material shall be } \\
\text { monitored if the } \\
\text { package: } \\
\text { (1) Is labeled } \\
\text { with a }\end{array}$ & $\begin{array}{l}\text { NV/YMP RCM } \\
\text { 423.4.b. Receipt } \\
\text { of packages } \\
\text { containing } \\
\text { radioactive } \\
\text { material: } \\
\text { b. Upon receipt } \\
\text { from radioactive } \\
\text { material } \\
\text { transportation, } \\
\text { external surfaces } \\
\text { of the packages } \\
\text { known to contain } \\
\text { radioactive } \\
\text { material shall be } \\
\text { monitored if the } \\
\text { package: } \\
\text { (1) Is labeled } \\
\text { with a }\end{array}$ & $\begin{array}{l}\text { Same as Column } \\
3\end{array}$ & $\begin{array}{l}\text { Same as Column } \\
3\end{array}$ & $\begin{array}{l}\text { Same as Column } \\
3\end{array}$ & $\begin{array}{l}\text { Same as Column } \\
3\end{array}$ & $\begin{array}{l}\text { Not applicable to } \\
\text { DRI. Under the } \\
\text { UNR Radioactive } \\
\text { Material License } \\
\text { number 16-13- } \\
\text { 0003-07, DRI } \\
\text { must follow the } \\
\text { UNR radioactive } \\
\text { material receipt } \\
\text { procedure as } \\
\text { outlined in UNR } \\
\text { Radiation Safety } \\
\text { Procedure III: } \\
\text { Radiation Source } \\
\text { Control. }\end{array}$ & $\begin{array}{l}\text { By written } \\
\text { agreement, the } \\
\text { RSPC performs } \\
\text { this service. }\end{array}$ \\
\hline
\end{tabular}




\section{NEVADA TEST SITE RADIATION PROTECTION PROGRAM}

\section{APPENDIX H}

COMPLIANCE DEMONSTRATION TABLE

\begin{tabular}{|c|c|c|c|c|c|c|c|c|}
\hline \multirow[t]{2}{*}{10 CFR 835} & $\begin{array}{c}\text { NV/YMP RCM } \\
\text { Rev } 5 \text { and } \\
\text { NTS RPP } \\
\text { Revision } 0 \\
\end{array}$ & $\begin{array}{c}\text { NSTec } \\
\text { Appendix A }\end{array}$ & $\begin{array}{c}\text { LLNL } \\
\text { Appendix B }\end{array}$ & $\begin{array}{c}\text { LANL } \\
\text { Appendix C }\end{array}$ & $\begin{array}{c}\text { SNL } \\
\text { Appendix D }\end{array}$ & $\begin{array}{c}\text { SNJV } \\
\text { Appendix E }\end{array}$ & $\begin{array}{c}\text { DRI } \\
\text { Appendix F }\end{array}$ & $\begin{array}{c}\text { WSI } \\
\text { Appendix G }\end{array}$ \\
\hline & $\begin{array}{l}\text { Implementation } \\
\text { Reference }\end{array}$ & $\begin{array}{l}\text { Implementation } \\
\text { Reference }\end{array}$ & $\begin{array}{l}\text { Implementation } \\
\text { Reference }\end{array}$ & $\begin{array}{l}\text { Implementation } \\
\text { Reference }\end{array}$ & $\begin{array}{l}\text { Implementation } \\
\text { Reference }\end{array}$ & $\begin{array}{l}\text { Implementation } \\
\text { Reference }\end{array}$ & $\begin{array}{l}\text { Implementation } \\
\text { Reference }\end{array}$ & $\begin{array}{l}\text { Implementation } \\
\text { Reference }\end{array}$ \\
\hline
\end{tabular}

\begin{tabular}{|c|c|c|c|c|c|c|c|c|}
\hline $\begin{array}{l}\text { material ( as defined at } \\
10 \text { CFR 71.4) on an } \\
\text { exclusive use vehicle } \\
\text { (as defined at } 10 \text { CFR } \\
71.4 \text { ); or } \\
\text { (3) Has evidence of } \\
\text { degradation, such as } \\
\text { packages that are } \\
\text { crushed, wet, or } \\
\text { damaged. }\end{array}$ & $\begin{array}{l}\text { Radioactive } \\
\text { White I, Yellow II, } \\
\text { or Yellow III label } \\
\text { (as specified in } \\
49 \text { CFR 172.403 } \\
\text { and 172.436- } \\
440 \text { ). } \\
\text { (2) Has been } \\
\text { transported as } \\
\text { low specific } \\
\text { activity material } \\
\text { (as defined in } 49 \\
\text { CFR 71.4) on an } \\
\text { exclusive use } \\
\text { vehicle (as } \\
\text { defined in 10 } \\
\text { CFR 71.4). (3) } \\
\text { Has evidence of } \\
\text { degradation, } \\
\text { such as } \\
\text { packages that } \\
\text { are crushed, wet, } \\
\text { or damaged. } \\
\end{array}$ & $\begin{array}{l}\text { Radioactive } \\
\text { White I, Yellow II, } \\
\text { or Yellow III label } \\
\text { (as specified in } \\
49 \text { CFR 172.403 } \\
\text { and 172.436- } \\
440 \text { ). } \\
\text { (2) Has been } \\
\text { transported as } \\
\text { low specific } \\
\text { activity material } \\
\text { (as defined in } 49 \\
\text { CFR 71.4) on an } \\
\text { exclusive use } \\
\text { vehicle (as } \\
\text { defined in 10 } \\
\text { CFR 71.4). (3) } \\
\text { Has evidence of } \\
\text { degradation, } \\
\text { such as } \\
\text { packages that } \\
\text { are crushed, wet, } \\
\text { or damaged. } \\
\end{array}$ & & & & & & \\
\hline $\begin{array}{l}405(c) \text { The monitoring } \\
\text { required by paragraph } \\
\text { (b) of this section shall } \\
\text { include: } \\
\text { (1) Measurements of } \\
\text { removable } \\
\text { contamination levels, } \\
\text { unless the package } \\
\text { contains only special } \\
\text { form (as defined at } 10\end{array}$ & $\begin{array}{l}\text { NV/YMP RCM } \\
\text { 423.4.c. Receipt } \\
\text { of packages } \\
\text { containing } \\
\text { radioactive } \\
\text { material: } \\
\text { c. The monitoring } \\
\text { required by } \\
\text { Article 423.4.b } \\
\text { shall include: } \\
\end{array}$ & $\begin{array}{l}\text { Revise: NV/YMP } \\
\text { RCM 423.4.c. } \\
\text { Receipt of } \\
\text { packages } \\
\text { containing } \\
\text { radioactive } \\
\text { material: } \\
\text { c. The monitoring } \\
\text { required by } \\
\text { Article 423.4.b } \\
\end{array}$ & $\begin{array}{l}\text { Same as Column } \\
3\end{array}$ & $\begin{array}{l}\text { Same as Column } \\
3\end{array}$ & $\begin{array}{l}\text { Same as Column } \\
3\end{array}$ & $\begin{array}{l}\text { Same as Column } \\
3\end{array}$ & $\begin{array}{l}\text { Not applicable to } \\
\text { DRI. Under the } \\
\text { UNR Radioactive } \\
\text { Material License } \\
\text { number } \\
16-13-0003-07, \\
\text { DRI must follow } \\
\text { the UNR } \\
\text { radioactive } \\
\text { material receipt } \\
\end{array}$ & $\begin{array}{l}\text { By written } \\
\text { agreement, the } \\
\text { RSPC provides } \\
\text { monitoring. }\end{array}$ \\
\hline
\end{tabular}




\section{NEVADA TEST SITE RADIATION PROTECTION PROGRAM}

\section{APPENDIX H}

COMPLIANCE DEMONSTRATION TABLE

\begin{tabular}{|c|c|c|c|c|c|c|c|c|}
\hline \multirow[t]{2}{*}{10 CFR 835} & $\begin{array}{l}\text { NV/YMP RCM } \\
\text { Rev } 5 \text { and } \\
\text { NTS RPP } \\
\text { Revision } 0 \\
\end{array}$ & $\begin{array}{c}\text { NSTec } \\
\text { Appendix A }\end{array}$ & $\begin{array}{c}\text { LLNL } \\
\text { Appendix B }\end{array}$ & $\begin{array}{c}\text { LANL } \\
\text { Appendix C }\end{array}$ & $\begin{array}{c}\text { SNL } \\
\text { Appendix D }\end{array}$ & $\begin{array}{c}\text { SNJV } \\
\text { Appendix E }\end{array}$ & $\begin{array}{c}\text { DRI } \\
\text { Appendix F }\end{array}$ & $\begin{array}{c}\text { WSI } \\
\text { Appendix G }\end{array}$ \\
\hline & $\begin{array}{l}\text { Implementation } \\
\text { Reference }\end{array}$ & $\begin{array}{c}\text { Implementation } \\
\text { Reference }\end{array}$ & $\begin{array}{l}\text { Implementation } \\
\text { Reference }\end{array}$ & $\begin{array}{l}\text { Implementation } \\
\text { Reference }\end{array}$ & $\begin{array}{l}\text { Implementation } \\
\text { Reference }\end{array}$ & $\begin{array}{l}\text { Implementation } \\
\text { Reference }\end{array}$ & $\begin{array}{l}\text { Implementation } \\
\text { Reference }\end{array}$ & $\begin{array}{l}\text { Implementation } \\
\text { Reference }\end{array}$ \\
\hline
\end{tabular}

\begin{tabular}{|c|c|c|c|c|c|c|c|c|}
\hline $\begin{array}{l}\text { CFR 71.4) or gaseous } \\
\text { radioactive material; } \\
\text { and } \\
\text { (2) Measurements of } \\
\text { the radiation levels, if } \\
\text { the package contains } \\
\text { a Type } B \text { quantity (as } \\
\text { defined at } 10 \text { CFR } \\
71.4 \text { ) of radioactive } \\
\text { material. }\end{array}$ & $\begin{array}{l}\text { Measurements of } \\
\text { removable } \\
\text { contamination } \\
\text { levels, unless the } \\
\text { package } \\
\text { contains only } \\
\text { special form, (as } \\
\text { defined in } \\
10 \text { CFR } 71.4 \text { ) or } \\
\text { gaseous } \\
\text { radioactive } \\
\text { material. } \\
\text { (2) } \\
\text { Measurements of } \\
\text { the radiation } \\
\text { levels, unless the } \\
\text { package } \\
\text { contains less } \\
\text { than a Type A } \\
\text { quantity (as } \\
\text { defined in } 10 \\
\text { CFR } 71.4 \text { ) of } \\
\text { radioactive } \\
\text { material. }\end{array}$ & $\begin{array}{l}\text { shall include: } \\
\text { (1) } \\
\text { Measurements of } \\
\text { removable } \\
\text { contamination } \\
\text { levels, unless the } \\
\text { package } \\
\text { contains only } \\
\text { special form, (as } \\
\text { defined in } \\
10 \text { CFR } 71.4 \text { ) or } \\
\text { gaseous } \\
\text { radioactive } \\
\text { material. } \\
\text { (2) } \\
\text { Measurements of } \\
\text { the radiation } \\
\text { levels, if the } \\
\text { package } \\
\text { contains a Type } \\
\text { B quantity (as } \\
\text { defined at } 10 \\
\text { CFR } 71.4 \text { ) of } \\
\text { radioactive } \\
\text { material }\end{array}$ & & & & & $\begin{array}{l}\text { procedure as } \\
\text { outlined in UNR } \\
\text { Radiation Safety } \\
\text { Procedure III: } \\
\text { Radiation Source } \\
\text { Control. }\end{array}$ & \\
\hline $\begin{array}{l}405(d) \text { The monitoring } \\
\text { required by paragraph } \\
\text { (b) of this section shall } \\
\text { be completed as soon } \\
\text { as practicable } \\
\text { following receipt of the } \\
\text { package, but not later } \\
\text { than } 8 \text { hours after the }\end{array}$ & $\begin{array}{l}\text { NV/YMP RCM } \\
\text { 423.4.d. Receipt } \\
\text { of packages } \\
\text { containing } \\
\text { radioactive } \\
\text { material. } \\
\text { d. The } \\
\text { monitoring } \\
\end{array}$ & $\begin{array}{l}\text { NV/YMP RCM } \\
\text { 423.4.d. Receipt } \\
\text { of packages } \\
\text { containing } \\
\text { radioactive } \\
\text { material. } \\
\text { d. The } \\
\text { monitoring } \\
\end{array}$ & $\begin{array}{l}\text { Same as Column } \\
3\end{array}$ & $\begin{array}{l}\text { Same as Column } \\
3\end{array}$ & $\begin{array}{l}\text { Same as Column } \\
3\end{array}$ & $\begin{array}{l}\text { Same as Column } \\
3\end{array}$ & $\begin{array}{l}\text { Not applicable to } \\
\text { DRI. Under the } \\
\text { UNR Radioactive } \\
\text { Material License } \\
\text { number 16-13- } \\
\text { 0003-07, DRI } \\
\text { must follow the } \\
\text { UNR radioactive } \\
\end{array}$ & $\begin{array}{l}\text { By written } \\
\text { agreement, the } \\
\text { RSPC provides } \\
\text { monitoring. }\end{array}$ \\
\hline
\end{tabular}




\section{NEVADA TEST SITE RADIATION PROTECTION PROGRAM}

\section{APPENDIX H}

COMPLIANCE DEMONSTRATION TABLE

\begin{tabular}{|c|c|c|c|c|c|c|c|c|}
\hline \multirow[t]{2}{*}{10 CFR 835} & $\begin{array}{c}\text { NV/YMP RCM } \\
\text { Rev } 5 \text { and } \\
\text { NTS RPP } \\
\text { Revision } 0 \\
\end{array}$ & $\begin{array}{c}\text { NSTec } \\
\text { Appendix A }\end{array}$ & $\begin{array}{c}\text { LLNL } \\
\text { Appendix B }\end{array}$ & $\begin{array}{c}\text { LANL } \\
\text { Appendix C }\end{array}$ & $\begin{array}{c}\text { SNL } \\
\text { Appendix D }\end{array}$ & $\begin{array}{c}\text { SNJV } \\
\text { Appendix E }\end{array}$ & $\begin{array}{c}\text { DRI } \\
\text { Appendix F }\end{array}$ & $\begin{array}{c}\text { WSI } \\
\text { Appendix G }\end{array}$ \\
\hline & $\begin{array}{l}\text { Implementation } \\
\text { Reference }\end{array}$ & $\begin{array}{l}\text { Implementation } \\
\text { Reference }\end{array}$ & $\begin{array}{l}\text { Implementation } \\
\text { Reference }\end{array}$ & $\begin{array}{l}\text { Implementation } \\
\text { Reference }\end{array}$ & $\begin{array}{l}\text { Implementation } \\
\text { Reference }\end{array}$ & $\begin{array}{l}\text { Implementation } \\
\text { Reference }\end{array}$ & $\begin{array}{l}\text { Implementation } \\
\text { Reference }\end{array}$ & $\begin{array}{l}\text { Implementation } \\
\text { Reference }\end{array}$ \\
\hline
\end{tabular}

\begin{tabular}{|c|c|c|c|c|c|c|c|c|}
\hline $\begin{array}{l}\text { beginning of the } \\
\text { working day following } \\
\text { receipt of the package. }\end{array}$ & $\begin{array}{l}\text { required by } \\
\text { Article } 423.4 . b \\
\text { shall be } \\
\text { completed as } \\
\text { soon as practical } \\
\text { following receipt } \\
\text { of the package, } \\
\text { but not later than } \\
8 \text { hours after the } \\
\text { beginning of the } \\
\text { working day } \\
\text { following receipt } \\
\text { of the package. } \\
\end{array}$ & $\begin{array}{l}\text { required by } \\
\text { Article } 423.4 . b \\
\text { shall be } \\
\text { completed as } \\
\text { soon as practical } \\
\text { following receipt } \\
\text { of the package, } \\
\text { but not later than } \\
8 \text { hours after the } \\
\text { beginning of the } \\
\text { working day } \\
\text { following receipt } \\
\text { of the package. } \\
\end{array}$ & & & & & $\begin{array}{l}\text { material receipt } \\
\text { procedure as } \\
\text { outlined in UNR } \\
\text { Radiation Safety } \\
\text { Procedure III: } \\
\text { Radiation Source } \\
\text { Control. }\end{array}$ & \\
\hline $\begin{array}{l}405(e) \text { Monitoring } \\
\text { pursuant to } \S \\
835.405(b) \text { is not } \\
\text { required for packages } \\
\text { transported on a DOE } \\
\text { site which have } \\
\text { remained under the } \\
\text { continuous } \\
\text { observation and } \\
\text { control of a DOE } \\
\text { employee or DOE } \\
\text { contractor employee } \\
\text { who is knowledgeable } \\
\text { of and implements } \\
\text { required exposure } \\
\text { control measures. }\end{array}$ & & $\begin{array}{l}\text { Add: NV/YMP } \\
\text { RCM 423.4.e } \\
\text { The Monitoring } \\
\text { required by } \\
\text { Article } 423.4 . b \text { is } \\
\text { not required for } \\
\text { packages } \\
\text { transported on } \\
\text { site which have } \\
\text { remained under } \\
\text { the continuous } \\
\text { observation and } \\
\text { control of a DOE } \\
\text { employee or } \\
\text { DOE contractor } \\
\text { employee who is } \\
\text { knowledgeable } \\
\text { of and } \\
\text { implements } \\
\text { required }\end{array}$ & $\begin{array}{l}\text { Same as Column } \\
3\end{array}$ & $\begin{array}{l}\text { Same as Column } \\
3\end{array}$ & $\begin{array}{l}\text { Same as Column } \\
3\end{array}$ & $\begin{array}{l}\text { Same as Column } \\
3\end{array}$ & $\begin{array}{l}\text { Same as Column } \\
3\end{array}$ & $\begin{array}{l}\text { Same as Column } \\
3\end{array}$ \\
\hline
\end{tabular}




\section{NEVADA TEST SITE RADIATION PROTECTION PROGRAM}

\section{APPENDIX H}

COMPLIANCE DEMONSTRATION TABLE

\begin{tabular}{|c|c|c|c|c|c|c|c|c|}
\hline \multirow[t]{2}{*}{10 CFR 835} & $\begin{array}{c}\text { NV/YMP RCM } \\
\text { Rev } 5 \text { and } \\
\text { NTS RPP } \\
\text { Revision } 0 \\
\end{array}$ & $\begin{array}{c}\text { NSTec } \\
\text { Appendix A }\end{array}$ & $\begin{array}{c}\text { LLNL } \\
\text { Appendix B }\end{array}$ & $\begin{array}{c}\text { LANL } \\
\text { Appendix C }\end{array}$ & $\begin{array}{c}\text { SNL } \\
\text { Appendix D }\end{array}$ & $\begin{array}{c}\text { SNJV } \\
\text { Appendix E }\end{array}$ & $\begin{array}{c}\text { DRI } \\
\text { Appendix F }\end{array}$ & $\begin{array}{c}\text { WSI } \\
\text { Appendix G }\end{array}$ \\
\hline & $\begin{array}{l}\text { Implementation } \\
\text { Reference }\end{array}$ & $\begin{array}{l}\text { Implementation } \\
\text { Reference }\end{array}$ & $\begin{array}{l}\text { Implementation } \\
\text { Reference }\end{array}$ & $\begin{array}{l}\text { Implementation } \\
\text { Reference }\end{array}$ & $\begin{array}{l}\text { Implementation } \\
\text { Reference }\end{array}$ & $\begin{array}{l}\text { Implementation } \\
\text { Reference }\end{array}$ & $\begin{array}{l}\text { Implementation } \\
\text { Reference }\end{array}$ & $\begin{array}{l}\text { Implementation } \\
\text { Reference }\end{array}$ \\
\hline
\end{tabular}

\begin{tabular}{|c|c|c|c|c|c|c|c|c|}
\hline & & $\begin{array}{l}\text { exposure control } \\
\text { measures. }\end{array}$ & & & & & & \\
\hline $\begin{array}{l}\text { Subpart F-Entry } \\
\text { Control Program } \\
\text { 835.501 Radiological } \\
\text { Areas. } \\
501 \text { (a) Personnel entry } \\
\text { control shall be } \\
\text { maintained for each } \\
\text { radiological area. }\end{array}$ & $\begin{array}{l}\text { NV/YMP RCM } \\
334.7 .01 \text { and } \\
335.5 .01 . \\
\text { Written } \\
\text { authorizations } \\
\text { shall be required } \\
\text { to control entry } \\
\text { into and permit } \\
\text { work to be } \\
\text { performed } \\
\text { within } \\
\text { radiological } \\
\text { areas. }\end{array}$ & $\begin{array}{l}\text { NV/YMP RCM } \\
334.7 .01 \text { and } \\
335.5 .01 \text {. } \\
\text { Written } \\
\text { authorizations } \\
\text { shall be required } \\
\text { to control entry } \\
\text { into and permit } \\
\text { work to be } \\
\text { performed } \\
\text { within } \\
\text { radiological } \\
\text { areas. }\end{array}$ & $\begin{array}{l}\text { Same as Column } \\
3\end{array}$ & $\begin{array}{l}\text { Same as Column } \\
3\end{array}$ & $\begin{array}{l}\text { Same as Column } \\
3\end{array}$ & $\begin{array}{l}\text { Same as Column } \\
3\end{array}$ & $\begin{array}{l}\text { NV/YMP RCM } \\
322.2 \text {. } \\
\text { Radiological } \\
\text { Work Permits } \\
\text { (RWPs) or } \\
\text { alternative, } \\
\text { formal } \\
\text { mechanism as } \\
\text { described in } \\
\text { Article } 322.9 \\
\text { shall be used to } \\
\text { control the } \\
\text { following } \\
\text { activities: } \\
\text { a. Entering } \\
\text { Radiation Areas. } \\
\text { b. Entering } \\
\text { Contamination } \\
\text { Areas. } \\
\text { c. Handling } \\
\text { materials with } \\
\text { removable } \\
\text { contamination } \\
\text { that exceed the } \\
\text { values of Table } \\
\text { 2-2. } \\
\text { DRI does not } \\
\text { have any } \\
\text { Radiological } \\
\text { Control areas, }\end{array}$ & $\begin{array}{l}\text { WSI/NV does not } \\
\text { have radiological } \\
\text { control } \\
\text { responsibilities } \\
\text { for any } \\
\text { radiological area. } \\
\text { The RSPC or TO } \\
\text { who has } \\
\text { radiological } \\
\text { control } \\
\text { responsibilities } \\
\text { for the } \\
\text { radiological area } \\
\text { is responsible for } \\
\text { ensuring that the } \\
\text { requirements of } \\
\text { this section are } \\
\text { met. WSI/NV } \\
\text { personnel will } \\
\text { comply with all } \\
\text { requirements } \\
\text { established by } \\
\text { the RSPC or TO. }\end{array}$ \\
\hline
\end{tabular}




\section{NEVADA TEST SITE RADIATION PROTECTION PROGRAM}

\section{APPENDIX H}

COMPLIANCE DEMONSTRATION TABLE

\begin{tabular}{|c|c|c|c|c|c|c|c|c|}
\hline \multirow[t]{2}{*}{10 CFR 835} & $\begin{array}{c}\text { NV/YMP RCM } \\
\text { Rev } 5 \text { and } \\
\text { NTS RPP } \\
\text { Revision } 0\end{array}$ & $\begin{array}{c}\text { NSTec } \\
\text { Appendix A }\end{array}$ & $\begin{array}{c}\text { LLNL } \\
\text { Appendix B }\end{array}$ & $\begin{array}{c}\text { LANL } \\
\text { Appendix C }\end{array}$ & $\begin{array}{c}\text { SNL } \\
\text { Appendix D }\end{array}$ & $\begin{array}{c}\text { SNJV } \\
\text { Appendix E }\end{array}$ & $\begin{array}{c}\text { DRI } \\
\text { Appendix F }\end{array}$ & $\begin{array}{c}\text { WSI } \\
\text { Appendix G }\end{array}$ \\
\hline & $\begin{array}{l}\text { Implementation } \\
\text { Reference }\end{array}$ & $\begin{array}{l}\text { Implementation } \\
\text { Reference }\end{array}$ & $\begin{array}{l}\text { Implementation } \\
\text { Reference }\end{array}$ & $\begin{array}{l}\text { Implementation } \\
\text { Reference }\end{array}$ & $\begin{array}{l}\text { Implementation } \\
\text { Reference }\end{array}$ & $\begin{array}{l}\text { Implementation } \\
\text { Reference }\end{array}$ & $\begin{array}{l}\text { Implementation } \\
\text { Reference }\end{array}$ & $\begin{array}{l}\text { Implementation } \\
\text { Reference }\end{array}$ \\
\hline
\end{tabular}

\begin{tabular}{|c|c|c|c|c|c|c|c|c|}
\hline & & & & & & & $\begin{array}{l}\text { but will comply } \\
\text { with the } \\
\text { requirements } \\
\text { established by } \\
\text { the RSPC or the } \\
\text { RWP as } \\
\text { applicable. }\end{array}$ & \\
\hline $\begin{array}{l}501(b) \text { The degree of } \\
\text { control shall be } \\
\text { commensurate with } \\
\text { existing and potential } \\
\text { radiological hazards } \\
\text { within the area. }\end{array}$ & $\begin{array}{l}\text { NV/YMP RCM } \\
322.8 \text {. The } \\
\text { degree of } \\
\text { personnel entry } \\
\text { control for } \\
\text { radiological } \\
\text { areas shall be } \\
\text { commensurate } \\
\text { with existing and } \\
\text { potential } \\
\text { radiological } \\
\text { hazards within } \\
\text { the area. } \\
\text { NV/YMP RCM } \\
\text { 334.7 02 and } \\
\text { 335.5.02. These } \\
\text { authorizations } \\
\text { shall specify } \\
\text { radiation } \\
\text { protection } \\
\text { measures } \\
\text { commensurate } \\
\text { with the existing } \\
\text { and potential } \\
\text { hazards. }\end{array}$ & $\begin{array}{l}\text { NV/YMP RCM } \\
322.8 \text {. The } \\
\text { degree of } \\
\text { personnel entry } \\
\text { control for } \\
\text { radiological } \\
\text { areas shall be } \\
\text { commensurate } \\
\text { with existing and } \\
\text { potential } \\
\text { radiological } \\
\text { hazards within } \\
\text { the area. } \\
\text { NV/YMP RCM } \\
334.702 \text { and } \\
\text { 335.5.02. These } \\
\text { authorizations } \\
\text { shall specify } \\
\text { radiation } \\
\text { protection } \\
\text { measures } \\
\text { commensurate } \\
\text { with the existing } \\
\text { and potential } \\
\text { hazards. }\end{array}$ & $\begin{array}{l}\text { Same as Column } \\
3\end{array}$ & $\begin{array}{l}\text { Same as Column } \\
3\end{array}$ & $\begin{array}{l}\text { Same as Column } \\
3\end{array}$ & $\begin{array}{l}\text { Same as Column } \\
3\end{array}$ & $\begin{array}{l}\text { DRI does not } \\
\text { have any } \\
\text { Radiological } \\
\text { Control areas, } \\
\text { but will comply } \\
\text { with the } \\
\text { requirements } \\
\text { established by } \\
\text { the RSPC or the } \\
\text { RWP as } \\
\text { applicable. }\end{array}$ & $\begin{array}{l}\text { WSI/NV does not } \\
\text { have radiological } \\
\text { control } \\
\text { responsibilities } \\
\text { for any } \\
\text { radiological area. } \\
\text { The RSPC or TO } \\
\text { who has } \\
\text { radiological } \\
\text { control } \\
\text { responsibilities } \\
\text { for the } \\
\text { radiological area } \\
\text { is responsible for } \\
\text { ensuring that the } \\
\text { requirements of } \\
\text { this section are } \\
\text { met. WSI/NV } \\
\text { personnel will } \\
\text { comply with all } \\
\text { requirements } \\
\text { established by } \\
\text { the RSPC or TO. }\end{array}$ \\
\hline
\end{tabular}




\section{NEVADA TEST SITE RADIATION PROTECTION PROGRAM}

\section{APPENDIX H}

COMPLIANCE DEMONSTRATION TABLE

\begin{tabular}{|c|c|c|c|c|c|c|c|c|}
\hline \multirow[t]{2}{*}{10 CFR 835} & $\begin{array}{c}\text { NV/YMP RCM } \\
\text { Rev } 5 \text { and } \\
\text { NTS RPP } \\
\text { Revision } 0 \\
\end{array}$ & $\begin{array}{c}\text { NSTec } \\
\text { Appendix A }\end{array}$ & $\begin{array}{c}\text { LLNL } \\
\text { Appendix B }\end{array}$ & $\begin{array}{c}\text { LANL } \\
\text { Appendix C }\end{array}$ & $\begin{array}{c}\text { SNL } \\
\text { Appendix D }\end{array}$ & $\begin{array}{c}\text { SNJV } \\
\text { Appendix E }\end{array}$ & $\begin{array}{c}\text { DRI } \\
\text { Appendix F }\end{array}$ & $\begin{array}{c}\text { WSI } \\
\text { Appendix G }\end{array}$ \\
\hline & $\begin{array}{l}\text { Implementation } \\
\text { Reference }\end{array}$ & $\begin{array}{l}\text { Implementation } \\
\text { Reference }\end{array}$ & $\begin{array}{l}\text { Implementation } \\
\text { Reference }\end{array}$ & $\begin{array}{l}\text { Implementation } \\
\text { Reference }\end{array}$ & $\begin{array}{l}\text { Implementation } \\
\text { Reference }\end{array}$ & $\begin{array}{l}\text { Implementation } \\
\text { Reference }\end{array}$ & $\begin{array}{l}\text { Implementation } \\
\text { Reference }\end{array}$ & $\begin{array}{l}\text { Implementation } \\
\text { Reference }\end{array}$ \\
\hline
\end{tabular}

\begin{tabular}{|c|c|c|c|c|c|c|c|c|}
\hline $\begin{array}{l}501(c) \text { One or more of } \\
\text { the following methods } \\
\text { shall be used to } \\
\text { ensure control: } \\
\text { (1) Signs and } \\
\text { barricades; } \\
\text { (2) Control devices on } \\
\text { entrances; } \\
\text { (3) Conspicuous } \\
\text { visual and/or audible } \\
\text { alarms; } \\
\text { (4) Locked entrance } \\
\text { ways; or } \\
\text { (5) Administrative } \\
\text { controls. }\end{array}$ & $\begin{array}{l}\text { NV/YMP } \\
231.1 .01 . \\
\text { Radiological } \\
\text { postings shall be } \\
\text { used to alert } \\
\text { personnel to the } \\
\text { presences of } \\
\text { radiation and } \\
\text { radioactive } \\
\text { materials and to } \\
\text { aid them in } \\
\text { minimizing } \\
\text { exposures and } \\
\text { preventing the } \\
\text { spread of } \\
\text { contamination. } \\
\text { NV/YMP RCM } \\
231.7 . \text { Rope, } \\
\text { tape, chain, and } \\
\text { similar barriers } \\
\text { used to } \\
\text { designate the } \\
\text { boundaries of } \\
\text { posted areas } \\
\text { should be yellow } \\
\text { or yellow and } \\
\text { magenta in color. } \\
\text { Existing barb } \\
\text { wire, chain link, } \\
\text { yellow rope, or } \\
\text { snow fencing is } \\
\text { acceptable at } \\
\end{array}$ & $\begin{array}{l}\text { NV/YMP } \\
231.1 .01 . \\
\text { Radiological } \\
\text { postings shall be } \\
\text { used to alert } \\
\text { personnel to the } \\
\text { presences of } \\
\text { radiation and } \\
\text { radioactive } \\
\text { materials and to } \\
\text { aid them in } \\
\text { minimizing } \\
\text { exposures and } \\
\text { preventing the } \\
\text { spread of } \\
\text { contamination. } \\
\text { Revise: NV/YMP } \\
\text { RCM } 231.7 . \\
\text { Rope, tape, } \\
\text { chain, and } \\
\text { similar barriers } \\
\text { used to } \\
\text { designate the } \\
\text { boundaries of } \\
\text { posted areas } \\
\text { should be yellow } \\
\text { or yellow and } \\
\text { magenta in color. } \\
\text { Existing barb } \\
\text { wire, chain link, } \\
\text { yellow rope, or } \\
\text { snow fencing is } \\
\end{array}$ & $\begin{array}{l}\text { Same as Column } \\
3\end{array}$ & $\begin{array}{l}\text { Same as Column } \\
3\end{array}$ & $\begin{array}{l}\text { Same as Column } \\
3\end{array}$ & $\begin{array}{l}\text { Same as Column } \\
3\end{array}$ & $\begin{array}{l}\text { DRI does not } \\
\text { have any } \\
\text { Radiological } \\
\text { Control areas, } \\
\text { but will comply } \\
\text { with the } \\
\text { requirements } \\
\text { established by } \\
\text { the RSPC or the } \\
\text { RWP as } \\
\text { applicable when } \\
\text { working in areas } \\
\text { which require } \\
\text { these controls. }\end{array}$ & $\begin{array}{l}\text { WSI/NV does not } \\
\text { have radiological } \\
\text { control } \\
\text { responsibilities } \\
\text { for any } \\
\text { radiological area. } \\
\text { The RSPC or TO } \\
\text { who has } \\
\text { radiological } \\
\text { control } \\
\text { responsibilities } \\
\text { for the } \\
\text { radiological area } \\
\text { is responsible for } \\
\text { ensuring that the } \\
\text { requirements of } \\
\text { this section are } \\
\text { met. WSI/NV } \\
\text { personnel will } \\
\text { comply with all } \\
\text { requirements } \\
\text { established by } \\
\text { the RSPC or TO. }\end{array}$ \\
\hline
\end{tabular}




\section{NEVADA TEST SITE RADIATION PROTECTION PROGRAM}

\section{APPENDIX H}

COMPLIANCE DEMONSTRATION TABLE

\begin{tabular}{|c|c|c|c|c|c|c|c|c|}
\hline \multirow[t]{2}{*}{10 CFR 835} & $\begin{array}{c}\text { NV/YMP RCM } \\
\text { Rev } 5 \text { and } \\
\text { NTS RPP } \\
\text { Revision } 0 \\
\end{array}$ & $\begin{array}{c}\text { NSTec } \\
\text { Appendix A }\end{array}$ & $\begin{array}{c}\text { LLNL } \\
\text { Appendix B }\end{array}$ & $\begin{array}{c}\text { LANL } \\
\text { Appendix C }\end{array}$ & $\begin{array}{c}\text { SNL } \\
\text { Appendix D }\end{array}$ & $\begin{array}{c}\text { SNJV } \\
\text { Appendix E }\end{array}$ & $\begin{array}{c}\text { DRI } \\
\text { Appendix F }\end{array}$ & $\begin{array}{c}\text { WSI } \\
\text { Appendix G }\end{array}$ \\
\hline & $\begin{array}{l}\text { Implementation } \\
\text { Reference }\end{array}$ & $\begin{array}{l}\text { Implementation } \\
\text { Reference }\end{array}$ & $\begin{array}{l}\text { Implementation } \\
\text { Reference }\end{array}$ & $\begin{array}{l}\text { Implementation } \\
\text { Reference }\end{array}$ & $\begin{array}{c}\text { Implementation } \\
\text { Reference }\end{array}$ & $\begin{array}{l}\text { Implementation } \\
\text { Reference }\end{array}$ & $\begin{array}{l}\text { Implementation } \\
\text { Reference }\end{array}$ & $\begin{array}{l}\text { Implementation } \\
\text { Reference }\end{array}$ \\
\hline
\end{tabular}

\section{NNSA/NSO or}

YMORD

facilities. These

barriers shall be

setup such that

they do not

impede the

intended use of

emergency exits

or evacuation

routes.

NV/YMP 231.8.

Posting of doors

or access gates

should be such

that the postings

remain visible

when the doors

and gates are

open or closed.

NV/YMP RCM

334.2. Physical

controls to

prevent

inadvertent or

unauthorized

access to High

and Very High

Radiation Areas

shall be

maintained acceptable at

NNSA/NSO or

OCRWM

facilities. These

barriers shall be

setup such that

they do not

impede the

intended use of

emergency exits

or evacuation

routes.

NV/YMP 231.8.

Posting of doors

or access gates

should be such

that the postings

remain visible

when the doors

and gates are

open or closed.

NV/YMP RCM

334.2. Physical

controls to

prevent

inadvertent or

unauthorized

access to High

and Very High

Radiation Areas

shall be

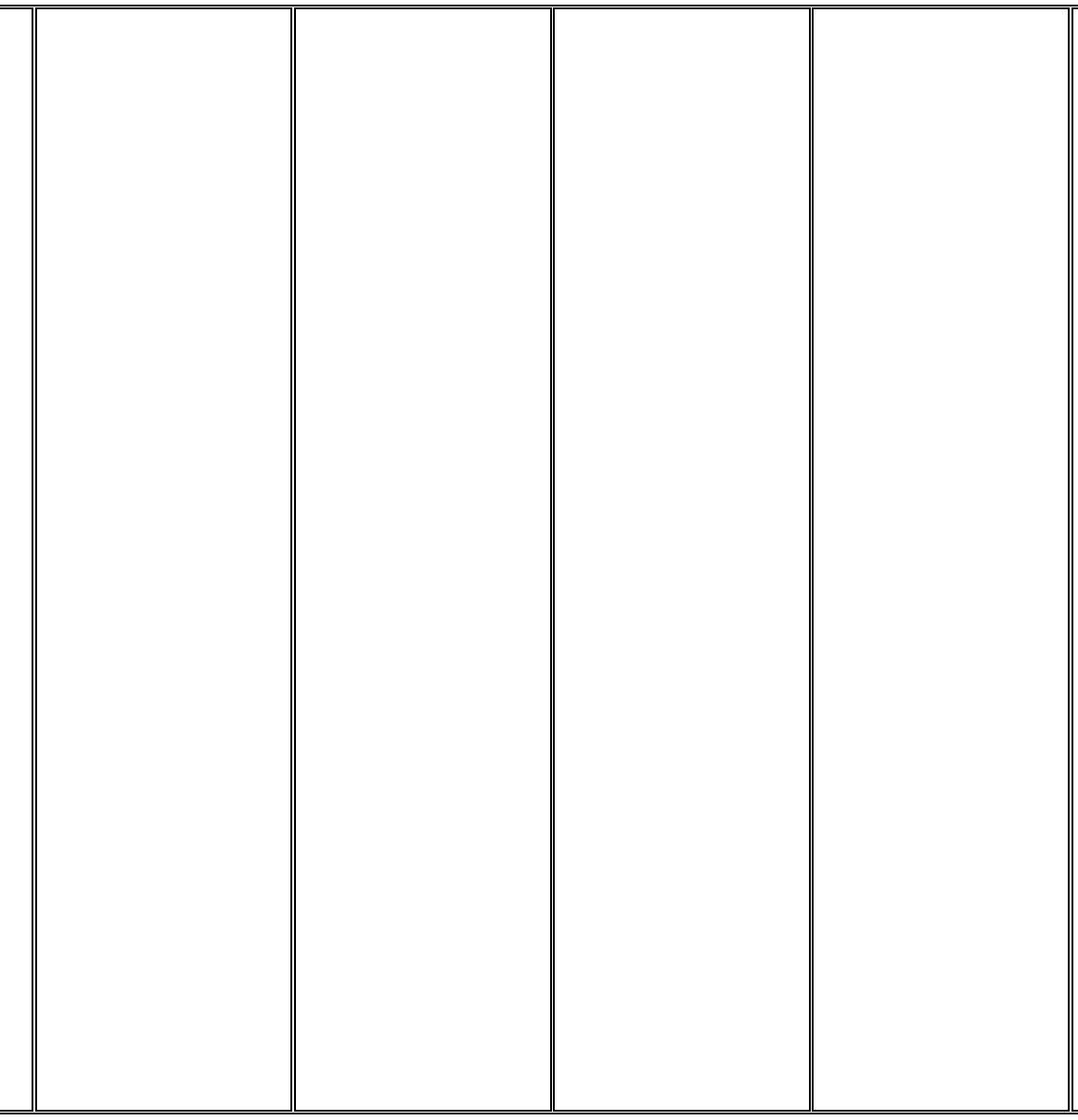




\section{NEVADA TEST SITE RADIATION PROTECTION PROGRAM}

\section{APPENDIX H}

COMPLIANCE DEMONSTRATION TABLE

\begin{tabular}{|c|c|c|c|c|c|c|c|c|}
\hline \multirow[t]{2}{*}{10 CFR 835} & $\begin{array}{c}\text { NV/YMP RCM } \\
\text { Rev } 5 \text { and } \\
\text { NTS RPP } \\
\text { Revision } 0 \\
\end{array}$ & $\begin{array}{c}\text { NSTec } \\
\text { Appendix A }\end{array}$ & $\begin{array}{c}\text { LLNL } \\
\text { Appendix B }\end{array}$ & $\begin{array}{c}\text { LANL } \\
\text { Appendix C }\end{array}$ & $\begin{array}{c}\text { SNL } \\
\text { Appendix D }\end{array}$ & $\begin{array}{c}\text { SNJV } \\
\text { Appendix E }\end{array}$ & $\begin{array}{c}\text { DRI } \\
\text { Appendix F }\end{array}$ & $\begin{array}{c}\text { WSI } \\
\text { Appendix G }\end{array}$ \\
\hline & $\begin{array}{l}\text { Implementation } \\
\text { Reference }\end{array}$ & $\begin{array}{l}\text { Implementation } \\
\text { Reference }\end{array}$ & $\begin{array}{l}\text { Implementation } \\
\text { Reference }\end{array}$ & $\begin{array}{l}\text { Implementation } \\
\text { Reference }\end{array}$ & $\begin{array}{c}\text { Implementation } \\
\text { Reference }\end{array}$ & $\begin{array}{l}\text { Implementation } \\
\text { Reference }\end{array}$ & $\begin{array}{l}\text { Implementation } \\
\text { Reference }\end{array}$ & $\begin{array}{l}\text { Implementation } \\
\text { Reference }\end{array}$ \\
\hline
\end{tabular}

according to

Appendix 3A.

NV/YMP RCM

322.1. RWPs

shall be used to

control the

following

activities:

a. Entering High

Radiation Areas.

b. Entering High

Contamination

Areas.

c. Entering

Airborne

Radioactivity

Areas.

NV/YMP RCM

322.2. RWPs or

an alternative

formal

mechanism

described in

Article 322.9

shall be used to

control the

following

activities: a.

Entering

Radiation Areas

b. Entering maintained

according to

Appendix 3A.

NV/YMP RCM

322.1. RWPs

shall be used to

control the

following

activities:

. Entering High

Radiation Areas.

b. Entering High

Contamination

Areas.

c. Entering

Airborne

Radioactivity

Areas.

NV/YMP RCM

322.2. RWPs or

an alternative

formal

mechanism

described in

Article 322.9

shall be used to

control the

following

activities: a.

Entering

Radiation Areas.

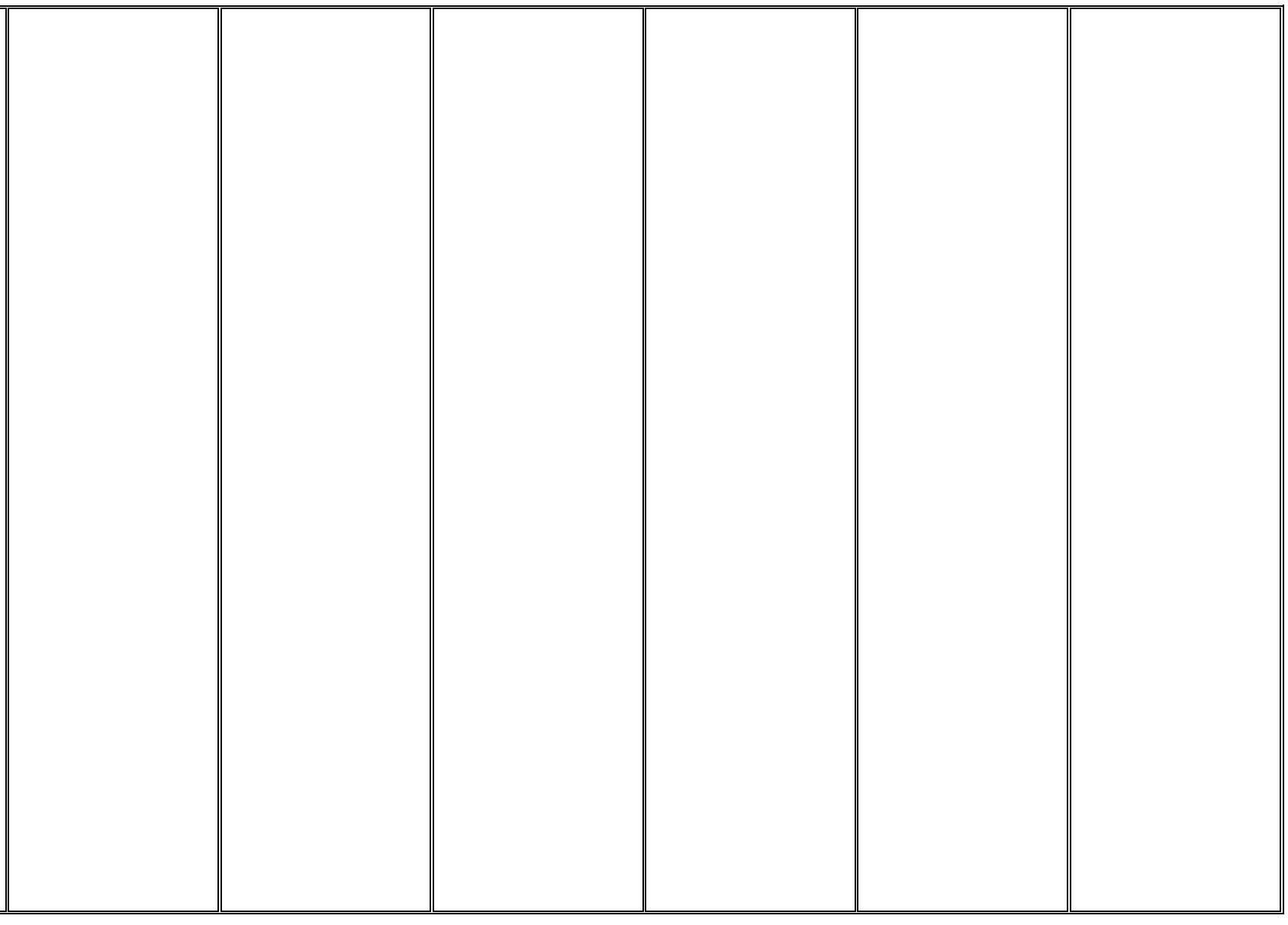




\section{NEVADA TEST SITE RADIATION PROTECTION PROGRAM}

\section{APPENDIX H}

COMPLIANCE DEMONSTRATION TABLE

\begin{tabular}{|c|c|c|c|c|c|c|c|c|}
\hline \multirow[t]{2}{*}{10 CFR 835} & $\begin{array}{c}\text { NV/YMP RCM } \\
\text { Rev } 5 \text { and } \\
\text { NTS RPP } \\
\text { Revision } 0 \\
\end{array}$ & $\begin{array}{c}\text { NSTec } \\
\text { Appendix A }\end{array}$ & $\begin{array}{c}\text { LLNL } \\
\text { Appendix B }\end{array}$ & $\begin{array}{c}\text { LANL } \\
\text { Appendix C }\end{array}$ & $\begin{array}{c}\text { SNL } \\
\text { Appendix D }\end{array}$ & $\begin{array}{c}\text { SNJV } \\
\text { Appendix E }\end{array}$ & $\begin{array}{c}\text { DRI } \\
\text { Appendix F }\end{array}$ & $\begin{array}{c}\text { WSI } \\
\text { Appendix G }\end{array}$ \\
\hline & $\begin{array}{l}\text { Implementation } \\
\text { Reference }\end{array}$ & $\begin{array}{l}\text { Implementation } \\
\text { Reference }\end{array}$ & $\begin{array}{l}\text { Implementation } \\
\text { Reference }\end{array}$ & $\begin{array}{l}\text { Implementation } \\
\text { Reference }\end{array}$ & $\begin{array}{c}\text { Implementation } \\
\text { Reference }\end{array}$ & $\begin{array}{l}\text { Implementation } \\
\text { Reference }\end{array}$ & $\begin{array}{l}\text { Implementation } \\
\text { Reference }\end{array}$ & $\begin{array}{l}\text { Implementation } \\
\text { Reference }\end{array}$ \\
\hline
\end{tabular}

\begin{tabular}{|c|c|c|c|c|c|c|c|c|}
\hline & $\begin{array}{l}\text { Contamination } \\
\text { Areas. } \\
\text { c. Handling } \\
\text { materials with } \\
\text { removable } \\
\text { contamination } \\
\text { that exceed the } \\
\text { values of Table } \\
2-2 \text {. }\end{array}$ & $\begin{array}{l}\text { b. Entering } \\
\text { Contamination } \\
\text { Areas. } \\
\text { c. Handling } \\
\text { materials with } \\
\text { removable } \\
\text { contamination } \\
\text { that exceed the } \\
\text { values of Table } \\
2-2 \text {. }\end{array}$ & & & & & & \\
\hline $\begin{array}{l}501(\mathrm{~d}) \text { Written } \\
\text { authorizations shall be } \\
\text { required to control } \\
\text { entry into and perform } \\
\text { work within } \\
\text { radiological areas. } \\
\text { These authorizations } \\
\text { shall specify radiation } \\
\text { protection measures } \\
\text { commensurate with } \\
\text { the existing and } \\
\text { potential hazards. }\end{array}$ & $\begin{array}{l}\text { NV/YMP RCM } \\
\text { 382.3. Written } \\
\text { authorizations, } \\
\text { including specific } \\
\text { radiation } \\
\text { protection } \\
\text { measures, shall } \\
\text { be required to } \\
\text { control entry into } \\
\text { and work within } \\
\text { radiological } \\
\text { areas. These } \\
\text { authorizations } \\
\text { may include } \\
\text { RWPs, technical } \\
\text { work documents, } \\
\text { administrative } \\
\text { procedures, and } \\
\text { other } \\
\text { administrative } \\
\text { controls. }\end{array}$ & $\begin{array}{l}\text { NV/YMP RCM } \\
382.3 \text {. Written } \\
\text { authorizations, } \\
\text { including specific } \\
\text { radiation } \\
\text { protection } \\
\text { measures, shall } \\
\text { be required to } \\
\text { control entry into } \\
\text { and work within } \\
\text { radiological } \\
\text { areas. These } \\
\text { authorizations } \\
\text { may include } \\
\text { RWPs, technical } \\
\text { work documents, } \\
\text { administrative } \\
\text { procedures, and } \\
\text { other } \\
\text { administrative } \\
\text { controls. }\end{array}$ & $\begin{array}{l}\text { Same as Column } \\
3\end{array}$ & $\begin{array}{l}\text { Same as Column } \\
3\end{array}$ & $\begin{array}{l}\text { Same as Column } \\
3\end{array}$ & $\begin{array}{l}\text { Same as Column } \\
3\end{array}$ & $\begin{array}{l}\text { DRI does not } \\
\text { have any } \\
\text { radiological } \\
\text { areas but will } \\
\text { comply with the } \\
\text { requirements } \\
\text { established by } \\
\text { the cognizant } \\
\text { TO. }\end{array}$ & $\begin{array}{l}\text { WSI/NV does not } \\
\text { have radiological } \\
\text { control } \\
\text { responsibilities } \\
\text { for any } \\
\text { radiological area. } \\
\text { The RSPC or TO } \\
\text { who has } \\
\text { radiological } \\
\text { control } \\
\text { responsibilities } \\
\text { for the } \\
\text { radiological area } \\
\text { is responsible for } \\
\text { ensuring that the } \\
\text { requirements of } \\
\text { this section are } \\
\text { met. WSI/NV } \\
\text { personnel will } \\
\text { comply with all } \\
\text { requirements } \\
\text { established by } \\
\text { the RSPC or TO. }\end{array}$ \\
\hline
\end{tabular}




\section{NEVADA TEST SITE RADIATION PROTECTION PROGRAM}

\section{APPENDIX H}

COMPLIANCE DEMONSTRATION TABLE

\begin{tabular}{|c|c|c|c|c|c|c|c|c|}
\hline \multirow[t]{2}{*}{10 CFR 835} & $\begin{array}{l}\text { NV/YMP RCM } \\
\text { Rev } 5 \text { and } \\
\text { NTS RPP } \\
\text { Revision } 0 \\
\end{array}$ & $\begin{array}{c}\text { NSTec } \\
\text { Appendix A }\end{array}$ & $\begin{array}{c}\text { LLNL } \\
\text { Appendix B }\end{array}$ & $\begin{array}{c}\text { LANL } \\
\text { Appendix C }\end{array}$ & $\begin{array}{c}\text { SNL } \\
\text { Appendix D }\end{array}$ & $\begin{array}{c}\text { SNJV } \\
\text { Appendix E }\end{array}$ & $\begin{array}{c}\text { DRI } \\
\text { Appendix F }\end{array}$ & $\begin{array}{c}\text { WSI } \\
\text { Appendix G }\end{array}$ \\
\hline & $\begin{array}{l}\text { Implementation } \\
\text { Reference }\end{array}$ & $\begin{array}{l}\text { Implementation } \\
\text { Reference }\end{array}$ & $\begin{array}{l}\text { Implementation } \\
\text { Reference }\end{array}$ & $\begin{array}{l}\text { Implementation } \\
\text { Reference }\end{array}$ & $\begin{array}{l}\text { Implementation } \\
\text { Reference }\end{array}$ & $\begin{array}{l}\text { Implementation } \\
\text { Reference }\end{array}$ & $\begin{array}{l}\text { Implementation } \\
\text { Reference }\end{array}$ & $\begin{array}{l}\text { Implementation } \\
\text { Reference }\end{array}$ \\
\hline
\end{tabular}

\begin{tabular}{|c|c|c|c|c|c|c|c|c|}
\hline $\begin{array}{l}501(\mathrm{e}) \text { No control(s) } \\
\text { shall be installed at } \\
\text { any radiological area } \\
\text { exit that would prevent } \\
\text { rapid evacuation of } \\
\text { personnel under } \\
\text { emergency conditions. }\end{array}$ & $\begin{array}{l}\text { NV/YMP RCM } \\
\text { Appendix 3A.3. } \\
\text { Physical access } \\
\text { controls over } \\
\text { High and Very } \\
\text { High Radiation } \\
\text { Areas shall be } \\
\text { established in } \\
\text { such a way that } \\
\text { they do not } \\
\text { prevent a person } \\
\text { from leaving the } \\
\text { area. } \\
\text { NV/YMP RCM } \\
231.7 .03 \text {. These } \\
\text { barriers shall be } \\
\text { set up such that } \\
\text { they do not } \\
\text { impede the } \\
\text { intended use of } \\
\text { emergency exits } \\
\text { or evacuation } \\
\text { routes. }\end{array}$ & $\begin{array}{l}\text { NV/YMP RCM } \\
\text { Appendix 3A.3. } \\
\text { Physical access } \\
\text { controls over } \\
\text { High and Very } \\
\text { High Radiation } \\
\text { Areas shall be } \\
\text { established in } \\
\text { such a way that } \\
\text { they do not } \\
\text { prevent a person } \\
\text { from leaving the } \\
\text { area. } \\
\text { NV/YMP RCM } \\
231.7 .03 \text {. These } \\
\text { barriers shall be } \\
\text { set up such that } \\
\text { they do not } \\
\text { impede the } \\
\text { intended use of } \\
\text { emergency exits } \\
\text { or evacuation } \\
\text { routes. }\end{array}$ & $\begin{array}{l}\text { Same as Column } \\
3\end{array}$ & $\begin{array}{l}\text { Same as Column } \\
3\end{array}$ & $\begin{array}{l}\text { Same as Column } \\
3\end{array}$ & $\begin{array}{l}\text { Same as Column } \\
3\end{array}$ & $\begin{array}{l}\text { Not a DRI } \\
\text { activity. This } \\
\text { service is } \\
\text { provided to DRI } \\
\text { by the RSPC. }\end{array}$ & $\begin{array}{l}\text { WSI/NV does not } \\
\text { have radiological } \\
\text { control } \\
\text { responsibilities } \\
\text { for any } \\
\text { radiological area. } \\
\text { The RSPC or TO } \\
\text { who has } \\
\text { radiological } \\
\text { control } \\
\text { responsibilities } \\
\text { for the } \\
\text { radiological area } \\
\text { is responsible for } \\
\text { ensuring that the } \\
\text { requirements of } \\
\text { this section are } \\
\text { met. WSI/NV } \\
\text { personnel will } \\
\text { comply with all } \\
\text { requirements } \\
\text { established by } \\
\text { the RSPC or TO. }\end{array}$ \\
\hline $\begin{array}{l}835.502 \text { High and } \\
\text { Very High Radiation } \\
\text { Areas. } \\
502(a) \text { The following } \\
\text { measures shall be } \\
\text { implemented for each } \\
\text { entry into a high } \\
\text { radiation area; }\end{array}$ & $\begin{array}{l}\text { NV/YMP RCM } \\
\text { 334.3.c and e. } \\
\text { The minimum } \\
\text { requirements for } \\
\text { entry into High } \\
\text { Radiation Areas } \\
\text { shall include the } \\
\text { following: } \\
\text { c. Primary and } \\
\end{array}$ & $\begin{array}{l}\text { Revise: NV/YMP } \\
\text { RCM 334.3.c } \\
\text { and e. The } \\
\text { minimum } \\
\text { requirements for } \\
\text { entry into High } \\
\text { Radiation Areas } \\
\text { shall include the } \\
\text { following: } \\
\end{array}$ & $\begin{array}{l}\text { Same as Column } \\
3\end{array}$ & $\begin{array}{l}\text { Same as Column } \\
3\end{array}$ & $\begin{array}{l}\text { Same as Column } \\
3\end{array}$ & $\begin{array}{l}\text { Same as Column } \\
3\end{array}$ & $\begin{array}{l}\text { DRI does not } \\
\text { typically conduct } \\
\text { work in areas of } \\
\text { high radiation. } \\
\text { Should entry be } \\
\text { required, } \\
\text { monitoring and } \\
\text { dosimetry } \\
\text { service would be } \\
\end{array}$ & $\begin{array}{l}\text { The content of } \\
\text { this section does } \\
\text { not apply to } \\
\text { WSI/NV, as } \\
\text { WSI/NV } \\
\text { personnel are } \\
\text { not permitted to } \\
\text { enter high or } \\
\text { very high }\end{array}$ \\
\hline
\end{tabular}




\section{NEVADA TEST SITE RADIATION PROTECTION PROGRAM}

\section{APPENDIX H}

COMPLIANCE DEMONSTRATION TABLE

\begin{tabular}{|c|c|c|c|c|c|c|c|c|}
\hline \multirow[t]{2}{*}{10 CFR 835} & $\begin{array}{c}\text { NV/YMP RCM } \\
\text { Rev } 5 \text { and } \\
\text { NTS RPP } \\
\text { Revision } 0 \\
\end{array}$ & $\begin{array}{c}\text { NSTec } \\
\text { Appendix A }\end{array}$ & $\begin{array}{c}\text { LLNL } \\
\text { Appendix B }\end{array}$ & $\begin{array}{c}\text { LANL } \\
\text { Appendix C }\end{array}$ & $\begin{array}{c}\text { SNL } \\
\text { Appendix D }\end{array}$ & $\begin{array}{c}\text { SNJV } \\
\text { Appendix E }\end{array}$ & $\begin{array}{c}\text { DRI } \\
\text { Appendix F }\end{array}$ & $\begin{array}{c}\text { WSI } \\
\text { Appendix G }\end{array}$ \\
\hline & $\begin{array}{l}\text { Implementation } \\
\text { Reference }\end{array}$ & $\begin{array}{l}\text { Implementation } \\
\text { Reference }\end{array}$ & $\begin{array}{l}\text { Implementation } \\
\text { Reference }\end{array}$ & $\begin{array}{l}\text { Implementation } \\
\text { Reference }\end{array}$ & $\begin{array}{l}\text { Implementation } \\
\text { Reference }\end{array}$ & $\begin{array}{l}\text { Implementation } \\
\text { Reference }\end{array}$ & $\begin{array}{l}\text { Implementation } \\
\text { Reference }\end{array}$ & $\begin{array}{l}\text { Implementation } \\
\text { Reference }\end{array}$ \\
\hline
\end{tabular}

\begin{tabular}{|c|c|c|c|c|c|c|c|c|}
\hline $\begin{array}{l}\text { (1) The area shall be } \\
\text { monitored as } \\
\text { necessary during } \\
\text { access to determine } \\
\text { the exposure rates to } \\
\text { which the individuals } \\
\text { are exposed; and } \\
\text { (2) Each individual } \\
\text { shall be monitored by } \\
\text { a supplemental } \\
\text { dosimetry device or } \\
\text { other means capable } \\
\text { of providing an } \\
\text { immediate estimate of } \\
\text { the individual's } \\
\text { integrated equivalent } \\
\text { dose to the whole } \\
\text { body during the entry. }\end{array}$ & $\begin{array}{l}\text { supplemental } \\
\text { dosimeters or } \\
\text { other means to } \\
\text { immediately } \\
\text { estimate deep } \\
\text { dose. } \\
\text { e. Area } \\
\text { monitoring, as } \\
\text { necessary, } \\
\text { during access to } \\
\text { determine the } \\
\text { exposure rates to } \\
\text { which the } \\
\text { individuals are } \\
\text { exposed. } \\
\text { NV/YMP RCM } \\
513.1 .01 . \\
\text { Pocket or } \\
\text { electronic } \\
\text { dosimeters shall } \\
\text { be issued to } \\
\text { personnel before } \\
\text { entry into a High } \\
\text { Radiation Area } \\
\text { (see Article } 334 \\
\text { for entry } \\
\text { requirements). }\end{array}$ & $\begin{array}{l}\text { c. Primary and } \\
\text { supplemental } \\
\text { dosimeters or } \\
\text { other means to } \\
\text { immediately } \\
\text { estimate } \\
\text { equivalent dose } \\
\text { to the whole } \\
\text { body. } \\
\text { e. Area } \\
\text { monitoring, as } \\
\text { necessary, } \\
\text { during access to } \\
\text { determine the } \\
\text { exposure rates to } \\
\text { which the } \\
\text { individuals are } \\
\text { exposed. } \\
\text { NV/YMP RCM } \\
513.1 .01 . \\
\text { Pocket or } \\
\text { electronic } \\
\text { dosimeters shall } \\
\text { be issued to } \\
\text { personnel before } \\
\text { entry into a High } \\
\text { Radiation Area } \\
\text { (see Article } 334 \\
\text { for entry } \\
\text { requirements). } \\
\end{array}$ & & & & & $\begin{array}{l}\text { provided to DRI } \\
\text { by the RSPC and } \\
\text { we would follow } \\
\text { all compliance } \\
\text { measures } \\
\text { established by } \\
\text { the cognizant } \\
\text { TO. }\end{array}$ & $\begin{array}{l}\text { radiation areas. } \\
\text { If access were } \\
\text { required, } \\
\text { WSI/NV would } \\
\text { comply with the } \\
\text { measures } \\
\text { established by } \\
\text { the cognizant } \\
\text { TO. }\end{array}$ \\
\hline $\begin{array}{l}\text { 502(b) Physical } \\
\text { controls. One or more }\end{array}$ & $\begin{array}{l}\text { NV/YMP RCM } \\
\text { Appendix 3A } 1 .\end{array}$ & $\begin{array}{l}\text { Revise: NV/YMP } \\
\text { RCM Appendix }\end{array}$ & $\begin{array}{l}\text { Same as Column } \\
3\end{array}$ & \begin{tabular}{|l|} 
Same as Column \\
3
\end{tabular} & $\begin{array}{l}\text { Same as Column } \\
3\end{array}$ & $\begin{array}{l}\text { Same as Column } \\
3\end{array}$ & $\begin{array}{l}\text { DRI does not } \\
\text { typically conduct }\end{array}$ & $\begin{array}{l}\text { The content of } \\
\text { this section does }\end{array}$ \\
\hline
\end{tabular}




\section{NEVADA TEST SITE RADIATION PROTECTION PROGRAM}

\section{APPENDIX H}

COMPLIANCE DEMONSTRATION TABLE

\begin{tabular}{|c|c|c|c|c|c|c|c|c|}
\hline \multirow[t]{2}{*}{10 CFR 835} & $\begin{array}{l}\text { NV/YMP RCM } \\
\text { Rev } 5 \text { and } \\
\text { NTS RPP } \\
\text { Revision } 0 \\
\end{array}$ & $\begin{array}{c}\text { NSTec } \\
\text { Appendix A }\end{array}$ & $\begin{array}{c}\text { LLNL } \\
\text { Appendix B }\end{array}$ & $\begin{array}{c}\text { LANL } \\
\text { Appendix C }\end{array}$ & $\begin{array}{c}\text { SNL } \\
\text { Appendix D }\end{array}$ & $\begin{array}{c}\text { SNJV } \\
\text { Appendix E }\end{array}$ & $\begin{array}{c}\text { DRI } \\
\text { Appendix F }\end{array}$ & $\begin{array}{c}\text { WSI } \\
\text { Appendix G }\end{array}$ \\
\hline & $\begin{array}{l}\text { Implementation } \\
\text { Reference }\end{array}$ & $\begin{array}{l}\text { Implementation } \\
\text { Reference }\end{array}$ & $\begin{array}{l}\text { Implementation } \\
\text { Reference }\end{array}$ & $\begin{array}{l}\text { Implementation } \\
\text { Reference }\end{array}$ & $\begin{array}{l}\text { Implementation } \\
\text { Reference }\end{array}$ & $\begin{array}{l}\text { Implementation } \\
\text { Reference }\end{array}$ & $\begin{array}{l}\text { Implementation } \\
\text { Reference }\end{array}$ & $\begin{array}{l}\text { Implementation } \\
\text { Reference }\end{array}$ \\
\hline
\end{tabular}

\section{of the following}

controls shall be used for each entrance or access point to a high radiation area where radiation levels exist such that an individual could exceed an equivalent dose to the whole body of 1 rem (0.01 Sv) in any one hour at 30 centimeters from the source or from any surface that the radiation penetrates:

(1) A control device that prevents entry to the area when high radiation levels exist or that, upon entry, causes the radiation level to be reduced below the level that defines a high

radiation area; (2) A device that functions automatically to prevent use or operation of the radiation source or field while individuals are in the area;
1. One or more of the following features should be used for each entrance or access point to a High Radiation Area and shall be used for each entrance or access point to a High Radiation Area where

radiation levels exist such that a person could exceed a wholebody dose of 1 rem in any one hour:

a. A control device that prevents entry to the area when high radiation levels exist or upon entry

causes the radiation level to be reduced below that level defining a High
3A 1. a-f.

1. One or more of the following features should be used for each entrance or access point to a High Radiation Area and shall be used for each entrance or access point to a High Radiation Area where radiation levels exist such that a person could exceed an equivalent dose to the whole body of 1 rem in any one hour:

a. A control

device that prevents entry to the area when high radiation levels exist or upon entry causes the radiation level to

be reduced

below that level work in areas of not apply to high radiation. Should entry be required, DRI will follow all compliance measures established by the cognizant TO WSI/NV, as WSI/NV personnel are not permitted to enter high or very high radiation areas. If access were required,

WSI/NV would comply with the measures established by

the cognizant TO. 


\section{NEVADA TEST SITE RADIATION PROTECTION PROGRAM}

\section{APPENDIX H}

COMPLIANCE DEMONSTRATION TABLE

\begin{tabular}{|c|c|c|c|c|c|c|c|c|}
\hline \multirow[t]{2}{*}{10 CFR 835} & $\begin{array}{c}\text { NV/YMP RCM } \\
\text { Rev } 5 \text { and } \\
\text { NTS RPP } \\
\text { Revision } 0 \\
\end{array}$ & $\begin{array}{c}\text { NSTec } \\
\text { Appendix A }\end{array}$ & $\begin{array}{c}\text { LLNL } \\
\text { Appendix B }\end{array}$ & $\begin{array}{c}\text { LANL } \\
\text { Appendix C }\end{array}$ & $\begin{array}{c}\text { SNL } \\
\text { Appendix D }\end{array}$ & $\begin{array}{c}\text { SNJV } \\
\text { Appendix E }\end{array}$ & $\begin{array}{c}\text { DRI } \\
\text { Appendix F }\end{array}$ & $\begin{array}{c}\text { WSI } \\
\text { Appendix G }\end{array}$ \\
\hline & $\begin{array}{l}\text { Implementation } \\
\text { Reference }\end{array}$ & $\begin{array}{l}\text { Implementation } \\
\text { Reference }\end{array}$ & $\begin{array}{l}\text { Implementation } \\
\text { Reference }\end{array}$ & $\begin{array}{l}\text { Implementation } \\
\text { Reference }\end{array}$ & $\begin{array}{l}\text { Implementation } \\
\text { Reference }\end{array}$ & $\begin{array}{l}\text { Implementation } \\
\text { Reference }\end{array}$ & $\begin{array}{l}\text { Implementation } \\
\text { Reference }\end{array}$ & $\begin{array}{l}\text { Implementation } \\
\text { Reference }\end{array}$ \\
\hline
\end{tabular}

\section{(3) A control device} that energizes a conspicuous visible or audible alarm signal so that the individual entering the high radiation area and the supervisor of the activity are made aware of the entry;

(4) Entryways that are locked. During

periods when access to the area is required positive control over each entry is maintained;

(5) Continuous direct or electronic

surveillance that is capable of preventing unauthorized entry;

(6) A control device that will automatically generate audible and visual alarm signals to alert personnel in the area before use or operation of the radiation source and in sufficient time to permit evacuation of the area or activation

\begin{tabular}{||l||l||} 
Radiation Area. & defining a High \\
b. A device that & Radiation Area. \\
functions & b. A device that \\
automatically to & functions \\
prevent the use & automatically to \\
of or operation of & prevent the use \\
the radiation & of or operation of \\
source or field & the radiation \\
while personnel & source or field \\
are in the area. & while personnel \\
c. A control & are in the area. \\
device that & c. A control \\
energizes a & device that \\
conspicuous & energizes a \\
visible or audible & conspicuous \\
alarm signal so & visible or audible \\
that the person & alarm signal so \\
entering the High & that the person \\
Radiation Area & entering the High \\
and the & Radiation Area \\
supervisor of the & and the \\
activity are made & supervisor of the \\
aware of the & activity are made \\
entry. & aware of the \\
d. Entryways that & entry. \\
are locked, & d. Entryways that \\
except during & are locked, \\
periods when & except during \\
access to the & periods when \\
area is required, & access to the \\
with positive & area is required, \\
control over each & with positive \\
entry. & control over each \\
\hline
\end{tabular}

Radiation Area.

of or operation of

are in the area.

A control

conspicuous

visible or audible

that the person

entering the High

and the

entry.

entry.

control over each 


\section{NEVADA TEST SITE RADIATION PROTECTION PROGRAM}

\section{APPENDIX H}

COMPLIANCE DEMONSTRATION TABLE

\begin{tabular}{|c|c|c|c|c|c|c|c|c|}
\hline \multirow[t]{2}{*}{10 CFR 835} & $\begin{array}{c}\text { NV/YMP RCM } \\
\text { Rev } 5 \text { and } \\
\text { NTS RPP } \\
\text { Revision } 0 \\
\end{array}$ & $\begin{array}{c}\text { NSTec } \\
\text { Appendix A }\end{array}$ & $\begin{array}{c}\text { LLNL } \\
\text { Appendix B }\end{array}$ & $\begin{array}{c}\text { LANL } \\
\text { Appendix C }\end{array}$ & $\begin{array}{c}\text { SNL } \\
\text { Appendix D }\end{array}$ & $\begin{array}{c}\text { SNJV } \\
\text { Appendix E }\end{array}$ & $\begin{array}{c}\text { DRI } \\
\text { Appendix F }\end{array}$ & $\begin{array}{c}\text { WSI } \\
\text { Appendix G }\end{array}$ \\
\hline & $\begin{array}{l}\text { Implementation } \\
\text { Reference }\end{array}$ & $\begin{array}{l}\text { Implementation } \\
\text { Reference }\end{array}$ & $\begin{array}{l}\text { Implementation } \\
\text { Reference }\end{array}$ & $\begin{array}{l}\text { Implementation } \\
\text { Reference }\end{array}$ & $\begin{array}{c}\text { Implementation } \\
\text { Reference }\end{array}$ & $\begin{array}{l}\text { Implementation } \\
\text { Reference }\end{array}$ & $\begin{array}{l}\text { Implementation } \\
\text { Reference }\end{array}$ & $\begin{array}{l}\text { Implementation } \\
\text { Reference }\end{array}$ \\
\hline
\end{tabular}

\begin{tabular}{|c|c|c|c|c|c|c|c|c|}
\hline $\begin{array}{l}\text { of a secondary control } \\
\text { device that will prevent } \\
\text { use or operation of the } \\
\text { source. }\end{array}$ & $\begin{array}{l}\text { e. Continuous } \\
\text { direct or } \\
\text { electronic } \\
\text { surveillance that } \\
\text { is capable of } \\
\text { preventing } \\
\text { unauthorized } \\
\text { entry. } \\
\text { f. A control } \\
\text { device that } \\
\text { automatically } \\
\text { generates } \\
\text { audible and } \\
\text { visual alarm } \\
\text { signals to alert } \\
\text { personnel in the } \\
\text { area before use } \\
\text { or operation of } \\
\text { the radiation } \\
\text { source and in } \\
\text { sufficient time to } \\
\text { permit } \\
\text { evacuation of the } \\
\text { area or activation } \\
\text { of a secondary } \\
\text { control device } \\
\text { that will prevent } \\
\text { the use of or } \\
\text { operation of the } \\
\text { source. }\end{array}$ & $\begin{array}{l}\text { entry. } \\
\text { e. Continuous } \\
\text { direct or } \\
\text { electronic } \\
\text { surveillance that } \\
\text { is capable of } \\
\text { preventing } \\
\text { unauthorized } \\
\text { entry. } \\
\text { f. A control } \\
\text { device that } \\
\text { automatically } \\
\text { generates } \\
\text { audible and } \\
\text { visual alarm } \\
\text { signals to alert } \\
\text { personnel in the } \\
\text { area before use } \\
\text { or operation of } \\
\text { the radiation } \\
\text { source and in } \\
\text { sufficient time to } \\
\text { permit } \\
\text { evacuation of the } \\
\text { area or activation } \\
\text { of a secondary } \\
\text { control device } \\
\text { that will prevent } \\
\text { the use of or } \\
\text { operation of the } \\
\text { source. }\end{array}$ & & & & & & \\
\hline $\begin{array}{l}502(\mathrm{c}) \text { Very high } \\
\text { radiation areas. In }\end{array}$ & $\begin{array}{l}\text { NV/YMP RCM } \\
\text { Appendix 3A. } 2 . \\
\end{array}$ & $\begin{array}{l}\text { NV/YMP RCM } \\
\text { Appendix 3A. } 2 . \\
\end{array}$ & $\begin{array}{l}\text { Same as Column } \\
3\end{array}$ & $\begin{array}{l}\text { Same as Column } \\
3\end{array}$ & $\begin{array}{l}\text { Same as Column } \\
3\end{array}$ & $\begin{array}{l}\text { Same as Column } \\
3\end{array}$ & $\begin{array}{l}\text { Not applicable. } \\
\text { DRI employees }\end{array}$ & $\begin{array}{l}\text { The content of } \\
\text { this section does }\end{array}$ \\
\hline
\end{tabular}




\section{NEVADA TEST SITE RADIATION PROTECTION PROGRAM}

\section{APPENDIX H}

COMPLIANCE DEMONSTRATION TABLE

\begin{tabular}{|c|c|c|c|c|c|c|c|c|}
\hline \multirow[t]{2}{*}{10 CFR 835} & $\begin{array}{l}\text { NV/YMP RCM } \\
\text { Rev } 5 \text { and } \\
\text { NTS RPP } \\
\text { Revision } 0 \\
\end{array}$ & $\begin{array}{c}\text { NSTec } \\
\text { Appendix A }\end{array}$ & $\begin{array}{c}\text { LLNL } \\
\text { Appendix B }\end{array}$ & $\begin{array}{c}\text { LANL } \\
\text { Appendix C }\end{array}$ & $\begin{array}{c}\text { SNL } \\
\text { Appendix D }\end{array}$ & $\begin{array}{c}\text { SNJV } \\
\text { Appendix E }\end{array}$ & $\begin{array}{c}\text { DRI } \\
\text { Appendix F }\end{array}$ & $\begin{array}{c}\text { WSI } \\
\text { Appendix G }\end{array}$ \\
\hline & $\begin{array}{l}\text { Implementation } \\
\text { Reference }\end{array}$ & $\begin{array}{l}\text { Implementation } \\
\text { Reference }\end{array}$ & $\begin{array}{l}\text { Implementation } \\
\text { Reference }\end{array}$ & $\begin{array}{l}\text { Implementation } \\
\text { Reference }\end{array}$ & $\begin{array}{l}\text { Implementation } \\
\text { Reference }\end{array}$ & $\begin{array}{l}\text { Implementation } \\
\text { Reference }\end{array}$ & $\begin{array}{l}\text { Implementation } \\
\text { Reference }\end{array}$ & $\begin{array}{l}\text { Implementation } \\
\text { Reference }\end{array}$ \\
\hline
\end{tabular}

\begin{tabular}{|c|c|c|c|c|c|c|c|c|}
\hline $\begin{array}{l}\text { addition to the above } \\
\text { requirements, } \\
\text { additional measures } \\
\text { shall be implemented } \\
\text { to ensure individuals } \\
\text { are not able to gain } \\
\text { unauthorized or } \\
\text { inadvertent access to } \\
\text { very high radiation } \\
\text { areas. }\end{array}$ & $\begin{array}{l}\text { In addition to the } \\
\text { above } \\
\text { requirements, } \\
\text { additional } \\
\text { measures shall } \\
\text { be implemented } \\
\text { to ensure } \\
\text { personnel are } \\
\text { not able to gain } \\
\text { access to Very } \\
\text { High Radiation } \\
\text { Areas. } \\
\text { NV/YMP RCM } \\
334.4 .01 \text {. } \\
\text { Workers shall be } \\
\text { prevented from } \\
\text { entry to Very } \\
\text { High Radiation } \\
\text { Areas. }\end{array}$ & $\begin{array}{l}\text { In addition to the } \\
\text { above } \\
\text { requirements, } \\
\text { additional } \\
\text { measures shall } \\
\text { be implemented } \\
\text { to ensure } \\
\text { personnel are } \\
\text { not able to gain } \\
\text { access to Very } \\
\text { High Radiation } \\
\text { Areas. } \\
\text { NV/YMP RCM } \\
334.4 .01 \text {. } \\
\text { Workers shall be } \\
\text { prevented from } \\
\text { entry to Very } \\
\text { High Radiation } \\
\text { Areas. }\end{array}$ & & & & & $\begin{array}{l}\text { do not enter Very } \\
\text { High Radiation } \\
\text { Areas. }\end{array}$ & $\begin{array}{l}\text { not apply to } \\
\text { WSI/NV, as } \\
\text { personnel are } \\
\text { not permitted to } \\
\text { enter Very High } \\
\text { Radiation Areas. } \\
\text { If access were } \\
\text { required, } \\
\text { WSI/NV would } \\
\text { comply with the } \\
\text { measures } \\
\text { established by } \\
\text { the cognizant } \\
\text { TO. }\end{array}$ \\
\hline $\begin{array}{l}502(\mathrm{~d}) \text { No control(s) } \\
\text { shall be established in } \\
\text { a high or very high } \\
\text { radiation area that } \\
\text { would prevent rapid } \\
\text { evacuation of } \\
\text { personnel. }\end{array}$ & $\begin{array}{l}\text { NV/YMP RCM } \\
\text { Appendix 3A.3. } \\
\text { Physical access } \\
\text { controls over } \\
\text { High and Very } \\
\text { High Radiation } \\
\text { Areas shall be } \\
\text { established in } \\
\text { such a way that } \\
\text { they do not } \\
\text { prevent a person } \\
\text { from leaving the } \\
\text { area. }\end{array}$ & $\begin{array}{l}\text { NV/YMP RCM } \\
\text { Appendix 3A.3. } \\
\text { Physical access } \\
\text { controls over } \\
\text { High and Very } \\
\text { High Radiation } \\
\text { Areas shall be } \\
\text { established in } \\
\text { such a way that } \\
\text { they do not } \\
\text { prevent a person } \\
\text { from leaving the } \\
\text { area. }\end{array}$ & $\begin{array}{l}\text { Same as Column } \\
3\end{array}$ & $\begin{array}{l}\text { Same as Column } \\
3\end{array}$ & $\begin{array}{l}\text { Same as Column } \\
3\end{array}$ & $\begin{array}{l}\text { Same as Column } \\
3\end{array}$ & $\begin{array}{l}\text { Not applicable to } \\
\text { DRI. DRI does } \\
\text { not conduct work } \\
\text { in High or Very } \\
\text { High Radiation } \\
\text { areas. }\end{array}$ & $\begin{array}{l}\text { The content of } \\
\text { this section does } \\
\text { not apply to } \\
\text { WSI/NV, as } \\
\text { WSI/NV } \\
\text { personnel are } \\
\text { not permitted to } \\
\text { enter High or } \\
\text { Very High } \\
\text { Radiation Areas. } \\
\text { If access were } \\
\text { required, } \\
\text { WSI/NV would }\end{array}$ \\
\hline
\end{tabular}




\section{NEVADA TEST SITE RADIATION PROTECTION PROGRAM}

\section{APPENDIX H}

COMPLIANCE DEMONSTRATION TABLE

\begin{tabular}{|c|c|c|c|c|c|c|c|c|}
\hline \multirow[t]{2}{*}{10 CFR 835} & $\begin{array}{c}\text { NV/YMP RCM } \\
\text { Rev } 5 \text { and } \\
\text { NTS RPP } \\
\text { Revision } 0 \\
\end{array}$ & $\begin{array}{c}\text { NSTec } \\
\text { Appendix A }\end{array}$ & $\begin{array}{c}\text { LLNL } \\
\text { Appendix B }\end{array}$ & $\begin{array}{c}\text { LANL } \\
\text { Appendix C }\end{array}$ & $\begin{array}{c}\text { SNL } \\
\text { Appendix D }\end{array}$ & $\begin{array}{c}\text { SNJV } \\
\text { Appendix E }\end{array}$ & $\begin{array}{c}\text { DRI } \\
\text { Appendix F }\end{array}$ & $\begin{array}{c}\text { WSI } \\
\text { Appendix G }\end{array}$ \\
\hline & $\begin{array}{l}\text { Implementation } \\
\text { Reference }\end{array}$ & $\begin{array}{l}\text { Implementation } \\
\text { Reference }\end{array}$ & $\begin{array}{l}\text { Implementation } \\
\text { Reference }\end{array}$ & $\begin{array}{l}\text { Implementation } \\
\text { Reference }\end{array}$ & $\begin{array}{c}\text { Implementation } \\
\text { Reference }\end{array}$ & $\begin{array}{l}\text { Implementation } \\
\text { Reference }\end{array}$ & $\begin{array}{l}\text { Implementation } \\
\text { Reference }\end{array}$ & $\begin{array}{l}\text { Implementation } \\
\text { Reference }\end{array}$ \\
\hline
\end{tabular}

\begin{tabular}{|c|c|c|c|c|c|c|c|c|}
\hline & $\begin{array}{l}\text { NV/YMP RCM } \\
231.7 .03 \text {. These } \\
\text { barriers shall be } \\
\text { set up such that } \\
\text { they do not } \\
\text { impede the } \\
\text { intended use of } \\
\text { emergency exits } \\
\text { or evacuation } \\
\text { routes. }\end{array}$ & $\begin{array}{l}\text { NV/YMP RCM } \\
231.7 .03 \text {. These } \\
\text { barriers shall be } \\
\text { set up such that } \\
\text { they do not } \\
\text { impede the } \\
\text { intended use of } \\
\text { emergency exits } \\
\text { or evacuation } \\
\text { routes. } \\
\end{array}$ & & & & & & $\begin{array}{l}\text { comply with the } \\
\text { measures } \\
\text { established by } \\
\text { the cognizant } \\
\text { TO. }\end{array}$ \\
\hline $\begin{array}{l}\text { Subpart G-Posting } \\
\text { and Labeling } \\
\text { 835.601 General } \\
\text { Requirements } \\
601(a) \text { Except as } \\
\text { otherwise provided in } \\
\text { this subpart, postings } \\
\text { and labels required by } \\
\text { this subpart shall } \\
\text { include the standard } \\
\text { radiation warning } \\
\text { trefoil in black or } \\
\text { magenta imposed } \\
\text { upon a yellow } \\
\text { background. }\end{array}$ & $\begin{array}{l}\text { NV/YMP RCM } \\
231.2 .02 \text { and.03. } \\
\text { Signs shall } \\
\text { contain the } \\
\text { standard } \\
\text { radiation symbol } \\
\text { ("trefoil") colored } \\
\text { magenta or black } \\
\text { on a yellow } \\
\text { background. } \\
\text { Lettering shall be } \\
\text { either magenta } \\
\text { or black. } \\
\text { NV/YMP RCM } \\
412.3 .01 \text { and } \\
.02 . \text { Labels } \\
\text { shall have a } \\
\text { yellow } \\
\text { background with } \\
\text { a magenta or } \\
\text { black standard } \\
\end{array}$ & $\begin{array}{l}\text { NV/YMP RCM } \\
231.2 .02 \text { and.03. } \\
\text { Signs shall } \\
\text { contain the } \\
\text { standard } \\
\text { radiation symbol } \\
\text { ("trefoil") colored } \\
\text { magenta or black } \\
\text { on a yellow } \\
\text { background. } \\
\text { Lettering shall be } \\
\text { either magenta } \\
\text { or black. } \\
\text { NV/YMP RCM } \\
412.3 .01 \text { and } \\
.02 . \text { Labels } \\
\text { shall have a } \\
\text { yellow } \\
\text { background with } \\
\text { a magenta or } \\
\text { black standard } \\
\end{array}$ & $\begin{array}{l}\text { Same as Column } \\
3\end{array}$ & $\begin{array}{l}\text { Same as Column } \\
3\end{array}$ & $\begin{array}{l}\text { Same as Column } \\
3\end{array}$ & $\begin{array}{l}\text { Same as Column } \\
3\end{array}$ & $\begin{array}{l}\text { Not applicable to } \\
\text { DRI. The RSPC } \\
\text { provides the } \\
\text { appropriate } \\
\text { signage and } \\
\text { labels. }\end{array}$ & $\begin{array}{l}\text { Posting and } \\
\text { labeling are } \\
\text { beyond the } \\
\text { scope of WSI/NV } \\
\text { radiological } \\
\text { control } \\
\text { responsibilities. } \\
\text { The RSPC } \\
\text { provides } \\
\text { appropriate signs } \\
\text { and labels. }\end{array}$ \\
\hline
\end{tabular}




\section{NEVADA TEST SITE RADIATION PROTECTION PROGRAM}

\section{APPENDIX H}

COMPLIANCE DEMONSTRATION TABLE

\begin{tabular}{|c|c|c|c|c|c|c|c|c|}
\hline \multirow[t]{2}{*}{10 CFR 835} & $\begin{array}{c}\text { NV/YMP RCM } \\
\text { Rev } 5 \text { and } \\
\text { NTS RPP } \\
\text { Revision } 0 \\
\end{array}$ & $\begin{array}{c}\text { NSTec } \\
\text { Appendix A }\end{array}$ & $\begin{array}{c}\text { LLNL } \\
\text { Appendix B }\end{array}$ & $\begin{array}{c}\text { LANL } \\
\text { Appendix C }\end{array}$ & $\begin{array}{c}\text { SNL } \\
\text { Appendix D }\end{array}$ & $\begin{array}{c}\text { SNJV } \\
\text { Appendix E }\end{array}$ & $\begin{array}{c}\text { DRI } \\
\text { Appendix F }\end{array}$ & $\begin{array}{c}\text { WSI } \\
\text { Appendix G }\end{array}$ \\
\hline & $\begin{array}{l}\text { Implementation } \\
\text { Reference }\end{array}$ & $\begin{array}{l}\text { Implementation } \\
\text { Reference }\end{array}$ & $\begin{array}{l}\text { Implementation } \\
\text { Reference }\end{array}$ & $\begin{array}{l}\text { Implementation } \\
\text { Reference }\end{array}$ & $\begin{array}{l}\text { Implementation } \\
\text { Reference }\end{array}$ & $\begin{array}{l}\text { Implementation } \\
\text { Reference }\end{array}$ & $\begin{array}{l}\text { Implementation } \\
\text { Reference }\end{array}$ & $\begin{array}{l}\text { Implementation } \\
\text { Reference }\end{array}$ \\
\hline
\end{tabular}

\begin{tabular}{|c|c|c|c|c|c|c|c|c|}
\hline & $\begin{array}{l}\text { radiation symbol. } \\
\text { Lettering shall be } \\
\text { magenta or } \\
\text { black. }\end{array}$ & $\begin{array}{l}\text { radiation symbol. } \\
\text { Lettering shall be } \\
\text { magenta or } \\
\text { black. }\end{array}$ & & & & & & \\
\hline $\begin{array}{l}601(\mathrm{~b}) \text { Signs required } \\
\text { by this subpart shall } \\
\text { be clearly and } \\
\text { conspicuously posted } \\
\text { and may include } \\
\text { radiological protection } \\
\text { instructions. }\end{array}$ & $\begin{array}{l}\text { NV/YMP RCM } \\
\text { 231.3.01. Signs } \\
\text { shall be } \\
\text { conspicuously } \\
\text { posted, clearly } \\
\text { worded, and may } \\
\text { include } \\
\text { radiological } \\
\text { control } \\
\text { instructions, } \\
\text { where } \\
\text { appropriate. }\end{array}$ & $\begin{array}{l}\text { NV/YMP RCM } \\
\text { 231.3.01. Signs } \\
\text { shall be } \\
\text { conspicuously } \\
\text { posted, clearly } \\
\text { worded, and may } \\
\text { include } \\
\text { radiological } \\
\text { control } \\
\text { instructions, } \\
\text { where } \\
\text { appropriate. }\end{array}$ & $\begin{array}{l}\text { Same as Column } \\
3\end{array}$ & $\begin{array}{l}\text { Same as Column } \\
3\end{array}$ & $\begin{array}{l}\text { Same as Column } \\
3\end{array}$ & $\begin{array}{l}\text { Same as Column } \\
3\end{array}$ & $\begin{array}{l}\text { This service is } \\
\text { provided to DRI } \\
\text { by the RSPC. }\end{array}$ & $\begin{array}{l}\text { Posting and } \\
\text { labeling are } \\
\text { beyond the } \\
\text { scope of WSI/NV } \\
\text { radiological } \\
\text { control } \\
\text { responsibilities. } \\
\text { The RSPC } \\
\text { provides } \\
\text { appropriate signs } \\
\text { and labels. }\end{array}$ \\
\hline $\begin{array}{l}601(\mathrm{c}) \text { The posting } \\
\text { and labeling } \\
\text { requirements in this } \\
\text { subpart may be } \\
\text { modified to reflect the } \\
\text { special considerations } \\
\text { of DOE activities } \\
\text { conducted at private } \\
\text { residences or } \\
\text { businesses. Such } \\
\text { modifications shall } \\
\text { provide the same level } \\
\text { of protection to } \\
\text { individuals as the } \\
\text { existing provisions in } \\
\text { this subpart. }\end{array}$ & $\begin{array}{l}\text { NV/YMP RCM } \\
231.10 \text {. The } \\
\text { posting and } \\
\text { labeling } \\
\text { requirements in } \\
\text { this Manual may } \\
\text { be modified to } \\
\text { reflect the } \\
\text { special } \\
\text { considerations of } \\
\text { DOE activities } \\
\text { conducted at } \\
\text { private } \\
\text { residences or } \\
\text { businesses. } \\
\text { Such } \\
\text { modifications }\end{array}$ & $\begin{array}{l}\text { NV/YMP RCM } \\
231.10 \text {. The } \\
\text { posting and } \\
\text { labeling } \\
\text { requirements in } \\
\text { this Manual may } \\
\text { be modified to } \\
\text { reflect the } \\
\text { special } \\
\text { considerations of } \\
\text { DOE activities } \\
\text { conducted at } \\
\text { private } \\
\text { residences or } \\
\text { businesses. } \\
\text { Such } \\
\text { modifications }\end{array}$ & $\begin{array}{l}\text { Operations } \\
\text { conducted by } \\
\text { LLNL at the NTS } \\
\text { do not include } \\
\text { activities at } \\
\text { private } \\
\text { residences or } \\
\text { businesses. }\end{array}$ & $\begin{array}{l}\text { This is outside } \\
\text { the scope of the } \\
\text { LANL/NTS } \\
\text { Radiological } \\
\text { Control Program. } \\
\text { Operations } \\
\text { conducted by } \\
\text { LANL at the NTS } \\
\text { do not include } \\
\text { activities at } \\
\text { private } \\
\text { residences or } \\
\text { businesses. }\end{array}$ & $\begin{array}{l}\text { SNL-NV is not } \\
\text { involved in any } \\
\text { remediation } \\
\text { activities at } \\
\text { private } \\
\text { residences nor } \\
\text { are there SNL } \\
\text { facilities, } \\
\text { operations or } \\
\text { processes at } \\
\text { private } \\
\text { residences or } \\
\text { businesses. }\end{array}$ & $\begin{array}{l}\text { Same as Column } \\
3\end{array}$ & $\begin{array}{l}\text { Not applicable to } \\
\text { DRI as } \\
\text { operations } \\
\text { conducted by } \\
\text { DRI at the NTS } \\
\text { do not include } \\
\text { activities at } \\
\text { private } \\
\text { residences or } \\
\text { businesses. }\end{array}$ & $\begin{array}{l}\text { Posting and } \\
\text { labeling are } \\
\text { beyond the } \\
\text { scope of WSI/NV } \\
\text { radiological } \\
\text { control } \\
\text { responsibilities. } \\
\text { The RSPC } \\
\text { provides } \\
\text { appropriate signs } \\
\text { and labels. }\end{array}$ \\
\hline
\end{tabular}

H-64 


\section{NEVADA TEST SITE RADIATION PROTECTION PROGRAM}

\section{APPENDIX H}

COMPLIANCE DEMONSTRATION TABLE

\begin{tabular}{|c|c|c|c||c||c||c||c||c|}
\hline \multirow{2}{*}{ 10 CFR 835 } & $\begin{array}{c}\text { NV/YMP RCM } \\
\text { Rev 5 and } \\
\text { NTS RPP } \\
\text { Revision 0 }\end{array}$ & Appendix A & Appendix B & Appendix C & Appendix D & SNJV \\
\cline { 2 - 7 } & $\begin{array}{c}\text { Implementation } \\
\text { Reference }\end{array}$ & $\begin{array}{c}\text { Implementation } \\
\text { Reference }\end{array}$ & $\begin{array}{c}\text { Implementation } \\
\text { Reference }\end{array}$ & $\begin{array}{c}\text { Implementation } \\
\text { Reference }\end{array}$ & $\begin{array}{c}\text { Implementation } \\
\text { Reference }\end{array}$ & $\begin{array}{c}\text { Implementation } \\
\text { Reference }\end{array}$ & $\begin{array}{c}\text { Implementation } \\
\text { Reference }\end{array}$ & $\begin{array}{c}\text { Implementation } \\
\text { Reference }\end{array}$ \\
\hline
\end{tabular}

\begin{tabular}{|c|c|c|c|c|c|c|c|c|}
\hline & $\begin{array}{l}\text { shall provide the } \\
\text { same level of } \\
\text { protection to } \\
\text { individuals as the } \\
\text { existing } \\
\text { provisions in this } \\
\text { manual. }\end{array}$ & $\begin{array}{l}\text { shall provide the } \\
\text { same level of } \\
\text { protection to } \\
\text { individuals as the } \\
\text { existing } \\
\text { provisions in this } \\
\text { manual. }\end{array}$ & & & & & & \\
\hline $\begin{array}{l}835.602 \text { Controlled } \\
\text { Areas. } \\
602(a) \text { Each access } \\
\text { point to a controlled } \\
\text { area (as defined in } \\
\S 835.2 \text { ) shall be } \\
\text { posted whenever } \\
\text { radiological areas or } \\
\text { radioactive material } \\
\text { areas exist in the area. } \\
\text { Individuals who enter } \\
\text { only controlled areas } \\
\text { without entering } \\
\text { radiological areas or } \\
\text { radioactive material } \\
\text { areas are not } \\
\text { expected to receive a } \\
\text { total effective dose of } \\
\text { more than } 0.1 \text { rem } \\
\text { (0.001 Sv) in a year. }\end{array}$ & $\begin{array}{l}\text { NV/YMP RCM } \\
232.1 \text {. Each } \\
\text { access point to a } \\
\text { Controlled Area } \\
\text { shall be posted. } \\
\text { When any other } \\
\text { radiological } \\
\text { warning signs } \\
\text { are present, the } \\
\text { Controlled Area } \\
\text { sign is not } \\
\text { required. } \\
\text { Individuals who } \\
\text { enter only the } \\
\text { Controlled Area } \\
\text { without entering } \\
\text { radiological } \\
\text { areas or RMAs } \\
\text { are not expected } \\
\text { to receive a } \\
\text { TEDE of more } \\
\text { than } 0.1 \text { rem } \\
\text { (0.001 sievert) in } \\
\text { a year. }\end{array}$ & $\begin{array}{l}\text { Revise: NV/YMP } \\
\text { RCM 232.1. } \\
\text { Each access } \\
\text { point to a } \\
\text { Controlled Area } \\
\text { shall be posted. } \\
\text { When any other } \\
\text { radiological } \\
\text { warning signs } \\
\text { are present, the } \\
\text { Controlled Area } \\
\text { sign is not } \\
\text { required. } \\
\text { Individuals who } \\
\text { enter only the } \\
\text { Controlled Area } \\
\text { without entering } \\
\text { radiological } \\
\text { areas or RMAs } \\
\text { are not expected } \\
\text { to receive a TED } \\
\text { of more than } 0.1 \\
\text { rem (0.001 } \\
\text { sievert) in a year. }\end{array}$ & $\begin{array}{l}\text { Same as Column } \\
3\end{array}$ & $\begin{array}{l}\text { Same as Column } \\
3\end{array}$ & $\begin{array}{l}\text { Same as Column } \\
3\end{array}$ & $\begin{array}{l}\text { Same as Column } \\
3\end{array}$ & $\begin{array}{l}\text { Not a DRI } \\
\text { activity. Posting } \\
\text { of access points } \\
\text { to a controlled } \\
\text { area is a service } \\
\text { provided to DRI } \\
\text { by the RSPC. If } \\
\text { access is } \\
\text { required DRI will } \\
\text { comply with } \\
\text { controls } \\
\text { established by } \\
\text { the cognizant } \\
\text { TO. }\end{array}$ & $\begin{array}{l}\text { Posting of } \\
\text { controlled areas } \\
\text { is beyond the } \\
\text { scope of WSI/NV } \\
\text { radiological } \\
\text { control } \\
\text { responsibilities. } \\
\text { The RSPC or TO } \\
\text { who has } \\
\text { radiological } \\
\text { control } \\
\text { responsibilities } \\
\text { for the controlled } \\
\text { area is } \\
\text { responsible for } \\
\text { ensuring that the } \\
\text { requirements of } \\
\text { this section are } \\
\text { met. If access is } \\
\text { required, } \\
\text { WSI/NV } \\
\text { personnel will } \\
\text { comply with all } \\
\text { controls } \\
\text { established by } \\
\text { the RSPC or TO. }\end{array}$ \\
\hline
\end{tabular}




\section{NEVADA TEST SITE RADIATION PROTECTION PROGRAM}

\section{APPENDIX H}

COMPLIANCE DEMONSTRATION TABLE

\begin{tabular}{|c|c|c|c|c|c|c|c|c|}
\hline \multirow[t]{2}{*}{10 CFR 835} & $\begin{array}{l}\text { NV/YMP RCM } \\
\text { Rev } 5 \text { and } \\
\text { NTS RPP } \\
\text { Revision } 0 \\
\end{array}$ & $\begin{array}{c}\text { NSTec } \\
\text { Appendix A }\end{array}$ & $\begin{array}{c}\text { LLNL } \\
\text { Appendix B }\end{array}$ & $\begin{array}{c}\text { LANL } \\
\text { Appendix C }\end{array}$ & $\begin{array}{c}\text { SNL } \\
\text { Appendix D }\end{array}$ & $\begin{array}{c}\text { SNJV } \\
\text { Appendix E }\end{array}$ & $\begin{array}{c}\text { DRI } \\
\text { Appendix F }\end{array}$ & $\begin{array}{c}\text { WSI } \\
\text { Appendix G }\end{array}$ \\
\hline & $\begin{array}{l}\text { Implementation } \\
\text { Reference }\end{array}$ & $\begin{array}{l}\text { Implementation } \\
\text { Reference }\end{array}$ & $\begin{array}{l}\text { Implementation } \\
\text { Reference }\end{array}$ & $\begin{array}{l}\text { Implementation } \\
\text { Reference }\end{array}$ & $\begin{array}{l}\text { Implementation } \\
\text { Reference }\end{array}$ & $\begin{array}{l}\text { Implementation } \\
\text { Reference }\end{array}$ & $\begin{array}{l}\text { Implementation } \\
\text { Reference }\end{array}$ & $\begin{array}{c}\text { Implementation } \\
\text { Reference }\end{array}$ \\
\hline
\end{tabular}

\begin{tabular}{|c|c|c|c|c|c|c|c|c|}
\hline $\begin{array}{l}602(b) \text { Signs used for } \\
\text { this purpose may be } \\
\text { selected by the } \\
\text { contractor to avoid } \\
\text { conflict with local } \\
\text { security requirements. }\end{array}$ & $\begin{array}{l}\text { NV/YMP RCM } \\
\text { 232.2. As a } \\
\text { minimum the } \\
\text { Controlled Area } \\
\text { posting shall } \\
\text { contain the } \\
\text { following } \\
\text { wording: } \\
\text { "CONTROLLED } \\
\text { AREA. THIS } \\
\text { AREA IS } \\
\text { CONTROLLED } \\
\text { FOR THE } \\
\text { PURPOSE OF } \\
\text { LIMITING } \\
\text { ACCESS TO } \\
\text { RADIATION OR } \\
\text { RADIOACTIVITY } \\
\text { GENERAL } \\
\text { EMPLOYEE } \\
\text { RADIOLOGICAL } \\
\text { TRAINING } \\
\text { (GERT) IS } \\
\text { REQUIRED FOR } \\
\text { ACCESS." }\end{array}$ & $\begin{array}{l}\text { NV/YMP RCM } \\
\text { 232.2. As a } \\
\text { minimum the } \\
\text { Controlled Area } \\
\text { posting shall } \\
\text { contain the } \\
\text { following } \\
\text { wording: } \\
\text { "CONTROLLED } \\
\text { AREA. THIS } \\
\text { AREA IS } \\
\text { CONTROLLED } \\
\text { FOR THE } \\
\text { PURPOSE OF } \\
\text { LIMITING } \\
\text { ACCESS TO } \\
\text { RADIATION OR } \\
\text { RADIOACTIVITY } \\
\text { GENERAL } \\
\text { EMPLOYEE } \\
\text { RADIOLOGICAL } \\
\text { TRAINING } \\
\text { (GERT) IS } \\
\text { REQUIRED FOR } \\
\text { ACCESS." }\end{array}$ & $\begin{array}{l}\text { Same as Column } \\
3\end{array}$ & $\begin{array}{l}\text { Same as Column } \\
3\end{array}$ & $\begin{array}{l}\text { Same as Column } \\
3\end{array}$ & $\begin{array}{l}\text { Same as Column } \\
3\end{array}$ & $\begin{array}{l}\text { Not a DRI } \\
\text { activity. Required } \\
\text { signage is } \\
\text { provided to DRI } \\
\text { by the RSPC. }\end{array}$ & $\begin{array}{l}\text { By written } \\
\text { agreement, the } \\
\text { RSPC provides } \\
\text { this service. }\end{array}$ \\
\hline $\begin{array}{l}835.603 \text { Radiological } \\
\text { Areas and } \\
\text { Radioactive Material } \\
\text { Areas. } \\
\text { Each access point to } \\
\text { radiological areas and } \\
\text { radioactive material } \\
\text { areas (as defined in } \\
\end{array}$ & $\begin{array}{l}\text { NV/YMP RCM } \\
231.2 .01 . \text { Each } \\
\text { access point to a } \\
\text { radiological area } \\
\text { shall be posted } \\
\text { according to } \\
\text { Tables 2-3 and } \\
2-4 \text {. } \\
\end{array}$ & $\begin{array}{l}\text { NV/YMP RCM } \\
231.2 .01 \text {. Each } \\
\text { access point to a } \\
\text { radiological area } \\
\text { shall be posted } \\
\text { according to } \\
\text { Tables } 2-3 \text { and } \\
2-4 \text {. } \\
\end{array}$ & $\begin{array}{l}\text { Same as Column } \\
3\end{array}$ & $\begin{array}{l}\text { Same as Column } \\
3\end{array}$ & $\begin{array}{l}\text { Same as Column } \\
3\end{array}$ & $\begin{array}{l}\text { Same as Column } \\
3\end{array}$ & $\begin{array}{l}\text { Not applicable. } \\
\text { DRI does not } \\
\text { have radiological } \\
\text { areas, but will } \\
\text { comply with any } \\
\text { requirements } \\
\text { established by } \\
\text { the postings } \\
\end{array}$ & $\begin{array}{l}\text { Not a WSI/NV } \\
\text { activity. WSI/NV } \\
\text { does not control } \\
\text { radiological } \\
\text { areas but will } \\
\text { comply with the } \\
\text { requirements } \\
\text { established by } \\
\end{array}$ \\
\hline
\end{tabular}




\section{NEVADA TEST SITE RADIATION PROTECTION PROGRAM}

\section{APPENDIX H}

COMPLIANCE DEMONSTRATION TABLE

\begin{tabular}{|c|c|c|c|c|c|c|c|c|}
\hline \multirow[t]{2}{*}{10 CFR 835} & $\begin{array}{l}\text { NV/YMP RCM } \\
\text { Rev } 5 \text { and } \\
\text { NTS RPP } \\
\text { Revision } 0 \\
\end{array}$ & $\begin{array}{c}\text { NSTec } \\
\text { Appendix A }\end{array}$ & $\begin{array}{c}\text { LLNL } \\
\text { Appendix B }\end{array}$ & $\begin{array}{c}\text { LANL } \\
\text { Appendix C }\end{array}$ & $\begin{array}{c}\text { SNL } \\
\text { Appendix D }\end{array}$ & $\begin{array}{c}\text { SNJV } \\
\text { Appendix E }\end{array}$ & $\begin{array}{c}\text { DRI } \\
\text { Appendix F }\end{array}$ & $\begin{array}{c}\text { WSI } \\
\text { Appendix G }\end{array}$ \\
\hline & $\begin{array}{l}\text { Implementation } \\
\text { Reference }\end{array}$ & $\begin{array}{l}\text { Implementation } \\
\text { Reference }\end{array}$ & $\begin{array}{l}\text { Implementation } \\
\text { Reference }\end{array}$ & $\begin{array}{l}\text { Implementation } \\
\text { Reference }\end{array}$ & $\begin{array}{l}\text { Implementation } \\
\text { Reference }\end{array}$ & $\begin{array}{l}\text { Implementation } \\
\text { Reference }\end{array}$ & $\begin{array}{l}\text { Implementation } \\
\text { Reference }\end{array}$ & $\begin{array}{l}\text { Implementation } \\
\text { Reference }\end{array}$ \\
\hline
\end{tabular}

\begin{tabular}{|c|c|c|c|c|c|c|c|c|}
\hline $\begin{array}{l}\S 835.2) \text { shall be } \\
\text { posted with } \\
\text { conspicuous signs } \\
\text { bearing the wording } \\
\text { provided in this } \\
\text { section. }\end{array}$ & $\begin{array}{l}\text { NV/YMP RCM } \\
236.1 .01 . \\
\text { Accessible areas } \\
\text { where items or } \\
\text { containers of } \\
\text { radioactive } \\
\text { material in } \\
\text { quantities } \\
\text { exceeding the } \\
\text { values provided } \\
\text { in Appendix 4A } \\
\text { are used, } \\
\text { handled, or } \\
\text { stored shall be } \\
\text { posted } \\
\text { "CAUTION, } \\
\text { RADIOACTIVE } \\
\text { MATERIAL." }\end{array}$ & $\begin{array}{l}\text { NV/YMP RCM } \\
236.1 .01 . \\
\text { Accessible areas } \\
\text { where items or } \\
\text { containers of } \\
\text { radioactive } \\
\text { material in } \\
\text { quantities } \\
\text { exceeding the } \\
\text { values provided } \\
\text { in Appendix 4A } \\
\text { are used, } \\
\text { handled, or } \\
\text { stored shall be } \\
\text { posted } \\
\text { "CAUTION, } \\
\text { RADIOACTIVE } \\
\text { MATERIAL." }\end{array}$ & & & & & $\begin{array}{l}\text { provided by the } \\
\text { RSPC or } \\
\text { cognizant TO. }\end{array}$ & the RSPC. \\
\hline $\begin{array}{l}603(a) \text { Radiation Area. } \\
\text { The words "Caution, } \\
\text { Radiation Area" shall } \\
\text { be posted at each } \\
\text { radiation area. }\end{array}$ & $\begin{array}{l}\text { NV/YMP RCM } \\
\text { Table 2-3, Item: } \\
\text { 1. Radiation } \\
\text { Area, >0.005 } \\
\text { rem in one hour } \\
\text { at } 30 \mathrm{~cm} \text {, } \\
\text { "CAUTION, } \\
\text { RADIATION } \\
\text { AREA." }\end{array}$ & $\begin{array}{l}\text { NV/YMP RCM } \\
\text { Table 2-3, Item: } \\
\text { 1. Radiation } \\
\text { Area, >0.005 } \\
\text { rem in one hour } \\
\text { at } 30 \mathrm{~cm} \text {, } \\
\text { "CAUTION, } \\
\text { RADIATION } \\
\text { AREA." }\end{array}$ & $\begin{array}{l}\text { Same as Column } \\
3\end{array}$ & $\begin{array}{l}\text { Same as Column } \\
3\end{array}$ & $\begin{array}{l}\text { Same as Column } \\
3\end{array}$ & $\begin{array}{l}\text { Same as Column } \\
3\end{array}$ & $\begin{array}{l}\text { Not applicable. } \\
\text { DRI does not } \\
\text { have radiological } \\
\text { areas but will } \\
\text { comply with any } \\
\text { requirements } \\
\text { established by } \\
\text { the postings } \\
\text { provided by the } \\
\text { RSPC or } \\
\text { cognizant TO. }\end{array}$ & $\begin{array}{l}\text { Not a WSI/NV } \\
\text { activity. WSI/NV } \\
\text { does not control } \\
\text { radiological } \\
\text { areas. }\end{array}$ \\
\hline $\begin{array}{l}\text { 603(b) High Radiation } \\
\text { Area. The words } \\
\text { "Caution, High }\end{array}$ & $\begin{array}{l}\text { NV/YMP RCM } \\
\text { Table 2-3 Item: } \\
\text { 2. High Radiation }\end{array}$ & $\begin{array}{l}\text { NV/YMP RCM } \\
\text { Table 2-3 Item: } \\
\text { 2. High Radiation }\end{array}$ & $\begin{array}{l}\text { Same as Column } \\
3\end{array}$ & $\begin{array}{l}\text { Same as Column } \\
3\end{array}$ & $\begin{array}{l}\text { Same as Column } \\
3\end{array}$ & $\begin{array}{l}\text { Same as Column } \\
3\end{array}$ & $\begin{array}{l}\text { Not applicable. } \\
\text { DRI does not } \\
\text { have radiological }\end{array}$ & $\begin{array}{l}\text { Not a WSI/NV } \\
\text { activity. WSI/NV } \\
\text { does not control }\end{array}$ \\
\hline
\end{tabular}




\section{NEVADA TEST SITE RADIATION PROTECTION PROGRAM}

\section{APPENDIX H}

COMPLIANCE DEMONSTRATION TABLE

\begin{tabular}{|c|c|c|c|c|c|c|c|c|}
\hline \multirow[t]{2}{*}{10 CFR 835} & $\begin{array}{c}\text { NV/YMP RCM } \\
\text { Rev } 5 \text { and } \\
\text { NTS RPP } \\
\text { Revision } 0 \\
\end{array}$ & $\begin{array}{c}\text { NSTec } \\
\text { Appendix A }\end{array}$ & $\begin{array}{c}\text { LLNL } \\
\text { Appendix B }\end{array}$ & $\begin{array}{c}\text { LANL } \\
\text { Appendix C }\end{array}$ & $\begin{array}{c}\text { SNL } \\
\text { Appendix D }\end{array}$ & $\begin{array}{c}\text { SNJV } \\
\text { Appendix E }\end{array}$ & $\begin{array}{c}\text { DRI } \\
\text { Appendix F }\end{array}$ & $\begin{array}{c}\text { WSI } \\
\text { Appendix G }\end{array}$ \\
\hline & $\begin{array}{l}\text { Implementation } \\
\text { Reference }\end{array}$ & $\begin{array}{l}\text { Implementation } \\
\text { Reference }\end{array}$ & $\begin{array}{l}\text { Implementation } \\
\text { Reference }\end{array}$ & $\begin{array}{l}\text { Implementation } \\
\text { Reference }\end{array}$ & $\begin{array}{l}\text { Implementation } \\
\text { Reference }\end{array}$ & $\begin{array}{l}\text { Implementation } \\
\text { Reference }\end{array}$ & $\begin{array}{l}\text { Implementation } \\
\text { Reference }\end{array}$ & $\begin{array}{l}\text { Implementation } \\
\text { Reference }\end{array}$ \\
\hline
\end{tabular}

\begin{tabular}{|c|c|c|c|c|c|c|c|c|}
\hline $\begin{array}{l}\text { Radiation Area" or } \\
\text { "Danger, High } \\
\text { Radiation Area" shall } \\
\text { be posted at each high } \\
\text { radiation area. }\end{array}$ & $\begin{array}{l}\text { Area, >0.1 rem in } \\
\text { one hour at } 30 \\
\text { cm, "CAUTION, } \\
\text { HIGH } \\
\text { RADIATION } \\
\text { AREA" or } \\
\text { "DANGER, HIGH } \\
\text { RADIATION } \\
\text { AREA." } \\
\end{array}$ & $\begin{array}{l}\text { Area, }>0.1 \text { rem in } \\
\text { one hour at } 30 \\
\text { cm, "CAUTION, } \\
\text { HIGH } \\
\text { RADIATION } \\
\text { AREA" or } \\
\text { "DANGER, HIGH } \\
\text { RADIATION } \\
\text { AREA." } \\
\end{array}$ & & & & & $\begin{array}{l}\text { areas but will } \\
\text { comply with any } \\
\text { requirements } \\
\text { established by } \\
\text { the postings } \\
\text { provided by the } \\
\text { RSPC or } \\
\text { cognizant TO. }\end{array}$ & $\begin{array}{l}\text { radiological } \\
\text { areas. }\end{array}$ \\
\hline $\begin{array}{l}603(\mathrm{c}) \text { Very High } \\
\text { Radiation Area. The } \\
\text { words "Grave Danger, } \\
\text { Very High Radiation } \\
\text { Area" shall be posted } \\
\text { at each very high } \\
\text { radiation area. }\end{array}$ & $\begin{array}{l}\text { NV/YMP RCM } \\
\text { Table 2-3, Item: } \\
\text { 3. Very High } \\
\text { Radiation Area, } \\
\text { > } 500 \text { rad in one } \\
\text { hour at } 1 \text { meter. } \\
\text { "GRAVE } \\
\text { DANGER, VERY } \\
\text { HIGH } \\
\text { RADIATION } \\
\text { AREA." }\end{array}$ & $\begin{array}{l}\text { NV/YMP RCM } \\
\text { Table 2-3, Item: } \\
\text { 3. Very High } \\
\text { Radiation Area, } \\
\text { >500 rad in one } \\
\text { hour at } 1 \text { meter. } \\
\text { "GRAVE } \\
\text { DANGER, VERY } \\
\text { HIGH } \\
\text { RADIATION } \\
\text { AREA." } \\
\end{array}$ & $\begin{array}{l}\text { Same as Column } \\
3\end{array}$ & $\begin{array}{l}\text { Same as Column } \\
3\end{array}$ & $\begin{array}{l}\text { Same as Column } \\
3\end{array}$ & $\begin{array}{l}\text { Same as Column } \\
3\end{array}$ & $\begin{array}{l}\text { Not a DRI } \\
\text { activity. DRI } \\
\text { does not have } \\
\text { radiological } \\
\text { areas and does } \\
\text { not conduct work } \\
\text { in very high } \\
\text { radiation areas }\end{array}$ & $\begin{array}{l}\text { Not a WSI/NV } \\
\text { activity. WSI/NV } \\
\text { does not control } \\
\text { radiological } \\
\text { areas. }\end{array}$ \\
\hline $\begin{array}{l}603(\mathrm{~d}) \text { Airborne } \\
\text { Radioactivity Area. } \\
\text { The words "Caution, } \\
\text { Airborne Radioactivity } \\
\text { Area" or "Danger, } \\
\text { Airborne Radioactivity } \\
\text { Area" shall be posted } \\
\text { at each airborne } \\
\text { radioactivity area. }\end{array}$ & $\begin{array}{l}\text { NV/YMP RCM } \\
\text { Table 2-4, Item: } \\
\text { 3. Airborne } \\
\text { Radioactivity. } \\
\text { Concentrations } \\
(\mu \mathrm{Ci} / \mathrm{ml})>\text { any } \\
\text { DAC value or } \\
\text { potential for } \\
\text { intakes } \\
\text { exceeding } 12 \\
\text { DAC hours/week } \\
\text { without } \\
\text { respiratory }\end{array}$ & $\begin{array}{l}\text { NV/YMP RCM } \\
\text { Table 2-4, Item: } \\
\text { 3. Airborne } \\
\text { Radioactivity. } \\
\text { Concentrations } \\
\text { ( } \mu \mathrm{Ci} / \mathrm{ml})>\text { any } \\
\text { DAC value or } \\
\text { potential for } \\
\text { intakes } \\
\text { exceeding } 12 \\
\text { DAC hours/week } \\
\text { without } \\
\text { respiratory } \\
\end{array}$ & $\begin{array}{l}\text { Same as Column } \\
3\end{array}$ & $\begin{array}{l}\text { Same as Column } \\
3\end{array}$ & $\begin{array}{l}\text { Same as Column } \\
3\end{array}$ & $\begin{array}{l}\text { Same as Column } \\
3\end{array}$ & $\begin{array}{l}\text { Not a DRI } \\
\text { activity. DRI } \\
\text { does not have } \\
\text { radiological } \\
\text { areas and does } \\
\text { not conduct work } \\
\text { in airborne } \\
\text { radioactivity } \\
\text { areas. }\end{array}$ & $\begin{array}{l}\text { Not a WSI/NV } \\
\text { activity. WSI/NV } \\
\text { does not control } \\
\text { radiological } \\
\text { areas. }\end{array}$ \\
\hline
\end{tabular}




\section{NEVADA TEST SITE RADIATION PROTECTION PROGRAM}

\section{APPENDIX H}

COMPLIANCE DEMONSTRATION TABLE

\begin{tabular}{|c|c|c|c|c|c|c|c|c|}
\hline \multirow[t]{2}{*}{10 CFR 835} & $\begin{array}{c}\text { NV/YMP RCM } \\
\text { Rev } 5 \text { and } \\
\text { NTS RPP } \\
\text { Revision } 0 \\
\end{array}$ & $\begin{array}{c}\text { NSTec } \\
\text { Appendix A }\end{array}$ & $\begin{array}{c}\text { LLNL } \\
\text { Appendix B }\end{array}$ & $\begin{array}{c}\text { LANL } \\
\text { Appendix C }\end{array}$ & $\begin{array}{c}\text { SNL } \\
\text { Appendix D }\end{array}$ & $\begin{array}{c}\text { SNJV } \\
\text { Appendix E }\end{array}$ & $\begin{array}{c}\text { DRI } \\
\text { Appendix F }\end{array}$ & $\begin{array}{c}\text { WSI } \\
\text { Appendix G }\end{array}$ \\
\hline & $\begin{array}{l}\text { Implementation } \\
\text { Reference }\end{array}$ & $\begin{array}{l}\text { Implementation } \\
\text { Reference }\end{array}$ & $\begin{array}{l}\text { Implementation } \\
\text { Reference }\end{array}$ & $\begin{array}{l}\text { Implementation } \\
\text { Reference }\end{array}$ & $\begin{array}{l}\text { Implementation } \\
\text { Reference }\end{array}$ & $\begin{array}{l}\text { Implementation } \\
\text { Reference }\end{array}$ & $\begin{array}{l}\text { Implementation } \\
\text { Reference }\end{array}$ & $\begin{array}{l}\text { Implementation } \\
\text { Reference }\end{array}$ \\
\hline
\end{tabular}

\begin{tabular}{|c|c|c|c|c|c|c|c|c|}
\hline & $\begin{array}{l}\text { protection. } \\
\text { "CAUTION, } \\
\text { AIRBORNE } \\
\text { RADIOACTIVITY } \\
\text { AREA" or } \\
\text { "DANGER, } \\
\text { AIRBORNE } \\
\text { RADIOACTIVITY } \\
\text { AREA." }\end{array}$ & \begin{tabular}{|l|} 
protection. \\
"CAUTION, \\
AIRBORNE \\
RADIOACTIVITY \\
AREA" or \\
"DANGER, \\
AIRBORNE \\
RADIOACTIVITY \\
AREA."
\end{tabular} & & & & & & \\
\hline $\begin{array}{l}603(e) \text { Contamination } \\
\text { Area. } \\
\text { The words "Caution, } \\
\text { Contamination Area" } \\
\text { shall be posted at } \\
\text { each contamination } \\
\text { area. }\end{array}$ & $\begin{array}{l}\text { NV/YMP RCM } \\
\text { Table 2-4, Item: } \\
1 . \\
\text { Contamination. } \\
\text { Removable } \\
\text { contamination } \\
\text { levels }>1 \text { time } \\
\text { but } \leq 100 \text { times } \\
\text { Table } \\
2-2 \text { values, } \\
\text { "CAUTION, } \\
\text { CONTAMINATION } \\
\text { AREA." }\end{array}$ & $\begin{array}{l}\text { NV/YMP RCM } \\
\text { Table 2-4, Item: } \\
1 . \\
\text { Contamination. } \\
\text { Removable } \\
\text { contamination } \\
\text { levels }>1 \text { time } \\
\text { but } \leq 100 \text { times } \\
\text { Table } \\
2-2 \text { values, } \\
\text { "CAUTION, } \\
\text { CONTAMINATION } \\
\text { AREA." } \\
\end{array}$ & $\begin{array}{l}\text { Same as Column } \\
3\end{array}$ & $\begin{array}{l}\text { Same as Column } \\
3\end{array}$ & $\begin{array}{l}\text { Same as Column } \\
3\end{array}$ & $\begin{array}{l}\text { Same as Column } \\
3\end{array}$ & $\begin{array}{l}\text { Not a DRI } \\
\text { activity. This } \\
\text { service is } \\
\text { provided to DRI } \\
\text { by the RSPC on } \\
\text { the NTS and as } \\
\text { requested at off- } \\
\text { site locations. }\end{array}$ & $\begin{array}{l}\text { Not a WSI/NV } \\
\text { activity. WSI/NV } \\
\text { does not control } \\
\text { radiological } \\
\text { areas. }\end{array}$ \\
\hline $\begin{array}{l}603(f) \text { High } \\
\text { Contamination Area. } \\
\text { The words "Caution, } \\
\text { High Contamination } \\
\text { Area" or "Danger, High } \\
\text { Contamination Area" } \\
\text { shall be posted at } \\
\text { each high } \\
\text { contamination area. }\end{array}$ & $\begin{array}{l}\text { NV/YMP RCM } \\
\text { Table 2-4, Item: } \\
\text { 2. High } \\
\text { Contamination. } \\
\text { Removable } \\
\text { contamination } \\
\text { levels }>100 \\
\text { times Table 2-2 } \\
\text { values. } \\
\text { "DANGER, HIGH } \\
\text { CONTAMINATION }\end{array}$ & \begin{tabular}{|l} 
NV/YMP RCM \\
Table 2-4, Item: \\
2. High \\
Contamination. \\
Removable \\
contamination \\
levels $>100$ \\
times Table 2-2 \\
values. \\
"DANGER, HIGH \\
CONTAMINATION \\
\end{tabular} & $\begin{array}{l}\text { Same as Column } \\
3\end{array}$ & $\begin{array}{l}\text { Same as Column } \\
3\end{array}$ & $\begin{array}{l}\text { Same as Column } \\
3\end{array}$ & $\begin{array}{l}\text { Same as Column } \\
3\end{array}$ & $\begin{array}{l}\text { Not a DRI } \\
\text { activity. This } \\
\text { service is } \\
\text { provided to DRI } \\
\text { by the RSPC on } \\
\text { the NTS and as } \\
\text { requested at off- } \\
\text { site locations. }\end{array}$ & $\begin{array}{l}\text { Not a WSI/NV } \\
\text { activity. WSI/NV } \\
\text { does not control } \\
\text { radiological } \\
\text { areas. }\end{array}$ \\
\hline
\end{tabular}




\section{NEVADA TEST SITE RADIATION PROTECTION PROGRAM}

\section{APPENDIX H}

COMPLIANCE DEMONSTRATION TABLE

\begin{tabular}{|c|c|c|c|c|c|c|c|c|}
\hline \multirow[t]{2}{*}{10 CFR 835} & $\begin{array}{c}\text { NV/YMP RCM } \\
\text { Rev } 5 \text { and } \\
\text { NTS RPP } \\
\text { Revision } 0 \\
\end{array}$ & $\begin{array}{c}\text { NSTec } \\
\text { Appendix A }\end{array}$ & $\begin{array}{c}\text { LLNL } \\
\text { Appendix B }\end{array}$ & $\begin{array}{c}\text { LANL } \\
\text { Appendix C }\end{array}$ & $\begin{array}{c}\text { SNL } \\
\text { Appendix D }\end{array}$ & $\begin{array}{c}\text { SNJV } \\
\text { Appendix E }\end{array}$ & $\begin{array}{c}\text { DRI } \\
\text { Appendix F }\end{array}$ & $\begin{array}{c}\text { WSI } \\
\text { Appendix G }\end{array}$ \\
\hline & $\begin{array}{l}\text { Implementation } \\
\text { Reference }\end{array}$ & $\begin{array}{l}\text { Implementation } \\
\text { Reference }\end{array}$ & $\begin{array}{l}\text { Implementation } \\
\text { Reference }\end{array}$ & $\begin{array}{l}\text { Implementation } \\
\text { Reference }\end{array}$ & $\begin{array}{l}\text { Implementation } \\
\text { Reference }\end{array}$ & $\begin{array}{l}\text { Implementation } \\
\text { Reference }\end{array}$ & $\begin{array}{l}\text { Implementation } \\
\text { Reference }\end{array}$ & $\begin{array}{l}\text { Implementation } \\
\text { Reference }\end{array}$ \\
\hline
\end{tabular}

\begin{tabular}{|c|c|c|c|c|c|c|c|c|}
\hline & $\begin{array}{l}\text { AREA" or } \\
\text { "CAUTION, } \\
\text { HIGH } \\
\text { CONTAMINATION } \\
\text { AREA." } \\
\end{array}$ & $\begin{array}{l}\text { AREA" or } \\
\text { "CAUTION, } \\
\text { HIGH } \\
\text { CONTAMINATION } \\
\text { AREA." } \\
\end{array}$ & & & & & & \\
\hline $\begin{array}{l}603(\mathrm{~g}) \text { Radioactive } \\
\text { Material Area. The } \\
\text { words "Caution, } \\
\text { Radioactive } \\
\text { Material(s)" shall be } \\
\text { posted at each } \\
\text { radioactive material } \\
\text { area. }\end{array}$ & $\begin{array}{l}\text { NV/YMP RCM } \\
236.1 .01 . \\
\text { Accessible areas } \\
\text { where items or } \\
\text { containers of } \\
\text { radioactive } \\
\text { material in } \\
\text { quantities } \\
\text { exceeding the } \\
\text { values provided } \\
\text { in Appendix 4A } \\
\text { are used, } \\
\text { handled, or } \\
\text { stored shall be } \\
\text { posted } \\
\text { "CAUTION, } \\
\text { RADIOACTIVE } \\
\text { MATERIAL." }\end{array}$ & $\begin{array}{l}\text { NV/YMP RCM } \\
236.1 .01 . \\
\text { Accessible areas } \\
\text { where items or } \\
\text { containers of } \\
\text { radioactive } \\
\text { material in } \\
\text { quantities } \\
\text { exceeding the } \\
\text { values provided } \\
\text { in Appendix 4A } \\
\text { are used, } \\
\text { handled, or } \\
\text { stored shall be } \\
\text { posted } \\
\text { "CAUTION, } \\
\text { RADIOACTIVE } \\
\text { MATERIAL." }\end{array}$ & $\begin{array}{l}\text { Same as Column } \\
3\end{array}$ & $\begin{array}{l}\text { Same as Column } \\
3\end{array}$ & $\begin{array}{l}\text { Same as Column } \\
3\end{array}$ & $\begin{array}{l}\text { Same as Column } \\
3\end{array}$ & $\begin{array}{l}\text { UNR RSM Policy } \\
\text { IV: Handling } \\
\text { Policies, Section } \\
\text { F.1, Posting of } \\
\text { Radiation Areas } \\
\text { (speaks to } \\
\text { RMAs). Required } \\
\text { signage for } \\
\text { materials } \\
\text { obtained under } \\
\text { the UNR } \\
\text { Radioactive } \\
\text { Material License } \\
\text { \#16-13-0003-07 } \\
\text { is provided to } \\
\text { DRI by the UNR } \\
\text { RSO. }\end{array}$ & $\begin{array}{l}\text { Not a WSI/NV } \\
\text { activity. WSI/NV } \\
\text { does not control } \\
\text { radioactive } \\
\text { material areas. }\end{array}$ \\
\hline $\begin{array}{l}835.604 \text { Exceptions } \\
\text { to Posting } \\
\text { Requirements. } \\
604(a) \text { Areas may be } \\
\text { excepted from the } \\
\text { posting requirements } \\
\text { of } \S 835.603 \text { for } \\
\text { periods of less than } 8 \\
\text { continuous hours }\end{array}$ & $\begin{array}{l}\text { NV/YMP RCM } \\
231.11 . a \text {. } \\
\text { Exceptions to } \\
\text { posting } \\
\text { requirements: } \\
\text { a. Areas may be } \\
\text { excepted from } \\
\text { the posting } \\
\text { requirements of } \\
10 \text { CFR } 835.603\end{array}$ & $\begin{array}{l}\text { NV/YMP RCM } \\
231.11 . a . \\
\text { Exceptions to } \\
\text { posting } \\
\text { requirements: } \\
\text { a. Areas may be } \\
\text { excepted from } \\
\text { the posting } \\
\text { requirements of } \\
10 \text { CFR } 835.603\end{array}$ & $\begin{array}{l}\text { Same as Column } \\
3\end{array}$ & $\begin{array}{l}\text { Same as Column } \\
3\end{array}$ & $\begin{array}{l}\text { Same as Column } \\
3\end{array}$ & $\begin{array}{l}\text { Same as Column } \\
3\end{array}$ & $\begin{array}{l}\text { Same as Column } \\
3\end{array}$ & $\begin{array}{l}\text { Not a WSI/NV } \\
\text { activity. WSI/NV } \\
\text { does not control } \\
\text { radiological } \\
\text { areas but will } \\
\text { comply with the } \\
\text { requirements } \\
\text { established by } \\
\text { the RSPC. }\end{array}$ \\
\hline
\end{tabular}




\section{NEVADA TEST SITE RADIATION PROTECTION PROGRAM}

\section{APPENDIX H}

COMPLIANCE DEMONSTRATION TABLE

\begin{tabular}{|c|c|c|c||c||c||c||c||c|}
\hline \multirow{2}{*}{ 10 CFR 835 } & $\begin{array}{c}\text { NV/YMP RCM } \\
\text { Rev 5 and } \\
\text { NTS RPP } \\
\text { Revision 0 }\end{array}$ & Appendix A & Appendix B & Appendix C & Appendix D & SNJV \\
\cline { 2 - 7 } & $\begin{array}{c}\text { Implementation } \\
\text { Reference }\end{array}$ & $\begin{array}{c}\text { Implementation } \\
\text { Reference }\end{array}$ & $\begin{array}{c}\text { Implementation } \\
\text { Reference }\end{array}$ & $\begin{array}{c}\text { Implementation } \\
\text { Reference }\end{array}$ & $\begin{array}{c}\text { Implementation } \\
\text { Reference }\end{array}$ & $\begin{array}{c}\text { Implementation } \\
\text { Reference }\end{array}$ & $\begin{array}{c}\text { Implementation } \\
\text { Reference }\end{array}$ & $\begin{array}{c}\text { Implementation } \\
\text { Reference }\end{array}$ \\
\hline
\end{tabular}

\begin{tabular}{|c|c|c|c|c|c|c|c|c|}
\hline $\begin{array}{l}\text { when placed under } \\
\text { continuous } \\
\text { observation and } \\
\text { control of an individual } \\
\text { knowledgeable of, and } \\
\text { empowered to } \\
\text { implement, required } \\
\text { access and exposure } \\
\text { control measures. }\end{array}$ & $\begin{array}{l}\text { for periods of } \\
\text { less than } 8 \\
\text { continuous hours } \\
\text { when placed } \\
\text { under continuous } \\
\text { observation and } \\
\text { control of an } \\
\text { individual } \\
\text { knowledgeable } \\
\text { of, and } \\
\text { empowered to } \\
\text { implement, } \\
\text { required access- } \\
\text { and exposure - } \\
\text { control } \\
\text { measures. }\end{array}$ & $\begin{array}{l}\text { for periods of } \\
\text { less than } 8 \\
\text { continuous hours } \\
\text { when placed } \\
\text { under continuous } \\
\text { observation and } \\
\text { control of an } \\
\text { individual } \\
\text { knowledgeable } \\
\text { of, and } \\
\text { empowered to } \\
\text { implement, } \\
\text { required access- } \\
\text { and exposure - } \\
\text { control } \\
\text { measures. }\end{array}$ & & & & & & \\
\hline $\begin{array}{l}604(\mathrm{~b}) \text { Areas may be } \\
\text { excepted from the } \\
\text { radioactive material } \\
\text { area posting } \\
\text { requirements of } \\
\S 835.603(\mathrm{~g}) \text { when: } \\
\text { (1) Posted in } \\
\text { accordance with } \\
\S 835.603(\mathrm{a}) \text { through } \\
\text { (f); or } \\
\text { (2) Each item or } \\
\text { container of } \\
\text { radioactive material is } \\
\text { labeled in accordance } \\
\text { with this subpart such } \\
\text { that individuals } \\
\text { entering the area are }\end{array}$ & $\begin{array}{l}\text { NV/YMP RCM } \\
231.11 . b \text {. } \\
\text { Exceptions to } \\
\text { posting } \\
\text { requirements: } \\
\text { b. Areas may be } \\
\text { excepted from } \\
\text { the RMA posting } \\
\text { requirements of } \\
10 \text { CFR } \\
835.603(g) \\
\text { when: } \\
\text { (1) Posted } \\
\text { according to } \\
10 \text { CFR } \\
835.603(a) \\
\text { through (f); or }\end{array}$ & $\begin{array}{l}\text { NV/YMP RCM } \\
\text { 231.11.b. } \\
\text { Exceptions to } \\
\text { posting } \\
\text { requirements: } \\
\text { b. Areas may be } \\
\text { excepted from } \\
\text { the RMA posting } \\
\text { requirements of } \\
10 \text { CFR } \\
835.603(g) \\
\text { when: } \\
\text { (1) Posted } \\
\text { according to } \\
10 \text { CFR } \\
835.603(a) \\
\text { through (f); or }\end{array}$ & $\begin{array}{l}\text { Same as Column } \\
3\end{array}$ & $\begin{array}{l}\text { Same as Column } \\
3\end{array}$ & $\begin{array}{l}\text { Same as Column } \\
3\end{array}$ & $\begin{array}{l}\text { Same as Column } \\
3\end{array}$ & $\begin{array}{l}\text { Same as Column } \\
3\end{array}$ & $\begin{array}{l}\text { Not a WSI/NV } \\
\text { activity. WSI/NV } \\
\text { does not control } \\
\text { radioactive } \\
\text { material areas. }\end{array}$ \\
\hline
\end{tabular}




\section{NEVADA TEST SITE RADIATION PROTECTION PROGRAM}

\section{APPENDIX H}

COMPLIANCE DEMONSTRATION TABLE

\begin{tabular}{|c|c|c|c|c|c|c|c|c|}
\hline \multirow[t]{2}{*}{10 CFR 835} & $\begin{array}{c}\text { NV/YMP RCM } \\
\text { Rev } 5 \text { and } \\
\text { NTS RPP } \\
\text { Revision } 0 \\
\end{array}$ & $\begin{array}{c}\text { NSTec } \\
\text { Appendix A }\end{array}$ & $\begin{array}{c}\text { LLNL } \\
\text { Appendix B }\end{array}$ & $\begin{array}{c}\text { LANL } \\
\text { Appendix C }\end{array}$ & $\begin{array}{c}\text { SNL } \\
\text { Appendix D }\end{array}$ & $\begin{array}{c}\text { SNJV } \\
\text { Appendix E }\end{array}$ & $\begin{array}{c}\text { DRI } \\
\text { Appendix F }\end{array}$ & $\begin{array}{c}\text { WSI } \\
\text { Appendix G }\end{array}$ \\
\hline & $\begin{array}{l}\text { Implementation } \\
\text { Reference }\end{array}$ & $\begin{array}{l}\text { Implementation } \\
\text { Reference }\end{array}$ & $\begin{array}{l}\text { Implementation } \\
\text { Reference }\end{array}$ & $\begin{array}{l}\text { Implementation } \\
\text { Reference }\end{array}$ & $\begin{array}{l}\text { Implementation } \\
\text { Reference }\end{array}$ & $\begin{array}{l}\text { Implementation } \\
\text { Reference }\end{array}$ & $\begin{array}{l}\text { Implementation } \\
\text { Reference }\end{array}$ & $\begin{array}{l}\text { Implementation } \\
\text { Reference }\end{array}$ \\
\hline
\end{tabular}

\begin{tabular}{|c|c|c|c|c|c|c|c|c|}
\hline $\begin{array}{l}\text { made aware of the } \\
\text { hazard; or } \\
\text { (3) The radioactive } \\
\text { material of concern } \\
\text { consists solely of } \\
\text { structures or installed } \\
\text { components which } \\
\text { have been activated } \\
\text { (i.e., such as by being } \\
\text { exposed to neutron } \\
\text { radiation or particles } \\
\text { produced in an } \\
\text { accelerator). }\end{array}$ & $\begin{array}{l}\text { (2) Each item or } \\
\text { container of } \\
\text { radioactive } \\
\text { material is } \\
\text { labeled } \\
\text { according to } 10 \\
\text { CFR } 835.605 \\
\text { such that } \\
\text { individuals } \\
\text { entering the area } \\
\text { are made aware } \\
\text { of the hazard; or } \\
\text { (3) The } \\
\text { radioactive } \\
\text { material of } \\
\text { concern consists } \\
\text { solely of } \\
\text { structures or } \\
\text { installed } \\
\text { components that } \\
\text { have been } \\
\text { activated (i.e., } \\
\text { such as being } \\
\text { exposed to } \\
\text { neutron radiation } \\
\text { or particles } \\
\text { produced in an } \\
\text { accelerator). }\end{array}$ & $\begin{array}{l}\text { (2) Each item or } \\
\text { container of } \\
\text { radioactive } \\
\text { material is } \\
\text { labeled } \\
\text { according to } 10 \\
\text { CFR } 835.605 \\
\text { such that } \\
\text { individuals } \\
\text { entering the area } \\
\text { are made aware } \\
\text { of the hazard; or } \\
\text { (3) The } \\
\text { radioactive } \\
\text { material of } \\
\text { concern consists } \\
\text { solely of } \\
\text { structures or } \\
\text { installed } \\
\text { components that } \\
\text { have been } \\
\text { activated (i.e., } \\
\text { such as being } \\
\text { exposed to } \\
\text { neutron radiation } \\
\text { or particles } \\
\text { produced in an } \\
\text { accelerator). }\end{array}$ & & & & & & \\
\hline $\begin{array}{l}604(c) \text { Areas } \\
\text { containing only } \\
\text { packages received } \\
\text { from radioactive } \\
\text { material transportation }\end{array}$ & $\begin{array}{l}\text { NV/YMP RCM } \\
\text { 231.11.c. } \\
\text { Exceptions to } \\
\text { posting } \\
\text { requirements: }\end{array}$ & $\begin{array}{l}\text { NV/YMP RCM } \\
\text { 231.11.c. } \\
\text { Exceptions to } \\
\text { posting } \\
\text { requirements: }\end{array}$ & $\begin{array}{l}\text { Same as Column } \\
3\end{array}$ & $\begin{array}{l}\text { Same as Column } \\
3\end{array}$ & $\begin{array}{l}\text { Same as Column } \\
3\end{array}$ & $\begin{array}{l}\text { Same as Column } \\
3\end{array}$ & $\begin{array}{l}\text { Same as Column } \\
3\end{array}$ & $\begin{array}{l}\text { Not a WSI/NV } \\
\text { activity. WSI/NV } \\
\text { does not control } \\
\text { radiological } \\
\text { areas. }\end{array}$ \\
\hline
\end{tabular}




\section{NEVADA TEST SITE RADIATION PROTECTION PROGRAM}

\section{APPENDIX H}

COMPLIANCE DEMONSTRATION TABLE

\begin{tabular}{|c|c|c|c||c||c||c||c||c|}
\hline \multirow{2}{*}{ 10 CFR 835 } & $\begin{array}{c}\text { NV/YMP RCM } \\
\text { Rev 5 and } \\
\text { NTS RPP } \\
\text { Revision 0 }\end{array}$ & Appendix A & Appendix B & Appendix C & Appendix D & SNJV \\
\cline { 2 - 7 } & $\begin{array}{c}\text { Implementation } \\
\text { Reference }\end{array}$ & $\begin{array}{c}\text { Implementation } \\
\text { Reference }\end{array}$ & $\begin{array}{c}\text { Implementation } \\
\text { Reference }\end{array}$ & $\begin{array}{c}\text { Implementation } \\
\text { Reference }\end{array}$ & $\begin{array}{c}\text { Implementation } \\
\text { Reference }\end{array}$ & $\begin{array}{c}\text { Implementation } \\
\text { Reference }\end{array}$ & $\begin{array}{c}\text { Implementation } \\
\text { Reference }\end{array}$ & $\begin{array}{c}\text { Implementation } \\
\text { Reference }\end{array}$ \\
\hline
\end{tabular}

\begin{tabular}{|c|c|c|c|c|c|c|c|c|}
\hline 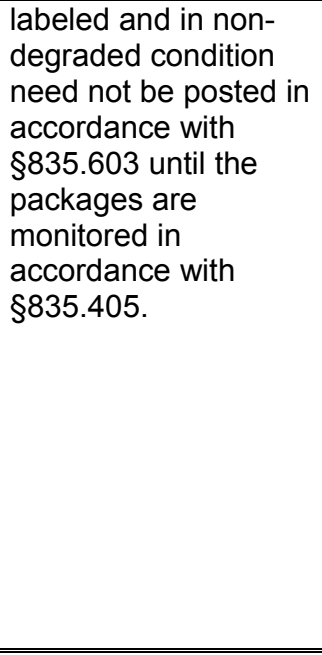 & $\begin{array}{l}\text { c. Areas } \\
\text { containing only } \\
\text { packages } \\
\text { received from } \\
\text { radioactive } \\
\text { material } \\
\text { transportation } \\
\text { labeled and in } \\
\text { non-degraded } \\
\text { condition need } \\
\text { not be posted } \\
\text { according to } \\
10 \text { CFR } 835.603 \\
\text { until the } \\
\text { packages are } \\
\text { monitored } \\
\text { according to } \\
10 \text { CFR } 835.405 .\end{array}$ & $\begin{array}{l}\text { c. Areas } \\
\text { containing only } \\
\text { packages } \\
\text { received from } \\
\text { radioactive } \\
\text { material } \\
\text { transportation } \\
\text { labeled and in } \\
\text { non-degraded } \\
\text { condition need } \\
\text { not be posted } \\
\text { according to } \\
10 \text { CFR } 835.603 \\
\text { until the } \\
\text { packages are } \\
\text { monitored } \\
\text { according to } \\
10 \text { CFR } 835.405 .\end{array}$ & & & & & & \\
\hline $\begin{array}{l}835.605 \text { Labeling } \\
\text { Items and } \\
\text { Containers. } \\
\text { Except as provided at } \\
\text { §835.606, each item } \\
\text { or container of } \\
\text { radioactive material } \\
\text { shall bear a durable, } \\
\text { clearly visible label } \\
\text { bearing the standard } \\
\text { radiation warning } \\
\text { trefoil and the words } \\
\text { "Caution, Radioactive } \\
\text { Material" or "Danger, } \\
\text { Radioactive Material." }\end{array}$ & $\begin{array}{l}\text { NV/YMP RCM } \\
412.1 \text {. Except as } \\
\text { provided in } \\
\text { Article } 412.2, \\
\text { each item or } \\
\text { container of } \\
\text { radioactive } \\
\text { material shall } \\
\text { bear a durable, } \\
\text { clearly visible } \\
\text { label bearing the } \\
\text { standard } \\
\text { radiation warning } \\
\text { trefoil and the } \\
\text { words "Caution, } \\
\end{array}$ & $\begin{array}{l}\text { NV/YMP RCM } \\
412.1 \text {. Except as } \\
\text { provided in } \\
\text { Article } 412.2, \\
\text { each item or } \\
\text { container of } \\
\text { radioactive } \\
\text { material shall } \\
\text { bear a durable, } \\
\text { clearly visible } \\
\text { label bearing the } \\
\text { standard } \\
\text { radiation warning } \\
\text { trefoil and the } \\
\text { words "Caution, } \\
\end{array}$ & $\begin{array}{l}\text { Same as Column } \\
3\end{array}$ & $\begin{array}{l}\text { Same as Column } \\
3\end{array}$ & $\begin{array}{l}\text { Same as Column } \\
3\end{array}$ & $\begin{array}{l}\text { Same as Column } \\
3\end{array}$ & $\begin{array}{l}\text { Same as Column } \\
3\end{array}$ & $\begin{array}{l}\text { Not applicable to } \\
\text { WSI/NV. The } \\
\text { RSPC or TO who } \\
\text { has radiological } \\
\text { control } \\
\text { responsibility for } \\
\text { an item or } \\
\text { container of } \\
\text { radiological } \\
\text { material is } \\
\text { responsible for } \\
\text { ensuring that the } \\
\text { requirements of } \\
\text { this section are } \\
\text { met. WSI/NV } \\
\end{array}$ \\
\hline
\end{tabular}




\section{NEVADA TEST SITE RADIATION PROTECTION PROGRAM}

\section{APPENDIX H}

COMPLIANCE DEMONSTRATION TABLE

\begin{tabular}{|c|c|c|c|c|c|c|c|c|}
\hline \multirow[t]{2}{*}{10 CFR 835} & $\begin{array}{l}\text { NV/YMP RCM } \\
\text { Rev } 5 \text { and } \\
\text { NTS RPP } \\
\text { Revision } 0 \\
\end{array}$ & $\begin{array}{c}\text { NSTec } \\
\text { Appendix A }\end{array}$ & $\begin{array}{c}\text { LLNL } \\
\text { Appendix B }\end{array}$ & $\begin{array}{c}\text { LANL } \\
\text { Appendix C }\end{array}$ & $\begin{array}{c}\text { SNL } \\
\text { Appendix D }\end{array}$ & $\begin{array}{c}\text { SNJV } \\
\text { Appendix E }\end{array}$ & $\begin{array}{c}\text { DRI } \\
\text { Appendix F }\end{array}$ & $\begin{array}{c}\text { WSI } \\
\text { Appendix G }\end{array}$ \\
\hline & $\begin{array}{l}\text { Implementation } \\
\text { Reference }\end{array}$ & $\begin{array}{l}\text { Implementation } \\
\text { Reference }\end{array}$ & $\begin{array}{l}\text { Implementation } \\
\text { Reference }\end{array}$ & $\begin{array}{l}\text { Implementation } \\
\text { Reference }\end{array}$ & $\begin{array}{l}\text { Implementation } \\
\text { Reference }\end{array}$ & $\begin{array}{l}\text { Implementation } \\
\text { Reference }\end{array}$ & $\begin{array}{l}\text { Implementation } \\
\text { Reference }\end{array}$ & $\begin{array}{l}\text { Implementation } \\
\text { Reference }\end{array}$ \\
\hline
\end{tabular}

\begin{tabular}{|c|c|c|c|c|c|c|c|c|}
\hline $\begin{array}{l}\text { The label shall also } \\
\text { provide sufficient } \\
\text { information to permit } \\
\text { individuals handling, } \\
\text { using, or working in } \\
\text { the vicinity of the items } \\
\text { or containers, to take } \\
\text { precautions to avoid or } \\
\text { control exposures. }\end{array}$ & $\begin{array}{l}\text { Radioactive } \\
\text { Material" or } \\
\text { Danger, } \\
\text { Radioactive } \\
\text { Material." The } \\
\text { label shall also } \\
\text { provide sufficient } \\
\text { information to } \\
\text { permit individuals } \\
\text { handling, using, } \\
\text { or working in the } \\
\text { vicinity of the } \\
\text { items or } \\
\text { containers to } \\
\text { take precautions } \\
\text { to avoid or } \\
\text { control } \\
\text { exposures. }\end{array}$ & $\begin{array}{l}\text { Radioactive } \\
\text { Material" or } \\
\text { Danger, } \\
\text { Radioactive } \\
\text { Material." The } \\
\text { label shall also } \\
\text { provide sufficient } \\
\text { information to } \\
\text { permit individuals } \\
\text { handling, using, } \\
\text { or working in the } \\
\text { vicinity of the } \\
\text { items or } \\
\text { containers to } \\
\text { take precautions } \\
\text { to avoid or } \\
\text { control } \\
\text { exposures. }\end{array}$ & & & & & & $\begin{array}{l}\text { personnel will } \\
\text { comply with all } \\
\text { requirements } \\
\text { established. }\end{array}$ \\
\hline $\begin{array}{l}835.606 \text { Exceptions } \\
\text { to Labeling } \\
\text { Requirements. } \\
606(a) \text { Items and } \\
\text { containers may be } \\
\text { excepted from the } \\
\text { radioactive material } \\
\text { labeling requirements } \\
\text { of } \S 835.605 \text { when: (1) } \\
\text { Used, handled, or } \\
\text { stored in areas posted } \\
\text { and controlled in } \\
\text { accordance with this } \\
\text { subpart and sufficient }\end{array}$ & $\begin{array}{l}\text { NV/YMP RCM } \\
411.2 \text {. Except } \\
\text { for accountable } \\
\text { sealed } \\
\text { radioactive } \\
\text { sources, } \\
\text { according to } \\
\text { Appendix 4A, } \\
\text { radioactive } \\
\text { material located } \\
\text { within Controlled } \\
\text { Areas, RMAs, or } \\
\text { radiological } \\
\text { areas does not } \\
\text { require specific }\end{array}$ & $\begin{array}{l}\text { NV/YMP RCM } \\
411.2 \text {. Except } \\
\text { for accountable } \\
\text { sealed } \\
\text { radioactive } \\
\text { sources, } \\
\text { according to } \\
\text { Appendix 4A, } \\
\text { radioactive } \\
\text { material located } \\
\text { within Controlled } \\
\text { Areas, RMAs, or } \\
\text { radiological } \\
\text { areas does not } \\
\text { require specific }\end{array}$ & $\begin{array}{l}\text { Same as Column } \\
3\end{array}$ & $\begin{array}{l}\text { Same as Column } \\
3\end{array}$ & $\begin{array}{l}\text { Same as Column } \\
3\end{array}$ & $\begin{array}{l}\text { Same as Column } \\
3\end{array}$ & $\begin{array}{l}\text { Same as Column } \\
3\end{array}$ & $\begin{array}{l}\text { Not applicable to } \\
\text { WSI/NV. The } \\
\text { RSPC or TO who } \\
\text { has radiological } \\
\text { control } \\
\text { responsibility for } \\
\text { an item or } \\
\text { container of } \\
\text { radiological } \\
\text { material is } \\
\text { responsible for } \\
\text { ensuring that the } \\
\text { requirements of } \\
\text { this section are } \\
\text { met. WSI/NV }\end{array}$ \\
\hline
\end{tabular}




\section{NEVADA TEST SITE RADIATION PROTECTION PROGRAM}

\section{APPENDIX H}

COMPLIANCE DEMONSTRATION TABLE

\begin{tabular}{|c|c|c|c|c|c|c|c|c|}
\hline \multirow[t]{2}{*}{10 CFR 835} & $\begin{array}{l}\text { NV/YMP RCM } \\
\text { Rev } 5 \text { and } \\
\text { NTS RPP } \\
\text { Revision } 0 \\
\end{array}$ & $\begin{array}{c}\text { NSTec } \\
\text { Appendix A }\end{array}$ & $\begin{array}{c}\text { LLNL } \\
\text { Appendix B }\end{array}$ & $\begin{array}{c}\text { LANL } \\
\text { Appendix C }\end{array}$ & $\begin{array}{c}\text { SNL } \\
\text { Appendix D }\end{array}$ & $\begin{array}{c}\text { SNJV } \\
\text { Appendix E }\end{array}$ & $\begin{array}{c}\text { DRI } \\
\text { Appendix F }\end{array}$ & $\begin{array}{c}\text { WSI } \\
\text { Appendix G }\end{array}$ \\
\hline & $\begin{array}{l}\text { Implementation } \\
\text { Reference }\end{array}$ & $\begin{array}{l}\text { Implementation } \\
\text { Reference }\end{array}$ & $\begin{array}{l}\text { Implementation } \\
\text { Reference }\end{array}$ & $\begin{array}{l}\text { Implementation } \\
\text { Reference }\end{array}$ & $\begin{array}{l}\text { Implementation } \\
\text { Reference }\end{array}$ & $\begin{array}{l}\text { Implementation } \\
\text { Reference }\end{array}$ & $\begin{array}{l}\text { Implementation } \\
\text { Reference }\end{array}$ & $\begin{array}{l}\text { Implementation } \\
\text { Reference }\end{array}$ \\
\hline
\end{tabular}

\section{information is provided to permit individuals to take precautions to} avoid or control exposures; or

(2) The quantity of radioactive material is less than one tenth of the values specified in appendix $E$ of this part and less than $0.1 \mathrm{Ci}$

(3) Packaged, labeled, and marked in

accordance with the regulations of the Department of

Transportation or DOE Orders governing radioactive material transportation; or

(4) Inaccessible, or accessible only to individuals authorized to handle or use them, or to work in the vicinity; or (5) Installed in manufacturing process, or other equipment, such as reactor components, piping, and tanks; or

\section{labeling or \\ packaging}

NV/YMP RCM

412.2.b., d., f.,

g., and $h$. The

following

subject to

labeling

requirements:

b. Items

packaged,

labeled, and

marked

according to the

regulations of the

U.S. Department

of Transportation

(DOT) or DOE

Orders governing

radioactive

material

transportation.

d. The quantity of

radioactive

material is less

than one tenth of

the values

specified in

Appendix 4A.

f. Inaccessible or

accessible only labeling or

packaging.

Revise: NV/YMP

RCM 412.2.b.,

d., f., g., and $h$.

The following

materials are not

subject to

labeling

requirements:

b. Items

packaged,

labeled, and

marked

according to the

regulations of the

.S. Department

of Transportation

(DOT) or DOE

Orders governing

radioactive

material

transportation.

d. The quantity of

radioactive

material is less

than one tenth of

the values

specified in

Appendix 4A and

less than $0.1 \mathrm{Ci}$.

f. Inaccessible or personnel will

comply with all

requirements

established 


\section{NEVADA TEST SITE RADIATION PROTECTION PROGRAM}

\section{APPENDIX H}

COMPLIANCE DEMONSTRATION TABLE

\begin{tabular}{|c|c|c|c|c|c|c|c|c|}
\hline \multirow[t]{2}{*}{10 CFR 835} & $\begin{array}{c}\text { NV/YMP RCM } \\
\text { Rev } 5 \text { and } \\
\text { NTS RPP } \\
\text { Revision } 0 \\
\end{array}$ & $\begin{array}{c}\text { NSTec } \\
\text { Appendix A }\end{array}$ & $\begin{array}{c}\text { LLNL } \\
\text { Appendix B }\end{array}$ & $\begin{array}{c}\text { LANL } \\
\text { Appendix C }\end{array}$ & $\begin{array}{c}\text { SNL } \\
\text { Appendix D }\end{array}$ & $\begin{array}{c}\text { SNJV } \\
\text { Appendix E }\end{array}$ & $\begin{array}{c}\text { DRI } \\
\text { Appendix F }\end{array}$ & $\begin{array}{c}\text { WSI } \\
\text { Appendix G }\end{array}$ \\
\hline & $\begin{array}{l}\text { Implementation } \\
\text { Reference }\end{array}$ & $\begin{array}{l}\text { Implementation } \\
\text { Reference }\end{array}$ & $\begin{array}{l}\text { Implementation } \\
\text { Reference }\end{array}$ & $\begin{array}{l}\text { Implementation } \\
\text { Reference }\end{array}$ & $\begin{array}{l}\text { Implementation } \\
\text { Reference }\end{array}$ & $\begin{array}{l}\text { Implementation } \\
\text { Reference }\end{array}$ & $\begin{array}{l}\text { Implementation } \\
\text { Reference }\end{array}$ & $\begin{array}{l}\text { Implementation } \\
\text { Reference }\end{array}$ \\
\hline
\end{tabular}

\begin{tabular}{|c|c|c|c|c|c|c|c|c|}
\hline $\begin{array}{l}\text { (6) The radioactive } \\
\text { material consists } \\
\text { solely of nuclear } \\
\text { weapons or their } \\
\text { components. }\end{array}$ & $\begin{array}{l}\text { to individuals } \\
\text { authorized to } \\
\text { handle or use } \\
\text { them or to work } \\
\text { in the vicinity of } \\
\text { the material. } \\
\text { g. Installed in } \\
\text { manufacturing, } \\
\text { processing, or } \\
\text { other equipment, } \\
\text { such as reactor } \\
\text { components, } \\
\text { piping, and } \\
\text { tanks. } \\
\text { h. The } \\
\text { radioactive } \\
\text { material consists } \\
\text { solely of nuclear } \\
\text { weapons or their } \\
\text { components. }\end{array}$ & $\begin{array}{l}\text { accessible only } \\
\text { to individuals } \\
\text { authorized to } \\
\text { handle or use } \\
\text { them or to work } \\
\text { in the vicinity of } \\
\text { the material. } \\
\text { g. Installed in } \\
\text { manufacturing, } \\
\text { processing, or } \\
\text { other equipment, } \\
\text { such as reactor } \\
\text { components, } \\
\text { piping, and } \\
\text { tanks. } \\
\text { h. The } \\
\text { radioactive } \\
\text { material consists } \\
\text { solely of nuclear } \\
\text { weapons or their } \\
\text { components. }\end{array}$ & & & & & & \\
\hline $\begin{array}{l}606(b) \text { Radioactive } \\
\text { material labels applied } \\
\text { to sealed radioactive } \\
\text { sources may be } \\
\text { excepted from the } \\
\text { color specifications of } \\
\S 835.601(a) .\end{array}$ & $\begin{array}{l}\text { NV/YMP RCM } \\
412.3 .03 . \\
\text { Radioactive } \\
\text { material labels } \\
\text { applied to sealed } \\
\text { radioactive } \\
\text { sources may be } \\
\text { excepted from } \\
\text { the color } \\
\text { specifications. }\end{array}$ & $\begin{array}{l}\text { NV/YMP RCM } \\
412.3 .03 . \\
\text { Radioactive } \\
\text { material labels } \\
\text { applied to sealed } \\
\text { radioactive } \\
\text { sources may be } \\
\text { excepted from } \\
\text { the color } \\
\text { specifications. } \\
\end{array}$ & $\begin{array}{l}\text { Same as Column } \\
3\end{array}$ & $\begin{array}{l}\text { Same as Column } \\
3\end{array}$ & $\begin{array}{l}\text { Same as Column } \\
3\end{array}$ & $\begin{array}{l}\text { Same as Column } \\
3\end{array}$ & $\begin{array}{l}\text { Same as Column } \\
3\end{array}$ & $\begin{array}{l}\text { Not applicable to } \\
\text { WSI/NV. } \\
\text { WSI/NV is not a } \\
\text { sealed } \\
\text { radioactive } \\
\text { source } \\
\text { custodian. }\end{array}$ \\
\hline $\begin{array}{l}\text { Subpart H-Records } \\
835.701 \text { General }\end{array}$ & $\begin{array}{l}\text { NV/YMP RCM } \\
711.01 .\end{array}$ & $\begin{array}{l}\text { NV/YMP RCM } \\
711.01 .\end{array}$ & $\begin{array}{l}\text { Same as Column } \\
3\end{array}$ & $\begin{array}{l}\text { Same as Column } \\
3\end{array}$ & $\begin{array}{l}\text { All records } \\
\text { pertaining to SNL }\end{array}$ & $\begin{array}{l}\text { Same as column } \\
3 \text { and Records }\end{array}$ & $\begin{array}{l}\text { Radiological } \\
\text { records for DRI }\end{array}$ & $\begin{array}{l}\text { Records } \\
\text { generated by }\end{array}$ \\
\hline
\end{tabular}




\section{NEVADA TEST SITE RADIATION PROTECTION PROGRAM}

\section{APPENDIX H}

COMPLIANCE DEMONSTRATION TABLE

\begin{tabular}{|c|c|c|c|c|c|c|c|c|}
\hline \multirow[t]{2}{*}{10 CFR 835} & $\begin{array}{c}\text { NV/YMP RCM } \\
\text { Rev } 5 \text { and } \\
\text { NTS RPP } \\
\text { Revision } 0 \\
\end{array}$ & $\begin{array}{c}\text { NSTec } \\
\text { Appendix A }\end{array}$ & $\begin{array}{c}\text { LLNL } \\
\text { Appendix B }\end{array}$ & $\begin{array}{c}\text { LANL } \\
\text { Appendix C }\end{array}$ & $\begin{array}{c}\text { SNL } \\
\text { Appendix D }\end{array}$ & $\begin{array}{c}\text { SNJV } \\
\text { Appendix E }\end{array}$ & $\begin{array}{c}\text { DRI } \\
\text { Appendix F }\end{array}$ & $\begin{array}{c}\text { WSI } \\
\text { Appendix G }\end{array}$ \\
\hline & $\begin{array}{l}\text { Implementation } \\
\text { Reference }\end{array}$ & $\begin{array}{l}\text { Implementation } \\
\text { Reference }\end{array}$ & $\begin{array}{l}\text { Implementation } \\
\text { Reference }\end{array}$ & $\begin{array}{l}\text { Implementation } \\
\text { Reference }\end{array}$ & $\begin{array}{l}\text { Implementation } \\
\text { Reference }\end{array}$ & $\begin{array}{l}\text { Implementation } \\
\text { Reference }\end{array}$ & $\begin{array}{l}\text { Implementation } \\
\text { Reference }\end{array}$ & $\begin{array}{l}\text { Implementation } \\
\text { Reference }\end{array}$ \\
\hline
\end{tabular}

\begin{tabular}{|c|c|c|c|c|c|c|c|c|}
\hline $\begin{array}{l}\text { Provisions } \\
701(a) \text { Records shall } \\
\text { be maintained to } \\
\text { document compliance } \\
\text { with this part and with } \\
\text { radiation protection } \\
\text { programs required by } \\
\S 835.101 \text {. }\end{array}$ & $\begin{array}{l}\text { Radiological } \\
\text { control records } \\
\text { shall be } \\
\text { maintained as } \\
\text { necessary to } \\
\text { document } \\
\text { compliance with } \\
\text { the requirements } \\
\text { of } 10 \text { CFR } 835 \text {. } \\
\text { NV/YMP RCM } \\
712.1 .01 . \\
\text { A radiological } \\
\text { records } \\
\text { management } \\
\text { program shall be } \\
\text { established by } \\
\text { each NNSA/NSO } \\
\text { and YMORD TO. }\end{array}$ & $\begin{array}{l}\text { Radiological } \\
\text { control records } \\
\text { shall be } \\
\text { maintained as } \\
\text { necessary to } \\
\text { document } \\
\text { compliance with } \\
\text { the requirements } \\
\text { of } 10 \text { CFR } 835 \text {. } \\
\text { Revise: NV/YMP } \\
\text { RCM 712.1.01. } \\
\text { A radiological } \\
\text { records } \\
\text { management } \\
\text { program shall be } \\
\text { established by } \\
\text { each NNSA/NSO } \\
\text { and OCRWM } \\
\text { TO. }\end{array}$ & & & $\begin{array}{l}\text { activities at NTS } \\
\text { are maintained } \\
\text { and archived by } \\
\text { the RSPC. }\end{array}$ & $\begin{array}{l}\text { generated by the } \\
\text { RSPC for } \\
\text { services } \\
\text { provided to } \\
\text { SNJV are } \\
\text { maintained by } \\
\text { the RSPC. }\end{array}$ & $\begin{array}{l}\text { generated by the } \\
\text { RSPC are } \\
\text { maintained by } \\
\text { the RSPC. Any } \\
\text { copies of } \\
\text { radiological } \\
\text { records received } \\
\text { by DRI from the } \\
\text { RSPC are kept } \\
\text { on file in the DRI } \\
\text { EH\&S Office for } \\
\text { a minimum of } \\
\text { three years, after } \\
\text { which medical } \\
\text { and exposure } \\
\text { records are sent } \\
\text { for long- term } \\
\text { storage to the } \\
\text { Business Center } \\
\text { North Risk } \\
\text { Management per } \\
\text { Nevada Systems } \\
\text { of Higher } \\
\text { Education policy. }\end{array}$ & $\begin{array}{l}\text { WSI/NV will be } \\
\text { maintained by } \\
\text { WSI/NV. By } \\
\text { written } \\
\text { agreement, } \\
\text { records } \\
\text { generated by the } \\
\text { RSPC will be } \\
\text { maintained by } \\
\text { the RSPC. }\end{array}$ \\
\hline $\begin{array}{l}701(b) \text { Unless } \\
\text { otherwise specified in } \\
\text { this subpart, records } \\
\text { shall be retained until } \\
\text { final disposition is } \\
\text { authorized by DOE. }\end{array}$ & $\begin{array}{l}\text { NV/YMP RCM } \\
711.04 \text {. Unless } \\
\text { otherwise } \\
\text { specified in this } \\
\text { section, records } \\
\text { shall be retained } \\
\text { until final } \\
\text { disposition is } \\
\text { authorized by }\end{array}$ & $\begin{array}{l}\text { Revise: NV/YMP } \\
\text { RCM } 711.04 \text {. } \\
\text { Unless otherwise } \\
\text { specified in this } \\
\text { section, records } \\
\text { shall be retained } \\
\text { until final } \\
\text { disposition is } \\
\text { authorized by }\end{array}$ & $\begin{array}{l}\text { Same as Column } \\
3\end{array}$ & $\begin{array}{l}\text { Same as Column } \\
3\end{array}$ & $\begin{array}{l}\text { All records } \\
\text { pertaining to SNL } \\
\text { activities at NTS } \\
\text { are maintained } \\
\text { and archived by } \\
\text { the RSPC. }\end{array}$ & $\begin{array}{l}\text { Same as Column } \\
3 \text { and Records } \\
\text { generated by the } \\
\text { RSPC for } \\
\text { services } \\
\text { provided to } \\
\text { SNJV are } \\
\text { maintained by } \\
\text { the RSPC. }\end{array}$ & $\begin{array}{l}\text { Radiological } \\
\text { records } \\
\text { generated by the } \\
\text { RSPC for DRI } \\
\text { are maintained } \\
\text { and archived by } \\
\text { the RSPC. }\end{array}$ & $\begin{array}{l}\text { By written } \\
\text { agreement, } \\
\text { records } \\
\text { generated by the } \\
\text { RSPC will be } \\
\text { maintained by } \\
\text { the RSPC. }\end{array}$ \\
\hline
\end{tabular}




\section{NEVADA TEST SITE RADIATION PROTECTION PROGRAM}

\section{APPENDIX H}

COMPLIANCE DEMONSTRATION TABLE

\begin{tabular}{|c|c|c|c|c|c|c|c|c|}
\hline \multirow[t]{2}{*}{10 CFR 835} & $\begin{array}{c}\text { NV/YMP RCM } \\
\text { Rev } 5 \text { and } \\
\text { NTS RPP } \\
\text { Revision } 0 \\
\end{array}$ & $\begin{array}{c}\text { NSTec } \\
\text { Appendix A }\end{array}$ & $\begin{array}{c}\text { LLNL } \\
\text { Appendix B }\end{array}$ & $\begin{array}{c}\text { LANL } \\
\text { Appendix C }\end{array}$ & $\begin{array}{c}\text { SNL } \\
\text { Appendix D }\end{array}$ & $\begin{array}{c}\text { SNJV } \\
\text { Appendix E }\end{array}$ & $\begin{array}{c}\text { DRI } \\
\text { Appendix F }\end{array}$ & $\begin{array}{c}\text { WSI } \\
\text { Appendix G }\end{array}$ \\
\hline & $\begin{array}{l}\text { Implementation } \\
\text { Reference }\end{array}$ & $\begin{array}{l}\text { Implementation } \\
\text { Reference }\end{array}$ & $\begin{array}{l}\text { Implementation } \\
\text { Reference }\end{array}$ & $\begin{array}{l}\text { Implementation } \\
\text { Reference }\end{array}$ & $\begin{array}{l}\text { Implementation } \\
\text { Reference }\end{array}$ & $\begin{array}{l}\text { Implementation } \\
\text { Reference }\end{array}$ & $\begin{array}{l}\text { Implementation } \\
\text { Reference }\end{array}$ & $\begin{array}{l}\text { Implementation } \\
\text { Reference }\end{array}$ \\
\hline
\end{tabular}

\begin{tabular}{|c|c|c|c|c|c|c|c|c|}
\hline & $\begin{array}{l}\text { NNSA/NSO or } \\
\text { YMORD TO. }\end{array}$ & $\begin{array}{l}\text { NNSA/NSO or } \\
\text { OCRWM TO. }\end{array}$ & & & & & & \\
\hline $\begin{array}{l}835.702 \text { Individual } \\
\text { Monitoring Records } \\
\text { 702(a) Except as } \\
\text { authorized by } \S \\
835.702(\text { b), records } \\
\text { shall be maintained to } \\
\text { document doses } \\
\text { received by all } \\
\text { individuals for whom } \\
\text { monitoring was } \\
\text { conducted and to } \\
\text { document doses } \\
\text { received during } \\
\text { planned special } \\
\text { exposures, unplanned } \\
\text { doses exceeding the } \\
\text { monitoring thresholds } \\
\text { of } \S 835.402, \text { and } \\
\text { authorized emergency } \\
\text { exposures. }\end{array}$ & $\begin{array}{l}\text { NV/YMP RCM } \\
722.1 .01 . \\
\text { Records of } \\
\text { doses received } \\
\text { by all individuals } \\
\text { for whom } \\
\text { individual } \\
\text { monitoring was } \\
\text { performed shall } \\
\text { be recorded in } \\
\text { the individual's } \\
\text { occupational } \\
\text { dose record and } \\
\text { shall be } \\
\text { maintained by } \\
\text { the RSPC. }\end{array}$ & $\begin{array}{l}\text { Revise: NV/YMP } \\
\text { RCM } 722.1 .01 . \\
\text { Except as } \\
\text { specified in } \\
722.10 \text { and } \\
722.11 \text {, records } \\
\text { of doses } \\
\text { received by all } \\
\text { individuals for } \\
\text { whom individual } \\
\text { monitoring was } \\
\text { conducted shall } \\
\text { be recorded in } \\
\text { the individual's } \\
\text { occupational } \\
\text { dose record and } \\
\text { shall be } \\
\text { maintained by } \\
\text { the RSPC. }\end{array}$ & $\begin{array}{l}\text { By written } \\
\text { agreement, the } \\
\text { LLNL Hazard } \\
\text { Control } \\
\text { Personnel } \\
\text { Dosimetry Team } \\
\text { records and } \\
\text { maintains LLNL } \\
\text { employee } \\
\text { occupational } \\
\text { dose provided by } \\
\text { the NTS RSPC. }\end{array}$ & $\begin{array}{l}\text { This is outside } \\
\text { the scope of the } \\
\text { LANL/NTS } \\
\text { Radiological } \\
\text { Control Program. } \\
\text { The LANL RP-2 } \\
\text { Radiation } \\
\text { Information } \\
\text { Management } \\
\text { Team records } \\
\text { and maintains } \\
\text { LANL employee } \\
\text { dose } \\
\text { assessments } \\
\text { provided by the } \\
\text { NTS RSPC. }\end{array}$ & $\begin{array}{l}\text { Same as Column } \\
3 \text { and Primary } \\
\text { dose records for } \\
\text { SNL personnel at } \\
\text { NTS are } \\
\text { maintained and } \\
\text { archived by } \\
\text { RSPC. Doses } \\
\text { received are } \\
\text { reported by } \\
\text { RSPC to SNL- } \\
\text { Albuquerque } \\
\text { Dosimetry } \\
\text { Records } \\
\text { Organization. }\end{array}$ & $\begin{array}{l}\text { Same as Column } \\
3 \text { and NV/YMP } \\
\text { RCM 141.3.e. } \\
\text { The RSPC shall } \\
\text { provide the } \\
\text { following: } \\
\text { e. External and } \\
\text { internal } \\
\text { dosimetry } \\
\text { services. } \\
\text { Records } \\
\text { generated by the } \\
\text { RSPC for } \\
\text { services } \\
\text { provided to } \\
\text { SNJV are } \\
\text { maintained by } \\
\text { the RSPC. }\end{array}$ & $\begin{array}{l}\text { Dosimetry } \\
\text { records } \\
\text { generated by } \\
\text { RSPC are } \\
\text { maintained by } \\
\text { the RSPC. } \\
\text { Cross reference } \\
\text { response to } \\
835.101(c) \text { of this } \\
\text { table. }\end{array}$ & $\begin{array}{l}\text { By written } \\
\text { agreement, the } \\
\text { RSPC provides } \\
\text { dosimetry } \\
\text { services to } \\
\text { WSI/NV. } \\
\text { Records } \\
\text { generated by the } \\
\text { RSPC will be } \\
\text { maintained by } \\
\text { the RSPC. }\end{array}$ \\
\hline $\begin{array}{l}702(b) \text { Recording of } \\
\text { the non-uniform } \\
\text { equivalent dose to the } \\
\text { skin is not required if } \\
\text { the dose is less than } 2 \\
\text { percent of the limit } \\
\text { specified for the skin } \\
\text { at } § 835.202(a)(4) \text {. } \\
\text { Recording of internal } \\
\text { dose (committed }\end{array}$ & $\begin{array}{l}\text { NV/YMP RCM } \\
722.1 .01 . \\
\text { Records of } \\
\text { doses received } \\
\text { by all individuals } \\
\text { for whom } \\
\text { individual } \\
\text { monitoring was } \\
\text { performed shall } \\
\text { be recorded in }\end{array}$ & $\begin{array}{l}\text { NV/YMP RCM } \\
722.1 .01 . \\
\text { Records of } \\
\text { doses received } \\
\text { by all individuals } \\
\text { for whom } \\
\text { individual } \\
\text { monitoring was } \\
\text { performed shall } \\
\text { be recorded in }\end{array}$ & $\begin{array}{l}\text { By written } \\
\text { agreement, the } \\
\text { LLNL Hazard } \\
\text { Control } \\
\text { Personnel } \\
\text { Dosimetry Team } \\
\text { records and } \\
\text { maintains LLNL } \\
\text { employee } \\
\text { occupational }\end{array}$ & $\begin{array}{l}\text { This is outside } \\
\text { the scope of the } \\
\text { LANL/NTS } \\
\text { Radiological } \\
\text { Control Program. } \\
\text { The LANL RP-2 } \\
\text { Radiation } \\
\text { Information } \\
\text { Management } \\
\text { Team records }\end{array}$ & $\begin{array}{l}\text { Primary dose } \\
\text { records for SNL } \\
\text { personnel at } \\
\text { NTS maintained } \\
\text { and archived by } \\
\text { RSPC. Doses } \\
\text { received } \\
\text { reported by } \\
\text { RSPC to SNL- } \\
\text { Albuquerque }\end{array}$ & $\begin{array}{l}\text { NV/YMP RCM } \\
\text { 141.3.e. The } \\
\text { RSPC shall } \\
\text { provide the } \\
\text { following: } \\
\text { (e) External and } \\
\text { internal } \\
\text { dosimetry } \\
\text { services. }\end{array}$ & $\begin{array}{l}\text { Dosimetry } \\
\text { records } \\
\text { generated by } \\
\text { RSPC are } \\
\text { maintained by } \\
\text { the RSPC. } \\
\text { Cross reference } \\
\text { response to } \\
835.101(\mathrm{c}) \text { of this } \\
\text { table. }\end{array}$ & $\begin{array}{l}\text { By written } \\
\text { agreement, the } \\
\text { RSPC provides } \\
\text { dosimetry } \\
\text { services to } \\
\text { WSI/NV and } \\
\text { maintains } \\
\text { individual } \\
\text { monitoring } \\
\text { records. }\end{array}$ \\
\hline
\end{tabular}

H-78 


\section{NEVADA TEST SITE RADIATION PROTECTION PROGRAM}

\section{APPENDIX H}

COMPLIANCE DEMONSTRATION TABLE

\begin{tabular}{|c|c|c|c|c|c|c|c|c|}
\hline \multirow[t]{2}{*}{10 CFR 835} & $\begin{array}{l}\text { NV/YMP RCM } \\
\text { Rev } 5 \text { and } \\
\text { NTS RPP } \\
\text { Revision } 0 \\
\end{array}$ & $\begin{array}{c}\text { NSTec } \\
\text { Appendix A }\end{array}$ & $\begin{array}{c}\text { LLNL } \\
\text { Appendix B }\end{array}$ & $\begin{array}{c}\text { LANL } \\
\text { Appendix C }\end{array}$ & $\begin{array}{c}\text { SNL } \\
\text { Appendix D }\end{array}$ & $\begin{array}{c}\text { SNJV } \\
\text { Appendix E }\end{array}$ & $\begin{array}{c}\text { DRI } \\
\text { Appendix F }\end{array}$ & $\begin{array}{c}\text { WSI } \\
\text { Appendix G }\end{array}$ \\
\hline & $\begin{array}{l}\text { Implementation } \\
\text { Reference }\end{array}$ & $\begin{array}{l}\text { Implementation } \\
\text { Reference }\end{array}$ & $\begin{array}{l}\text { Implementation } \\
\text { Reference }\end{array}$ & $\begin{array}{l}\text { Implementation } \\
\text { Reference }\end{array}$ & $\begin{array}{l}\text { Implementation } \\
\text { Reference }\end{array}$ & $\begin{array}{l}\text { Implementation } \\
\text { Reference }\end{array}$ & $\begin{array}{l}\text { Implementation } \\
\text { Reference }\end{array}$ & $\begin{array}{c}\text { Implementation } \\
\text { Reference }\end{array}$ \\
\hline
\end{tabular}

\begin{tabular}{|l|}
\hline effective dose or \\
committed equivalent \\
dose) is not required \\
for any monitoring \\
result estimated to \\
correspond to an \\
individual receiving \\
less than 0.01 rem \\
(0.1 mSv) committed \\
effective dose. The \\
bioassay or air \\
monitoring result used \\
to make the estimate \\
shall be maintained in \\
accordance with $\S$ \\
835.703 (b) and the \\
unrecorded internal \\
dose estimated for any \\
individual in a year \\
shall not exceed the \\
applicable monitoring \\
threshold at $§$ \\
835.402 (c).
\end{tabular}

the individual's

occupational

dose record and

shall be

maintained by

the RSPC.

NV/YMP RCM

722.10.

Recording of the

non-uniform

shallow dose

equivalent to the

skin is not

required if the

dose is less than

2 percent of the

limit specified for

the skin in Table

2-1.

the individual's
occupational
dose record and
shall be
maintained by
the RSPC.
NV/YMP RCM
722.10 .
Recording of the
non-uniform
shallow dose
equivalent to the
skin is not
required if the
dose is less than
2 percent of the
limit specified for
the skin in Table
$2-1$.
Add: NV/YMP
RCM 722.11
Recording of
internal dose
(committed
effective dose or
committed
equivalent dose)
is not required
for any
monitoring result

estimated to

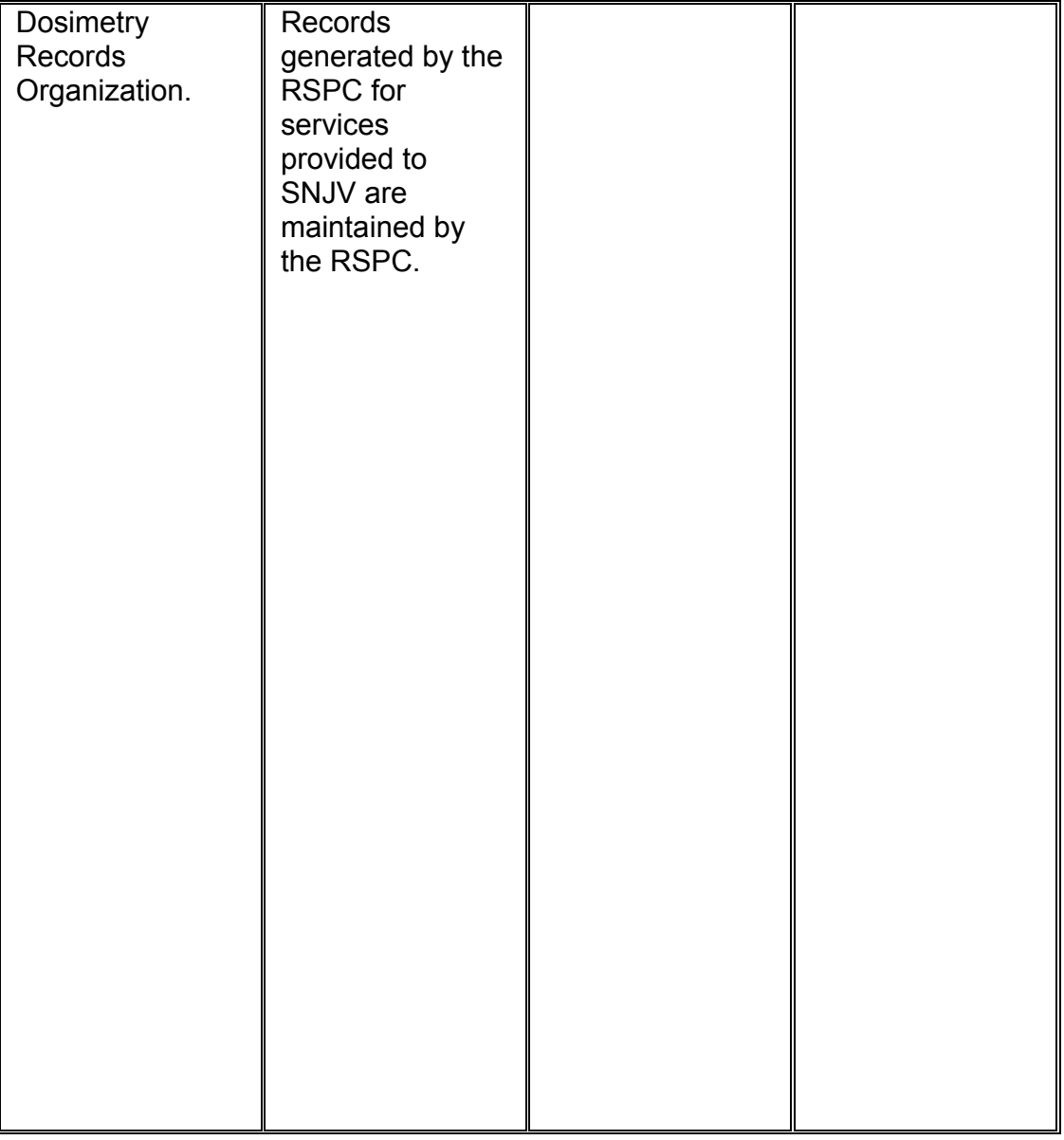




\section{NEVADA TEST SITE RADIATION PROTECTION PROGRAM}

\section{APPENDIX H}

COMPLIANCE DEMONSTRATION TABLE

\begin{tabular}{|c|c|c|c|c|c|c|c|c|}
\hline \multirow[t]{2}{*}{10 CFR 835} & $\begin{array}{c}\text { NV/YMP RCM } \\
\text { Rev } 5 \text { and } \\
\text { NTS RPP } \\
\text { Revision } 0 \\
\end{array}$ & $\begin{array}{c}\text { NSTec } \\
\text { Appendix A }\end{array}$ & $\begin{array}{c}\text { LLNL } \\
\text { Appendix B }\end{array}$ & $\begin{array}{c}\text { LANL } \\
\text { Appendix C }\end{array}$ & $\begin{array}{c}\text { SNL } \\
\text { Appendix D }\end{array}$ & $\begin{array}{c}\text { SNJV } \\
\text { Appendix E }\end{array}$ & $\begin{array}{c}\text { DRI } \\
\text { Appendix F }\end{array}$ & $\begin{array}{c}\text { WSI } \\
\text { Appendix G }\end{array}$ \\
\hline & $\begin{array}{l}\text { Implementation } \\
\text { Reference }\end{array}$ & $\begin{array}{l}\text { Implementation } \\
\text { Reference }\end{array}$ & $\begin{array}{l}\text { Implementation } \\
\text { Reference }\end{array}$ & $\begin{array}{l}\text { Implementation } \\
\text { Reference }\end{array}$ & $\begin{array}{c}\text { Implementation } \\
\text { Reference }\end{array}$ & $\begin{array}{l}\text { Implementation } \\
\text { Reference }\end{array}$ & $\begin{array}{l}\text { Implementation } \\
\text { Reference }\end{array}$ & $\begin{array}{l}\text { Implementation } \\
\text { Reference }\end{array}$ \\
\hline
\end{tabular}

\begin{tabular}{|c|c|c|c|c|c|c|c|c|}
\hline & & $\begin{array}{l}\text { correspond to an } \\
\text { individual } \\
\text { receiving less } \\
\text { than } 0.01 \text { rem } \\
\text { committed } \\
\text { effective dose. } \\
\text { The bioassay or } \\
\text { air monitoring } \\
\text { result used to } \\
\text { make the } \\
\text { estimate shall be } \\
\text { maintained in } \\
\text { accordance with } \\
\S 835.703(\text { b) and } \\
\text { the unrecorded } \\
\text { internal dose } \\
\text { estimated for any } \\
\text { individual in a } \\
\text { year shall not } \\
\text { exceed the } \\
\text { applicable } \\
\text { monitoring } \\
\text { threshold in } \\
\text { Article } 521.1 . \\
\end{array}$ & & & & & & \\
\hline $\begin{array}{l}\text { 702(c) The records } \\
\text { required by this } \\
\text { section shall: } \\
\text { (1) Be sufficient to } \\
\text { evaluate compliance } \\
\text { with subpart C of this } \\
\text { part; } \\
\text { (2) Be sufficient to } \\
\text { provide dose }\end{array}$ & $\begin{array}{l}\text { NV/YMP RCM } \\
712.1 .02 \text {. This } \\
\text { program shall } \\
\text { ensure that } \\
\text { auditable records } \\
\text { and reports are } \\
\text { controlled } \\
\text { through the } \\
\text { stages of } \\
\end{array}$ & $\begin{array}{l}\text { NV/YMP RCM } \\
712.1 .02 \text {. This } \\
\text { program shall } \\
\text { ensure that } \\
\text { auditable records } \\
\text { and reports are } \\
\text { controlled } \\
\text { through the } \\
\text { stages of }\end{array}$ & $\begin{array}{l}\text { By written } \\
\text { agreement, the } \\
\text { LLNL Hazard } \\
\text { Control } \\
\text { Personnel } \\
\text { Dosimetry Team } \\
\text { records and } \\
\text { maintains LLNL } \\
\text { employee } \\
\end{array}$ & $\begin{array}{l}\text { This is outside } \\
\text { the scope of the } \\
\text { LANL/NTS } \\
\text { Radiological } \\
\text { Control Program. } \\
\text { The LANL RP-2 } \\
\text { Radiation } \\
\text { Information } \\
\text { Management }\end{array}$ & $\begin{array}{l}\text { Primary dose } \\
\text { records for SNL } \\
\text { personnel at } \\
\text { NTS maintained } \\
\text { and archived by } \\
\text { RSPC. Doses } \\
\text { received } \\
\text { reported by } \\
\text { RSPC to SNL- } \\
\end{array}$ & $\begin{array}{l}\text { NV/YMP RCM } \\
\text { 141.3.e. The } \\
\text { RSPC shall } \\
\text { provide the } \\
\text { following: } \\
\text { (e) External and } \\
\text { internal } \\
\text { dosimetry } \\
\text { services. }\end{array}$ & $\begin{array}{l}\text { Dosimetry } \\
\text { service is } \\
\text { provided by the } \\
\text { RSPC, which is } \\
\text { responsible for } \\
\text { maintaining a } \\
\text { sufficient staff of } \\
\text { site-trained } \\
\text { radiological }\end{array}$ & $\begin{array}{l}\text { By written } \\
\text { agreement, the } \\
\text { RSPC provides } \\
\text { dosimetry } \\
\text { services to } \\
\text { WSI/NV and } \\
\text { maintains } \\
\text { individual } \\
\text { monitoring }\end{array}$ \\
\hline
\end{tabular}

$\mathrm{H}-80$ 


\section{NEVADA TEST SITE RADIATION PROTECTION PROGRAM}

\section{APPENDIX H}

COMPLIANCE DEMONSTRATION TABLE

\begin{tabular}{|c|c|c|c|c|c|c|c|c|}
\hline \multirow[t]{2}{*}{10 CFR 835} & $\begin{array}{c}\text { NV/YMP RCM } \\
\text { Rev } 5 \text { and } \\
\text { NTS RPP } \\
\text { Revision } 0 \\
\end{array}$ & $\begin{array}{c}\text { NSTec } \\
\text { Appendix A }\end{array}$ & $\begin{array}{c}\text { LLNL } \\
\text { Appendix B }\end{array}$ & $\begin{array}{c}\text { LANL } \\
\text { Appendix C }\end{array}$ & $\begin{array}{c}\text { SNL } \\
\text { Appendix D }\end{array}$ & $\begin{array}{c}\text { SNJV } \\
\text { Appendix E }\end{array}$ & $\begin{array}{c}\text { DRI } \\
\text { Appendix F }\end{array}$ & $\begin{array}{c}\text { WSI } \\
\text { Appendix G }\end{array}$ \\
\hline & $\begin{array}{l}\text { Implementation } \\
\text { Reference }\end{array}$ & $\begin{array}{l}\text { Implementation } \\
\text { Reference }\end{array}$ & $\begin{array}{l}\text { Implementation } \\
\text { Reference }\end{array}$ & $\begin{array}{l}\text { Implementation } \\
\text { Reference }\end{array}$ & $\begin{array}{l}\text { Implementation } \\
\text { Reference }\end{array}$ & $\begin{array}{l}\text { Implementation } \\
\text { Reference }\end{array}$ & $\begin{array}{l}\text { Implementation } \\
\text { Reference }\end{array}$ & $\begin{array}{l}\text { Implementation } \\
\text { Reference }\end{array}$ \\
\hline
\end{tabular}

\section{information necessary} to complete reports required by subpart I of this part;

(3) Include the results of monitoring used to assess the following

quantities for external dose received during the year:

(i) The effective dose from external sources of radiation (equivalent dose to the whole

body may be used as effective dose for external exposure); (ii) The equivalent dose to the lens of the eye;

(iii) The equivalent dose to the skin; and (iv) The equivalent dose to the

extremities.

(4) Include the

following information for internal dose resulting from intakes received during the year:

(i) Committed effective dose;

\section{creation,}

distribution, use,

arrangement,

storage, retrieval, media

conversion (if applicable), and disposition.

NV/YMP RCM

722.1.02. These records shall be sufficient to evaluate

compliance with all applicable dose limits and monitoring and reporting

requirements.

NV/YMP RCM

722.4.a-d. The records shall include the

following

quantities for external dose

received during the year:

a. The effective dose equivalent from external

\section{creation,}

distribution, use,

arrangement,

storage, retrieval, media

conversion (if applicable), and disposition.

\section{NV/YMP RCM}

722.1.02. These records shall be sufficient to evaluate

compliance with all applicable dose limits and monitoring and reporting

requirements.

Revise: NV/YMP RCM 722.4.a-d. The records shall include the following quantities for external dose received during the year:

a. The effective dose from

\begin{tabular}{|c|c|c|c|}
\hline $\begin{array}{l}\text { occupational } \\
\text { dose provided } \\
\text { the NTS RSP }\end{array}$ & $\begin{array}{l}\text { Team records } \\
\text { and maintains } \\
\text { LANL employee } \\
\text { dose } \\
\text { assessments } \\
\text { provided by the } \\
\text { NTS RSPC. }\end{array}$ & $\begin{array}{l}\text { Albuquerque } \\
\text { Dosimetry } \\
\text { Records } \\
\text { Organization. } \\
\text { For internal } \\
\text { doses received } \\
\text { by SNL } \\
\text { personnel at } \\
\text { NTS, only the } \\
\text { assigned doses } \\
\text { are reported to } \\
\text { SNL- } \\
\text { Albuquerque } \\
\text { Dosimetry } \\
\text { Records } \\
\text { Organization. All } \\
\text { records } \\
\text { associated with } \\
\text { whole body } \\
\text { counts, } \\
\text { specimen } \\
\text { analysis results, } \\
\text { etc. maintained } \\
\text { by RSPC. } \\
\text { For SNL } \\
\text { personnel } \\
\text { primary dose } \\
\text { records are } \\
\text { maintained by } \\
\text { Dosimetry } \\
\text { Records } \\
\end{array}$ & $\begin{array}{l}\text { Records } \\
\text { generated by the } \\
\text { RSPC for } \\
\text { services } \\
\text { provided to } \\
\text { SNJV are } \\
\text { maintained by } \\
\text { the RSPC. }\end{array}$ \\
\hline
\end{tabular}

records.

control personnel to accommodate the needs of the TOs (NV/YMP RCM 141.2 and 3).

Primary dose records for DRI personnel on NNSA/NSO projects are maintained and archived by RSPC. Doses received are reported by RSPC to DRI.

Cross reference response to 835.101(c) of this table.
By written agreement, dosimetry records are generated and maintained by the RSPC. 


\section{NEVADA TEST SITE RADIATION PROTECTION PROGRAM}

\section{APPENDIX H}

COMPLIANCE DEMONSTRATION TABLE

\begin{tabular}{|c|c|c|c|c|c|c|c|c|}
\hline \multirow[t]{2}{*}{10 CFR 835} & $\begin{array}{l}\text { NV/YMP RCM } \\
\text { Rev } 5 \text { and } \\
\text { NTS RPP } \\
\text { Revision } 0 \\
\end{array}$ & $\begin{array}{c}\text { NSTec } \\
\text { Appendix A }\end{array}$ & $\begin{array}{c}\text { LLNL } \\
\text { Appendix B }\end{array}$ & $\begin{array}{c}\text { LANL } \\
\text { Appendix C }\end{array}$ & $\begin{array}{c}\text { SNL } \\
\text { Appendix D }\end{array}$ & $\begin{array}{c}\text { SNJV } \\
\text { Appendix E }\end{array}$ & $\begin{array}{c}\text { DRI } \\
\text { Appendix F }\end{array}$ & $\begin{array}{c}\text { WSI } \\
\text { Appendix G }\end{array}$ \\
\hline & $\begin{array}{l}\text { Implementation } \\
\text { Reference }\end{array}$ & $\begin{array}{l}\text { Implementation } \\
\text { Reference }\end{array}$ & $\begin{array}{l}\text { Implementation } \\
\text { Reference }\end{array}$ & $\begin{array}{l}\text { Implementation } \\
\text { Reference }\end{array}$ & $\begin{array}{l}\text { Implementation } \\
\text { Reference }\end{array}$ & $\begin{array}{l}\text { Implementation } \\
\text { Reference }\end{array}$ & $\begin{array}{l}\text { Implementation } \\
\text { Reference }\end{array}$ & $\begin{array}{c}\text { Implementation } \\
\text { Reference }\end{array}$ \\
\hline
\end{tabular}

\begin{tabular}{l}
\hline (ii) Committed \\
equivalent dose to any \\
organ or tissue of
\end{tabular}

organ or tissue of

concern; and

(iii) Identity of

radionuclides.

(5) Include the

following quantities for

the summation of the

external and internal

dose:

(i) Total effective dose

in a year;

(ii) For any organ or

tissue assigned an

internal dose during

the year, the sum of

the equivalent dose to

the whole body from

external exposures

and the committed

equivalent dose to that

organ or tissue; and

(iii) Cumulative total

effective dose.

(6) Include the

equivalent dose to the

embryo/fetus of a

declared pregnant

sources of

radiation (deep

dose equivalent

may be used as

effective dose

equivalent for

external

exposure).

b. The lens of the

eye dose

equivalent.

c. The shallow

dose equivalent

to the skin.

d. The shallow

dose equivalent

to the

extremities.

\section{NV/YMP RCM}

722.5. a-c.

Internal dose

records shall

include the

following:

a. Applicable

whole body and

lung counting

results (including

chest wall

thickness

measurements

where

external sources

of radiation

b. The equivalent

dose to the lens

of the eye

c. The equivalent

dose to the skin

d. The equivalent

dose to the

extremities

Revise: NV/YMP

RCM 722.5. a-c.

Internal dose

records shall

include the

following

information for

internal dose

resulting from

intakes received

during the year:

a. Committed

effective dose

b. Committed

equivalent dose

to any organ or

tissue of concern

. Identity of

radionuclides

Revise: NV/YMP

RCM 722.6. a-c.

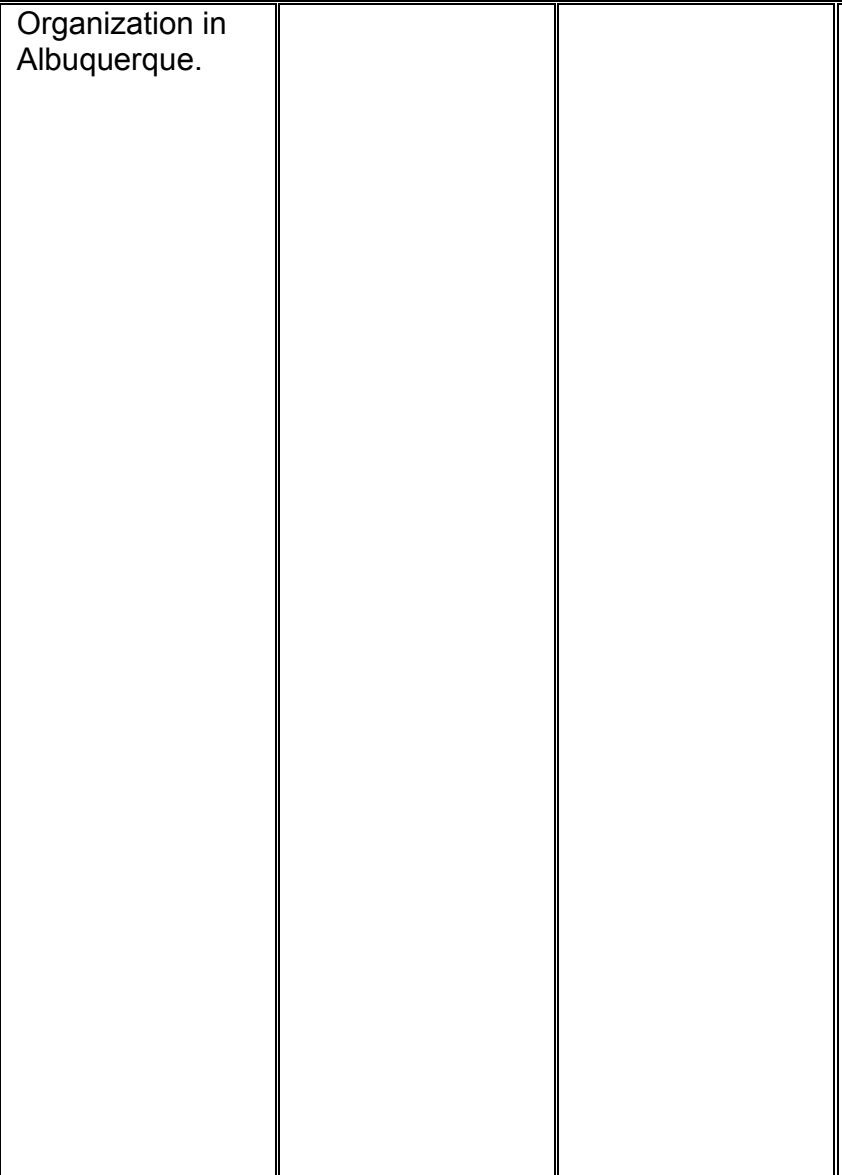




\section{NEVADA TEST SITE RADIATION PROTECTION PROGRAM}

\section{APPENDIX H}

COMPLIANCE DEMONSTRATION TABLE

\begin{tabular}{|c|c|c|c|c|c|c|c|c|}
\hline \multirow[t]{2}{*}{10 CFR 835} & $\begin{array}{c}\text { NV/YMP RCM } \\
\text { Rev } 5 \text { and } \\
\text { NTS RPP } \\
\text { Revision } 0 \\
\end{array}$ & $\begin{array}{c}\text { NSTec } \\
\text { Appendix A }\end{array}$ & $\begin{array}{c}\text { LLNL } \\
\text { Appendix B }\end{array}$ & $\begin{array}{c}\text { LANL } \\
\text { Appendix C }\end{array}$ & $\begin{array}{c}\text { SNL } \\
\text { Appendix D }\end{array}$ & $\begin{array}{c}\text { SNJV } \\
\text { Appendix E }\end{array}$ & $\begin{array}{c}\text { DRI } \\
\text { Appendix F }\end{array}$ & $\begin{array}{c}\text { WSI } \\
\text { Appendix G }\end{array}$ \\
\hline & $\begin{array}{l}\text { Implementation } \\
\text { Reference }\end{array}$ & $\begin{array}{l}\text { Implementation } \\
\text { Reference }\end{array}$ & $\begin{array}{l}\text { Implementation } \\
\text { Reference }\end{array}$ & $\begin{array}{l}\text { Implementation } \\
\text { Reference }\end{array}$ & $\begin{array}{c}\text { Implementation } \\
\text { Reference }\end{array}$ & $\begin{array}{l}\text { Implementation } \\
\text { Reference }\end{array}$ & $\begin{array}{l}\text { Implementation } \\
\text { Reference }\end{array}$ & $\begin{array}{l}\text { Implementation } \\
\text { Reference }\end{array}$ \\
\hline
\end{tabular}

\section{applicable)}

b. Applicable

urine, fecal, and

specimen

analysis results,

including

estimated intake

and identity of

radionuclides.

c. Dose

assessment, as

required.

NV/YMP RCM

722.6. a-C.

Include the

following

quantities for the

summation of the

external and

internal dose:

a. TEDE in a

year.

b. For any organ

or tissue

assigned an

internal dose

during the year,

the sum of the

deep dose

equivalent from

external

nclude the

following

quantities for the

summation of the

external and

internal dose:

a. TED in a year

b. For any organ

or tissue

assigned an

internal dose

during the year,

the sum of the

quivalent dose

to the whole

body from

external

exposures and

the committed

equivalent dose

to that organ or

issue

c. Cumulative

TED

Revise: NV/YMP

RCM 722.7.

Include the

equivalent dose

to the

embryo/fetus of a

declared

exposure and

pregnant worker. 


\section{NEVADA TEST SITE RADIATION PROTECTION PROGRAM}

\section{APPENDIX H}

COMPLIANCE DEMONSTRATION TABLE

\begin{tabular}{|c|c|c|c|c|c|c|c|c|}
\hline \multirow[t]{2}{*}{10 CFR 835} & $\begin{array}{l}\text { NV/YMP RCM } \\
\text { Rev } 5 \text { and } \\
\text { NTS RPP } \\
\text { Revision } 0 \\
\end{array}$ & $\begin{array}{c}\text { NSTec } \\
\text { Appendix A }\end{array}$ & $\begin{array}{c}\text { LLNL } \\
\text { Appendix B }\end{array}$ & $\begin{array}{c}\text { LANL } \\
\text { Appendix C }\end{array}$ & $\begin{array}{c}\text { SNL } \\
\text { Appendix D }\end{array}$ & $\begin{array}{c}\text { SNJV } \\
\text { Appendix E }\end{array}$ & $\begin{array}{c}\text { DRI } \\
\text { Appendix F }\end{array}$ & $\begin{array}{c}\text { WSI } \\
\text { Appendix G }\end{array}$ \\
\hline & $\begin{array}{l}\text { Implementation } \\
\text { Reference }\end{array}$ & $\begin{array}{l}\text { Implementation } \\
\text { Reference }\end{array}$ & $\begin{array}{l}\text { Implementation } \\
\text { Reference }\end{array}$ & $\begin{array}{l}\text { Implementation } \\
\text { Reference }\end{array}$ & $\begin{array}{l}\text { Implementation } \\
\text { Reference }\end{array}$ & $\begin{array}{l}\text { Implementation } \\
\text { Reference }\end{array}$ & $\begin{array}{l}\text { Implementation } \\
\text { Reference }\end{array}$ & $\begin{array}{l}\text { Implementation } \\
\text { Reference }\end{array}$ \\
\hline
\end{tabular}

\begin{tabular}{|c|c|c|c|c|c|c|c|c|}
\hline & $\begin{array}{l}\text { the committed } \\
\text { dose equivalent } \\
\text { to that organ or } \\
\text { tissue. } \\
\text { c. Cumulative } \\
\text { TEDE. } \\
\text { NV/YMP RCM } \\
722.7 \text {. Include } \\
\text { the dose } \\
\text { equivalent to the } \\
\text { embryo/fetus of a } \\
\text { declared } \\
\text { pregnant worker. }\end{array}$ & & & & & & & \\
\hline $\begin{array}{l}702(\mathrm{~d}) \text { Documentation } \\
\text { of all occupational } \\
\text { doses received during } \\
\text { the current year, } \\
\text { except for doses } \\
\text { resulting from planned } \\
\text { special exposures } \\
\text { conducted in } \\
\text { compliance with } \\
\S 835.204 \text { and } \\
\text { emergency exposures } \\
\text { authorized in } \\
\text { accordance with } \\
\S 835.1302(\mathrm{~d}) \text {, shall be } \\
\text { obtained to } \\
\text { demonstrate } \\
\text { compliance with } \\
\S 835.202(a) \text {. If } \\
\text { complete records }\end{array}$ & $\begin{array}{l}\text { NV/YMP RCM } \\
721.1 .01-02 . \\
\text { Documentation } \\
\text { of all } \\
\text { occupational } \\
\text { doses received } \\
\text { during the } \\
\text { current year, } \\
\text { except for doses } \\
\text { resulting from } \\
\text { planned special } \\
\text { exposures and } \\
\text { emergency } \\
\text { exposures, shall } \\
\text { be obtained to } \\
\text { demonstrate } \\
\text { compliance with } \\
\text { occupational } \\
\text { dose limits for } \\
\end{array}$ & $\begin{array}{l}\text { NV/YMP RCM } \\
721.1 .01-02 . \\
\text { Documentation } \\
\text { of all } \\
\text { occupational } \\
\text { doses received } \\
\text { during the } \\
\text { current year, } \\
\text { except for doses } \\
\text { resulting from } \\
\text { planned special } \\
\text { exposures and } \\
\text { emergency } \\
\text { exposures, shall } \\
\text { be obtained to } \\
\text { demonstrate } \\
\text { compliance with } \\
\text { occupational } \\
\text { dose limits for } \\
\end{array}$ & $\begin{array}{l}\text { By written } \\
\text { agreement, the } \\
\text { LLNL Hazard } \\
\text { Control } \\
\text { Personnel } \\
\text { Dosimetry Team } \\
\text { records and } \\
\text { maintains LLNL } \\
\text { employee } \\
\text { occupational } \\
\text { dose provided by } \\
\text { the NTS RSPC. }\end{array}$ & $\begin{array}{l}\text { This is outside } \\
\text { the scope of the } \\
\text { LANL/NTS } \\
\text { Radiological } \\
\text { Control Program. } \\
\text { The LANL RP-2 } \\
\text { Radiation } \\
\text { Information } \\
\text { Management } \\
\text { Team records } \\
\text { and maintains } \\
\text { LANL employee } \\
\text { dose } \\
\text { assessments } \\
\text { provided by the } \\
\text { NTS RSPC. }\end{array}$ & $\begin{array}{l}\text { NV/YMP RCM } \\
722.1 .02 \text {. These } \\
\text { records shall be } \\
\text { sufficient to } \\
\text { evaluate } \\
\text { compliance with } \\
\text { all applicable } \\
\text { dose limits and } \\
\text { monitoring and } \\
\text { reporting } \\
\text { requirements. } \\
\text { For SNL } \\
\text { personnel } \\
\text { primary dose } \\
\text { records are } \\
\text { maintained by } \\
\text { Dosimetry } \\
\text { Records }\end{array}$ & $\begin{array}{l}\text { NV/YMP RCM } \\
141.3 . e . \text { The } \\
\text { RSPC shall } \\
\text { provide the } \\
\text { following: } \\
\text { e. External and } \\
\text { internal } \\
\text { dosimetry } \\
\text { services. } \\
\text { Records } \\
\text { generated by the } \\
\text { RSPC for } \\
\text { services } \\
\text { provided to } \\
\text { SNJV are } \\
\text { maintained by } \\
\text { the RSPC. }\end{array}$ & $\begin{array}{l}\text { Primary dose } \\
\text { records for DRI } \\
\text { personnel on } \\
\text { NNSA/NSO } \\
\text { projects are } \\
\text { maintained and } \\
\text { archived by } \\
\text { RSPC. Doses } \\
\text { received are } \\
\text { reported by } \\
\text { RSPC to DRI. } \\
\text { Cross reference } \\
\text { response to } \\
835.101(\mathrm{c}) \text { of this } \\
\text { table. }\end{array}$ & $\begin{array}{l}\text { By written } \\
\text { agreement, the } \\
\text { RSPC provides } \\
\text { dosimetry } \\
\text { services to } \\
\text { WSI/NV and } \\
\text { maintains } \\
\text { individual } \\
\text { monitoring } \\
\text { records. }\end{array}$ \\
\hline
\end{tabular}

H-84 


\section{NEVADA TEST SITE RADIATION PROTECTION PROGRAM}

\section{APPENDIX H}

COMPLIANCE DEMONSTRATION TABLE

\begin{tabular}{|c|c|c|c||c||c||c||c||c|}
\hline \multirow{2}{*}{ 10 CFR 835 } & $\begin{array}{c}\text { NV/YMP RCM } \\
\text { Rev 5 and } \\
\text { NTS RPP } \\
\text { Revision 0 }\end{array}$ & Appendix A & Appendix B & Appendix C & Appendix D & SNJV \\
\cline { 2 - 7 } & $\begin{array}{c}\text { Implementation } \\
\text { Reference }\end{array}$ & $\begin{array}{c}\text { Implementation } \\
\text { Reference }\end{array}$ & $\begin{array}{c}\text { Implementation } \\
\text { Reference }\end{array}$ & $\begin{array}{c}\text { Implementation } \\
\text { Reference }\end{array}$ & $\begin{array}{c}\text { Implementation } \\
\text { Reference }\end{array}$ & $\begin{array}{c}\text { Implementation } \\
\text { Reference }\end{array}$ & $\begin{array}{c}\text { Implementation } \\
\text { Reference }\end{array}$ & $\begin{array}{c}\text { Implementation } \\
\text { Reference }\end{array}$ \\
\hline
\end{tabular}

\begin{tabular}{|c|c|c|c|c|c|c|c|c|}
\hline $\begin{array}{l}\text { documenting previous } \\
\text { occupational dose } \\
\text { during the year cannot } \\
\text { be obtained, a written } \\
\text { estimate signed by the } \\
\text { individual may be } \\
\text { accepted to } \\
\text { demonstrate } \\
\text { compliance. }\end{array}$ & $\begin{array}{l}\text { general } \\
\text { employees. If } \\
\text { complete records } \\
\text { documenting } \\
\text { previous } \\
\text { occupational } \\
\text { dose during the } \\
\text { year cannot be } \\
\text { obtained, a } \\
\text { written estimate } \\
\text { signed by the } \\
\text { individual may be } \\
\text { accepted to } \\
\text { demonstrate } \\
\text { compliance. } \\
\end{array}$ & $\begin{array}{l}\text { general } \\
\text { employees. If } \\
\text { complete records } \\
\text { documenting } \\
\text { previous } \\
\text { occupational } \\
\text { dose during the } \\
\text { year cannot be } \\
\text { obtained, a } \\
\text { written estimate } \\
\text { signed by the } \\
\text { individual may be } \\
\text { accepted to } \\
\text { demonstrate } \\
\text { compliance. }\end{array}$ & & & $\begin{array}{l}\text { Organization in } \\
\text { Albuquerque. }\end{array}$ & & & \\
\hline $\begin{array}{l}702(e) \text { For radiological } \\
\text { workers whose } \\
\text { occupational dose is } \\
\text { monitored in } \\
\text { accordance with } \\
\$ 835.402 \text {, reasonable } \\
\text { efforts shall be made } \\
\text { to obtain complete } \\
\text { records of prior years } \\
\text { occupational internal } \\
\text { and external dose. }\end{array}$ & $\begin{array}{l}\text { NV/YMP RCM } \\
721.2 \text {. } \\
\text { Reasonable } \\
\text { efforts shall be } \\
\text { made to obtain } \\
\text { complete records } \\
\text { of previous } \\
\text { years' } \\
\text { occupational } \\
\text { internal and } \\
\text { external doses } \\
\text { for radiological } \\
\text { workers whose } \\
\text { occupational } \\
\text { dose is } \\
\text { monitored } \\
\text { according to } \\
10 \text { CFR } 835.402 . \\
\end{array}$ & $\begin{array}{l}\text { NV/YMP RCM } \\
721.2 \text {. } \\
\text { Reasonable } \\
\text { efforts shall be } \\
\text { made to obtain } \\
\text { complete records } \\
\text { of previous } \\
\text { years' } \\
\text { occupational } \\
\text { internal and } \\
\text { external doses } \\
\text { for radiological } \\
\text { workers whose } \\
\text { occupational } \\
\text { dose is } \\
\text { monitored } \\
\text { according to } \\
10 \text { CFR } 835.402 . \\
\end{array}$ & $\begin{array}{l}\text { By written } \\
\text { agreement, the } \\
\text { LLNL Hazard } \\
\text { Control } \\
\text { Personnel } \\
\text { Dosimetry Team } \\
\text { records and } \\
\text { maintains LLNL } \\
\text { employee } \\
\text { occupational } \\
\text { dose provided by } \\
\text { the NTS RSPC. }\end{array}$ & $\begin{array}{l}\text { This is outside } \\
\text { the scope of the } \\
\text { LANL/NTS } \\
\text { Radiological } \\
\text { Control Program. } \\
\text { The LANL RP-2 } \\
\text { Radiation } \\
\text { Information } \\
\text { Management } \\
\text { Team records } \\
\text { and maintains } \\
\text { LANL employee } \\
\text { dose } \\
\text { assessments } \\
\text { provided by the } \\
\text { NTS RSPC. }\end{array}$ & $\begin{array}{l}\text { For SNL } \\
\text { personnel } \\
\text { primary dose } \\
\text { records are } \\
\text { maintained by } \\
\text { Dosimetry } \\
\text { Records } \\
\text { Organization in } \\
\text { Albuquerque. }\end{array}$ & $\begin{array}{l}\text { NV/YMP RCM } \\
\text { 141.3.e. The } \\
\text { RSPC shall } \\
\text { provide the } \\
\text { following: } \\
\text { e. External and } \\
\text { internal } \\
\text { dosimetry } \\
\text { services. } \\
\text { Records } \\
\text { generated by the } \\
\text { RSPC for } \\
\text { services } \\
\text { provided to } \\
\text { SNJV are } \\
\text { maintained by } \\
\text { the RSPC. }\end{array}$ & $\begin{array}{l}\text { Cross reference } \\
\text { NV/YMP RCM } \\
721 \text { and UNR } \\
\text { RSM Procedure } \\
\text { XIII: Personnel } \\
\text { Monitoring, } \\
\text { Section 3, } \\
\text { Records. B. } \\
\text { Records of Prior } \\
\text { Exposure. } \\
\text { Dosimetry } \\
\text { services are } \\
\text { provided to DRI } \\
\text { by the RSPC. } \\
\text { Records from } \\
\text { these services } \\
\text { are maintained } \\
\end{array}$ & $\begin{array}{l}\text { By written } \\
\text { agreement, the } \\
\text { RSPC provides } \\
\text { dosimetry } \\
\text { services to } \\
\text { WSI/NV and } \\
\text { maintains } \\
\text { individual } \\
\text { monitoring } \\
\text { records. }\end{array}$ \\
\hline
\end{tabular}




\section{NEVADA TEST SITE RADIATION PROTECTION PROGRAM}

\section{APPENDIX H}

COMPLIANCE DEMONSTRATION TABLE

\begin{tabular}{|c|c|c|c|c|c|c|c|c|}
\hline \multirow[t]{2}{*}{10 CFR 835} & $\begin{array}{c}\text { NV/YMP RCM } \\
\text { Rev } 5 \text { and } \\
\text { NTS RPP } \\
\text { Revision } 0 \\
\end{array}$ & $\begin{array}{c}\text { NSTec } \\
\text { Appendix A }\end{array}$ & $\begin{array}{c}\text { LLNL } \\
\text { Appendix B }\end{array}$ & $\begin{array}{c}\text { LANL } \\
\text { Appendix C }\end{array}$ & $\begin{array}{c}\text { SNL } \\
\text { Appendix D }\end{array}$ & $\begin{array}{c}\text { SNJV } \\
\text { Appendix E }\end{array}$ & $\begin{array}{c}\text { DRI } \\
\text { Appendix F }\end{array}$ & $\begin{array}{c}\text { WSI } \\
\text { Appendix G }\end{array}$ \\
\hline & $\begin{array}{l}\text { Implementation } \\
\text { Reference }\end{array}$ & $\begin{array}{l}\text { Implementation } \\
\text { Reference }\end{array}$ & $\begin{array}{l}\text { Implementation } \\
\text { Reference }\end{array}$ & $\begin{array}{l}\text { Implementation } \\
\text { Reference }\end{array}$ & $\begin{array}{l}\text { Implementation } \\
\text { Reference }\end{array}$ & $\begin{array}{l}\text { Implementation } \\
\text { Reference }\end{array}$ & $\begin{array}{l}\text { Implementation } \\
\text { Reference }\end{array}$ & $\begin{array}{l}\text { Implementation } \\
\text { Reference }\end{array}$ \\
\hline
\end{tabular}

\begin{tabular}{|c|c|c|c|c|c|c|c|c|}
\hline & & & & & & & by the RSPC. & \\
\hline $\begin{array}{l}702(f) \text { The records } \\
\text { specified in this } \\
\text { section that are } \\
\text { identified with a } \\
\text { specific individual shall } \\
\text { be readily available to } \\
\text { that individual. }\end{array}$ & $\begin{array}{l}\text { NV/YMP RCM } \\
781.1 . b \text {. Detailed } \\
\text { information } \\
\text { concerning an } \\
\text { individual's } \\
\text { exposure shall } \\
\text { be made } \\
\text { available to that } \\
\text { individual, upon } \\
\text { request, } \\
\text { consistent with } \\
\text { the Privacy Act } \\
\text { of } 1974, \text { which } \\
\text { contains } \\
\text { requirements to } \\
\text { protect the } \\
\text { privacy of } \\
\text { individual } \\
\text { records. }\end{array}$ & $\begin{array}{l}\text { NV/YMP RCM } \\
781.1 . b . \\
\text { Detailed } \\
\text { information } \\
\text { concerning an } \\
\text { individual's } \\
\text { exposure shall } \\
\text { be made } \\
\text { available to that } \\
\text { individual, upon } \\
\text { request, } \\
\text { consistent with } \\
\text { the Privacy Act } \\
\text { of } 1974, \text { which } \\
\text { contains } \\
\text { requirements to } \\
\text { protect the } \\
\text { privacy of } \\
\text { individual } \\
\text { records. }\end{array}$ & $\begin{array}{l}\text { By written } \\
\text { agreement, the } \\
\text { LLNL Hazard } \\
\text { Control } \\
\text { Personnel } \\
\text { Dosimetry Team } \\
\text { records and } \\
\text { maintains LLNL } \\
\text { employee } \\
\text { occupational } \\
\text { dose provided by } \\
\text { the NTS RSPC. }\end{array}$ & $\begin{array}{l}\text { This is outside } \\
\text { the scope of the } \\
\text { LANL/NTS } \\
\text { Radiological } \\
\text { Control Program. } \\
\text { The LANL RP-2 } \\
\text { Radiation } \\
\text { Information } \\
\text { Management } \\
\text { Team records } \\
\text { and maintains } \\
\text { LANL employee } \\
\text { dose } \\
\text { assessments } \\
\text { provided by the } \\
\text { NTS RSPC. }\end{array}$ & $\begin{array}{l}\text { For SNL } \\
\text { personnel } \\
\text { primary dose } \\
\text { records are } \\
\text { maintained by } \\
\text { Dosimetry } \\
\text { Records } \\
\text { Organization in } \\
\text { Albuquerque. }\end{array}$ & $\begin{array}{l}\text { NV/YMP RCM } \\
\text { 141.3.e. The } \\
\text { RSPC shall } \\
\text { provide the } \\
\text { following: } \\
\text { (e) External and } \\
\text { internal } \\
\text { dosimetry } \\
\text { services. } \\
\text { Records } \\
\text { generated by the } \\
\text { RSPC for } \\
\text { services } \\
\text { provided to } \\
\text { SNJV are } \\
\text { maintained by } \\
\text { the RSPC. }\end{array}$ & $\begin{array}{l}\text { Same as Column } \\
3 \\
\text { DRI distributes } \\
\text { individual } \\
\text { records received } \\
\text { from the RSPC } \\
\text { as required by } \\
\text { NAC 459.786 } \\
\text { and UNR RCM } \\
\text { Procedure XIII: } \\
\text { Personnel } \\
\text { Monitoring, } \\
\text { Section 3, } \\
\text { Records, A. } \\
\text { Personnel } \\
\text { Exposure } \\
\text { Records. }\end{array}$ & $\begin{array}{l}\text { By written } \\
\text { agreement, the } \\
\text { RSPC provides } \\
\text { dosimetry } \\
\text { services and } \\
\text { maintains } \\
\text { individual } \\
\text { monitoring } \\
\text { records. }\end{array}$ \\
\hline $\begin{array}{l}702(\mathrm{~g}) \text { Data necessary } \\
\text { for future verification } \\
\text { or reassessment of the } \\
\text { recorded doses shall } \\
\text { be recorded. }\end{array}$ & $\begin{array}{l}\text { NV/YMP RCM } \\
722.3 .03 . \\
\text { Procedures, } \\
\text { data, and } \\
\text { supporting } \\
\text { information } \\
\text { needed to } \\
\text { reconfirm a } \\
\text { person's dose at } \\
\text { a later date shall } \\
\text { be maintained. }\end{array}$ & $\begin{array}{l}\text { NV/YMP RCM } \\
722.3 .03 . \\
\text { Procedures, } \\
\text { data, and } \\
\text { supporting } \\
\text { information } \\
\text { needed to } \\
\text { reconfirm a } \\
\text { person's dose at } \\
\text { a later date shall } \\
\text { be maintained. }\end{array}$ & $\begin{array}{l}\text { By written } \\
\text { agreement, the } \\
\text { LLNL Hazard } \\
\text { Control } \\
\text { Personnel } \\
\text { Dosimetry Team } \\
\text { records and } \\
\text { maintains LLNL } \\
\text { employee } \\
\text { occupational } \\
\text { dose provided by } \\
\text { the NTS RSPC. }\end{array}$ & $\begin{array}{l}\text { This is outside } \\
\text { the scope of the } \\
\text { LANL/NTS } \\
\text { Radiological } \\
\text { Control Program. } \\
\text { The LANL RP-2 } \\
\text { Radiation } \\
\text { Information } \\
\text { Management } \\
\text { Team records } \\
\text { and maintains } \\
\text { LANL employee }\end{array}$ & $\begin{array}{l}\text { These data are } \\
\text { maintained by } \\
\text { the RSPC for } \\
\text { SNL personnel. }\end{array}$ & $\begin{array}{l}\text { NV/YMP RCM } \\
\text { 141.3.e. The } \\
\text { RSPC shall } \\
\text { provide the } \\
\text { following: } \\
\text { (e) External and } \\
\text { internal } \\
\text { dosimetry } \\
\text { services. } \\
\text { Records } \\
\text { generated by the }\end{array}$ & $\begin{array}{l}\text { Data are } \\
\text { maintained by } \\
\text { the RSPC for } \\
\text { DRI personnel. } \\
\text { DRI maintains } \\
\text { any copies as } \\
\text { required by } 29 \\
\text { CFR } 1910.1020 .\end{array}$ & $\begin{array}{l}\text { By written } \\
\text { agreement, the } \\
\text { RSPC provides } \\
\text { dosimetry } \\
\text { services to } \\
\text { WSI/NV and } \\
\text { maintains } \\
\text { individual } \\
\text { monitoring } \\
\text { records. }\end{array}$ \\
\hline
\end{tabular}

H-86 


\section{NEVADA TEST SITE RADIATION PROTECTION PROGRAM}

\section{APPENDIX H}

COMPLIANCE DEMONSTRATION TABLE

\begin{tabular}{|c|c|c|c|c|c|c|c|c|}
\hline \multirow[t]{2}{*}{10 CFR 835} & $\begin{array}{l}\text { NV/YMP RCM } \\
\text { Rev } 5 \text { and } \\
\text { NTS RPP } \\
\text { Revision } 0 \\
\end{array}$ & $\begin{array}{c}\text { NSTec } \\
\text { Appendix A }\end{array}$ & $\begin{array}{c}\text { LLNL } \\
\text { Appendix B }\end{array}$ & $\begin{array}{c}\text { LANL } \\
\text { Appendix C }\end{array}$ & $\begin{array}{c}\text { SNL } \\
\text { Appendix D }\end{array}$ & $\begin{array}{c}\text { SNJV } \\
\text { Appendix E }\end{array}$ & $\begin{array}{c}\text { DRI } \\
\text { Appendix F }\end{array}$ & $\begin{array}{c}\text { WSI } \\
\text { Appendix G }\end{array}$ \\
\hline & $\begin{array}{l}\text { Implementation } \\
\text { Reference }\end{array}$ & $\begin{array}{c}\text { Implementation } \\
\text { Reference }\end{array}$ & $\begin{array}{l}\text { Implementation } \\
\text { Reference }\end{array}$ & $\begin{array}{l}\text { Implementation } \\
\text { Reference }\end{array}$ & $\begin{array}{l}\text { Implementation } \\
\text { Reference }\end{array}$ & $\begin{array}{l}\text { Implementation } \\
\text { Reference }\end{array}$ & $\begin{array}{l}\text { Implementation } \\
\text { Reference }\end{array}$ & $\begin{array}{l}\text { Implementation } \\
\text { Reference }\end{array}$ \\
\hline
\end{tabular}

\begin{tabular}{|c|c|c|c|c|c|c|c|c|}
\hline & & & & $\begin{array}{l}\text { dose } \\
\text { assessments } \\
\text { provided by the } \\
\text { NTS RSPC. }\end{array}$ & & $\begin{array}{l}\text { RSPC for } \\
\text { services } \\
\text { provided to } \\
\text { SNJV are } \\
\text { maintained by } \\
\text { the RSPC. }\end{array}$ & & \\
\hline $\begin{array}{l}702(\mathrm{~h}) \text { All records } \\
\text { required by this } \\
\text { section shall be } \\
\text { transferred to the DOE } \\
\text { upon cessation of } \\
\text { activities at the site } \\
\text { that could cause } \\
\text { exposure to } \\
\text { individuals. }\end{array}$ & $\begin{array}{l}\text { NV/YMP RCM } \\
711.03 \text {. Upon } \\
\text { cessation of } \\
\text { activities that } \\
\text { could result in } \\
\text { the occupational } \\
\text { exposure of } \\
\text { individuals, all } \\
\text { required records } \\
\text { shall be } \\
\text { transferred to } \\
\text { NNSA/NSO. } \\
\text { NV/YMP RCM } \\
712.3 \text {. DOE G } \\
1324.5 B \text {, "Guide } \\
\text { for DOE 1324.5B } \\
\text { Records } \\
\text { Management," } \\
\text { provides } \\
\text { implementing } \\
\text { instructions, } \\
\text { records inventory } \\
\text { requirements, } \\
\text { disposition } \\
\text { schedules, and } \\
\text { provisions for }\end{array}$ & $\begin{array}{l}\text { NV/YMP RCM } \\
711.03 \text {. Upon } \\
\text { cessation of } \\
\text { activities that } \\
\text { could result in } \\
\text { the occupational } \\
\text { exposure of } \\
\text { individuals, all } \\
\text { required records } \\
\text { shall be } \\
\text { transferred to } \\
\text { NNSA/NSO. } \\
\text { NV/YMP RCM } \\
712.3 \text {. DOE G } \\
1324.5 B, \text { "Guide } \\
\text { for DOE 1324.5B } \\
\text { Records } \\
\text { Management," } \\
\text { provides } \\
\text { implementing } \\
\text { instructions, } \\
\text { records inventory } \\
\text { requirements, } \\
\text { disposition } \\
\text { schedules, and } \\
\text { provisions for }\end{array}$ & $\begin{array}{l}\text { By written } \\
\text { agreement, the } \\
\text { LLNL Hazard } \\
\text { Control } \\
\text { Personnel } \\
\text { Dosimetry Team } \\
\text { records and } \\
\text { maintains LLNL } \\
\text { employee } \\
\text { occupational } \\
\text { dose provided by } \\
\text { the NTS RSPC. }\end{array}$ & $\begin{array}{l}\text { This is outside } \\
\text { the scope of the } \\
\text { LANL/NTS } \\
\text { Radiological } \\
\text { Control Program. } \\
\text { The LANL RP-2 } \\
\text { Radiation } \\
\text { Information } \\
\text { Management } \\
\text { Team records } \\
\text { and maintains } \\
\text { LANL employee } \\
\text { dose } \\
\text { assessments } \\
\text { provided by the } \\
\text { NTS RSPC. }\end{array}$ & $\begin{array}{l}\text { For SNL } \\
\text { personnel } \\
\text { primary dose } \\
\text { records are } \\
\text { maintained by } \\
\text { Dosimetry } \\
\text { Records } \\
\text { Organization in } \\
\text { Albuquerque. }\end{array}$ & $\begin{array}{l}\text { RCM 141.3.e. } \\
\text { The RSPC shall } \\
\text { provide the } \\
\text { following: } \\
\text { (e) External and } \\
\text { internal } \\
\text { dosimetry } \\
\text { services. } \\
\text { Records } \\
\text { generated by the } \\
\text { RSPC for } \\
\text { services } \\
\text { provided to } \\
\text { SNJV are } \\
\text { maintained by } \\
\text { the RSPC. }\end{array}$ & $\begin{array}{l}\text { Dosimetry } \\
\text { services are } \\
\text { provided to DRI } \\
\text { by the RSPC and } \\
\text { records } \\
\text { generated from } \\
\text { these services } \\
\text { are maintained } \\
\text { by the RSPC, } \\
\text { therefore the } \\
\text { RSPC would be } \\
\text { responsible for } \\
\text { record transfer. }\end{array}$ & $\begin{array}{l}\text { By written } \\
\text { agreement, the } \\
\text { RSPC provides } \\
\text { dosimetry } \\
\text { services to } \\
\text { WSI/NV and } \\
\text { maintains } \\
\text { individual } \\
\text { monitoring } \\
\text { records. }\end{array}$ \\
\hline
\end{tabular}




\section{NEVADA TEST SITE RADIATION PROTECTION PROGRAM}

\section{APPENDIX H}

COMPLIANCE DEMONSTRATION TABLE

\begin{tabular}{|c|c|c|c||c||c||c||c||c|}
\hline \multirow{2}{*}{ 10 CFR 835 } & $\begin{array}{c}\text { NV/YMP RCM } \\
\text { Rev 5 and } \\
\text { NTS RPP } \\
\text { Revision 0 }\end{array}$ & Appendix A & Appendix B & Appendix C & Appendix D & SNJV \\
\cline { 2 - 7 } & $\begin{array}{c}\text { Implementation } \\
\text { Reference }\end{array}$ & $\begin{array}{c}\text { Implementation } \\
\text { Reference }\end{array}$ & $\begin{array}{c}\text { Implementation } \\
\text { Reference }\end{array}$ & $\begin{array}{c}\text { Implementation } \\
\text { Reference }\end{array}$ & $\begin{array}{c}\text { Implementation } \\
\text { Reference }\end{array}$ & $\begin{array}{c}\text { Implementation } \\
\text { Reference }\end{array}$ & $\begin{array}{c}\text { Implementation } \\
\text { Reference }\end{array}$ & $\begin{array}{c}\text { Implementation } \\
\text { Reference }\end{array}$ \\
\hline
\end{tabular}

\begin{tabular}{|c|c|c|c|c|c|c|c|c|}
\hline & $\begin{array}{l}\text { transferring } \\
\text { records. }\end{array}$ & $\begin{array}{l}\text { transferring } \\
\text { records. }\end{array}$ & & & & & & \\
\hline $\begin{array}{l}835.703 \text { Other } \\
\text { Monitoring Records. } \\
\text { The following } \\
\text { information shall be } \\
\text { documented and } \\
\text { maintained: } \\
703(a) \text { Results of } \\
\text { monitoring for } \\
\text { radiation and } \\
\text { radioactive material as } \\
\text { required by subpart E } \\
\text { and L of this part, } \\
\text { except for monitoring } \\
\text { required by } \\
\text { §835.1102(d); }\end{array}$ & $\begin{array}{l}\text { NV/YMP RCM } \\
751.1 .01 . \\
\text { Radiological } \\
\text { control programs } \\
\text { require the } \\
\text { performance of } \\
\text { radiation, } \\
\text { airborne } \\
\text { radioactivity, and } \\
\text { contamination } \\
\text { surveys to } \\
\text { determine } \\
\text { existing } \\
\text { conditions in a } \\
\text { given location. } \\
\\
\text { NV/YMP RCM } \\
751.2 \text {. a and e. } \\
\text { Records shall be } \\
\text { maintained to } \\
\text { document the } \\
\text { following } \\
\text { information: } \\
\text { a. Results of } \\
\text { monitoring and } \\
\text { surveys for } \\
\text { radiation and } \\
\text { radioactive } \\
\text { materials. } \\
\text { e. Results of } \\
\text { surveys of }\end{array}$ & $\begin{array}{l}\text { NV/YMP RCM } \\
751.1 .01 . \\
\text { Radiological } \\
\text { control programs } \\
\text { require the } \\
\text { performance of } \\
\text { radiation, } \\
\text { airborne } \\
\text { radioactivity, and } \\
\text { contamination } \\
\text { surveys to } \\
\text { determine } \\
\text { existing } \\
\text { conditions in a } \\
\text { given location. } \\
\\
\text { NV/YMP RCM } \\
751.2 \text {. a and e. } \\
\text { Records shall be } \\
\text { maintained to } \\
\text { document the } \\
\text { following } \\
\text { information: } \\
\text { a. Results of } \\
\text { monitoring and } \\
\text { surveys for } \\
\text { radiation and } \\
\text { radioactive } \\
\text { materials. } \\
\text { e. Results of } \\
\text { surveys of }\end{array}$ & $\begin{array}{l}\text { The LLNL } \\
\text { Radiological } \\
\text { Control Program } \\
\text { maintains results } \\
\text { of monitoring for } \\
\text { radiation and } \\
\text { radioactive } \\
\text { material as } \\
\text { required by } \\
10 \text { CFR } 835 \\
\text { Subparts E and } \\
\text { L, except for } \\
\text { monitoring } \\
\text { required by } \\
835.1102(d) .\end{array}$ & $\begin{array}{l}\text { Results of } \\
\text { documented } \\
\text { radiological } \\
\text { surveys are } \\
\text { provided to and } \\
\text { maintained by } \\
\text { the NTS RSPC. } \\
\text { This is outside } \\
\text { the scope of the } \\
\text { LANL/NTS } \\
\text { Radiological } \\
\text { Control } \\
\text { Program... } \\
\text { The NTS RSPC } \\
\text { provides trained } \\
\text { and qualified } \\
\text { Radiological } \\
\text { Control } \\
\text { Technicians to } \\
\text { perform and } \\
\text { document } \\
\text { radiological } \\
\text { surveys per NTS } \\
\text { RSPC } \\
\text { procedures } \\
\text { compliant with } \\
10 \text { CFR } 835 .\end{array}$ & $\begin{array}{l}\text { SNL-NV } \\
\text { depends on the } \\
\text { expertise of the } \\
\text { RSPC to perform } \\
\text { radiological } \\
\text { monitoring in the } \\
\text { workplace, } \\
\text { personnel } \\
\text { monitoring, } \\
\text { release of } \\
\text { materials and } \\
\text { equipment, and } \\
\text { maintenance and } \\
\text { calibration of } \\
\text { instruments and } \\
\text { individual } \\
\text { monitoring } \\
\text { devices. } \\
\text { Records } \\
\text { generated in } \\
\text { performing these } \\
\text { services are } \\
\text { retained by the } \\
\text { RSPC. SNL-NV } \\
\text { retains summary } \\
\text { reports provided } \\
\text { by the RSPC } \\
\text { following } \\
\text { radiological } \\
\text { activities. }\end{array}$ & $\begin{array}{l}\text { Same as Column } \\
3 \text { and Records } \\
\text { generated by the } \\
\text { RSPC for } \\
\text { services } \\
\text { provided to } \\
\text { SNJV are } \\
\text { maintained by } \\
\text { the RSPC. }\end{array}$ & $\begin{array}{l}\text { DRI depends on } \\
\text { the expertise of } \\
\text { the RSPC to } \\
\text { perform } \\
\text { radiological } \\
\text { monitoring in the } \\
\text { workplace, } \\
\text { personnel } \\
\text { monitoring, } \\
\text { release of } \\
\text { materials and } \\
\text { equipment, and } \\
\text { maintenance and } \\
\text { calibration of } \\
\text { instruments and } \\
\text { individual } \\
\text { monitoring } \\
\text { devices. } \\
\text { Records } \\
\text { generated in } \\
\text { performing these } \\
\text { services are } \\
\text { retained by the } \\
\text { RSPC. DRI } \\
\text { retains summary } \\
\text { reports provided } \\
\text { by the RSPC } \\
\text { following } \\
\text { radiological } \\
\text { activities. }\end{array}$ & $\begin{array}{l}\text { By written } \\
\text { agreement, the } \\
\text { RSPC conducts } \\
\text { monitoring for } \\
\text { radiation and } \\
\text { radioactive } \\
\text { material. The } \\
\text { RSPC will } \\
\text { maintain all } \\
\text { monitoring } \\
\text { records. }\end{array}$ \\
\hline
\end{tabular}

H-88 


\section{NEVADA TEST SITE RADIATION PROTECTION PROGRAM}

\section{APPENDIX H}

COMPLIANCE DEMONSTRATION TABLE

\begin{tabular}{|c|c|c|c|c|c|c|c|c|}
\hline \multirow[t]{2}{*}{10 CFR 835} & $\begin{array}{c}\text { NV/YMP RCM } \\
\text { Rev } 5 \text { and } \\
\text { NTS RPP } \\
\text { Revision } 0 \\
\end{array}$ & $\begin{array}{c}\text { NSTec } \\
\text { Appendix A }\end{array}$ & $\begin{array}{c}\text { LLNL } \\
\text { Appendix B }\end{array}$ & $\begin{array}{c}\text { LANL } \\
\text { Appendix C }\end{array}$ & $\begin{array}{c}\text { SNL } \\
\text { Appendix D }\end{array}$ & $\begin{array}{c}\text { SNJV } \\
\text { Appendix E }\end{array}$ & $\begin{array}{c}\text { DRI } \\
\text { Appendix F }\end{array}$ & $\begin{array}{c}\text { WSI } \\
\text { Appendix G }\end{array}$ \\
\hline & $\begin{array}{l}\text { Implementation } \\
\text { Reference }\end{array}$ & $\begin{array}{l}\text { Implementation } \\
\text { Reference }\end{array}$ & $\begin{array}{l}\text { Implementation } \\
\text { Reference }\end{array}$ & $\begin{array}{l}\text { Implementation } \\
\text { Reference }\end{array}$ & $\begin{array}{l}\text { Implementation } \\
\text { Reference }\end{array}$ & $\begin{array}{l}\text { Implementation } \\
\text { Reference }\end{array}$ & $\begin{array}{l}\text { Implementation } \\
\text { Reference }\end{array}$ & $\begin{array}{l}\text { Implementation } \\
\text { Reference }\end{array}$ \\
\hline
\end{tabular}

\begin{tabular}{|c|c|c|c|c|c|c|c|c|}
\hline & $\begin{array}{l}\text { radioactive } \\
\text { material } \\
\text { packages } \\
\text { received from } \\
\text { transportation. }\end{array}$ & \begin{tabular}{|l|} 
radioactive \\
material \\
packages \\
received from \\
transportation.
\end{tabular} & & & & & & \\
\hline $\begin{array}{l}703(b) \text { Results of } \\
\text { monitoring used to } \\
\text { determine individual } \\
\text { occupational dose } \\
\text { from external and } \\
\text { internal sources; }\end{array}$ & $\begin{array}{l}\text { NV/YMP RCM } \\
751.2 . b . \\
\text { Records shall be } \\
\text { maintained to } \\
\text { document the } \\
\text { following } \\
\text { information: } \\
\text { b. Results of } \\
\text { monitoring and } \\
\text { calculations used } \\
\text { to determine } \\
\text { individual } \\
\text { occupational } \\
\text { exposures. }\end{array}$ & $\begin{array}{l}\text { NV/YMP RCM } \\
751.2 . b . \\
\text { Records shall be } \\
\text { maintained to } \\
\text { document the } \\
\text { following } \\
\text { information: } \\
\text { b. Results of } \\
\text { monitoring and } \\
\text { calculations used } \\
\text { to determine } \\
\text { individual } \\
\text { occupational } \\
\text { exposures. }\end{array}$ & $\begin{array}{l}\text { This service is } \\
\text { provided to LLNL } \\
\text { at the NTS by } \\
\text { the RSPC. }\end{array}$ & $\begin{array}{l}\text { This is outside } \\
\text { the scope of the } \\
\text { LANL/NTS } \\
\text { Radiological } \\
\text { Control Program. } \\
\text { The LANL RP-2 } \\
\text { Radiation } \\
\text { Information } \\
\text { Management } \\
\text { Team records } \\
\text { and maintains } \\
\text { LANL employee } \\
\text { dose } \\
\text { assessments } \\
\text { provided by the } \\
\text { NTS RSPC. }\end{array}$ & $\begin{array}{l}\text { SNL-NV } \\
\text { depends on the } \\
\text { expertise of the } \\
\text { RSPC to perform } \\
\text { radiological } \\
\text { monitoring in the } \\
\text { workplace, } \\
\text { personnel } \\
\text { monitoring, } \\
\text { release of } \\
\text { materials and } \\
\text { equipment, and } \\
\text { maintenance and } \\
\text { calibration of } \\
\text { instruments and } \\
\text { individual } \\
\text { monitoring } \\
\text { devices. } \\
\text { Records } \\
\text { generated in } \\
\text { performing these } \\
\text { services are } \\
\text { retained by the } \\
\text { RSPC. SNL-NV } \\
\text { retains summary } \\
\text { reports provided } \\
\text { by the RSPC } \\
\text { following }\end{array}$ & $\begin{array}{l}\text { RCM 141.3.e. } \\
\text { The RSPC shall } \\
\text { provide the } \\
\text { following: } \\
\text { e. External and } \\
\text { internal } \\
\text { dosimetry } \\
\text { services. } \\
\text { Records } \\
\text { generated by the } \\
\text { RSPC for } \\
\text { services } \\
\text { provided to } \\
\text { SNJV are } \\
\text { maintained by } \\
\text { the RSPC. }\end{array}$ & \begin{tabular}{|l|} 
DRI depends on \\
the expertise of \\
the RSPC to \\
perform \\
radiological \\
monitoring in the \\
workplace, \\
personnel \\
monitoring, \\
release of \\
materials and \\
equipment, and \\
maintenance and \\
calibration of \\
instruments and \\
individual \\
monitoring \\
devices. \\
Records \\
generated in \\
performing these \\
services are \\
retained by the \\
RSPC. DRI \\
retains summary \\
reports provided \\
by the RSPC \\
following \\
\end{tabular} & $\begin{array}{l}\text { By written } \\
\text { agreement, the } \\
\text { RSPC conducts } \\
\text { monitoring and } \\
\text { will maintain all } \\
\text { monitoring } \\
\text { records. }\end{array}$ \\
\hline
\end{tabular}




\section{NEVADA TEST SITE RADIATION PROTECTION PROGRAM}

\section{APPENDIX H}

COMPLIANCE DEMONSTRATION TABLE

\begin{tabular}{|c|c|c|c||c||c||c||c||c|}
\hline \multirow{2}{*}{ 10 CFR 835 } & $\begin{array}{c}\text { NV/YMP RCM } \\
\text { Rev 5 and } \\
\text { NTS RPP } \\
\text { Revision 0 }\end{array}$ & Appendix A & Appendix B & Appendix C & Appendix D & SNJV \\
\cline { 2 - 7 } & $\begin{array}{c}\text { Implementation } \\
\text { Reference }\end{array}$ & $\begin{array}{c}\text { Implementation } \\
\text { Reference }\end{array}$ & $\begin{array}{c}\text { Implementation } \\
\text { Reference }\end{array}$ & $\begin{array}{c}\text { Implementation } \\
\text { Reference }\end{array}$ & $\begin{array}{c}\text { Implementation } \\
\text { Reference }\end{array}$ & $\begin{array}{c}\text { Implementation } \\
\text { Reference }\end{array}$ & $\begin{array}{c}\text { Implementation } \\
\text { Reference }\end{array}$ & $\begin{array}{c}\text { Implementation } \\
\text { Reference }\end{array}$ \\
\hline
\end{tabular}

\begin{tabular}{|c|c|c|c|c|c|c|c|c|}
\hline & & & & & $\begin{array}{l}\text { radiological } \\
\text { activities. }\end{array}$ & & $\begin{array}{l}\text { radiological } \\
\text { activities. }\end{array}$ & \\
\hline $\begin{array}{l}703(\mathrm{c}) \text { Results of } \\
\text { monitoring for the } \\
\text { release and control of } \\
\text { material and } \\
\text { equipment as required } \\
\text { by §835.1101; and }\end{array}$ & $\begin{array}{l}\text { NV/YMP RCM } \\
421.5 \text {. Results of } \\
\text { monitoring for } \\
\text { the release and } \\
\text { control of } \\
\text { material and } \\
\text { equipment as } \\
\text { required by } \\
\text { Articles } 421.1 \text {, } \\
421.2 \text {, and } 421.3 \\
\text { shall be } \\
\text { documented and } \\
\text { maintained. } \\
\text { NV/YMP RCM } \\
751.2 \text {. C. } \\
\text { Records shall be } \\
\text { maintained to } \\
\text { document the } \\
\text { following } \\
\text { information: } \\
\text { c. Results of } \\
\text { surveys for } \\
\text { release of } \\
\text { materials from } \\
\text { radiological } \\
\text { areas. }\end{array}$ & $\begin{array}{l}\text { NV/YMP RCM } \\
421.5 \text {. Results of } \\
\text { monitoring for } \\
\text { the release and } \\
\text { control of } \\
\text { material and } \\
\text { equipment as } \\
\text { required by } \\
\text { Articles } 421.1 \text {, } \\
421.2 \text {, and } 421.3 \\
\text { shall be } \\
\text { documented and } \\
\text { maintained. } \\
\text { NV/YMP RCM } \\
751.2 \text {. C. } \\
\text { Records shall be } \\
\text { maintained to } \\
\text { document the } \\
\text { following } \\
\text { information: } \\
\text { c. Results of } \\
\text { surveys for } \\
\text { release of } \\
\text { materials from } \\
\text { radiological } \\
\text { areas. }\end{array}$ & $\begin{array}{l}\text { The LLNL } \\
\text { Radiological } \\
\text { Control Program } \\
\text { maintains results } \\
\text { of monitoring for } \\
\text { the release and } \\
\text { control of } \\
\text { material and } \\
\text { equipment as } \\
\text { required by } \\
835.1101 \text {. }\end{array}$ & $\begin{array}{l}\text { This is outside } \\
\text { the scope of the } \\
\text { LANL/NTS } \\
\text { Radiological } \\
\text { Control Program. } \\
\text { The NTS RSPC } \\
\text { provides trained } \\
\text { and qualified } \\
\text { Radiological } \\
\text { Control } \\
\text { Technicians to } \\
\text { perform and } \\
\text { document } \\
\text { radiological } \\
\text { surveys per NTS } \\
\text { RSPC } \\
\text { procedures } \\
\text { compliant with } 10 \\
\text { CFR } 835 .\end{array}$ & $\begin{array}{l}\text { SNL-NV } \\
\text { depends on the } \\
\text { expertise of the } \\
\text { RSPC to perform } \\
\text { radiological } \\
\text { monitoring in the } \\
\text { workplace, } \\
\text { personnel } \\
\text { monitoring, } \\
\text { release of } \\
\text { materials and } \\
\text { equipment, and } \\
\text { maintenance and } \\
\text { calibration of } \\
\text { instruments and } \\
\text { individual } \\
\text { monitoring } \\
\text { devices. } \\
\text { Records } \\
\text { generated in } \\
\text { performing these } \\
\text { services are } \\
\text { retained by the } \\
\text { RSPC. SNL-NV } \\
\text { retains reports } \\
\text { provided by the } \\
\text { RSPC following } \\
\text { radiological } \\
\text { activities. }\end{array}$ & $\begin{array}{l}\text { Same as Column } \\
3 \text { and Records } \\
\text { generated for } \\
\text { SNJV by the } \\
\text { RSPC are } \\
\text { maintained by } \\
\text { the RSPC. }\end{array}$ & $\begin{array}{l}\text { Release surveys } \\
\text { are obtained as a } \\
\text { service from the } \\
\text { RSPC. Records } \\
\text { generated from } \\
\text { these surveys } \\
\text { are maintained } \\
\text { by the RSPC. }\end{array}$ & $\begin{array}{l}\text { By written } \\
\text { agreement, the } \\
\text { RSPC conducts } \\
\text { monitoring and } \\
\text { will maintain all } \\
\text { monitoring } \\
\text { records. }\end{array}$ \\
\hline $\begin{array}{l}703(d) \text { Results of } \\
\text { maintenance and }\end{array}$ & $\begin{array}{l}\text { NV/YMP RCM } \\
761.1 .\end{array}$ & $\begin{array}{l}\text { NV/YMP RCM } \\
761.1 .\end{array}$ & $\begin{array}{l}\text { The NTS RSPC } \\
\text { provides }\end{array}$ & $\begin{array}{l}\text { This is outside } \\
\text { the scope of the }\end{array}$ & $\begin{array}{l}\text { SNL-NV } \\
\text { depends on the }\end{array}$ & $\begin{array}{l}\text { Same as Column } \\
3 \text { and Records }\end{array}$ & $\begin{array}{l}\text { DRI depends on } \\
\text { the expertise of }\end{array}$ & $\begin{array}{l}\text { Not applicable to } \\
\text { WSI/NV. }\end{array}$ \\
\hline
\end{tabular}

H-90 


\section{NEVADA TEST SITE RADIATION PROTECTION PROGRAM}

\section{APPENDIX H}

COMPLIANCE DEMONSTRATION TABLE

\begin{tabular}{|c|c|c|c|c|c|c|c|c|}
\hline \multirow[t]{2}{*}{10 CFR 835} & $\begin{array}{c}\text { NV/YMP RCM } \\
\text { Rev } 5 \text { and } \\
\text { NTS RPP } \\
\text { Revision } 0 \\
\end{array}$ & $\begin{array}{c}\text { NSTec } \\
\text { Appendix A }\end{array}$ & $\begin{array}{c}\text { LLNL } \\
\text { Appendix B }\end{array}$ & $\begin{array}{c}\text { LANL } \\
\text { Appendix C }\end{array}$ & $\begin{array}{c}\text { SNL } \\
\text { Appendix D }\end{array}$ & $\begin{array}{c}\text { SNJV } \\
\text { Appendix E }\end{array}$ & $\begin{array}{c}\text { DRI } \\
\text { Appendix F }\end{array}$ & $\begin{array}{c}\text { WSI } \\
\text { Appendix G }\end{array}$ \\
\hline & $\begin{array}{l}\text { Implementation } \\
\text { Reference }\end{array}$ & $\begin{array}{l}\text { Implementation } \\
\text { Reference }\end{array}$ & $\begin{array}{l}\text { Implementation } \\
\text { Reference }\end{array}$ & $\begin{array}{l}\text { Implementation } \\
\text { Reference }\end{array}$ & $\begin{array}{l}\text { Implementation } \\
\text { Reference }\end{array}$ & $\begin{array}{l}\text { Implementation } \\
\text { Reference }\end{array}$ & $\begin{array}{l}\text { Implementation } \\
\text { Reference }\end{array}$ & $\begin{array}{l}\text { Implementation } \\
\text { Reference }\end{array}$ \\
\hline
\end{tabular}

\section{calibration performed} on instruments and equipment as required by $\S 835.401(b)$.

\section{Calibration}

records for fixed,

portable and

laboratory

radiation-

measuring

equipment and

individual

monitoring

devices shall be

maintained and

include

frequencies,

method, dates,

personnel,

training, and

traceability of

calibration

sources to

National Institute

of Standards and

Technology (see

Article 562.1) or

other acceptable

standards.

\section{NV/YMP RCM}

761.3.

Maintenance

histories,

corrective

actions taken,

and calibration

\section{Calibration}

records for fixed,

portable and

laboratory

radiation-

measuring

equipment and

individual

monitoring

devices shall be

maintained and

include

frequencies,

method, dates,

personnel,

training, and

traceability of

calibration

sources to

National Institute

of Standards and

Technology (see

Article 562.1) or

other acceptable

standards.

\section{NV/YMP RCM}

761.3.

Maintenance

histories,

corrective

actions taken,

and calibration instrument

calibration

services for the

NTS and

maintains the

records of

radiological

survey

instrument

calibrations

required by

835.401(b).

\section{LANL/NTS \\ expertise of the}

Radiological

Control Program.

The NTS RSPC

provides

instrument

calibration

services for the

NTS and

maintains the

records of

radiological

survey

instrument

calibrations in

accordance with

10 CFR 835.
RSPC to perform

radiological

monitoring in the

workplace,

personnel

monitoring,

release of

materials and

equipment, and

maintenance and

calibration of

instruments and

individual

monitoring

devices.

Records

generated in

performing these

services are

retained by the

RSPC. SNL-NV

retains summary

reports provided

by the RSPC

following

radiological

activities. generated for

SNJV by the

RSPC are

maintained by

the RSPC.

the RSPC.

the RSPC to
perform
radiological
monitoring in the
workplace,
personnel
monitoring,
release of
materials and
equipment, and
maintenance and
calibration of
instruments and
individual
monitoring
devices.
Records
generated in
performing these
services are
retained by the
RSPC. DRI
retains summary
reports provided
by the RSPC
following
radiological
activities.

he RSP to

WSI/NV does not

have radiation

measuring

instruments or

equipment. 


\section{NEVADA TEST SITE RADIATION PROTECTION PROGRAM}

\section{APPENDIX H}

COMPLIANCE DEMONSTRATION TABLE

\begin{tabular}{|c|c|c|c|c|c|c|c|c|}
\hline \multirow[t]{2}{*}{10 CFR 835} & $\begin{array}{c}\text { NV/YMP RCM } \\
\text { Rev } 5 \text { and } \\
\text { NTS RPP } \\
\text { Revision } 0 \\
\end{array}$ & $\begin{array}{c}\text { NSTec } \\
\text { Appendix A }\end{array}$ & $\begin{array}{c}\text { LLNL } \\
\text { Appendix B }\end{array}$ & $\begin{array}{c}\text { LANL } \\
\text { Appendix C }\end{array}$ & $\begin{array}{c}\text { SNL } \\
\text { Appendix D }\end{array}$ & $\begin{array}{c}\text { SNJV } \\
\text { Appendix E }\end{array}$ & $\begin{array}{c}\text { DRI } \\
\text { Appendix F }\end{array}$ & $\begin{array}{c}\text { WSI } \\
\text { Appendix G }\end{array}$ \\
\hline & $\begin{array}{l}\text { Implementation } \\
\text { Reference }\end{array}$ & $\begin{array}{l}\text { Implementation } \\
\text { Reference }\end{array}$ & $\begin{array}{l}\text { Implementation } \\
\text { Reference }\end{array}$ & $\begin{array}{l}\text { Implementation } \\
\text { Reference }\end{array}$ & $\begin{array}{l}\text { Implementation } \\
\text { Reference }\end{array}$ & $\begin{array}{l}\text { Implementation } \\
\text { Reference }\end{array}$ & $\begin{array}{l}\text { Implementation } \\
\text { Reference }\end{array}$ & $\begin{array}{l}\text { Implementation } \\
\text { Reference }\end{array}$ \\
\hline
\end{tabular}

\begin{tabular}{|c|c|c|c|c|c|c|c|c|}
\hline & $\begin{array}{l}\text { results for each } \\
\text { instrument shall } \\
\text { be created and } \\
\text { retained. }\end{array}$ & $\begin{array}{l}\text { results for each } \\
\text { instrument shall } \\
\text { be created and } \\
\text { retained. }\end{array}$ & & & & & & \\
\hline $\begin{array}{l}835.704 \\
\text { Administrative } \\
\text { Records. } \\
\text { 704(a) Training } \\
\text { records shall be } \\
\text { maintained, as } \\
\text { necessary, to } \\
\text { demonstrate } \\
\text { compliance with } \\
\text { \$35.901. }\end{array}$ & $\begin{array}{l}\text { NV/YMP RCM } \\
725.1 .01 . \\
\text { Records of } \\
\text { training and } \\
\text { qualification in } \\
\text { radiological } \\
\text { control shall be } \\
\text { maintained to } \\
\text { demonstrate that } \\
\text { a person } \\
\text { received } \\
\text { appropriate } \\
\text { information to } \\
\text { perform the work } \\
\text { assignment in a } \\
\text { safe manner. }\end{array}$ & $\begin{array}{l}\text { NV/YMP RCM } \\
725.1 .01 \text {. } \\
\text { Records of } \\
\text { training and } \\
\text { qualification in } \\
\text { radiological } \\
\text { control shall be } \\
\text { maintained to } \\
\text { demonstrate that } \\
\text { a person } \\
\text { received } \\
\text { appropriate } \\
\text { information to } \\
\text { perform the work } \\
\text { assignment in a } \\
\text { safe manner. }\end{array}$ & $\begin{array}{l}\text { Radiological } \\
\text { training is } \\
\text { performed and } \\
\text { documented by } \\
\text { LLNL Training } \\
\text { Office or by the } \\
\text { NTS RSPC. }\end{array}$ & $\begin{array}{l}\text { This is outside } \\
\text { the scope of the } \\
\text { LANL/NTS } \\
\text { Radiological } \\
\text { Control Program. } \\
\text { This radiological } \\
\text { training is } \\
\text { performed and } \\
\text { documented by } \\
\text { LANL Central } \\
\text { Training - } \\
\text { Environment, } \\
\text { Safety, and } \\
\text { Health (CT-ESH) } \\
\text { in Los Alamos or } \\
\text { by the NTS } \\
\text { RSPC. }\end{array}$ & $\begin{array}{l}\text { Training records } \\
\text { for SNL-NV } \\
\text { personnel shall } \\
\text { be maintained by } \\
\text { the organization } \\
\text { providing the } \\
\text { training. }\end{array}$ & $\begin{array}{l}\text { Same as Column } \\
3 \text { and Records } \\
\text { generated for } \\
\text { SNJV by the } \\
\text { RSPC are } \\
\text { maintained by } \\
\text { the RSPC. }\end{array}$ & $\begin{array}{l}\text { Training records } \\
\text { for DRI } \\
\text { personnel shall } \\
\text { be maintained by } \\
\text { the organization } \\
\text { providing the } \\
\text { training. }\end{array}$ & $\begin{array}{l}\text { Training records } \\
\text { for WSI shall be } \\
\text { maintained by } \\
\text { the organization } \\
\text { providing the } \\
\text { training. }\end{array}$ \\
\hline $\begin{array}{l}704(\mathrm{~b}) \text { Actions taken } \\
\text { to maintain } \\
\text { occupational } \\
\text { exposures as low as } \\
\text { reasonably } \\
\text { achievable, including } \\
\text { the actions required } \\
\text { for this purpose by } \\
\S 835.101 \text {, as well as } \\
\text { facility design and } \\
\text { control actions } \\
\text { required by }\end{array}$ & $\begin{array}{l}\text { NV/YMP RCM } \\
712.1 \text {. d. A } \\
\text { radiological } \\
\text { records } \\
\text { management } \\
\text { program shall be } \\
\text { established by } \\
\text { each NNSA/NSO } \\
\text { and YMORD TO. } \\
\text { This program } \\
\text { shall ensure that } \\
\text { auditable records }\end{array}$ & $\begin{array}{l}\text { Revise: NV/YMP } \\
\text { RCM 712.1. d. } \\
\text { A radiological } \\
\text { records } \\
\text { management } \\
\text { program shall be } \\
\text { established by } \\
\text { each NNSA/NSO } \\
\text { and OCRWM } \\
\text { TO. This } \\
\text { program shall } \\
\text { ensure that }\end{array}$ & $\begin{array}{l}\text { The records } \\
\text { generated for the } \\
\text { NTS Contractor's } \\
\text { Sitewide ALARA } \\
\text { Committee } \\
\text { (SWAC) shall be } \\
\text { maintained by } \\
\text { the RSPC. }\end{array}$ & $\begin{array}{l}\text { ALARA design } \\
\text { reviews are } \\
\text { outside the } \\
\text { scope of the } \\
\text { LANL/NTS } \\
\text { Radiological } \\
\text { Control Program. } \\
\text { The LANL/RP-3 } \\
\text { Radiological } \\
\text { Engineering } \\
\text { Team performs } \\
\text { and documents }\end{array}$ & $\begin{array}{l}\text { The records } \\
\text { generated for the } \\
\text { NTS Contractor's } \\
\text { Sitewide ALARA } \\
\text { Committee } \\
\text { (SWAC) shall be } \\
\text { maintained by } \\
\text { the RSPC. }\end{array}$ & $\begin{array}{l}\text { The records } \\
\text { generated for the } \\
\text { NTS Contractor's } \\
\text { Sitewide ALARA } \\
\text { Committee } \\
\text { (SWAC) shall be } \\
\text { maintained by } \\
\text { the RSPC. }\end{array}$ & $\begin{array}{l}\text { Not applicable to } \\
\text { DRI. Facility } \\
\text { design and } \\
\text { ALARA review } \\
\text { are outside the } \\
\text { scope of DRI } \\
\text { NTS activities. } \\
\\
\text { The records } \\
\text { generated for the } \\
\text { NTS Contractor's } \\
\text { SWAC shall be } \\
\end{array}$ & $\begin{array}{l}\text { The records } \\
\text { generated for the } \\
\text { NTS Contractor's } \\
\text { Sitewide ALARA } \\
\text { Committee } \\
\text { (SWAC) shall be } \\
\text { maintained by } \\
\text { the RSPC. }\end{array}$ \\
\hline
\end{tabular}

$$
\text { H-92 }
$$




\section{NEVADA TEST SITE RADIATION PROTECTION PROGRAM}

\section{APPENDIX H}

COMPLIANCE DEMONSTRATION TABLE

\begin{tabular}{|c|c|c|c|c|c|c|c|c|}
\hline \multirow[t]{2}{*}{10 CFR 835} & $\begin{array}{l}\text { NV/YMP RCM } \\
\text { Rev } 5 \text { and } \\
\text { NTS RPP } \\
\text { Revision } 0 \\
\end{array}$ & $\begin{array}{c}\text { NSTec } \\
\text { Appendix A }\end{array}$ & $\begin{array}{c}\text { LLNL } \\
\text { Appendix B }\end{array}$ & $\begin{array}{c}\text { LANL } \\
\text { Appendix C }\end{array}$ & $\begin{array}{c}\text { SNL } \\
\text { Appendix D }\end{array}$ & $\begin{array}{c}\text { SNJV } \\
\text { Appendix E }\end{array}$ & $\begin{array}{c}\text { DRI } \\
\text { Appendix F }\end{array}$ & $\begin{array}{c}\text { WSI } \\
\text { Appendix G }\end{array}$ \\
\hline & $\begin{array}{l}\text { Implementation } \\
\text { Reference }\end{array}$ & $\begin{array}{l}\text { Implementation } \\
\text { Reference }\end{array}$ & $\begin{array}{l}\text { Implementation } \\
\text { Reference }\end{array}$ & $\begin{array}{l}\text { Implementation } \\
\text { Reference }\end{array}$ & $\begin{array}{l}\text { Implementation } \\
\text { Reference }\end{array}$ & $\begin{array}{l}\text { Implementation } \\
\text { Reference }\end{array}$ & $\begin{array}{l}\text { Implementation } \\
\text { Reference }\end{array}$ & $\begin{array}{c}\text { Implementation } \\
\text { Reference }\end{array}$ \\
\hline
\end{tabular}

\begin{tabular}{|c|c|c|c|c|c|c|c|c|}
\hline $\begin{array}{l}\text { \$835.1001, } \\
835.1002, \text { and } \\
\text { 835.1003, shall be } \\
\text { documented. }\end{array}$ & $\begin{array}{l}\text { and reports are } \\
\text { controlled } \\
\text { through the } \\
\text { stages of } \\
\text { creation, } \\
\text { distribution, use, } \\
\text { arrangement, } \\
\text { storage, retrieval, } \\
\text { media } \\
\text { conversion (if } \\
\text { applicable), and } \\
\text { disposition. The } \\
\text { records } \\
\text { management } \\
\text { program shall } \\
\text { include items a } \\
\text { through k below, } \\
\text { and should } \\
\text { include the } \\
\text { remaining items: } \\
\text { d. ALARA } \\
\text { records. } \\
\text { The records } \\
\text { generated for the } \\
\text { NTS Contractor's } \\
\text { Sitewide ALARA } \\
\text { Committee } \\
\text { (SWAC) shall be } \\
\text { maintained by } \\
\text { NSTec. }\end{array}$ & $\begin{array}{l}\text { auditable records } \\
\text { and reports are } \\
\text { controlled } \\
\text { through the } \\
\text { stages of } \\
\text { creation, } \\
\text { distribution, use, } \\
\text { arrangement, } \\
\text { storage, retrieval, } \\
\text { media } \\
\text { conversion (if } \\
\text { applicable), and } \\
\text { disposition. The } \\
\text { records } \\
\text { management } \\
\text { program shall } \\
\text { include items a } \\
\text { through k below, } \\
\text { and should } \\
\text { include the } \\
\text { remaining items: } \\
\text { d. ALARA } \\
\text { records. } \\
\text { The records } \\
\text { generated for the } \\
\text { NTS Contractor's } \\
\text { Sitewide ALARA } \\
\text { Committee } \\
\text { (SWAC) shall be } \\
\text { maintained by } \\
\text { NSTec. }\end{array}$ & & $\begin{array}{l}\text { the ALARA } \\
\text { review of the } \\
\text { design of new } \\
\text { LANL/NTS } \\
\text { facilities or the } \\
\text { modification of } \\
\text { existing } \\
\text { LANL/NTS } \\
\text { facilities. } \\
\text { LANL/NTS } \\
\text { performs and } \\
\text { documents } \\
\text { ALARA reviews } \\
\text { of radiological } \\
\text { jobs. } \\
\text { The records } \\
\text { generated for the } \\
\text { NTS Contractor's } \\
\text { Sitewide ALARA } \\
\text { Committee } \\
\text { (SWAC) shall be } \\
\text { maintained by } \\
\text { the RSPC. }\end{array}$ & & & $\begin{array}{l}\text { maintained by } \\
\text { the RSPC. }\end{array}$ & \\
\hline $\begin{array}{l}704(\mathrm{c}) \text { Records shall } \\
\text { be maintained to }\end{array}$ & $\begin{array}{l}\text { NV/YMP RCM } \\
\text { 712.1.03.k. }\end{array}$ & $\begin{array}{l}\text { NV/YMP RCM } \\
712.1 .03 . \mathrm{k} . \\
\end{array}$ & $\begin{array}{l}\text { Same as Column } \\
3\end{array}$ & $\begin{array}{l}\text { Same as Column } \\
3\end{array}$ & $\begin{array}{l}\text { SNL-NV will } \\
\text { participate in the }\end{array}$ & $\begin{array}{l}\text { Same as Column } \\
3\end{array}$ & $\begin{array}{l}\text { Cross Reference } \\
\text { NV/YMP RCM } \\
\end{array}$ & $\begin{array}{l}\text { Same as Column } \\
3\end{array}$ \\
\hline
\end{tabular}




\section{NEVADA TEST SITE RADIATION PROTECTION PROGRAM}

\section{APPENDIX H}

COMPLIANCE DEMONSTRATION TABLE

\begin{tabular}{|c|c|c|c||c||c||c||c||c|}
\hline \multirow{2}{*}{ 10 CFR 835 } & $\begin{array}{c}\text { NV/YMP RCM } \\
\text { Rev 5 and } \\
\text { NTS RPP } \\
\text { Revision 0 }\end{array}$ & Appendix A & Appendix B & Appendix C & Appendix D & SNJV \\
\cline { 2 - 7 } & $\begin{array}{c}\text { Implementation } \\
\text { Reference }\end{array}$ & $\begin{array}{c}\text { Implementation } \\
\text { Reference }\end{array}$ & $\begin{array}{c}\text { Implementation } \\
\text { Reference }\end{array}$ & $\begin{array}{c}\text { Implementation } \\
\text { Reference }\end{array}$ & $\begin{array}{c}\text { Implementation } \\
\text { Reference }\end{array}$ & $\begin{array}{c}\text { Implementation } \\
\text { Reference }\end{array}$ & $\begin{array}{c}\text { Implementation } \\
\text { Reference }\end{array}$ & $\begin{array}{c}\text { Implementation } \\
\text { Reference }\end{array}$ \\
\hline
\end{tabular}

\begin{tabular}{|c|c|c|c|c|c|c|c|c|}
\hline $\begin{array}{l}\text { document the results } \\
\text { of internal audits and } \\
\text { other reviews of } \\
\text { program content and } \\
\text { implementation. }\end{array}$ & $\begin{array}{l}\text { The records } \\
\text { management } \\
\text { program shall } \\
\text { include items a } \\
\text { through k below, } \\
\text { and should } \\
\text { include the } \\
\text { remaining items: } \\
\text { k. Records that } \\
\text { document the } \\
\text { results of internal } \\
\text { audits, } \\
\text { assessments, } \\
\text { and other } \\
\text { reviews of } \\
\text { program content } \\
\text { and } \\
\text { implementation. }\end{array}$ & $\begin{array}{l}\text { The records } \\
\text { management } \\
\text { program shall } \\
\text { include items a } \\
\text { through k below, } \\
\text { and should } \\
\text { include the } \\
\text { remaining items: } \\
\text { k. Records that } \\
\text { document the } \\
\text { results of internal } \\
\text { audits, } \\
\text { assessments, } \\
\text { and other } \\
\text { reviews of } \\
\text { program content } \\
\text { and } \\
\text { implementation. }\end{array}$ & & & $\begin{array}{l}\text { NTS RCM } \\
\text { internal audit } \\
\text { program. } \\
\text { Records will be } \\
\text { retained by the } \\
\text { SNL-NV ES\&H } \\
\text { representative. }\end{array}$ & & $\begin{array}{l}712.1 .03 . k \\
\text { DRI will } \\
\text { participate in the } \\
\text { NTS RCM } \\
\text { internal audit } \\
\text { program. The } \\
\text { RSPC will } \\
\text { maintain the } \\
\text { original copy of } \\
\text { these } \\
\text { assessments. } \\
\text { Copies received } \\
\text { by DRI will be } \\
\text { retained by the } \\
\text { DRI ES\&H office } \\
\text { for a minimum of } \\
\text { three years after } \\
\text { each } \\
\text { assessment } \\
\text { cycle has been } \\
\text { completed. }\end{array}$ & \\
\hline $\begin{array}{l}704(d) \text { Written } \\
\text { declarations of } \\
\text { pregnancy, including } \\
\text { the estimated date of } \\
\text { conception, and } \\
\text { revocations of } \\
\text { declarations of } \\
\text { pregnancy shall be } \\
\text { maintained. }\end{array}$ & $\begin{array}{l}\text { NV/YMP RCM } \\
723.2 \text {. Written } \\
\text { declaration of } \\
\text { pregnancy, } \\
\text { including the } \\
\text { estimated date of } \\
\text { conception, and } \\
\text { revocations of } \\
\text { declaration of } \\
\text { pregnancy shall } \\
\text { be maintained. }\end{array}$ & $\begin{array}{l}\text { NV/YMP RCM } \\
723.2 \text {. Written } \\
\text { declaration of } \\
\text { pregnancy, } \\
\text { including the } \\
\text { estimated date of } \\
\text { conception, and } \\
\text { revocations of } \\
\text { declaration of } \\
\text { pregnancy shall } \\
\text { be maintained. }\end{array}$ & $\begin{array}{l}\text { Written } \\
\text { declarations of } \\
\text { pregnancy are } \\
\text { maintained by } \\
\text { LLNL } \\
\text { Occupational } \\
\text { Medicine in } \\
\text { Livermore. }\end{array}$ & $\begin{array}{l}\text { This is outside } \\
\text { the scope of the } \\
\text { LANL/NTS } \\
\text { Radiological } \\
\text { Control Program. } \\
\text { Written } \\
\text { declarations of } \\
\text { pregnancy are } \\
\text { maintained by } \\
\text { LANL } \\
\text { Occupational } \\
\text { Medicine in Los } \\
\end{array}$ & $\begin{array}{l}\text { These records } \\
\text { will be } \\
\text { maintained by } \\
\text { Albuquerque } \\
\text { External } \\
\text { Dosimetry } \\
\text { Section. }\end{array}$ & $\begin{array}{l}\text { These records } \\
\text { are generated } \\
\text { within SNJV, line } \\
\text { management is } \\
\text { notified, and a } \\
\text { copy is } \\
\text { forwarded to } \\
\text { SNJV human } \\
\text { resources. The } \\
\text { original } \\
\text { declaration is } \\
\text { forwarded to the }\end{array}$ & $\begin{array}{l}\text { These records } \\
\text { are maintained } \\
\text { by Business } \\
\text { Center "North" } \\
\text { Risk } \\
\text { Management. }\end{array}$ & $\begin{array}{l}\text { Same as Column } \\
3\end{array}$ \\
\hline
\end{tabular}

H-94 


\section{NEVADA TEST SITE RADIATION PROTECTION PROGRAM}

\section{APPENDIX H}

COMPLIANCE DEMONSTRATION TABLE

\begin{tabular}{|c|c|c|c||c||c||c||c||c|}
\hline \multirow{2}{*}{ 10 CFR 835 } & $\begin{array}{c}\text { NV/YMP RCM } \\
\text { Rev 5 and } \\
\text { NTS RPP } \\
\text { Revision 0 }\end{array}$ & Appendix A & Appendix B & Appendix C & Appendix D & SNJV \\
\cline { 2 - 7 } & $\begin{array}{c}\text { Implementation } \\
\text { Reference }\end{array}$ & $\begin{array}{c}\text { Implementation } \\
\text { Reference }\end{array}$ & $\begin{array}{c}\text { Implementation } \\
\text { Reference }\end{array}$ & $\begin{array}{c}\text { Implementation } \\
\text { Reference }\end{array}$ & $\begin{array}{c}\text { Implementation } \\
\text { Reference }\end{array}$ & $\begin{array}{c}\text { Implementation } \\
\text { Reference }\end{array}$ & $\begin{array}{c}\text { Implementation } \\
\text { Reference }\end{array}$ & $\begin{array}{c}\text { Implementation } \\
\text { Reference }\end{array}$ \\
\hline
\end{tabular}

\begin{tabular}{|c|c|c|c|c|c|c|c|c|}
\hline & & & & Alamos. & & $\begin{array}{l}\text { RSPC as a } \\
\text { dosimetry record. }\end{array}$ & & \\
\hline $\begin{array}{l}704(e) \text { Changes in } \\
\text { equipment, } \\
\text { techniques, and } \\
\text { procedures used for } \\
\text { monitoring shall be } \\
\text { documented. }\end{array}$ & $\begin{array}{l}\text { NV/YMP RCM } \\
551.3 \text {. The RCO } \\
\text { shall document } \\
\text { changes in } \\
\text { equipment, } \\
\text { techniques, and } \\
\text { procedures used } \\
\text { for monitoring. }\end{array}$ & $\begin{array}{l}\text { NV/YMP RCM } \\
551.3 \text {. The RCO } \\
\text { shall document } \\
\text { changes in } \\
\text { equipment, } \\
\text { techniques, and } \\
\text { procedures used } \\
\text { for monitoring. }\end{array}$ & $\begin{array}{l}\text { Same as Column } \\
3\end{array}$ & $\begin{array}{l}\text { Same as Column } \\
3\end{array}$ & $\begin{array}{l}\text { This service is } \\
\text { provided to } \\
\text { SNL-NV by the } \\
\text { RSPC. }\end{array}$ & $\begin{array}{l}\text { Same as Column } \\
3\end{array}$ & $\begin{array}{l}\text { Not applicable to } \\
\text { DRI operations. } \\
\text { This service is } \\
\text { provided to DRI } \\
\text { by the RSPC. }\end{array}$ & $\begin{array}{l}\text { Not applicable to } \\
\text { WSI/NV } \\
\text { operations. By } \\
\text { written } \\
\text { agreement, } \\
\text { monitoring is } \\
\text { provided by the } \\
\text { RSPC. The } \\
\text { RSPC is } \\
\text { responsible for } \\
\text { documenting } \\
\text { changes in } \\
\text { equipment, } \\
\text { techniques, and } \\
\text { procedures used } \\
\text { for monitoring. }\end{array}$ \\
\hline $\begin{array}{l}704(f) \text { Records shall } \\
\text { be maintained as } \\
\text { necessary to } \\
\text { demonstrate } \\
\text { compliance with the } \\
\text { requirements of } \\
\S \S 835.1201 \text { and } \\
835.1202 \text { for sealed } \\
\text { radioactive source } \\
\text { control, inventory, and } \\
\text { source leak tests. }\end{array}$ & $\begin{array}{l}\text { NV/YMP RCM } \\
755.01 \text {. Records } \\
\text { shall be } \\
\text { maintained as } \\
\text { necessary to } \\
\text { demonstrate } \\
\text { compliance with } \\
\text { Article 431.01 } \\
\text { and 431.2.a-e. }\end{array}$ & $\begin{array}{l}\text { NV/YMP RCM } \\
755.01 \text {. Records } \\
\text { shall be } \\
\text { maintained as } \\
\text { necessary to } \\
\text { demonstrate } \\
\text { compliance with } \\
\text { Article 431.01 } \\
\text { and 431.2.a-e. }\end{array}$ & $\begin{array}{l}\text { Same as Column } \\
3\end{array}$ & $\begin{array}{l}\text { Same as Column } \\
3\end{array}$ & $\begin{array}{l}\text { Same as Column } \\
3\end{array}$ & $\begin{array}{l}\text { Same as Column } \\
3\end{array}$ & $\begin{array}{l}\text { Sealed sources } \\
\text { owned by DRI } \\
\text { are licensed for } \\
\text { use under the } \\
\text { UNR Radioactive } \\
\text { Material License } \\
\# 16-13-0003-07 . \\
\text { See UNR RSM } \\
\text { Procedure III: } \\
\text { Radiation Source } \\
\text { Control } \\
\text { Procedures, } \\
\text { Procedure VI: } \\
\text { Radiation Source } \\
\text { Storage } \\
\end{array}$ & $\begin{array}{l}\text { Not applicable to } \\
\text { WSI/NV. } \\
\text { WSI/NV is not a } \\
\text { sealed } \\
\text { radioactive } \\
\text { source custodian } \\
\text { and is not } \\
\text { responsible for } \\
\text { sealed } \\
\text { radioactive } \\
\text { source control, } \\
\text { inventory, or } \\
\text { source leak } \\
\text { tests. }\end{array}$ \\
\hline
\end{tabular}

H-95 


\section{NEVADA TEST SITE RADIATION PROTECTION PROGRAM}

\section{APPENDIX H}

COMPLIANCE DEMONSTRATION TABLE

\begin{tabular}{|c|c|c|c|c|c|c|c|c|}
\hline \multirow[t]{2}{*}{10 CFR 835} & $\begin{array}{c}\text { NV/YMP RCM } \\
\text { Rev } 5 \text { and } \\
\text { NTS RPP } \\
\text { Revision } 0 \\
\end{array}$ & $\begin{array}{c}\text { NSTec } \\
\text { Appendix A }\end{array}$ & $\begin{array}{c}\text { LLNL } \\
\text { Appendix B }\end{array}$ & $\begin{array}{c}\text { LANL } \\
\text { Appendix C }\end{array}$ & $\begin{array}{c}\text { SNL } \\
\text { Appendix D }\end{array}$ & $\begin{array}{c}\text { SNJV } \\
\text { Appendix E }\end{array}$ & $\begin{array}{c}\text { DRI } \\
\text { Appendix F }\end{array}$ & $\begin{array}{c}\text { WSI } \\
\text { Appendix G }\end{array}$ \\
\hline & $\begin{array}{l}\text { Implementation } \\
\text { Reference }\end{array}$ & $\begin{array}{l}\text { Implementation } \\
\text { Reference }\end{array}$ & $\begin{array}{l}\text { Implementation } \\
\text { Reference }\end{array}$ & $\begin{array}{l}\text { Implementation } \\
\text { Reference }\end{array}$ & $\begin{array}{l}\text { Implementation } \\
\text { Reference }\end{array}$ & $\begin{array}{l}\text { Implementation } \\
\text { Reference }\end{array}$ & $\begin{array}{l}\text { Implementation } \\
\text { Reference }\end{array}$ & $\begin{array}{l}\text { Implementation } \\
\text { Reference }\end{array}$ \\
\hline
\end{tabular}

\begin{tabular}{|c|c|c|c|c|c|c|c|c|}
\hline & & & & & & & \begin{tabular}{|l} 
Procedures, and \\
Procedure XII: \\
Leak Testing \\
Procedure. \\
The RSPC \\
provides leak \\
testing and \\
inventory \\
services for DRI \\
sealed sources \\
used and stored \\
at the NTS. \\
Copies of these \\
reports are \\
forwarded to the \\
UNR radiation \\
safety office \\
upon receipt.
\end{tabular} & \\
\hline $\begin{array}{l}\text { Subpart I-Reports to } \\
\text { Individuals } \\
\text { 835.801 Reports to } \\
\text { individuals } \\
801 \text { (a) Radiation } \\
\text { exposure data for } \\
\text { individuals monitored } \\
\text { in accordance with } \\
\S 835.402 \text { shall be } \\
\text { reported as specified } \\
\text { in this section. The } \\
\text { information shall } \\
\text { include the data } \\
\end{array}$ & $\begin{array}{l}\text { NV/YMP RCM } \\
781.1 . a \text {. Annual } \\
\text { and Current } \\
\text { Dosimetry } \\
\text { Reports } \\
\text { a. Personnel who } \\
\text { are monitored by } \\
\text { the personnel } \\
\text { dosimetry } \\
\text { program } \\
\text { according to } \\
10 \text { CFR } 835.402 \\
\text { shall be provided } \\
\text { an annual report } \\
\text { of their dose } \\
\end{array}$ & $\begin{array}{l}\text { NV/YMP RCM } \\
\text { 781.1.a. Annual } \\
\text { and Current } \\
\text { Dosimetry } \\
\text { Reports } \\
\text { a. Personnel who } \\
\text { are monitored by } \\
\text { the personnel } \\
\text { dosimetry } \\
\text { program } \\
\text { according to } \\
10 \text { CFR } 835.402 \\
\text { shall be provided } \\
\text { an annual report } \\
\text { of their dose } \\
\end{array}$ & $\begin{array}{l}\text { LLNL-N has an } \\
\text { agreement in } \\
\text { place where the } \\
\text { RSPC provides } \\
\text { dosimetry } \\
\text { information to } \\
\text { LLNL-Livermore, } \\
\text { and LLNL- } \\
\text { Livermore } \\
\text { generates all } \\
\text { reports to } \\
\text { individuals. }\end{array}$ & $\begin{array}{l}\text { This is outside } \\
\text { the scope of the } \\
\text { LANL/NTS } \\
\text { Radiological } \\
\text { Control Program. } \\
\text { The LANL RP-2 } \\
\text { Radiation } \\
\text { Information } \\
\text { Management } \\
\text { Team records } \\
\text { and maintains } \\
\text { LANL employee } \\
\text { dose } \\
\text { assessments } \\
\text { provided by the } \\
\end{array}$ & $\begin{array}{l}\text { This report shall } \\
\text { be provided to } \\
\text { SNL personnel } \\
\text { by the Dosimetry } \\
\text { Records } \\
\text { Organization in } \\
\text { Albuquerque. }\end{array}$ & $\begin{array}{l}\text { NV/YMP RCM } \\
141.3 . e . \text { The } \\
\text { RSPC shall } \\
\text { provide the } \\
\text { following: } \\
\text { e. External and } \\
\text { internal } \\
\text { dosimetry } \\
\text { services. } \\
\text { Records } \\
\text { generated by the } \\
\text { RSPC for } \\
\text { services } \\
\text { provided to } \\
\end{array}$ & $\begin{array}{l}\text { Dosimetry } \\
\text { services are } \\
\text { provided to DRI } \\
\text { by RSPC. The } \\
\text { RSPC mails } \\
\text { these reports to } \\
\text { the address of } \\
\text { record for the } \\
\text { monitored } \\
\text { individual. If no } \\
\text { address is on } \\
\text { file, the reports } \\
\text { are sent in } \\
\text { sealed } \\
\text { envelopes to DRI } \\
\end{array}$ & $\begin{array}{l}\text { By written } \\
\text { agreement, } \\
\text { dosimetry } \\
\text { services are } \\
\text { provided by the } \\
\text { RSPC. } \\
\text { By written } \\
\text { agreement, the } \\
\text { RSPC provides } \\
\text { dosimetry } \\
\text { services to } \\
\text { WSI/NV and } \\
\text { maintains } \\
\text { individual } \\
\end{array}$ \\
\hline
\end{tabular}

H-96 


\section{NEVADA TEST SITE RADIATION PROTECTION PROGRAM}

\section{APPENDIX H}

COMPLIANCE DEMONSTRATION TABLE

\begin{tabular}{|c|c|c|c||c||c||c||c||c|}
\hline \multirow{2}{*}{ 10 CFR 835 } & $\begin{array}{c}\text { NV/YMP RCM } \\
\text { Rev 5 and } \\
\text { NTS RPP } \\
\text { Revision 0 }\end{array}$ & Appendix A & Appendix B & Appendix C & Appendix D & SNJV \\
\cline { 2 - 7 } & $\begin{array}{c}\text { Implementation } \\
\text { Reference }\end{array}$ & $\begin{array}{c}\text { Implementation } \\
\text { Reference }\end{array}$ & $\begin{array}{c}\text { Implementation } \\
\text { Reference }\end{array}$ & $\begin{array}{c}\text { Implementation } \\
\text { Reference }\end{array}$ & $\begin{array}{c}\text { Implementation } \\
\text { Reference }\end{array}$ & $\begin{array}{c}\text { Implementation } \\
\text { Reference }\end{array}$ & $\begin{array}{c}\text { Implementation } \\
\text { Reference }\end{array}$ & $\begin{array}{c}\text { Implementation } \\
\text { Reference }\end{array}$ \\
\hline
\end{tabular}

\begin{tabular}{|c|c|c|c|c|c|c|c|c|}
\hline $\begin{array}{l}\text { required under } \\
\S 835.702 \text {. (c). Each } \\
\text { notification and report } \\
\text { shall be in writing and } \\
\text { include: the DOE site } \\
\text { or facility name, the } \\
\text { name of the individual, } \\
\text { and the individual's } \\
\text { social security } \\
\text { number, employee } \\
\text { number, or other } \\
\text { unique identification } \\
\text { number. }\end{array}$ & $\begin{array}{l}\text { including the } \\
\text { information } \\
\text { required by } 10 \\
\text { CFR } 835.702(\mathrm{c}) \text {. } \\
\text { NV/YMP RCM } \\
781.3 \text {. Reports } \\
\text { of individual } \\
\text { doses shall } \\
\text { include the site } \\
\text { or facility name, } \\
\text { the individual's } \\
\text { name and social } \\
\text { security number } \\
\text { or employee } \\
\text { number or other } \\
\text { unique } \\
\text { identifiers. }\end{array}$ & $\begin{array}{l}\text { including the } \\
\text { information } \\
\text { required by } 10 \\
\text { CFR } 835.702(\mathrm{c}) \text {. } \\
\text { NV/YMP RCM } \\
781.3 \text {. Reports } \\
\text { of individual } \\
\text { doses shall } \\
\text { include the site } \\
\text { or facility name, } \\
\text { the individual's } \\
\text { name and social } \\
\text { security number } \\
\text { or employee } \\
\text { number or other } \\
\text { unique } \\
\text { identifiers. }\end{array}$ & & $\begin{array}{l}\text { NTS RSPC. } \\
\text { The LANL/NTS } \\
\text { ESH-12 } \\
\text { Radiation } \\
\text { Information } \\
\text { Management } \\
\text { Team records } \\
\text { and maintains } \\
\text { LANL employee } \\
\text { dose } \\
\text { assessments. }\end{array}$ & & $\begin{array}{l}\text { SNJV are } \\
\text { maintained by } \\
\text { the RSPC. }\end{array}$ & $\begin{array}{l}\text { EH\&S who then } \\
\text { sends them on to } \\
\text { the individual. }\end{array}$ & records. \\
\hline $\begin{array}{l}801(\mathrm{~b}) \text { Upon the } \\
\text { request from an } \\
\text { individual terminating } \\
\text { employment, records } \\
\text { of exposure shall be } \\
\text { provided to that } \\
\text { individual as soon as } \\
\text { the data are available, } \\
\text { but not later than } 90 \\
\text { days after termination. } \\
\text { A written estimate of } \\
\text { the radiation dose } \\
\text { received by that } \\
\text { employee based on } \\
\text { available information }\end{array}$ & $\begin{array}{l}\text { NV/YMP RCM } \\
781.2 \text {. } \\
\text { Termination } \\
\text { Dosimetry } \\
\text { Reports. } \\
\text { Upon the request } \\
\text { from an } \\
\text { individual } \\
\text { terminating } \\
\text { employment, } \\
\text { records of } \\
\text { exposure shall } \\
\text { be provided to } \\
\text { that individual as } \\
\text { soon as the data }\end{array}$ & $\begin{array}{l}\text { NV/YMP RCM } \\
781.2 \text {. } \\
\text { Termination } \\
\text { Dosimetry } \\
\text { Reports. } \\
\text { Upon the request } \\
\text { from an } \\
\text { individual } \\
\text { terminating } \\
\text { employment, } \\
\text { records of } \\
\text { exposure shall } \\
\text { be provided to } \\
\text { that individual as } \\
\text { soon as the data }\end{array}$ & $\begin{array}{l}\text { LLNL-N has an } \\
\text { agreement in } \\
\text { place where the } \\
\text { RSPC provides } \\
\text { dosimetry } \\
\text { information to } \\
\text { LLNL-Livermore, } \\
\text { and LLNL- } \\
\text { Livermore } \\
\text { generates all } \\
\text { reports to } \\
\text { individuals. }\end{array}$ & $\begin{array}{l}\text { This is outside } \\
\text { the scope of the } \\
\text { LANL/NTS } \\
\text { Radiological } \\
\text { Control Program. } \\
\text { The LANL RP-2 } \\
\text { Radiation } \\
\text { Information } \\
\text { Management } \\
\text { Team records } \\
\text { and maintains } \\
\text { LANL employee } \\
\text { dose } \\
\text { assessments } \\
\text { provided by the }\end{array}$ & $\begin{array}{l}\text { This report shall } \\
\text { be provided to } \\
\text { SNL personnel } \\
\text { by the Dosimetry } \\
\text { Records } \\
\text { Organization in } \\
\text { Albuquerque. }\end{array}$ & $\begin{array}{l}\text { NV/YMP RCM } \\
\text { 141.3.e. The } \\
\text { RSPC shall } \\
\text { provide the } \\
\text { following: } \\
\text { e. External and } \\
\text { internal } \\
\text { dosimetry } \\
\text { services. } \\
\text { Records } \\
\text { generated by the } \\
\text { RSPC for } \\
\text { services } \\
\text { provided to }\end{array}$ & $\begin{array}{l}\text { Dosimetry } \\
\text { services are } \\
\text { provided to DRI } \\
\text { by RSPC. The } \\
\text { RSPC mails } \\
\text { these reports to } \\
\text { the address of } \\
\text { record for the } \\
\text { monitored } \\
\text { individual. If no } \\
\text { address is on } \\
\text { file, the reports } \\
\text { are sent in } \\
\text { sealed } \\
\text { envelopes to DRI }\end{array}$ & $\begin{array}{l}\text { By written } \\
\text { agreement, the } \\
\text { RSPC provides } \\
\text { dosimetry } \\
\text { services to } \\
\text { WSI/NV and } \\
\text { maintains } \\
\text { individual } \\
\text { records. }\end{array}$ \\
\hline
\end{tabular}

H-97 


\section{NEVADA TEST SITE RADIATION PROTECTION PROGRAM}

\section{APPENDIX H}

COMPLIANCE DEMONSTRATION TABLE

\begin{tabular}{|c|c|c|c||c||c||c||c||c|}
\hline \multirow{2}{*}{ 10 CFR 835 } & $\begin{array}{c}\text { NV/YMP RCM } \\
\text { Rev 5 and } \\
\text { NTS RPP } \\
\text { Revision 0 }\end{array}$ & Appendix A & Appendix B & Appendix C & Appendix D & SNJV \\
\cline { 2 - 7 } & $\begin{array}{c}\text { Implementation } \\
\text { Reference }\end{array}$ & $\begin{array}{c}\text { Implementation } \\
\text { Reference }\end{array}$ & $\begin{array}{c}\text { Implementation } \\
\text { Reference }\end{array}$ & $\begin{array}{c}\text { Implementation } \\
\text { Reference }\end{array}$ & $\begin{array}{c}\text { Implementation } \\
\text { Reference }\end{array}$ & $\begin{array}{c}\text { Implementation } \\
\text { Reference }\end{array}$ & $\begin{array}{c}\text { Implementation } \\
\text { Reference }\end{array}$ & $\begin{array}{c}\text { Implementation } \\
\text { Reference }\end{array}$ \\
\hline
\end{tabular}

\begin{tabular}{|c|c|c|c|c|c|c|c|c|}
\hline $\begin{array}{l}\text { shall be provided at } \\
\text { the time of termination, } \\
\text { if requested. }\end{array}$ & $\begin{array}{l}\text { are available, but } \\
\text { not later than } 90 \\
\text { days after } \\
\text { termination. A } \\
\text { written estimate } \\
\text { of the radiation } \\
\text { dose received by } \\
\text { that employee } \\
\text { based on } \\
\text { available } \\
\text { information shall } \\
\text { be provided at } \\
\text { the time of } \\
\text { termination, if } \\
\text { requested. } \\
\end{array}$ & $\begin{array}{l}\text { are available, but } \\
\text { not later than } 90 \\
\text { days after } \\
\text { termination. A } \\
\text { written estimate } \\
\text { of the radiation } \\
\text { dose received by } \\
\text { that employee } \\
\text { based on } \\
\text { available } \\
\text { information shall } \\
\text { be provided at } \\
\text { the time of } \\
\text { termination, if } \\
\text { requested. }\end{array}$ & & NTS RSPC. & & $\begin{array}{l}\text { SNJV are } \\
\text { maintained by } \\
\text { the RSPC. }\end{array}$ & $\begin{array}{l}\text { EH\&S who then } \\
\text { sends them on to } \\
\text { the individual. }\end{array}$ & \\
\hline $\begin{array}{l}801(\mathrm{c}) \text { Each DOE- or } \\
\text { DOE-contractor- } \\
\text { operated site or facility } \\
\text { shall, on an annual } \\
\text { basis, provide a } \\
\text { radiation dose report } \\
\text { to each individual } \\
\text { monitored during the } \\
\text { year at that site or } \\
\text { facility in accordance } \\
\text { with } \$ 835.402 \text {. }\end{array}$ & $\begin{array}{l}\text { NV/YMP RCM } \\
781.1 . a \text {. Annual } \\
\text { and Current } \\
\text { Dosimetry } \\
\text { Reports } \\
\text { a. Personnel who } \\
\text { are monitored by } \\
\text { the personnel } \\
\text { dosimetry } \\
\text { program } \\
\text { according to } \\
10 \text { CFR } 835.402 \\
\text { shall be provided } \\
\text { an annual report } \\
\text { of their dose } \\
\text { including the } \\
\text { information } \\
\text { required by } 10 \\
\end{array}$ & $\begin{array}{l}\text { NV/YMP RCM } \\
781.1 . a \text {. Annual } \\
\text { and Current } \\
\text { Dosimetry } \\
\text { Reports } \\
\text { a. Personnel who } \\
\text { are monitored by } \\
\text { the personnel } \\
\text { dosimetry } \\
\text { program } \\
\text { according to } \\
10 \text { CFR } 835.402 \\
\text { shall be provided } \\
\text { an annual report } \\
\text { of their dose } \\
\text { including the } \\
\text { information } \\
\text { required by } 10\end{array}$ & $\begin{array}{l}\text { LLNL-N has an } \\
\text { agreement in } \\
\text { place where the } \\
\text { RSPC provides } \\
\text { dosimetry } \\
\text { information to } \\
\text { LLNL-Livermore, } \\
\text { and LLNL- } \\
\text { Livermore } \\
\text { generates all } \\
\text { reports to } \\
\text { individuals. }\end{array}$ & $\begin{array}{l}\text { This is outside } \\
\text { the scope of the } \\
\text { LANL/NTS } \\
\text { Radiological } \\
\text { Control Program. } \\
\text { The LANL RP-2 } \\
\text { Radiation } \\
\text { Information } \\
\text { Management } \\
\text { Team records } \\
\text { and maintains } \\
\text { LANL employee } \\
\text { dose } \\
\text { assessments } \\
\text { provided by the } \\
\text { NTS RSPC. }\end{array}$ & $\begin{array}{l}\text { This report shall } \\
\text { be provided to } \\
\text { SNL personnel } \\
\text { by the Dosimetry } \\
\text { Records } \\
\text { Organization in } \\
\text { Albuquerque. }\end{array}$ & $\begin{array}{l}\text { RCM 141.3.e. } \\
\text { The RSPC shall } \\
\text { provide the } \\
\text { following: } \\
\text { (e) External and } \\
\text { internal } \\
\text { dosimetry } \\
\text { services. } \\
\text { Records } \\
\text { generated by the } \\
\text { RSPC for } \\
\text { services } \\
\text { provided to } \\
\text { SNJV are } \\
\text { maintained by } \\
\text { the RSPC. }\end{array}$ & $\begin{array}{l}\text { Dosimetry } \\
\text { services are } \\
\text { provided to DRI } \\
\text { by RSPC. The } \\
\text { RSPC mails } \\
\text { these reports to } \\
\text { the address of } \\
\text { record for the } \\
\text { monitored } \\
\text { individual. If no } \\
\text { address is on } \\
\text { file, the reports } \\
\text { are sent in } \\
\text { sealed } \\
\text { envelopes to DRI } \\
\text { EH\&S who then } \\
\text { sends them on to } \\
\text { the individual. }\end{array}$ & $\begin{array}{l}\text { By written } \\
\text { agreement, the } \\
\text { RSPC provides } \\
\text { dosimetry } \\
\text { services to } \\
\text { WSI/NV. }\end{array}$ \\
\hline
\end{tabular}




\section{NEVADA TEST SITE RADIATION PROTECTION PROGRAM}

\section{APPENDIX H}

COMPLIANCE DEMONSTRATION TABLE

\begin{tabular}{|c|c|c|c|c|c|c|c|c|}
\hline \multirow[t]{2}{*}{10 CFR 835} & $\begin{array}{c}\text { NV/YMP RCM } \\
\text { Rev } 5 \text { and } \\
\text { NTS RPP } \\
\text { Revision } 0 \\
\end{array}$ & $\begin{array}{c}\text { NSTec } \\
\text { Appendix A }\end{array}$ & $\begin{array}{c}\text { LLNL } \\
\text { Appendix B }\end{array}$ & $\begin{array}{c}\text { LANL } \\
\text { Appendix C }\end{array}$ & $\begin{array}{c}\text { SNL } \\
\text { Appendix D }\end{array}$ & $\begin{array}{c}\text { SNJV } \\
\text { Appendix E }\end{array}$ & $\begin{array}{c}\text { DRI } \\
\text { Appendix F }\end{array}$ & $\begin{array}{c}\text { WSI } \\
\text { Appendix G }\end{array}$ \\
\hline & $\begin{array}{l}\text { Implementation } \\
\text { Reference }\end{array}$ & $\begin{array}{l}\text { Implementation } \\
\text { Reference }\end{array}$ & $\begin{array}{l}\text { Implementation } \\
\text { Reference }\end{array}$ & $\begin{array}{l}\text { Implementation } \\
\text { Reference }\end{array}$ & $\begin{array}{l}\text { Implementation } \\
\text { Reference }\end{array}$ & $\begin{array}{l}\text { Implementation } \\
\text { Reference }\end{array}$ & $\begin{array}{l}\text { Implementation } \\
\text { Reference }\end{array}$ & $\begin{array}{l}\text { Implementation } \\
\text { Reference }\end{array}$ \\
\hline
\end{tabular}

\section{1(d) Detailed} information concerning any individual's exposure shall be made available to the individual upon request of that individual, consistent with the provisions of the Privacy Act ( 5 U.S.C. 552a).

\section{\begin{tabular}{|l||l|} 
CFR 835.702(c). & CFR 835.702(c). \\
\hline
\end{tabular}}

801(e) When a DOE contractor is required to report to the

Department, pursuant to Departmental requirements for occurrence reporting and processing, any exposure of an NV/YMP RCM

781.1.b. Annual and Current Dosimetry Reports

b. Detailed information concerning an individual's exposure shall be made available to that individual, upon request, consistent with the Privacy Act of 1974, which contains requirements to protect the privacy of individual records.

\begin{tabular}{||l||}
\hline CFR 835.702(c). \\
\hline NV/YMP RCM \\
781.1.b. Annual \\
and Current \\
Dosimetry \\
Reports \\
b. Detailed \\
information \\
concerning an \\
individual's \\
exposure shall \\
be made \\
available to that \\
individual, upon \\
request, \\
consistent with \\
the Privacy Act \\
of 1974, which \\
contains \\
requirements to \\
protect the \\
privacy of \\
individual \\
records. \\
\hline NV/YMP RCM \\
781.4. Reports \\
of individual \\
exposure to \\
radiation or \\
radioactive \\
material required \\
under DOE M \\
231.1-2, \\
\hline
\end{tabular}

NV/YMP RCM 781.4. Reports of individual exposure to radiation or radioactive material required under DOE M 231.1-2,

LLNL-N has an
agreement in place where the RSPC provides dosimetry information to LLNL-Livermore, and LLNLLivermore generates all reports to individuals.

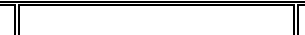

This is outside

the scope of the LANL/NTS

Radiological

Control Program.

The LANL RP-2

Radiation

Information

Management

Team records

and maintains

LANL employee

dose

assessments

provided by the

NTS RSPC.

\section{The requirement}

for a planned

special exposure

is outside the

scope of LLNL

activities. LLNL-

$\mathrm{N}$ has an

agreement in

place where the

\begin{tabular}{|l||}
\hline Provided by \\
Dosimetry \\
Records \\
Organization in \\
Albuquerque. \\
\hline \\
\\
\hline
\end{tabular}

RCM 141.3.e.

The RSPC shal

provide the

following:

(e) External and

internal

dosimetry

services.

Records

generated by the

RSPC for

services

provided to

SNJV are

maintained by

the RSPC.

\begin{tabular}{|c|c|}
\hline $\begin{array}{l}\text { Dosimetry } \\
\text { services are } \\
\text { provided to DRI } \\
\text { by RSPC. The } \\
\text { RSPC mails } \\
\text { these reports to } \\
\text { the address of } \\
\text { record for the } \\
\text { monitored } \\
\text { individual. If no } \\
\text { address is on } \\
\text { file, the reports } \\
\text { are sent in } \\
\text { sealed } \\
\text { envelopes to DRI } \\
\text { EH\&S, who then } \\
\text { sends them on to } \\
\text { the individual. }\end{array}$ & $\begin{array}{l}\text { Same as Column } \\
3\end{array}$ \\
\hline $\begin{array}{l}\text { NOTE: The } \\
\text { requirement for a } \\
\text { planned special } \\
\text { exposure is } \\
\text { outside the } \\
\text { scope of DRI's } \\
\text { NTS activities } \\
\text { and as such is } \\
\text { not applicable. }\end{array}$ & $\begin{array}{l}\text { Same as Column } \\
3\end{array}$ \\
\hline
\end{tabular}

Same as Column

LANL/NTS

Contram.

The requirement

is outside the
3

$$
\text { H-99 }
$$




\section{NEVADA TEST SITE RADIATION PROTECTION PROGRAM}

\section{APPENDIX H}

COMPLIANCE DEMONSTRATION TABLE

\begin{tabular}{|c|c|c|c||c||c||c||c||c|}
\hline \multirow{2}{*}{ 10 CFR 835 } & $\begin{array}{c}\text { NV/YMP RCM } \\
\text { Rev 5 and } \\
\text { NTS RPP } \\
\text { Revision 0 }\end{array}$ & Appendix A & Appendix B & Appendix C & Appendix D & SNJV \\
\cline { 2 - 7 } & $\begin{array}{c}\text { Implementation } \\
\text { Reference }\end{array}$ & $\begin{array}{c}\text { Implementation } \\
\text { Reference }\end{array}$ & $\begin{array}{c}\text { Implementation } \\
\text { Reference }\end{array}$ & $\begin{array}{c}\text { Implementation } \\
\text { Reference }\end{array}$ & $\begin{array}{c}\text { Implementation } \\
\text { Reference }\end{array}$ & $\begin{array}{c}\text { Implementation } \\
\text { Reference }\end{array}$ & $\begin{array}{c}\text { Implementation } \\
\text { Reference }\end{array}$ & $\begin{array}{c}\text { Implementation } \\
\text { Reference }\end{array}$ \\
\hline
\end{tabular}

\begin{tabular}{|c|c|c|c|c|c|c|c|c|}
\hline $\begin{array}{l}\text { individual to radiation } \\
\text { and/or radioactive } \\
\text { material, or planned } \\
\text { special exposure in } \\
\text { accordance with } \\
\S 835.204(e) \text {, the } \\
\text { contractor shall also } \\
\text { provide that individual } \\
\text { with a report on his or } \\
\text { her exposure data } \\
\text { included therein. Such } \\
\text { report shall be } \\
\text { transmitted at a time } \\
\text { not later than the } \\
\text { transmittal to the } \\
\text { Department. }\end{array}$ & $\begin{array}{l}\text { "Occurrence } \\
\text { Reporting and } \\
\text { Processing of } \\
\text { Operations } \\
\text { Information" shall } \\
\text { be submitted to } \\
\text { DOE or } \\
\text { NNSA/NSO } \\
\text { according to } \\
\text { departmental } \\
\text { occurrence } \\
\text { reporting } \\
\text { requirements. } \\
\text { Copies of the } \\
\text { individual dose } \\
\text { information } \\
\text { contained in } \\
\text { these reports } \\
\text { shall be provided } \\
\text { to the affected } \\
\text { individual at a } \\
\text { time not later } \\
\text { than transmittal } \\
\text { of the report to } \\
\text { the DOE or } \\
\text { NNSA/NSO. }\end{array}$ & $\begin{array}{l}\text { "Occurrence } \\
\text { Reporting and } \\
\text { Processing of } \\
\text { Operations } \\
\text { Information" shall } \\
\text { be submitted to } \\
\text { DOE or } \\
\text { NNSA/NSO } \\
\text { according to } \\
\text { departmental } \\
\text { occurrence } \\
\text { reporting } \\
\text { requirements. } \\
\text { Copies of the } \\
\text { individual dose } \\
\text { information } \\
\text { contained in } \\
\text { these reports } \\
\text { shall be provided } \\
\text { to the affected } \\
\text { individual at a } \\
\text { time not later } \\
\text { than transmittal } \\
\text { of the report to } \\
\text { the DOE or } \\
\text { NNSA/NSO. }\end{array}$ & $\begin{array}{l}\text { RSPC provides } \\
\text { dosimetry } \\
\text { information to } \\
\text { LLNL-Livermore, } \\
\text { and LLNL- } \\
\text { Livermore } \\
\text { generates all } \\
\text { reports to } \\
\text { individuals. }\end{array}$ & $\begin{array}{l}\text { scope of } \\
\text { LANL/NTS } \\
\text { activities. The } \\
\text { LANL RP-2 } \\
\text { Radiation } \\
\text { Information } \\
\text { Management } \\
\text { Team records } \\
\text { and maintains } \\
\text { LANL employee } \\
\text { dose } \\
\text { assessments } \\
\text { provided by the } \\
\text { NTS RSPC. }\end{array}$ & & & & \\
\hline $\begin{array}{l}\text { Subpart J-Radiation } \\
\text { Safety Training } \\
\text { 835.901 Radiation } \\
\text { Safety } \\
\text { Training. }\end{array}$ & $\begin{array}{l}\text { NV/YMP RCM } \\
621.01-02 . \\
\text { Individuals who } \\
\text { may enter } \\
\text { Controlled Areas } \\
\text { and encounter } \\
\text { radiological }\end{array}$ & $\begin{array}{l}\text { NV/YMP RCM } \\
621.01-02 . \\
\text { Individuals who } \\
\text { may enter } \\
\text { Controlled Areas } \\
\text { and encounter } \\
\text { radiological }\end{array}$ & $\begin{array}{l}\text { Same as Column } \\
3\end{array}$ & $\begin{array}{l}\text { Same as Column } \\
3\end{array}$ & $\begin{array}{l}\text { Same as Column } \\
3\end{array}$ & $\begin{array}{l}\text { Same as Column } \\
3\end{array}$ & $\begin{array}{l}\text { Cross reference } \\
\text { NV/YMP RCM } \\
621.01,621.02, \\
612.3 .02 . \\
\text { DRI is in } \\
\text { compliance with }\end{array}$ & $\begin{array}{l}\text { Same as Column } \\
3\end{array}$ \\
\hline
\end{tabular}

H-100 


\section{NEVADA TEST SITE RADIATION PROTECTION PROGRAM}

\section{APPENDIX H}

COMPLIANCE DEMONSTRATION TABLE

\begin{tabular}{|c|c|c|c||c||c||c||c||c|}
\hline \multirow{2}{*}{ 10 CFR 835 } & $\begin{array}{c}\text { NV/YMP RCM } \\
\text { Rev 5 and } \\
\text { NTS RPP } \\
\text { Revision 0 }\end{array}$ & Appendix A & Appendix B & Appendix C & Appendix D & SNJV \\
\cline { 2 - 7 } & $\begin{array}{c}\text { Implementation } \\
\text { Reference }\end{array}$ & $\begin{array}{c}\text { Implementation } \\
\text { Reference }\end{array}$ & $\begin{array}{c}\text { Implementation } \\
\text { Reference }\end{array}$ & $\begin{array}{c}\text { Implementation } \\
\text { Reference }\end{array}$ & $\begin{array}{c}\text { Implementation } \\
\text { Reference }\end{array}$ & $\begin{array}{c}\text { Implementation } \\
\text { Reference }\end{array}$ & $\begin{array}{c}\text { Implementation } \\
\text { Reference }\end{array}$ & $\begin{array}{c}\text { Implementation } \\
\text { Reference }\end{array}$ \\
\hline
\end{tabular}

\begin{tabular}{|c|c|c|c|c|c|c|c|c|}
\hline $\begin{array}{l}\text { 901(a) Each individual } \\
\text { shall complete } \\
\text { radiation safety } \\
\text { training on the topics } \\
\text { established at } \\
\text { §35.901(c) } \\
\text { commensurate with } \\
\text { the hazards in the } \\
\text { area and the required } \\
\text { controls: } \\
\text { (1) Before being } \\
\text { permitted unescorted } \\
\text { access to controlled } \\
\text { areas; and } \\
\text { (2) Before receiving } \\
\text { occupational dose } \\
\text { during access to } \\
\text { controlled areas at a } \\
\text { DOE site or facility. }\end{array}$ & $\begin{array}{l}\text { barriers, } \\
\text { postings, or } \\
\text { radioactive } \\
\text { materials shall } \\
\text { complete GERT } \\
\text { unless RW-I, } \\
\text { RW-II, or RCT } \\
\text { training is } \\
\text { current. This } \\
\text { training shall be } \\
\text { successfully } \\
\text { completed before } \\
\text { receiving } \\
\text { occupational } \\
\text { radiation dose. } \\
\text { NV/YMP RCM } \\
612.3 .02 . \\
\text { Documentation } \\
\text { of previous } \\
\text { training shall } \\
\text { include the } \\
\text { individual's } \\
\text { name, date of } \\
\text { training, topics } \\
\text { covered, and the } \\
\text { name of the } \\
\text { certifying official. }\end{array}$ & $\begin{array}{l}\text { barriers, } \\
\text { postings, or } \\
\text { radioactive } \\
\text { materials shall } \\
\text { complete GERT } \\
\text { unless RW-I, } \\
\text { RW-II, or RCT } \\
\text { training is } \\
\text { current. This } \\
\text { training shall be } \\
\text { successfully } \\
\text { completed before } \\
\text { receiving } \\
\text { occupational } \\
\text { radiation dose. } \\
\text { NV/YMP RCM } \\
612.3 .02 \text {. } \\
\text { Documentation } \\
\text { of previous } \\
\text { training shall } \\
\text { include the } \\
\text { individual's } \\
\text { name, date of } \\
\text { training, topics } \\
\text { covered, and the } \\
\text { name of the } \\
\text { certifying official. }\end{array}$ & & & & & $\begin{array}{l}\text { the training } \\
\text { requirement. } \\
\text { Except for } \\
\text { GERT, which is } \\
\text { done in-house } \\
\text { using an RSPC- } \\
\text { developed CBT, } \\
\text { training is } \\
\text { provided by the } \\
\text { RSPC. GERT } \\
\text { records are } \\
\text { submitted to the } \\
\text { RSPC, and with } \\
\text { the balance of } \\
\text { training } \\
\text { generated by } \\
\text { them, records } \\
\text { are maintained } \\
\text { by the RSPC. } \\
\text { Records } \\
\text { received by DRI } \\
\text { attendees are } \\
\text { entered into a } \\
\text { training data } \\
\text { base by the DRI } \\
\text { Classified and } \\
\text { Unclassified } \\
\text { Security Officer } \\
\text { or designee. }\end{array}$ & \\
\hline $\begin{array}{l}901(\mathrm{~b}) \text { Each individual } \\
\text { shall demonstrate } \\
\text { knowledge of the } \\
\text { radiation safety }\end{array}$ & $\begin{array}{l}\text { NV/YMP RCM } \\
613.1 .01 . \\
\text { Examinations for } \\
\text { RW-I and RW-II } \\
\end{array}$ & $\begin{array}{l}\text { NV/YMP RCM } \\
613.1 .01 . \\
\text { Examinations for } \\
\text { RW-I and RW-II } \\
\end{array}$ & $\begin{array}{l}\text { Radiological } \\
\text { training is } \\
\text { performed and } \\
\text { documented by } \\
\end{array}$ & $\begin{array}{l}\text { This is outside } \\
\text { the scope of the } \\
\text { LANL/NTS } \\
\text { Radiological }\end{array}$ & $\begin{array}{l}\text { Same as Column } \\
3\end{array}$ & $\begin{array}{l}\text { Same as Column } \\
3\end{array}$ & $\begin{array}{l}\text { Cross reference } \\
\text { NV/YMP RCM } \\
613.1 .01, \\
631.1 . d, 631.1, \\
\end{array}$ & $\begin{array}{l}\text { Same as Column } \\
3\end{array}$ \\
\hline
\end{tabular}

H-101 


\section{NEVADA TEST SITE RADIATION PROTECTION PROGRAM}

\section{APPENDIX H}

COMPLIANCE DEMONSTRATION TABLE

\begin{tabular}{|c|c|c|c|c|c|c|c|c|}
\hline \multirow[t]{2}{*}{10 CFR 835} & $\begin{array}{c}\text { NV/YMP RCM } \\
\text { Rev } 5 \text { and } \\
\text { NTS RPP } \\
\text { Revision } 0 \\
\end{array}$ & $\begin{array}{c}\text { NSTec } \\
\text { Appendix A }\end{array}$ & $\begin{array}{c}\text { LLNL } \\
\text { Appendix B }\end{array}$ & $\begin{array}{c}\text { LANL } \\
\text { Appendix C }\end{array}$ & $\begin{array}{c}\text { SNL } \\
\text { Appendix D }\end{array}$ & $\begin{array}{c}\text { SNJV } \\
\text { Appendix E }\end{array}$ & $\begin{array}{c}\text { DRI } \\
\text { Appendix F }\end{array}$ & $\begin{array}{c}\text { WSI } \\
\text { Appendix G }\end{array}$ \\
\hline & $\begin{array}{l}\text { Implementation } \\
\text { Reference }\end{array}$ & $\begin{array}{l}\text { Implementation } \\
\text { Reference }\end{array}$ & $\begin{array}{l}\text { Implementation } \\
\text { Reference }\end{array}$ & $\begin{array}{l}\text { Implementation } \\
\text { Reference }\end{array}$ & $\begin{array}{l}\text { Implementation } \\
\text { Reference }\end{array}$ & $\begin{array}{l}\text { Implementation } \\
\text { Reference }\end{array}$ & $\begin{array}{l}\text { Implementation } \\
\text { Reference }\end{array}$ & $\begin{array}{l}\text { Implementation } \\
\text { Reference }\end{array}$ \\
\hline
\end{tabular}

\begin{tabular}{|c|c|c|c|c|c|}
\hline $\begin{array}{l}\text { training topics } \\
\text { established in } \\
\S 835.901(\mathrm{c}) \text {, } \\
\text { commensurate with } \\
\text { the hazards in the } \\
\text { area and required } \\
\text { controls, by successful } \\
\text { completion of an } \\
\text { examination and } \\
\text { performance } \\
\text { demonstrations: } \\
\text { (1) Before being } \\
\text { permitted unescorted } \\
\text { access to radiological } \\
\text { areas; and } \\
\text { (2) Before performing } \\
\text { unescorted } \\
\text { assignments as a } \\
\text { radiological worker. }\end{array}$ & $\begin{array}{l}\text { training and RCT } \\
\text { qualification shall } \\
\text { be used to } \\
\text { demonstrate } \\
\text { knowledge of the } \\
\text { radiation safety } \\
\text { training topics } \\
\text { presented in the } \\
\text { course material. } \\
\text { NV/YMP RCM } \\
613.1 .04 . d \text {. The } \\
\text { examination } \\
\text { process should } \\
\text { require: } \\
\text { (d) In addition to } \\
\text { an examination, } \\
\text { RW-I, RW-II, and } \\
\text { RCT personnel } \\
\text { in training } \\
\text { classes shall be } \\
\text { required to } \\
\text { complete } \\
\text { performance } \\
\text { demonstrations } \\
\text { commensurate } \\
\text { with their duties. } \\
\text { NV/YMP RCM } \\
631.1 \text {. RW-I or } \\
\text { RW-II training is } \\
\text { required for } \\
\text { unescorted entry } \\
\text { into areas as }\end{array}$ & $\begin{array}{l}\text { training and RCT } \\
\text { qualification shall } \\
\text { be used to } \\
\text { demonstrate } \\
\text { knowledge of the } \\
\text { radiation safety } \\
\text { training topics } \\
\text { presented in the } \\
\text { course material. } \\
\text { NV/YMP RCM } \\
613.1 .04 \text {.d. The } \\
\text { examination } \\
\text { process should } \\
\text { require: } \\
\text { (d) In addition to } \\
\text { an examination, } \\
\text { RW-I, RW-II, and } \\
\text { RCT personnel } \\
\text { in training } \\
\text { classes shall be } \\
\text { required to } \\
\text { complete } \\
\text { performance } \\
\text { demonstrations } \\
\text { commensurate } \\
\text { with their duties. } \\
\text { NV/YMP RCM } \\
631.1 \text {. RW-I or } \\
\text { RW-II training is } \\
\text { required for } \\
\text { unescorted entry } \\
\text { into areas as }\end{array}$ & $\begin{array}{l}\text { LLNL Training } \\
\text { Office or by the } \\
\text { NTS RSPC. }\end{array}$ & $\begin{array}{l}\text { Control Program. } \\
\text { This radiological } \\
\text { training is } \\
\text { performed and } \\
\text { documented by } \\
\text { LANL CT-ESH in } \\
\text { Los Alamos or by } \\
\text { the NTS RSPC. }\end{array}$ & $\begin{array}{l}632.01 \text { and } \\
633.01 . \\
\text { DRI is in } \\
\text { compliance with } \\
\text { this training } \\
\text { requirement. } \\
\text { Except for } \\
\text { GERT, which is } \\
\text { done in-house } \\
\text { using an RSPC- } \\
\text { developed CBT, } \\
\text { training is } \\
\text { provided by the } \\
\text { RSPC. GERT } \\
\text { records are } \\
\text { submitted to the } \\
\text { RSPC, and with } \\
\text { the balance of } \\
\text { training } \\
\text { generated by } \\
\text { them, records } \\
\text { are maintained } \\
\text { by the RSPC. } \\
\text { Records } \\
\text { received by DRI } \\
\text { attendees are } \\
\text { entered into a } \\
\text { training data } \\
\text { base by the DRI } \\
\text { Classified and } \\
\text { Unclassified } \\
\text { Security Officer }\end{array}$ \\
\hline
\end{tabular}




\section{NEVADA TEST SITE RADIATION PROTECTION PROGRAM}

\section{APPENDIX H}

COMPLIANCE DEMONSTRATION TABLE

\begin{tabular}{|c|c|c|c|c|c|c|c|c|}
\hline \multirow[t]{2}{*}{10 CFR 835} & $\begin{array}{c}\text { NV/YMP RCM } \\
\text { Rev } 5 \text { and } \\
\text { NTS RPP } \\
\text { Revision } 0 \\
\end{array}$ & $\begin{array}{c}\text { NSTec } \\
\text { Appendix A }\end{array}$ & $\begin{array}{c}\text { LLNL } \\
\text { Appendix B }\end{array}$ & $\begin{array}{c}\text { LANL } \\
\text { Appendix C }\end{array}$ & $\begin{array}{c}\text { SNL } \\
\text { Appendix D }\end{array}$ & $\begin{array}{c}\text { SNJV } \\
\text { Appendix E }\end{array}$ & $\begin{array}{c}\text { DRI } \\
\text { Appendix F }\end{array}$ & $\begin{array}{c}\text { WSI } \\
\text { Appendix G }\end{array}$ \\
\hline & $\begin{array}{l}\text { Implementation } \\
\text { Reference }\end{array}$ & $\begin{array}{l}\text { Implementation } \\
\text { Reference }\end{array}$ & $\begin{array}{l}\text { Implementation } \\
\text { Reference }\end{array}$ & $\begin{array}{l}\text { Implementation } \\
\text { Reference }\end{array}$ & $\begin{array}{c}\text { Implementation } \\
\text { Reference }\end{array}$ & $\begin{array}{l}\text { Implementation } \\
\text { Reference }\end{array}$ & $\begin{array}{l}\text { Implementation } \\
\text { Reference }\end{array}$ & $\begin{array}{l}\text { Implementation } \\
\text { Reference }\end{array}$ \\
\hline
\end{tabular}

stated in Table

6-1.

NV/YMP RCM

632.01. Workers

whose job

assignments

involve working

with radioactive

materials or entry

into Radiation

Areas or RMAs

and

Underground

RMAs (greater

than 100

$\mathrm{mrem} / \mathrm{yr}$ ), shall

complete RW-I

training.

NV/YMP RCM

633.01. Workers

whose job

assignments

involve entry into

High Radiation

Areas,

Contamination

Areas, High

Contamination

Areas, and

Airborne

Radioactivity

\begin{tabular}{l}
\hline stated in Table \\
6-1. \\
NV/YMP RCM \\
632.01. Workers \\
whose job \\
assignments \\
involve working \\
with radioactive \\
materials or entry \\
into Radiation \\
Areas or RMAs \\
and \\
Underground \\
RMAs (greater \\
than 100 \\
mrem/yr), shall \\
complete RW-I \\
training. \\
NV/YMP RCM \\
633.01. Workers \\
whose job \\
assignments \\
involve entry into \\
High Radiation \\
Areas, \\
Contamination \\
Areas, High \\
Contamination \\
Areas, and \\
Airborne \\
Radioactivity \\
\hline
\end{tabular}

or designee. 


\section{NEVADA TEST SITE RADIATION PROTECTION PROGRAM}

\section{APPENDIX H}

COMPLIANCE DEMONSTRATION TABLE

\begin{tabular}{|c|c|c|c||c||c||c||c||c|}
\hline \multirow{2}{*}{ 10 CFR 835 } & $\begin{array}{c}\text { NV/YMP RCM } \\
\text { Rev 5 and } \\
\text { NTS RPP } \\
\text { Revision 0 }\end{array}$ & Appendix A & Appendix B & Appendix C & Appendix D & SNJV \\
\cline { 2 - 7 } & $\begin{array}{c}\text { Implementation } \\
\text { Reference }\end{array}$ & $\begin{array}{c}\text { Implementation } \\
\text { Reference }\end{array}$ & $\begin{array}{c}\text { Implementation } \\
\text { Reference }\end{array}$ & $\begin{array}{c}\text { Implementation } \\
\text { Reference }\end{array}$ & $\begin{array}{c}\text { Implementation } \\
\text { Reference }\end{array}$ & $\begin{array}{c}\text { Implementation } \\
\text { Reference }\end{array}$ & $\begin{array}{c}\text { Implementation } \\
\text { Reference }\end{array}$ & $\begin{array}{c}\text { Implementation } \\
\text { Reference }\end{array}$ \\
\hline
\end{tabular}

\begin{tabular}{|c|c|c|c|c|c|c|c|c|}
\hline & $\begin{array}{l}\text { Areas shall } \\
\text { complete } \\
\text { RW-II training. }\end{array}$ & $\begin{array}{l}\text { Areas shall } \\
\text { complete } \\
\text { RW-II training. }\end{array}$ & & & & & & \\
\hline $\begin{array}{l}901 \text { (c) Radiation } \\
\text { safety training shall } \\
\text { include the following } \\
\text { topics, to the extent } \\
\text { appropriate to each } \\
\text { individual's prior } \\
\text { training, work } \\
\text { assignments, and } \\
\text { degree of exposure to } \\
\text { potential radiological } \\
\text { hazards: } \\
\text { (1) Risks of exposure } \\
\text { to radiation and } \\
\text { radioactive materials, } \\
\text { including prenatal } \\
\text { radiation exposure; } \\
\text { (2) Basic radiological } \\
\text { fundamentals and } \\
\text { radiation protection } \\
\text { concepts; } \\
\text { (3) Physical design } \\
\text { features, } \\
\text { administrative } \\
\text { controls, limits, } \\
\text { policies, procedures, } \\
\text { alarms, and other } \\
\text { measures } \\
\text { implemented at the } \\
\text { facility to manage } \\
\text { doses and maintain } \\
\end{array}$ & $\begin{array}{l}\text { NV/YMP RCM } \\
612.1 . \\
\text { Standardized } \\
\text { core course } \\
\text { training material } \\
\text { shall be used for } \\
\text { GERT, RW-I, } \\
\text { RW-II, and RCT } \\
\text { training. The } \\
\text { standardized } \\
\text { core courses are } \\
\text { presented and } \\
\text { site-specific } \\
\text { information is } \\
\text { added. }\end{array}$ & $\begin{array}{l}\text { NV/YMP RCM } \\
612.1 . \\
\text { Standardized } \\
\text { core course } \\
\text { training material } \\
\text { shall be used for } \\
\text { GERT, RW-I, } \\
\text { RW-II, and RCT } \\
\text { training. The } \\
\text { standardized } \\
\text { core courses are } \\
\text { presented and } \\
\text { site-specific } \\
\text { information is } \\
\text { added. }\end{array}$ & $\begin{array}{l}\text { This is outside } \\
\text { the scope of the } \\
\text { LLNL-N } \\
\text { Radiological } \\
\text { Control } \\
\text { Program. This } \\
\text { radiological } \\
\text { training is } \\
\text { performed and } \\
\text { documented by } \\
\text { LLNL in } \\
\text { Livermore or by } \\
\text { the NTS RSPC. }\end{array}$ & $\begin{array}{l}\text { This radiological } \\
\text { training is } \\
\text { performed and } \\
\text { documented by } \\
\text { LANL CT-ESH in } \\
\text { Los Alamos or by } \\
\text { the NTS RSPC. } \\
\text { LANL/NTS is } \\
\text { responsible to } \\
\text { assure that } \\
\text { radiological } \\
\text { training is current } \\
\text { (has been } \\
\text { performed within } \\
\text { the previous } 24 \\
\text { months). }\end{array}$ & $\begin{array}{l}\text { Same as Column } \\
3\end{array}$ & $\begin{array}{l}\text { Same as Column } \\
3\end{array}$ & \begin{tabular}{|l|} 
Not applicable to \\
DRI Radiation \\
Safety Training \\
content is not \\
developed by \\
DRI as radiation \\
safety training for \\
DRI employees \\
is provided by \\
the RSPC and/or \\
the UNR RSO \\
dependent on \\
what the affected \\
employee's job \\
entails.
\end{tabular} & $\begin{array}{l}\text { WSI/NV or the } \\
\text { RSPC may } \\
\text { provide GERT } \\
\text { training for WSI } \\
\text { employees. The } \\
\text { RSPC provides } \\
\text { RW-I and RW-II } \\
\text { training. }\end{array}$ \\
\hline
\end{tabular}




\section{NEVADA TEST SITE RADIATION PROTECTION PROGRAM}

\section{APPENDIX H}

COMPLIANCE DEMONSTRATION TABLE

\begin{tabular}{|c|c|c|c|c|c|c|c|c|}
\hline \multirow[t]{2}{*}{10 CFR 835} & $\begin{array}{l}\text { NV/YMP RCM } \\
\text { Rev } 5 \text { and } \\
\text { NTS RPP } \\
\text { Revision } 0 \\
\end{array}$ & $\begin{array}{c}\text { NSTec } \\
\text { Appendix A }\end{array}$ & $\begin{array}{c}\text { LLNL } \\
\text { Appendix B }\end{array}$ & $\begin{array}{c}\text { LANL } \\
\text { Appendix C }\end{array}$ & $\begin{array}{c}\text { SNL } \\
\text { Appendix D }\end{array}$ & $\begin{array}{c}\text { SNJV } \\
\text { Appendix E }\end{array}$ & $\begin{array}{c}\text { DRI } \\
\text { Appendix F }\end{array}$ & $\begin{array}{c}\text { WSI } \\
\text { Appendix G }\end{array}$ \\
\hline & $\begin{array}{l}\text { Implementation } \\
\text { Reference }\end{array}$ & $\begin{array}{l}\text { Implementation } \\
\text { Reference }\end{array}$ & $\begin{array}{l}\text { Implementation } \\
\text { Reference }\end{array}$ & $\begin{array}{l}\text { Implementation } \\
\text { Reference }\end{array}$ & $\begin{array}{l}\text { Implementation } \\
\text { Reference }\end{array}$ & $\begin{array}{l}\text { Implementation } \\
\text { Reference }\end{array}$ & $\begin{array}{l}\text { Implementation } \\
\text { Reference }\end{array}$ & $\begin{array}{c}\text { Implementation } \\
\text { Reference }\end{array}$ \\
\hline
\end{tabular}

\begin{tabular}{|c|c|c|c|c|c|c|c|c|}
\hline $\begin{array}{l}\text { doses ALARA } \\
\text { including both routine } \\
\text { and emergency } \\
\text { actions; } \\
\text { (4) Individual rights } \\
\text { and responsibilities as } \\
\text { related to } \\
\text { implementation of the } \\
\text { facility radiation } \\
\text { protection program; } \\
\text { (5) Individual } \\
\text { responsibilities for } \\
\text { implementing ALARA } \\
\text { measures required by } \\
\text { §835.101; and } \\
\text { (6) Individual exposure } \\
\text { reports that may be } \\
\text { requested in } \\
\text { accordance with } \\
\S 835.801 .\end{array}$ & & & & & & & & \\
\hline $\begin{array}{l}901(\mathrm{~d}) \text { When an escort } \\
\text { is used in lieu of } \\
\text { training in accordance } \\
\text { with paragraph }(a) \text { or } \\
\text { (b) of this section, the } \\
\text { escort shall: } \\
\text { (1) Have completed } \\
\text { radiation safety } \\
\text { training, examinations, } \\
\text { and performance } \\
\text { demonstrations } \\
\text { required for entry to } \\
\text { the area and }\end{array}$ & $\begin{array}{l}\text { NV/YMP RCM } \\
657 . \text { When an } \\
\text { escort is used in } \\
\text { lieu of training } \\
\text { according to } \\
\text { Chapter 3, Part } \\
\text { 3, "Entry and Exit } \\
\text { Requirements" } \\
\text { (Articles 331, } \\
333,334,335 \text {, } \\
\text { 336, and 365), } \\
\text { the escort shall: } \\
\text { 1. Have }\end{array}$ & $\begin{array}{l}\text { NV/YMP RCM } \\
657 . \text { When an } \\
\text { escort is used in } \\
\text { lieu of training } \\
\text { according to } \\
\text { Chapter 3, Part } \\
3 \text {, "Entry and Exit } \\
\text { Requirements" } \\
\text { (Articles 331, } \\
333,334,335, \\
336, \text { and 365), } \\
\text { the escort shall: } \\
\text { 1. Have }\end{array}$ & $\begin{array}{l}\text { Same as Column } \\
3\end{array}$ & $\begin{array}{l}\text { Same as Column } \\
3\end{array}$ & $\begin{array}{l}\text { Same as Column } \\
3\end{array}$ & $\begin{array}{l}\text { Same as Column } \\
3\end{array}$ & $\begin{array}{l}\text { Same as Column } \\
3\end{array}$ & $\begin{array}{l}\text { Same as Column } \\
3\end{array}$ \\
\hline
\end{tabular}




\section{NEVADA TEST SITE RADIATION PROTECTION PROGRAM}

\section{APPENDIX H}

COMPLIANCE DEMONSTRATION TABLE

\begin{tabular}{|c|c|c|c|c|c|c|c|c|}
\hline \multirow[t]{2}{*}{10 CFR 835} & $\begin{array}{l}\text { NV/YMP RCM } \\
\text { Rev } 5 \text { and } \\
\text { NTS RPP } \\
\text { Revision } 0 \\
\end{array}$ & $\begin{array}{c}\text { NSTec } \\
\text { Appendix A }\end{array}$ & $\begin{array}{c}\text { LLNL } \\
\text { Appendix B }\end{array}$ & $\begin{array}{c}\text { LANL } \\
\text { Appendix C }\end{array}$ & $\begin{array}{c}\text { SNL } \\
\text { Appendix D }\end{array}$ & $\begin{array}{c}\text { SNJV } \\
\text { Appendix E }\end{array}$ & $\begin{array}{c}\text { DRI } \\
\text { Appendix F }\end{array}$ & $\begin{array}{c}\text { WSI } \\
\text { Appendix G }\end{array}$ \\
\hline & $\begin{array}{l}\text { Implementation } \\
\text { Reference }\end{array}$ & $\begin{array}{l}\text { Implementation } \\
\text { Reference }\end{array}$ & $\begin{array}{l}\text { Implementation } \\
\text { Reference }\end{array}$ & $\begin{array}{l}\text { Implementation } \\
\text { Reference }\end{array}$ & $\begin{array}{l}\text { Implementation } \\
\text { Reference }\end{array}$ & $\begin{array}{l}\text { Implementation } \\
\text { Reference }\end{array}$ & $\begin{array}{l}\text { Implementation } \\
\text { Reference }\end{array}$ & $\begin{array}{l}\text { Implementation } \\
\text { Reference }\end{array}$ \\
\hline
\end{tabular}

\begin{tabular}{|c|c|c|c|c|c|c|c|c|}
\hline $\begin{array}{l}\text { performance of the } \\
\text { work; and (2) Ensure } \\
\text { that all escorted } \\
\text { individuals comply with } \\
\text { the documented } \\
\text { radiation protection } \\
\text { program. }\end{array}$ & $\begin{array}{l}\text { completed } \\
\text { radiation safety } \\
\text { training, } \\
\text { examinations, } \\
\text { and performance } \\
\text { demonstrations } \\
\text { required for entry } \\
\text { into the area and } \\
\text { performance of } \\
\text { the work. } \\
\text { 2. Ensure that } \\
\text { all escorted } \\
\text { individuals } \\
\text { comply with the } \\
\text { documented } \\
\text { radiation } \\
\text { protection } \\
\text { program. }\end{array}$ & $\begin{array}{l}\text { completed } \\
\text { radiation safety } \\
\text { training, } \\
\text { examinations, } \\
\text { and performance } \\
\text { demonstrations } \\
\text { required for entry } \\
\text { into the area and } \\
\text { performance of } \\
\text { the work. } \\
\text { 2. Ensure that } \\
\text { all escorted } \\
\text { individuals } \\
\text { comply with the } \\
\text { documented } \\
\text { radiation } \\
\text { protection } \\
\text { program. }\end{array}$ & & & & & & \\
\hline $\begin{array}{l}901(\mathrm{e}) \text { Radiation } \\
\text { safety training shall be } \\
\text { provided to individuals } \\
\text { when there is a } \\
\text { significant change to } \\
\text { radiation protection } \\
\text { policies and } \\
\text { procedures that may } \\
\text { affect the individual } \\
\text { and at intervals not to } \\
\text { exceed } 24 \text { months. } \\
\text { Such training provided } \\
\text { for individuals subject } \\
\text { to the requirements of } \\
\S 835.901(b)(1) \text { and }\end{array}$ & $\begin{array}{l}\text { NV/YMP RCM } \\
613.3 . a . \text { GERT, } \\
\text { RW-I, RW-II, and } \\
\text { RCT training } \\
\text { shall be } \\
\text { completed every } \\
24 \text { months. } \\
\text { a. Changes to } \\
\text { the program shall } \\
\text { be incorporated } \\
\text { as they are } \\
\text { identified and a } \\
\text { decision made } \\
\text { by the RadCon } \\
\text { Managers' }\end{array}$ & $\begin{array}{l}\text { NV/YMP RCM } \\
613.3 . a . \text { GERT, } \\
\text { RW-I, RW-II, and } \\
\text { RCT training } \\
\text { shall be } \\
\text { completed every } \\
24 \text { months. } \\
\text { a. Changes to } \\
\text { the program shall } \\
\text { be incorporated } \\
\text { as they are } \\
\text { identified and a } \\
\text { decision made } \\
\text { by the RadCon } \\
\text { Managers' }\end{array}$ & $\begin{array}{l}\text { Radiological } \\
\text { training is } \\
\text { performed and } \\
\text { documented by } \\
\text { LLNL Training } \\
\text { Office or by the } \\
\text { RSPC. }\end{array}$ & $\begin{array}{l}\text { This radiological } \\
\text { training is } \\
\text { performed and } \\
\text { documented by } \\
\text { LANL CT-ESH in } \\
\text { Los Alamos or by } \\
\text { the NTS RSPC. }\end{array}$ & $\begin{array}{l}\text { Same as Column } \\
3\end{array}$ & $\begin{array}{l}\text { Same as Column } \\
3\end{array}$ & $\begin{array}{l}\text { Same as Column } \\
3\end{array}$ & $\begin{array}{l}\text { Same as Column } \\
3\end{array}$ \\
\hline
\end{tabular}




\section{NEVADA TEST SITE RADIATION PROTECTION PROGRAM}

\section{APPENDIX H}

COMPLIANCE DEMONSTRATION TABLE

\begin{tabular}{|c|c|c|c|c|c|c|c|c|}
\hline \multirow[t]{2}{*}{10 CFR 835} & $\begin{array}{l}\text { NV/YMP RCM } \\
\text { Rev } 5 \text { and } \\
\text { NTS RPP } \\
\text { Revision } 0 \\
\end{array}$ & $\begin{array}{c}\text { NSTec } \\
\text { Appendix A }\end{array}$ & $\begin{array}{c}\text { LLNL } \\
\text { Appendix B }\end{array}$ & $\begin{array}{c}\text { LANL } \\
\text { Appendix C }\end{array}$ & $\begin{array}{c}\text { SNL } \\
\text { Appendix D }\end{array}$ & $\begin{array}{c}\text { SNJV } \\
\text { Appendix E }\end{array}$ & $\begin{array}{c}\text { DRI } \\
\text { Appendix F }\end{array}$ & $\begin{array}{c}\text { WSI } \\
\text { Appendix G }\end{array}$ \\
\hline & $\begin{array}{l}\text { Implementation } \\
\text { Reference }\end{array}$ & $\begin{array}{c}\text { Implementation } \\
\text { Reference }\end{array}$ & $\begin{array}{l}\text { Implementation } \\
\text { Reference }\end{array}$ & $\begin{array}{l}\text { Implementation } \\
\text { Reference }\end{array}$ & $\begin{array}{l}\text { Implementation } \\
\text { Reference }\end{array}$ & $\begin{array}{l}\text { Implementation } \\
\text { Reference }\end{array}$ & $\begin{array}{l}\text { Implementation } \\
\text { Reference }\end{array}$ & $\begin{array}{l}\text { Implementation } \\
\text { Reference }\end{array}$ \\
\hline
\end{tabular}

\begin{tabular}{|c|c|c|c|c|c|c|c|c|}
\hline $\begin{array}{l}\text { (b) (2) shall include } \\
\text { successful completion } \\
\text { of an examination. }\end{array}$ & $\begin{array}{l}\text { Council whether } \\
\text { retraining before } \\
\text { the expiration of } \\
\text { the } 24-\text { month } \\
\text { period is needed. }\end{array}$ & $\begin{array}{l}\text { Council whether } \\
\text { retraining before } \\
\text { the expiration of } \\
\text { the } 24 \text {-month } \\
\text { period is needed. }\end{array}$ & & & & & & \\
\hline \multicolumn{9}{|l|}{$\begin{array}{l}835.902-835.903 \\
\text { [Reserved] }\end{array}$} \\
\hline $\begin{array}{l}\text { Subpart K--Design } \\
\text { and Control. } \\
\text { 835.1001 Design and } \\
\text { control. } \\
\text { 1001(a) Measures } \\
\text { shall be taken to } \\
\text { maintain radiation } \\
\text { exposure in controlled } \\
\text { areas ALARA through } \\
\text { engineered and } \\
\text { administrative } \\
\text { controls. The primary } \\
\text { methods used shall be } \\
\text { engineered controls } \\
\text { (e.g., confinement, } \\
\text { ventilation, remote } \\
\text { handling, and } \\
\text { shielding.) } \\
\text { Administrative controls } \\
\text { shall be employed only } \\
\text { as supplemental } \\
\text { methods to control } \\
\text { radiation exposure. }\end{array}$ & $\begin{array}{l}\text { NV/YMP RCM } \\
311.02-03 \text {. The } \\
\text { primary methods } \\
\text { used to maintain } \\
\text { exposures } \\
\text { ALARA shall be } \\
\text { facility and } \\
\text { equipment } \\
\text { design features. } \\
\text { These features } \\
\text { shall be } \\
\text { augmented by } \\
\text { administrative } \\
\text { and procedural } \\
\text { requirements. }\end{array}$ & $\begin{array}{l}\text { Revise: NV/YMP } \\
\text { RCM } 311.01-03 . \\
\text { Measures shall } \\
\text { be taken to } \\
\text { maintain } \\
\text { radiation } \\
\text { exposure in } \\
\text { controlled areas } \\
\text { ALARA through } \\
\text { engineered and } \\
\text { administrative } \\
\text { controls. The } \\
\text { primary methods } \\
\text { used shall be } \\
\text { engineered } \\
\text { controls (e.g., } \\
\text { confinement, } \\
\text { ventilation, } \\
\text { remote handling, } \\
\text { and shielding). } \\
\text { Administrative } \\
\text { controls shall be } \\
\text { employed only } \\
\text { as supplemental } \\
\text { methods to } \\
\text { control radiation }\end{array}$ & $\begin{array}{l}\text { Actions taken to } \\
\text { maintain } \\
\text { personnel } \\
\text { exposures } \\
\text { ALARA through } \\
\text { administrative } \\
\text { controls are } \\
\text { documented } \\
\text { through LLNL } \\
\text { Narrative } \\
\text { Section, } 4.0 \text { and } \\
\text { NTS RPP } \\
\text { Narrative Section } \\
7.0 \text { ALARA } \\
\text { Program. } \\
\text { LLNL-N will be } \\
\text { responsible for } \\
\text { looking at all } \\
\text { ALARA reviews } \\
\text { made on the } \\
\text { design of all } \\
\text { facilities for } \\
\text { which LLNL-N } \\
\text { has operational } \\
\text { responsibility and } \\
\text { commenting on }\end{array}$ & $\begin{array}{l}\text { By written } \\
\text { agreement } \\
\text { between } \\
\text { LANL/NTS and } \\
\text { the LANL/RP-3 } \\
\text { Radiological } \\
\text { Engineering } \\
\text { Team, the } \\
\text { LANL/RP-3 } \\
\text { Radiological } \\
\text { Engineering } \\
\text { Team will } \\
\text { perform and } \\
\text { document the } \\
\text { ALARA reviews } \\
\text { of the design of } \\
\text { new NTS } \\
\text { facilities or the } \\
\text { modification of } \\
\text { existing NTS } \\
\text { facilities by } \\
\text { LANL/NTS. }\end{array}$ & $\begin{array}{l}\text { Same as Column } \\
3\end{array}$ & $\begin{array}{l}\text { NV/YMP RCM } \\
316.2 \text {. } \\
\text { Administrative } \\
\text { controls, } \\
\text { including access } \\
\text { restrictions and } \\
\text { the use of } \\
\text { specific work } \\
\text { practices } \\
\text { designed to } \\
\text { minimize } \\
\text { airborne } \\
\text { radioactivity, } \\
\text { shall be used as } \\
\text { the secondary } \\
\text { method to } \\
\text { minimize worker } \\
\text { internal } \\
\text { exposure. }\end{array}$ & $\begin{array}{l}\text { Not applicable to } \\
\text { DRI. Facility and } \\
\text { equipment } \\
\text { design to } \\
\text { achieve ALARA } \\
\text { are outside the } \\
\text { scope of DRI } \\
\text { activities. } \\
\text { Actions taken to } \\
\text { maintain } \\
\text { personnel } \\
\text { exposures } \\
\text { ALARA through } \\
\text { administrative } \\
\text { controls are } \\
\text { documented } \\
\text { through DRI } \\
\text { Narrative Section } \\
4.0 \text { and NTS } \\
\text { RPP Narrative } \\
\text { Section } 7.0 \\
\text { ALARA Program. }\end{array}$ & $\begin{array}{l}\text { Facility and } \\
\text { equipment } \\
\text { design and } \\
\text { control to } \\
\text { maintain } \\
\text { radiation } \\
\text { exposure in } \\
\text { controlled areas } \\
\text { ALARA is } \\
\text { beyond the } \\
\text { scope of WSI/NV } \\
\text { radiological } \\
\text { control } \\
\text { responsibilities. } \\
\text { The WSI/NV } \\
\text { ES\&H section } \\
\text { will review all } \\
\text { operations } \\
\text { including } \\
\text { WSI/NV } \\
\text { personnel to } \\
\text { maintain } \\
\text { radiation } \\
\text { exposure } \\
\text { ALARA. }\end{array}$ \\
\hline
\end{tabular}

$\mathrm{H}-107$ 


\section{NEVADA TEST SITE RADIATION PROTECTION PROGRAM}

\section{APPENDIX H}

COMPLIANCE DEMONSTRATION TABLE

\begin{tabular}{|c|c|c|c|c|c|c|c|c|}
\hline \multirow[t]{2}{*}{10 CFR 835} & $\begin{array}{c}\text { NV/YMP RCM } \\
\text { Rev } 5 \text { and } \\
\text { NTS RPP } \\
\text { Revision } 0 \\
\end{array}$ & $\begin{array}{c}\text { NSTec } \\
\text { Appendix A }\end{array}$ & $\begin{array}{c}\text { LLNL } \\
\text { Appendix B }\end{array}$ & $\begin{array}{c}\text { LANL } \\
\text { Appendix C }\end{array}$ & $\begin{array}{c}\text { SNL } \\
\text { Appendix D }\end{array}$ & $\begin{array}{c}\text { SNJV } \\
\text { Appendix E }\end{array}$ & $\begin{array}{c}\text { DRI } \\
\text { Appendix F }\end{array}$ & $\begin{array}{c}\text { WSI } \\
\text { Appendix G }\end{array}$ \\
\hline & $\begin{array}{l}\text { Implementation } \\
\text { Reference }\end{array}$ & $\begin{array}{l}\text { Implementation } \\
\text { Reference }\end{array}$ & $\begin{array}{l}\text { Implementation } \\
\text { Reference }\end{array}$ & $\begin{array}{l}\text { Implementation } \\
\text { Reference }\end{array}$ & $\begin{array}{c}\text { Implementation } \\
\text { Reference }\end{array}$ & $\begin{array}{l}\text { Implementation } \\
\text { Reference }\end{array}$ & $\begin{array}{l}\text { Implementation } \\
\text { Reference }\end{array}$ & $\begin{array}{l}\text { Implementation } \\
\text { Reference }\end{array}$ \\
\hline
\end{tabular}

\begin{tabular}{|c|c|c|c|c|c|c|c|c|}
\hline & & exposure. & $\begin{array}{l}\text { and providing } \\
\text { appropriate input } \\
\text { to the review } \\
\text { process. }\end{array}$ & & & & & $\begin{array}{l}\text { WSI/NV will } \\
\text { comply with all } \\
\text { administrative } \\
\text { controls } \\
\text { employed by the } \\
\text { TO with } \\
\text { radiological } \\
\text { control } \\
\text { responsibilities. } \\
\end{array}$ \\
\hline $\begin{array}{l}1001(b) \text { For specific } \\
\text { activities where use of } \\
\text { engineered controls is } \\
\text { demonstrated to be } \\
\text { impractical, } \\
\text { administrative controls } \\
\text { shall be used to } \\
\text { maintain radiation } \\
\text { exposures ALARA. }\end{array}$ & $\begin{array}{l}\text { NV/YMP RCM } \\
311.02-03 \text {. The } \\
\text { primary methods } \\
\text { used to maintain } \\
\text { exposures } \\
\text { ALARA shall be } \\
\text { facility and } \\
\text { equipment } \\
\text { design features. } \\
\text { These features } \\
\text { shall be } \\
\text { augmented by } \\
\text { administrative } \\
\text { and procedural } \\
\text { requirements. }\end{array}$ & $\begin{array}{l}\text { Add: NV/YMP } \\
\text { RCM } 311.05 \text {. } \\
\text { For specific } \\
\text { activities where } \\
\text { use of } \\
\text { engineered } \\
\text { controls is } \\
\text { demonstrated to } \\
\text { be impractical, } \\
\text { administrative } \\
\text { controls shall be } \\
\text { used to maintain } \\
\text { radiation } \\
\text { exposures } \\
\text { ALARA. }\end{array}$ & $\begin{array}{l}\text { Actions taken to } \\
\text { maintain } \\
\text { personnel } \\
\text { exposures } \\
\text { ALARA through } \\
\text { administrative } \\
\text { controls are } \\
\text { documented } \\
\text { through LLNL } \\
\text { Narrative Section } \\
\text { 4.0 and } \\
\text { NTS RPP } \\
\text { Narrative Section } \\
\text { 7.0 ALARA } \\
\text { Program. }\end{array}$ & $\begin{array}{l}\text { By written } \\
\text { agreement } \\
\text { between } \\
\text { LANL/NTS and } \\
\text { the LANL/RP-3 } \\
\text { Radiological } \\
\text { Engineering } \\
\text { Team, the } \\
\text { LANL/RP-3 } \\
\text { Radiological } \\
\text { Engineering } \\
\text { Team will } \\
\text { perform and } \\
\text { document the } \\
\text { ALARA review of } \\
\text { the design of } \\
\text { new LANL/NTS } \\
\text { facilities or the } \\
\text { modification of } \\
\text { existing } \\
\text { LANL/NTS } \\
\text { facilities. }\end{array}$ & $\begin{array}{l}\text { NV/YMP RCM } \\
311 \text {. Technical } \\
\text { requirements for } \\
\text { the conduct of } \\
\text { work, including } \\
\text { construction, } \\
\text { modifications, } \\
\text { operations, } \\
\text { maintenance, } \\
\text { and } \\
\text { decommissioning } \\
\text { shall incorporate } \\
\text { radiological } \\
\text { criteria to ensure } \\
\text { safety and } \\
\text { maintain } \\
\text { radiation } \\
\text { exposures } \\
\text { ALARA. The } \\
\text { primary methods } \\
\text { used to maintain } \\
\text { exposures } \\
\text { ALARA shall be } \\
\text { facility and }\end{array}$ & $\begin{array}{l}\text { Same as Column } \\
3\end{array}$ & \begin{tabular}{|l} 
NV/YMP RCM \\
311. Technical \\
requirements for \\
the conduct of \\
work, including \\
construction, \\
modifications, \\
operations, \\
maintenance, \\
and \\
decommissioning \\
shall incorporate \\
radiological \\
criteria to ensure \\
safety and \\
maintain \\
radiation \\
exposures \\
ALARA. The \\
primary methods \\
used to maintain \\
exposures \\
ALARA shall be \\
facility and \\
\end{tabular} & $\begin{array}{l}\text { NV/YMP RCM } \\
311 \text {. Technical } \\
\text { requirements for } \\
\text { the conduct of } \\
\text { work, including } \\
\text { construction, } \\
\text { modifications, } \\
\text { operations, } \\
\text { maintenance, } \\
\text { and } \\
\text { decommissioning } \\
\text { shall incorporate } \\
\text { radiological } \\
\text { criteria to ensure } \\
\text { safety and } \\
\text { maintain } \\
\text { radiation } \\
\text { exposures } \\
\text { ALARA. The } \\
\text { primary methods } \\
\text { used to maintain } \\
\text { exposures } \\
\text { ALARA shall be } \\
\text { facility and }\end{array}$ \\
\hline
\end{tabular}

H-108 


\section{NEVADA TEST SITE RADIATION PROTECTION PROGRAM}

\section{APPENDIX H}

COMPLIANCE DEMONSTRATION TABLE

\begin{tabular}{|c|c|c|c|c|c|c|c|c|}
\hline \multirow[t]{2}{*}{10 CFR 835} & $\begin{array}{l}\text { NV/YMP RCM } \\
\text { Rev } 5 \text { and } \\
\text { NTS RPP } \\
\text { Revision } 0 \\
\end{array}$ & $\begin{array}{c}\text { NSTec } \\
\text { Appendix A }\end{array}$ & $\begin{array}{c}\text { LLNL } \\
\text { Appendix B }\end{array}$ & $\begin{array}{c}\text { LANL } \\
\text { Appendix C }\end{array}$ & $\begin{array}{c}\text { SNL } \\
\text { Appendix D }\end{array}$ & $\begin{array}{c}\text { SNJV } \\
\text { Appendix E }\end{array}$ & $\begin{array}{c}\text { DRI } \\
\text { Appendix F }\end{array}$ & $\begin{array}{c}\text { WSI } \\
\text { Appendix G }\end{array}$ \\
\hline & $\begin{array}{l}\text { Implementation } \\
\text { Reference }\end{array}$ & $\begin{array}{l}\text { Implementation } \\
\text { Reference }\end{array}$ & $\begin{array}{l}\text { Implementation } \\
\text { Reference }\end{array}$ & $\begin{array}{l}\text { Implementation } \\
\text { Reference }\end{array}$ & $\begin{array}{l}\text { Implementation } \\
\text { Reference }\end{array}$ & $\begin{array}{l}\text { Implementation } \\
\text { Reference }\end{array}$ & $\begin{array}{l}\text { Implementation } \\
\text { Reference }\end{array}$ & $\begin{array}{l}\text { Implementation } \\
\text { Reference }\end{array}$ \\
\hline
\end{tabular}

\begin{tabular}{|c|c|c|c|c|c|c|c|c|}
\hline & & & & & $\begin{array}{l}\text { equipment } \\
\text { design features. } \\
\text { These features } \\
\text { shall be } \\
\text { augmented by } \\
\text { administrative } \\
\text { and procedural } \\
\text { requirements. } \\
\text { The design and } \\
\text { planning } \\
\text { processes shall } \\
\text { incorporate } \\
\text { radiological } \\
\text { considerations in } \\
\text { the early } \\
\text { planning stages. }\end{array}$ & & $\begin{array}{l}\text { equipment } \\
\text { design features. } \\
\text { These features } \\
\text { shall be } \\
\text { augmented by } \\
\text { administrative } \\
\text { and procedural } \\
\text { requirements. } \\
\text { The design and } \\
\text { planning } \\
\text { processes shall } \\
\text { incorporate } \\
\text { radiological } \\
\text { considerations in } \\
\text { the early } \\
\text { planning stages. }\end{array}$ & $\begin{array}{l}\text { equipment } \\
\text { design features. } \\
\text { These features } \\
\text { shall be } \\
\text { augmented by } \\
\text { administrative } \\
\text { and procedural } \\
\text { requirements. } \\
\text { The design and } \\
\text { planning } \\
\text { processes shall } \\
\text { incorporate } \\
\text { radiological } \\
\text { considerations in } \\
\text { the early } \\
\text { planning stages. }\end{array}$ \\
\hline $\begin{array}{l}835.1002 \text { Facility } \\
\text { design and } \\
\text { modifications. } \\
\text { During the design of } \\
\text { new facilities or } \\
\text { modification of existing } \\
\text { facilities, the following } \\
\text { objectives shall be } \\
\text { adopted: } \\
1002(a) \text { Optimization } \\
\text { methods shall be used } \\
\text { to assure that } \\
\text { occupational exposure } \\
\text { is maintained ALARA } \\
\text { in developing and } \\
\text { justifying facility design }\end{array}$ & $\begin{array}{l}\text { NV/YMP RCM } \\
312.7 . \\
\text { Optimization } \\
\text { methods shall be } \\
\text { used to ensure } \\
\text { that occupational } \\
\text { exposure is } \\
\text { maintained } \\
\text { ALARA in } \\
\text { developing and } \\
\text { justifying facility } \\
\text { design and } \\
\text { physical controls } \\
\text { for new facilities } \\
\text { or modifications } \\
\text { of existing } \\
\text { facilities. }\end{array}$ & $\begin{array}{l}\text { NV/YMP RCM } \\
312.7 . \\
\text { Optimization } \\
\text { methods shall be } \\
\text { used to ensure } \\
\text { that occupational } \\
\text { exposure is } \\
\text { maintained } \\
\text { ALARA in } \\
\text { developing and } \\
\text { justifying facility } \\
\text { design and } \\
\text { physical controls } \\
\text { for new facilities } \\
\text { or modifications } \\
\text { of existing } \\
\text { facilities. }\end{array}$ & $\begin{array}{l}\text { LLNL-N will be } \\
\text { responsible for } \\
\text { reviewing all } \\
\text { ALARA reviews } \\
\text { made on the } \\
\text { design of all } \\
\text { facilities for } \\
\text { which LLNL-N } \\
\text { has operational } \\
\text { responsibility and } \\
\text { commenting on } \\
\text { and providing } \\
\text { appropriate input } \\
\text { to the review } \\
\text { process. }\end{array}$ & $\begin{array}{l}\text { This is outside } \\
\text { the scope of the } \\
\text { LANL/NTS } \\
\text { Radiological } \\
\text { Control Program. } \\
\text { By written } \\
\text { agreement } \\
\text { between } \\
\text { LANL/NTS and } \\
\text { the LANL/RP-3 } \\
\text { Radiological } \\
\text { Engineering } \\
\text { Team, the } \\
\text { LANL/RP-3 } \\
\text { Radiological } \\
\text { Engineering } \\
\text { Team will }\end{array}$ & $\begin{array}{l}\text { Same as Column } \\
3\end{array}$ & $\begin{array}{l}\text { Same as Column } \\
3\end{array}$ & $\begin{array}{l}\text { Not applicable to } \\
\text { DRI. Facility and } \\
\text { equipment } \\
\text { design to } \\
\text { achieve ALARA } \\
\text { are outside the } \\
\text { scope of DRI } \\
\text { activities. }\end{array}$ & $\begin{array}{l}\text { Not applicable to } \\
\text { WSI/NV } \\
\text { operations. } \\
\text { Facility design } \\
\text { and } \\
\text { modifications are } \\
\text { outside the } \\
\text { scope of WSI/NV } \\
\text { radiological } \\
\text { control } \\
\text { responsibilities. }\end{array}$ \\
\hline
\end{tabular}

H-109 


\section{NEVADA TEST SITE RADIATION PROTECTION PROGRAM}

\section{APPENDIX H}

COMPLIANCE DEMONSTRATION TABLE

\begin{tabular}{|c|c|c|c|c|c|c|c|c|}
\hline \multirow[t]{2}{*}{10 CFR 835} & $\begin{array}{l}\text { NV/YMP RCM } \\
\text { Rev } 5 \text { and } \\
\text { NTS RPP } \\
\text { Revision } 0 \\
\end{array}$ & $\begin{array}{c}\text { NSTec } \\
\text { Appendix A }\end{array}$ & $\begin{array}{c}\text { LLNL } \\
\text { Appendix B }\end{array}$ & $\begin{array}{c}\text { LANL } \\
\text { Appendix C }\end{array}$ & $\begin{array}{c}\text { SNL } \\
\text { Appendix D }\end{array}$ & $\begin{array}{c}\text { SNJV } \\
\text { Appendix E }\end{array}$ & $\begin{array}{c}\text { DRI } \\
\text { Appendix F }\end{array}$ & $\begin{array}{c}\text { WSI } \\
\text { Appendix G }\end{array}$ \\
\hline & $\begin{array}{l}\text { Implementation } \\
\text { Reference }\end{array}$ & $\begin{array}{l}\text { Implementation } \\
\text { Reference }\end{array}$ & $\begin{array}{l}\text { Implementation } \\
\text { Reference }\end{array}$ & $\begin{array}{l}\text { Implementation } \\
\text { Reference }\end{array}$ & $\begin{array}{l}\text { Implementation } \\
\text { Reference }\end{array}$ & $\begin{array}{l}\text { Implementation } \\
\text { Reference }\end{array}$ & $\begin{array}{l}\text { Implementation } \\
\text { Reference }\end{array}$ & $\begin{array}{l}\text { Implementation } \\
\text { Reference }\end{array}$ \\
\hline
\end{tabular}

\begin{tabular}{|c|c|c|c|c|c|c|c|c|}
\hline and physical controls. & & & & $\begin{array}{l}\text { perform and } \\
\text { document the } \\
\text { A3LARA review } \\
\text { of the design of } \\
\text { new LANL/NTS } \\
\text { facilities or the } \\
\text { modification of } \\
\text { existing } \\
\text { LANL/NTS } \\
\text { facilities. }\end{array}$ & & & & \\
\hline $\begin{array}{l}\text { 1002(b) The design } \\
\text { objective for } \\
\text { controlling personnel } \\
\text { exposure from } \\
\text { external sources of } \\
\text { radiation in areas of } \\
\text { continuous } \\
\text { occupational } \\
\text { occupancy ( } 2000 \\
\text { hours per year) shall } \\
\text { be to maintain } \\
\text { exposure levels below } \\
\text { an average of } 0.5 \\
\text { millirem (5 } 4 \text { Sv) per } \\
\text { hour and as far below } \\
\text { this average as is } \\
\text { reasonably } \\
\text { achievable. The } \\
\text { design objectives for } \\
\text { exposure rates for } \\
\text { potential exposure to a } \\
\text { radiological worker } \\
\text { where occupancy } \\
\end{array}$ & $\begin{array}{l}\text { NV/YMP RCM } \\
128.1 . a-b . \\
\text { General design } \\
\text { criteria for new } \\
\text { facilities and } \\
\text { major } \\
\text { modifications to } \\
\text { existing facilities } \\
\text { are contained in } \\
10 \text { CFR } 835 \text { and } \\
\text { DOE Order } \\
6430.1 A \text {, } \\
\text { "General Design } \\
\text { Criteria." In } \\
\text { addition, the } \\
\text { following } \\
\text { radiological } \\
\text { control design } \\
\text { criteria are } \\
\text { provided for new } \\
\text { facilities and } \\
\text { major } \\
\text { modifications to } \\
\end{array}$ & $\begin{array}{l}\text { Revise: NV/YMP } \\
\text { RCM 128.1.a-b. } \\
\text { General design } \\
\text { criteria for new } \\
\text { facilities and } \\
\text { major } \\
\text { modifications to } \\
\text { existing facilities } \\
\text { are contained in } \\
10 \text { CFR } 835 \text { and } \\
\text { DOE Order } \\
420.1 B \text {, "Facility } \\
\text { Safety." In } \\
\text { addition, the } \\
\text { following } \\
\text { radiological } \\
\text { control design } \\
\text { criteria are } \\
\text { provided for new } \\
\text { facilities and } \\
\text { major } \\
\text { modifications to } \\
\text { existing facilities: }\end{array}$ & $\begin{array}{l}\text { LLNL-N will be } \\
\text { responsible for } \\
\text { reviewing all } \\
\text { ALARA reviews } \\
\text { made on the } \\
\text { design of all } \\
\text { facilities for } \\
\text { which LLNL-N } \\
\text { has operational } \\
\text { responsibility and } \\
\text { commenting on } \\
\text { and providing } \\
\text { appropriate input } \\
\text { to the review } \\
\text { process. }\end{array}$ & $\begin{array}{l}\text { This is outside } \\
\text { the scope of the } \\
\text { LANL/NTS } \\
\text { Radiological } \\
\text { Control Program. } \\
\text { By written } \\
\text { agreement } \\
\text { between } \\
\text { LANL/NTS and } \\
\text { the LANL/RP-3 } \\
\text { Radiological } \\
\text { Engineering } \\
\text { Team, the } \\
\text { LANL/RP-3 } \\
\text { Radiological } \\
\text { Engineering } \\
\text { Team will } \\
\text { perform and } \\
\text { document the } \\
\text { ALARA review of } \\
\text { the design of } \\
\text { new LANL/NTS } \\
\text { facilities or the }\end{array}$ & $\begin{array}{l}\text { Same as Column } \\
3\end{array}$ & $\begin{array}{l}\text { Same as Column } \\
3\end{array}$ & $\begin{array}{l}\text { Not applicable to } \\
\text { DRI. Facility and } \\
\text { equipment } \\
\text { design to } \\
\text { achieve ALARA } \\
\text { are outside the } \\
\text { scope of DRI } \\
\text { activities. }\end{array}$ & $\begin{array}{l}\text { Not applicable to } \\
\text { WSI/NV } \\
\text { operations. } \\
\text { Facility design } \\
\text { and } \\
\text { modifications are } \\
\text { outside the } \\
\text { scope of WSI/NV } \\
\text { radiological } \\
\text { control } \\
\text { responsibilities. }\end{array}$ \\
\hline
\end{tabular}

H-110 


\section{NEVADA TEST SITE RADIATION PROTECTION PROGRAM}

\section{APPENDIX H}

COMPLIANCE DEMONSTRATION TABLE

\begin{tabular}{|c|c|c|c|c|c|c|c|c|}
\hline \multirow[t]{2}{*}{10 CFR 835} & $\begin{array}{c}\text { NV/YMP RCM } \\
\text { Rev } 5 \text { and } \\
\text { NTS RPP } \\
\text { Revision } 0 \\
\end{array}$ & $\begin{array}{c}\text { NSTec } \\
\text { Appendix A }\end{array}$ & $\begin{array}{c}\text { LLNL } \\
\text { Appendix B }\end{array}$ & $\begin{array}{c}\text { LANL } \\
\text { Appendix C }\end{array}$ & $\begin{array}{c}\text { SNL } \\
\text { Appendix D }\end{array}$ & $\begin{array}{c}\text { SNJV } \\
\text { Appendix E }\end{array}$ & $\begin{array}{c}\text { DRI } \\
\text { Appendix F }\end{array}$ & $\begin{array}{c}\text { WSI } \\
\text { Appendix G }\end{array}$ \\
\hline & $\begin{array}{l}\text { Implementation } \\
\text { Reference }\end{array}$ & $\begin{array}{l}\text { Implementation } \\
\text { Reference }\end{array}$ & $\begin{array}{l}\text { Implementation } \\
\text { Reference }\end{array}$ & $\begin{array}{l}\text { Implementation } \\
\text { Reference }\end{array}$ & $\begin{array}{l}\text { Implementation } \\
\text { Reference }\end{array}$ & $\begin{array}{l}\text { Implementation } \\
\text { Reference }\end{array}$ & $\begin{array}{l}\text { Implementation } \\
\text { Reference }\end{array}$ & $\begin{array}{l}\text { Implementation } \\
\text { Reference }\end{array}$ \\
\hline
\end{tabular}

\begin{tabular}{|c|c|c|c|c|c|c|c|c|}
\hline $\begin{array}{l}\text { differs from the above } \\
\text { shall be ALARA and } \\
\text { shall not exceed } 20 \\
\text { percent of the } \\
\text { applicable standards } \\
\text { in } \$ 835.202 \text {. }\end{array}$ & $\begin{array}{l}\text { existing facilities: } \\
\text { a. For areas of } \\
\text { continuous } \\
\text { occupancy } \\
\text { ( } 2,000 \text { hours per } \\
\text { year), the design } \\
\text { objective shall be } \\
\text { to maintain the } \\
\text { average } \\
\text { exposure levels } \\
\text { ALARA and shall } \\
\text { not exceed } \\
0.5 \text { mrem per } \\
\text { hour. } \\
\text { b. If occupancy is } \\
\text { not continuous, } \\
\text { the design } \\
\text { objective shall be } \\
\text { to maintain } \\
\text { doses ALARA } \\
\text { and shall not } \\
\text { exceed } 20 \\
\text { percent of the } \\
\text { occupational } \\
\text { dose limits } \\
\text { provided in Table } \\
2-1 \text {. }\end{array}$ & $\begin{array}{l}\text { a. For areas of } \\
\text { continuous } \\
\text { occupancy } \\
\text { ( } 2,000 \text { hours per } \\
\text { year), the design } \\
\text { objective shall be } \\
\text { to maintain the } \\
\text { average } \\
\text { exposure levels } \\
\text { ALARA and shall } \\
\text { not exceed } \\
0.5 \text { mrem per } \\
\text { hour. } \\
\text { b. If occupancy is } \\
\text { not continuous, } \\
\text { the design } \\
\text { objective shall be } \\
\text { to maintain } \\
\text { doses ALARA } \\
\text { and shall not } \\
\text { exceed } 20 \\
\text { percent of the } \\
\text { occupational } \\
\text { dose limits } \\
\text { provided in Table } \\
2-1 \text {. }\end{array}$ & & $\begin{array}{l}\text { modification of } \\
\text { existing } \\
\text { LANL/NTS } \\
\text { facilities. }\end{array}$ & & & & \\
\hline $\begin{array}{l}\text { 1002(c) Regarding the } \\
\text { control of airborne } \\
\text { radioactive material, } \\
\text { the design objective } \\
\text { shall be, under normal } \\
\text { conditions, to avoid }\end{array}$ & $\begin{array}{l}\text { NV/YMP RCM } \\
316.1 . \\
\text { Engineering } \\
\text { controls, } \\
\text { including } \\
\text { containment of }\end{array}$ & $\begin{array}{l}\text { NV/YMP RCM } \\
316.1 . \\
\text { Engineering } \\
\text { controls, } \\
\text { including } \\
\text { containment of }\end{array}$ & $\begin{array}{l}\text { LLNL-N will be } \\
\text { responsible for } \\
\text { reviewing all } \\
\text { ALARA reviews } \\
\text { made on the } \\
\text { design of all }\end{array}$ & $\begin{array}{l}\text { This is outside } \\
\text { the scope of the } \\
\text { LANL/NTS } \\
\text { Radiological } \\
\text { Control Program. } \\
\text { By written }\end{array}$ & $\begin{array}{l}\text { Same as Column } \\
3\end{array}$ & $\begin{array}{l}\text { Same as Column } \\
3\end{array}$ & $\begin{array}{l}\text { Not applicable to } \\
\text { DRI. Facility and } \\
\text { equipment } \\
\text { design to } \\
\text { achieve ALARA } \\
\text { are outside the }\end{array}$ & $\begin{array}{l}\text { Not applicable to } \\
\text { WSI/NV } \\
\text { operations. } \\
\text { Facility design } \\
\text { and } \\
\text { modifications are }\end{array}$ \\
\hline
\end{tabular}

H-111 


\section{NEVADA TEST SITE RADIATION PROTECTION PROGRAM}

\section{APPENDIX H}

COMPLIANCE DEMONSTRATION TABLE

\begin{tabular}{|c|c|c|c|c|c|c|c|c|}
\hline \multirow[t]{2}{*}{10 CFR 835} & $\begin{array}{c}\text { NV/YMP RCM } \\
\text { Rev } 5 \text { and } \\
\text { NTS RPP } \\
\text { Revision } 0 \\
\end{array}$ & $\begin{array}{c}\text { NSTec } \\
\text { Appendix A }\end{array}$ & $\begin{array}{c}\text { LLNL } \\
\text { Appendix B }\end{array}$ & $\begin{array}{c}\text { LANL } \\
\text { Appendix C }\end{array}$ & $\begin{array}{c}\text { SNL } \\
\text { Appendix D }\end{array}$ & $\begin{array}{c}\text { SNJV } \\
\text { Appendix E }\end{array}$ & $\begin{array}{c}\text { DRI } \\
\text { Appendix F }\end{array}$ & $\begin{array}{c}\text { WSI } \\
\text { Appendix G }\end{array}$ \\
\hline & $\begin{array}{l}\text { Implementation } \\
\text { Reference }\end{array}$ & $\begin{array}{l}\text { Implementation } \\
\text { Reference }\end{array}$ & $\begin{array}{l}\text { Implementation } \\
\text { Reference }\end{array}$ & $\begin{array}{l}\text { Implementation } \\
\text { Reference }\end{array}$ & $\begin{array}{l}\text { Implementation } \\
\text { Reference }\end{array}$ & $\begin{array}{l}\text { Implementation } \\
\text { Reference }\end{array}$ & $\begin{array}{l}\text { Implementation } \\
\text { Reference }\end{array}$ & $\begin{array}{l}\text { Implementation } \\
\text { Reference }\end{array}$ \\
\hline
\end{tabular}

\begin{tabular}{|c|c|c|c|c|c|c|c|c|}
\hline $\begin{array}{l}\text { releases to the } \\
\text { workplace atmosphere } \\
\text { and in any situation, to } \\
\text { control the inhalation } \\
\text { of such material by } \\
\text { workers to levels that } \\
\text { are ALARA; } \\
\text { confinement and } \\
\text { ventilation shall } \\
\text { normally be used. }\end{array}$ & $\begin{array}{l}\text { radioactive } \\
\text { material at the } \\
\text { source, shall be } \\
\text { the primary } \\
\text { method of } \\
\text { minimizing } \\
\text { airborne } \\
\text { radioactivity and } \\
\text { internal exposure } \\
\text { to workers. }\end{array}$ & $\begin{array}{l}\text { radioactive } \\
\text { material at the } \\
\text { source, shall be } \\
\text { the primary } \\
\text { method of } \\
\text { minimizing } \\
\text { airborne } \\
\text { radioactivity and } \\
\text { internal exposure } \\
\text { to workers. }\end{array}$ & $\begin{array}{l}\text { facilities for } \\
\text { which LLNL-N } \\
\text { has operational } \\
\text { responsibility and } \\
\text { commenting on } \\
\text { and providing } \\
\text { appropriate input } \\
\text { to the review } \\
\text { process. }\end{array}$ & $\begin{array}{l}\text { agreement } \\
\text { between } \\
\text { LANL/NTS and } \\
\text { the LANL/RP-3 } \\
\text { Radiological } \\
\text { Engineering } \\
\text { Team, the } \\
\text { LANL/RP-3 } \\
\text { Radiological } \\
\text { Engineering } \\
\text { Team will } \\
\text { perform and } \\
\text { document the } \\
\text { ALARA review of } \\
\text { the design of } \\
\text { new LANL/NTS } \\
\text { facilities or the } \\
\text { modification of } \\
\text { existing } \\
\text { LANL/NTS } \\
\text { facilities. }\end{array}$ & & & $\begin{array}{l}\text { scope of DRI } \\
\text { activities. }\end{array}$ & $\begin{array}{l}\text { outside the } \\
\text { scope of WSI/NV } \\
\text { radiological } \\
\text { control } \\
\text { responsibilities. }\end{array}$ \\
\hline $\begin{array}{l}1002(d) \text { The design or } \\
\text { modification of a } \\
\text { facility and the } \\
\text { selection of materials } \\
\text { shall include features } \\
\text { that facilitate } \\
\text { operations, } \\
\text { maintenance, } \\
\text { decontamination, and } \\
\text { decommissioning. }\end{array}$ & $\begin{array}{l}\text { NV/YMP RCM } \\
\text { 128.1.e. In } \\
\text { addition, the } \\
\text { following } \\
\text { radiological } \\
\text { control design } \\
\text { criteria are } \\
\text { provided for new } \\
\text { facilities and } \\
\text { major } \\
\text { modifications to } \\
\text { existing facilities: }\end{array}$ & $\begin{array}{l}\text { NV/YMP RCM } \\
\text { 128.1.e. In } \\
\text { addition, the } \\
\text { following } \\
\text { radiological } \\
\text { control design } \\
\text { criteria are } \\
\text { provided for new } \\
\text { facilities and } \\
\text { major } \\
\text { modifications to } \\
\text { existing facilities: }\end{array}$ & $\begin{array}{l}\text { LLNL-N will be } \\
\text { responsible for } \\
\text { reviewing all } \\
\text { ALARA reviews } \\
\text { made on the } \\
\text { design of all } \\
\text { facilities for } \\
\text { which LLNL-N } \\
\text { has operational } \\
\text { responsibility and } \\
\text { commenting on } \\
\text { and providing }\end{array}$ & $\begin{array}{l}\text { This is outside } \\
\text { the scope of the } \\
\text { LANL/NTS } \\
\text { Radiological } \\
\text { Control Program. } \\
\text { By written } \\
\text { agreement } \\
\text { between } \\
\text { LANL/NTS and } \\
\text { the LANL/RP-3 } \\
\text { Radiological } \\
\text { Engineering }\end{array}$ & $\begin{array}{l}\text { Same as Column } \\
3\end{array}$ & $\begin{array}{l}\text { NV/YMP RCM } \\
128.1 . e . \text { In } \\
\text { addition, the } \\
\text { following } \\
\text { radiological } \\
\text { control design } \\
\text { criteria are } \\
\text { provided for new } \\
\text { facilities and } \\
\text { major } \\
\text { modifications to } \\
\text { existing facilities: }\end{array}$ & $\begin{array}{l}\text { Not applicable to } \\
\text { DRI. Facility and } \\
\text { equipment } \\
\text { design to } \\
\text { achieve ALARA } \\
\text { are outside the } \\
\text { scope of DRI } \\
\text { activities. }\end{array}$ & $\begin{array}{l}\text { Not applicable to } \\
\text { WSI/NV } \\
\text { operations. } \\
\text { Facility design } \\
\text { and } \\
\text { modifications are } \\
\text { outside the } \\
\text { scope of WSI/NV } \\
\text { radiological } \\
\text { control } \\
\text { responsibilities. }\end{array}$ \\
\hline
\end{tabular}

$\mathrm{H}-112$ 


\section{NEVADA TEST SITE RADIATION PROTECTION PROGRAM}

\section{APPENDIX H}

COMPLIANCE DEMONSTRATION TABLE

\begin{tabular}{|c|c|c|c|c|c|c|c|c|}
\hline \multirow[t]{2}{*}{10 CFR 835} & $\begin{array}{l}\text { NV/YMP RCM } \\
\text { Rev } 5 \text { and } \\
\text { NTS RPP } \\
\text { Revision } 0 \\
\end{array}$ & $\begin{array}{c}\text { NSTec } \\
\text { Appendix A }\end{array}$ & $\begin{array}{c}\text { LLNL } \\
\text { Appendix B }\end{array}$ & $\begin{array}{c}\text { LANL } \\
\text { Appendix C }\end{array}$ & $\begin{array}{c}\text { SNL } \\
\text { Appendix D }\end{array}$ & $\begin{array}{c}\text { SNJV } \\
\text { Appendix E }\end{array}$ & $\begin{array}{c}\text { DRI } \\
\text { Appendix F }\end{array}$ & $\begin{array}{c}\text { WSI } \\
\text { Appendix G }\end{array}$ \\
\hline & $\begin{array}{l}\text { Implementation } \\
\text { Reference }\end{array}$ & $\begin{array}{c}\text { Implementation } \\
\text { Reference }\end{array}$ & $\begin{array}{l}\text { Implementation } \\
\text { Reference }\end{array}$ & $\begin{array}{l}\text { Implementation } \\
\text { Reference }\end{array}$ & $\begin{array}{l}\text { Implementation } \\
\text { Reference }\end{array}$ & $\begin{array}{l}\text { Implementation } \\
\text { Reference }\end{array}$ & $\begin{array}{l}\text { Implementation } \\
\text { Reference }\end{array}$ & $\begin{array}{l}\text { Implementation } \\
\text { Reference }\end{array}$ \\
\hline
\end{tabular}

\begin{tabular}{|c|c|c|c|c|c|c|c|c|}
\hline & $\begin{array}{l}\text { e. Efficiency of } \\
\text { maintenance, } \\
\text { decontamination, } \\
\text { operations, and } \\
\text { decommissioning } \\
\text { shall be } \\
\text { maximized. }\end{array}$ & $\begin{array}{l}\text { e. Efficiency of } \\
\text { maintenance, } \\
\text { decontamination, } \\
\text { operations, and } \\
\text { decommissioning } \\
\text { shall be } \\
\text { maximized. }\end{array}$ & $\begin{array}{l}\text { appropriate input } \\
\text { to the review } \\
\text { process. }\end{array}$ & $\begin{array}{l}\text { Team, the } \\
\text { LANL/RP-3 } \\
\text { Radiological } \\
\text { Engineering } \\
\text { Team will } \\
\text { perform and } \\
\text { document the } \\
\text { ALARA review of } \\
\text { the design of } \\
\text { new LANL/NTS } \\
\text { facilities or the } \\
\text { modification of } \\
\text { existing } \\
\text { LANL/NTS } \\
\text { facilities. }\end{array}$ & & $\begin{array}{l}\text { e. Efficiency of } \\
\text { maintenance, } \\
\text { decontamination, } \\
\text { operations, and } \\
\text { decommissioning } \\
\text { shall be } \\
\text { maximized. }\end{array}$ & & \\
\hline $\begin{array}{l}835.1003 \text { Workplace } \\
\text { controls } \\
\text { During routine } \\
\text { operations, the } \\
\text { combination of } \\
\text { engineered and } \\
\text { administrative controls } \\
\text { shall provide that: } \\
\text { 1003(a) The } \\
\text { anticipated } \\
\text { occupational dose to } \\
\text { general employees } \\
\text { shall not exceed the } \\
\text { limits established at } \\
\S 835.202 ; \text { and }\end{array}$ & $\begin{array}{l}\text { NV/YMP RCM } \\
211.1 .01 . \\
\text { NNSA/NSO and } \\
\text { YMORD TOs } \\
\text { have established } \\
\text { the annual } \\
\text { Administrative } \\
\text { Control Level at } \\
500 \text { mrem total } \\
\text { effective dose } \\
\text { equivalent } \\
\text { (TEDE). } \\
\text { NV/YMP RCM } \\
\text { 213.1. Except for } \\
\text { emergency } \\
\text { exposures } \\
\text { authorized }\end{array}$ & $\begin{array}{l}\text { Revise: NV/YMP } \\
\text { RCM 211.1. } 01 . \\
\text { NNSA/NSO and } \\
\text { OCRWM TOs } \\
\text { have established } \\
\text { the annual } \\
\text { Administrative } \\
\text { Control Level at } \\
500 \text { mrem total } \\
\text { effective dose } \\
\text { (TED). } \\
\text { Revise: NV/YMP } \\
\text { RCM 213.1. } \\
\text { Except for } \\
\text { emergency } \\
\text { exposures } \\
\text { authorized }\end{array}$ & $\begin{array}{l}\text { Same as Column } \\
3\end{array}$ & $\begin{array}{l}\text { Same as Column } \\
3\end{array}$ & $\begin{array}{l}\text { Same as Column } \\
3\end{array}$ & $\begin{array}{l}\text { Same as Column } \\
3\end{array}$ & $\begin{array}{l}\text { Same as Column } \\
3\end{array}$ & $\begin{array}{l}\text { Same as Column } \\
3\end{array}$ \\
\hline
\end{tabular}




\section{NEVADA TEST SITE RADIATION PROTECTION PROGRAM}

\section{APPENDIX H}

COMPLIANCE DEMONSTRATION TABLE

\begin{tabular}{|c|c|c|c|c|c|c|c|c|}
\hline \multirow[t]{2}{*}{10 CFR 835} & $\begin{array}{c}\text { NV/YMP RCM } \\
\text { Rev } 5 \text { and } \\
\text { NTS RPP } \\
\text { Revision } 0 \\
\end{array}$ & $\begin{array}{c}\text { NSTec } \\
\text { Appendix A }\end{array}$ & $\begin{array}{c}\text { LLNL } \\
\text { Appendix B }\end{array}$ & $\begin{array}{c}\text { LANL } \\
\text { Appendix C }\end{array}$ & $\begin{array}{c}\text { SNL } \\
\text { Appendix D }\end{array}$ & $\begin{array}{c}\text { SNJV } \\
\text { Appendix E }\end{array}$ & $\begin{array}{c}\text { DRI } \\
\text { Appendix F }\end{array}$ & $\begin{array}{c}\text { WSI } \\
\text { Appendix G }\end{array}$ \\
\hline & $\begin{array}{l}\text { Implementation } \\
\text { Reference }\end{array}$ & $\begin{array}{l}\text { Implementation } \\
\text { Reference }\end{array}$ & $\begin{array}{l}\text { Implementation } \\
\text { Reference }\end{array}$ & $\begin{array}{l}\text { Implementation } \\
\text { Reference }\end{array}$ & $\begin{array}{c}\text { Implementation } \\
\text { Reference }\end{array}$ & $\begin{array}{l}\text { Implementation } \\
\text { Reference }\end{array}$ & $\begin{array}{l}\text { Implementation } \\
\text { Reference }\end{array}$ & $\begin{array}{l}\text { Implementation } \\
\text { Reference }\end{array}$ \\
\hline
\end{tabular}

\section{according to}

10 CFR

835.1302, the

occupational

dose received by

general

employees shall

be controlled

such that the

following limits

are not

exceeded in a

year.

a. A TEDE of 5

rem $(0.05$

sievert);

b. The sum of

the deep dose

equivalent for

external

exposures and

the committed

dose equivalent

to any organ or

tissue other than

the lens of the

eye of 50 rem

( 0.5 sievert);

c. A lens of the

eye dose

equivalent of 15

rem $(0.15$

according to

10 CFR

835.1302, the

occupational

dose received by

general

employees shall

be controlled

such that the

following limits

are not exceeded

in a year.

a. A TED of 5

rems $(0.05$

sievert);

b. The sum of

the equivalent

dose to the

whole body for

external

exposures and

the committed

equivalent dose

to any organ or

tissue other than

the lens of the

eye of 50 rems

( 0.5 sievert);

. An equivalent

dose to the lens

of the eye of 15

rems $(0.15$

sievert); and

sievert); and

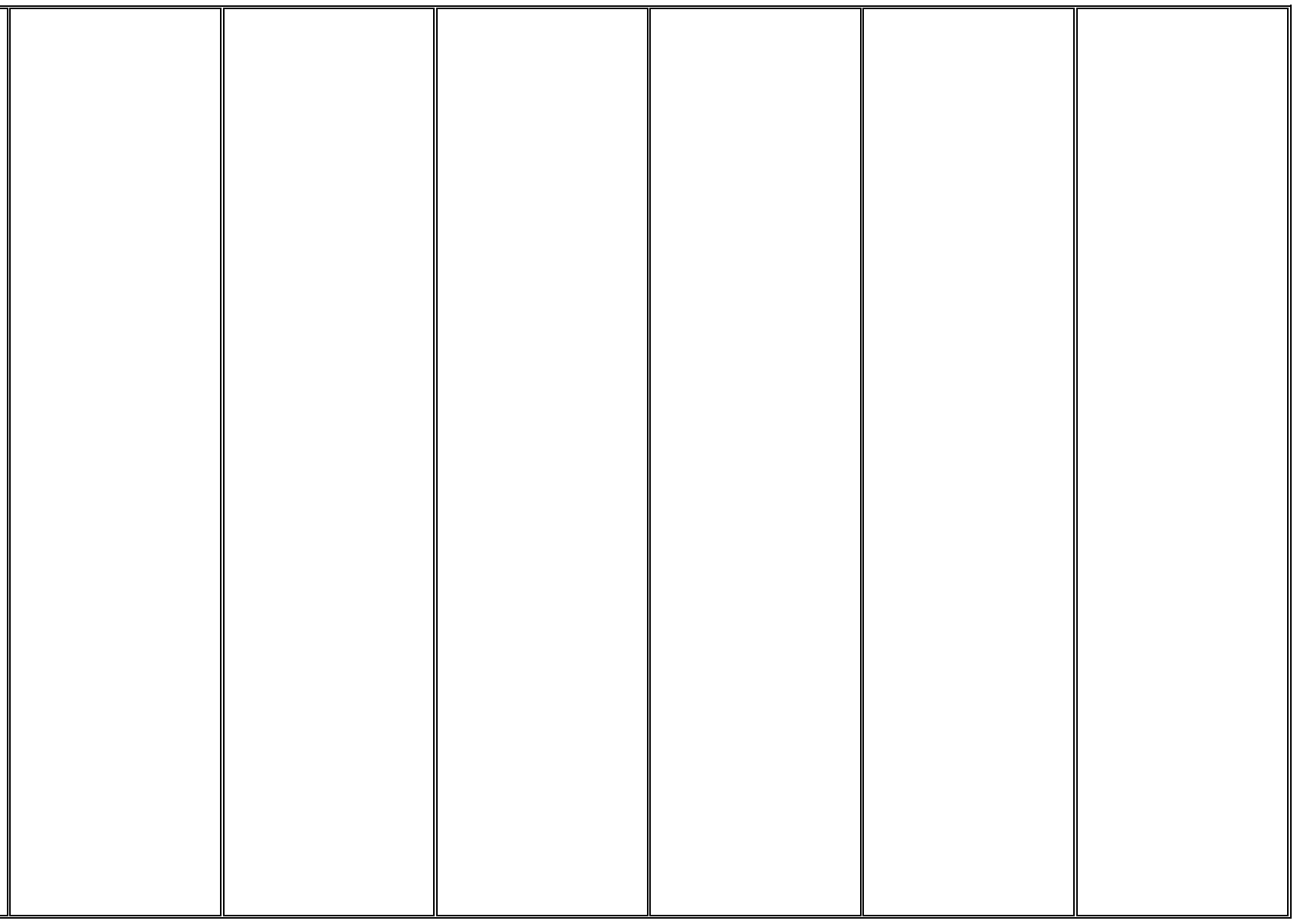




\section{NEVADA TEST SITE RADIATION PROTECTION PROGRAM}

\section{APPENDIX H}

COMPLIANCE DEMONSTRATION TABLE

\begin{tabular}{|c|c|c|c|c|c|c|c|c|}
\hline \multirow[t]{2}{*}{10 CFR 835} & $\begin{array}{c}\text { NV/YMP RCM } \\
\text { Rev } 5 \text { and } \\
\text { NTS RPP } \\
\text { Revision } 0 \\
\end{array}$ & $\begin{array}{c}\text { NSTec } \\
\text { Appendix A }\end{array}$ & $\begin{array}{c}\text { LLNL } \\
\text { Appendix B }\end{array}$ & $\begin{array}{c}\text { LANL } \\
\text { Appendix C }\end{array}$ & $\begin{array}{c}\text { SNL } \\
\text { Appendix D }\end{array}$ & $\begin{array}{c}\text { SNJV } \\
\text { Appendix E }\end{array}$ & $\begin{array}{c}\text { DRI } \\
\text { Appendix F }\end{array}$ & $\begin{array}{c}\text { WSI } \\
\text { Appendix G }\end{array}$ \\
\hline & $\begin{array}{l}\text { Implementation } \\
\text { Reference }\end{array}$ & $\begin{array}{l}\text { Implementation } \\
\text { Reference }\end{array}$ & $\begin{array}{l}\text { Implementation } \\
\text { Reference }\end{array}$ & $\begin{array}{l}\text { Implementation } \\
\text { Reference }\end{array}$ & $\begin{array}{c}\text { Implementation } \\
\text { Reference }\end{array}$ & $\begin{array}{l}\text { Implementation } \\
\text { Reference }\end{array}$ & $\begin{array}{l}\text { Implementation } \\
\text { Reference }\end{array}$ & $\begin{array}{l}\text { Implementation } \\
\text { Reference }\end{array}$ \\
\hline
\end{tabular}

\section{d. A shallow}

dose equivalent

of 50 rem $(0.5$

sievert) to the

skin or to any

extremity.

Deep dose

equivalent to the

whole body may

be used as the

effective dose

equivalent for

external

exposures. The

TEDE during a

year shall be

determined by

summing the

effective dose

equivalent from

external

exposures and

the CEDE from

intakes during

the year and

shall be used

when

demonstrating

compliance with

Table 2-1 dose

limits. All

occupational

d. An equivalent dose to the skin or to an extremity

of 50 rems $(0.5$

sievert.

The equivalent

dose to the

whole body may

be used as the

effective dose for

external

exposures. The

TED during a

year shall be

determined by

summing the

effective dose

from external

exposures and

the CED from

intakes during

the year and

shall be used

when

demonstrating

compliance with

Table 2-1 dose

limits. All

occupational

doses received

during the

doses received

current year

||

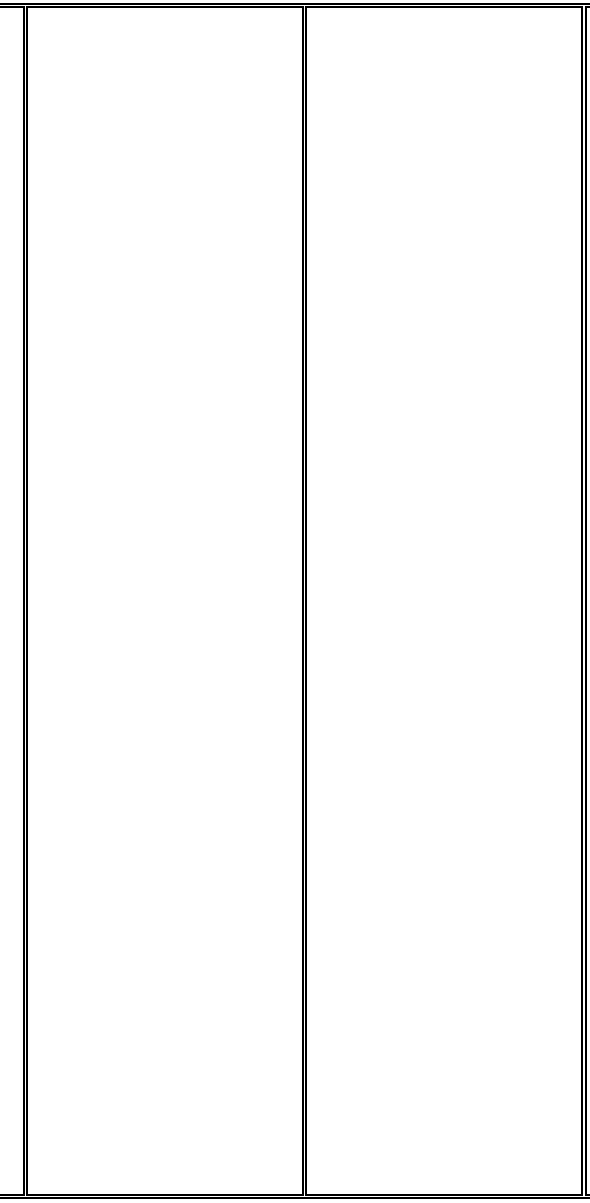




\section{NEVADA TEST SITE RADIATION PROTECTION PROGRAM}

\section{APPENDIX H}

COMPLIANCE DEMONSTRATION TABLE

\begin{tabular}{|c|c|c|c|c|c|c|c|c|}
\hline \multirow[t]{2}{*}{10 CFR 835} & $\begin{array}{c}\text { NV/YMP RCM } \\
\text { Rev } 5 \text { and } \\
\text { NTS RPP } \\
\text { Revision } 0 \\
\end{array}$ & $\begin{array}{c}\text { NSTec } \\
\text { Appendix A }\end{array}$ & $\begin{array}{c}\text { LLNL } \\
\text { Appendix B }\end{array}$ & $\begin{array}{c}\text { LANL } \\
\text { Appendix C }\end{array}$ & $\begin{array}{c}\text { SNL } \\
\text { Appendix D }\end{array}$ & $\begin{array}{c}\text { SNJV } \\
\text { Appendix E }\end{array}$ & $\begin{array}{c}\text { DRI } \\
\text { Appendix F }\end{array}$ & $\begin{array}{c}\text { WSI } \\
\text { Appendix G }\end{array}$ \\
\hline & $\begin{array}{l}\text { Implementation } \\
\text { Reference }\end{array}$ & $\begin{array}{l}\text { Implementation } \\
\text { Reference }\end{array}$ & $\begin{array}{l}\text { Implementation } \\
\text { Reference }\end{array}$ & $\begin{array}{l}\text { Implementation } \\
\text { Reference }\end{array}$ & $\begin{array}{c}\text { Implementation } \\
\text { Reference }\end{array}$ & $\begin{array}{l}\text { Implementation } \\
\text { Reference }\end{array}$ & $\begin{array}{l}\text { Implementation } \\
\text { Reference }\end{array}$ & $\begin{array}{l}\text { Implementation } \\
\text { Reference }\end{array}$ \\
\hline
\end{tabular}

\begin{tabular}{|c|c|c|c|c|c|c|c|c|}
\hline & $\begin{array}{l}\text { during the } \\
\text { current year } \\
\text { except } \\
\text { emergency } \\
\text { exposures } \\
\text { authorized } \\
\text { according to } \\
10 \text { CFR } \\
835.1302 \text { shall } \\
\text { be included. } \\
\text { Occupational } \\
\text { dose limits are } \\
\text { summarized in } \\
\text { Table 2-1. }\end{array}$ & $\begin{array}{l}\text { emergency } \\
\text { exposures } \\
\text { authorized } \\
\text { according to } \\
10 \mathrm{CFR} \\
835.1302 \text { shall } \\
\text { be included. } \\
\text { Occupational } \\
\text { dose limits are } \\
\text { summarized in } \\
\text { Table 2-1. } \\
\text { Add: NV/YMP } \\
\text { RCM 311.06: } \\
\text { During routine } \\
\text { operations, the } \\
\text { combination of } \\
\text { engineered and } \\
\text { administrative } \\
\text { controls shall } \\
\text { provide that: } \\
\text { The anticipated } \\
\text { occupational } \\
\text { dose to general } \\
\text { employees shall } \\
\text { not exceed the } \\
\text { limits established } \\
\text { in Table 2-1. }\end{array}$ & & & & & & \\
\hline $\begin{array}{l}\text { 1003(b) The ALARA } \\
\text { process is utilized for } \\
\text { personnel exposures } \\
\text { to ionizing radiation. }\end{array}$ & $\begin{array}{l}\text { NV/YMP RCM } \\
\text { 111. ALARA .02. } \\
\text { As Low As } \\
\text { Reasonably } \\
\text { Achievable. }\end{array}$ & $\begin{array}{l}\text { Add: RCM } \\
\text { 111.ALARA.01 } \\
\text { The ALARA } \\
\text { process is } \\
\text { utilized for }\end{array}$ & $\begin{array}{l}\text { Same as Column } \\
3\end{array}$ & $\begin{array}{l}\text { Same as Column } \\
3\end{array}$ & $\begin{array}{l}\text { Same as Column } \\
3\end{array}$ & $\begin{array}{l}\text { Same as Column } \\
3\end{array}$ & $\begin{array}{l}\text { DRI Appendix F, } \\
\text { Narrative } \\
\text { Section: } 4.0 \\
\text { ALARA } \\
\text { Commitment. }\end{array}$ & $\begin{array}{l}\text { Same as Column } \\
3\end{array}$ \\
\hline
\end{tabular}

H-116 


\section{NEVADA TEST SITE RADIATION PROTECTION PROGRAM}

\section{APPENDIX H}

COMPLIANCE DEMONSTRATION TABLE

\begin{tabular}{|c|c|c|c|c|c|c|c|c|}
\hline \multirow[t]{2}{*}{10 CFR 835} & $\begin{array}{c}\text { NV/YMP RCM } \\
\text { Rev } 5 \text { and } \\
\text { NTS RPP } \\
\text { Revision } 0 \\
\end{array}$ & $\begin{array}{c}\text { NSTec } \\
\text { Appendix A }\end{array}$ & $\begin{array}{c}\text { LLNL } \\
\text { Appendix B }\end{array}$ & $\begin{array}{c}\text { LANL } \\
\text { Appendix C }\end{array}$ & $\begin{array}{c}\text { SNL } \\
\text { Appendix D }\end{array}$ & $\begin{array}{c}\text { SNJV } \\
\text { Appendix E }\end{array}$ & $\begin{array}{c}\text { DRI } \\
\text { Appendix F }\end{array}$ & $\begin{array}{c}\text { WSI } \\
\text { Appendix G }\end{array}$ \\
\hline & $\begin{array}{l}\text { Implementation } \\
\text { Reference }\end{array}$ & $\begin{array}{l}\text { Implementation } \\
\text { Reference }\end{array}$ & $\begin{array}{l}\text { Implementation } \\
\text { Reference }\end{array}$ & $\begin{array}{l}\text { Implementation } \\
\text { Reference }\end{array}$ & $\begin{array}{l}\text { Implementation } \\
\text { Reference }\end{array}$ & $\begin{array}{l}\text { Implementation } \\
\text { Reference }\end{array}$ & $\begin{array}{l}\text { Implementation } \\
\text { Reference }\end{array}$ & $\begin{array}{l}\text { Implementation } \\
\text { Reference }\end{array}$ \\
\hline
\end{tabular}

\begin{tabular}{|c|c|c|c|c|c|c|c|c|}
\hline & $\begin{array}{l}\text { Radiation } \\
\text { exposure of the } \\
\text { work force and } \\
\text { public shall be } \\
\text { controlled such } \\
\text { that radiation } \\
\text { exposures are } \\
\text { maintained within } \\
\text { acceptable limits } \\
\text { and as far below } \\
\text { these limits as is } \\
\text { reasonably } \\
\text { achievable. } \\
\end{array}$ & $\begin{array}{l}\text { personnel } \\
\text { exposures to } \\
\text { ionizing } \\
\text { radiation. }\end{array}$ & & & & & & \\
\hline 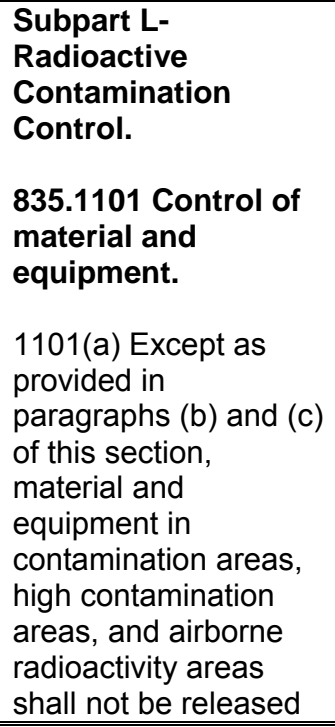 & $\begin{array}{l}\text { NV/YMP RCM } \\
\text { 421.1. Except as } \\
\text { provided in } \\
\text { Articles } 421.2 \\
\text { and } 421.3, \\
\text { material and } \\
\text { equipment in } \\
\text { Contamination } \\
\text { Areas, High } \\
\text { Contamination } \\
\text { Areas, and } \\
\text { Airborne } \\
\text { Radioactivity } \\
\text { Areas shall not } \\
\text { be released to a } \\
\text { Controlled Area } \\
\text { if: } \\
\text { a. Removable } \\
\text { surface } \\
\text { contamination }\end{array}$ & $\begin{array}{l}\text { NV/YMP RCM } \\
\text { 421.1. Except as } \\
\text { provided in } \\
\text { Articles } 421.2 \\
\text { and } 421.3, \\
\text { material and } \\
\text { equipment in } \\
\text { Contamination } \\
\text { Areas, High } \\
\text { Contamination } \\
\text { Areas, and } \\
\text { Airborne } \\
\text { Radioactivity } \\
\text { Areas shall not } \\
\text { be released to a } \\
\text { Controlled Area } \\
\text { if: } \\
\text { a. Removable } \\
\text { surface } \\
\text { contamination } \\
\end{array}$ & $\begin{array}{l}\text { Same as Column } \\
3\end{array}$ & $\begin{array}{l}\text { Same as Column } \\
3\end{array}$ & $\begin{array}{l}\text { SNL-NV does } \\
\text { not release } \\
\text { materials and } \\
\text { equipment from } \\
\text { radiological } \\
\text { areas at NTS. } \\
\text { This service is } \\
\text { provided for SNL } \\
\text { by the RSPC. }\end{array}$ & $\begin{array}{l}\text { Same as Column } \\
3\end{array}$ & $\begin{array}{l}\text { Not applicable. } \\
\text { DRI does not } \\
\text { release materials } \\
\text { and equipment } \\
\text { from radiological } \\
\text { areas at NTS. } \\
\text { This service is } \\
\text { provided to DRI } \\
\text { by the RSPC. }\end{array}$ & $\begin{array}{l}\text { Not applicable. } \\
\text { Release of } \\
\text { material and } \\
\text { equipment is } \\
\text { beyond the } \\
\text { scope of WSI/NV } \\
\text { radiological } \\
\text { control } \\
\text { responsibilities. }\end{array}$ \\
\hline
\end{tabular}




\section{NEVADA TEST SITE RADIATION PROTECTION PROGRAM}

\section{APPENDIX H}

COMPLIANCE DEMONSTRATION TABLE

\begin{tabular}{|c|c|c|c||c||c||c||c||c|}
\hline \multirow{2}{*}{ 10 CFR 835 } & $\begin{array}{c}\text { NV/YMP RCM } \\
\text { Rev 5 and } \\
\text { NTS RPP } \\
\text { Revision 0 }\end{array}$ & Appendix A & Appendix B & Appendix C & Appendix D & SNJV \\
\cline { 2 - 7 } & $\begin{array}{c}\text { Implementation } \\
\text { Reference }\end{array}$ & $\begin{array}{c}\text { Implementation } \\
\text { Reference }\end{array}$ & $\begin{array}{c}\text { Implementation } \\
\text { Reference }\end{array}$ & $\begin{array}{c}\text { Implementation } \\
\text { Reference }\end{array}$ & $\begin{array}{c}\text { Implementation } \\
\text { Reference }\end{array}$ & $\begin{array}{c}\text { Implementation } \\
\text { Reference }\end{array}$ & $\begin{array}{c}\text { Implementation } \\
\text { Reference }\end{array}$ & $\begin{array}{c}\text { Implementation } \\
\text { Reference }\end{array}$ \\
\hline
\end{tabular}

\begin{tabular}{|c|c|c|c|c|c|c|c|c|}
\hline $\begin{array}{l}\text { to a controlled area if: } \\
\text { (1) Removable } \\
\text { surface contamination } \\
\text { levels on accessible } \\
\text { surfaces exceed the } \\
\text { removable surface } \\
\text { contamination values } \\
\text { specified in Appendix } \\
\text { D of this part; or } \\
\text { (2) Prior use suggests } \\
\text { that the removable } \\
\text { surface contamination } \\
\text { levels on inaccessible } \\
\text { surfaces are likely to } \\
\text { exceed the removable } \\
\text { surface contamination } \\
\text { values specified in } \\
\text { Appendix D of this } \\
\text { part. }\end{array}$ & $\begin{array}{l}\text { levels on } \\
\text { accessible } \\
\text { surfaces exceed } \\
\text { the removable } \\
\text { surface } \\
\text { contamination } \\
\text { values specified } \\
\text { in Table } 2-2 \text {. } \\
\text { b. Prior use } \\
\text { suggests that the } \\
\text { removable } \\
\text { surface } \\
\text { contamination } \\
\text { levels on the } \\
\text { inaccessible } \\
\text { surfaces are } \\
\text { likely to exceed } \\
\text { the removable } \\
\text { surface } \\
\text { contamination } \\
\text { values specified } \\
\text { in Table 2-2. } \\
\end{array}$ & $\begin{array}{l}\text { levels on } \\
\text { accessible } \\
\text { surfaces exceed } \\
\text { the removable } \\
\text { surface } \\
\text { contamination } \\
\text { values specified } \\
\text { in Table 2-2. } \\
\text { b. Prior use } \\
\text { suggests that the } \\
\text { removable } \\
\text { surface } \\
\text { contamination } \\
\text { levels on the } \\
\text { inaccessible } \\
\text { surfaces are } \\
\text { likely to exceed } \\
\text { the removable } \\
\text { surface } \\
\text { contamination } \\
\text { values specified } \\
\text { in Table 2-2. } \\
\end{array}$ & & & & & & \\
\hline $\begin{array}{l}1101(b) \text { Material and } \\
\text { equipment exceeding } \\
\text { the removable surface } \\
\text { contamination values } \\
\text { specified in appendix } \\
\text { D of this part may be } \\
\text { conditionally released } \\
\text { for movement on-site } \\
\text { from one radiological } \\
\text { area for immediate } \\
\text { placement in another }\end{array}$ & $\begin{array}{l}\text { NV/YMP RCM } \\
\text { 421.3. Material } \\
\text { and equipment } \\
\text { exceeding the } \\
\text { removable } \\
\text { contamination } \\
\text { values specified } \\
\text { in Table } 2-2 \text { may } \\
\text { be conditionally } \\
\text { released for } \\
\text { movement onsite }\end{array}$ & $\begin{array}{l}\text { NV/YMP RCM } \\
\text { 421.3. Material } \\
\text { and equipment } \\
\text { exceeding the } \\
\text { removable } \\
\text { contamination } \\
\text { values specified } \\
\text { in Table } 2-2 \text { may } \\
\text { be conditionally } \\
\text { released for } \\
\text { movement onsite }\end{array}$ & $\begin{array}{l}\text { Same as Column } \\
3\end{array}$ & $\begin{array}{l}\text { Same as Column } \\
3\end{array}$ & $\begin{array}{l}\text { SNL-NV does } \\
\text { not release } \\
\text { materials and } \\
\text { equipment from } \\
\text { radiological } \\
\text { areas at NTS. } \\
\text { This service is } \\
\text { provided for SNL } \\
\text { by the RSPC. }\end{array}$ & $\begin{array}{l}\text { Same as Column } \\
3\end{array}$ & $\begin{array}{l}\text { Not applicable. } \\
\text { DRI does not } \\
\text { release materials } \\
\text { and equipment } \\
\text { from radiological } \\
\text { areas at NTS. } \\
\text { This service is } \\
\text { provided to DRI } \\
\text { by the RSPC. }\end{array}$ & $\begin{array}{l}\text { Not applicable. } \\
\text { Release of } \\
\text { material and } \\
\text { equipment is } \\
\text { beyond the } \\
\text { scope of WSI/NV } \\
\text { radiological } \\
\text { control } \\
\text { responsibilities. }\end{array}$ \\
\hline
\end{tabular}




\section{NEVADA TEST SITE RADIATION PROTECTION PROGRAM}

\section{APPENDIX H}

COMPLIANCE DEMONSTRATION TABLE

\begin{tabular}{|c|c|c|c||c||c||c||c||c|}
\hline \multirow{2}{*}{ 10 CFR 835 } & $\begin{array}{c}\text { NV/YMP RCM } \\
\text { Rev 5 and } \\
\text { NTS RPP } \\
\text { Revision 0 }\end{array}$ & Appendix A & Appendix B & Appendix C & Appendix D & SNJV \\
\cline { 2 - 7 } & $\begin{array}{c}\text { Implementation } \\
\text { Reference }\end{array}$ & $\begin{array}{c}\text { Implementation } \\
\text { Reference }\end{array}$ & $\begin{array}{c}\text { Implementation } \\
\text { Reference }\end{array}$ & $\begin{array}{c}\text { Implementation } \\
\text { Reference }\end{array}$ & $\begin{array}{c}\text { Implementation } \\
\text { Reference }\end{array}$ & $\begin{array}{c}\text { Implementation } \\
\text { Reference }\end{array}$ & $\begin{array}{c}\text { Implementation } \\
\text { Reference }\end{array}$ & $\begin{array}{c}\text { Implementation } \\
\text { Reference }\end{array}$ \\
\hline
\end{tabular}

\begin{tabular}{|c|c|c|c|c|c|c|c|c|}
\hline $\begin{array}{l}\text { radiological area only } \\
\text { if appropriate } \\
\text { monitoring is } \\
\text { performed and } \\
\text { appropriate controls } \\
\text { for the movement are } \\
\text { established and } \\
\text { exercised. }\end{array}$ & $\begin{array}{l}\text { from one } \\
\text { radiological area } \\
\text { for immediate } \\
\text { placement in } \\
\text { another } \\
\text { radiological area } \\
\text { only if } \\
\text { appropriate } \\
\text { monitoring is } \\
\text { performed and } \\
\text { appropriate } \\
\text { controls for } \\
\text { movement are } \\
\text { established and } \\
\text { exercised. }\end{array}$ & $\begin{array}{l}\text { from one } \\
\text { radiological area } \\
\text { for immediate } \\
\text { placement in } \\
\text { another } \\
\text { radiological area } \\
\text { only if } \\
\text { appropriate } \\
\text { monitoring is } \\
\text { performed and } \\
\text { appropriate } \\
\text { controls for } \\
\text { movement are } \\
\text { established and } \\
\text { exercised. }\end{array}$ & & & & & & \\
\hline $\begin{array}{l}1101(\mathrm{c}) \text { Material and } \\
\text { equipment with fixed } \\
\text { contamination levels } \\
\text { that exceed the total } \\
\text { surface contamination } \\
\text { values specified in } \\
\text { appendix D of this part } \\
\text { may be released for } \\
\text { use in controlled areas } \\
\text { outside of radiological } \\
\text { areas only under the } \\
\text { following conditions: } \\
\text { (1) Removable surface } \\
\text { contamination levels } \\
\text { are below the } \\
\text { removable surface } \\
\text { contamination values } \\
\text { specified in appendix }\end{array}$ & $\begin{array}{l}\text { NV/YMP RCM } \\
421.2 \text {. Material } \\
\text { and equipment } \\
\text { with fixed } \\
\text { contamination } \\
\text { levels that } \\
\text { exceed the total } \\
\text { surface } \\
\text { contamination } \\
\text { values specified } \\
\text { in Table } 2-2 \text { may } \\
\text { be released for } \\
\text { use in Controlled } \\
\text { Areas outside of } \\
\text { radiological } \\
\text { areas only under } \\
\text { the following } \\
\text { conditions: } \\
\end{array}$ & $\begin{array}{l}\text { NV/YMP RCM } \\
421.2 \text {. Material } \\
\text { and equipment } \\
\text { with fixed } \\
\text { contamination } \\
\text { levels that } \\
\text { exceed the total } \\
\text { surface } \\
\text { contamination } \\
\text { values specified } \\
\text { in Table } 2-2 \text { may } \\
\text { be released for } \\
\text { use in Controlled } \\
\text { Areas outside of } \\
\text { radiological } \\
\text { areas only under } \\
\text { the following } \\
\text { conditions: } \\
\end{array}$ & $\begin{array}{l}\text { Same as Column } \\
3\end{array}$ & $\begin{array}{l}\text { Same as Column } \\
3\end{array}$ & $\begin{array}{l}\text { SNL-NV does } \\
\text { not release } \\
\text { materials and } \\
\text { equipment from } \\
\text { radiological } \\
\text { areas at NTS. } \\
\text { This service is } \\
\text { provided for SNL } \\
\text { by the RSPC. }\end{array}$ & $\begin{array}{l}\text { Same as Column } \\
3\end{array}$ & $\begin{array}{l}\text { Not applicable. } \\
\text { DRI does not } \\
\text { release materials } \\
\text { and equipment } \\
\text { from radiological } \\
\text { areas at NTS. } \\
\text { This service is } \\
\text { provided to DRI } \\
\text { by the RSPC. }\end{array}$ & $\begin{array}{l}\text { Not applicable. } \\
\text { Release of } \\
\text { material and } \\
\text { equipment is } \\
\text { beyond the } \\
\text { scope of WSI/NV } \\
\text { radiological } \\
\text { control } \\
\text { responsibilities. }\end{array}$ \\
\hline
\end{tabular}




\section{NEVADA TEST SITE RADIATION PROTECTION PROGRAM}

\section{APPENDIX H}

COMPLIANCE DEMONSTRATION TABLE

\begin{tabular}{|c|c|c|c|c|c|c|c|c|}
\hline \multirow[t]{2}{*}{10 CFR 835} & $\begin{array}{l}\text { NV/YMP RCM } \\
\text { Rev } 5 \text { and } \\
\text { NTS RPP } \\
\text { Revision } 0 \\
\end{array}$ & $\begin{array}{c}\text { NSTec } \\
\text { Appendix A }\end{array}$ & $\begin{array}{c}\text { LLNL } \\
\text { Appendix B }\end{array}$ & $\begin{array}{c}\text { LANL } \\
\text { Appendix C }\end{array}$ & $\begin{array}{c}\text { SNL } \\
\text { Appendix D }\end{array}$ & $\begin{array}{c}\text { SNJV } \\
\text { Appendix E }\end{array}$ & $\begin{array}{c}\text { DRI } \\
\text { Appendix F }\end{array}$ & $\begin{array}{c}\text { WSI } \\
\text { Appendix G }\end{array}$ \\
\hline & $\begin{array}{l}\text { Implementation } \\
\text { Reference }\end{array}$ & $\begin{array}{l}\text { Implementation } \\
\text { Reference }\end{array}$ & $\begin{array}{l}\text { Implementation } \\
\text { Reference }\end{array}$ & $\begin{array}{l}\text { Implementation } \\
\text { Reference }\end{array}$ & $\begin{array}{l}\text { Implementation } \\
\text { Reference }\end{array}$ & $\begin{array}{l}\text { Implementation } \\
\text { Reference }\end{array}$ & $\begin{array}{l}\text { Implementation } \\
\text { Reference }\end{array}$ & $\begin{array}{l}\text { Implementation } \\
\text { Reference }\end{array}$ \\
\hline
\end{tabular}

\begin{tabular}{|c|c|c|c|c|c|c|c|c|}
\hline $\begin{array}{l}\text { D of this part; and } \\
\text { (2) The material or } \\
\text { equipment is routinely } \\
\text { monitored and clearly } \\
\text { marked or labeled to } \\
\text { alert personnel of the } \\
\text { contaminated status. }\end{array}$ & $\begin{array}{l}\text { a. Removable } \\
\text { surface } \\
\text { contamination } \\
\text { levels are below } \\
\text { the removable } \\
\text { surface } \\
\text { contamination } \\
\text { values specified } \\
\text { in Table 2-2. } \\
\text { b. The material } \\
\text { or equipment is } \\
\text { routinely } \\
\text { monitored and } \\
\text { clearly marked or } \\
\text { labeled to alert } \\
\text { personnel of the } \\
\text { contaminated } \\
\text { status. }\end{array}$ & $\begin{array}{l}\text { a. Removable } \\
\text { surface } \\
\text { contamination } \\
\text { levels are below } \\
\text { the removable } \\
\text { surface } \\
\text { contamination } \\
\text { values specified } \\
\text { in Table 2-2. } \\
\text { b. The material } \\
\text { or equipment is } \\
\text { routinely } \\
\text { monitored and } \\
\text { clearly marked or } \\
\text { labeled to alert } \\
\text { personnel of the } \\
\text { contaminated } \\
\text { status. }\end{array}$ & & & & & & \\
\hline $\begin{array}{l}\text { 835.1102 Control of } \\
\text { areas } \\
\text { 1102(a) Appropriate } \\
\text { controls shall be } \\
\text { maintained and } \\
\text { verified which prevent } \\
\text { the inadvertent } \\
\text { transfer of removable } \\
\text { contamination to } \\
\text { locations outside of } \\
\text { radiological areas } \\
\text { under normal } \\
\text { operating conditions. }\end{array}$ & $\begin{array}{l}\text { NV/YMP RCM } \\
337.01 \text {. Controls } \\
\text { shall be } \\
\text { implemented as } \\
\text { necessary to } \\
\text { prevent the } \\
\text { spread of } \\
\text { removable } \\
\text { contamination } \\
\text { outside of } \\
\text { radiological } \\
\text { areas under } \\
\text { normal operating } \\
\text { conditions. }\end{array}$ & $\begin{array}{l}\text { NV/YMP RCM } \\
337.01 \text {. Controls } \\
\text { shall be } \\
\text { implemented as } \\
\text { necessary to } \\
\text { prevent the } \\
\text { spread of } \\
\text { removable } \\
\text { contamination } \\
\text { outside of } \\
\text { radiological } \\
\text { areas under } \\
\text { normal operating } \\
\text { conditions. }\end{array}$ & $\begin{array}{l}\text { Same as Column } \\
3\end{array}$ & $\begin{array}{l}\text { Same as Column } \\
3\end{array}$ & $\begin{array}{l}\text { Same as Column } \\
3\end{array}$ & $\begin{array}{l}\text { Same as Column } \\
3\end{array}$ & $\begin{array}{l}\text { Same as Column } \\
3\end{array}$ & $\begin{array}{l}\text { Not applicable. } \\
\text { WSI/NV does not } \\
\text { have any } \\
\text { radiological } \\
\text { areas under its } \\
\text { jurisdiction. } \\
\text { WSI/NV will } \\
\text { comply with all } \\
\text { controls } \\
\text { employed by the } \\
\text { RSPC or TO who } \\
\text { has radiological } \\
\text { control } \\
\text { responsibilities } \\
\text { for an area. }\end{array}$ \\
\hline
\end{tabular}




\section{NEVADA TEST SITE RADIATION PROTECTION PROGRAM}

\section{APPENDIX H}

COMPLIANCE DEMONSTRATION TABLE

\begin{tabular}{|c|c|c|c|c|c|c|c|c|}
\hline \multirow[t]{2}{*}{10 CFR 835} & $\begin{array}{l}\text { NV/YMP RCM } \\
\text { Rev } 5 \text { and } \\
\text { NTS RPP } \\
\text { Revision } 0 \\
\end{array}$ & $\begin{array}{c}\text { NSTec } \\
\text { Appendix A }\end{array}$ & $\begin{array}{c}\text { LLNL } \\
\text { Appendix B }\end{array}$ & $\begin{array}{c}\text { LANL } \\
\text { Appendix C }\end{array}$ & $\begin{array}{c}\text { SNL } \\
\text { Appendix D }\end{array}$ & $\begin{array}{c}\text { SNJV } \\
\text { Appendix E }\end{array}$ & $\begin{array}{c}\text { DRI } \\
\text { Appendix F }\end{array}$ & $\begin{array}{c}\text { WSI } \\
\text { Appendix G }\end{array}$ \\
\hline & $\begin{array}{l}\text { Implementation } \\
\text { Reference }\end{array}$ & $\begin{array}{l}\text { Implementation } \\
\text { Reference }\end{array}$ & $\begin{array}{l}\text { Implementation } \\
\text { Reference }\end{array}$ & $\begin{array}{l}\text { Implementation } \\
\text { Reference }\end{array}$ & $\begin{array}{l}\text { Implementation } \\
\text { Reference }\end{array}$ & $\begin{array}{l}\text { Implementation } \\
\text { Reference }\end{array}$ & $\begin{array}{l}\text { Implementation } \\
\text { Reference }\end{array}$ & $\begin{array}{l}\text { Implementation } \\
\text { Reference }\end{array}$ \\
\hline
\end{tabular}

\begin{tabular}{|c|c|c|c|c|c|c|c|c|}
\hline & $\begin{array}{l}\text { NV/YMP RCM } \\
551.1 . e . \\
\text { Monitoring of } \\
\text { individuals and } \\
\text { areas shall be } \\
\text { performed to: } \\
\text { Verify the } \\
\text { effectiveness of } \\
\text { engineering and } \\
\text { administrative } \\
\text { controls in } \\
\text { containing } \\
\text { radioactive } \\
\text { material and } \\
\text { reducing } \\
\text { radiation } \\
\text { exposure. }\end{array}$ & $\begin{array}{l}\text { NV/YMP RCM } \\
551.1 . e . \\
\text { Monitoring of } \\
\text { individuals and } \\
\text { areas shall be } \\
\text { performed to: } \\
\text { Verify the } \\
\text { effectiveness of } \\
\text { engineering and } \\
\text { administrative } \\
\text { controls in } \\
\text { containing } \\
\text { radioactive } \\
\text { material and } \\
\text { reducing } \\
\text { radiation } \\
\text { exposure. }\end{array}$ & & & & & & \\
\hline $\begin{array}{l}1102(b) \text { Any area in } \\
\text { which contamination } \\
\text { levels exceed the } \\
\text { values specified in } \\
\text { Appendix D of this part } \\
\text { shall be controlled in a } \\
\text { manner } \\
\text { commensurate with } \\
\text { the physical and } \\
\text { chemical } \\
\text { characteristics of the } \\
\text { contaminant, the } \\
\text { radionuclides present, } \\
\text { and the fixed and } \\
\text { removable surface } \\
\text { contamination levels. }\end{array}$ & $\begin{array}{l}\text { NV/YMP RCM } \\
235 \text {. } \\
\text { 1. Areas shall be } \\
\text { posted to alert } \\
\text { personnel to } \\
\text { contamination } \\
\text { according to } \\
\text { Table 2-4 and } \\
\text { Article } 231 . \\
\text { 2. The physical } \\
\text { and chemical } \\
\text { characteristics } \\
\text { of, and the } \\
\text { radionuclides } \\
\text { present in, the } \\
\text { contamination }\end{array}$ & $\begin{array}{l}\text { NV/YMP RCM } \\
235 \text {. } \\
\text { 1. Areas shall be } \\
\text { posted to alert } \\
\text { personnel to } \\
\text { contamination } \\
\text { according to } \\
\text { Table 2-4 and } \\
\text { Article } 231 . \\
\text { 2. The physical } \\
\text { and chemical } \\
\text { characteristics } \\
\text { of, and the } \\
\text { radionuclides } \\
\text { present in, the } \\
\text { contamination }\end{array}$ & $\begin{array}{l}\text { Same as Column } \\
3\end{array}$ & $\begin{array}{l}\text { Same as Column } \\
3\end{array}$ & $\begin{array}{l}\text { Same as Column } \\
3\end{array}$ & $\begin{array}{l}\text { Same as Column } \\
3\end{array}$ & $\begin{array}{l}\text { Same as Column } \\
3\end{array}$ & $\begin{array}{l}\text { Not applicable. } \\
\text { WSI/NV does not } \\
\text { have any } \\
\text { radiological } \\
\text { areas under its } \\
\text { jurisdiction. } \\
\text { WSI/NV will } \\
\text { comply with all } \\
\text { controls } \\
\text { employed by the } \\
\text { RSPC or TO who } \\
\text { has radiological } \\
\text { control } \\
\text { responsibilities } \\
\text { for an area. }\end{array}$ \\
\hline
\end{tabular}

H-121 


\section{NEVADA TEST SITE RADIATION PROTECTION PROGRAM}

\section{APPENDIX H}

COMPLIANCE DEMONSTRATION TABLE

\begin{tabular}{|c|c|c|c|c|c|c|c|c|}
\hline \multirow[t]{2}{*}{10 CFR 835} & $\begin{array}{l}\text { NV/YMP RCM } \\
\text { Rev } 5 \text { and } \\
\text { NTS RPP } \\
\text { Revision } 0 \\
\end{array}$ & $\begin{array}{c}\text { NSTec } \\
\text { Appendix A }\end{array}$ & $\begin{array}{c}\text { LLNL } \\
\text { Appendix B }\end{array}$ & $\begin{array}{c}\text { LANL } \\
\text { Appendix C }\end{array}$ & $\begin{array}{c}\text { SNL } \\
\text { Appendix D }\end{array}$ & $\begin{array}{c}\text { SNJV } \\
\text { Appendix E }\end{array}$ & $\begin{array}{c}\text { DRI } \\
\text { Appendix F }\end{array}$ & $\begin{array}{c}\text { WSI } \\
\text { Appendix G }\end{array}$ \\
\hline & $\begin{array}{l}\text { Implementation } \\
\text { Reference }\end{array}$ & $\begin{array}{l}\text { Implementation } \\
\text { Reference }\end{array}$ & $\begin{array}{l}\text { Implementation } \\
\text { Reference }\end{array}$ & $\begin{array}{l}\text { Implementation } \\
\text { Reference }\end{array}$ & $\begin{array}{l}\text { Implementation } \\
\text { Reference }\end{array}$ & $\begin{array}{l}\text { Implementation } \\
\text { Reference }\end{array}$ & $\begin{array}{l}\text { Implementation } \\
\text { Reference }\end{array}$ & $\begin{array}{l}\text { Implementation } \\
\text { Reference }\end{array}$ \\
\hline
\end{tabular}

\begin{tabular}{|c|c|c|c|c|c|c|c|c|}
\hline & $\begin{array}{l}\text { will be } \\
\text { considered in } \\
\text { determining the } \\
\text { limiting } \\
\text { conditions and/or } \\
\text { access controls } \\
\text { to be specified } \\
\text { on the RWP. }\end{array}$ & $\begin{array}{l}\text { will be } \\
\text { considered in } \\
\text { determining the } \\
\text { limiting } \\
\text { conditions and/or } \\
\text { access controls } \\
\text { to be specified } \\
\text { on the RWP. }\end{array}$ & & & & & & \\
\hline $\begin{array}{l}\text { 1102(c) Areas } \\
\text { accessible to } \\
\text { individuals where the } \\
\text { measured total surface } \\
\text { contamination levels } \\
\text { exceed, but the } \\
\text { removable surface } \\
\text { contamination levels } \\
\text { are less than, } \\
\text { corresponding surface } \\
\text { contamination values } \\
\text { specified in Appendix } \\
\text { D of this part, shall be } \\
\text { controlled as follows } \\
\text { when located outside } \\
\text { of radiological areas: } \\
\text { (1) The area shall be } \\
\text { routinely monitored to } \\
\text { ensure the removable } \\
\text { surface contamination } \\
\text { level remains below } \\
\text { the removable surface } \\
\text { contamination values } \\
\text { specified in Appendix } \\
\text { D of this part; and (2) }\end{array}$ & $\begin{array}{l}\text { NV/YMP RCM } \\
\text { 222.3.a-b. Areas } \\
\text { or items } \\
\text { accessible to } \\
\text { individuals where } \\
\text { the measured } \\
\text { total surface } \\
\text { contamination } \\
\text { levels exceed, } \\
\text { but the } \\
\text { removable } \\
\text { surface } \\
\text { contamination } \\
\text { levels are less } \\
\text { than, } \\
\text { corresponding } \\
\text { surface } \\
\text { contamination } \\
\text { values specified } \\
\text { in Table 2-2, } \\
\text { shall be } \\
\text { controlled as } \\
\text { follows when } \\
\text { located outside } \\
\text { of radiological }\end{array}$ & $\begin{array}{l}\text { NV/YMP RCM } \\
\text { 222.3.a-b. Areas } \\
\text { or items } \\
\text { accessible to } \\
\text { individuals where } \\
\text { the measured } \\
\text { total surface } \\
\text { contamination } \\
\text { levels exceed, } \\
\text { but the } \\
\text { removable } \\
\text { surface } \\
\text { contamination } \\
\text { levels are less } \\
\text { than, } \\
\text { corresponding } \\
\text { surface } \\
\text { contamination } \\
\text { values specified } \\
\text { in Table 2-2, } \\
\text { shall be } \\
\text { controlled as } \\
\text { follows when } \\
\text { located outside } \\
\text { of radiological }\end{array}$ & $\begin{array}{l}\text { Same as Column } \\
3\end{array}$ & $\begin{array}{l}\text { Same as Column } \\
3\end{array}$ & $\begin{array}{l}\text { Same as Column } \\
3\end{array}$ & $\begin{array}{l}\text { Same as Column } \\
3\end{array}$ & $\begin{array}{l}\text { Same as Column } \\
3\end{array}$ & $\begin{array}{l}\text { Not applicable. } \\
\text { WSI/NV does not } \\
\text { have any } \\
\text { radiological } \\
\text { areas under its } \\
\text { jurisdiction. } \\
\text { WSI/NV will } \\
\text { comply with all } \\
\text { controls } \\
\text { employed by the } \\
\text { RSPC or TO who } \\
\text { has radiological } \\
\text { control } \\
\text { responsibilities } \\
\text { for an area. }\end{array}$ \\
\hline
\end{tabular}




\section{NEVADA TEST SITE RADIATION PROTECTION PROGRAM}

\section{APPENDIX H}

COMPLIANCE DEMONSTRATION TABLE

\begin{tabular}{|c|c|c|c|c|c|c|c|c|}
\hline \multirow[t]{2}{*}{10 CFR 835} & $\begin{array}{c}\text { NV/YMP RCM } \\
\text { Rev } 5 \text { and } \\
\text { NTS RPP } \\
\text { Revision } 0 \\
\end{array}$ & $\begin{array}{c}\text { NSTec } \\
\text { Appendix A }\end{array}$ & $\begin{array}{c}\text { LLNL } \\
\text { Appendix B }\end{array}$ & $\begin{array}{c}\text { LANL } \\
\text { Appendix C }\end{array}$ & $\begin{array}{c}\text { SNL } \\
\text { Appendix D }\end{array}$ & $\begin{array}{c}\text { SNJV } \\
\text { Appendix E }\end{array}$ & $\begin{array}{c}\text { DRI } \\
\text { Appendix F }\end{array}$ & $\begin{array}{c}\text { WSI } \\
\text { Appendix G }\end{array}$ \\
\hline & $\begin{array}{l}\text { Implementation } \\
\text { Reference }\end{array}$ & $\begin{array}{l}\text { Implementation } \\
\text { Reference }\end{array}$ & $\begin{array}{l}\text { Implementation } \\
\text { Reference }\end{array}$ & $\begin{array}{l}\text { Implementation } \\
\text { Reference }\end{array}$ & $\begin{array}{c}\text { Implementation } \\
\text { Reference }\end{array}$ & $\begin{array}{l}\text { Implementation } \\
\text { Reference }\end{array}$ & $\begin{array}{l}\text { Implementation } \\
\text { Reference }\end{array}$ & $\begin{array}{l}\text { Implementation } \\
\text { Reference }\end{array}$ \\
\hline
\end{tabular}

\begin{tabular}{|c|c|c|c|c|c|c|c|c|}
\hline $\begin{array}{l}\text { The area shall be } \\
\text { conspicuously marked } \\
\text { to warn individuals of } \\
\text { the contaminated } \\
\text { status. }\end{array}$ & $\begin{array}{l}\text { areas: } \\
\text { a. The area or } \\
\text { item shall be } \\
\text { routinely } \\
\text { monitored to } \\
\text { ensure the } \\
\text { removable } \\
\text { surface } \\
\text { contamination } \\
\text { level remains } \\
\text { below the } \\
\text { removable } \\
\text { surface } \\
\text { contamination } \\
\text { values specified } \\
\text { in Table 2-2. } \\
\text { b. The area or } \\
\text { item shall be } \\
\text { conspicuously } \\
\text { marked to warn } \\
\text { individuals of the } \\
\text { contaminated } \\
\text { status. }\end{array}$ & $\begin{array}{l}\text { areas: } \\
\text { a. The area or } \\
\text { item shall be } \\
\text { routinely } \\
\text { monitored to } \\
\text { ensure the } \\
\text { removable } \\
\text { surface } \\
\text { contamination } \\
\text { level remains } \\
\text { below the } \\
\text { removable } \\
\text { surface } \\
\text { contamination } \\
\text { values specified } \\
\text { in Table 2-2. } \\
\text { b. The area or } \\
\text { item shall be } \\
\text { conspicuously } \\
\text { marked to warn } \\
\text { individuals of the } \\
\text { contaminated } \\
\text { status. }\end{array}$ & & & & & & \\
\hline $\begin{array}{l}1102(d) \text { Individuals } \\
\text { exiting contamination, } \\
\text { high contamination, or } \\
\text { airborne radioactivity } \\
\text { areas shall be } \\
\text { monitored, as } \\
\text { appropriate, for the } \\
\text { presence of surface } \\
\text { contamination. }\end{array}$ & $\begin{array}{l}\text { NV/YMP RCM } \\
338.1 . \\
\text { Individuals } \\
\text { exiting } \\
\text { Contamination, } \\
\text { High } \\
\text { Contamination, } \\
\text { or Airborne } \\
\text { Radioactivity } \\
\text { Areas shall be } \\
\end{array}$ & $\begin{array}{l}\text { NV/YMP RCM } \\
338.1 . \\
\text { Individuals } \\
\text { exiting } \\
\text { Contamination, } \\
\text { High } \\
\text { Contamination, } \\
\text { or Airborne } \\
\text { Radioactivity } \\
\text { Areas shall be } \\
\end{array}$ & $\begin{array}{l}\text { Same as Column } \\
3\end{array}$ & $\begin{array}{l}\text { Same as Column } \\
3\end{array}$ & $\begin{array}{l}\text { Same as Column } \\
3\end{array}$ & $\begin{array}{l}\text { Same as Column } \\
3\end{array}$ & $\begin{array}{l}\text { Same as Column } \\
3\end{array}$ & $\begin{array}{l}\text { Not applicable. } \\
\text { WSI/NV does not } \\
\text { have any } \\
\text { radiological } \\
\text { areas under its } \\
\text { jurisdiction. } \\
\text { WSI/NV will } \\
\text { comply with all } \\
\text { controls } \\
\text { employed by the }\end{array}$ \\
\hline
\end{tabular}




\section{NEVADA TEST SITE RADIATION PROTECTION PROGRAM}

\section{APPENDIX H}

COMPLIANCE DEMONSTRATION TABLE

\begin{tabular}{|c|c|c|c|c|c|c|c|c|}
\hline \multirow[t]{2}{*}{10 CFR 835} & $\begin{array}{c}\text { NV/YMP RCM } \\
\text { Rev } 5 \text { and } \\
\text { NTS RPP } \\
\text { Revision } 0 \\
\end{array}$ & $\begin{array}{c}\text { NSTec } \\
\text { Appendix A }\end{array}$ & $\begin{array}{c}\text { LLNL } \\
\text { Appendix B }\end{array}$ & $\begin{array}{c}\text { LANL } \\
\text { Appendix C }\end{array}$ & $\begin{array}{c}\text { SNL } \\
\text { Appendix D }\end{array}$ & $\begin{array}{c}\text { SNJV } \\
\text { Appendix E }\end{array}$ & $\begin{array}{c}\text { DRI } \\
\text { Appendix F }\end{array}$ & $\begin{array}{c}\text { WSI } \\
\text { Appendix G }\end{array}$ \\
\hline & $\begin{array}{l}\text { Implementation } \\
\text { Reference }\end{array}$ & $\begin{array}{l}\text { Implementation } \\
\text { Reference }\end{array}$ & $\begin{array}{l}\text { Implementation } \\
\text { Reference }\end{array}$ & $\begin{array}{l}\text { Implementation } \\
\text { Reference }\end{array}$ & $\begin{array}{l}\text { Implementation } \\
\text { Reference }\end{array}$ & $\begin{array}{l}\text { Implementation } \\
\text { Reference }\end{array}$ & $\begin{array}{l}\text { Implementation } \\
\text { Reference }\end{array}$ & $\begin{array}{l}\text { Implementation } \\
\text { Reference }\end{array}$ \\
\hline
\end{tabular}

\begin{tabular}{|c|c|c|c|c|c|c|c|c|}
\hline & $\begin{array}{l}\text { monitored, as } \\
\text { appropriate, for } \\
\text { the presence of } \\
\text { surface } \\
\text { contamination. }\end{array}$ & $\begin{array}{l}\text { monitored, as } \\
\text { appropriate, for } \\
\text { the presence of } \\
\text { surface } \\
\text { contamination. }\end{array}$ & & & & & & $\begin{array}{l}\text { RSPC or TO who } \\
\text { has radiological } \\
\text { control } \\
\text { responsibilities } \\
\text { for an area. }\end{array}$ \\
\hline $\begin{array}{l}1102(e) \text { Protective } \\
\text { clothing shall be } \\
\text { required for entry to } \\
\text { areas in which } \\
\text { removable } \\
\text { contamination exists at } \\
\text { levels exceeding the } \\
\text { removable surface } \\
\text { contamination values } \\
\text { specified in Appendix } \\
\text { D of this part. }\end{array}$ & $\begin{array}{l}\text { NV/YMP RCM } \\
325.1 . a-b . \\
\text { Personnel shall } \\
\text { wear PC during } \\
\text { the following } \\
\text { activities: } \\
\text { a. Handling of } \\
\text { contaminated } \\
\text { materials with } \\
\text { removable } \\
\text { contamination in } \\
\text { excess of Table } \\
\text { 2-2 levels. } \\
\text { b. Work in } \\
\text { Contamination, } \\
\text { High } \\
\text { Contamination, } \\
\text { and Airborne } \\
\text { Radioactivity } \\
\text { Areas. }\end{array}$ & $\begin{array}{l}\text { NV/YMP RCM } \\
\text { 325.1.a-b. } \\
\text { Personnel shall } \\
\text { wear PC during } \\
\text { the following } \\
\text { activities: } \\
\text { a. Handling of } \\
\text { contaminated } \\
\text { materials with } \\
\text { removable } \\
\text { contamination in } \\
\text { excess of Table } \\
\text { 2-2 levels. } \\
\text { b. Work in } \\
\text { Contamination, } \\
\text { High } \\
\text { Contamination, } \\
\text { and Airborne } \\
\text { Radioactivity } \\
\text { Areas. }\end{array}$ & $\begin{array}{l}\text { Same as Column } \\
3\end{array}$ & $\begin{array}{l}\text { Same as Column } \\
3\end{array}$ & $\begin{array}{l}\text { Same as Column } \\
3\end{array}$ & $\begin{array}{l}\text { Same as Column } \\
3\end{array}$ & $\begin{array}{l}\text { Same as Column } \\
3 \text { and NV/YMP } \\
\text { RCM 325.1.c. } \\
\text { As directed by } \\
\text { the RCO or as } \\
\text { required by the } \\
\text { RWP. See also } \\
\text { Appendix 3B, } \\
\text { Table 3B-1. }\end{array}$ & $\begin{array}{l}\text { Maintaining and } \\
\text { verifying } \\
\text { appropriate } \\
\text { controls, such as } \\
\text { use of protective } \\
\text { clothing, are } \\
\text { beyond the } \\
\text { scope of WSI/NV } \\
\text { radiological } \\
\text { control } \\
\text { responsibilities. } \\
\text { WSI/NV will } \\
\text { comply with all } \\
\text { controls } \\
\text { employed by the } \\
\text { RSPC or TO who } \\
\text { has radiological } \\
\text { control } \\
\text { responsibilities } \\
\text { for an area. }\end{array}$ \\
\hline $\begin{array}{l}\text { Subpart M-Sealed } \\
\text { Radioactive Source } \\
\text { Control } \\
\text { 835.1201 Sealed } \\
\text { Radioactive Source } \\
\text { Control. } \\
\text { Sealed radioactive }\end{array}$ & $\begin{array}{l}\text { NV/YMP RCM } \\
431.01 . \text { Sealed } \\
\text { radioactive } \\
\text { sources shall be } \\
\text { used, handled, } \\
\text { and stored in a } \\
\text { manner } \\
\text { commensurate }\end{array}$ & $\begin{array}{l}\text { NV/YMP RCM } \\
431.01 \text {. Sealed } \\
\text { radioactive } \\
\text { sources shall be } \\
\text { used, handled, } \\
\text { and stored in a } \\
\text { manner } \\
\text { commensurate }\end{array}$ & $\begin{array}{l}\text { Same as Column } \\
3\end{array}$ & $\begin{array}{l}\text { Same as Column } \\
3\end{array}$ & $\begin{array}{l}\text { Same as Column } \\
3\end{array}$ & $\begin{array}{l}\text { Same as Column } \\
3\end{array}$ & $\begin{array}{l}\text { Same as Column } \\
3\end{array}$ & $\begin{array}{l}\text { Same as Column } \\
3\end{array}$ \\
\hline
\end{tabular}

$\mathrm{H}-124$ 


\section{NEVADA TEST SITE RADIATION PROTECTION PROGRAM}

\section{APPENDIX H}

COMPLIANCE DEMONSTRATION TABLE

\begin{tabular}{|c|c|c|c||c||c||c||c||c|}
\hline \multirow{2}{*}{ 10 CFR 835 } & $\begin{array}{c}\text { NV/YMP RCM } \\
\text { Rev 5 and } \\
\text { NTS RPP } \\
\text { Revision 0 }\end{array}$ & Appendix A & Appendix B & Appendix C & Appendix D & SNJV \\
\cline { 2 - 7 } & $\begin{array}{c}\text { Implementation } \\
\text { Reference }\end{array}$ & $\begin{array}{c}\text { Implementation } \\
\text { Reference }\end{array}$ & $\begin{array}{c}\text { Implementation } \\
\text { Reference }\end{array}$ & $\begin{array}{c}\text { Implementation } \\
\text { Reference }\end{array}$ & $\begin{array}{c}\text { Implementation } \\
\text { Reference }\end{array}$ & $\begin{array}{c}\text { Implementation } \\
\text { Reference }\end{array}$ & $\begin{array}{c}\text { Implementation } \\
\text { Reference }\end{array}$ & $\begin{array}{c}\text { Implementation } \\
\text { Reference }\end{array}$ \\
\hline
\end{tabular}

\begin{tabular}{|c|c|c|c|c|c|c|c|c|}
\hline $\begin{array}{l}\text { sources shall be used, } \\
\text { handled, and stored in } \\
\text { a manner } \\
\text { commensurate with } \\
\text { the hazards } \\
\text { associated with } \\
\text { operations involving } \\
\text { sources. }\end{array}$ & $\begin{array}{l}\text { with the hazards } \\
\text { associated with } \\
\text { operations } \\
\text { involving the } \\
\text { sources. }\end{array}$ & $\begin{array}{l}\text { with the hazards } \\
\text { associated with } \\
\text { operations } \\
\text { involving the } \\
\text { sources. }\end{array}$ & & & & & & \\
\hline $\begin{array}{l}\mathbf{8 3 5 . 1 2 0 2} \\
\text { Accountable Sealed } \\
\text { Radioactive Sources } \\
\text { 1202(a) Each } \\
\text { accountable sealed } \\
\text { radioactive source } \\
\text { shall be inventoried at } \\
\text { intervals not to exceed } \\
\text { six months. This } \\
\text { inventory shall: } \\
\text { (1) Establish the } \\
\text { physical location of } \\
\text { each accountable } \\
\text { sealed radioactive } \\
\text { source; } \\
\text { (2) Verify the presence } \\
\text { and adequacy of } \\
\text { associated postings } \\
\text { and labels; and } \\
\text { (3) Establish the } \\
\text { adequacy of storage } \\
\text { locations, containers, } \\
\text { and devices. }\end{array}$ & $\begin{array}{l}\text { NV/YMP RCM } \\
431.2 . a \text {. The } \\
\text { requirements for } \\
\text { inventory and } \\
\text { leak testing of } \\
\text { accountable } \\
\text { sealed sources } \\
\text { are: } \\
\text { a. Each } \\
\text { accountable } \\
\text { sealed } \\
\text { radioactive } \\
\text { source shall be } \\
\text { inventoried at } \\
\text { intervals not to } \\
\text { exceed six } \\
\text { months. The } \\
\text { inventory shall: } \\
\text { (1) Establish the } \\
\text { physical location } \\
\text { of each } \\
\text { accountable } \\
\text { sealed } \\
\text { radioactive } \\
\text { source. }\end{array}$ & $\begin{array}{l}\text { NV/YMP RCM } \\
\text { 431.2.a. The } \\
\text { requirements for } \\
\text { inventory and } \\
\text { leak testing of } \\
\text { accountable } \\
\text { sealed sources } \\
\text { are: } \\
\text { a. Each } \\
\text { accountable } \\
\text { sealed } \\
\text { radioactive } \\
\text { source shall be } \\
\text { inventoried at } \\
\text { intervals not to } \\
\text { exceed six } \\
\text { months. The } \\
\text { inventory shall: } \\
\text { (1) Establish the } \\
\text { physical location } \\
\text { of each } \\
\text { accountable } \\
\text { sealed } \\
\text { radioactive } \\
\text { source. }\end{array}$ & $\begin{array}{l}\text { Same as Column } \\
3\end{array}$ & $\begin{array}{l}\text { Same as Column } \\
3\end{array}$ & $\begin{array}{l}\text { Same as Column } \\
3\end{array}$ & $\begin{array}{l}\text { Same as Column } \\
3\end{array}$ & $\begin{array}{l}\text { Sealed sources } \\
\text { owned by DRI } \\
\text { are licensed for } \\
\text { use under the } \\
\text { UNR Radioactive } \\
\text { Material License } \\
\text { \#16-13-0003-07. } \\
\text { See UNR RSM } \\
\text { Procedure III: } \\
\text { Radiation Source } \\
\text { Control } \\
\text { Procedures. The } \\
\text { RSPC provides } \\
\text { inventory } \\
\text { services for DRI } \\
\text { sealed sources } \\
\text { used and stored } \\
\text { at the NTS. } \\
\text { Copies of these } \\
\text { reports are } \\
\text { forwarded to the } \\
\text { UNR radiation } \\
\text { safety office } \\
\text { upon receipt. }\end{array}$ & $\begin{array}{l}\text { Not applicable to } \\
\text { WSI/NV } \\
\text { operations. } \\
\text { WSI/NV does not } \\
\text { maintain custody } \\
\text { of accountable } \\
\text { sealed sources } \\
\text { used in its } \\
\text { operations; } \\
\text { therefore, the } \\
\text { inventory of } \\
\text { accountable } \\
\text { sealed } \\
\text { radioactive } \\
\text { sources is } \\
\text { beyond the } \\
\text { scope of WSI/NV } \\
\text { radiological } \\
\text { control } \\
\text { responsibilities. }\end{array}$ \\
\hline
\end{tabular}




\section{NEVADA TEST SITE RADIATION PROTECTION PROGRAM}

\section{APPENDIX H}

COMPLIANCE DEMONSTRATION TABLE

\begin{tabular}{|c|c|c|c|c|c|c|c|c|}
\hline \multirow[t]{2}{*}{10 CFR 835} & $\begin{array}{c}\text { NV/YMP RCM } \\
\text { Rev } 5 \text { and } \\
\text { NTS RPP } \\
\text { Revision } 0 \\
\end{array}$ & $\begin{array}{c}\text { NSTec } \\
\text { Appendix A }\end{array}$ & $\begin{array}{c}\text { LLNL } \\
\text { Appendix B }\end{array}$ & $\begin{array}{c}\text { LANL } \\
\text { Appendix C }\end{array}$ & $\begin{array}{c}\text { SNL } \\
\text { Appendix D }\end{array}$ & $\begin{array}{c}\text { SNJV } \\
\text { Appendix E }\end{array}$ & $\begin{array}{c}\text { DRI } \\
\text { Appendix F }\end{array}$ & $\begin{array}{c}\text { WSI } \\
\text { Appendix G }\end{array}$ \\
\hline & $\begin{array}{l}\text { Implementation } \\
\text { Reference }\end{array}$ & $\begin{array}{l}\text { Implementation } \\
\text { Reference }\end{array}$ & $\begin{array}{l}\text { Implementation } \\
\text { Reference }\end{array}$ & $\begin{array}{l}\text { Implementation } \\
\text { Reference }\end{array}$ & $\begin{array}{l}\text { Implementation } \\
\text { Reference }\end{array}$ & $\begin{array}{l}\text { Implementation } \\
\text { Reference }\end{array}$ & $\begin{array}{l}\text { Implementation } \\
\text { Reference }\end{array}$ & $\begin{array}{l}\text { Implementation } \\
\text { Reference }\end{array}$ \\
\hline
\end{tabular}

\begin{tabular}{|c|c|c|c|c|c|c|c|c|}
\hline & $\begin{array}{l}\text { (2) Verify the } \\
\text { appropriate } \\
\text { postings and } \\
\text { labels. } \\
\text { (3) Establish the } \\
\text { adequacy of } \\
\text { storage } \\
\text { locations, } \\
\text { containers, and } \\
\text { devices. } \\
\end{array}$ & $\begin{array}{l}\text { (2) Verify the } \\
\text { appropriate } \\
\text { postings and } \\
\text { labels. } \\
\text { (3) Establish the } \\
\text { adequacy of } \\
\text { storage } \\
\text { locations, } \\
\text { containers, and } \\
\text { devices. } \\
\end{array}$ & & & & & & \\
\hline $\begin{array}{l}\text { 1202(b) Except for } \\
\text { sealed radioactive } \\
\text { sources consisting } \\
\text { solely of gaseous } \\
\text { radioactive material or } \\
\text { tritium, each } \\
\text { accountable sealed } \\
\text { radioactive source } \\
\text { shall be subject to a } \\
\text { source leak test upon } \\
\text { receipt, when damage } \\
\text { is suspected, and at } \\
\text { intervals not to exceed } \\
\text { six months. Source } \\
\text { leak tests shall be } \\
\text { capable of detecting } \\
\text { radioactive material } \\
\text { leakage equal to or } \\
\text { exceeding } 0.005 \mu \mathrm{Ci} \text {. }\end{array}$ & $\begin{array}{l}\text { NV/YMP RCM } \\
431.2 . \text {. The } \\
\text { requirements for } \\
\text { inventory and } \\
\text { leak testing of } \\
\text { accountable } \\
\text { sealed sources } \\
\text { are: } \\
\text { b. Except for } \\
\text { sealed } \\
\text { radioactive } \\
\text { sources } \\
\text { consisting solely } \\
\text { of gaseous } \\
\text { radioactive } \\
\text { material or } \\
\text { tritium, each } \\
\text { accountable } \\
\text { sealed } \\
\text { radioactive } \\
\text { source shall be } \\
\text { leak tested upon } \\
\text { receipt, when } \\
\end{array}$ & $\begin{array}{l}\text { NV/YMP RCM } \\
\text { 431.2.b. The } \\
\text { requirements for } \\
\text { inventory and } \\
\text { leak testing of } \\
\text { accountable } \\
\text { sealed sources } \\
\text { are: } \\
\text { b. Except for } \\
\text { sealed } \\
\text { radioactive } \\
\text { sources } \\
\text { consisting solely } \\
\text { of gaseous } \\
\text { radioactive } \\
\text { material or } \\
\text { tritium, each } \\
\text { accountable } \\
\text { sealed } \\
\text { radioactive } \\
\text { source shall be } \\
\text { leak tested upon } \\
\text { receipt, when } \\
\end{array}$ & $\begin{array}{l}\text { Same as Column } \\
3\end{array}$ & $\begin{array}{l}\text { Same as Column } \\
3\end{array}$ & $\begin{array}{l}\text { Same as Column } \\
3\end{array}$ & $\begin{array}{l}\text { Same as Column } \\
3\end{array}$ & $\begin{array}{l}\text { Sealed sources } \\
\text { owned by DRI } \\
\text { are licensed for } \\
\text { use under the } \\
\text { UNR Radioactive } \\
\text { Material License } \\
\text { \#16-13-0003-07. } \\
\text { See UNR RSM } \\
\text { Procedure XII: } \\
\text { Leak Testing } \\
\text { Procedure. The } \\
\text { RSPC provides } \\
\text { leak testing } \\
\text { services for DRI } \\
\text { sealed sources } \\
\text { used and stored } \\
\text { at the NTS. } \\
\text { Copies of these } \\
\text { reports are } \\
\text { forwarded to the } \\
\text { UNR radiation } \\
\text { safety office } \\
\text { upon receipt. } \\
\end{array}$ & $\begin{array}{l}\text { Not applicable to } \\
\text { WSI/NV } \\
\text { operations. } \\
\text { WSI/NV does not } \\
\text { maintain custody } \\
\text { of accountable } \\
\text { sealed sources } \\
\text { used in its } \\
\text { operations; } \\
\text { therefore source } \\
\text { leak tests are } \\
\text { beyond the } \\
\text { scope of WSI/NV } \\
\text { radiological } \\
\text { control } \\
\text { responsibilities. }\end{array}$ \\
\hline
\end{tabular}




\section{NEVADA TEST SITE RADIATION PROTECTION PROGRAM}

\section{APPENDIX H}

COMPLIANCE DEMONSTRATION TABLE

\begin{tabular}{|c|c|c|c|c|c|c|c|c|}
\hline \multirow[t]{2}{*}{10 CFR 835} & $\begin{array}{c}\text { NV/YMP RCM } \\
\text { Rev } 5 \text { and } \\
\text { NTS RPP } \\
\text { Revision } 0 \\
\end{array}$ & $\begin{array}{c}\text { NSTec } \\
\text { Appendix A }\end{array}$ & $\begin{array}{c}\text { LLNL } \\
\text { Appendix B }\end{array}$ & $\begin{array}{c}\text { LANL } \\
\text { Appendix C }\end{array}$ & $\begin{array}{c}\text { SNL } \\
\text { Appendix D }\end{array}$ & $\begin{array}{c}\text { SNJV } \\
\text { Appendix E }\end{array}$ & $\begin{array}{c}\text { DRI } \\
\text { Appendix F }\end{array}$ & $\begin{array}{c}\text { WSI } \\
\text { Appendix G }\end{array}$ \\
\hline & $\begin{array}{l}\text { Implementation } \\
\text { Reference }\end{array}$ & $\begin{array}{l}\text { Implementation } \\
\text { Reference }\end{array}$ & $\begin{array}{l}\text { Implementation } \\
\text { Reference }\end{array}$ & $\begin{array}{l}\text { Implementation } \\
\text { Reference }\end{array}$ & $\begin{array}{l}\text { Implementation } \\
\text { Reference }\end{array}$ & $\begin{array}{l}\text { Implementation } \\
\text { Reference }\end{array}$ & $\begin{array}{l}\text { Implementation } \\
\text { Reference }\end{array}$ & $\begin{array}{l}\text { Implementation } \\
\text { Reference }\end{array}$ \\
\hline
\end{tabular}

\begin{tabular}{|c|c|c|c|c|c|c|c|c|}
\hline & $\begin{array}{l}\text { damage is } \\
\text { suspected and at } \\
\text { intervals not to } \\
\text { exceed six } \\
\text { months. Source } \\
\text { leak tests shall } \\
\text { be capable of } \\
\text { detecting } \\
\text { radioactive } \\
\text { material leakage } \\
=0.005 \mu \mathrm{Ci} \text {. }\end{array}$ & $\begin{array}{l}\text { damage is } \\
\text { suspected and at } \\
\text { intervals not to } \\
\text { exceed six } \\
\text { months. Source } \\
\text { leak tests shall } \\
\text { be capable of } \\
\text { detecting } \\
\text { radioactive } \\
\text { material leakage } \\
=0.005 \mu \mathrm{Ci} \text {. }\end{array}$ & & & & & & \\
\hline $\begin{array}{l}1202(\mathrm{c}) \\
\text { Notwithstanding the } \\
\text { requirements of } \\
\text { paragraph (b) of this } \\
\text { section, an } \\
\text { accountable sealed } \\
\text { radioactive source is } \\
\text { not subject to periodic } \\
\text { source leak testing if } \\
\text { that source has been } \\
\text { removed from service. } \\
\text { Such sources shall be } \\
\text { stored in a controlled } \\
\text { location, subject to } \\
\text { periodic inventory as } \\
\text { required by paragraph } \\
\text { (a) of this section, and } \\
\text { subject to source leak } \\
\text { testing prior to being } \\
\text { returned to service. }\end{array}$ & $\begin{array}{l}\text { NV/YMP RCM } \\
\text { 431.2.c. The } \\
\text { requirements for } \\
\text { inventory and } \\
\text { leak testing of } \\
\text { accountable } \\
\text { sealed sources } \\
\text { are: } \\
\text { c. An } \\
\text { accountable } \\
\text { sealed } \\
\text { radioactive } \\
\text { source that has } \\
\text { been removed } \\
\text { from service is } \\
\text { not subject to } \\
\text { periodic leak } \\
\text { testing. It must, } \\
\text { however be } \\
\text { stored in a } \\
\text { controlled } \\
\text { location and be }\end{array}$ & $\begin{array}{l}\text { NV/YMP RCM } \\
\text { 431.2.c. The } \\
\text { requirements for } \\
\text { inventory and } \\
\text { leak testing of } \\
\text { accountable } \\
\text { sealed sources } \\
\text { are: } \\
\text { c. An } \\
\text { accountable } \\
\text { sealed } \\
\text { radioactive } \\
\text { source that has } \\
\text { been removed } \\
\text { from service is } \\
\text { not subject to } \\
\text { periodic leak } \\
\text { testing. It must, } \\
\text { however be } \\
\text { stored in a } \\
\text { controlled } \\
\text { location and be }\end{array}$ & $\begin{array}{l}\text { Same as Column } \\
3\end{array}$ & $\begin{array}{l}\text { Same as Column } \\
3\end{array}$ & $\begin{array}{l}\text { Same as Column } \\
3\end{array}$ & $\begin{array}{l}\text { Same as Column } \\
3\end{array}$ & $\begin{array}{l}\text { Sealed sources } \\
\text { owned by DRI } \\
\text { are licensed for } \\
\text { use under the } \\
\text { UNR Radioactive } \\
\text { Material License } \\
\text { \#16-13-0003-07. } \\
\text { See UNR RSM } \\
\text { Procedure XII: } \\
\text { Leak Testing } \\
\text { Procedure. The } \\
\text { RSPC provides } \\
\text { leak testing and } \\
\text { inventory } \\
\text { services for DRI } \\
\text { sealed sources } \\
\text { used and stored } \\
\text { at the NTS. } \\
\text { Copies of these } \\
\text { reports are } \\
\text { forwarded to the } \\
\text { UNR radiation }\end{array}$ & $\begin{array}{l}\text { Not applicable to } \\
\text { WSI/NV } \\
\text { operations. } \\
\text { WSI/NV does not } \\
\text { maintain custody } \\
\text { of accountable } \\
\text { sealed sources } \\
\text { used in its } \\
\text { operations; } \\
\text { therefore, source } \\
\text { leak tests are } \\
\text { beyond the } \\
\text { scope of WSI/NV } \\
\text { radiological } \\
\text { control } \\
\text { responsibilities. }\end{array}$ \\
\hline
\end{tabular}




\section{NEVADA TEST SITE RADIATION PROTECTION PROGRAM}

\section{APPENDIX H}

COMPLIANCE DEMONSTRATION TABLE

\begin{tabular}{|c|c|c|c|c|c|c|c|c|}
\hline \multirow[t]{2}{*}{10 CFR 835} & $\begin{array}{c}\text { NV/YMP RCM } \\
\text { Rev } 5 \text { and } \\
\text { NTS RPP } \\
\text { Revision } 0 \\
\end{array}$ & $\begin{array}{c}\text { NSTec } \\
\text { Appendix A }\end{array}$ & $\begin{array}{c}\text { LLNL } \\
\text { Appendix B }\end{array}$ & $\begin{array}{c}\text { LANL } \\
\text { Appendix C }\end{array}$ & $\begin{array}{c}\text { SNL } \\
\text { Appendix D }\end{array}$ & $\begin{array}{c}\text { SNJV } \\
\text { Appendix E }\end{array}$ & $\begin{array}{c}\text { DRI } \\
\text { Appendix F }\end{array}$ & $\begin{array}{c}\text { WSI } \\
\text { Appendix G }\end{array}$ \\
\hline & $\begin{array}{l}\text { Implementation } \\
\text { Reference }\end{array}$ & $\begin{array}{l}\text { Implementation } \\
\text { Reference }\end{array}$ & $\begin{array}{l}\text { Implementation } \\
\text { Reference }\end{array}$ & $\begin{array}{l}\text { Implementation } \\
\text { Reference }\end{array}$ & $\begin{array}{l}\text { Implementation } \\
\text { Reference }\end{array}$ & $\begin{array}{l}\text { Implementation } \\
\text { Reference }\end{array}$ & $\begin{array}{l}\text { Implementation } \\
\text { Reference }\end{array}$ & $\begin{array}{l}\text { Implementation } \\
\text { Reference }\end{array}$ \\
\hline
\end{tabular}

\begin{tabular}{|c|c|c|c|c|c|c|c|c|}
\hline & $\begin{array}{l}\text { inventoried } \\
\text { according to } \\
\text { Article } 431.2 . a . \\
\text { An accountable } \\
\text { sealed } \\
\text { radioactive } \\
\text { source must be } \\
\text { leak tested } \\
\text { before restoring } \\
\text { it to service. }\end{array}$ & $\begin{array}{l}\text { inventoried } \\
\text { according to } \\
\text { Article 431.2.a. } \\
\text { An accountable } \\
\text { sealed } \\
\text { radioactive } \\
\text { source must be } \\
\text { leak tested } \\
\text { before restoring } \\
\text { it to service. }\end{array}$ & & & & & $\begin{array}{l}\text { safety office } \\
\text { upon receipt. }\end{array}$ & \\
\hline $\begin{array}{l}1202(d) \\
\text { Notwithstanding the } \\
\text { requirements of } \\
\text { paragraphs (a) and (b) } \\
\text { of this section, an } \\
\text { accountable sealed } \\
\text { radioactive source is } \\
\text { not subject to periodic } \\
\text { inventory and source } \\
\text { leak testing if that } \\
\text { source is located in an } \\
\text { area that is unsafe for } \\
\text { human entry or } \\
\text { otherwise } \\
\text { inaccessible. }\end{array}$ & $\begin{array}{l}\text { NV/YMP RCM } \\
431.2 . \text {. The } \\
\text { requirements for } \\
\text { inventory and } \\
\text { leak testing of } \\
\text { accountable } \\
\text { sealed sources } \\
\text { are: } \\
\text { d. An } \\
\text { accountable } \\
\text { sealed } \\
\text { radioactive } \\
\text { source that is } \\
\text { located in an } \\
\text { area that is } \\
\text { unsafe for } \\
\text { human entry or is } \\
\text { inaccessible is } \\
\text { not subject to } \\
\text { inventory or leak } \\
\text { testing } \\
\text { requirements. }\end{array}$ & $\begin{array}{l}\text { NV/YMP RCM } \\
431.2 . d \text {. The } \\
\text { requirements for } \\
\text { inventory and } \\
\text { leak testing of } \\
\text { accountable } \\
\text { sealed sources } \\
\text { are: } \\
\text { d. An } \\
\text { accountable } \\
\text { sealed } \\
\text { radioactive } \\
\text { source that is } \\
\text { located in an } \\
\text { area that is } \\
\text { unsafe for } \\
\text { human entry or is } \\
\text { inaccessible is } \\
\text { not subject to } \\
\text { inventory or leak } \\
\text { testing } \\
\text { requirements. }\end{array}$ & $\begin{array}{l}\text { Same as Column } \\
3\end{array}$ & $\begin{array}{l}\text { Same as Column } \\
3\end{array}$ & $\begin{array}{l}\text { Same as Column } \\
3\end{array}$ & $\begin{array}{l}\text { Same as Column } \\
3\end{array}$ & $\begin{array}{l}\text { Sealed sources } \\
\text { owned by DRI } \\
\text { are licensed for } \\
\text { use under the } \\
\text { UNR Radioactive } \\
\text { Material License } \\
\# 16-13-0003-07 . \\
\text { See UNR RSM } \\
\text { Procedure XII: } \\
\text { Leak Testing } \\
\text { Procedure. }\end{array}$ & $\begin{array}{l}\text { Not applicable to } \\
\text { WSI/NV } \\
\text { operations. } \\
\text { WSI/NV does not } \\
\text { maintain custody } \\
\text { of accountable } \\
\text { sealed sources } \\
\text { used in its } \\
\text { operations; } \\
\text { therefore, source } \\
\text { leak tests are } \\
\text { beyond the } \\
\text { scope of WSI/NV } \\
\text { radiological } \\
\text { control } \\
\text { responsibilities. }\end{array}$ \\
\hline 1202(e) An & NV/YMP RCM & NV/YMP RCM & Same as Column & Same as Column & Same as Column & Same as Column & Any sealed & Not applicable to \\
\hline
\end{tabular}

$\mathrm{H}-128$ 


\section{NEVADA TEST SITE RADIATION PROTECTION PROGRAM}

\section{APPENDIX H}

COMPLIANCE DEMONSTRATION TABLE

\begin{tabular}{|c|c|c|c|c|c|c|c|c|}
\hline \multirow[t]{2}{*}{10 CFR 835} & $\begin{array}{l}\text { NV/YMP RCM } \\
\text { Rev } 5 \text { and } \\
\text { NTS RPP } \\
\text { Revision } 0 \\
\end{array}$ & $\begin{array}{c}\text { NSTec } \\
\text { Appendix A }\end{array}$ & $\begin{array}{c}\text { LLNL } \\
\text { Appendix B }\end{array}$ & $\begin{array}{c}\text { LANL } \\
\text { Appendix C }\end{array}$ & $\begin{array}{c}\text { SNL } \\
\text { Appendix D }\end{array}$ & $\begin{array}{c}\text { SNJV } \\
\text { Appendix E }\end{array}$ & $\begin{array}{c}\text { DRI } \\
\text { Appendix F }\end{array}$ & $\begin{array}{c}\text { WSI } \\
\text { Appendix G }\end{array}$ \\
\hline & $\begin{array}{l}\text { Implementation } \\
\text { Reference }\end{array}$ & $\begin{array}{l}\text { Implementation } \\
\text { Reference }\end{array}$ & $\begin{array}{l}\text { Implementation } \\
\text { Reference }\end{array}$ & $\begin{array}{l}\text { Implementation } \\
\text { Reference }\end{array}$ & $\begin{array}{l}\text { Implementation } \\
\text { Reference }\end{array}$ & $\begin{array}{l}\text { Implementation } \\
\text { Reference }\end{array}$ & $\begin{array}{l}\text { Implementation } \\
\text { Reference }\end{array}$ & $\begin{array}{c}\text { Implementation } \\
\text { Reference }\end{array}$ \\
\hline
\end{tabular}

\begin{tabular}{|c|c|c|c|c|c|c|c|c|}
\hline $\begin{array}{l}\text { accountable sealed } \\
\text { radioactive source } \\
\text { found to be leaking } \\
\text { radioactive material } \\
\text { shall be controlled in a } \\
\text { manner that minimizes } \\
\text { the spread of } \\
\text { radioactive } \\
\text { contamination. }\end{array}$ & $\begin{array}{l}431.2 . e . \text { The } \\
\text { requirements for } \\
\text { inventory and } \\
\text { leak testing of } \\
\text { accountable } \\
\text { sealed sources } \\
\text { are: } \\
\text { e. An } \\
\text { accountable } \\
\text { sealed } \\
\text { radioactive } \\
\text { source found to } \\
\text { be leaking } \\
\text { radioactive } \\
\text { material at any } \\
\text { level of } \\
\text { measured } \\
\text { contamination } \\
\text { shall be } \\
\text { controlled in a } \\
\text { manner that } \\
\text { minimizes the } \\
\text { spread of } \\
\text { contamination. }\end{array}$ & $\begin{array}{l}431.2 . e . \text { The } \\
\text { requirements for } \\
\text { inventory and } \\
\text { leak testing of } \\
\text { accountable } \\
\text { sealed sources } \\
\text { are: } \\
\text { e. An } \\
\text { accountable } \\
\text { sealed } \\
\text { radioactive } \\
\text { source found to } \\
\text { be leaking } \\
\text { radioactive } \\
\text { material at any } \\
\text { level of } \\
\text { measured } \\
\text { contamination } \\
\text { shall be } \\
\text { controlled in a } \\
\text { manner that } \\
\text { minimizes the } \\
\text { spread of } \\
\text { contamination. }\end{array}$ & 3 & 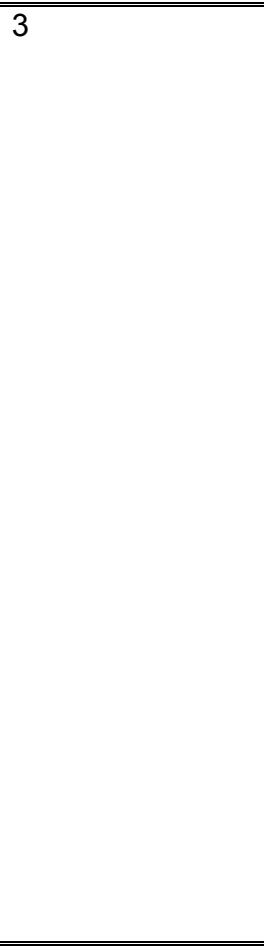 & 3 & 3 & $\begin{array}{l}\text { source used by } \\
\text { DRI fall under } \\
\text { the UNR } \\
\text { Radioactive } \\
\text { Material License } \\
\text { \#16-13-0003-07. } \\
\text { The RSPC } \\
\text { provides leak } \\
\text { testing services } \\
\text { for DRI. Any } \\
\text { sealed source } \\
\text { found to be } \\
\text { leaking must be } \\
\text { immediately } \\
\text { reported to the } \\
\text { UNR RSO, who } \\
\text { will make the } \\
\text { required } \\
\text { notifications to } \\
\text { the state and will } \\
\text { deal with the } \\
\text { situation per } \\
\text { UNR RSM } \\
\text { Procedure XII: } \\
\text { Leak Testing } \\
\text { Procedure. }\end{array}$ & $\begin{array}{l}\text { WSI/NV } \\
\text { operations. } \\
\text { WSI/NV does not } \\
\text { maintain custody } \\
\text { of accountable } \\
\text { sealed sources } \\
\text { used in its } \\
\text { operations; } \\
\text { therefore, source } \\
\text { leak tests are } \\
\text { beyond the } \\
\text { scope of WSI/NV } \\
\text { radiological } \\
\text { control } \\
\text { responsibilities. }\end{array}$ \\
\hline $\begin{array}{l}\text { Subpart N-- } \\
\text { Emergency } \\
\text { Exposure Situations } \\
835.1301 \text { General } \\
\text { provisions. }\end{array}$ & $\begin{array}{l}\text { NV/YMP RCM } \\
213.5 . \text { A general } \\
\text { employee whose } \\
\text { occupational } \\
\text { dose has } \\
\text { exceeded any of } \\
\text { the limits }\end{array}$ & $\begin{array}{l}\text { Revise a.: } \\
\text { NV/YMP RCM } \\
\text { 213.5. A general } \\
\text { employee whose } \\
\text { occupational } \\
\text { dose has } \\
\text { exceeded any of }\end{array}$ & $\begin{array}{l}\text { Operations which } \\
\text { could potentially } \\
\text { require } \\
\text { emergency } \\
\text { exposures to } \\
\text { personnel in } \\
\text { excess of the }\end{array}$ & $\begin{array}{l}\text { This is outside } \\
\text { the scope of the } \\
\text { LANL/NTS } \\
\text { Radiological } \\
\text { Control Program. } \\
\text { Operations which } \\
\text { could potentially }\end{array}$ & $\begin{array}{l}\text { Same as Column } \\
3\end{array}$ & $\begin{array}{l}\text { Same as Column } \\
3\end{array}$ & $\begin{array}{l}\text { Not applicable to } \\
\text { DRI. Operations } \\
\text { which could } \\
\text { potentially } \\
\text { require } \\
\text { emergency } \\
\text { exposures to } \\
\end{array}$ & $\begin{array}{l}\text { WSI/NV does not } \\
\text { have a } \\
\text { procedure for } \\
\text { emergency } \\
\text { exposure } \\
\text { situations. In the } \\
\text { unlikely event }\end{array}$ \\
\hline
\end{tabular}

H-129 


\section{NEVADA TEST SITE RADIATION PROTECTION PROGRAM}

\section{APPENDIX H}

COMPLIANCE DEMONSTRATION TABLE

\begin{tabular}{|c|c|c|c|c|c|c|c|c|}
\hline \multirow[t]{2}{*}{10 CFR 835} & $\begin{array}{c}\text { NV/YMP RCM } \\
\text { Rev } 5 \text { and } \\
\text { NTS RPP } \\
\text { Revision } 0 \\
\end{array}$ & $\begin{array}{c}\text { NSTec } \\
\text { Appendix A }\end{array}$ & $\begin{array}{c}\text { LLNL } \\
\text { Appendix B }\end{array}$ & $\begin{array}{c}\text { LANL } \\
\text { Appendix C }\end{array}$ & $\begin{array}{c}\text { SNL } \\
\text { Appendix D }\end{array}$ & $\begin{array}{c}\text { SNJV } \\
\text { Appendix E }\end{array}$ & $\begin{array}{c}\text { DRI } \\
\text { Appendix F }\end{array}$ & $\begin{array}{c}\text { WSI } \\
\text { Appendix G }\end{array}$ \\
\hline & $\begin{array}{l}\text { Implementation } \\
\text { Reference }\end{array}$ & $\begin{array}{l}\text { Implementation } \\
\text { Reference }\end{array}$ & $\begin{array}{l}\text { Implementation } \\
\text { Reference }\end{array}$ & $\begin{array}{l}\text { Implementation } \\
\text { Reference }\end{array}$ & $\begin{array}{l}\text { Implementation } \\
\text { Reference }\end{array}$ & $\begin{array}{l}\text { Implementation } \\
\text { Reference }\end{array}$ & $\begin{array}{l}\text { Implementation } \\
\text { Reference }\end{array}$ & $\begin{array}{l}\text { Implementation } \\
\text { Reference }\end{array}$ \\
\hline
\end{tabular}

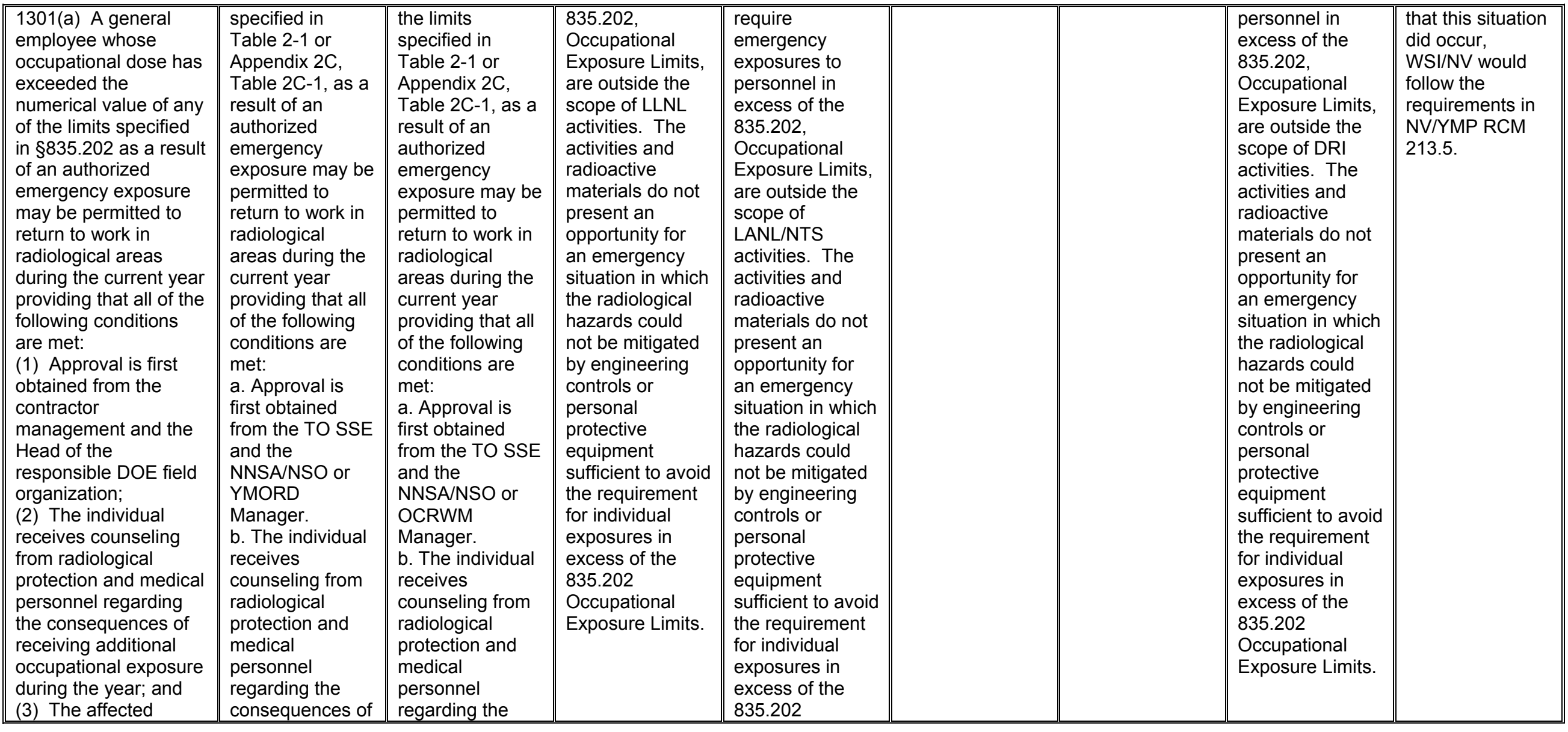

$\mathrm{H}-130$ 


\section{NEVADA TEST SITE RADIATION PROTECTION PROGRAM}

\section{APPENDIX H}

COMPLIANCE DEMONSTRATION TABLE

\begin{tabular}{|c|c|c|c||c||c||c||c||c|}
\hline \multirow{2}{*}{ 10 CFR 835 } & $\begin{array}{c}\text { NV/YMP RCM } \\
\text { Rev 5 and } \\
\text { NTS RPP } \\
\text { Revision 0 }\end{array}$ & Appendix A & Appendix B & Appendix C & Appendix D & SNJV \\
\cline { 2 - 7 } & $\begin{array}{c}\text { Implementation } \\
\text { Reference }\end{array}$ & $\begin{array}{c}\text { Implementation } \\
\text { Reference }\end{array}$ & $\begin{array}{c}\text { Implementation } \\
\text { Reference }\end{array}$ & $\begin{array}{c}\text { Implementation } \\
\text { Reference }\end{array}$ & $\begin{array}{c}\text { Implementation } \\
\text { Reference }\end{array}$ & $\begin{array}{c}\text { Implementation } \\
\text { Reference }\end{array}$ & $\begin{array}{c}\text { Implementation } \\
\text { Reference }\end{array}$ & $\begin{array}{c}\text { Implementation } \\
\text { Reference }\end{array}$ \\
\hline
\end{tabular}

\begin{tabular}{|c|c|c|c|c|c|c|c|c|}
\hline $\begin{array}{l}\text { employee agrees to } \\
\text { return to radiological } \\
\text { work. }\end{array}$ & $\begin{array}{l}\text { receiving } \\
\text { additional } \\
\text { occupational } \\
\text { exposure during } \\
\text { the year. } \\
\text { c. The affected } \\
\text { employee agrees } \\
\text { to return to } \\
\text { radiological work. }\end{array}$ & $\begin{array}{l}\text { consequences of } \\
\text { receiving } \\
\text { additional } \\
\text { occupational } \\
\text { exposure during } \\
\text { the year. } \\
\text { c. The affected } \\
\text { employee agrees } \\
\text { to return to } \\
\text { radiological work. }\end{array}$ & & $\begin{array}{l}\text { Occupational } \\
\text { Exposure Limits. }\end{array}$ & & & & \\
\hline $\begin{array}{l}1301(b) \text { All doses } \\
\text { exceeding the limits } \\
\text { specified in } \$ 835.202 \\
\text { shall be recorded in } \\
\text { the affected } \\
\text { individual's occupation } \\
\text { dose record. }\end{array}$ & $\begin{array}{l}\text { NV/YMP RCM } \\
722.1 .01 . \\
\text { Records of } \\
\text { doses received } \\
\text { by all individuals } \\
\text { for whom } \\
\text { individual } \\
\text { monitoring was } \\
\text { performed shall } \\
\text { be recorded in } \\
\text { the individual's } \\
\text { occupational } \\
\text { dose record and } \\
\text { shall be } \\
\text { maintained by } \\
\text { the RSPC. }\end{array}$ & $\begin{array}{l}\text { NV/YMP RCM } \\
722.1 .01 . \\
\text { Records of } \\
\text { doses received } \\
\text { by all individuals } \\
\text { for whom } \\
\text { individual } \\
\text { monitoring was } \\
\text { performed shall } \\
\text { be recorded in } \\
\text { the individual's } \\
\text { occupational } \\
\text { dose record and } \\
\text { shall be } \\
\text { maintained by } \\
\text { the RSPC. }\end{array}$ & $\begin{array}{l}\text { Operations which } \\
\text { could potentially } \\
\text { require } \\
\text { emergency } \\
\text { exposures to } \\
\text { personnel in } \\
\text { excess of the } \\
835.202 \text {, } \\
\text { Occupational } \\
\text { Exposure Limits, } \\
\text { are outside the } \\
\text { scope of LLNL } \\
\text { activities. The } \\
\text { activities and } \\
\text { radioactive } \\
\text { materials do not } \\
\text { present an } \\
\text { opportunity for } \\
\text { an emergency } \\
\text { situation in which } \\
\text { the radiological } \\
\text { hazards could } \\
\text { not be mitigated }\end{array}$ & $\begin{array}{l}\text { This is outside } \\
\text { the scope of the } \\
\text { LANL/NTS } \\
\text { Radiological } \\
\text { Control Program. } \\
\text { Operations which } \\
\text { could potentially } \\
\text { require } \\
\text { emergency } \\
\text { exposures to } \\
\text { personnel in } \\
\text { excess of the } \\
\text { 835.202, } \\
\text { Occupational } \\
\text { Exposure Limits, } \\
\text { are outside the } \\
\text { scope of } \\
\text { LANL/NTS } \\
\text { activities. The } \\
\text { activities and } \\
\text { radioactive } \\
\text { materials do not } \\
\text { present an }\end{array}$ & $\begin{array}{l}\text { These records } \\
\text { shall be } \\
\text { maintained by } \\
\text { the dosimetry } \\
\text { records section } \\
\text { in Albuquerque. }\end{array}$ & $\begin{array}{l}\text { Records } \\
\text { generated by the } \\
\text { RSPC for } \\
\text { services } \\
\text { provided to } \\
\text { SNJV are } \\
\text { maintained by } \\
\text { the RSPC. } \\
\text { NV/YMP RCM } \\
\text { 141.3.e. The } \\
\text { RSPC shall } \\
\text { provide the } \\
\text { following: } \\
\text { e. External and } \\
\text { internal } \\
\text { dosimetry } \\
\text { services. }\end{array}$ & $\begin{array}{l}\text { Not applicable to } \\
\text { DRI. Operations } \\
\text { which could } \\
\text { potentially } \\
\text { require } \\
\text { emergency } \\
\text { exposures to } \\
\text { personnel in } \\
\text { excess of the } \\
835.202 \text {, } \\
\text { Occupational } \\
\text { Exposure Limits, } \\
\text { are outside the } \\
\text { scope of DRI } \\
\text { activities. The } \\
\text { activities and } \\
\text { radioactive } \\
\text { materials do not } \\
\text { present an } \\
\text { opportunity for } \\
\text { an emergency } \\
\text { situation in which } \\
\text { the radiological }\end{array}$ & $\begin{array}{l}\text { By written } \\
\text { agreement, the } \\
\text { RSPC provides } \\
\text { dosimetry } \\
\text { services to } \\
\text { WSI/NV and } \\
\text { maintains } \\
\text { dosimetry } \\
\text { records } \\
\text { generated from } \\
\text { these services. }\end{array}$ \\
\hline
\end{tabular}

H-131 


\section{NEVADA TEST SITE RADIATION PROTECTION PROGRAM}

\section{APPENDIX H}

COMPLIANCE DEMONSTRATION TABLE

\begin{tabular}{|c|c|c|c|c|c|c|c|c|}
\hline \multirow[t]{2}{*}{10 CFR 835} & $\begin{array}{l}\text { NV/YMP RCM } \\
\text { Rev } 5 \text { and } \\
\text { NTS RPP } \\
\text { Revision } 0 \\
\end{array}$ & $\begin{array}{c}\text { NSTec } \\
\text { Appendix A }\end{array}$ & $\begin{array}{c}\text { LLNL } \\
\text { Appendix B }\end{array}$ & $\begin{array}{c}\text { LANL } \\
\text { Appendix C }\end{array}$ & $\begin{array}{c}\text { SNL } \\
\text { Appendix D }\end{array}$ & $\begin{array}{c}\text { SNJV } \\
\text { Appendix E }\end{array}$ & $\begin{array}{c}\text { DRI } \\
\text { Appendix F }\end{array}$ & $\begin{array}{c}\text { WSI } \\
\text { Appendix G }\end{array}$ \\
\hline & $\begin{array}{l}\text { Implementation } \\
\text { Reference }\end{array}$ & $\begin{array}{l}\text { Implementation } \\
\text { Reference }\end{array}$ & $\begin{array}{l}\text { Implementation } \\
\text { Reference }\end{array}$ & $\begin{array}{l}\text { Implementation } \\
\text { Reference }\end{array}$ & $\begin{array}{l}\text { Implementation } \\
\text { Reference }\end{array}$ & $\begin{array}{l}\text { Implementation } \\
\text { Reference }\end{array}$ & $\begin{array}{l}\text { Implementation } \\
\text { Reference }\end{array}$ & $\begin{array}{l}\text { Implementation } \\
\text { Reference }\end{array}$ \\
\hline
\end{tabular}

\begin{tabular}{|c|c|c|c|c|c|c|c|c|}
\hline & & & $\begin{array}{l}\text { by engineering } \\
\text { controls or } \\
\text { personal } \\
\text { protective } \\
\text { equipment } \\
\text { sufficient to avoid } \\
\text { the requirement } \\
\text { for individual } \\
\text { exposures in } \\
\text { excess of the } \\
835.202 \\
\text { Occupational } \\
\text { Exposure Limits. }\end{array}$ & $\begin{array}{l}\text { opportunity for } \\
\text { an emergency } \\
\text { situation in which } \\
\text { the radiological } \\
\text { hazards could } \\
\text { not be mitigated } \\
\text { by engineering } \\
\text { controls or } \\
\text { personal } \\
\text { protective } \\
\text { equipment } \\
\text { sufficient to avoid } \\
\text { the requirement } \\
\text { for individual } \\
\text { exposures in } \\
\text { excess of the } \\
835.202 \\
\text { Occupational } \\
\text { Exposure Limits. }\end{array}$ & & & $\begin{array}{l}\text { hazards could } \\
\text { not be mitigated } \\
\text { by engineering } \\
\text { controls or } \\
\text { personal } \\
\text { protective } \\
\text { equipment } \\
\text { sufficient to avoid } \\
\text { the requirement } \\
\text { for individual } \\
\text { exposures in } \\
\text { excess of the } \\
835.202 \\
\text { Occupational } \\
\text { Exposure Limits. }\end{array}$ & \\
\hline $\begin{array}{l}1301(\mathrm{c}) \text { When the } \\
\text { conditions under which } \\
\text { a dose was received in } \\
\text { excess of the limits } \\
\text { specified in } \S 835.202 \text {, } \\
\text { except those doses } \\
\text { received in } \\
\text { accordance with } \\
\S 835.204, \text { have been } \\
\text { eliminated, operating } \\
\text { management shall } \\
\text { notify the Head of the } \\
\text { responsible DOE field } \\
\text { organization. }\end{array}$ & $\begin{array}{l}\text { NV/YMP RCM } \\
\text { Appendix } 2 A \text {, } \\
\text { Table } 2 A-1 \text { Note: } \\
3.01 \text {. When the } \\
\text { conditions under } \\
\text { which a dose } \\
\text { was received in } \\
\text { excess of the } \\
\text { limits specified in } \\
10 \text { CFR } 835.202 \\
\text { have been } \\
\text { eliminated, } \\
\text { operating } \\
\text { management }\end{array}$ & $\begin{array}{l}\text { Revise: NV/YMP } \\
\text { RCM Appendix } \\
\text { 2A, Table 2A-1 } \\
\text { Note: } 3.01 . \\
\text { When the } \\
\text { conditions under } \\
\text { which a dose } \\
\text { was received in } \\
\text { excess of the } \\
\text { limits specified in } \\
10 \text { CFR } 835.202 \\
\text { have been } \\
\text { eliminated, } \\
\text { operating }\end{array}$ & $\begin{array}{l}\text { Operations which } \\
\text { could potentially } \\
\text { require } \\
\text { emergency } \\
\text { exposures to } \\
\text { personnel in } \\
\text { excess of the } \\
835.202, \\
\text { Occupational } \\
\text { Exposure Limits, } \\
\text { are outside the } \\
\text { scope of LLNL } \\
\text { activities. The } \\
\text { activities and } \\
\end{array}$ & $\begin{array}{l}\text { This is outside } \\
\text { the scope of the } \\
\text { LANL/NTS } \\
\text { Radiological } \\
\text { Control Program. } \\
\text { Operations which } \\
\text { could potentially } \\
\text { require } \\
\text { emergency } \\
\text { exposures to } \\
\text { personnel in } \\
\text { excess of the } \\
\text { 835.202, } \\
\text { Occupational } \\
\end{array}$ & $\begin{array}{l}\text { Same as Column } \\
3\end{array}$ & $\begin{array}{l}\text { Same as Column } \\
3\end{array}$ & $\begin{array}{l}\text { Not applicable to } \\
\text { DRI. Operations } \\
\text { which could } \\
\text { potentially } \\
\text { require } \\
\text { emergency } \\
\text { exposures to } \\
\text { personnel in } \\
\text { excess of the } \\
835.202 \text {, } \\
\text { Occupational } \\
\text { Exposure Limits, } \\
\text { are outside the } \\
\text { scope of DRI }\end{array}$ & $\begin{array}{l}\text { Not applicable to } \\
\text { WSI/NV } \\
\text { operations. } \\
\text { Operations which } \\
\text { could potentially } \\
\text { require } \\
\text { emergency } \\
\text { exposures to } \\
\text { personnel in } \\
\text { excess of the } \\
835.202 \text {, } \\
\text { Occupational } \\
\text { Exposure Limits, } \\
\text { are outside the }\end{array}$ \\
\hline
\end{tabular}

H-132 


\section{NEVADA TEST SITE RADIATION PROTECTION PROGRAM}

\section{APPENDIX H}

COMPLIANCE DEMONSTRATION TABLE

\begin{tabular}{|c|c|c|c|c|c|c|c|c|}
\hline \multirow[t]{2}{*}{10 CFR 835} & $\begin{array}{c}\text { NV/YMP RCM } \\
\text { Rev } 5 \text { and } \\
\text { NTS RPP } \\
\text { Revision } 0 \\
\end{array}$ & $\begin{array}{c}\text { NSTec } \\
\text { Appendix A }\end{array}$ & $\begin{array}{c}\text { LLNL } \\
\text { Appendix B }\end{array}$ & $\begin{array}{c}\text { LANL } \\
\text { Appendix C }\end{array}$ & $\begin{array}{c}\text { SNL } \\
\text { Appendix D }\end{array}$ & $\begin{array}{c}\text { SNJV } \\
\text { Appendix E }\end{array}$ & $\begin{array}{c}\text { DRI } \\
\text { Appendix F }\end{array}$ & $\begin{array}{c}\text { WSI } \\
\text { Appendix G }\end{array}$ \\
\hline & $\begin{array}{l}\text { Implementation } \\
\text { Reference }\end{array}$ & $\begin{array}{l}\text { Implementation } \\
\text { Reference }\end{array}$ & $\begin{array}{l}\text { Implementation } \\
\text { Reference }\end{array}$ & $\begin{array}{l}\text { Implementation } \\
\text { Reference }\end{array}$ & $\begin{array}{l}\text { Implementation } \\
\text { Reference }\end{array}$ & $\begin{array}{l}\text { Implementation } \\
\text { Reference }\end{array}$ & $\begin{array}{l}\text { Implementation } \\
\text { Reference }\end{array}$ & $\begin{array}{l}\text { Implementation } \\
\text { Reference }\end{array}$ \\
\hline
\end{tabular}

\begin{tabular}{|c|c|c|c|c|c|c|c|c|}
\hline & $\begin{array}{l}\text { shall notify the } \\
\text { NNSA/NSO or } \\
\text { YMORD } \\
\text { Manager. }\end{array}$ & $\begin{array}{l}\text { management } \\
\text { shall notify the } \\
\text { NNSA/NSO or } \\
\text { OCRWM } \\
\text { Manager. }\end{array}$ & $\begin{array}{l}\text { radioactive } \\
\text { materials do not } \\
\text { present an } \\
\text { opportunity for } \\
\text { an emergency } \\
\text { situation in which } \\
\text { the radiological } \\
\text { hazards could } \\
\text { not be mitigated } \\
\text { by engineering } \\
\text { controls or } \\
\text { personal } \\
\text { protective } \\
\text { equipment } \\
\text { sufficient to avoid } \\
\text { the requirement } \\
\text { for individual } \\
\text { exposures in } \\
\text { excess of the } \\
\text { 835.202 } \\
\text { Occupational } \\
\text { Exposure Limits. }\end{array}$ & $\begin{array}{l}\text { Exposure Limits, } \\
\text { are outside the } \\
\text { scope of } \\
\text { LANL/NTS } \\
\text { activities. The } \\
\text { activities and } \\
\text { radioactive } \\
\text { materials do not } \\
\text { present an } \\
\text { opportunity for } \\
\text { an emergency } \\
\text { situation in which } \\
\text { the radiological } \\
\text { hazards could } \\
\text { not be mitigated } \\
\text { by engineering } \\
\text { controls or } \\
\text { personal } \\
\text { protective } \\
\text { equipment } \\
\text { sufficient to avoid } \\
\text { the requirement } \\
\text { for individual } \\
\text { exposures in } \\
\text { excess of the } \\
\text { 835.202 } \\
\text { Occupational } \\
\text { Exposure Limits. } \\
\end{array}$ & & & $\begin{array}{l}\text { activities. The } \\
\text { activities and } \\
\text { radioactive } \\
\text { materials do not } \\
\text { present an } \\
\text { opportunity for } \\
\text { an emergency } \\
\text { situation in which } \\
\text { the radiological } \\
\text { hazards could } \\
\text { not be mitigated } \\
\text { by engineering } \\
\text { controls or } \\
\text { personal } \\
\text { protective } \\
\text { equipment } \\
\text { sufficient to avoid } \\
\text { the requirement } \\
\text { for individual } \\
\text { exposures in } \\
\text { excess of the } \\
835.202 \\
\text { Occupational } \\
\text { Exposure Limits. }\end{array}$ & $\begin{array}{l}\text { scope of WSI/NV } \\
\text { activities. }\end{array}$ \\
\hline $\begin{array}{l}1301(d) \text { Operations } \\
\text { which have been } \\
\text { suspended as a result } \\
\text { of a dose in excess of } \\
\text { the limits specified in }\end{array}$ & $\begin{array}{l}\text { NV/YMP RCM } \\
\text { Appendix 2-A, } \\
\text { Table 2A-1 } \\
\text { Notes: } 3.02 \text {. } \\
\text { Operations after }\end{array}$ & $\begin{array}{l}\text { Revise: NV/YMP } \\
\text { RCM Appendix } \\
\text { 2-A, Table 2A-1 } \\
\text { Notes: } 3.02 \text {. } \\
\text { Operations which }\end{array}$ & $\begin{array}{l}\text { Operations which } \\
\text { could potentially } \\
\text { require } \\
\text { emergency } \\
\text { exposures to }\end{array}$ & $\begin{array}{l}\text { This is outside } \\
\text { the scope of the } \\
\text { LANL/NTS } \\
\text { Radiological } \\
\text { Control Program. }\end{array}$ & $\begin{array}{l}\text { Same as Column } \\
3\end{array}$ & $\begin{array}{l}\text { Same as Column } \\
3\end{array}$ & $\begin{array}{l}\text { Not applicable to } \\
\text { DRI. Operations } \\
\text { which could } \\
\text { potentially } \\
\text { require }\end{array}$ & $\begin{array}{l}\text { Not applicable to } \\
\text { WSI/NV } \\
\text { operations. } \\
\text { Operations which } \\
\text { could potentially }\end{array}$ \\
\hline
\end{tabular}

$\mathrm{H}-133$ 


\section{NEVADA TEST SITE RADIATION PROTECTION PROGRAM}

\section{APPENDIX H}

COMPLIANCE DEMONSTRATION TABLE

\begin{tabular}{|c|c|c|c|c|c|c|c|c|}
\hline \multirow[t]{2}{*}{10 CFR 835} & $\begin{array}{c}\text { NV/YMP RCM } \\
\text { Rev } 5 \text { and } \\
\text { NTS RPP } \\
\text { Revision } 0 \\
\end{array}$ & $\begin{array}{c}\text { NSTec } \\
\text { Appendix A }\end{array}$ & $\begin{array}{c}\text { LLNL } \\
\text { Appendix B }\end{array}$ & $\begin{array}{c}\text { LANL } \\
\text { Appendix C }\end{array}$ & $\begin{array}{c}\text { SNL } \\
\text { Appendix D }\end{array}$ & $\begin{array}{c}\text { SNJV } \\
\text { Appendix E }\end{array}$ & $\begin{array}{c}\text { DRI } \\
\text { Appendix F }\end{array}$ & $\begin{array}{c}\text { WSI } \\
\text { Appendix G }\end{array}$ \\
\hline & $\begin{array}{l}\text { Implementation } \\
\text { Reference }\end{array}$ & $\begin{array}{l}\text { Implementation } \\
\text { Reference }\end{array}$ & $\begin{array}{l}\text { Implementation } \\
\text { Reference }\end{array}$ & $\begin{array}{l}\text { Implementation } \\
\text { Reference }\end{array}$ & $\begin{array}{l}\text { Implementation } \\
\text { Reference }\end{array}$ & $\begin{array}{l}\text { Implementation } \\
\text { Reference }\end{array}$ & $\begin{array}{l}\text { Implementation } \\
\text { Reference }\end{array}$ & $\begin{array}{l}\text { Implementation } \\
\text { Reference }\end{array}$ \\
\hline
\end{tabular}

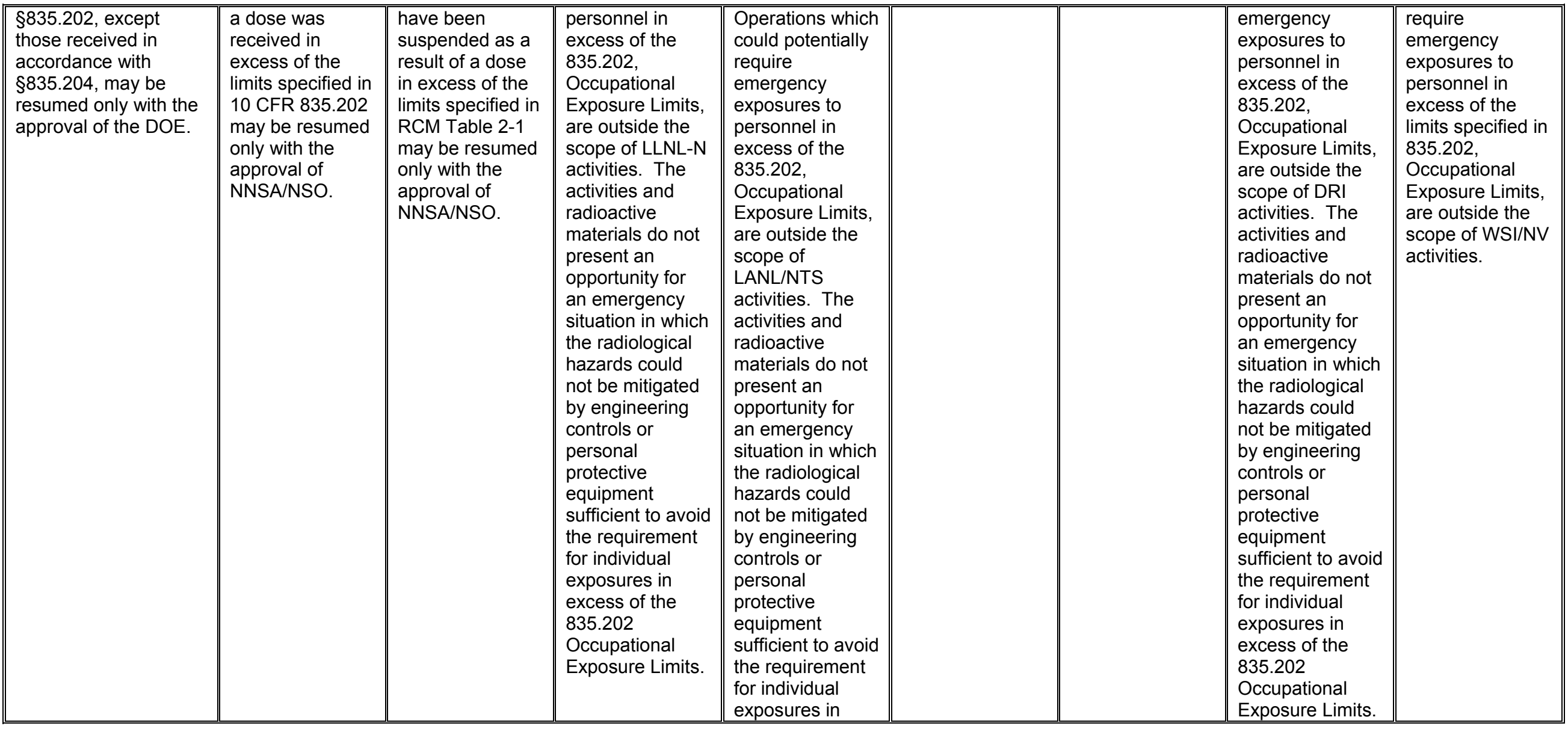

H-134 


\section{NEVADA TEST SITE RADIATION PROTECTION PROGRAM}

\section{APPENDIX H}

COMPLIANCE DEMONSTRATION TABLE

\begin{tabular}{|c|c|c|c||c||c||c||c||c|}
\hline \multirow{2}{*}{ 10 CFR 835 } & $\begin{array}{c}\text { NV/YMP RCM } \\
\text { Rev 5 and } \\
\text { NTS RPP } \\
\text { Revision 0 }\end{array}$ & Appendix A & Appendix B & Appendix C & Appendix D & SNJV \\
\cline { 2 - 7 } & $\begin{array}{c}\text { Implementation } \\
\text { Reference }\end{array}$ & $\begin{array}{c}\text { Implementation } \\
\text { Reference }\end{array}$ & $\begin{array}{c}\text { Implementation } \\
\text { Reference }\end{array}$ & $\begin{array}{c}\text { Implementation } \\
\text { Reference }\end{array}$ & $\begin{array}{c}\text { Implementation } \\
\text { Reference }\end{array}$ & $\begin{array}{c}\text { Implementation } \\
\text { Reference }\end{array}$ & $\begin{array}{c}\text { Implementation } \\
\text { Reference }\end{array}$ & $\begin{array}{c}\text { Implementation } \\
\text { Reference }\end{array}$ \\
\hline
\end{tabular}

\begin{tabular}{|c|c|c|c|c|c|c|c|c|}
\hline & & & & $\begin{array}{l}\text { excess of the } \\
835.202 \\
\\
\text { Occupational } \\
\text { Exposure Limits. }\end{array}$ & & & & \\
\hline $\begin{array}{l}835.1302 \text { Emergency } \\
\text { exposure situations. } \\
\text { 1302(a) The risk of } \\
\text { injury to those } \\
\text { individuals involved in } \\
\text { rescue and recovery } \\
\text { operations shall be } \\
\text { minimized. }\end{array}$ & $\begin{array}{l}\text { NV/YMP RCM } \\
\text { 213.4.02.a. } \\
\text { For compliance } \\
\text { with 10 CFR } \\
835.1302 \text {, in } \\
\text { emergency } \\
\text { exposure } \\
\text { situations the } \\
\text { following must } \\
\text { apply: } \\
\text { a. The risk of } \\
\text { injury to those } \\
\text { individuals } \\
\text { involved in } \\
\text { rescue and } \\
\text { recovery } \\
\text { operations shall } \\
\text { be minimized. }\end{array}$ & $\begin{array}{l}\text { NV/YMP RCM } \\
\text { 213.4.02.a. } \\
\text { For compliance } \\
\text { with 10 CFR } \\
835.1302 \text {, in } \\
\text { emergency } \\
\text { exposure } \\
\text { situations the } \\
\text { following must } \\
\text { apply: } \\
\text { a. The risk of } \\
\text { injury to those } \\
\text { individuals } \\
\text { involved in } \\
\text { rescue and } \\
\text { recovery } \\
\text { operations shall } \\
\text { be minimized. }\end{array}$ & $\begin{array}{l}\text { Operations which } \\
\text { could potentially } \\
\text { require } \\
\text { emergency } \\
\text { exposures to } \\
\text { personnel in } \\
\text { excess of the } \\
835.202, \\
\text { Occupational } \\
\text { Exposure Limits, } \\
\text { are outside the } \\
\text { scope of LLNL-N } \\
\text { activities. The } \\
\text { activities and } \\
\text { radioactive } \\
\text { materials do not } \\
\text { present an } \\
\text { opportunity for } \\
\text { an emergency } \\
\text { situation in which } \\
\text { the radiological } \\
\text { hazards could } \\
\text { not be mitigated } \\
\text { by engineering } \\
\text { controls or } \\
\text { personal } \\
\text { protective } \\
\text { equipment }\end{array}$ & $\begin{array}{l}\text { This is outside } \\
\text { the scope of the } \\
\text { LANL/NTS } \\
\text { Radiological } \\
\text { Control Program. } \\
\text { Operations which } \\
\text { could potentially } \\
\text { require } \\
\text { emergency } \\
\text { exposures to } \\
\text { personnel in } \\
\text { excess of the } \\
\text { 835.202, } \\
\text { Occupational } \\
\text { Exposure Limits, } \\
\text { are outside the } \\
\text { scope of } \\
\text { LANL/NTS } \\
\text { activities. The } \\
\text { activities and } \\
\text { radioactive } \\
\text { materials do not } \\
\text { present an } \\
\text { opportunity for } \\
\text { an emergency } \\
\text { situation in which } \\
\text { the radiological } \\
\text { hazards could } \\
\end{array}$ & $\begin{array}{l}\text { There are } \\
\text { currently no } \\
\text { operations being } \\
\text { performed at } \\
\text { SNL/NTS } \\
\text { facilities, } \\
\text { operations, or } \\
\text { processes } \\
\text { wherein } \\
\text { emergency } \\
\text { exposures to } \\
\text { personnel in } \\
\text { excess of } \\
835.202 \\
\text { occupational } \\
\text { dose limits can } \\
\text { be envisioned. } \\
\text { SNL Radiological } \\
\text { Protection } \\
\text { Procedures } \\
\text { Manual, MN } \\
471016, \text { Chapter } \\
11, \text { Radiological } \\
\text { Incidents, } \\
\text { Section 4.12 } \\
\text { "Emergency } \\
\text { Exposure } \\
\text { Situations" } \\
\end{array}$ & $\begin{array}{l}\text { Not Applicable. } \\
\text { Operations which } \\
\text { could potentially } \\
\text { require } \\
\text { emergency } \\
\text { exposures to } \\
\text { personnel in } \\
\text { excess of the } \\
835.202, \\
\text { Occupational } \\
\text { Exposure Limits, } \\
\text { are outside the } \\
\text { scope of SNJV } \\
\text { activities. SNJV } \\
\text { will not conduct } \\
\text { activities which } \\
\text { could result such } \\
\text { emergency } \\
\text { operations } \\
\text { without revision } \\
\text { and subsequent } \\
\text { approval of this } \\
\text { RPP. }\end{array}$ & \begin{tabular}{|l} 
Not applicable to \\
DRI. Operations \\
which could \\
potentially \\
require \\
emergency \\
exposures to \\
personnel in \\
excess of the \\
835.202, \\
Occupational \\
Exposure Limits, \\
are outside the \\
scope of DRI \\
activities. The \\
activities and \\
radioactive \\
materials do not \\
present an \\
opportunity for \\
an emergency \\
situation in which \\
the radiological \\
hazards could \\
not be mitigated \\
by engineering \\
controls or \\
personal \\
\end{tabular} & $\begin{array}{l}\text { Not applicable to } \\
\text { WSI/NV } \\
\text { operations. } \\
\text { WSI/NV has a } \\
\text { contractual } \\
\text { agreement with } \\
\text { NNSA/NSO that } \\
\text { precludes rescue } \\
\text { and recovery } \\
\text { activities, or } \\
\text { other activities } \\
\text { that may result in } \\
\text { emergency } \\
\text { exposure } \\
\text { situations. } \\
\text { Rescue and } \\
\text { recovery } \\
\text { operations for } \\
\text { security related } \\
\text { incidents are } \\
\text { delegated to the } \\
\text { Federal Bureau } \\
\text { of Investigation } \\
\text { through a } \\
\text { Memorandum of } \\
\text { Agreement. }\end{array}$ \\
\hline
\end{tabular}

H-135 


\section{NEVADA TEST SITE RADIATION PROTECTION PROGRAM}

\section{APPENDIX H}

COMPLIANCE DEMONSTRATION TABLE

\begin{tabular}{|c|c|c|c|c|c|c|c|c|}
\hline \multirow[t]{2}{*}{10 CFR 835} & $\begin{array}{c}\text { NV/YMP RCM } \\
\text { Rev } 5 \text { and } \\
\text { NTS RPP } \\
\text { Revision } 0 \\
\end{array}$ & $\begin{array}{c}\text { NSTec } \\
\text { Appendix A }\end{array}$ & $\begin{array}{c}\text { LLNL } \\
\text { Appendix B }\end{array}$ & $\begin{array}{c}\text { LANL } \\
\text { Appendix C }\end{array}$ & $\begin{array}{c}\text { SNL } \\
\text { Appendix D }\end{array}$ & $\begin{array}{c}\text { SNJV } \\
\text { Appendix E }\end{array}$ & $\begin{array}{c}\text { DRI } \\
\text { Appendix F }\end{array}$ & $\begin{array}{c}\text { WSI } \\
\text { Appendix G }\end{array}$ \\
\hline & $\begin{array}{l}\text { Implementation } \\
\text { Reference }\end{array}$ & $\begin{array}{l}\text { Implementation } \\
\text { Reference }\end{array}$ & $\begin{array}{l}\text { Implementation } \\
\text { Reference }\end{array}$ & $\begin{array}{l}\text { Implementation } \\
\text { Reference }\end{array}$ & $\begin{array}{l}\text { Implementation } \\
\text { Reference }\end{array}$ & $\begin{array}{l}\text { Implementation } \\
\text { Reference }\end{array}$ & $\begin{array}{l}\text { Implementation } \\
\text { Reference }\end{array}$ & $\begin{array}{l}\text { Implementation } \\
\text { Reference }\end{array}$ \\
\hline
\end{tabular}

\begin{tabular}{|c|c|c|c|c|c|c|c|c|}
\hline & & & $\begin{array}{l}\text { sufficient to avoid } \\
\text { the requirement } \\
\text { for individual } \\
\text { exposures in } \\
\text { excess of the } \\
835.202 \\
\text { Occupational } \\
\text { Exposure Limits. }\end{array}$ & $\begin{array}{l}\text { not be mitigated } \\
\text { by engineering } \\
\text { controls or } \\
\text { personal } \\
\text { protective } \\
\text { equipment } \\
\text { sufficient to avoid } \\
\text { the requirement } \\
\text { for individual } \\
\text { exposures in } \\
\text { excess of the } \\
835.202 \\
\text { Occupational } \\
\text { Exposure Limits. } \\
\end{array}$ & $\begin{array}{l}\text { implements the } \\
\text { requirements of } \\
\S 835.1302 \text {. }\end{array}$ & & \begin{tabular}{|l} 
protective \\
equipment \\
sufficient to avoid \\
the requirement \\
for individual \\
exposures in \\
excess of the \\
835.202 \\
Occupational \\
Exposure Limits.
\end{tabular} & \\
\hline $\begin{array}{l}1302 \text { (b) Operating } \\
\text { management shall } \\
\text { weigh actual and } \\
\text { potential risks against } \\
\text { the benefits to be } \\
\text { gained. }\end{array}$ & $\begin{array}{l}\text { NV/YMP RCM } \\
213.4 .02 . b . \\
\text { For compliance } \\
\text { with } 10 \text { CFR } \\
835.1302, \text { in } \\
\text { emergency } \\
\text { exposure } \\
\text { situations the } \\
\text { following must } \\
\text { apply: } \\
\text { b. Operating } \\
\text { management } \\
\text { shall weigh } \\
\text { actual and } \\
\text { potential risks } \\
\text { against the } \\
\text { benefits to be } \\
\text { gained. }\end{array}$ & $\begin{array}{l}\text { NV/YMP RCM } \\
\text { 213.4.02.b. } \\
\text { For compliance } \\
\text { with 10 CFR } \\
835.1302, \text { in } \\
\text { emergency } \\
\text { exposure } \\
\text { situations the } \\
\text { following must } \\
\text { apply: } \\
\text { b. Operating } \\
\text { management } \\
\text { shall weigh } \\
\text { actual and } \\
\text { potential risks } \\
\text { against the } \\
\text { benefits to be } \\
\text { gained. }\end{array}$ & $\begin{array}{l}\text { Operations which } \\
\text { could potentially } \\
\text { require } \\
\text { emergency } \\
\text { exposures to } \\
\text { personnel in } \\
\text { excess of the } \\
835.202, \\
\text { Occupational } \\
\text { Exposure Limits, } \\
\text { are outside the } \\
\text { scope of LLNL-N } \\
\text { activities. The } \\
\text { activities and } \\
\text { radioactive } \\
\text { materials do not } \\
\text { present an } \\
\text { opportunity for } \\
\text { an emergency } \\
\end{array}$ & $\begin{array}{l}\text { This is outside } \\
\text { the scope of the } \\
\text { LANL/NTS } \\
\text { Radiological } \\
\text { Control Program. } \\
\text { Operations which } \\
\text { could potentially } \\
\text { require } \\
\text { emergency } \\
\text { exposures to } \\
\text { personnel in } \\
\text { excess of the } \\
835.202 \text {, } \\
\text { Occupational } \\
\text { Exposure Limits, } \\
\text { are outside the } \\
\text { scope of } \\
\text { LANL/NTS } \\
\text { activities. The }\end{array}$ & $\begin{array}{l}\text { There are } \\
\text { currently no } \\
\text { operations being } \\
\text { performed at } \\
\text { SNL/NTS } \\
\text { facilities, } \\
\text { operations or } \\
\text { processes } \\
\text { wherein } \\
\text { emergency } \\
\text { exposures to } \\
\text { personnel in } \\
\text { excess of } \\
835.202 \\
\text { occupational } \\
\text { dose limits can } \\
\text { be envisioned. } \\
\text { SNL Radiological } \\
\text { Protection }\end{array}$ & $\begin{array}{l}\text { Not Applicable. } \\
\text { Operations which } \\
\text { could potentially } \\
\text { require } \\
\text { emergency } \\
\text { exposures to } \\
\text { personnel in } \\
\text { excess of the } \\
835.202, \\
\text { Occupational } \\
\text { Exposure Limits, } \\
\text { are outside the } \\
\text { scope of SNJV } \\
\text { activities. SNJV } \\
\text { will not conduct } \\
\text { activities which } \\
\text { could result such } \\
\text { emergency } \\
\text { operations }\end{array}$ & $\begin{array}{l}\text { Not applicable to } \\
\text { DRI. Operations } \\
\text { which could } \\
\text { potentially } \\
\text { require } \\
\text { emergency } \\
\text { exposures to } \\
\text { personnel in } \\
\text { excess of the } \\
835.202, \\
\text { Occupational } \\
\text { Exposure Limits, } \\
\text { are outside the } \\
\text { scope of DRI } \\
\text { activities. The } \\
\text { activities and } \\
\text { radioactive } \\
\text { materials do not } \\
\text { present an }\end{array}$ & $\begin{array}{l}\text { Not applicable to } \\
\text { WSI/NV } \\
\text { operations. } \\
\text { WSI/NV has a } \\
\text { contractual } \\
\text { agreement with } \\
\text { DOE/NV that } \\
\text { precludes rescue } \\
\text { and recovery } \\
\text { activities, or } \\
\text { other activities } \\
\text { that may result in } \\
\text { emergency } \\
\text { exposure } \\
\text { situations. } \\
\text { Rescue and } \\
\text { recovery } \\
\text { operations for } \\
\text { security related }\end{array}$ \\
\hline
\end{tabular}

H-136 


\section{NEVADA TEST SITE RADIATION PROTECTION PROGRAM}

\section{APPENDIX H}

COMPLIANCE DEMONSTRATION TABLE

\begin{tabular}{|c|c|c|c|c|c|c|c|c|}
\hline \multirow[t]{2}{*}{10 CFR 835} & $\begin{array}{c}\text { NV/YMP RCM } \\
\text { Rev } 5 \text { and } \\
\text { NTS RPP } \\
\text { Revision } 0 \\
\end{array}$ & $\begin{array}{c}\text { NSTec } \\
\text { Appendix A }\end{array}$ & $\begin{array}{c}\text { LLNL } \\
\text { Appendix B }\end{array}$ & $\begin{array}{c}\text { LANL } \\
\text { Appendix C }\end{array}$ & $\begin{array}{c}\text { SNL } \\
\text { Appendix D }\end{array}$ & $\begin{array}{c}\text { SNJV } \\
\text { Appendix E }\end{array}$ & $\begin{array}{c}\text { DRI } \\
\text { Appendix F }\end{array}$ & $\begin{array}{c}\text { WSI } \\
\text { Appendix G }\end{array}$ \\
\hline & $\begin{array}{l}\text { Implementation } \\
\text { Reference }\end{array}$ & $\begin{array}{l}\text { Implementation } \\
\text { Reference }\end{array}$ & $\begin{array}{l}\text { Implementation } \\
\text { Reference }\end{array}$ & $\begin{array}{l}\text { Implementation } \\
\text { Reference }\end{array}$ & $\begin{array}{l}\text { Implementation } \\
\text { Reference }\end{array}$ & $\begin{array}{l}\text { Implementation } \\
\text { Reference }\end{array}$ & $\begin{array}{l}\text { Implementation } \\
\text { Reference }\end{array}$ & $\begin{array}{l}\text { Implementation } \\
\text { Reference }\end{array}$ \\
\hline
\end{tabular}

\begin{tabular}{|c|c|c|c|c|c|c|c|c|}
\hline & & & $\begin{array}{l}\text { situation in which } \\
\text { the radiological } \\
\text { hazards could } \\
\text { not be mitigated } \\
\text { by engineering } \\
\text { controls or } \\
\text { personal } \\
\text { protective } \\
\text { equipment } \\
\text { sufficient to avoid } \\
\text { the requirement } \\
\text { for individual } \\
\text { exposures in } \\
\text { excess of the } \\
\text { 835.202 } \\
\text { Occupational } \\
\text { Exposure Limits. }\end{array}$ & $\begin{array}{l}\text { activities and } \\
\text { radioactive } \\
\text { materials do not } \\
\text { present an } \\
\text { opportunity for } \\
\text { an emergency } \\
\text { situation in which } \\
\text { the radiological } \\
\text { hazards could } \\
\text { not be mitigated } \\
\text { by engineering } \\
\text { controls or } \\
\text { personal } \\
\text { protective } \\
\text { equipment } \\
\text { sufficient to avoid } \\
\text { the requirement } \\
\text { for individual } \\
\text { exposures in } \\
\text { excess of the } \\
835.202 \\
\text { Occupational } \\
\text { Exposure Limits. }\end{array}$ & \begin{tabular}{|l} 
Procedures \\
Manual, MN \\
471016, Chapter \\
11, Radiological \\
Incidents, \\
Section 4.12 \\
"Emergency \\
Exposure \\
Situations" \\
implements the \\
requirements of \\
§835.1302.
\end{tabular} & $\begin{array}{l}\text { without revision } \\
\text { and subsequent } \\
\text { approval of this } \\
\text { RPP. }\end{array}$ & $\begin{array}{l}\text { opportunity for } \\
\text { an emergency } \\
\text { situation in which } \\
\text { the radiological } \\
\text { hazards could } \\
\text { not be mitigated } \\
\text { by engineering } \\
\text { controls or } \\
\text { personal } \\
\text { protective } \\
\text { equipment } \\
\text { sufficient to avoid } \\
\text { the requirement } \\
\text { for individual } \\
\text { exposures in } \\
\text { excess of the } \\
\text { 835.202 } \\
\text { Occupational } \\
\text { Exposure Limits. }\end{array}$ & $\begin{array}{l}\text { incidents are } \\
\text { delegated to the } \\
\text { Federal Bureau } \\
\text { of Investigation } \\
\text { through a } \\
\text { Memorandum of } \\
\text { Agreement. }\end{array}$ \\
\hline $\begin{array}{l}1302 \text { (c) No individual } \\
\text { shall be required to } \\
\text { perform rescue action } \\
\text { that might involve } \\
\text { substantial personal } \\
\text { risk. }\end{array}$ & $\begin{array}{l}\text { NV/YMP RCM } \\
\text { 213.4.02.c. } \\
\text { For compliance } \\
\text { with } 10 \text { CFR } \\
835.1302 \text {, in } \\
\text { emergency } \\
\text { exposure } \\
\text { situations the } \\
\text { following must } \\
\text { apply: }\end{array}$ & $\begin{array}{l}\text { NV/YMP RCM } \\
\text { 213.4.02.c. } \\
\text { For compliance } \\
\text { with } 10 \text { CFR } \\
835.1302 \text {, in } \\
\text { emergency } \\
\text { exposure } \\
\text { situations the } \\
\text { following must } \\
\text { apply: }\end{array}$ & $\begin{array}{l}\text { Operations which } \\
\text { could potentially } \\
\text { require } \\
\text { emergency } \\
\text { exposures to } \\
\text { personnel in } \\
\text { excess of the } \\
835.202, \\
\text { Occupational } \\
\text { Exposure Limits, }\end{array}$ & $\begin{array}{l}\text { This is outside } \\
\text { the scope of the } \\
\text { LANL/NTS } \\
\text { Radiological } \\
\text { Control Program. } \\
\text { Operations which } \\
\text { could potentially } \\
\text { require } \\
\text { emergency } \\
\text { exposures to }\end{array}$ & $\begin{array}{l}\text { There are } \\
\text { currently no } \\
\text { operations being } \\
\text { performed at } \\
\text { SNL/NTS } \\
\text { facilities, } \\
\text { operations or } \\
\text { processes } \\
\text { wherein } \\
\text { emergency }\end{array}$ & $\begin{array}{l}\text { Not Applicable. } \\
\text { Operations which } \\
\text { could potentially } \\
\text { require } \\
\text { emergency } \\
\text { exposures to } \\
\text { personnel in } \\
\text { excess of the } \\
835.202, \\
\text { Occupational }\end{array}$ & $\begin{array}{l}\text { Not applicable to } \\
\text { DRI. Operations } \\
\text { which could } \\
\text { potentially } \\
\text { require } \\
\text { emergency } \\
\text { exposures to } \\
\text { personnel in } \\
\text { excess of the } \\
835.202 \text {, }\end{array}$ & $\begin{array}{l}\text { Not applicable to } \\
\text { WSI/NV } \\
\text { operations. } \\
\text { WSI/NV has a } \\
\text { contractual } \\
\text { agreement with } \\
\text { DOE/NV that } \\
\text { precludes rescue } \\
\text { and recovery } \\
\text { activities, or }\end{array}$ \\
\hline
\end{tabular}

$\mathrm{H}-137$ 


\section{NEVADA TEST SITE RADIATION PROTECTION PROGRAM}

\section{APPENDIX H}

COMPLIANCE DEMONSTRATION TABLE

\begin{tabular}{|c|c|c|c|c|c|c|c|c|}
\hline \multirow[t]{2}{*}{10 CFR 835} & $\begin{array}{c}\text { NV/YMP RCM } \\
\text { Rev } 5 \text { and } \\
\text { NTS RPP } \\
\text { Revision } 0 \\
\end{array}$ & $\begin{array}{c}\text { NSTec } \\
\text { Appendix A }\end{array}$ & $\begin{array}{c}\text { LLNL } \\
\text { Appendix B }\end{array}$ & $\begin{array}{c}\text { LANL } \\
\text { Appendix C }\end{array}$ & $\begin{array}{c}\text { SNL } \\
\text { Appendix D }\end{array}$ & $\begin{array}{c}\text { SNJV } \\
\text { Appendix E }\end{array}$ & $\begin{array}{c}\text { DRI } \\
\text { Appendix F }\end{array}$ & $\begin{array}{c}\text { WSI } \\
\text { Appendix G }\end{array}$ \\
\hline & $\begin{array}{l}\text { Implementation } \\
\text { Reference }\end{array}$ & $\begin{array}{l}\text { Implementation } \\
\text { Reference }\end{array}$ & $\begin{array}{l}\text { Implementation } \\
\text { Reference }\end{array}$ & $\begin{array}{l}\text { Implementation } \\
\text { Reference }\end{array}$ & $\begin{array}{l}\text { Implementation } \\
\text { Reference }\end{array}$ & $\begin{array}{l}\text { Implementation } \\
\text { Reference }\end{array}$ & $\begin{array}{l}\text { Implementation } \\
\text { Reference }\end{array}$ & $\begin{array}{l}\text { Implementation } \\
\text { Reference }\end{array}$ \\
\hline
\end{tabular}

\begin{tabular}{|c|c|c|c|c|c|c|c|c|}
\hline & $\begin{array}{l}\text { c. No individual } \\
\text { shall be required } \\
\text { to perform } \\
\text { rescue action } \\
\text { that might } \\
\text { involve } \\
\text { substantial } \\
\text { personal risk. }\end{array}$ & $\begin{array}{l}\text { c. No individual } \\
\text { shall be required } \\
\text { to perform } \\
\text { rescue action } \\
\text { that might } \\
\text { involve } \\
\text { substantial } \\
\text { personal risk. }\end{array}$ & $\begin{array}{l}\text { are outside the } \\
\text { scope of LLNL-N } \\
\text { activities. The } \\
\text { activities and } \\
\text { radioactive } \\
\text { materials do not } \\
\text { present an } \\
\text { opportunity for } \\
\text { an emergency } \\
\text { situation in which } \\
\text { the radiological } \\
\text { hazards could } \\
\text { not be mitigated } \\
\text { by engineering } \\
\text { controls or } \\
\text { personal } \\
\text { protective } \\
\text { equipment } \\
\text { sufficient to avoid } \\
\text { the requirement } \\
\text { for individual } \\
\text { exposures in } \\
\text { excess of the } \\
835.202 \\
\text { Occupational } \\
\text { Exposure Limits. }\end{array}$ & $\begin{array}{l}\text { personnel in } \\
\text { excess of the } \\
835.202, \\
\text { Occupational } \\
\text { Exposure Limits, } \\
\text { are outside the } \\
\text { scope of } \\
\text { LANL/NTS } \\
\text { activities. The } \\
\text { activities and } \\
\text { radioactive } \\
\text { materials do not } \\
\text { present an } \\
\text { opportunity for } \\
\text { an emergency } \\
\text { situation in which } \\
\text { the radiological } \\
\text { hazards could } \\
\text { not be mitigated } \\
\text { by engineering } \\
\text { controls or } \\
\text { personal } \\
\text { protective } \\
\text { equipment } \\
\text { sufficient to avoid } \\
\text { the requirement } \\
\text { for individual } \\
\text { exposures in } \\
\text { excess of the } \\
\text { 835.202 } \\
\text { Occupational } \\
\text { Exposure Limits. }\end{array}$ & $\begin{array}{l}\text { exposures to } \\
\text { personnel in } \\
\text { excess of } \\
835.202 \\
\text { occupational } \\
\text { dose limits can } \\
\text { be envisioned. } \\
\text { SNL Radiological } \\
\text { Protection } \\
\text { Procedures } \\
\text { Manual, MN } \\
471016, \text { Chapter } \\
11, \text { Radiological } \\
\text { Incidents, } \\
\text { Section } 4.12 \\
\text { "Emergency } \\
\text { Exposure } \\
\text { Situations" } \\
\text { implements the } \\
\text { requirements of } \\
\text { §835.1302. }\end{array}$ & $\begin{array}{l}\text { Exposure Limits, } \\
\text { are outside the } \\
\text { scope of SNJV } \\
\text { activities. SNJV } \\
\text { will not conduct } \\
\text { activities which } \\
\text { could result such } \\
\text { emergency } \\
\text { operations } \\
\text { without revision } \\
\text { and subsequent } \\
\text { approval of this } \\
\text { RPP. }\end{array}$ & $\begin{array}{l}\text { Occupational } \\
\text { Exposure Limits, } \\
\text { are outside the } \\
\text { scope of DRI } \\
\text { activities. The } \\
\text { activities and } \\
\text { radioactive } \\
\text { materials do not } \\
\text { present an } \\
\text { opportunity for } \\
\text { an emergency } \\
\text { situation in which } \\
\text { the radiological } \\
\text { hazards could } \\
\text { not be mitigated } \\
\text { by engineering } \\
\text { controls or } \\
\text { personal } \\
\text { protective } \\
\text { equipment } \\
\text { sufficient to avoid } \\
\text { the requirement } \\
\text { for individual } \\
\text { exposures in } \\
\text { excess of the } \\
835.202 \\
\text { Occupational } \\
\text { Exposure Limits. }\end{array}$ & $\begin{array}{l}\text { other activities } \\
\text { that may result in } \\
\text { emergency } \\
\text { exposure } \\
\text { situations. } \\
\text { Rescue and } \\
\text { recovery } \\
\text { operations for } \\
\text { security related } \\
\text { incidents are } \\
\text { delegated to the } \\
\text { Federal Bureau } \\
\text { of Investigation } \\
\text { through a } \\
\text { Memorandum of } \\
\text { Agreement. }\end{array}$ \\
\hline 1302(d) Each & NV/YMP RCM & NV/YMP RCM & Operations which & This is outside & In the extremely & Not Applicable. & Cross reference & Not applicable to \\
\hline
\end{tabular}

$\mathrm{H}-138$ 


\section{NEVADA TEST SITE RADIATION PROTECTION PROGRAM}

\section{APPENDIX H}

COMPLIANCE DEMONSTRATION TABLE

\begin{tabular}{|c|c|c|c||c||c||c||c||c|}
\hline \multirow{2}{*}{ 10 CFR 835 } & $\begin{array}{c}\text { NV/YMP RCM } \\
\text { Rev 5 and } \\
\text { NTS RPP } \\
\text { Revision 0 }\end{array}$ & Appendix A & Appendix B & Appendix C & Appendix D & SNJV \\
\cline { 2 - 7 } & $\begin{array}{c}\text { Implementation } \\
\text { Reference }\end{array}$ & $\begin{array}{c}\text { Implementation } \\
\text { Reference }\end{array}$ & $\begin{array}{c}\text { Implementation } \\
\text { Reference }\end{array}$ & $\begin{array}{c}\text { Implementation } \\
\text { Reference }\end{array}$ & $\begin{array}{c}\text { Implementation } \\
\text { Reference }\end{array}$ & $\begin{array}{c}\text { Implementation } \\
\text { Reference }\end{array}$ & $\begin{array}{c}\text { Implementation } \\
\text { Reference }\end{array}$ & $\begin{array}{c}\text { Implementation } \\
\text { Reference }\end{array}$ \\
\hline
\end{tabular}

individual authorized to perform emergency actions likely to result in occupational doses exceeding the values of the limits provided at $\S 835.202(a)$ shall be trained in accordance with $\S 835.901(\mathrm{~b})$ and briefed beforehand on the known or anticipated hazards to which the individual will be subjected. 213.4.d. For compliance with 10 CFR

835.1302 , in emergency exposure situations the following must apply:

d. Each

individual authorized to perform emergency actions likely to result in occupational doses exceeding the values of the limits provided in 10 CFR

835.202(a) shall be trained according to 10 CFR 835.901.b and briefed beforehand on the known or anticipated hazards to which the individual will be subjected.

\section{4.d. For} compliance with 10 CFR

835.1302, in emergency exposure situations the following must apply: d. Each individual authorized to perform emergency actions likely to result in occupational doses exceeding the values of the limits provided in 10 CFR

835.202(a) shall be trained according to 10 CFR 835.901.b and briefed beforehand on the known or anticipated

hazards to which the individual will be subjected.

\begin{tabular}{|l|l|}
\hline could potentially & the scope of the \\
require & LANL/NTS \\
emergency & Radiological \\
exposures to & Control Program. \\
personnel in & Operations which \\
excess of the & could potentially \\
835.202, & require \\
Occupational & emergency \\
Exposure Limits, & exposures to \\
are outside the & personnel in \\
scope of LLNL-N & excess of the \\
activities. The & 835.202, \\
activities and & Occupational \\
radioactive & Exposure Limits, \\
materials do not & are outside the \\
present an & scope of \\
opportunity for & LANL/NTS \\
an emergency & activities. The \\
situation in which & activities and \\
the radiological & radioactive \\
hazards could & materials do not \\
not be mitigated & present an \\
by engineering & opportunity for \\
controls or & an emergency \\
personal & situation in which \\
protective & the radiological \\
equipment & hazards could \\
sufficient to avoid \\
the requirement & not be mitigated \\
for individual & by engineering \\
exposures in & controls or \\
excess of the & personal \\
835.202 & protective \\
equipment \\
\hline
\end{tabular}

unlikely case that an SNL-NV employee should be exposed to high levels of radiation during an emergency, that individual shall have been trained at the

Radiation Worker II level and shall be briefed beforehand on the known or anticipated hazards to which the individual will be subjected. Such rescue and recovery action shall be performed by volunteers.

Operations which
could potentially
require
emergency
exposures to
personnel in
excess of the
835.202,
Occupational
Exposure Limits,
are outside the
scope of SNJV
activities. SNJV
will not conduct
activities which
could result such
emergency
operations
without revision
and subsequent
approval of this
RPP.
NV/YMP RCM WSI/NV Not applicable to DRI. Operations which could potentially require emergency exposures to personnel in excess of the 835.202, Occupational Exposure Limits, are outside the scope of DRI activities. The activities and radioactive materials do not present an opportunity for an emergency situation in which the radiological hazards could not be mitigated by engineering controls or personal protective equipment 


\section{NEVADA TEST SITE RADIATION PROTECTION PROGRAM}

\section{APPENDIX H}

COMPLIANCE DEMONSTRATION TABLE

\begin{tabular}{|c|c|c|c|c|c|c|c|c|}
\hline \multirow[t]{2}{*}{10 CFR 835} & $\begin{array}{c}\text { NV/YMP RCM } \\
\text { Rev } 5 \text { and } \\
\text { NTS RPP } \\
\text { Revision } 0 \\
\end{array}$ & $\begin{array}{c}\text { NSTec } \\
\text { Appendix A }\end{array}$ & $\begin{array}{c}\text { LLNL } \\
\text { Appendix B }\end{array}$ & $\begin{array}{c}\text { LANL } \\
\text { Appendix C }\end{array}$ & $\begin{array}{c}\text { SNL } \\
\text { Appendix D }\end{array}$ & $\begin{array}{c}\text { SNJV } \\
\text { Appendix E }\end{array}$ & $\begin{array}{c}\text { DRI } \\
\text { Appendix F }\end{array}$ & $\begin{array}{c}\text { WSI } \\
\text { Appendix G }\end{array}$ \\
\hline & $\begin{array}{l}\text { Implementation } \\
\text { Reference }\end{array}$ & $\begin{array}{l}\text { Implementation } \\
\text { Reference }\end{array}$ & $\begin{array}{l}\text { Implementation } \\
\text { Reference }\end{array}$ & $\begin{array}{l}\text { Implementation } \\
\text { Reference }\end{array}$ & $\begin{array}{l}\text { Implementation } \\
\text { Reference }\end{array}$ & $\begin{array}{l}\text { Implementation } \\
\text { Reference }\end{array}$ & $\begin{array}{l}\text { Implementation } \\
\text { Reference }\end{array}$ & $\begin{array}{l}\text { Implementation } \\
\text { Reference }\end{array}$ \\
\hline
\end{tabular}

\begin{tabular}{|c|c|c|c|c|c|c|c|c|}
\hline & & & $\begin{array}{l}\text { Occupational } \\
\text { Exposure Limits. }\end{array}$ & $\begin{array}{l}\text { sufficient to avoid } \\
\text { the requirement } \\
\text { for individual } \\
\text { exposures in } \\
\text { excess of the } \\
835.202 \\
\text { Occupational } \\
\text { Exposure Limits. }\end{array}$ & & & $\begin{array}{l}\text { sufficient to avoid } \\
\text { the requirement } \\
\text { for individual } \\
\text { exposures in } \\
\text { excess of the } \\
835.202 \\
\text { Occupational } \\
\text { Exposure Limits. }\end{array}$ & \\
\hline \multicolumn{9}{|l|}{835.1303 [Reserved] } \\
\hline $\begin{array}{l}835.1304 \text { Nuclear } \\
\text { accident dosimetry. } \\
\text { 1304(a) Installations } \\
\text { possessing sufficient } \\
\text { quantities of fissile } \\
\text { material to potentially } \\
\text { constitute a critical } \\
\text { mass, such that the } \\
\text { excessive exposure of } \\
\text { individuals to radiation } \\
\text { from a nuclear } \\
\text { accident is possible, } \\
\text { shall provide nuclear } \\
\text { accident dosimetry for } \\
\text { those individuals. }\end{array}$ & $\begin{array}{l}\text { There is no } \\
\text { identifiable } \\
\text { credible criticality } \\
\text { accident } \\
\text { scenario for } \\
\text { NSTec } \\
\text { operations. } \\
\text { Therefore, there } \\
\text { is currently no } \\
\text { requirement for a } \\
\text { Nuclear Accident } \\
\text { Dosimetry } \\
\text { system when a } \\
\text { credible criticality } \\
\text { accident } \\
\text { scenario does } \\
\text { not exist. } \\
\text { The RSPC is } \\
\text { developing a } \\
\text { nuclear accident } \\
\text { dosimetry }\end{array}$ & $\begin{array}{l}\text { There is no } \\
\text { identifiable } \\
\text { credible criticality } \\
\text { accident } \\
\text { scenario for } \\
\text { NSTec } \\
\text { operations. } \\
\text { Therefore, there } \\
\text { is currently no } \\
\text { requirement for a } \\
\text { Nuclear Accident } \\
\text { Dosimetry } \\
\text { system when a } \\
\text { credible criticality } \\
\text { accident } \\
\text { scenario does } \\
\text { not exist. } \\
\text { The RSPC is } \\
\text { developing a } \\
\text { nuclear accident } \\
\text { dosimetry } \\
\end{array}$ & $\begin{array}{l}\text { Same as Column } \\
3\end{array}$ & $\begin{array}{l}\text { Same as Column } \\
3\end{array}$ & $\begin{array}{l}\text { No contractor } \\
\text { commitment } \\
\text { required. The } \\
\text { RSPC provides } \\
\text { nuclear accident } \\
\text { dosimetry. }\end{array}$ & $\begin{array}{l}\text { No contractor } \\
\text { commitment } \\
\text { required. The } \\
\text { RSPC provides } \\
\text { nuclear accident } \\
\text { dosimetry. }\end{array}$ & $\begin{array}{l}\text { No contractor } \\
\text { commitment } \\
\text { required. The } \\
\text { RSPC provides } \\
\text { nuclear accident } \\
\text { dosimetry. }\end{array}$ & $\begin{array}{l}\text { No contractor } \\
\text { commitment } \\
\text { required. The } \\
\text { RSPC provides } \\
\text { nuclear accident } \\
\text { dosimetry. }\end{array}$ \\
\hline
\end{tabular}




\section{NEVADA TEST SITE RADIATION PROTECTION PROGRAM}

\section{APPENDIX H}

COMPLIANCE DEMONSTRATION TABLE

\begin{tabular}{|c|c|c|c||c||c||c||c||c|}
\hline \multirow{2}{*}{ 10 CFR 835 } & $\begin{array}{c}\text { NV/YMP RCM } \\
\text { Rev 5 and } \\
\text { NTS RPP } \\
\text { Revision 0 }\end{array}$ & Appendix A & Appendix B & Appendix C & Appendix D & SNJV \\
\cline { 2 - 7 } & $\begin{array}{c}\text { Implementation } \\
\text { Reference }\end{array}$ & $\begin{array}{c}\text { Implementation } \\
\text { Reference }\end{array}$ & $\begin{array}{c}\text { Implementation } \\
\text { Reference }\end{array}$ & $\begin{array}{c}\text { Implementation } \\
\text { Reference }\end{array}$ & $\begin{array}{c}\text { Implementation } \\
\text { Reference }\end{array}$ & $\begin{array}{c}\text { Implementation } \\
\text { Reference }\end{array}$ & $\begin{array}{c}\text { Implementation } \\
\text { Reference }\end{array}$ & $\begin{array}{c}\text { Implementation } \\
\text { Reference }\end{array}$ \\
\hline
\end{tabular}

\begin{tabular}{|c|c|c|c|c|c|c|c|c|}
\hline & $\begin{array}{l}\text { program that will } \\
\text { be in place if } \\
\text { needed for the } \\
\text { Criticality } \\
\text { Experiments } \\
\text { Facility. }\end{array}$ & $\begin{array}{l}\text { program that will } \\
\text { be in place if } \\
\text { needed for the } \\
\text { Criticality } \\
\text { Experiments } \\
\text { Facility. }\end{array}$ & & & & & & \\
\hline $\begin{array}{l}\text { 1304(b) Nuclear } \\
\text { accident dosimetry } \\
\text { shall include the } \\
\text { following: } \\
\text { (1) A method to } \\
\text { conduct initial } \\
\text { screening of } \\
\text { individuals involved in } \\
\text { a nuclear accident to } \\
\text { determine whether } \\
\text { significant exposures } \\
\text { to radiation occurred; } \\
\text { (2) Methods and } \\
\text { equipment for analysis } \\
\text { of biological materials; } \\
\text { (3) A system of fixed } \\
\text { nuclear accident } \\
\text { dosimeter units; and } \\
\text { (4) Personal nuclear } \\
\text { accident dosimeters. }\end{array}$ & $\begin{array}{l}\text { NV/YMP RCM } \\
515.2 \text {. Nuclear } \\
\text { accident } \\
\text { dosimetry shall } \\
\text { include the } \\
\text { following: } \\
\text { a. A method to } \\
\text { conduct initial } \\
\text { screening of } \\
\text { individuals } \\
\text { involved in a } \\
\text { nuclear accident } \\
\text { to determine } \\
\text { whether } \\
\text { significant } \\
\text { exposures to } \\
\text { radiation } \\
\text { occurred } \\
\text { b. Methods and } \\
\text { equipment for } \\
\text { analysis of } \\
\text { biological } \\
\text { materials; } \\
\text { c. A system of } \\
\text { fixed nuclear } \\
\text { accident } \\
\text { dosimeter units; }\end{array}$ & $\begin{array}{l}\text { NV/YMP RCM } \\
515.2 \text {. Nuclear } \\
\text { accident } \\
\text { dosimetry shall } \\
\text { include the } \\
\text { following: } \\
\text { a. A method to } \\
\text { conduct initial } \\
\text { screening of } \\
\text { individuals } \\
\text { involved in a } \\
\text { nuclear accident } \\
\text { to determine } \\
\text { whether } \\
\text { significant } \\
\text { exposures to } \\
\text { radiation } \\
\text { occurred } \\
\text { b. Methods and } \\
\text { equipment for } \\
\text { analysis of } \\
\text { biological } \\
\text { materials; } \\
\text { c. A system of } \\
\text { fixed nuclear } \\
\text { accident } \\
\text { dosimeter units; }\end{array}$ & $\begin{array}{l}\text { No contractor } \\
\text { commitment } \\
\text { required. The } \\
\text { RSPC will } \\
\text { provide nuclear } \\
\text { accident } \\
\text { dosimetry as } \\
\text { necessary. }\end{array}$ & $\begin{array}{l}\text { No contractor } \\
\text { commitment } \\
\text { required. The } \\
\text { RSPC will } \\
\text { provide nuclear } \\
\text { accident } \\
\text { dosimetry as } \\
\text { necessary. }\end{array}$ & $\begin{array}{l}\text { No contractor } \\
\text { commitment } \\
\text { required. The } \\
\text { RSPC will } \\
\text { provide nuclear } \\
\text { accident } \\
\text { dosimetry as } \\
\text { necessary. }\end{array}$ & $\begin{array}{l}\text { No contractor } \\
\text { commitment } \\
\text { required. The } \\
\text { RSPC provides } \\
\text { nuclear accident } \\
\text { dosimetry. }\end{array}$ & $\begin{array}{l}\text { No contractor } \\
\text { commitment } \\
\text { required. The } \\
\text { RSPC will } \\
\text { provide nuclear } \\
\text { accident } \\
\text { dosimetry as } \\
\text { necessary. }\end{array}$ & $\begin{array}{l}\text { No contractor } \\
\text { commitment } \\
\text { required. The } \\
\text { RSPC will } \\
\text { provide nuclear } \\
\text { accident } \\
\text { dosimetry as } \\
\text { necessary. }\end{array}$ \\
\hline
\end{tabular}

H-141 


\section{NEVADA TEST SITE RADIATION PROTECTION PROGRAM}

\section{APPENDIX H}

COMPLIANCE DEMONSTRATION TABLE

\begin{tabular}{|c|c|c|c|c|c|c|c|c|}
\hline \multirow[t]{2}{*}{10 CFR 835} & $\begin{array}{c}\text { NV/YMP RCM } \\
\text { Rev } 5 \text { and } \\
\text { NTS RPP } \\
\text { Revision } 0 \\
\end{array}$ & $\begin{array}{c}\text { NSTec } \\
\text { Appendix A }\end{array}$ & $\begin{array}{c}\text { LLNL } \\
\text { Appendix B }\end{array}$ & $\begin{array}{c}\text { LANL } \\
\text { Appendix C }\end{array}$ & $\begin{array}{c}\text { SNL } \\
\text { Appendix D }\end{array}$ & $\begin{array}{c}\text { SNJV } \\
\text { Appendix E }\end{array}$ & $\begin{array}{c}\text { DRI } \\
\text { Appendix F }\end{array}$ & $\begin{array}{c}\text { WSI } \\
\text { Appendix G }\end{array}$ \\
\hline & $\begin{array}{l}\text { Implementation } \\
\text { Reference }\end{array}$ & $\begin{array}{l}\text { Implementation } \\
\text { Reference }\end{array}$ & $\begin{array}{l}\text { Implementation } \\
\text { Reference }\end{array}$ & $\begin{array}{l}\text { Implementation } \\
\text { Reference }\end{array}$ & $\begin{array}{l}\text { Implementation } \\
\text { Reference }\end{array}$ & $\begin{array}{l}\text { Implementation } \\
\text { Reference }\end{array}$ & $\begin{array}{l}\text { Implementation } \\
\text { Reference }\end{array}$ & $\begin{array}{l}\text { Implementation } \\
\text { Reference }\end{array}$ \\
\hline
\end{tabular}

\begin{tabular}{|c|c|c|c|c|c|c|c|c|}
\hline & $\begin{array}{l}\text { and } \\
\text { d. A method to } \\
\text { ensure that } \\
\text { personal nuclear } \\
\text { accident } \\
\text { dosimeters are } \\
\text { worn by all } \\
\text { individuals who } \\
\text { enter locations in } \\
\text { which installed } \\
\text { criticality alarm } \\
\text { systems are } \\
\text { required. } \\
\end{array}$ & $\begin{array}{l}\text { and } \\
\text { d. A method to } \\
\text { ensure that } \\
\text { personal nuclear } \\
\text { accident } \\
\text { dosimeters are } \\
\text { worn by all } \\
\text { individuals who } \\
\text { enter locations in } \\
\text { which installed } \\
\text { criticality alarm } \\
\text { systems are } \\
\text { required. } \\
\end{array}$ & & & & & & \\
\hline $\begin{array}{l}\text { Appendix A to Part } \\
\text { 835--Derived Air } \\
\text { Concentrations } \\
\text { (DAC) for Controlling } \\
\text { Radiation Exposures } \\
\text { to Workers at DOE } \\
\text { Facilities. } \\
\text { The data presented in } \\
\text { appendix A are to be } \\
\text { used for controlling } \\
\text { individual internal } \\
\text { doses in accordance } \\
\text { with §835.209, } \\
\text { identifying the need for } \\
\text { air monitoring in } \\
\text { accordance with } \\
\text { §835.403, and } \\
\text { identifying and posting } \\
\text { airborne radioactivity }\end{array}$ & $\begin{array}{l}\text { NV/YMP RCM } \\
\text { 223.1. The data } \\
\text { presented in } \\
10 \text { CFR } 835 \\
\text { Appendix A, } \\
\text { "Derived Air } \\
\text { Concentrations } \\
\text { (DACs) for } \\
\text { Controlling } \\
\text { Radiation } \\
\text { Exposure to } \\
\text { Workers at DOE } \\
\text { Facilities," are to } \\
\text { be used for } \\
\text { controlling } \\
\text { individual internal } \\
\text { doses according } \\
\text { to } 10 \text { CFR } \\
835.209, \\
\text { identifying the }\end{array}$ & $\begin{array}{l}\text { Revise: NV/YMP } \\
\text { RCM 223.1. The } \\
\text { data presented in } \\
10 \text { CFR } 835 \\
\text { Appendix A, } \\
\text { "Derived Air } \\
\text { Concentrations } \\
\text { (DAC) for } \\
\text { Controlling } \\
\text { Radiation } \\
\text { Exposure to } \\
\text { Workers at DOE } \\
\text { Facilities," are to } \\
\text { be used for } \\
\text { controlling } \\
\text { individual internal } \\
\text { doses and 10 } \\
\text { CFR } 835 \\
\text { Appendix C, } \\
\text { "Derived Air }\end{array}$ & $\begin{array}{l}\text { Same as Column } \\
3\end{array}$ & $\begin{array}{l}\text { Same as Column } \\
3\end{array}$ & $\begin{array}{l}\text { Same as Column } \\
3\end{array}$ & $\begin{array}{l}\text { Same as Column } \\
3\end{array}$ & \begin{tabular}{|l} 
Same as Column \\
3
\end{tabular} & $\begin{array}{l}\text { Same as Column } \\
3 \text { and Identifying } \\
\text { the need for air } \\
\text { monitoring and } \\
\text { identifying and } \\
\text { posting airborne } \\
\text { radioactivity } \\
\text { areas are } \\
\text { beyond the } \\
\text { scope of WSI/NV } \\
\text { operations. }\end{array}$ \\
\hline
\end{tabular}




\section{NEVADA TEST SITE RADIATION PROTECTION PROGRAM}

\section{APPENDIX H}

COMPLIANCE DEMONSTRATION TABLE

\begin{tabular}{|c|c|c|c|c|c|c|c|c|}
\hline \multirow[t]{2}{*}{10 CFR 835} & $\begin{array}{l}\text { NV/YMP RCM } \\
\text { Rev } 5 \text { and } \\
\text { NTS RPP } \\
\text { Revision } 0 \\
\end{array}$ & $\begin{array}{c}\text { NSTec } \\
\text { Appendix A }\end{array}$ & $\begin{array}{c}\text { LLNL } \\
\text { Appendix B }\end{array}$ & $\begin{array}{c}\text { LANL } \\
\text { Appendix C }\end{array}$ & $\begin{array}{c}\text { SNL } \\
\text { Appendix D }\end{array}$ & $\begin{array}{c}\text { SNJV } \\
\text { Appendix E }\end{array}$ & $\begin{array}{c}\text { DRI } \\
\text { Appendix F }\end{array}$ & $\begin{array}{c}\text { WSI } \\
\text { Appendix G }\end{array}$ \\
\hline & $\begin{array}{l}\text { Implementation } \\
\text { Reference }\end{array}$ & $\begin{array}{l}\text { Implementation } \\
\text { Reference }\end{array}$ & $\begin{array}{l}\text { Implementation } \\
\text { Reference }\end{array}$ & $\begin{array}{l}\text { Implementation } \\
\text { Reference }\end{array}$ & $\begin{array}{l}\text { Implementation } \\
\text { Reference }\end{array}$ & $\begin{array}{l}\text { Implementation } \\
\text { Reference }\end{array}$ & $\begin{array}{l}\text { Implementation } \\
\text { Reference }\end{array}$ & $\begin{array}{c}\text { Implementation } \\
\text { Reference }\end{array}$ \\
\hline
\end{tabular}

\section{areas in accordance with §835.603(d). The DAC values are given for individual radionuclides. For known mixtures of} radionuclides,

determine the sum of the ratio of the observed

concentration of a particular radionuclide and its corresponding DAC for all

radionuclides in the mixture. If this sum exceeds unity (1), then DAC has been

exceeded. For unknown radionuclides, the most restrictive DAC (lowest value) for those isotopes not known to be absent shall be used. For any single radionuclide not listed in appendix $A$ with decay mode other than alpha emission or spontaneous fission and with radioactive half-life greater that

\begin{tabular}{|c|c|}
\hline $\begin{array}{l}\text { need for air } \\
\text { monitoring } \\
\text { according to } \\
10 \text { CFR } 835.403 \text {, } \\
\text { and identifying } \\
\text { and Airborne } \\
\text { Radioactivity } \\
\text { Areas according } \\
\text { to } 10 \text { CFR } \\
835.603(d) \text {. } \\
\text { NV/YMP RCM } \\
223.3 \text {. For } \\
\text { known mixtures } \\
\text { of radionuclides, } \\
\text { the sum of the } \\
\text { ratio of the } \\
\text { observed } \\
\text { concentration of } \\
\text { a particular } \\
\text { radionuclide and } \\
\text { its corresponding } \\
\text { DAC, for all } \\
\text { radionuclides in } \\
\text { the mixture, must } \\
\text { not exceed } 1.0 . \\
\text { For unknown } \\
\text { radionuclides, } \\
\text { the most } \\
\text { restrictive DAC } \\
\text { (lowest value) for } \\
\text { those isotopes } \\
\text { not known to be }\end{array}$ & $\begin{array}{l}\text { Concentrations } \\
\text { (DAC) for } \\
\text { Workers From } \\
\text { External } \\
\text { Exposure During } \\
\text { Immersion in a } \\
\text { Cloud of } \\
\text { Airborne } \\
\text { Radioactive } \\
\text { Material," are to } \\
\text { be used for } \\
\text { controlling } \\
\text { individual } \\
\text { external doses } \\
\text { according to } 10 \\
\text { CFR } 835.209, \\
\text { identifying the } \\
\text { need for air } \\
\text { monitoring } \\
\text { according to } \\
10 \text { CFR } 835.403 \text {, } \\
\text { and identifying } \\
\text { and Airborne } \\
\text { Radioactivity } \\
\text { Areas according } \\
\text { to } 10 \text { CFR } \\
835.603(d) \text {. } \\
\text { Revise: NV/YMP } \\
\text { RCM 223.3. For } \\
\text { known mixtures } \\
\text { of radionuclides, } \\
\text { the sum of the }\end{array}$ \\
\hline
\end{tabular}

need for air monitoring according 10 CFR

NV/YMP RCM 223.3. For ratio of the served

tration of DAC, for all For unknown the most not known to be

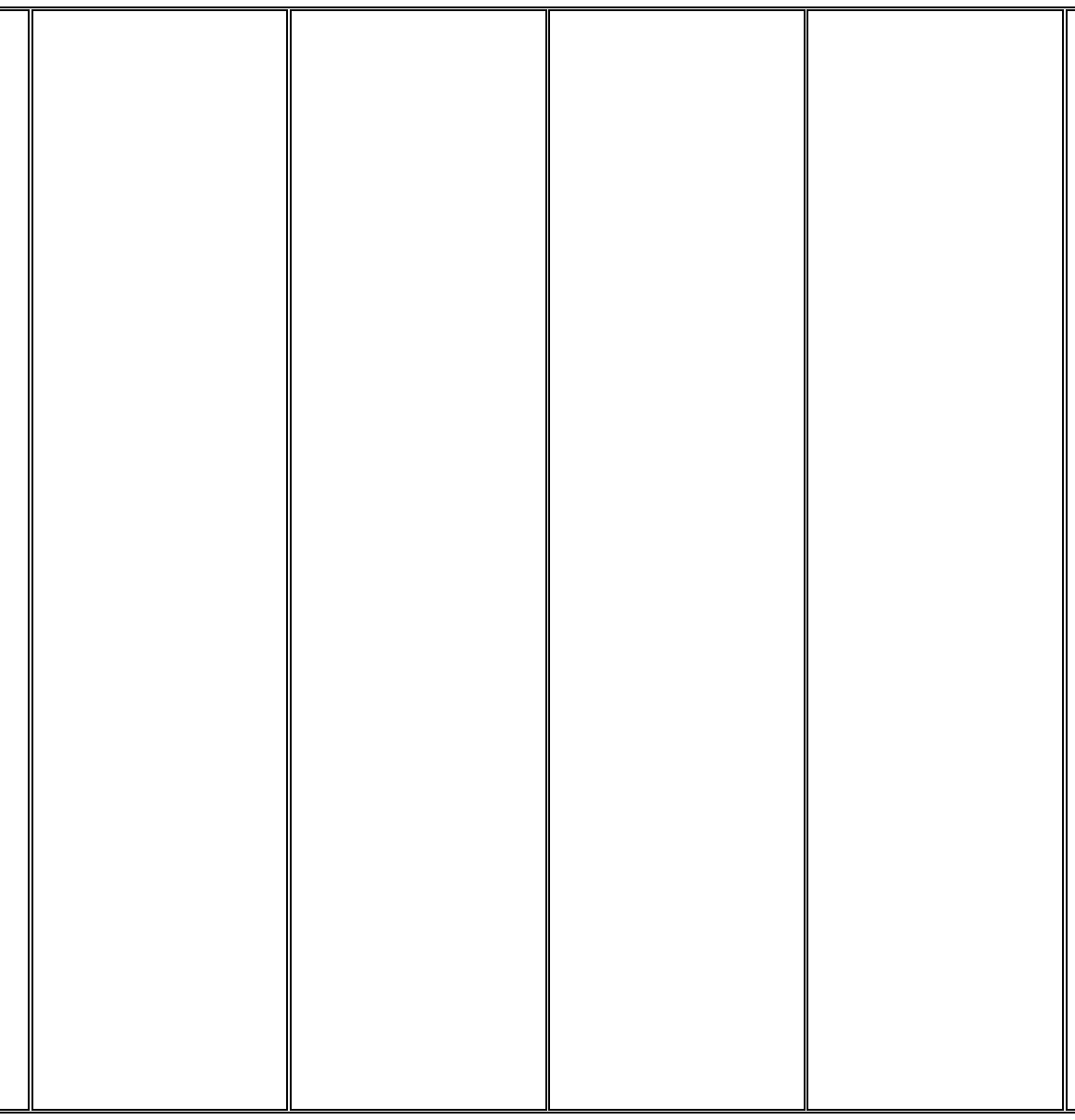




\section{NEVADA TEST SITE RADIATION PROTECTION PROGRAM}

\section{APPENDIX H}

COMPLIANCE DEMONSTRATION TABLE

\begin{tabular}{|c|c|c|c|c|c|c|c|c|}
\hline \multirow[t]{2}{*}{10 CFR 835} & $\begin{array}{l}\text { NV/YMP RCM } \\
\text { Rev } 5 \text { and } \\
\text { NTS RPP } \\
\text { Revision } 0 \\
\end{array}$ & $\begin{array}{c}\text { NSTec } \\
\text { Appendix A }\end{array}$ & $\begin{array}{c}\text { LLNL } \\
\text { Appendix B }\end{array}$ & $\begin{array}{c}\text { LANL } \\
\text { Appendix C }\end{array}$ & $\begin{array}{c}\text { SNL } \\
\text { Appendix D }\end{array}$ & $\begin{array}{c}\text { SNJV } \\
\text { Appendix E }\end{array}$ & $\begin{array}{c}\text { DRI } \\
\text { Appendix F }\end{array}$ & $\begin{array}{c}\text { WSI } \\
\text { Appendix G }\end{array}$ \\
\hline & $\begin{array}{l}\text { Implementation } \\
\text { Reference }\end{array}$ & $\begin{array}{l}\text { Implementation } \\
\text { Reference }\end{array}$ & $\begin{array}{l}\text { Implementation } \\
\text { Reference }\end{array}$ & $\begin{array}{l}\text { Implementation } \\
\text { Reference }\end{array}$ & $\begin{array}{l}\text { Implementation } \\
\text { Reference }\end{array}$ & $\begin{array}{l}\text { Implementation } \\
\text { Reference }\end{array}$ & $\begin{array}{l}\text { Implementation } \\
\text { Reference }\end{array}$ & $\begin{array}{c}\text { Implementation } \\
\text { Reference }\end{array}$ \\
\hline
\end{tabular}

\begin{tabular}{|c|c|c|}
\hline 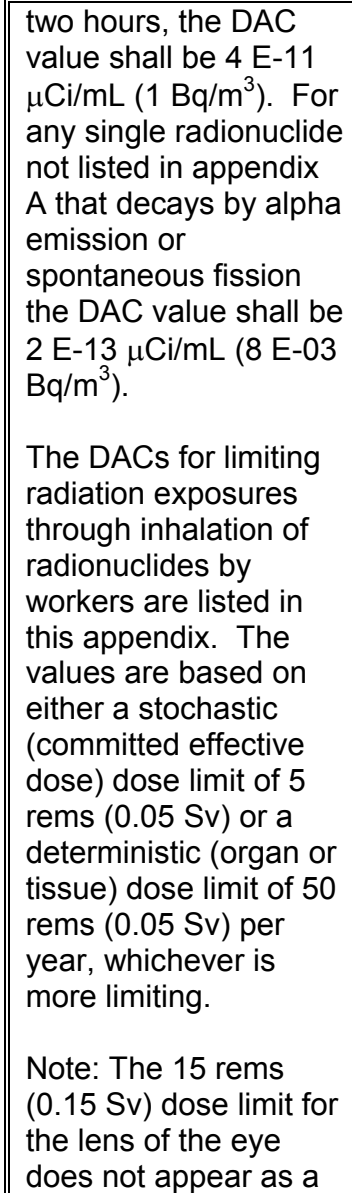 & $\begin{array}{l}\text { absent shall be } \\
\text { used. }\end{array}$ & $\begin{array}{l}\text { ratio of the } \\
\text { observed } \\
\text { concentration of } \\
\text { a particular } \\
\text { radionuclide and } \\
\text { its corresponding } \\
\text { DAC, for all } \\
\text { radionuclides in } \\
\text { the mixture, must } \\
\text { not exceed 1.0. } \\
\text { For unknown } \\
\text { radionuclides, } \\
\text { the most } \\
\text { restrictive DAC } \\
\text { (lowest value) for } \\
\text { those isotopes } \\
\text { not known to be } \\
\text { absent shall be } \\
\text { used. For any } \\
\text { single } \\
\text { radionuclide not } \\
\text { listed in } \\
\text { Appendix A with } \\
\text { decay mode } \\
\text { other than alpha } \\
\text { emission or } \\
\text { spontaneous } \\
\text { fission and with } \\
\text { radioactive half- } \\
\text { life greater than } \\
\text { two hours, the } \\
\text { DAC value shall } \\
\text { be } 4 \text { E-11 }\end{array}$ \\
\hline
\end{tabular}

does not appear as a

|




\section{NEVADA TEST SITE RADIATION PROTECTION PROGRAM}

\section{APPENDIX H}

COMPLIANCE DEMONSTRATION TABLE

\begin{tabular}{|c|c|c|c|c|c|c|c|c|}
\hline \multirow[t]{2}{*}{10 CFR 835} & $\begin{array}{c}\text { NV/YMP RCM } \\
\text { Rev } 5 \text { and } \\
\text { NTS RPP } \\
\text { Revision } 0 \\
\end{array}$ & $\begin{array}{c}\text { NSTec } \\
\text { Appendix A }\end{array}$ & $\begin{array}{c}\text { LLNL } \\
\text { Appendix B }\end{array}$ & $\begin{array}{c}\text { LANL } \\
\text { Appendix C }\end{array}$ & $\begin{array}{c}\text { SNL } \\
\text { Appendix D }\end{array}$ & $\begin{array}{c}\text { SNJV } \\
\text { Appendix E }\end{array}$ & $\begin{array}{c}\text { DRI } \\
\text { Appendix F }\end{array}$ & $\begin{array}{c}\text { WSI } \\
\text { Appendix G }\end{array}$ \\
\hline & $\begin{array}{l}\text { Implementation } \\
\text { Reference }\end{array}$ & $\begin{array}{l}\text { Implementation } \\
\text { Reference }\end{array}$ & $\begin{array}{l}\text { Implementation } \\
\text { Reference }\end{array}$ & $\begin{array}{l}\text { Implementation } \\
\text { Reference }\end{array}$ & $\begin{array}{c}\text { Implementation } \\
\text { Reference }\end{array}$ & $\begin{array}{l}\text { Implementation } \\
\text { Reference }\end{array}$ & $\begin{array}{l}\text { Implementation } \\
\text { Reference }\end{array}$ & $\begin{array}{l}\text { Implementation } \\
\text { Reference }\end{array}$ \\
\hline
\end{tabular}

\begin{tabular}{|c|c|c|c|c|c|c|c|c|}
\hline $\begin{array}{l}\text { absorption types } \\
\text { correspond to: Type } \mathrm{F} \\
100 \% \text { at } 10 \text { minutes; } \\
\text { Type } \mathrm{M}, 10 \% \text { at } 10 \\
\text { minutes and } 90 \% \text { at } \\
140 \text { days; and Type S } \\
0.1 \% \text { at } 10 \text { minutes } \\
\text { and } 99.9 \% \text { at } 7000 \\
\text { days. The DACs are } \\
\text { listed by radionuclide, } \\
\text { in order of increasing } \\
\text { atomic mass, and are } \\
\text { based on the } \\
\text { assumption that the } \\
\text { particle size } \\
\text { distribution } 5 \\
\text { micrometers AMAD is } \\
\text { used. For situations } \\
\text { where the particle size } \\
\text { distribution is known t } \\
\text { differ significantly from } \\
5 \text { micrometers AMAD, } \\
\text { appropriate } \\
\text { corrections may be } \\
\text { made to both the } \\
\text { estimated dose to } \\
\text { workers and the } \\
\text { DACs. }\end{array}$ & & & & & & & & \\
\hline \multicolumn{9}{|l|}{$\begin{array}{l}\text { APPENDIX B TO PART } \\
835 \text { [RESERVED] }\end{array}$} \\
\hline $\begin{array}{l}\text { Appendix C- to Part } \\
\text { 835-Derived Air }\end{array}$ & $\begin{array}{l}\text { Currently, not } \\
\text { applicable to }\end{array}$ & $\begin{array}{l}\text { Revise: NV/YMP } \\
\text { RCM 223.1. The }\end{array}$ & $\begin{array}{l}\text { Currently, not } \\
\text { applicable to }\end{array}$ & $\begin{array}{l}\text { Currently, not } \\
\text { applicable to }\end{array}$ & $\begin{array}{l}\text { Currently, not } \\
\text { applicable to }\end{array}$ & $\begin{array}{l}\text { Currently, not } \\
\text { applicable to }\end{array}$ & $\begin{array}{l}\text { Currently, not } \\
\text { applicable to DRI }\end{array}$ & $\begin{array}{l}\text { Currently, not } \\
\text { applicable to }\end{array}$ \\
\hline
\end{tabular}

H-146 


\section{NEVADA TEST SITE RADIATION PROTECTION PROGRAM}

\section{APPENDIX H}

COMPLIANCE DEMONSTRATION TABLE

\begin{tabular}{|c|c|c|c|c|c|c|c|c|}
\hline \multirow[t]{2}{*}{10 CFR 835} & $\begin{array}{l}\text { NV/YMP RCM } \\
\text { Rev } 5 \text { and } \\
\text { NTS RPP } \\
\text { Revision } 0 \\
\end{array}$ & $\begin{array}{c}\text { NSTec } \\
\text { Appendix A }\end{array}$ & $\begin{array}{c}\text { LLNL } \\
\text { Appendix B }\end{array}$ & $\begin{array}{c}\text { LANL } \\
\text { Appendix C }\end{array}$ & $\begin{array}{c}\text { SNL } \\
\text { Appendix D }\end{array}$ & $\begin{array}{c}\text { SNJV } \\
\text { Appendix E }\end{array}$ & $\begin{array}{c}\text { DRI } \\
\text { Appendix F }\end{array}$ & $\begin{array}{c}\text { WSI } \\
\text { Appendix G }\end{array}$ \\
\hline & $\begin{array}{l}\text { Implementation } \\
\text { Reference }\end{array}$ & $\begin{array}{l}\text { Implementation } \\
\text { Reference }\end{array}$ & $\begin{array}{l}\text { Implementation } \\
\text { Reference }\end{array}$ & $\begin{array}{l}\text { Implementation } \\
\text { Reference }\end{array}$ & $\begin{array}{l}\text { Implementation } \\
\text { Reference }\end{array}$ & $\begin{array}{l}\text { Implementation } \\
\text { Reference }\end{array}$ & $\begin{array}{l}\text { Implementation } \\
\text { Reference }\end{array}$ & $\begin{array}{c}\text { Implementation } \\
\text { Reference }\end{array}$ \\
\hline
\end{tabular}

\begin{tabular}{|c|c|c|c|c|c|c|c|c|}
\hline $\begin{array}{l}\text { Concentrations } \\
\text { (DAC) for Workers } \\
\text { From External } \\
\text { Exposure During } \\
\text { Immersion in a Cloud } \\
\text { of Airborne } \\
\text { Radioactive Material } \\
\text { a. The data presented } \\
\text { in Appendix C are to } \\
\text { be used for controlling } \\
\text { occupational } \\
\text { exposures in } \\
\text { accordance with } \\
\S 835.209, \text { identifying } \\
\text { the need for air } \\
\text { monitoring in } \\
\text { accordance with } \\
\S 835.403 \text { and } \\
\text { identifying the need for } \\
\text { posting of airborne } \\
\text { radioactivity areas in } \\
\text { accordance with } \\
\S 835.603(d) \text {. } \\
\\
\text { b. The air immersion } \\
\text { DAC values shown in } \\
\text { this appendix are } \\
\text { based on the } \\
\text { stochastic dose limit of } \\
5 \text { rems ( } 0.05 \text { sievert) } \\
\text { per year. Four } \\
\text { columns of information }\end{array}$ & $\begin{array}{l}\text { NSTec } \\
\text { Operations at the } \\
\text { NTS. }\end{array}$ & $\begin{array}{l}\text { data presented in } \\
10 \text { CFR } 835 \\
\text { Appendix A, } \\
\text { "Derived Air } \\
\text { Concentrations } \\
\text { (DAC) for } \\
\text { Controlling } \\
\text { Radiation } \\
\text { Exposure to } \\
\text { Workers at DOE } \\
\text { Facilities," are to } \\
\text { be used for } \\
\text { controlling } \\
\text { individual internal } \\
\text { doses and } 10 \\
\text { CFR 835 } \\
\text { Appendix C, } \\
\text { "Derived Air } \\
\text { Concentrations } \\
\text { (DAC) for } \\
\text { Workers From } \\
\text { External } \\
\text { Exposure During } \\
\text { Immersion in a } \\
\text { Cloud of } \\
\text { Airborne } \\
\text { Radioactive } \\
\text { Material," are to } \\
\text { be used for } \\
\text { controlling } \\
\text { individual } \\
\text { external doses } \\
\text { according to } 10\end{array}$ & $\begin{array}{l}\text { LLNL-N } \\
\text { Operations. }\end{array}$ & $\begin{array}{l}\text { LANL/NTS } \\
\text { Operations. }\end{array}$ & $\begin{array}{l}\text { SNL Operations } \\
\text { at the NTS. }\end{array}$ & $\begin{array}{l}\text { SNJV Operations } \\
\text { at the NTS. }\end{array}$ & $\begin{array}{l}\text { Operations at the } \\
\text { NTS. }\end{array}$ & $\begin{array}{l}\text { WSI/NV } \\
\text { Operations at the } \\
\text { NTS. }\end{array}$ \\
\hline
\end{tabular}




\section{NEVADA TEST SITE RADIATION PROTECTION PROGRAM}

\section{APPENDIX H}

COMPLIANCE DEMONSTRATION TABLE

\begin{tabular}{|c|c|c|c|c|c|c|c|c|}
\hline \multirow[t]{2}{*}{10 CFR 835} & $\begin{array}{c}\text { NV/YMP RCM } \\
\text { Rev } 5 \text { and } \\
\text { NTS RPP } \\
\text { Revision } 0 \\
\end{array}$ & $\begin{array}{c}\text { NSTec } \\
\text { Appendix A }\end{array}$ & $\begin{array}{c}\text { LLNL } \\
\text { Appendix B }\end{array}$ & $\begin{array}{c}\text { LANL } \\
\text { Appendix C }\end{array}$ & $\begin{array}{c}\text { SNL } \\
\text { Appendix D }\end{array}$ & $\begin{array}{c}\text { SNJV } \\
\text { Appendix E }\end{array}$ & $\begin{array}{c}\text { DRI } \\
\text { Appendix F }\end{array}$ & $\begin{array}{c}\text { WSI } \\
\text { Appendix G }\end{array}$ \\
\hline & $\begin{array}{l}\text { Implementation } \\
\text { Reference }\end{array}$ & $\begin{array}{l}\text { Implementation } \\
\text { Reference }\end{array}$ & $\begin{array}{l}\text { Implementation } \\
\text { Reference }\end{array}$ & $\begin{array}{l}\text { Implementation } \\
\text { Reference }\end{array}$ & $\begin{array}{c}\text { Implementation } \\
\text { Reference }\end{array}$ & $\begin{array}{l}\text { Implementation } \\
\text { Reference }\end{array}$ & $\begin{array}{l}\text { Implementation } \\
\text { Reference }\end{array}$ & $\begin{array}{l}\text { Implementation } \\
\text { Reference }\end{array}$ \\
\hline
\end{tabular}

\section{are presented:}

(1) radionuclide;

(2) half-life in units of seconds (s), minutes

(min), hours (h), days

(d), or years (yr);

(3) air immersion DAC

in units of $\mu \mathrm{Ci} / \mathrm{ml}$; and

(4) air immersion DAC

in units of $\mathrm{Bq} / \mathrm{m} 3$.

The data are listed by

radionuclide in order of

increasing atomic

mass. The air

immersion DACs were

calculated for a

continuous,

nonshielded exposure

via immersion in a

semi-infinite cloud of

airborne radioactive

material. The DACs

listed in this appendix

may be modified to

allow for submersion

in a cloud of finite

dimensions.

c. The DAC values are

given for individual

radionuclides. For

known mixtures of

radionuclides,

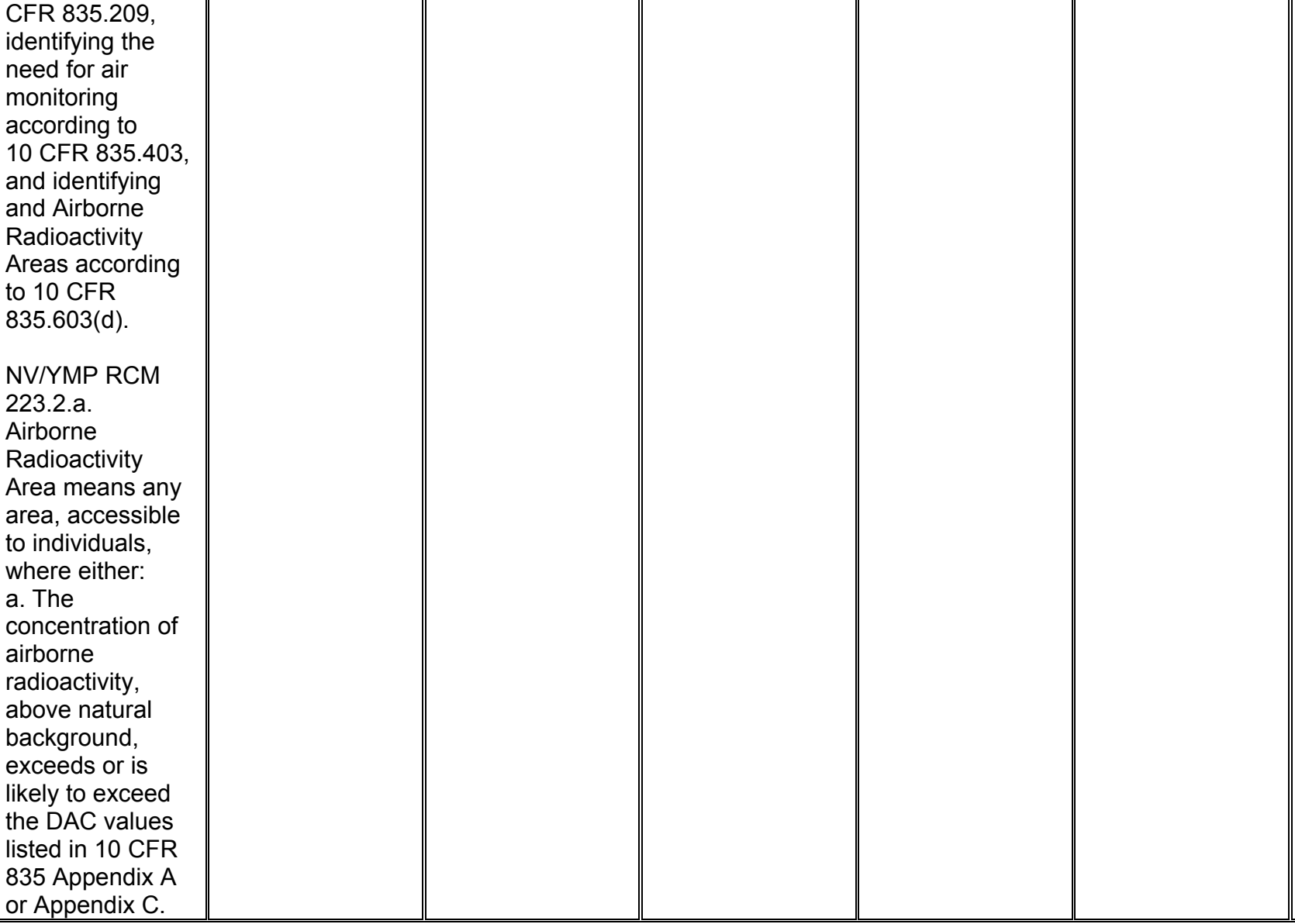

H-148 


\section{NEVADA TEST SITE RADIATION PROTECTION PROGRAM}

\section{APPENDIX H}

COMPLIANCE DEMONSTRATION TABLE

\begin{tabular}{|c|c|c|c|c|c|c|c|c|}
\hline \multirow[t]{2}{*}{10 CFR 835} & $\begin{array}{c}\text { NV/YMP RCM } \\
\text { Rev } 5 \text { and } \\
\text { NTS RPP } \\
\text { Revision } 0 \\
\end{array}$ & $\begin{array}{c}\text { NSTec } \\
\text { Appendix A }\end{array}$ & $\begin{array}{c}\text { LLNL } \\
\text { Appendix B }\end{array}$ & $\begin{array}{c}\text { LANL } \\
\text { Appendix C }\end{array}$ & $\begin{array}{c}\text { SNL } \\
\text { Appendix D }\end{array}$ & $\begin{array}{c}\text { SNJV } \\
\text { Appendix E }\end{array}$ & $\begin{array}{c}\text { DRI } \\
\text { Appendix F }\end{array}$ & $\begin{array}{c}\text { WSI } \\
\text { Appendix G }\end{array}$ \\
\hline & $\begin{array}{l}\text { Implementation } \\
\text { Reference }\end{array}$ & $\begin{array}{l}\text { Implementation } \\
\text { Reference }\end{array}$ & $\begin{array}{l}\text { Implementation } \\
\text { Reference }\end{array}$ & $\begin{array}{l}\text { Implementation } \\
\text { Reference }\end{array}$ & $\begin{array}{l}\text { Implementation } \\
\text { Reference }\end{array}$ & $\begin{array}{l}\text { Implementation } \\
\text { Reference }\end{array}$ & $\begin{array}{l}\text { Implementation } \\
\text { Reference }\end{array}$ & $\begin{array}{l}\text { Implementation } \\
\text { Reference }\end{array}$ \\
\hline
\end{tabular}

\begin{tabular}{|c|c|c|c|c|c|c|c|c|}
\hline $\begin{array}{l}\text { determine the sum of } \\
\text { the ratio of the } \\
\text { observed } \\
\text { concentration of a } \\
\text { particular radionuclide } \\
\text { and its corresponding } \\
\text { DAC for all } \\
\text { radionuclides in the } \\
\text { mixture. If this sum } \\
\text { exceeds unity (1), then } \\
\text { the DAC has been } \\
\text { exceeded. For } \\
\text { unknown } \\
\text { radionuclides, the } \\
\text { most restrictive DAC } \\
\text { (lowest value) for } \\
\text { those isotopes not } \\
\text { known to be absent } \\
\text { shall be used. }\end{array}$ & & $\begin{array}{l}\text { Revise: NV/YMP } \\
\text { RCM 223.3.01- } \\
02 . \text { For known } \\
\text { mixtures of } \\
\text { radionuclides, } \\
\text { the sum of the } \\
\text { ratio of the } \\
\text { observed } \\
\text { concentration of } \\
\text { a particular } \\
\text { radionuclide and } \\
\text { its corresponding } \\
\text { DAC, for all } \\
\text { radionuclides in } \\
\text { the mixture, must } \\
\text { not exceed } 1.0 . \\
\text { For unknown } \\
\text { radionuclides, } \\
\text { the most } \\
\text { restrictive DAC } \\
\text { (lowest value) for } \\
\text { those isotopes } \\
\text { not known to be } \\
\text { absent shall be } \\
\text { used. }\end{array}$ & & & & & & \\
\hline $\begin{array}{l}\text { Appendix D to Part } \\
\text { 835-Surface } \\
\text { Contamination } \\
\text { Values. } \\
\text { The data presented in } \\
\text { Appendix D are to be }\end{array}$ & $\begin{array}{l}\text { NV/YMP RCM } \\
\text { Table 2-2, } \\
\text { Columns 1-3. }\end{array}$ & $\begin{array}{l}\text { Revise: NV/YMP } \\
\text { RCM Table 2-2 } \\
\text { Footnote } 6 \\
{ }^{6} \text { Tritium } \\
\text { contamination } \\
\text { may diffuse into } \\
\end{array}$ & $\begin{array}{l}\text { Same as Column } \\
3\end{array}$ & $\begin{array}{l}\text { Same as Column } \\
3\end{array}$ & $\begin{array}{l}\text { Same as Column } \\
3\end{array}$ & $\begin{array}{l}\text { Same as Column } \\
3\end{array}$ & $\begin{array}{l}\text { No Contractor } \\
\text { Commitment } \\
\text { Required. The } \\
\text { RSPC provides } \\
\text { this service. }\end{array}$ & $\begin{array}{l}\text { By written } \\
\text { agreement, the } \\
\text { RSPC provides } \\
\text { this service to } \\
\text { WSI/NV. }\end{array}$ \\
\hline
\end{tabular}

H-149 


\section{NEVADA TEST SITE RADIATION PROTECTION PROGRAM}

\section{APPENDIX H}

COMPLIANCE DEMONSTRATION TABLE

\begin{tabular}{|c|c|c|c|c|c|c|c|c|}
\hline \multirow[t]{2}{*}{10 CFR 835} & $\begin{array}{c}\text { NV/YMP RCM } \\
\text { Rev } 5 \text { and } \\
\text { NTS RPP } \\
\text { Revision } 0 \\
\end{array}$ & $\begin{array}{c}\text { NSTec } \\
\text { Appendix A }\end{array}$ & $\begin{array}{c}\text { LLNL } \\
\text { Appendix B }\end{array}$ & $\begin{array}{c}\text { LANL } \\
\text { Appendix C }\end{array}$ & $\begin{array}{c}\text { SNL } \\
\text { Appendix D }\end{array}$ & $\begin{array}{c}\text { SNJV } \\
\text { Appendix E }\end{array}$ & $\begin{array}{c}\text { DRI } \\
\text { Appendix F }\end{array}$ & $\begin{array}{c}\text { WSI } \\
\text { Appendix G }\end{array}$ \\
\hline & $\begin{array}{l}\text { Implementation } \\
\text { Reference }\end{array}$ & $\begin{array}{l}\text { Implementation } \\
\text { Reference }\end{array}$ & $\begin{array}{l}\text { Implementation } \\
\text { Reference }\end{array}$ & $\begin{array}{l}\text { Implementation } \\
\text { Reference }\end{array}$ & $\begin{array}{c}\text { Implementation } \\
\text { Reference }\end{array}$ & $\begin{array}{l}\text { Implementation } \\
\text { Reference }\end{array}$ & $\begin{array}{l}\text { Implementation } \\
\text { Reference }\end{array}$ & $\begin{array}{l}\text { Implementation } \\
\text { Reference }\end{array}$ \\
\hline
\end{tabular}

\begin{tabular}{|c|c|}
\hline $\begin{array}{l}\text { used for identifying } \\
\text { and posting } \\
\text { contamination and } \\
\text { high contamination } \\
\text { areas in accordance } \\
\text { with §835.603(e) and } \\
\text { (f) and identifying the } \\
\text { need for surface } \\
\text { contamination } \\
\text { monitoring and control } \\
\text { in accordance with } \\
\text {8} 835.1101 \text { and } 1102 . \\
\text { The Table for Surface } \\
\text { Contamination Values } \\
\text { in dpm/100cm }{ }^{2} \text { remain } \\
\text { the same except for } \\
\text { Tritium and STCs } \\
\text { Total (Fixed + } \\
\text { Removable) column } \\
\text { and the addition to } \\
\text { Footnote } 6 . \\
6 \text { Tritium } \\
\text { contamination may } \\
\text { diffuse into the volume } \\
\text { or matrix of materials. } \\
\text { Evaluation of surface } \\
\text { contamination shall } \\
\text { consider the extent to } \\
\text { which such } \\
\text { contamination may } \\
\text { migrate to the surface }\end{array}$ & $\begin{array}{l}\text { the volume or } \\
\text { matrix of } \\
\text { materials. } \\
\text { Evaluation of } \\
\text { surface } \\
\text { contamination } \\
\text { shall consider } \\
\text { the extent to } \\
\text { which such } \\
\text { contamination } \\
\text { may migrate to } \\
\text { the surface in } \\
\text { order to ensure } \\
\text { the surface } \\
\text { contamination } \\
\text { value provided in } \\
\text { this appendix is } \\
\text { not exceeded. } \\
\text { Once this } \\
\text { contamination } \\
\text { migrates to the } \\
\text { surface, it may } \\
\text { be removable, } \\
\text { not fixed; } \\
\text { therefore, a } \\
\text { "Total" value } \\
\text { does not apply. } \\
\text { In certain cases, } \\
\text { a "Total" value of } \\
10,000 \text { dpm/100 } \\
\text { cm² may be } \\
\text { applicable either } \\
\text { to metals of the }\end{array}$ \\
\hline
\end{tabular}

migrate to the surface

to metals of the

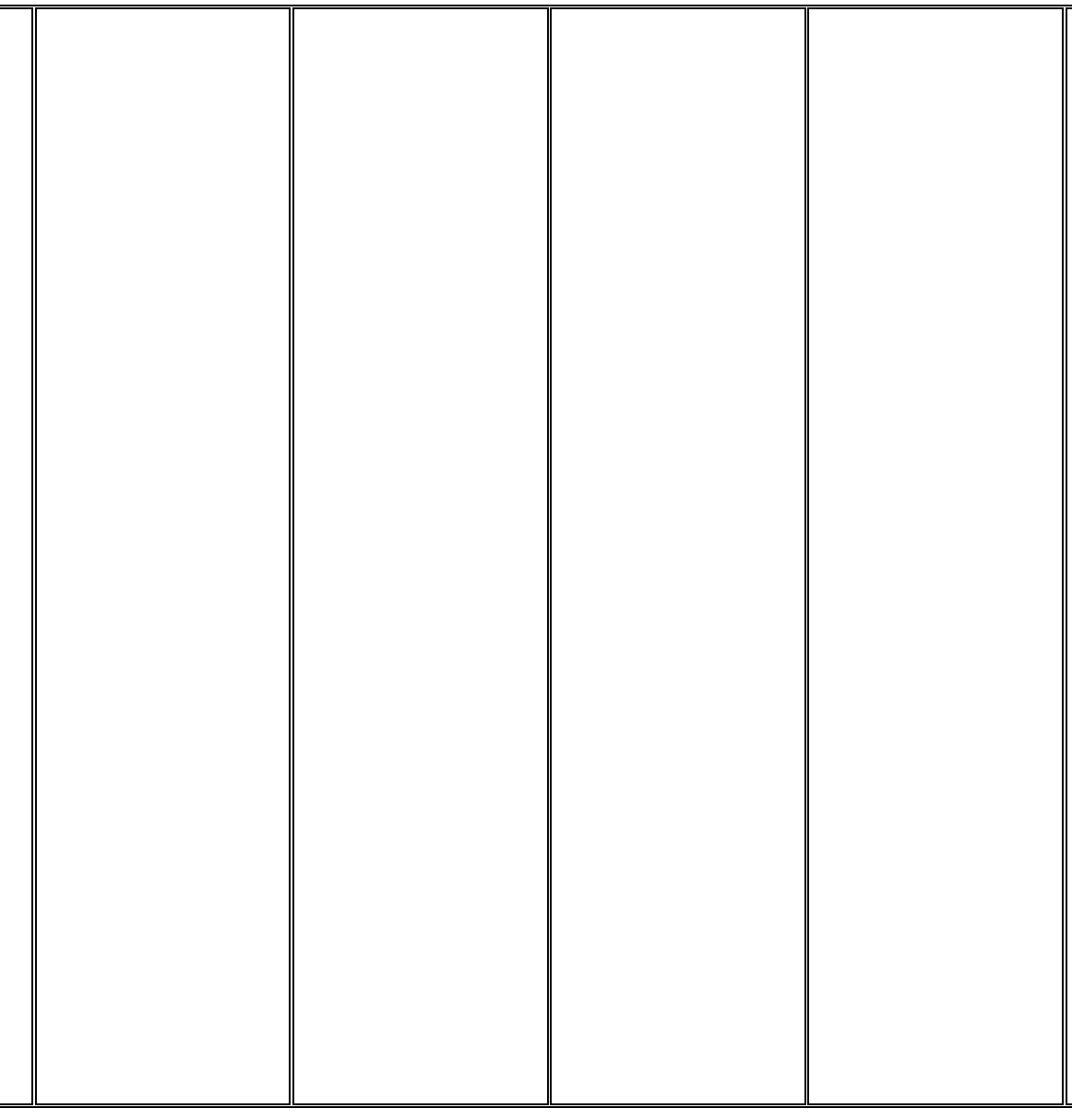




\section{NEVADA TEST SITE RADIATION PROTECTION PROGRAM}

\section{APPENDIX H}

COMPLIANCE DEMONSTRATION TABLE

\begin{tabular}{|c|c|c|c|c|c|c|c|c|}
\hline \multirow[t]{2}{*}{10 CFR 835} & $\begin{array}{c}\text { NV/YMP RCM } \\
\text { Rev } 5 \text { and } \\
\text { NTS RPP } \\
\text { Revision } 0 \\
\end{array}$ & $\begin{array}{c}\text { NSTec } \\
\text { Appendix A }\end{array}$ & $\begin{array}{c}\text { LLNL } \\
\text { Appendix B }\end{array}$ & $\begin{array}{c}\text { LANL } \\
\text { Appendix C }\end{array}$ & $\begin{array}{c}\text { SNL } \\
\text { Appendix D }\end{array}$ & $\begin{array}{c}\text { SNJV } \\
\text { Appendix E }\end{array}$ & $\begin{array}{c}\text { DRI } \\
\text { Appendix F }\end{array}$ & $\begin{array}{c}\text { WSI } \\
\text { Appendix G }\end{array}$ \\
\hline & $\begin{array}{l}\text { Implementation } \\
\text { Reference }\end{array}$ & $\begin{array}{l}\text { Implementation } \\
\text { Reference }\end{array}$ & $\begin{array}{l}\text { Implementation } \\
\text { Reference }\end{array}$ & $\begin{array}{l}\text { Implementation } \\
\text { Reference }\end{array}$ & $\begin{array}{c}\text { Implementation } \\
\text { Reference }\end{array}$ & $\begin{array}{l}\text { Implementation } \\
\text { Reference }\end{array}$ & $\begin{array}{l}\text { Implementation } \\
\text { Reference }\end{array}$ & $\begin{array}{l}\text { Implementation } \\
\text { Reference }\end{array}$ \\
\hline
\end{tabular}

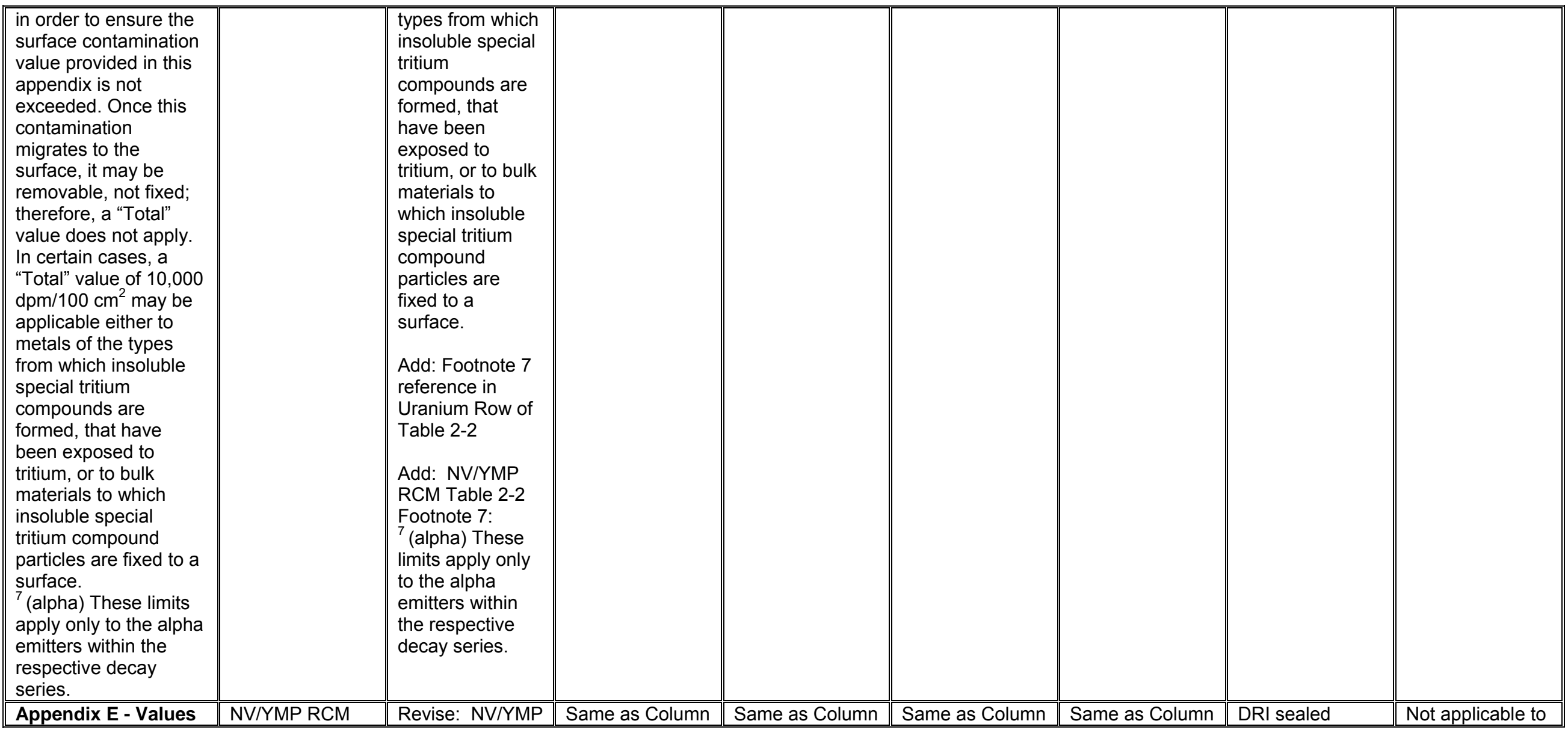




\section{NEVADA TEST SITE RADIATION PROTECTION PROGRAM}

\section{APPENDIX H}

COMPLIANCE DEMONSTRATION TABLE

\begin{tabular}{|c|c|c|c|c|c|c|c|c|}
\hline \multirow[t]{2}{*}{10 CFR 835} & $\begin{array}{l}\text { NV/YMP RCM } \\
\text { Rev } 5 \text { and } \\
\text { NTS RPP } \\
\text { Revision } 0 \\
\end{array}$ & $\begin{array}{c}\text { NSTec } \\
\text { Appendix A }\end{array}$ & $\begin{array}{c}\text { LLNL } \\
\text { Appendix B }\end{array}$ & $\begin{array}{c}\text { LANL } \\
\text { Appendix C }\end{array}$ & $\begin{array}{c}\text { SNL } \\
\text { Appendix D }\end{array}$ & $\begin{array}{c}\text { SNJV } \\
\text { Appendix E }\end{array}$ & $\begin{array}{c}\text { DRI } \\
\text { Appendix F }\end{array}$ & $\begin{array}{c}\text { WSI } \\
\text { Appendix G }\end{array}$ \\
\hline & $\begin{array}{l}\text { Implementation } \\
\text { Reference }\end{array}$ & $\begin{array}{l}\text { Implementation } \\
\text { Reference }\end{array}$ & $\begin{array}{l}\text { Implementation } \\
\text { Reference }\end{array}$ & $\begin{array}{l}\text { Implementation } \\
\text { Reference }\end{array}$ & $\begin{array}{l}\text { Implementation } \\
\text { Reference }\end{array}$ & $\begin{array}{l}\text { Implementation } \\
\text { Reference }\end{array}$ & $\begin{array}{l}\text { Implementation } \\
\text { Reference }\end{array}$ & $\begin{array}{c}\text { Implementation } \\
\text { Reference }\end{array}$ \\
\hline
\end{tabular}

\begin{tabular}{|c|c|c|c|c|c|c|c|c|}
\hline $\begin{array}{l}\text { for Establishing } \\
\text { Sealed Radioactive } \\
\text { Source } \\
\text { Accountability and } \\
\text { Radioactive Material } \\
\text { Posting and Labeling } \\
\text { Requirements. } \\
\text { The data presented in } \\
\text { Appendix E are to be } \\
\text { used for identifying } \\
\text { accountable sealed } \\
\text { radioactive sources } \\
\text { and radioactive } \\
\text { material areas as } \\
\text { those terms are } \\
\text { defined at } \$ 835.2(a) \text {, } \\
\text { establishing the need } \\
\text { for radioactive material } \\
\text { area posting in } \\
\text { accordance with } \\
\text { §835.603(g), and } \\
\text { establishing the need } \\
\text { for radioactive material } \\
\text { labeling in accordance } \\
\text { with §835.605. } \\
\text { Any alpha emitting } \\
\text { radionuclide not listed } \\
\text { in appendix E and } \\
\text { mixtures of alpha } \\
\text { emitters of unknown } \\
\text { composition have a }\end{array}$ & "Table 4A & $\begin{array}{l}\text { RCM Appendix } \\
4 \mathrm{~A} \text { with new } \\
\text { Accountability } \\
\text { values. } \\
\text { Revise: NV/YMP } \\
\text { RCM Appendix } \\
4 \mathrm{~A} \text { - Footnote } 2 \\
\text { With the } \\
\text { exception that } \\
\text { any type of STC } \\
\text { has a value of } 10 \\
\text { Ci, any } \\
\text { radionuclide } \\
\text { other than alpha } \\
\text { emitting } \\
\text { radionuclides not } \\
\text { listed in } \\
\text { Appendix } 4 \mathrm{~A} \text { and } \\
\text { mixtures of beta } \\
\text { emitters of } \\
\text { unknown } \\
\text { composition } \\
\text { have a value of } \\
100 \mu \text { Ci. }\end{array}$ & 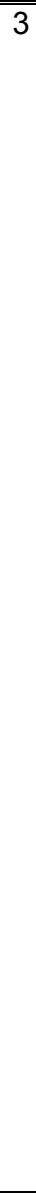 & 3 & 3 & 3 & $\begin{array}{l}\text { sources fall } \\
\text { under the } \\
\text { requirements of } \\
\text { the UNR } \\
\text { Radioactive } \\
\text { Material License } \\
\text { \#16-13-0003-07; } \\
\text { however, DRI } \\
\text { does not } \\
\text { participate in the } \\
\text { source } \\
\text { accountability } \\
\text { inventory at the } \\
\text { NTS via the } \\
\text { services } \\
\text { provided by the } \\
\text { RSPC. }\end{array}$ & $\begin{array}{l}\text { WSI/NV } \\
\text { operations. } \\
\text { WSI/NV is not a } \\
\text { sealed source } \\
\text { custodian. }\end{array}$ \\
\hline
\end{tabular}




\section{NEVADA TEST SITE RADIATION PROTECTION PROGRAM}

\section{APPENDIX H}

COMPLIANCE DEMONSTRATION TABLE

\begin{tabular}{|c|c|c|c|c|c|c|c|c|}
\hline \multirow[t]{2}{*}{10 CFR 835} & $\begin{array}{c}\text { NV/YMP RCM } \\
\text { Rev } 5 \text { and } \\
\text { NTS RPP } \\
\text { Revision } 0 \\
\end{array}$ & $\begin{array}{c}\text { NSTec } \\
\text { Appendix A }\end{array}$ & $\begin{array}{c}\text { LLNL } \\
\text { Appendix B }\end{array}$ & $\begin{array}{c}\text { LANL } \\
\text { Appendix C }\end{array}$ & $\begin{array}{c}\text { SNL } \\
\text { Appendix D }\end{array}$ & $\begin{array}{c}\text { SNJV } \\
\text { Appendix E }\end{array}$ & $\begin{array}{c}\text { DRI } \\
\text { Appendix F }\end{array}$ & $\begin{array}{c}\text { WSI } \\
\text { Appendix G }\end{array}$ \\
\hline & $\begin{array}{l}\text { Implementation } \\
\text { Reference }\end{array}$ & $\begin{array}{l}\text { Implementation } \\
\text { Reference }\end{array}$ & $\begin{array}{l}\text { Implementation } \\
\text { Reference }\end{array}$ & $\begin{array}{l}\text { Implementation } \\
\text { Reference }\end{array}$ & $\begin{array}{c}\text { Implementation } \\
\text { Reference }\end{array}$ & $\begin{array}{l}\text { Implementation } \\
\text { Reference }\end{array}$ & $\begin{array}{l}\text { Implementation } \\
\text { Reference }\end{array}$ & $\begin{array}{l}\text { Implementation } \\
\text { Reference }\end{array}$ \\
\hline
\end{tabular}

\section{value of $10 \mu \mathrm{Ci}$.}

With the exception that any type of STC has a value of $10 \mathrm{Ci}$, any

radionuclide other than alpha emitting

radionuclides not listed

in appendix $E$ and

mixtures of beta

emitters of unknown

composition have a

value of $100 \mu \mathrm{Ci}$.

Note: Where there is involved a mixture of radionuclides in known amounts, derive the

value for the mixture

as follows: determine, for each radionuclide

in the mixture, the ratio

between the quantity

present in the mixture

and the value

otherwise established

for the specific

radionuclide when not

in the mixture. If the

sum of such ratios for

all radionuclides in the

mixture exceeds unity

(1), then the

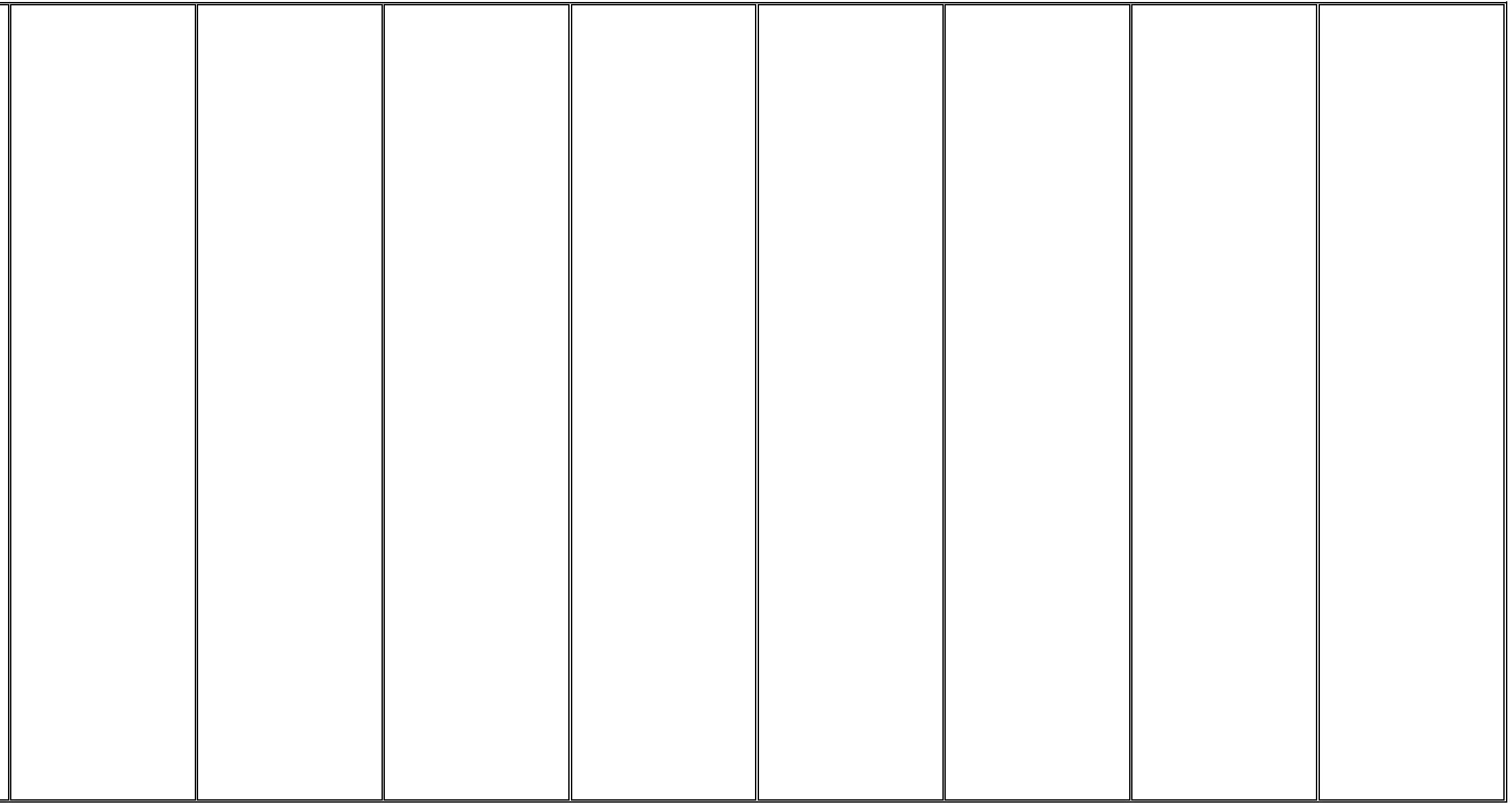




\section{NEVADA TEST SITE RADIATION PROTECTION PROGRAM}

\section{APPENDIX H}

COMPLIANCE DEMONSTRATION TABLE

\begin{tabular}{|c|c|c|c|c|c|c|c|c|}
\hline \multirow[t]{2}{*}{10 CFR 835} & $\begin{array}{c}\text { NV/YMP RCM } \\
\text { Rev } 5 \text { and } \\
\text { NTS RPP } \\
\text { Revision } 0 \\
\end{array}$ & $\begin{array}{c}\text { NSTec } \\
\text { Appendix A }\end{array}$ & $\begin{array}{c}\text { LLNL } \\
\text { Appendix B }\end{array}$ & $\begin{array}{c}\text { LANL } \\
\text { Appendix C }\end{array}$ & $\begin{array}{c}\text { SNL } \\
\text { Appendix D }\end{array}$ & $\begin{array}{c}\text { SNJV } \\
\text { Appendix E }\end{array}$ & $\begin{array}{c}\text { DRI } \\
\text { Appendix F }\end{array}$ & $\begin{array}{c}\text { WSI } \\
\text { Appendix G }\end{array}$ \\
\hline & $\begin{array}{l}\text { Implementation } \\
\text { Reference }\end{array}$ & $\begin{array}{l}\text { Implementation } \\
\text { Reference }\end{array}$ & $\begin{array}{l}\text { Implementation } \\
\text { Reference }\end{array}$ & $\begin{array}{l}\text { Implementation } \\
\text { Reference }\end{array}$ & $\begin{array}{c}\text { Implementation } \\
\text { Reference }\end{array}$ & $\begin{array}{l}\text { Implementation } \\
\text { Reference }\end{array}$ & $\begin{array}{l}\text { Implementation } \\
\text { Reference }\end{array}$ & $\begin{array}{l}\text { Implementation } \\
\text { Reference }\end{array}$ \\
\hline
\end{tabular}

accountability criterion

has been exceeded. 